\title{
Program Modalidades Flexibles: Integrated Curriculum Guide-Primer semestre
}

Population Council

Follow this and additional works at: https://knowledgecommons.popcouncil.org/departments_sbsr-pgy

Part of the Civic and Community Engagement Commons, Family, Life Course, and Society Commons, and the Gender Equity in Education Commons How does access to this work benefit you? Let us know!

\section{Recommended Citation}

"Program Modalidades Flexibles: Integrated Curriculum Guide-Primer semestre." Guatemala City: Population Council, 2018. 

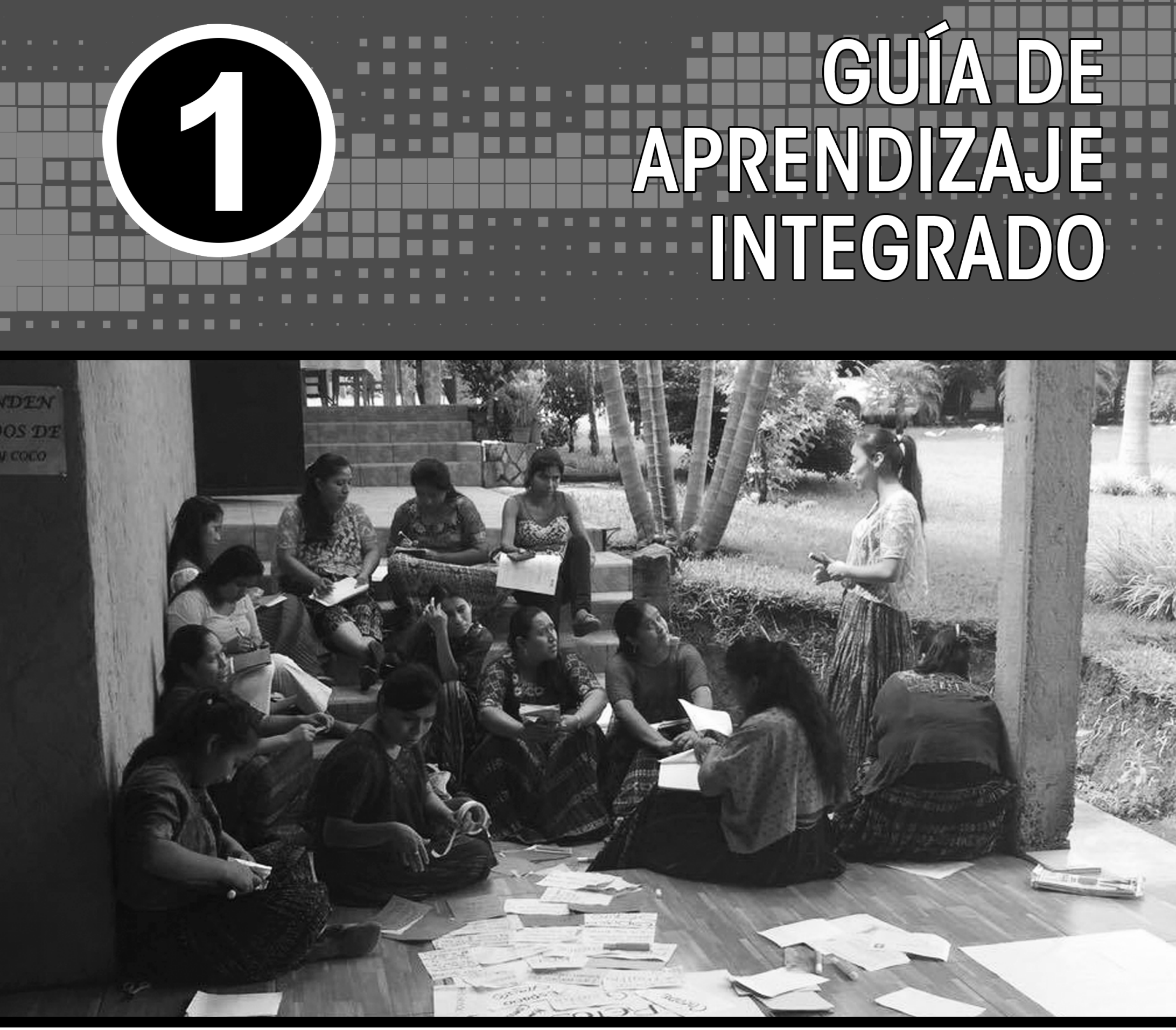

Programa Modalidades Flexibles Nivel de Educación Media, Ciclo de Educación Básica Segunda etapa, primer semestre

\section{POPULATION Itaes Everencia Imparate.

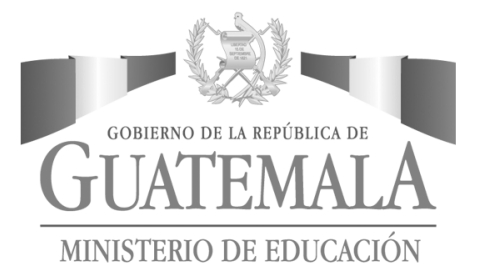 \\ NoVo Foundation create. change.}




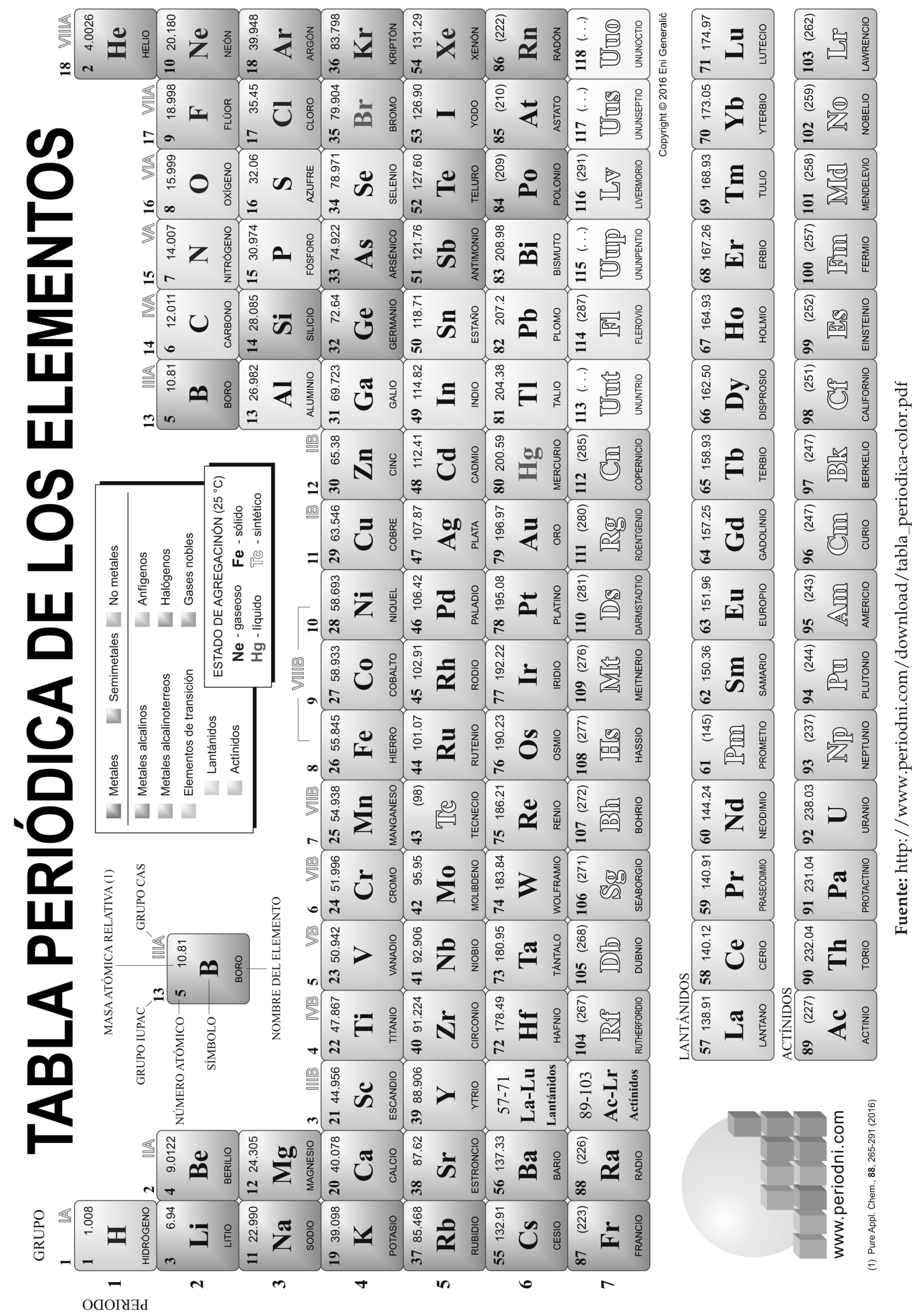




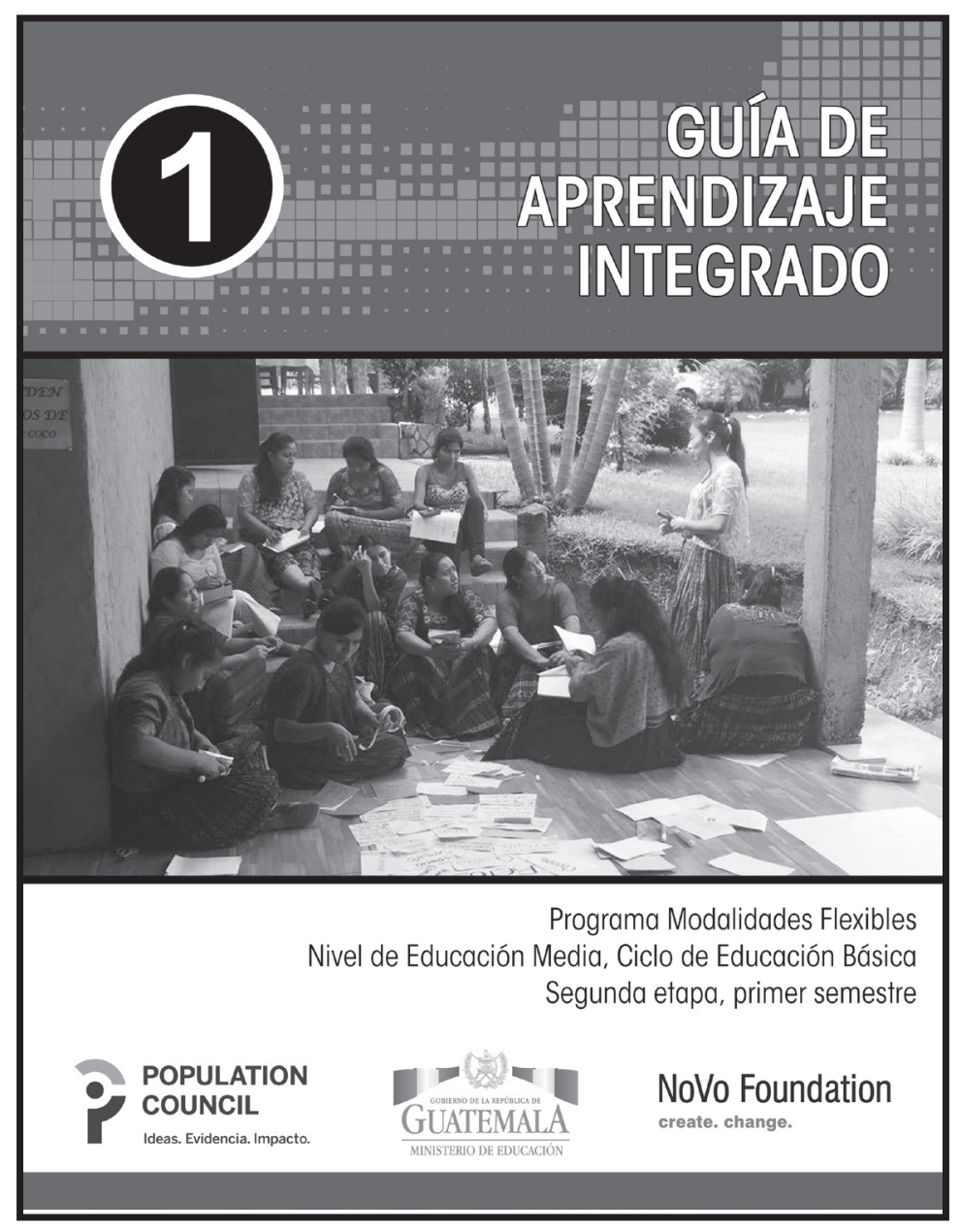

\section{Programa Modalidades Flexibles}

Nivel de Educación Media, Ciclo de Educación Básica Segunda etapa

La Guía de aprendizaje integrado para la segunda etapa del Programa de Modalidades Flexibles es una obra colectiva, creada, diseñada, realizada y supervisada por el siguiente equipo:

María Cecilia Garcés Jorge Luis Galindo Arandi Héctor Fernando Reyes Gramajo Iduvina Hernández Batres

\section{Autoría:}

Gloria Hernández Maria Isabel Escobedo Gladis Fidelina Barrientos González Héctor Fernando Reyes Gramajo Margarita Ramírez Vargas Julio Floresache Claudia Roche
Coordinación y supervisión Edición

Adecuación al enfoque de derechos humanos y perspectiva de género

Comunicación y Lenguaje

Matemáticas

Ciencias Naturales

Ciencias Sociales y formación ciudadana

Productividad y Desarrollo

Expresión Artística

Diseño de cubierta y realización gráfica

\section{POPULATION} COUNCIL

Ideas. Evidencia. Impacto.

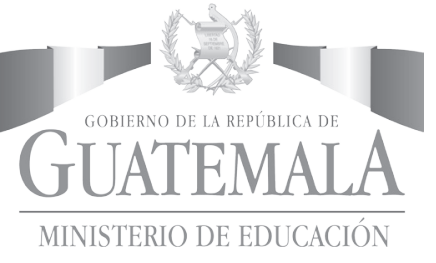

NoVo Foundation

create. change. 


\title{
Autoridades del Ministerio de Educación
}

\author{
Oscar Hugo López Rivas \\ Ministro de Educación \\ Héctor Alejandro Canto Mejía \\ Viceministro Técnico de Educación \\ María Eugenia Barrios Robles de Mejía \\ Viceministra Administrativa de Educación \\ Daniel Domingo López \\ Viceministro de Educación Bilingüe e Intercultural \\ José Inocente Moreno Cámbara \\ Viceministro de Diseño y Verificación de la Calidad Educativa \\ Juan de Dios Simón Sotz \\ Director General de Educación Extraescolar, DIGEEX.
}

D.R. (C) 2016

Population Council/Ministerio de Educación de Guatemala

19 Avenida 0-35 zona 15 Vista Hermosa II

Ciudad de Guatemala 01015

Guatemala

Producto centroamericano, hecho en Guatemala

ISBN

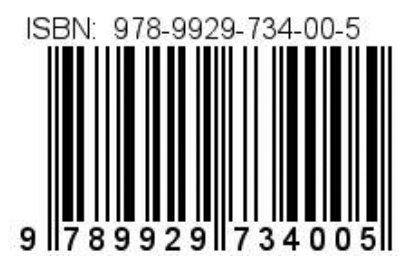

Impreso en

\section{NOTA:}

Esta publicación se realiza con el apoyo técnico de Population Council en el marco de apoyo al Ministerio de Educación de Guatemala; y en particular al fortalecimiento de programas con modalidades flexibles de la Dirección General de Educación Extraescolar, DIGEEX.

Los derechos patrimoniales de autor de este material son del Ministerio de Educación de Guatemala y Population Council.

Se permite la reproducción parcial o total de la obra y por cualquier medio; siempre y cuando se cite la fuente, se reconozcan los créditos institucionales y morales del equipo de creación, edición y realización y no se alteren los contenidos; únicamente con finalidades educativas. Queda prohibido todo uso de estos materiales, de sus reproducciones o de sus traducciones con fines comerciales.

La creación y publicación de esta obra fue posible gracias al financiamiento de: NoVo Foundation 


\section{Presentación}

Guatemala ha enfrentado grandes desafíos para garantizar a sus habitantes el acceso a la educación. La universalización del Nivel de Educación Primaria a nivel nacional trae, a la vez, la necesidad de ofrecer una respuesta al deseo de la población joven por continuar sus estudios en Ciclo Básico. La inexistencia de Institutos en las comunidades más alejadas representa, particularmente para las mujeres jóvenes, mayores retos para continuar su vida escolar. Estos retos son tanto económicos como sociales. Ante esta realidad el Population Council, en el marco del Programa Abriendo Oportunidades ${ }^{\circledR}$, se suma a los esfuerzos de la Dirección General de Educación Extraescolar -DIGEEX- del Ministerio de Educación para acercar el Nivel de Educación Media a las comunidades. Esto se está logrando al incorporar el Programa Modalidades Flexibles para Ciclo Básico como componente clave en la atención a la población joven y más excluida del sistema escolar.

Esta estrategia ofrece una alternativa flexible de estudio a jóvenes y personas adultas que han completado el Nivel de Educación Primaria y por diversas razones no han podido continuar sus estudios en el Ciclo Básico. La iniciativa por completar los recursos educativos necesarios para el este ciclo del Programa Modalidades Flexibles es motivada por la evidencia recabada por el Population Council y otras organizaciones socias de la DIGEEX. Mediante el diseño y elaboración de esta guía de aprendizaje se ofrece un recurso para estudiantes y docentes, que están participando en el semestre I de la etapa II del Ciclo Básico del programa Modalidades Flexibles. Su diseño responde específicamente a la modalidad semipresencial y de integración curricular por proyectos. El abordaje de Modalidades Flexibles desarrolla competencias de todas las áreas curriculares enfocándose en el conocimiento de la comunidad, su promoción y el desarrollo sostenible. Cuenta con recursos para trabajar en casa, para trabajar junto al personal docente y para realizar actividades en conjunto con compañeras y compañeros de la clase.

Este material se ha realizado como complemento del programa Abriendo Oportunidades ${ }^{\circledR}$ de Population Council en estrecha relación y colaboración con la Dirección General de Educación Extraescolar y la Dirección General de Currículo del Ministerio de Educación. Esta primera edición constituye el material para pilotaje que luego será sometido a un proceso de validación. Este estará a cargo de tutoras y estudiantes del componente Abriendo Oportunidades a la educación media a través de Modalidades Flexibles liderado por Population Council, actualmente implementado en los municipios de San Luis, Dolores y Poptún Petén. 


\section{Tu libro por dentro}

Esta Guía de aprendizaje me servirá en mi formación como estudiante del Programa Modalidades Flexibles durante el primer semestre de la segunda etapa del Ciclo Básico, Nivel Medio. Consta de 3 proyectos, 3 evaluaciones y 20 semanas de trabajo integrado.

Al realizar cada uno de los proyectos educativos desarrollaré competencias mediante la investigación-acción, la autoformación, el trabajo colaborativo, la reflexión y la autoevaluación.

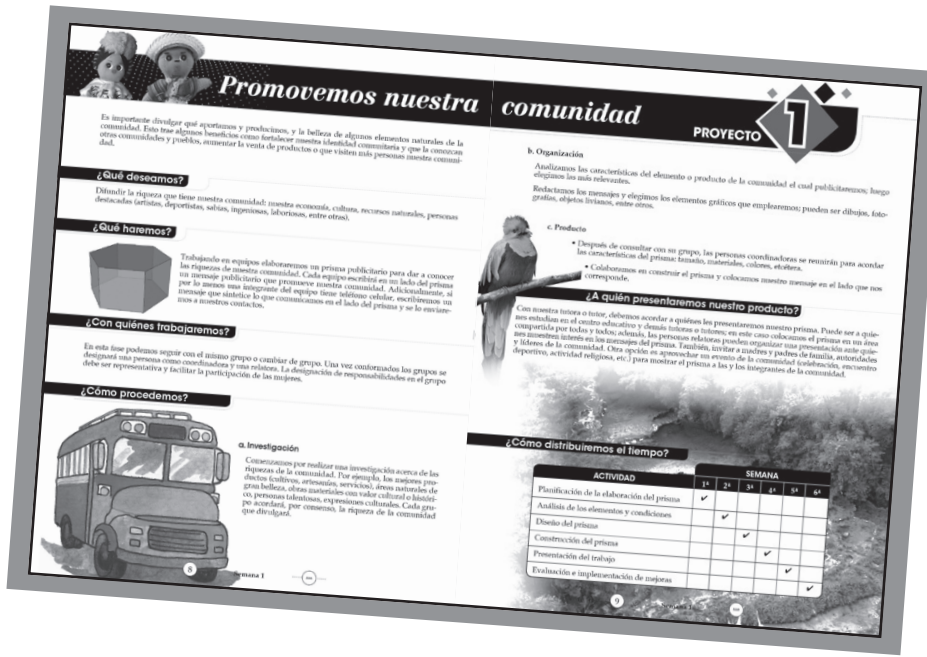

En la Guía de aprendizaje, encontraré la siguiente iconografía para lograr un aprendizaje significativo.

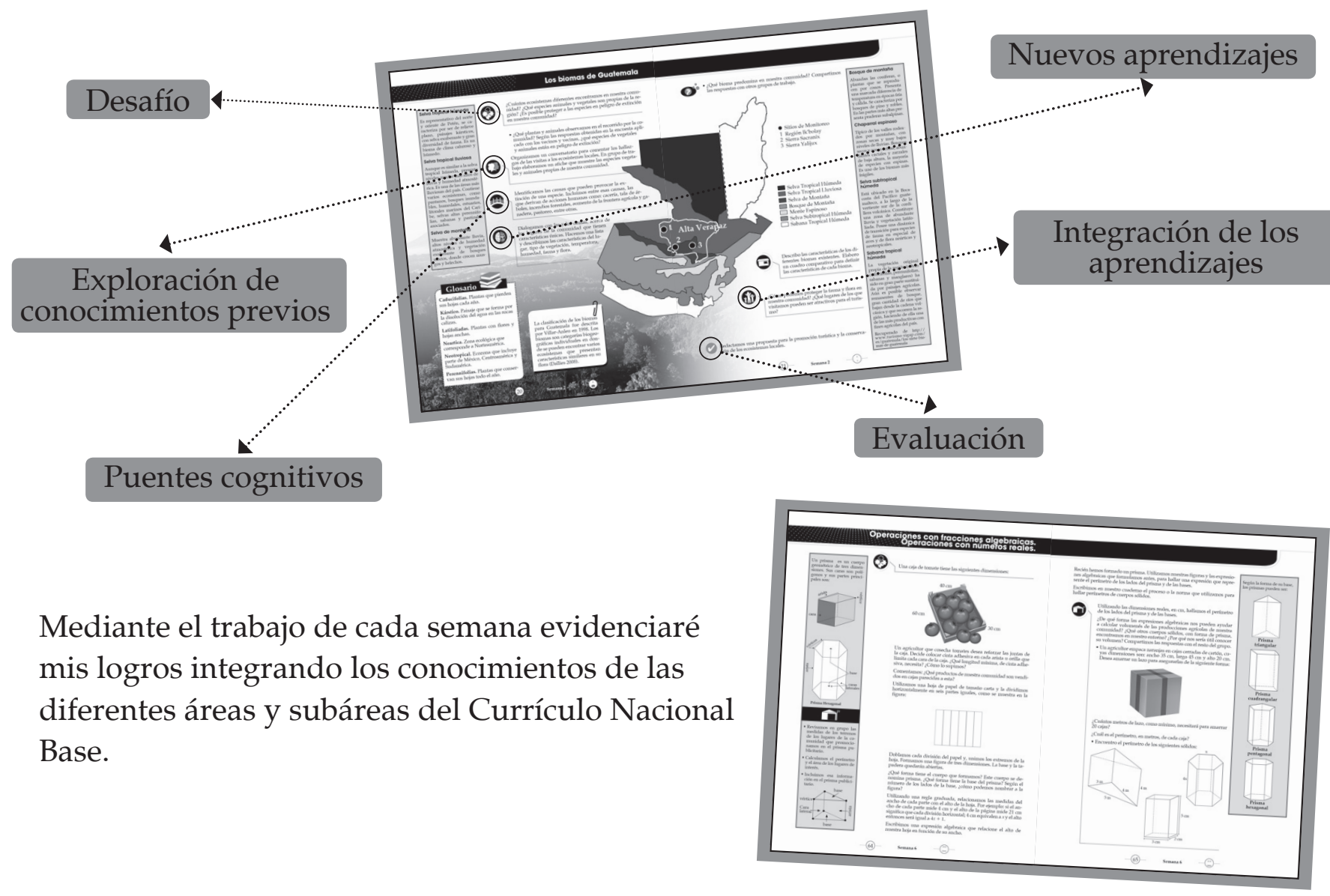


Aprenderé la importancia de cuidar la equidad de género, el respeto a las demás personas, así como a ejercer y defender los derechos humanos, incluidos los derechos de la Madre Tierra
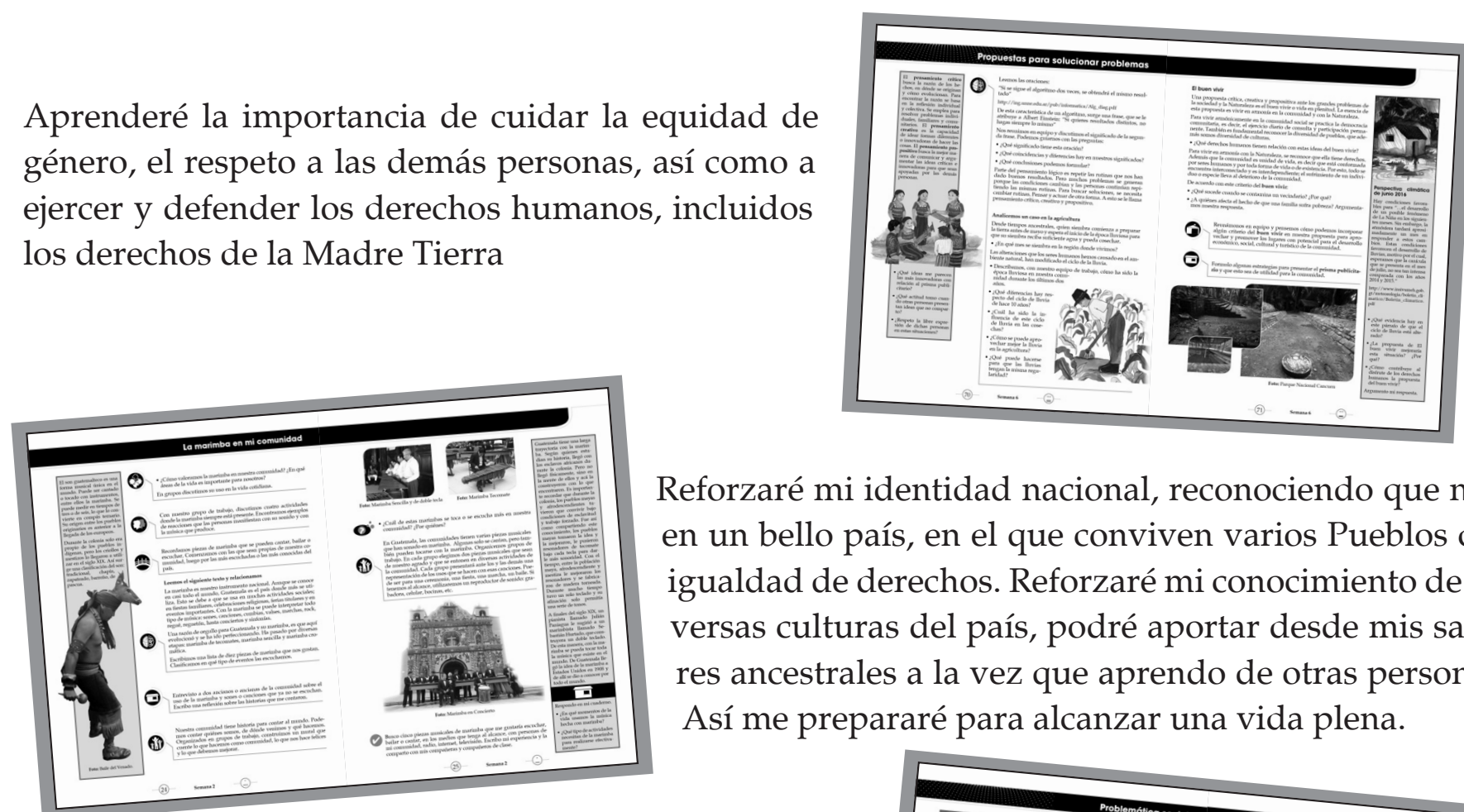

Reforzaré mi identidad nacional, reconociendo que nací en un bello país, en el que conviven varios Pueblos con igualdad de derechos. Reforzaré mi conocimiento de diversas culturas del país, podré aportar desde mis saberes ancestrales a la vez que aprendo de otras personas. Así me prepararé para alcanzar una vida plena.

Tendré la oportunidad de participar en espacios democráticos y ejercer mi ciudadanía de forma responsable, en respeto y aprecio por todas las culturas del país.

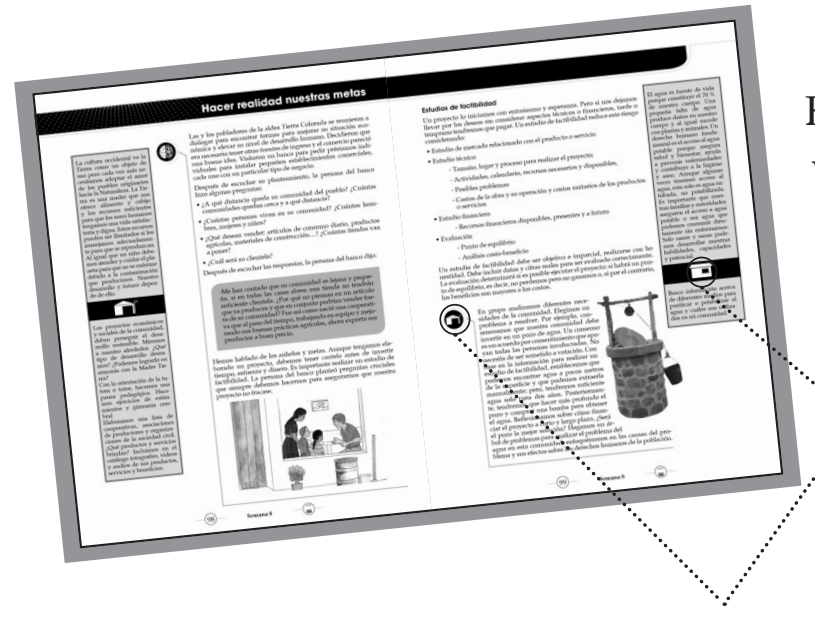

Al finalizar cada proyecto autoevaluaré el desarrollo de mis competencias.

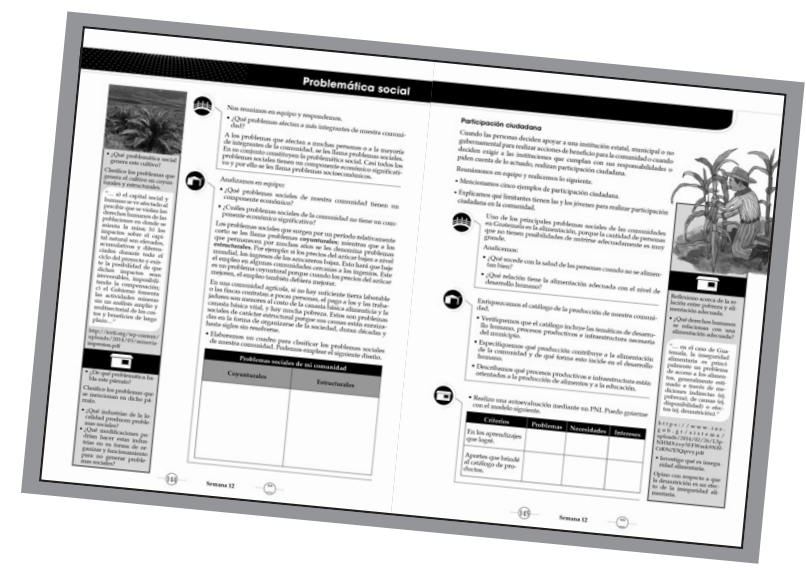

En cada una de las páginas, completaré actividades variadas e interesantes que están adecuadas a mi realidad personal, social, cultural y económica. Las podré realizar en el espacio de convergencia andragógica (ECA) o en casa.

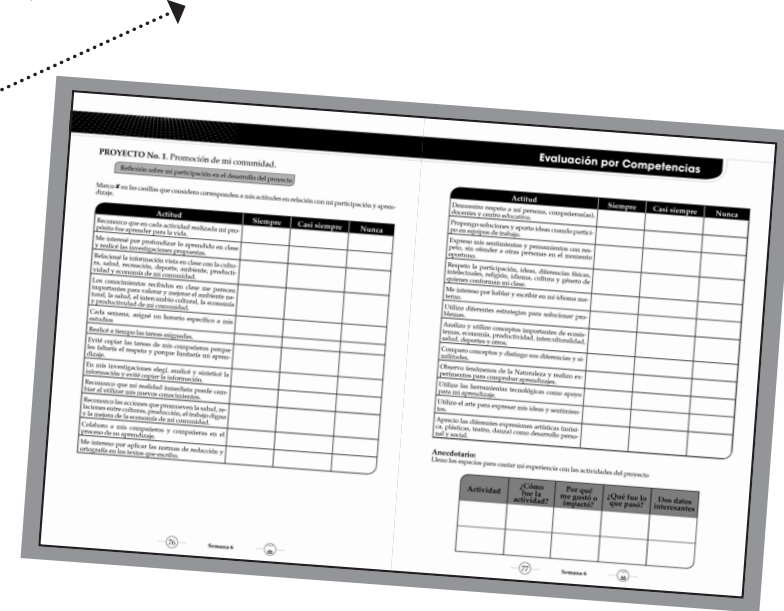




\section{ÍNDICE}

\section{Proyecto 1}

Promovemos nuestra comunidad

Semana 1 10

Semana 2 16

Semana 3 28

Semana 4 40

Semana 5 52

Semana 6 64

Evaluación Proyecto 1

Proyecto 2

Productos y servicios de nuestra comunidad

Semana 7

Semana 8

Semana 9

104

Semana 10

106

Semana 11

128

Semana 12

140

Evaluación Proyecto 2 


\section{Proyecto 3}

Uso sustentable de los recursos naturales

Semana 13

Semana 14

168

Semana 15

Semana 16

Semana 17 204

Semana 18 216

Semana 19 228

Semana 20 240

Evaluación Proyecto 3

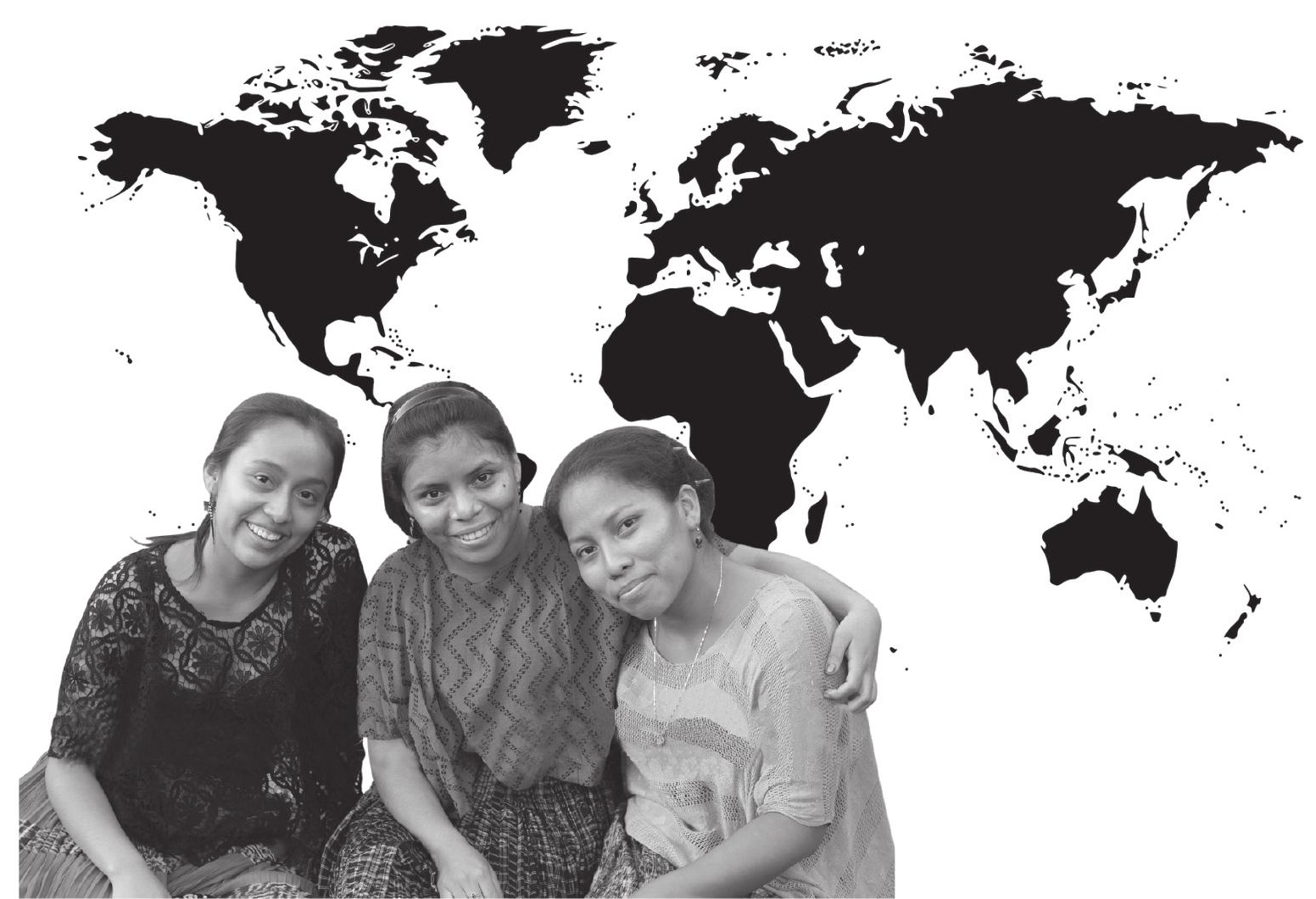




\section{Promovemos nuestra}

Es importante divulgar qué aportamos y producimos, y la belleza de algunos elementos naturales de la comunidad. Esto trae algunos beneficios como fortalecer nuestra identidad comunitaria y que la conozcan otras comunidades y pueblos, aumentar la venta de productos o que visiten más personas nuestra comunidad.

\section{¿Qué deseamos?}

Difundir la riqueza que tiene nuestra comunidad: nuestra economía, cultura, recursos naturales, personas destacadas (artistas, deportistas, sabias, ingeniosas, laboriosas, entre otras).

\section{¿Qué haremos?}

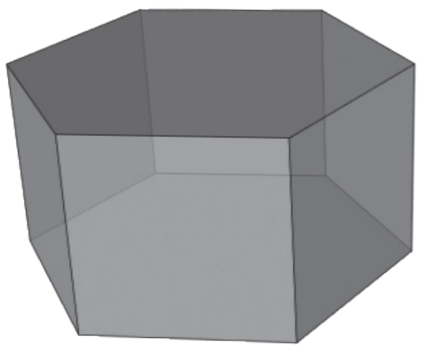

Trabajando en equipos elaboraremos un prisma publicitario para dar a conocer las riquezas de nuestra comunidad. Cada equipo escribirá en un lado del prisma un mensaje publicitario que promueve nuestra comunidad. Adicionalmente, si por lo menos una integrante del equipo tiene teléfono celular, escribiremos un mensaje que sintetice lo que comunicamos en el lado del prisma y se lo enviaremos a nuestros contactos.

\section{¿Con quiénes trabajaremos?}

En esta fase podemos seguir con el mismo grupo o cambiar de grupo. Una vez conformados los grupos se designará una persona como coordinadora y una relatora. La designación de responsabilidades en el grupo debe ser representativa y facilitar la participación de las mujeres.

\section{¿Cómo procedemos?}

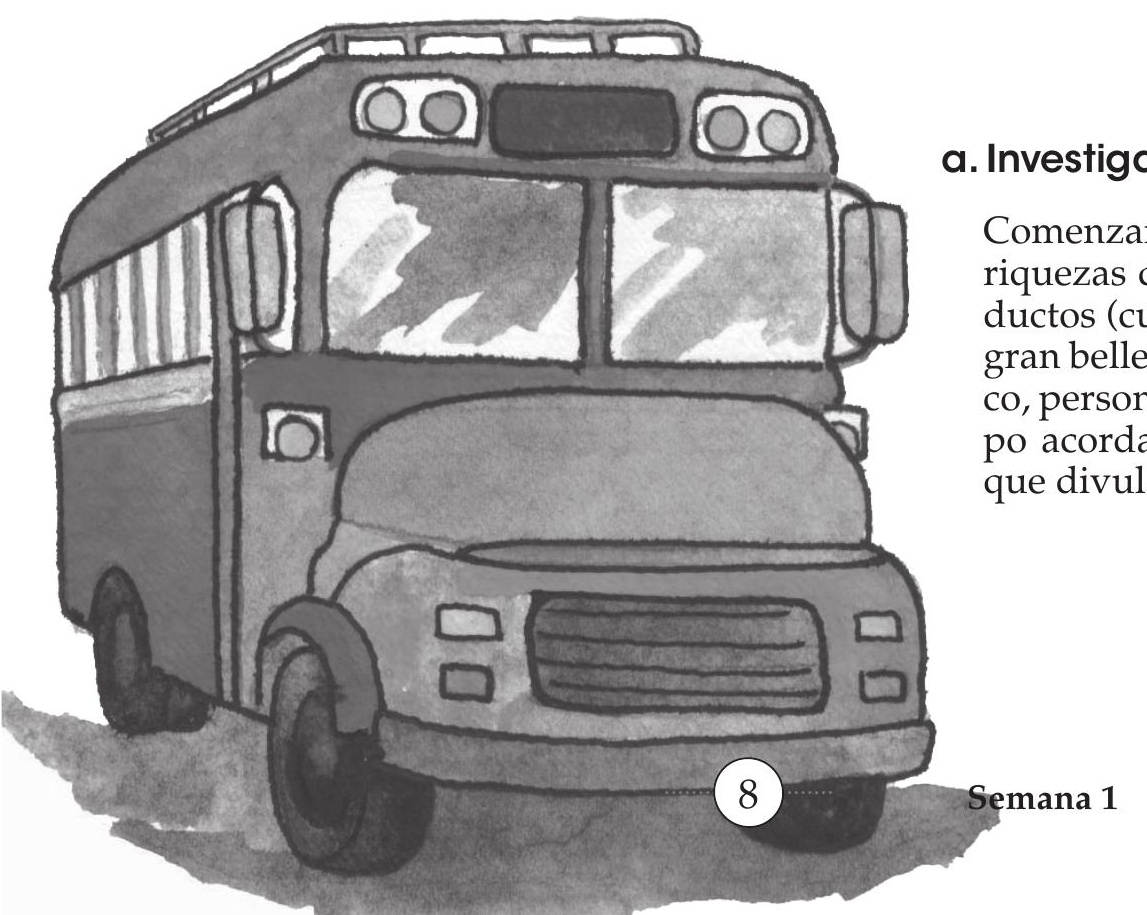




\section{comunidad}

\section{b. Organización}

Analizamos las características del elemento o producto de la comunidad el cual publicitaremos; luego elegimos las más relevantes.

Redactamos los mensajes y elegimos los elementos gráficos que emplearemos; pueden ser dibujos, fotografías, objetos livianos, entre otros.

\section{c. Producto}

- Después de consultar con su grupo, las personas coordinadoras se reunirán para acordar las características del prisma: tamaño, materiales, colores, etcétera.

- Colaboramos en construir el prisma y colocamos nuestro mensaje en el lado que nos corresponde.

\section{¿A quién presentaremos nuestro producto?}

Con nuestra tutora o tutor, debemos acordar a quiénes les presentaremos nuestro prisma. Puede ser a quienes estudian en el centro educativo y demás tutoras o tutores; en este caso colocamos el prisma en un área compartida por todas y todos; además, las personas relatoras pueden organizar una presentación ante quienes muestren interés en los mensajes del prisma. También, invitar a madres y padres de familia, autoridades y líderes de la comunidad. Otra opción es aprovechar un evento de la comunidad (celebración, encuentro deportivo, actividad religiosa, etc.) para mostrar el prisma a las y los integrantes de la comunidad.

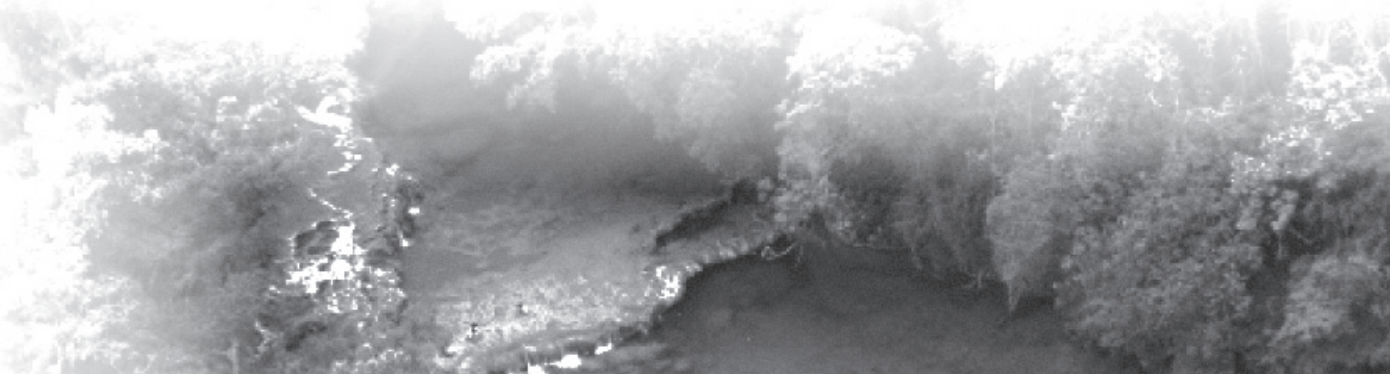

\section{¿Cómo distribuiremos el tiempo?}

\begin{tabular}{|c|c|c|c|c|c|c|}
\hline+2 & & & & & & \\
\hline ACTIVIDAD & $1^{\underline{a}}$ & $2^{\mathrm{a}}$ & $3^{\mathrm{a}}$ & $4^{\mathrm{a}}$ & $5^{\underline{a}}$ & $6^{\underline{a}}$ \\
\hline Planificación de la elaboración del prisma & $\checkmark$ & & & & & \\
\hline Análisis de los elementos y condiciones & & $\checkmark$ & & & & \\
\hline Diseño del prisma & & & $\checkmark$ & & & \\
\hline Construcción del prisma & & & & $\checkmark$ & & \\
\hline Presentación del trabajo & & & & & $\checkmark$ & \\
\hline Evaluación e implementación de mejoras & & & & & & $\checkmark$ \\
\hline
\end{tabular}




\section{El habla y el lenguaje}

Para que las personas, al hablar, puedan entenderse, es necesario que usen la misma lengua. Este es el conjunto de signos lingüísticos y reglas que se usan para combinarlos y formar mensajes. Los Acuerdos de Paz, reconocen el derecho de usar la lengua materna; así como la importancia de reconocer, valorar, proteger e impulsar los idiomas originarios.

La Constitución Política de la República de Guatemala reconoce la libertad e igualdad en el Artículo 4o. "En Guatemala todos los seres humanos son libres e iguales en dignidad y derechos. El hombre y la mujer, cualquiera que sea su estado civil, tienen iguales oportunidades y responsabilidades".

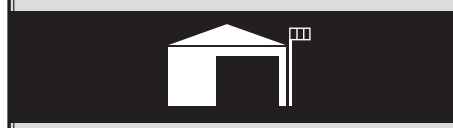

Elaboramos una lista de preguntas para entrevistar a personas de la comunidad.
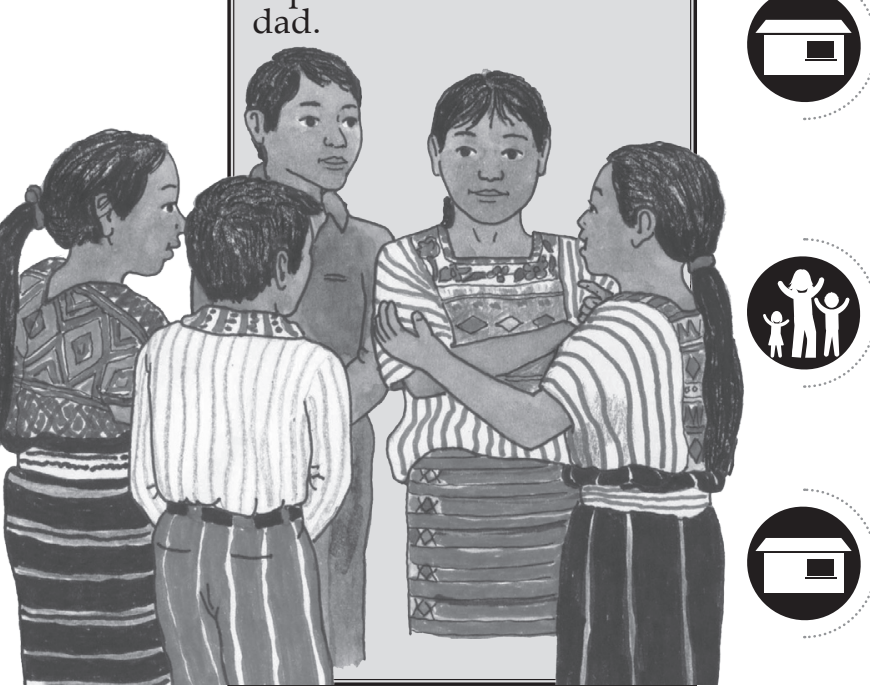

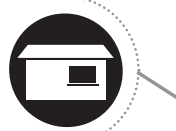

Averiguo cómo la comunicación entre las y los miembros de la familia ha cambiado con el tiempo. Entrevisto a varias personas de nuestra comunidad usando mi idioma materno. Con ayuda de fichas anoto las preguntas y respuestas.

Analicemos en grupo, ¿cómo se manifiesta la comunicación entre las familias? ¿Cómo se comunican las personas de diferentes generaciones, sexo o etnia? ¿Por qué es importante establecer una comunicación respetuosa durante el noviazgo?

Además del habla, ¿de qué otra manera nos comunicamos?

En grupo, averigüemos aparte del español, ¿cuántos idiomas propios del país se habla en Guatemala? Identifiquemos los idiomas que se hablan en la comunidad. ¿Qué retos de comunicación han surgido? ¿Cómo se han resuelto?

¿Cómo podemos aprovechar la diversidad de lenguas para mejorar esta comunicación? ¿Cómo nos ayuda hablar más idiomas?

Conversemos en grupo acerca de la importancia de la igualdad en la comunicación entre mujeres y hombres.

\section{Cómo nos comunicamos}

La comunicación entre las personas se da por medio de diferentes lenguajes: gestos, señales, música y escritura. El más usado es el de la palabra. Nos permite expresar con claridad lo que pensamos y sentimos.

Casi todos poseemos el lenguaje o la capacidad de comunicarnos oralmente, pero no hablamos la misma lengua. El habla es el uso cotidiano que le damos a esa lengua.

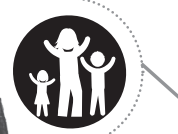

Pido a mi familia que me comparta tres refranes que se usan en mi comunidad. Los escribo en español y en inglés usando un diccionario.

Dialogamos acerca de las razones de los resultados de las entrevistas y cómo se fomenta la adecuada comunicación en nuestras familias y comunidad. 


\section{Conjuntos numéricos}

Comentemos. ¿Cuál es el total de población de nuestra comunidad? ¿Podemos tener un dato exacto o solo una estimación del número de habitantes?

El conjunto de los números reales se puede representar así:

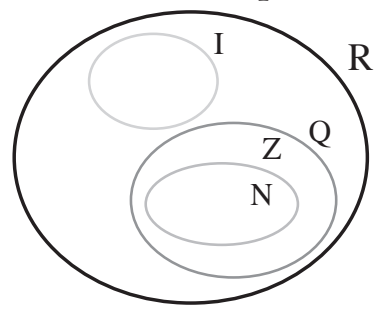

¿Qué significa cada letra? Anotamos un ejemplo de cada subconjunto.

El total de población de nuestra comunidad puede considerarse un conjunto universo. Identificamos grupos de población de la comunidad que comparten características propias dentro de ese universo.

Reflexiono y contesto. ¿El número de personas que habita una comunidad tiene relación con su desarrollo económico? Ubico en una línea del tiempo el estimado de la población en mi comunidad en el presente año y hace 5 y 10 años. ¿Qué cambios he observado en la comunidad durante este tiempo? ¿Tienen relación con el cambio en la cantidad de habitantes?

Los números reales son los números que se expresan en forma decimal finita y decimal infinita. Escribo las propiedades de cada operación de los números reales. Completo con un ejemplo para cada caso.

Investigo. ¿Qué es un monomio y qué es un polinomio? Escribo dos ejemplos de cada uno.

Comentemos. ¿Qué beneficios trae a mi comunidad conocer el conjunto de los números reales? ¿Qué cálculos matemáticos son útiles a los miembros de mi comunidad?
Los números enteros comprenden los números positivos, negativos y el cero. Los números enteros positivos también se conocen como números naturales.

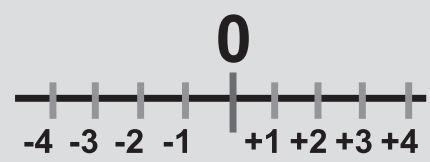

Escribo dos ejemplos de situaciones en las que he utilizado números positivos $\mathrm{y}$ negativos.

- Utilizo cuadrados de papel para operar con números enteros. Coloreo una de sus caras con color oscuro y la otra, la dejo sin colorear. Las partes oscuras representan -1 y las claras, 1 .

- ¿Qué pasa cuándo opero $-1+1$ ?

- ¿Podría decir que un cuadrado oscuro neutraliza a un cuadrado claro?

- Utilizo los cuadrados para efectuar sumas y restas con números enteros.

- Copio en mi cuaderno los cuadrados que utilicé y luego, con números, escribo las operaciones.

- Comentamos sobre el método que utilizamos.

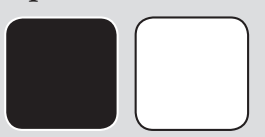

Supongamos que en el centro de nuestra región el número de habitantes por $\mathrm{m}^{2}$ es de 2.1 personas; en el norte, es de 2 personas; y en el sur, es de 3 personas.

a) Si la región central mide $150 \mathrm{~m}^{2}$ y la región sur mide $115 \mathrm{~m}^{2}$, ¿en qué región hay más habitantes?, ¿cuál es la diferencia de habitantes entre ambas regiones?

b) Para el área norte la expresión 2x indica la cantidad de habitantes por metro cuadrado. ¿Cuántos habitantes habrá en $980.5 \mathrm{~m}^{2}$ ? ¿Cuántos metros cuadrados ocuparán 1458 personas?

c) ¿Qué número entero utilizo para expresar un descenso de 188 habitantes en la población? ¿Y para expresar un aumento de 3500 ?

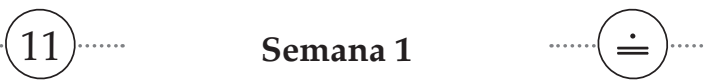




\section{Plantas y animales de la comunidad}

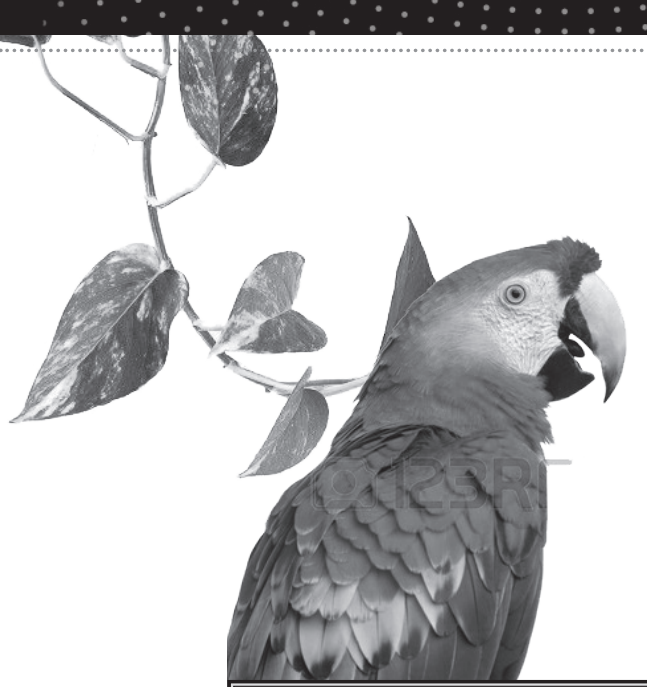

Para describir una situación o explicar un hecho natural se realiza una investigación y se elabora un documento que proporcione información de manera ordenada. Esa información se expone en un informe científico que incluye:

- El propósito de la investigación ¿Para qué?

- Los procedimientos utilizados para realizarla ¿Cómo?

- Las muestras observadas ¿Qué?

- Los instrumentos utilizados para colección de datos ¿Con qué?

- Los datos que se colectaron ¿Qué se encontró?

- El análisis de esos datos ¿Qué significa?

- Los hallazgos ¿Por qué?

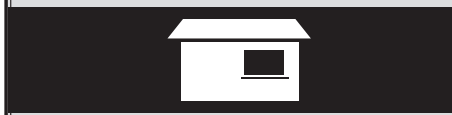

Elaboro una ficha por cada aspecto que incluye el informe.

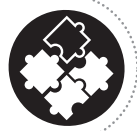

¿Qué plantas y animales son propios de nuestra comunidad? ¿Qué consecuencias puede tener la tala de árboles para la vida silvestre y humana?

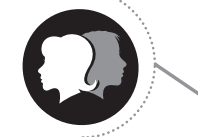

Con mi grupo de trabajo, describimos diferentes lugares de la comunidad en los que se observan formas de vida animal y vegetal. Explicamos cómo se alimentan, dónde duermen, qué actividades realizan durante el día.

Analizamos qué aspectos de las formas de vida existentes en la comunidad son los más importantes para investigar.

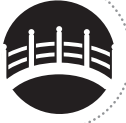

Con mi grupo de trabajo, redactamos una encuesta para recabar información relacionada con los seres vivos que habitan en la comunidad. Incluimos algunos ítems acerca de las especies locales en peligro de extinción.

Dialogamos acerca de cómo se observan las especies de vegetales y animales que comparten nuestra comunidad y de qué manera se pueden clasificar. Exponemos nuestras conclusiones ante otros grupos de trabajo y encontramos ideas coincidentes y complementarias.

Visitamos lugares de la comunidad para realizar observaciones directas; bosques, fuentes hídricas naturales, lugares de cultivo y otros que existan. Las fuentes hídricas son todas las corrientes de agua ya sea subterránea o sobre la superficie.

Utilizamos la encuesta y consultamos con vecinas y vecinos acerca de las especies vegetales y animales en peligro de extinción en nuestra comunidad.

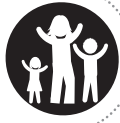

¿En nuestra comunidad hay alguna especie de vida silvestre que sea objeto de caza para venta, alimento o exportación? ¿Cuáles derechos se lesionan cuando un ecosistema se daña por acción humana?

Elaboramos una presentación de propuestas para conservación de la vida silvestre, usando afiches o diapositivas power point. 


\section{Transformación del paisaje natural por acciones humanas}
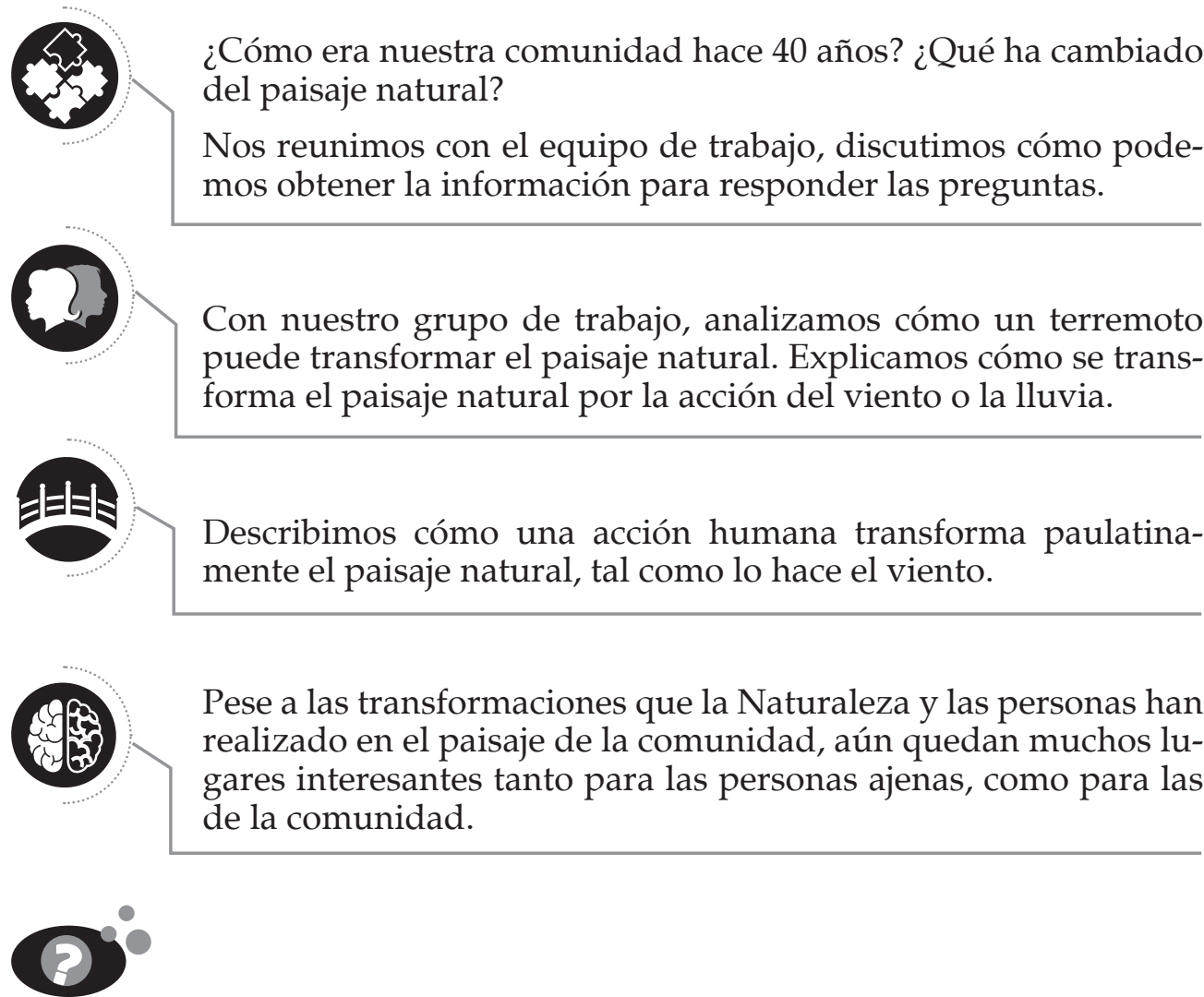

- ¿Cuáles son los sitios naturales más bellos en nuestra comunidad?

- ¿Qué construcciones antiguas o de valor cultural hay en nuestra comunidad?

- ¿En dónde se producen o venden productos que pueden ser de interés para el turismo o la comunidad?

Elaboremos una lista con los sitios naturales más atractivos, lugares de interés cultural y económico de nuestra comunidad.

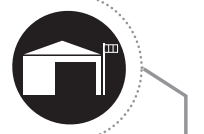

Distribuyámonos los sitios que nos parecen de mayor interés, visitémoslos y dibujémoslos. Si tenemos acceso a un teléfono celular con cámara, tomémosles fotografías o video.

Los seres humanos necesitan aprovechar los recursos naturales, pero sin dañar el ambiente natural. ¿Cómo logramos esto? ¿Qué ejemplos hay en nuestra comunidad?

\section{Desaparición del} pato Poc

El pato poc era una especie propia de Guatemala que habitaba el lago de Atitlán, pero tres cambios en su entorno provocaron su extinción: 1. Eliminación del tul a las orillas del lago le dejó sin el hábitat para su reproducción, 2. Introducción del pez de rapiña Micropterus Salmoides disminuyó su fuente de alimentación y 3 . El terremoto de 1976 redujo el nivel del agua en el lago, lo que hizo secar los tules.

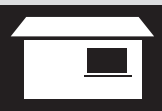

Con respecto a la desaparición del pato Poc, respondo en mi cuaderno:

- ¿Qué acciones humanas contribuyeron a su desaparición?

- ¿Qué fenómeno natural contribuyó?

- ¿Cuál es la utilidad de una entrevista?

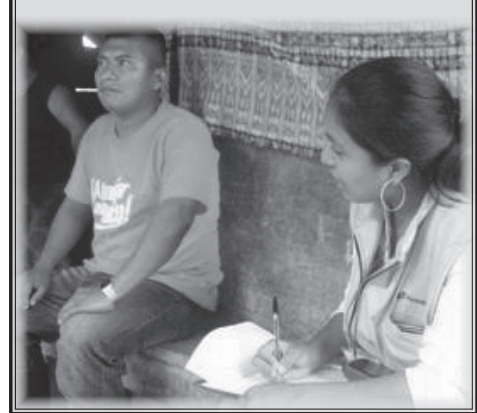

\section{Respondamos.}

- ¿Qué acciones humanas han dañado más el paisaje natural de nuestra comunidad?

Compartamos con la clase nuestros dibujos, fotografías o videos de los lugares de interés. 
El punto es la parte más elemental del arte plástico. Al unir una sucesión de puntos surge una línea. De la unión de líneas rectas, curvas y mixtas surgen las formas. Al combinar formas con colores se consiguen texturas que enriquecen el efecto visual.

Permiten la representación de objetos y formas diversas, hasta llegar a la composición. Esta convierte el arte plástico en un medio de expresión de ideas y sentimientos.

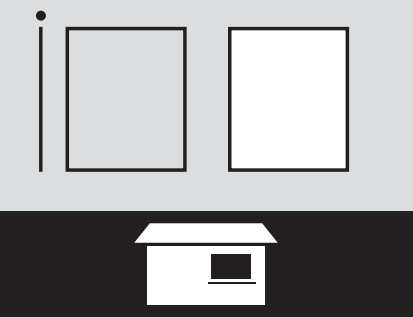

Anoto cinco temas que quiero contar con dibujos; puede ser lo que me hace sentir feliz o algo que me causa problema. Realizo uno y lo comparto en clase.

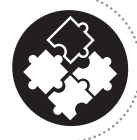

¿Cómo podemos usar líneas y colores para contar una historia? ¿Qué historia ¿Qué historia de la comunidad nos gustaría contar con líneas y colores?

En grupos, seleccionamos las historias que contaremos.

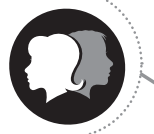

Con nuestro grupo de trabajo, analizamos tres maneras de contar historias con líneas y colores. Encontramos ejemplos de historietas con dibujos, graffitis o murales. Explicamos lo que cuentan las imágenes de un dibujo.

Vemos anuncios publicitarios que solo tienen dibujos y colores. Describimos las historias que cuentan esos anuncios.

\section{Leemos el siguiente texto y observamos}

Todos los objetos pueden ser dibujados con líneas y decorados con colores. Paisajes, figuras humanas, historietas gráficas, símbolos de computadoras y celulares se pueden dibujar, porque tienen líneas rectas, curvas y mixtas.

Anotamos diez objetos de nuestro entorno. Clasificamos cuáles usan líneas rectas, curvas y mixtas. Dibujamos, en una hoja de papel, tres objetos por cada tipo de línea.

Realizo una composición visual para contar una historia. Uso los tres tipos de líneas y colores a mi gusto.

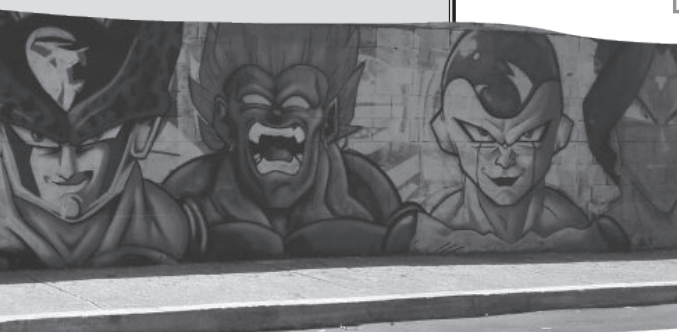

Nuestra comunidad tiene historia para contar al mundo. Podemos contar quiénes somos, de dónde venimos y qué hacemos. Organizados en grupos de trabajo y a lo largo del proyecto, incluimos en el prisma lo que hacemos como comunidad, lo que nos hace felices y lo que debemos mejorar. Elegimos

- ¿Cómo podemos usar este conocimiento para elaborar nuestro proyecto con un prisma publicitario? un sitio de la comunidad para exponerlo.

Hagamos una pausa pedagógica para reconocer artistas y deportistas destacados de nuestro país. Primero realicemos ejercicios de respiración y luego en dos equipos, corremos por turnos, para ver de cerca y reconocer a las personas que nos presenta el tutor.

- ¿En cuáles áreas de la vida usamos la expresión plástica con líneas y colores para expresarnos con arte?

- ¿Qué tipo de mensajes podemos expresar, usando las artes plásticas, con líneas y colores? 


\section{Desarollo sustentable}

Reflexionemos sobre el desarrollo de nuestra comunidad. ¿Se está desarrollando de manera sustentable? ¿Cuándo el desarrollo económico perjudica al medio ambiente? ¿De qué manera el medio ambiente influye positiva o negativamente en nuestra salud?

La transformación del paisaje tiene consecuencias en nuestro bienestar. Anoto en mi cuaderno un cambio positivo y uno negativo; sus orígenes, causas y consecuencias.

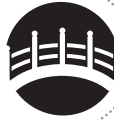

Describo cómo la comunidad reaccionó y solucionó una crisis de salud, desastre o falta de ingresos. ¿Qué ocasionó la crisis? ¿Se alcanzó un equilibrio? ¿Qué acciones faltan todavía?

Desarrollo humano es la capacidad de las personas de ser y hacer en condiciones de igualdad y oportunidad. Para el Estado es importante que las personas desarrollen estas condiciones. Conozcamos las políticas públicas municipales que promueven el desarrollo humano y verifiquemos su cumplimiento.

Converso con una persona técnica que llega a mi comunidad para conocer sobre algún proyecto comunitario que realice acciones en favor del desarrollo sustentable.

En clase completamos el siguiente organizador gráfico sobre el estado del desarrollo social, desarrollo económico y la protección del ambiente en la comunidad. Luego, reflexionamos. ¿Estamos en camino del desarrollo sustentable?

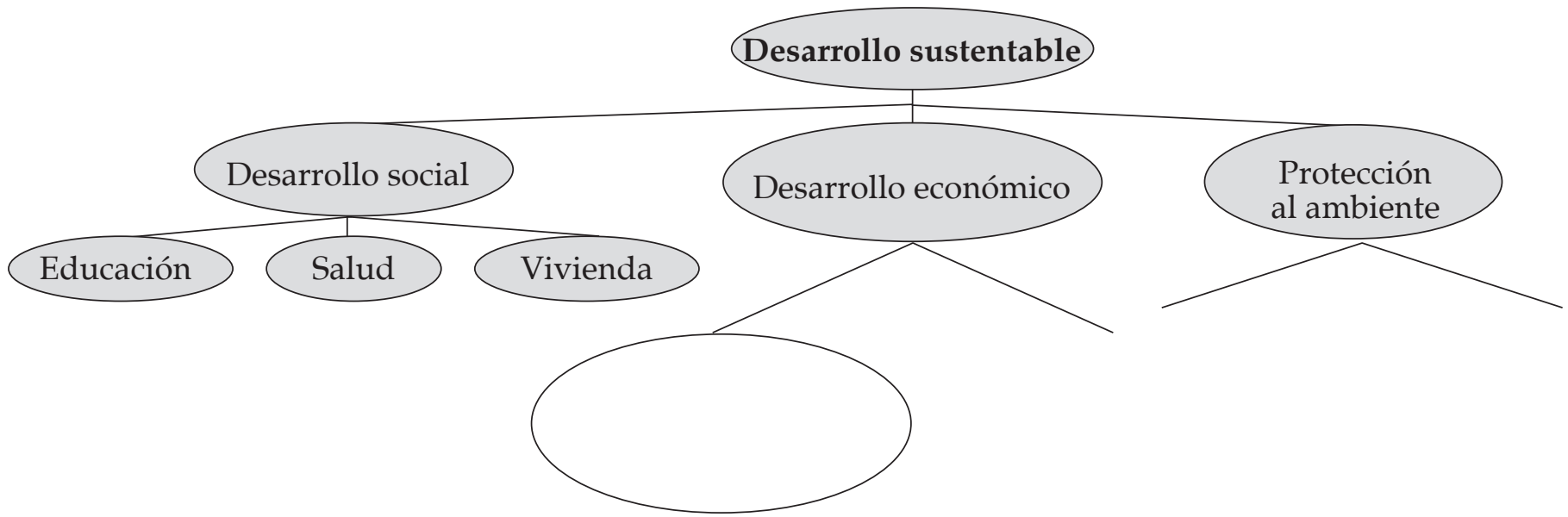

El equilibrio entre el desarrollo social, el desarrollo económico y la protección del medio ambiente es la única forma de alcanzar el desarrollo sustentable, el cual busca la satisfacción de nuestras necesidades sin comprometer la satisfacción de las necesidades de futuras generaciones (Informe "Nuestro Futuro Común", Comisión Mundial sobre el Medio Ambiente y el Desarrollo, 1987).

Recuperado de: http:// www.un.org/es/ga/president/65/issues/sustdev.sht$\mathrm{ml}$

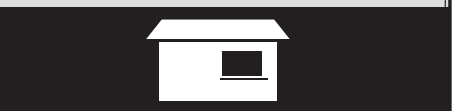

El desarrollo sustentable es como un banco de tres patas. ¿Lograríamos equilibrio con una pata corta? Por ejemplo:

- ¿Qué sucede si tenemos vivienda pero no, fuente de ingresos económicos?

- ¿Qué sucede si tenemos salud e ingresos económicos, pero nuestra comunidad es vulnerable ante f e nóm e n o s naturales?

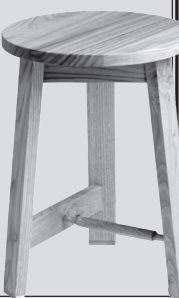




\section{Medios de comunicación masiva}

Su función es la de informar, recrear, educar en el lenguaje, crear opinión en sus receptores e intercambiar visiones diferentes del mundo. A la vez, mantienen al mundo al día de lo que pasa a nivel nacional e internacional. Son fundamentales en esta época porque nos proveen de información, noticias e imágenes del mundo en que vivimos. Los que más llegan al público son la prensa (periódicos y revistas), la radio, el cine, la televisión y la internet. Si reflexionamos sobre el desarrollo de nuestra comunidad, ¿tendríamos el mismo progreso si no contáramos con los medios de comunicación? ¿Cómo podríamos beneficiarnos más de estos medios para promover nuestro desarrollo?

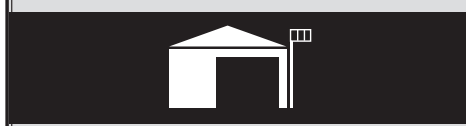

Elijamos un programa de radio comunitaria o un periódico local que nos enseñe algo para mejorar nuestras condiciones de vida y analicemos cómo nos ayuda a progresar.

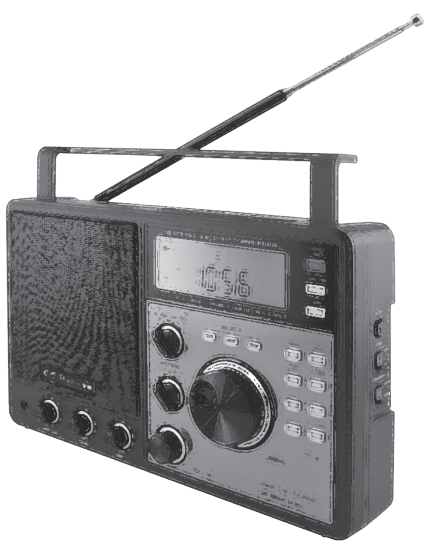

\section{La argumentación}

es un tipo de discurso que pretende defender una opinión y persuadir de ella a un receptor mediante pruebas y razonamientos. Para ello se vale principalmente de los siguientes recursos: la lógica (leyes del razonamiento humano), la dialéctica (se ejercita el diálogo para probar o refutar algo) y la retórica (uso de recursos verbales con el fin de persuadir por medio de la emoción). El razonamiento básico es una secuencia de proposiciones (oraciones) en la cual una de ellas, llamada conclusión, se obtiene de las dos restantes, llamadas premisas. El razonamiento también se conoce como silogismo.

Cuando los razonamientos son falsos se llaman falacias. Se pueden cometer por ignorancia o a voluntad, como una manera de convencer mediante la razón. Las más comunes son:

Contra la persona: descalifica la personalidad del interlocutor: No debemos escuchar lo que usted propone, todos sabemos que es extranjera.

Falacia de autoridad: se usa el prestigio de una persona conocida para respaldar el argumento: Esta crema da resultados, la usa Jennifer.

Falacia de consenso: apela a la opinión de las mayorías: Toda la comunidad opina que las niñas deben quedarse trabajando en casa en vez de ir a estudiar.

Falacia por misericordia: se usa cuando no se tiene razón y se apela a la bondad del interlocutor: Tome en cuenta, señor juez, al dictar su sentencia, que el reo es también padre de familia.
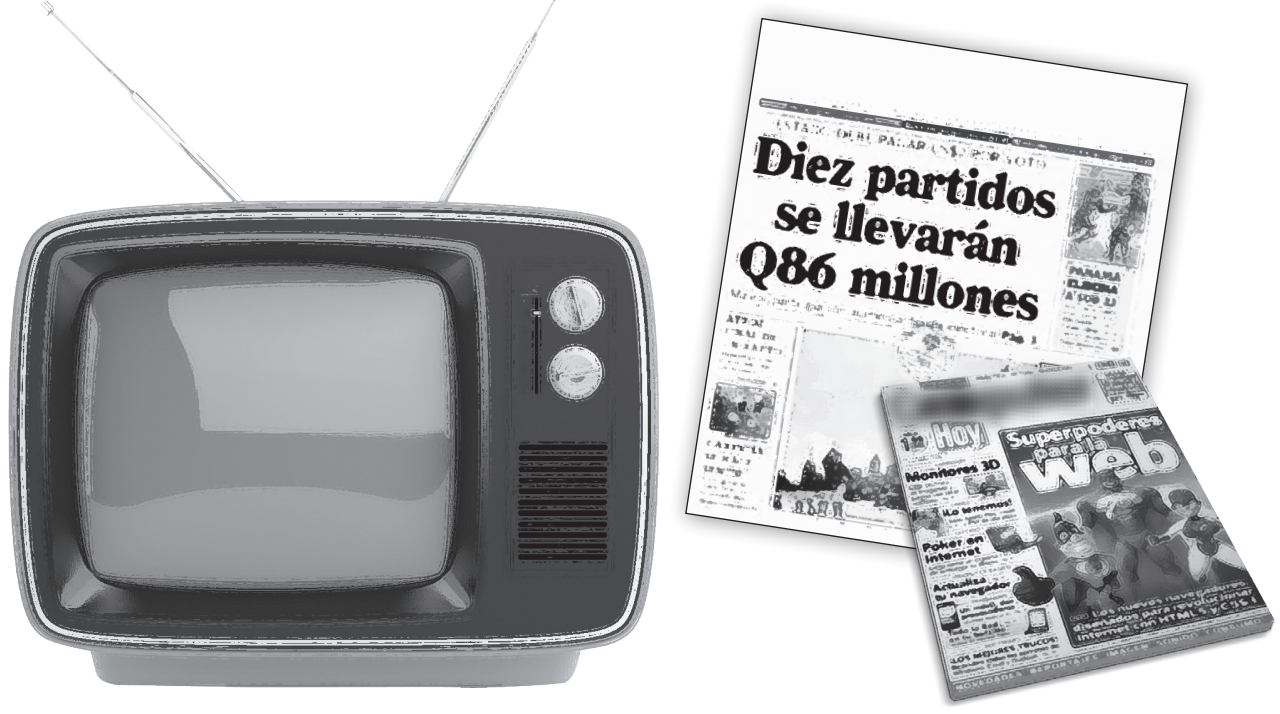

Revisemos los diferentes discursos que aparecen en la radio, en el periódico y en la publicidad. Analicémoslos desde el punto de vista de la argumentación: ¿encontramos razonamientos válidos? ¿Qué tipos de falacias podemos identificar? 


\section{Tipos de análisis gramatical}

Existen tres variantes básicas y dependen del punto de vista que se analicen los elementos de la oración:

Análisis morfológico: se centra en el estudio de la forma de cada palabra para determinar de qué clase es. Ejemplo: "Hermana" es una palabra que admite variación de género y número y pertenece a la clase de los sustantivos comunes.

Análisis sintáctico: estudia la función que desempeñan las palabras y los distintos grupos de palabras que componen la oración. Ejemplo: en la oración: "Mi hermana llegará pronto." El grupo de palabras "Mi hermana" desempeña la función de sujeto de la oración. Y el resto, "llegará pronto.", constituye el predicado.

Análisis sintagmático: consiste en determinar el papel que las palabras desempeñan dentro de cada sintagma: su núcleo y la función de las palabras que lo rodean (los determinantes, modificadores y complementos).

- Compartamos opinión con otras personas de nuestra comunidad respecto de lo siguiente: ¿Cuáles son nuestros derechos a la información pública? ¿Qué medios de comunicación lo favorecen en nuestra comunidad? ¿Qué costo puede tener este recurso?

- Analizo un periódico, una revista, un programa de radio y uno de televisión. ¿Cuáles son sus secciones, características, extensión e implicaciones? ¿Qué tipo de argumentación encontramos en cada uno? ¿Cómo presentan a las mujeres? ¿Qué les falta para reflejar nuestra realidad?

Desarrollamos en clase un cartel gráfico con los efectos y riesgos de los medios de comunicación. Puede ser similar al siguiente:

Efectos y riesgos - Medios de comunicación masiva

\begin{tabular}{|c|l|l|l|l|l|}
\hline Radio & Políticos & Sociales & Deportivos & Culturales & De salud \\
\hline Televisión & & & & & \\
\hline Periódicos & & & & & \\
\hline Cine & & & & & \\
\hline Internet & & & & & \\
\hline
\end{tabular}

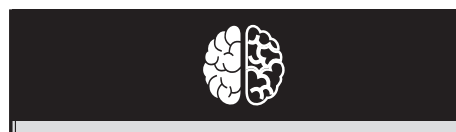

Partes de la Gramática

La gramática estudia la estructura y funcionamiento de cada lengua para poder formar palabras y combinarlas en oraciones. Sus partes fundamentales son:

La morfología: abarca el estudio interno de las palabras para delimitar, definir y clasificar sus unidades de género, tiempo, modo, número y establece los tipos de palabras: sustantivos, adjetivos, verbos, pronombres.

La sintaxis: estudia el orden, la coordinación y subordinación de las palabras y su relación en una oración, por ejemplo, la ubicación del sujeto y el predicado dentro de una oración.

La fonética: estudia las diferentes pronunciaciones de un mismo sonido en una letra, por ejemplo, los sonidos de la [b] si son suaves o fuertes.

La fonología: estudia los cambios de sonidos en las palabras y se interesa por saber si ese cambio de sonido provoca un diferente significado.

La semántica: estudia el significado de las palabras y las oraciones que se forman con ellas. 


\section{Operaciones básicas con polinomios Productos notables}

Los productos notables son multiplicaciones de expresiones algebraicas cuyo resultado podemos conocer a simple vista.

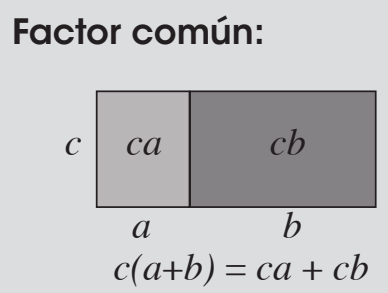

\section{Cuadrado de un} binomio:

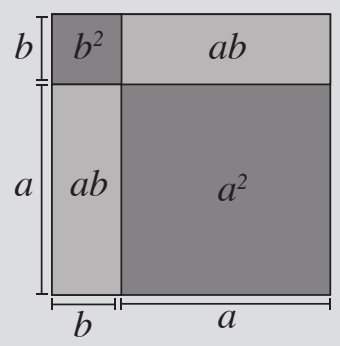

$$
\begin{aligned}
& (a+b)^{2} \\
& =a^{2}+b^{2}+a b+a b \\
& =a^{2}+2 a b+b^{2}
\end{aligned}
$$

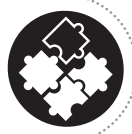

- ¿Qué lugares de mi comunidad tienen forma de cuadrilátero?

- ¿Hay alguna cancha deportiva dentro de mi comunidad? ¿Qué forma tiene?

- ¿Cómo podemos conocer el tamaño de esos lugares?

Utilicemos algún objeto que tengamos a la mano para medir el largo y ancho del salón. Podemos usar un cuaderno, regla, lápiz $\mathrm{u}$ otro objeto que tenga, al menos, un lado recto. Empleamos una regla graduada en centímetros para medir la parte final que no logremos medir con el objeto utilizado. Observamos la figura y a continuación, dibujamos un esquema parecido.

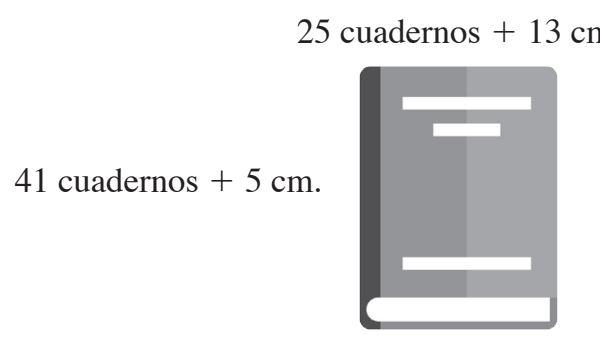

Utilizamos una letra para representar la medida desconocida del instrumento que usamos y escribimos dos expresiones algebraicas del espacio que medimos. En el ejemplo anterior, las expresiones pueden ser:

$$
\begin{gathered}
\text { Ancho: } x+13 \\
\text { Largo: } x+5
\end{gathered}
$$

Escribimos una expresión para el área de la superficie, medida en función del largo del objeto utilizado. Efectuamos el producto y comparamos respuestas.

Utilizamos los cuadrados que usamos en la semana anterior para construir más figuras. Esta vez: un cuadrado mayor, un cuadrado menor que representa una unidad y dos rectángulos del mismo tamaño. Un lado de las figuras debe ser oscuro y otro claro. La relación de tamaños se muestra en la imagen:

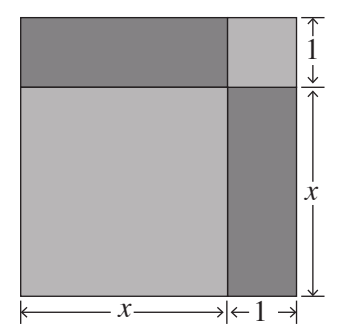

Podemos utilizar las siguientes medidas: $10 \mathrm{~cm}$ para la longitud de los lados del cuadrado, $10 \mathrm{~cm}$ para el largo del rectángulo y $2 \mathrm{~cm}$ para su ancho. El cuadrado menor deberá tener $2 \mathrm{~cm}$ de lado. Corto varios juegos de piezas para poder utilizarlas más de una vez.

- ¿Qué relación existe entre la longitud de los lados del cuadrado grande y el largo de los rectángulos?

- ¿Cómo puedo escribir una expresión para el área del cuadrado mayor? 
Las figuras que construimos tienen los siguientes valores:
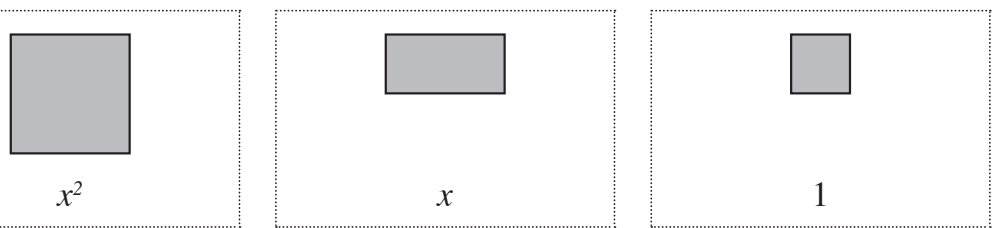

Si utilizamos las figuras por su lado oscuro el valor será el mismo, pero tendrán signo negativo.

Recordemos que una pieza clara neutraliza a una pieza oscura.

Para multiplicar expresiones algebraicas debemos colocar los factores en una matriz que forme un cuadrilátero. Luego debemos acomodar las piezas para completar la multiplicación.

$$
(x-2)(x-2)
$$

Coloco los factores utilizando mis piezas algebraicas.

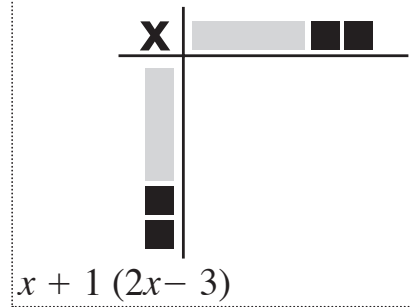

Acomodo las piezas que sean necesarias para completar el cuadrilátero. Este será mi producto.

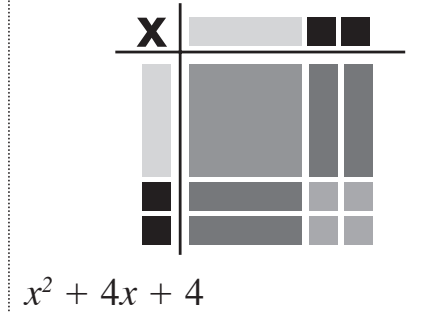

$x^{2}+4 x+4$

Si realizamos el procedimiento a la inversa, debemos acomodar los factores.

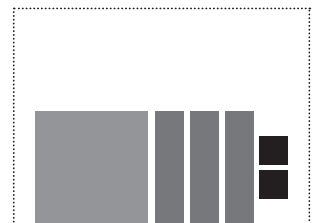
.

Empleo mis piezas algebraicas para efectuar los siguientes productos. Copio la distribución de las figuras en mi cuaderno y luego sustituir la palabra: utilizo por empleo lenguaje algebraico para expresar la operación.
a) $(x+3)(x+1)$
b) $(x-1)(x+2)$
c) $(x+3)^{2}$

Para resolver potencias de binomios podemos utilizar el triángulo de Pascal. En este triángulo están indicados los coeficientes que se deben incluir en la potencia desarrollada.

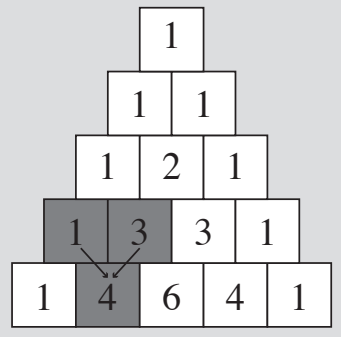

Los coeficientes de la fila siguiente corresponden a la suma de los dos términos superiores.

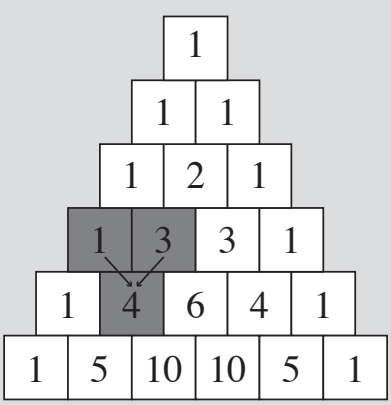

La factorización es el proceso inverso de los productos notables. Al factorizar debo busca dos o más factores que den como producto la expresión indicada. Las expresiones que no pueden factorizarse son conocidas como polinomios primos.

Escribimos una norma que explique el procedimiento que debemos efectuar para multiplicar dos binomios y escribimos una para factorizar un trinomio.

Comentamos: ¿qué relación existe entre ambas normas? Anotamos las ideas principales.

Utilizamos las piezas algebraicas para efectuar los siguientes productos y factorizaciones.
a) $(x+1)(x-2)=$
c) $(2 x+1)(x+1)=$
e) $x^{2}-6 x+8=$
b) $(x-3)(x-2)=$
d) $x^{2}+2 x+1=$ 


\section{Los biomas de Guatemala}

\section{Selva tropical húmeda}

Es representativo del norte y oriente de Petén, se caracteriza por ser de relieve plano, paisajes kársticos, con selva exuberante y gran diversidad de fauna. Es un bioma de clima caluroso y húmedo.

\section{Selva tropical lluviosa}

Aunque es similar a la selva niveles mucho más altos de lluvia y humedad atmosférica. Es una de las áreas más varios ecosistemas, como pantanos, bosques inundables, humedales, estuarios, litorales marinos del Caribe, selvas altas perennifolias, sabanas y pastizales asociados.

\section{Selva de montaña}

Muestra abundante lluvia, altos niveles de humedad atmosférica y vegetación exuberante de bosques mixtos, donde crecen musgos y helechos. tropical húmeda, presenta lluviosas del país. Contiene

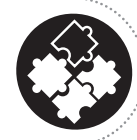

¿Cuántos ecosistemas diferentes encontramos en nuestra comunidad? ¿Qué especies animales y vegetales son propias de la región? ¿Es posible proteger a las especies en peligro de extinción en nuestra comunidad?

- ¿Qué plantas y animales observamos en el recorrido por la comunidad? Según las respuestas obtenidas en la encuesta aplicada con los vecinos y vecinas, ¿qué especies de vegetales y animales están en peligro de extinción?

Organizamos un conversatorio para comentar los hallazgos de las visitas a los ecosistemas locales. En grupo de trabajo elaboramos un afiche que muestre las especies vegetales y animales propias de nuestra comunidad.

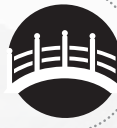

Identificamos las causas que pueden provocar la extinción de una especie. Incluimos entre esas causas, las que derivan de acciones humanas como: cacería, tala de árboles, incendios forestales, aumento de la frontera agrícola y ganadera, pastoreo, entre otras.

Dialogamos con las y los demás, acerca de los lugares de la comunidad que tienen características únicas. Hacemos una lista y describimos las características del lugar, tipo de vegetación, temperatura, humedad, fauna y flora.

\section{Glosario}

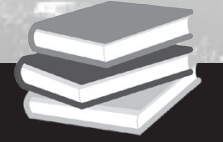

Caducifolias. Plantas que pierden sus hojas cada año.

Kárstico. Paisaje que se forma por la disolución del agua en las rocas calizas.

Latifoliadas. Plantas con flores y hojas anchas.

Neartica. Zona ecológica que corresponde a Norteamérica.

Neotropical. Ecozona que incluye parte de México, Centroamérica y Sudamérica.

Perennifolias. Plantas que conservan sus hojas todo el año. 
- ¿Qué bioma predomina en nuestra comunidad? Compartimos las respuestas con otros grupos de trabajo.

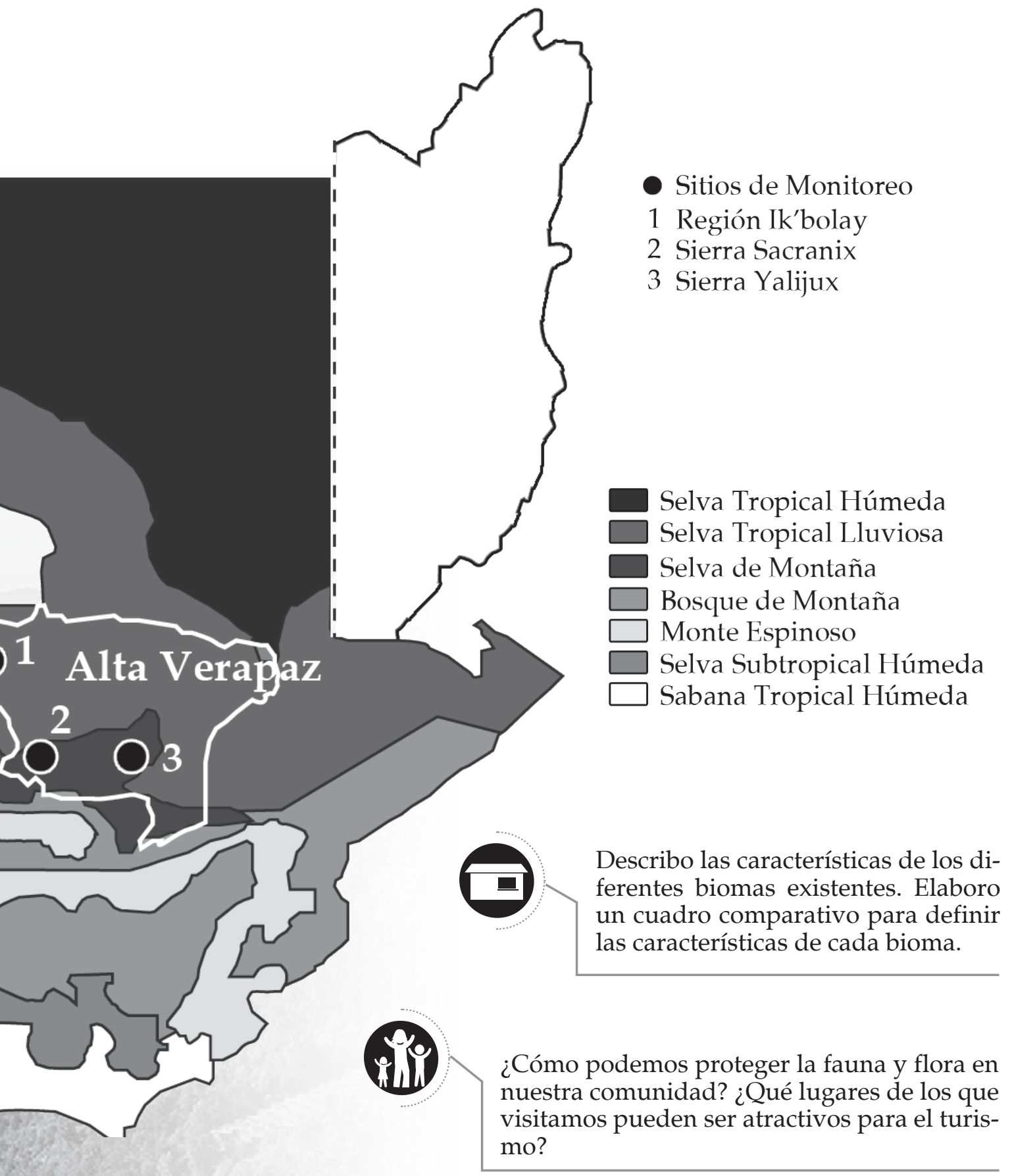

Redactamos una propuesta para la promoción turística y la conservación de los ecosistemas locales.

\section{Bosque de montaña}

Abundan las coníferas, o plantas que se reproducen por conos. Presenta una marcada diferencia de temperatura en épocas fría y cálida. Se caracteriza por bosques de pino y robles. En las partes más altas presenta praderas subalpinas.

\section{Chaparral espinoso}

Típico de los valles rodeados por montañas, con zonas secas y muy bajos niveles de lluvias. Bosques secos y zonas áridas, abundantes cactales y zarzales de baja altura, la mayoría de especies con espinas. Es uno de los biomas más frágiles.

\section{Selva subtropical húmeda}

Está ubicado en la Bocacosta del Pacífico guatemalteco, a lo largo de la vertiente sur de la cordillera volcánica. Constituye una zona de abundante lluvia y vegetación latifoliada. Posee una dinámica de transición para especies de fauna en especial de aves y de flora neárticas y neotropicales.

\section{Sabana tropical húmeda}

La vegetación original propia de la región (selvas caducifolias, perennifolias, sabanas y manglares) ha sido en gran parte sustituida por paisajes agrícolas. Aún es posible observar remanentes de bosque, gran cantidad de ríos que bajan desde la cadena volcánica y que recorren la región, haciendo de ella una de las más productivas con fines agrícolas del país.

Recuperado de http:// www.turismo-sigap.com/ es/guatemala/los-siete-biomas-de-guatemala 


\section{Diagnóstico de nuestra realidad social}

\section{La sabiduría ancestral y la justicia}

Para resolver un conflicto en una comunidad maya, primero se avisa a la autoridad ancestral, quien preguntará a las partes qué personas desean que participen en el juicio. Se cita a todas las mencionadas y cada una expone su punto de vista. Dialogan y se trata de llegar a un consenso para resolver el problema. Si no se resuelve, la autoridad ancestral fijará un tiempo para verificar la información. De nuevo, se convoca a dialogar a las partes y si no hay resolución, la autoridad llamará la atención a quienes hayan cometido faltas. Las instará a reflexionar y aconsejará.

Las personas reconocerán sus faltas, pedirán perdón y se comprometerán a reparar los daños. La autoridad toma la decisión final e insta a las personas afectadas a perdonar y olvidar.

http:/ / biblioteca.oj.gob.gt/digitales/41202.pdf

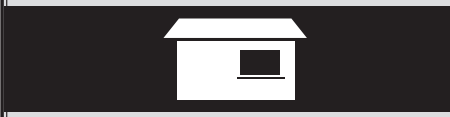

Pregunto a las personas de mayor edad cuál es su experiencia o conocimiento de esta forma de resolver los conflictos y su opinión sobre dicho procedimiento.

Respondo en mi cuaderno.

- ¿Qué cuidados le daría a este río para para evitar que se extingan las especies que en él habitan?
- ¿Cuáles son los aspectos positivos de nuestra comunidad?

- ¿Cuáles son algunos de sus problemas?

\section{Baloncesto de caja}

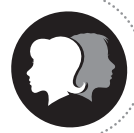

Nos organizamos en equipos. Procuramos que haya un grupo equitativo de mujeres y hombres. Sobre una mesa, pupitre o escritorio colocaremos una caja abierta y vacía. En un trozo de papel para reusar, cada quien anotaremos un aspecto positivo de la comunidad, por ejemplo: buenos líderes y lideresas, formas pacíficas de resolver problemas o cuidados del ambiente natural. En el reverso del papel, escribiremos un problema que afecte a nuestra comunidad, por ejemplo: pobreza, desempleo, escasez del agua potable, violencia, corrupción o delincuencia. Estrujaremos o haremos una pelota. A una distancia que establezca nuestra tutora o tutor, lanzaremos la pelota a la caja vacía. Cuando alguien enceste o introduzca la pelota de papel en la caja, aplaudiremos. Si falla, corearemos porras para animarle, por ejemplo: ¡Sí podemos! ¡Ánimo! ¡Te apoyamos!

Cuando todas y todos hayamos lanzado nuestra pelota de papel, cada quien tomará una, no importa quién la lanzó, ni si está en la caja o fuera de ella. Nos reuniremos con las y los integrantes del equipo, estiraremos las hojas des estrujaremos las pelotas y en orden leeremos cada aspecto positivo y cada problema anotado.

Elegimos los aspectos positivos con los que por mayoría estemos de acuerdo y los anotaremos en una lista. En forma similar, seleccionaremos los problemas que afectan a la mayoría. Dejaremos como problemas pendientes los que afectan a pocos. $\mathrm{Si}$ por ejemplo: alguien anotó que no hay caminos; pero este es un problema de derecho de paso de una sola familia, daremos preferencia al problema de escasez de agua potable; si este afectara a muchas familias.

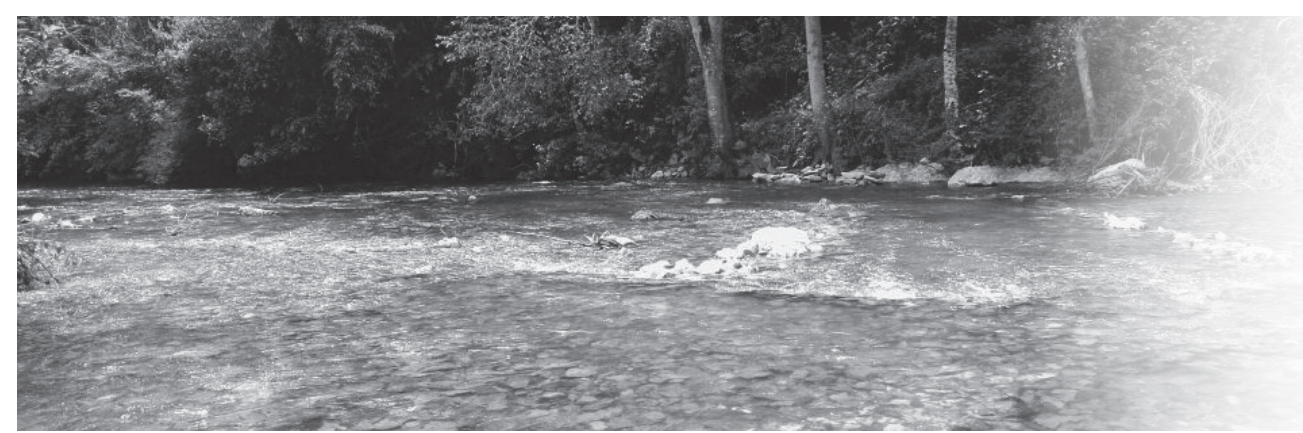

Foto: Río Mopán II - Petén 
Compartiremos las listas con los otros equipos. La información obtenida nos servirá para anotarla en nuestra moneda gigante.

Todas las comunidades tienen medios para divulgar noticias o información de mucho interés para sus habitantes. Observo la forma en que a mi hogar llega información de la comunidad, del país o del mundo. Algunos medios pueden ser:

\begin{tabular}{|c|c|c|c|c|}
\hline Radio comunitaria & Televisión Prensa \\
Correo electrónico Altoparlante & De casa en casa \\
& Asamblea comunitaria
\end{tabular}

Respondo en mi cuaderno.

- ¿Cuál de los medios de comunicación es el más utilizado en mi comunidad?

• ¿En cuál confío más?

• ¿Cuál es el que más me agrada?

- ¿Qué medios no se emplean en mi comunidad? ¿Por qué?

Para divulgar los aspectos positivos de la comunidad, ¿qué medio de comunicación es el más adecuado?
Internet se ha convertido en el medio de comunicación más utilizado en el mundo, seguido por la televisión. En Guatemala el medio de comunicación más utilizado es la radio, seguido también por la televisión y por la internet.

Respondo en mi cuaderno.

- ¿Qué puedo hacer para tener acceso a internet?

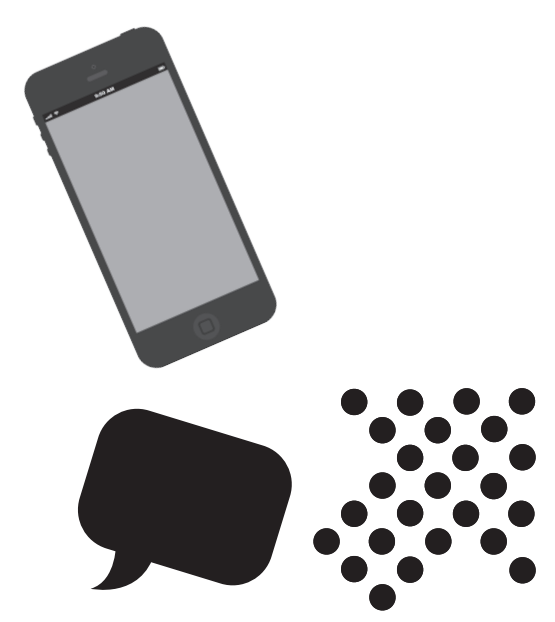

Documentamos por medio de fotografías, vídeos, grabaciones con el teléfono las actividades, expresiones culturales y otros elementos a incluir en el prisma.

Elegimos uno de los aspectos positivos de la comunidad. Con el equipo de trabajo, reservamos un espacio en el prisma publicitario para divulgarlo. Analizamos los problemas de la comunidad y analizamos posibles soluciones.

- ¿Qué aspectos positivos tienen estos medios de comunicación? ¿Cuáles son sus aspectos negativos? ¿Por qué?

- ¿Cuáles sirven mejor para promover nuestra comunidad?
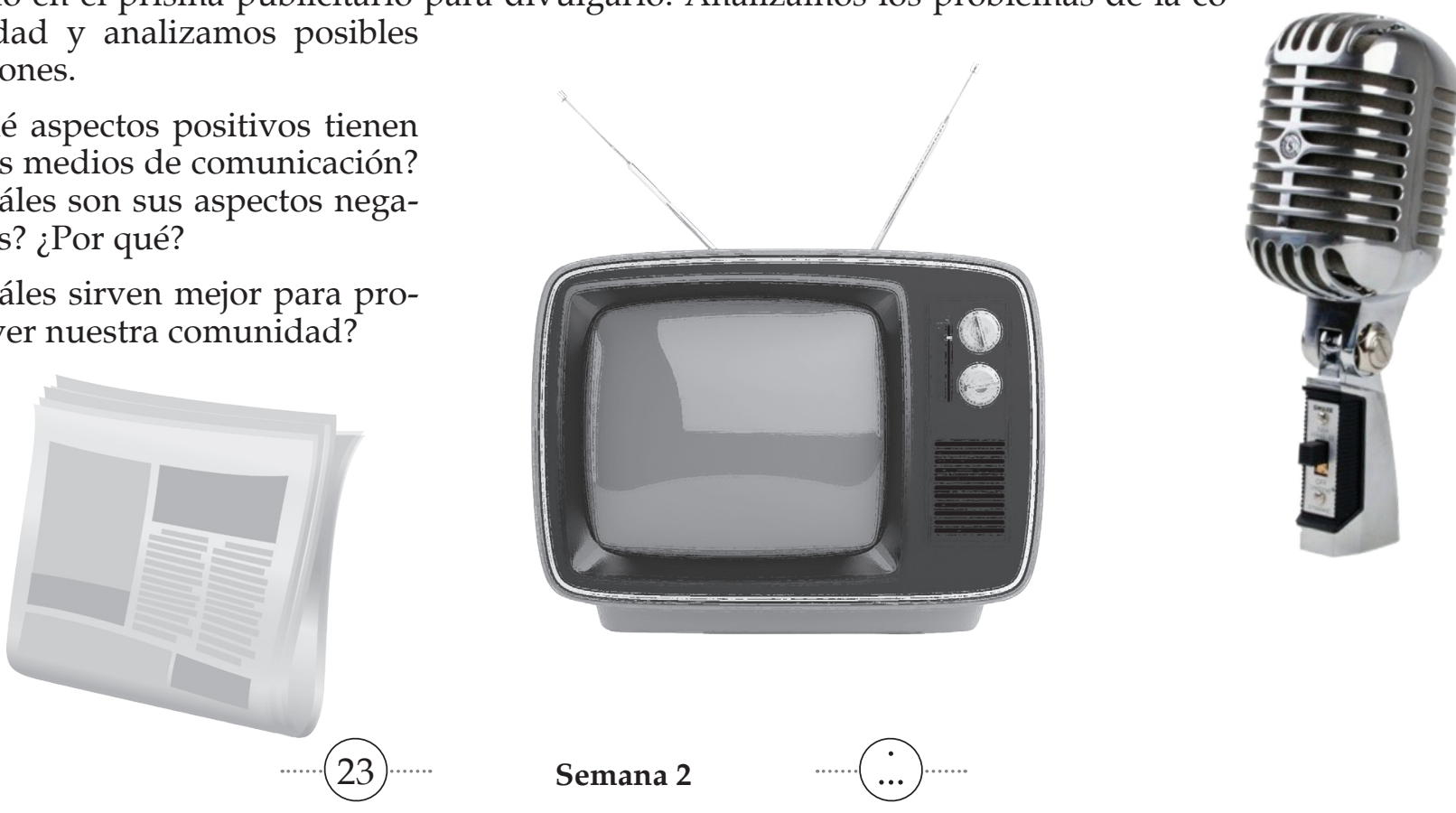
El son guatemalteco es una forma musical única en el mundo. Puede ser cantado o tocado con instrumentos, entre ellos la marimba. Se puede medir en tiempos de tres o de seis, lo que lo convierte en compás ternario. $\mathrm{Su}$ origen entre los pueblos originarios es anterior a la llegada de los europeos.

Durante la colonia solo era propio de los pueblos indígenas, pero los criollos y mestizos lo llegaron a utilizar en el siglo XIX. Así surge una clasificación del son: tradicional, chapín, zapateado, barreño, de pascua.

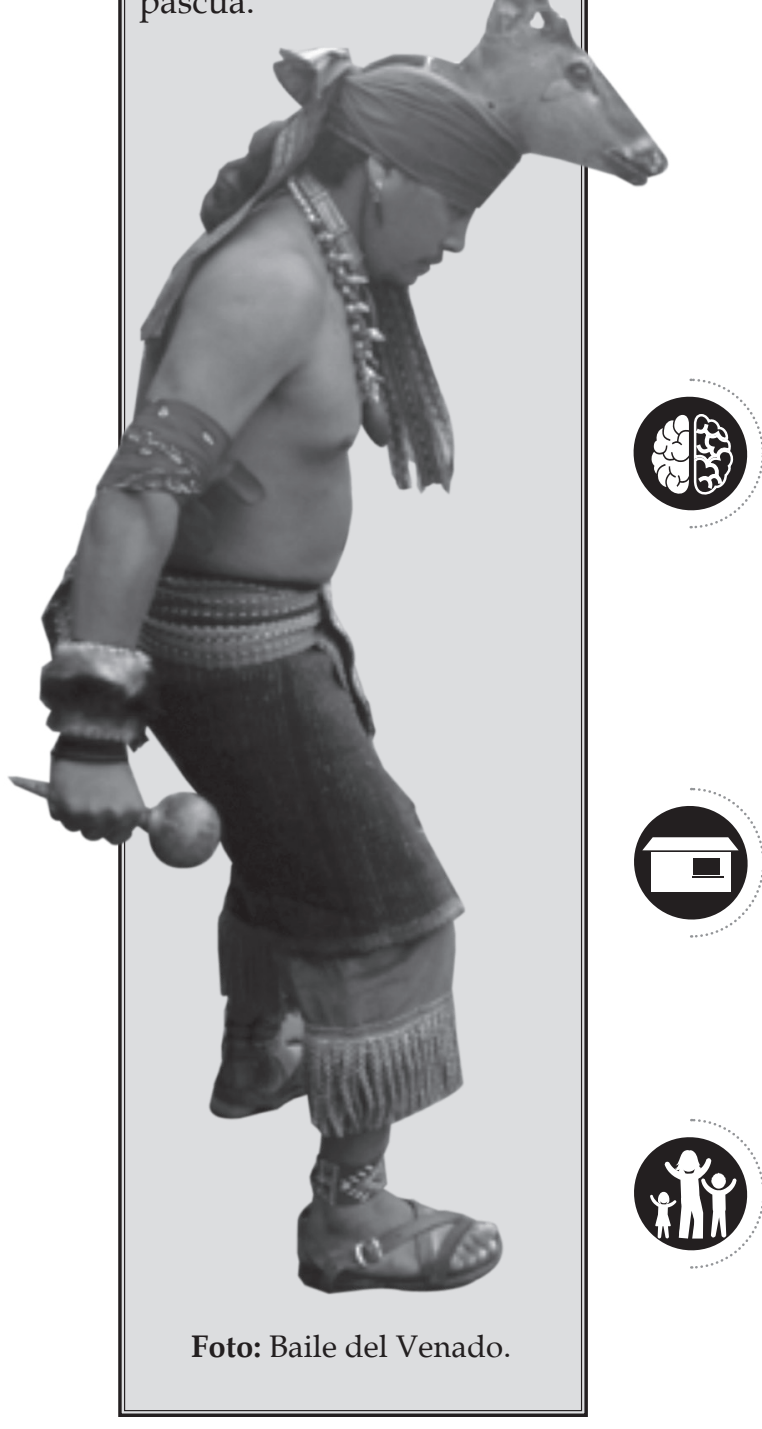

- ¿Cómo valoramos la marimba en nuestra comunidad? ¿En qué áreas de la vida es importante para nosotros?

En grupos discutimos su uso en la vida cotidiana.

Con nuestro grupo de trabajo, discutimos cuatro actividades donde la marimba siempre está presente. Encontramos ejemplos de reacciones que las personas manifiestan con su sonido y con la música que produce.

Recordamos piezas de marimba que se pueden cantar, bailar o escuchar. Comenzamos con las que sean propias de nuestra comunidad, luego por las más escuchadas o las más conocidas del país.

\section{Leemos el siguiente texto y relacionamos}

La marimba es nuestro instrumento nacional. Aunque se conoce en casi todo el mundo, Guatemala es el país donde más se utiliza. Esto se debe a que se usa en muchas actividades sociales; en fiestas familiares, celebraciones religiosas, ferias titulares y en eventos importantes. Con la marimba se puede interpretar todo tipo de música: sones, canciones, cumbias, valses, marchas, rock, regué, reguetón, hasta conciertos y sinfonías.

Una razón de orgullo para Guatemala y su marimba, es que aquí evolucionó y se ha ido perfeccionando. Ha pasado por diversas etapas: marimba de tecomates, marimba sencilla y marimba cromática.

Escribimos una lista de diez piezas de marimba que nos gustan. Clasificamos en qué tipo de eventos las escuchamos.

Entrevisto a dos ancianos o ancianas de la comunidad sobre el uso de la marimba y sones o canciones que ya no se escuchan. Escribo una reflexión sobre las historias que me contaron.

Nuestra comunidad tiene historia para contar al mundo. Podemos contar quiénes somos, de dónde venimos y qué hacemos. Organizados en grupos de trabajo, construimos un mural que cuente lo que hacemos como comunidad, lo que nos hace felices y lo que debemos mejorar. 


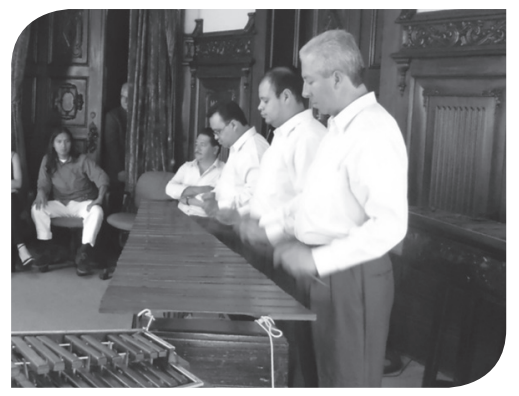

Foto: Marimba Sencilla y de doble tecla

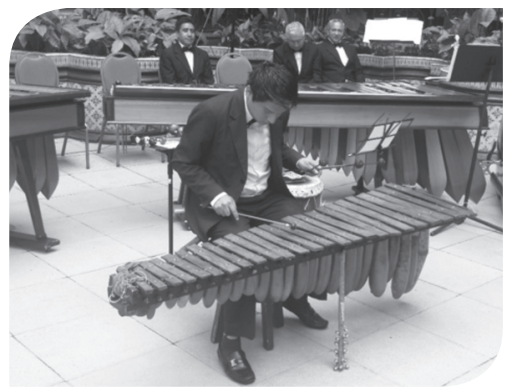

Foto: Marimba Tecomate

- ¿Cuál de estas marimbas se toca o se escucha más en nuestra comunidad? ¿Por quiénes?

En Guatemala, las comunidades tienen varias piezas musicales que han sonado en marimba. Algunas solo se cantan, pero también pueden tocarse con la marimba. Organicemos grupos de trabajo. En cada grupo elegimos dos piezas musicales que sean de nuestro agrado y que se entonen en diversas actividades de la comunidad. Cada grupo presentará ante los y las demás una representación de los usos que se hacen con esas canciones. Puede ser para una ceremonia, una fiesta, una marcha, un baile. Si tenemos al alcance, utilizaremos un reproductor de sonido: grabadora, celular, bocinas, etc.

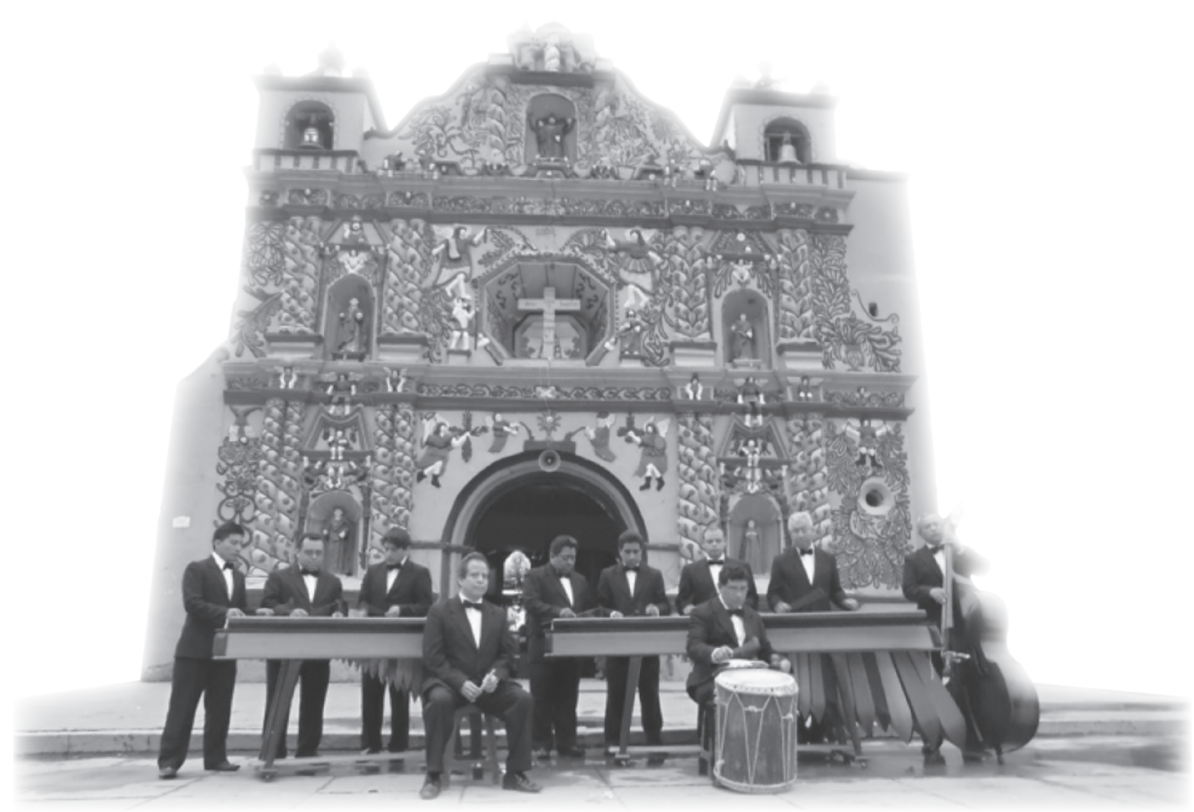

Foto: Marimba en Concierto

Busco cinco piezas musicales de marimba que me gustaría escuchar, bailar o cantar, en los medios que tenga al alcance, con personas de mi comunidad, radio, internet, televisión. Escribo mi experiencia y la comparto con mis compañeras y compañeros de clase.

Guatemala tiene una larga trayectoria con la marimba. Según quienes estudian su historia, llegó con los esclavos africanos durante la colonia. Pero no llegó físicamente, sino en la mente de ellos y acá la construyeron con lo que encontraron. Es importante recordar que durante la colonia, los pueblos mayas $y$ afrodescendientes tuvieron que convivir bajo condiciones de esclavitud y trabajo forzado. Fue así como compartiendo este conocimiento, los pueblos mayas tomaron la idea $y$ la mejoraron, le pusieron resonadores de tecomate bajo cada tecla para darle más sonoridad. Con el tiempo, entre la población maya, afrodescendiente y mestiza le mejoraron los resonadores y se fabricaron de madera torneada. Durante mucho tiempo tuvo un solo teclado y su afinación solo permitía una serie de tonos.

A finales del siglo XIX, un pianista llamado Julián Paniagua le sugirió a un marimbista llamado Sebastián Hurtado, que construyera un doble teclado. De esta manera, con la marimba se pueda tocar toda la música que existe en el mundo. De Guatemala llegó la idea de la marimba a Estados Unidos en 1908 y de allí se dio a conocer por todo el mundo.

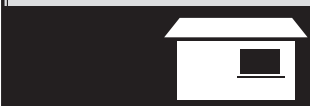

Respondo en mi cuaderno.

- ¿En qué momentos de la vida usamos la música hecha con marimba?

- ¿Qué tipo de actividades necesitan de la marimba para realizarse efectivamente?

(25) Semana 2




\section{Personas emprendedoras y con liderazgo}

Una comunidad es un conjunto de personas que comparten historia, vivencias, sueños y esperanzas. El tipo de relación entre las personas es importante para el bienestar y desarrollo común. La comunidad necesita de líderes y lideresas que sientan y proyecten el espíritu del grupo, como también, que ordenen y guíen los esfuerzos de todas y todos para alcanzar un logro común.

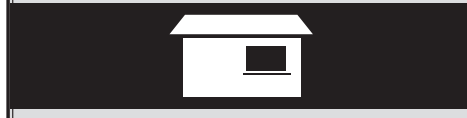

En mi comunidad existen varios líderes y lideresas. Son fáciles de identificar pues son personas reconocidas y a quienes se busca por su sabiduría, consejos, ayuda, conocimientos y para tomar decisiones en diferentes campos: salud, espiritualidad, negocios, conflictos y otros. Escribo una lista de los líderes y lideresas de mi comunidad $y$ pregunto a varias personas cómo ayudan a la comunidad.

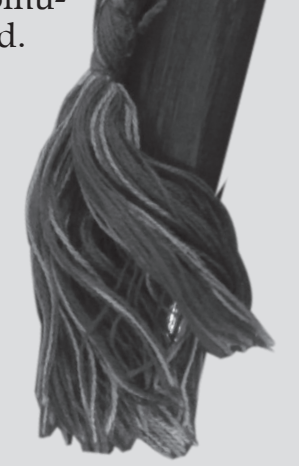

Foto: Vara edilicia.

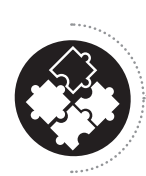

¿Cuál es el papel de los líderes y lideresas en la familia, la escuela, el trabajo, la comunidad, nuestro país? ¿Puede existir un grupo sin liderazgo? ¿Son positivos todos los líderes y lideresas? ¿Qué características comparten las lideresas y líderes positivos? Pensemos también en líderes y lideresas en el campo agrícola, artesanal, comercial, negocios, cooperativas, sindicatos u otros.

Recordemos una experiencia exitosa comercial o de organización de nuestra comunidad o una comunidad vecina. ¿De quién fue la idea? ¿Quién tomó el liderazgo? ¿Cómo convenció a las demás personas de que su idea era buena? ¿Quiénes se motivaron a unirse primero? ¿Cómo fue el proceso hasta que la idea resultó exitosa? ¿Qué dificultades encontraron? ¿Cómo las superaron?

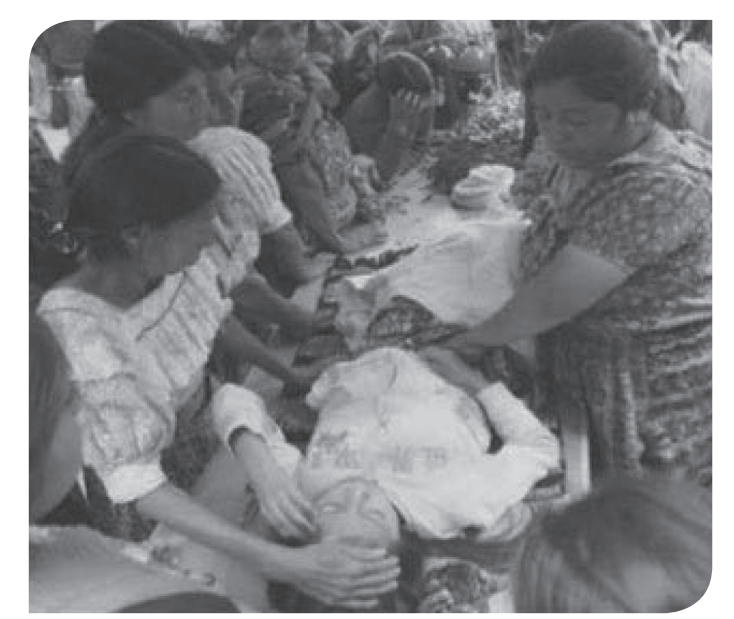

Foto: Comadronas atendiendo a una embarazada.

Presentemos nuestros aprendizajes a la comunidad. Escribamos en una hoja de papel el proceso de organización que usamos para elaborar nuestros proyectos: cuántos grupos, quiénes integran esos grupos, cómo organizamos los grupos, cómo tomamos decisiones, qué factores tomamos en cuenta para realizar nuestro proyecto. ¿Alguien toma el liderazgo? ¿El grupo se conforma rápidamente o se negocia? ¿Se incluye a todas y todos los integrantes del grupo? ¿Tienen posiciones de liderazgo las mujeres? ¿Se incluye a personas con capacidades o circunstancias familiares diferentes a la de la mayoría del grupo?

La palabra liderazgo proviene del anglo-sajón laed, camino y laeden, viajar. Liderazgo es viajar por el camino construido para el bien común. Para lograr el futuro trazado, quien ejerce el liderazgo, debe antes imaginarlo, compartirlo y motivar a las y los otros para alcanzar la meta. Para ello las acciones individuales deben estar en armonía con los objetivos del grupo.

"Visión sin acción es un ensueño, pero acción sin visión es una pesadilla." (Mark Twain) 
Conversemos en familia. ¿Cuáles son nuestros propósitos individuales? ¿Cuáles son nuestros anhelos como familia? ¿Qué estamos haciendo para lograr nuestras metas individuales y familiares?
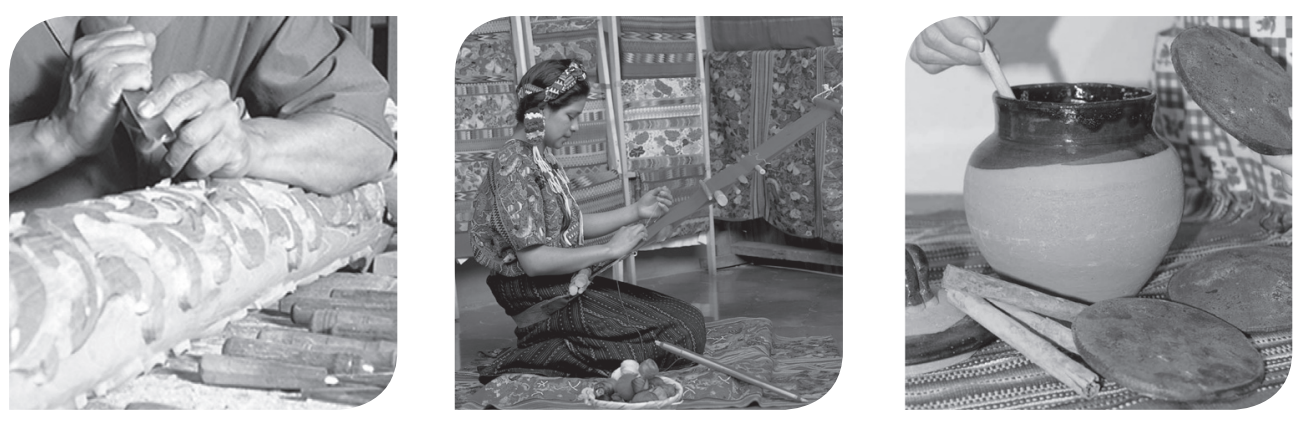

En nuestra comunidad hay lideresas y líderes sociales y empresariales. Cada tipo de liderazgo se manifiesta de manera diferente. Converso con una lideresa o líder de la comunidad y le pido me cuente su historia de vida. En clase utilizamos una tabla comparativa. Anotamos los distintos procesos que han vivido las personas con las que conversamos.

\begin{tabular}{|l|l|l|}
\hline Nombre & $\begin{array}{c}\text { Características } \\
\text { personales }\end{array}$ & $\begin{array}{c}\text { Tipo de } \\
\text { liderazgo }\end{array}$ \\
\hline & & \\
\hline & & \\
\hline
\end{tabular}

\begin{tabular}{|l|c|c|c|}
\hline $\begin{array}{c}\text { Cómo } \\
\text { inició }\end{array}$ & $\begin{array}{c}\text { Cómo se } \\
\text { guió }\end{array}$ & $\begin{array}{c}\text { Retos o } \\
\text { dificultades }\end{array}$ & Satisfacciones \\
\hline & & & \\
\hline & & & \\
& & & \\
\hline
\end{tabular}

¿Tenemos cualidades de líder o lideresa? Analizamos las características de los líderes y lideresas de la comunidad en la tabla que elaboramos y nos examinamos a nosotras y nosotros mismos. Dialoguemos en nuestro idioma materno. No hay buen líder sin un buen equipo, ¿somos parte de un equipo?, ¿qué posición ocupamos? Recordemos que el liderazgo se aplica en diferentes ámbitos de la vida y no necesariamente en varios y todos al mismo tiempo.
Las personas emprendedoras tienen ideas nuevas, no tienen miedo a los retos y se arriesgan para alcanzar sus metas, por ejemplo: la idea para fabricar un producto diferente o la de realizar o vender algo tradicional, de manera diferente. Algunos emprendimientos son comerciales, con el fin exclusivo de obtener ganancias. Hay emprendimientos sociales para generar beneficios sociales o ambientales.

Don Mariano vive en Huehuetenango. Produce habas para vender en las vísperas del $1^{2}$ de noviembre, como ingrediente para el fiambre. Planifica su cosecha para esa época y así comercializar su producto cuando hay mucha demanda. Vende todo su producto y así gana más dinero, porque resuelve a tiempo, una necesidad de quienes le compran.

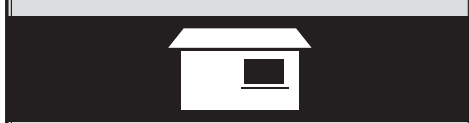

Escribo en mi cuaderno una idea para generar ingresos, una para solucionar un problema y una para responder a la demanda de un producto o servicio.

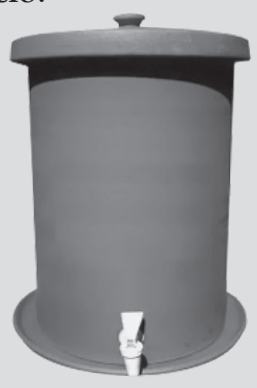

Hay empresas sociales que con sus ganancias, regalan parte de sus productos a poblaciones necesitadas. 


\section{Factorización de trinomios}

Un trinomio es un polinomio que consta de 3 términos. Los trinomios que representan áreas o superficies pueden ser factorizables. Observamos los siguientes trinomios:

- $x^{2}+6 x+9$

- $x^{2}+14 x+49$

- $6 x^{2}+5 x-4$

Discutimos las características que observamos.
Ana y Miguel caminaron a lo largo y a lo ancho de dos terrenos con forma de cuadriláteros. Ana caminó una distancia desconocida " $x$ " pasos y 6 pasos más en cada uno de sus lados. Miguel, en cambio, caminó la misma distancia " $x$ " pasos y 3 pasos más en un lado del terreno y en el otro lado recorrió " $x$ " pasos y 5 pasos más.

Realizamos dos esquemas que representen las dimensiones de los terrenos que Ana y Miguel caminaron. Discutimos nuestras propuestas.

- ¿Cuál de las siguientes imágenes podría corresponder al terreno por el cuál caminó Ana? ¿Y Miguel? Compartimos nuestras respuestas.
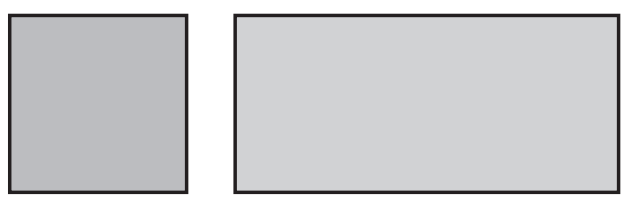

- ¿Puedo saber qué forma tienen los terrenos que se ilustraron? ¿Quién de los dos recorrió un terreno cuadrado? ¿Quién de los dos recorrió un terreno rectangular? ¿Cómo lo sé?

Luego de haber elegido que terreno corresponde a cada quién escribimos las medidas propuestas para cada terreno. Discutimos nuestras respuestas.

- ¿Cómo pudimos saber qué forma tienen los terrenos que se ilustraron? ¿A simple vista podemos saber quién de los dos recorrió más terreno? ¿Quién de los dos recorrió el terreno más pequeño? ¿Cómo lo sabemos?

Si suponemos que:

$$
x=90
$$

- ¿Cuál es la longitud, en pasos, de los lados del terreno que recorrió Ana? ¿cuál es la longitud del terreno que recorrió Miguel? ¿Cuál de los dos terrenos es más grande?

Si suponemos ahora que:

$$
x=52
$$

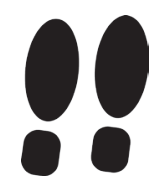

- ¿Qué terreno es más grande?

Supongamos ahora que:

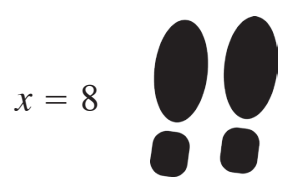

- ¿Qué ocurre? ¿Qué terreno tiene menos superficie? ¿Qué podemos concluir del ejercicio anterior? 
- Escribo una expresión que represente el área del terreno que recorrió Miguel y otra que represente el área del terreno que recorrió Ana.

- Efectúo el producto con las figuras algebraicas y lo copio en mi cuaderno. Observo que ambas expresiones son trinomios.

- Anoto sus características y comparo estos productos con la forma de los terrenos.

- ¿Qué trinomio corresponde al terreno cuadrado? ¿Qué trinomio corresponde al terreno rectangular?

Con las figuras algebraicas represento el área de otros dos cuadrados y otros dos rectángulos. Utilizo la letra x para representar una longitud desconocida y agrego cierta cantidad de pasos conocidos. Represento mi trabajo en el cuaderno.

Comparamos el trabajo realizado en casa y discutimos las diferentes propuestas.

Elaboramos una norma o instrucción que explique el tipo de trinomio que obtendremos al efectuar productos que representen superficies cuadradas. ¿Y una que represente superficies rectangulares?

Trabajamos de forma inversa y descomponemos en dos factores algunos trinomios que representen áreas.

Por ejemplo; en la siguiente figura se encuentra representado un producto.

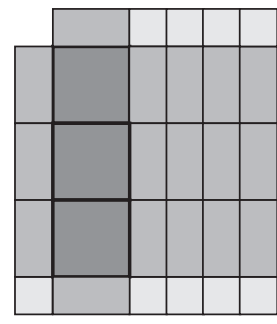

El trinomio que resulta de este producto es:

$3 x^{2}+13 x+4$

- ¿Cuáles son los factores que lo formaron?

- ¿Existen otros factores que formen el mismo trinomio?

Continuamos utilizando las figuras algebraicas para factorizar los siguientes trinomios:

$$
\begin{aligned}
& \text { - } x^{2}+4 x+4 \\
& \text { - } x^{2}+8 x+16 \\
& \text { - } x^{2}+8 x+15 \\
& \text { - } x^{2}-4 x+3 \\
& \text { - } x^{2}+2 x-15
\end{aligned}
$$

Hagamos una pausa. Formamos un círculo y realizamos respiraciones. Luego escogemos una pareja, con la cual nos colocamos de espaldas. Al ritmo de la música nos pasamos un pelota por el lado derecho. Al final pueden escribir una ecuación para estimar la cantidad de vueltas que dio la pelota.
Una fracción algebraica es el cociente entre dos o más expresiones algebraicas. Por ejemplo, la fracción que relaciona el ancho y el largo del terreno que caminó Miguel es:

$$
\frac{x+3}{x+5}
$$

- ¿Qué otras relaciones podemos representar como fracciones algebraicas?

- Escribimos algunos ejemplos de fracciones algebraicas que representen situaciones Conocidas; por ejemplo: la relación entre la edad actual de una persona y la edad que tendrá en 10 años.

$$
\frac{e}{e}+3
$$

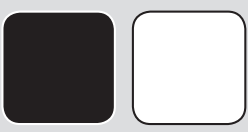




\section{Nuestro trabajo y el medio ambiente}

\section{El derecho a un trabajo digno}

Todas y todos tenemos el derecho a un trabajo digno, que nos provea satisfacción al realizarlo y condiciones adecuadas de vida. Que nos dé recursos para tener alimentación balanceada, salud, vivienda con servicios básicos, educación, recreación y bienestar.

El derecho al trabajo está protegido por la Constitución Política de la República de Guatemala (Artículo No. 106). Todo lo relativo al trabajo: contrato, horarios, horas de trabajo, licencias por maternidad y otros; está reglamentado en el Código de Trabajo (Decreto 1441 del Congreso de la República). Si los derechos de un trabajador o trabajadora son violados, puede poner una denuncia en un juzgado de trabajo.

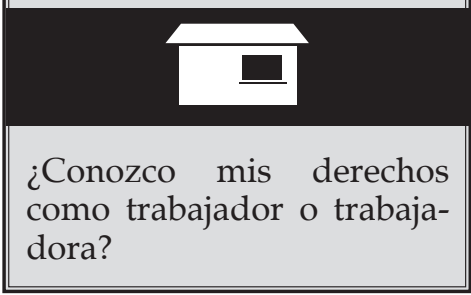

La Naturaleza es fuente de todas las materias primas que las personas utilizan tal cual o modifican para su uso. Aún los plásticos tienen su origen en elementos de la Naturaleza. Todo lo que nos rodea y usamos diariamente, como los teléfonos celulares, están elaborados con elementos tomados de la Naturaleza, incluyendo minerales.

La Naturaleza nos provee salud y alimento, pero también es una fuente de trabajo. La Naturaleza, de la cual formamos parte, se mantiene en un constante ciclo. Los seres y fenómenos de la Naturaleza están en constante renovación e interrelación. Debemos aprender a respetarla, valorarla y usar sus recursos de manera sustentable. Así podremos aspirar a un desarrollo sustentable. Esto significa que podremos satisfacer las necesidades del presente sin comprometer la capacidad de futuras generaciones de que puedan satisfacer sus propias necesidades.

\section{¿Cómo influye esto en nuestro trabajo?}

Una persona que se dedica a la carpintería, por ejemplo, necesita de madera para realizar su trabajo. La madera procede de árboles en bosques; para que exista una constante fuente de materia prima, es decir, madera de calidad, es necesario que el bosque se regenere continuamente, ya sea naturalmente o por medio de plantaciones. Además, para que la madera sea de buena calidad se necesita que los árboles tengan un espacio adecuado para crecer y la tierra sea rica en nutrientes. Los bosques, además de ser fuente de materia prima, albergan a muchas especies vegetales y animales. Valoremos los regalos que la naturaleza nos da utilizando bien los recursos, sin desperdiciar, reduciendo y regulando el consumo, reutilizando, reparando y reciclando.

Reflexionemos sobre un oficio que se realiza en la comunidad. ¿Se realizan las tareas respetando el ciclo de la Naturaleza? ¿Se desperdician recursos? ¿Se reutiliza? ¿Se repara? ¿Se recicla? ¿Cómo se regula el uso de los recursos naturales?

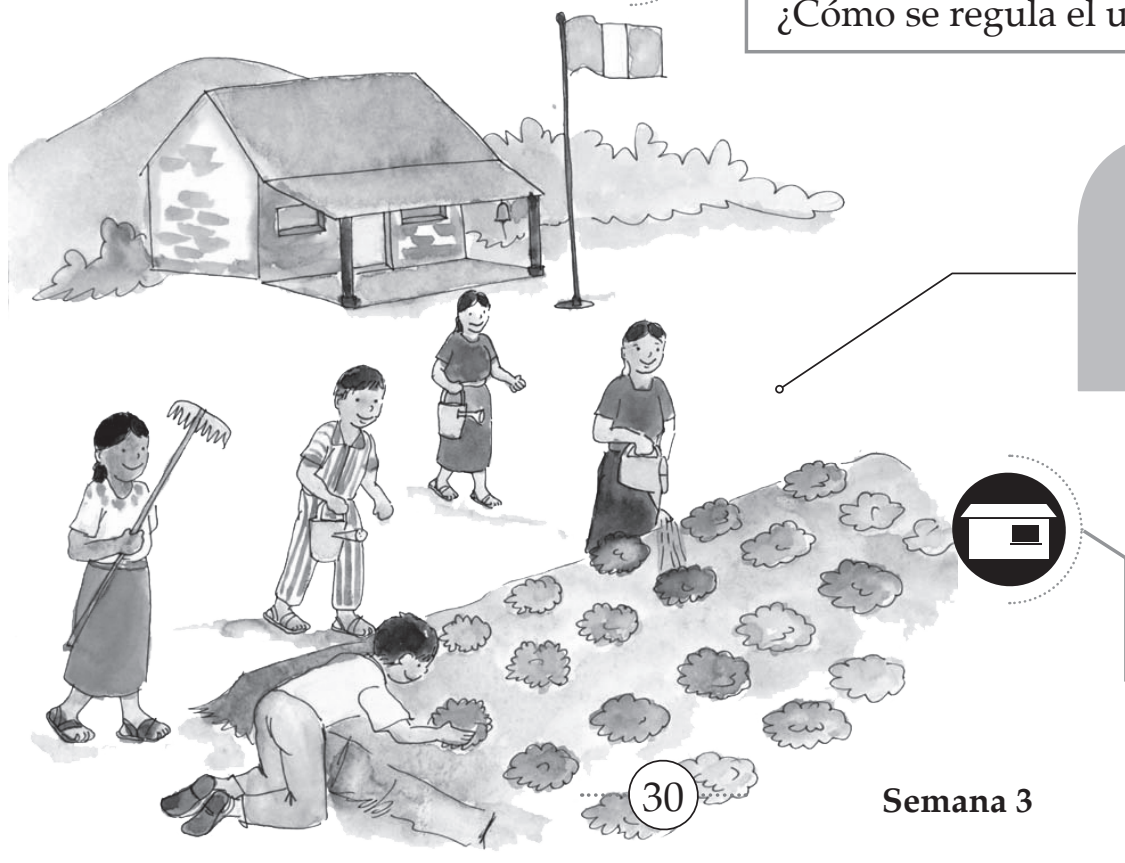

Dar a conocer a la comunidad en varios idiomas es mejor para que más personas puedan entender.

Escribe en tu idioma materno, en castellano y en un idioma extranjero una oración que cuenta la historia del principal trabajo de esta comunidad. 
La Naturaleza es fuente de inspiración para muchos trabajos artísticos. El arte es un trabajo duro, y a veces poco apreciado, que necesita constancia, paciencia, perseverancia, práctica y conocimiento. La pintura, la música, la literatura, la fotografía, los tejidos no solo son fuente de inspiración y expresión del o la artista, sino también un reflejo de su tiempo: muestran la cultura, la historia y el pensamiento de una sociedad en un momento determinado.

Algunos sonidos de la música maya reproducen los sonidos de la Naturaleza, especialmente, de pájaros. Los bordados de los huipiles representan a muchos animales, pero ¿sabemos qué representan? ¿Conocemos las tradiciones de nuestro pueblo? Oigamos a los abuelos y las abuelas y conoceremos más sobre nuestro origen, nuestro pueblo, nosotras y nosotros mismos.

\section{(10)}

La fotografía nos ayuda a conocer visualmente momentos de nuestra historia. ¿Cómo ha cambiado el paisaje de nuestra comunidad? ¿Cómo es el paisaje donde viven nuestras y nuestros familiares en el extranjero? Conozcamos cómo ha cambiado nuestra comunidad. Consigamos fotografías antiguas o pidámosle a personas mayores que nos describan cómo era la comunidad cuando eran niñas o niños, elaboremos un dibujo. En clase reflexionemos sobre los cambios de nuestra comunidad y sus alrededores y el impacto en nuestras vidas. ¿Qué tan diferente es nuestra vida de la de nuestras abuelas y abuelos? ¿De la de nuestros padres y madres? ¿Estamos respetando la Naturaleza y procurando un desarrollo sustentable?

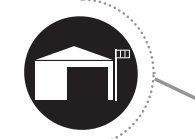

Conversamos en plenaria acerca de las y los artistas y artesanos de la comunidad. ¿Es apreciado su trabajo? ¿A quiénes del grupo les gustaría dedicarse a una actividad similar? Incluimos la información obtenida en el proyecto.

Luego de la visita a las y los artistas escribamos en nuestro idioma materno un segmento publicitario de esta persona para incluir en el prisma. Cuidamos la gramática y la ortografía.

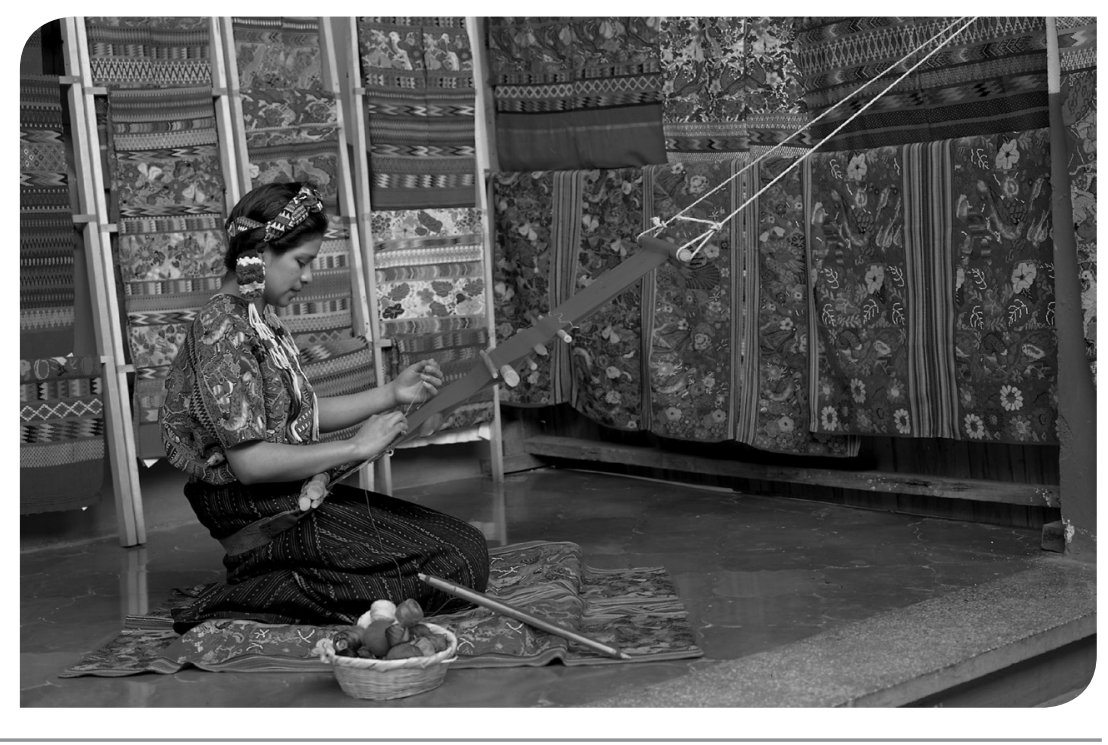

En Guatemala existen bastantes y grandes artistas. El arte es un trabajo como todos los demás y merece ser retribuido como cualquier otro: por el tiempo y conocimientos dedicados, la maestría y calidad del trabajo y por lo que nos representa, así como a la sociedad.

María Mercedes Coroy, por su actuación en la película Ixcanul, ha ganado varios premios internacionales. Luis González Palma ha retratado el alma de las y los guatemaltecos con su cámara fotográfica. Humberto Ak'abal muestra en su poesía el sentir de la población maya. Benvenuto Chavajay, utiliza sus raíces mayas para representar el sentir de la sociedad actual a tráves de las artes visuales. Sara Curruchich con su canto defiende los derechos de los pueblos indígenas.

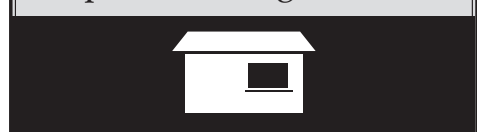

Conozcamos a las y los artistas de nuestra comunidad o municipio. Visitemos a una persona que se dedica a la música, danza, tejido, artesanía, fotografía, artes gráficas.

Conozcamos su trabajo pero también averigüemos qué siente cuándo lo hace, qué le mueve y qué desea transmitir. 


\section{Conceptos de Ciencias Sociales para analizar una situación}

Causa. Hecho o circunstancia que es la raíz, origen o fundamento de otra.

Problema. Es todo conjunto de hechos o circunstancias que dificultan la consecución de un fin o la obtención de determinado nivel de satisfacción.

Consecuencia. Acontecimiento que se deriva, resulta o deviene de otro hecho.

- ¿Cuál es la fuente de agua más cercana a mi comunidad?

- ¿Qué características tiene el agua de esa fuente?

- ¿Qué cuidados le dan los miembros de mi comunidad?

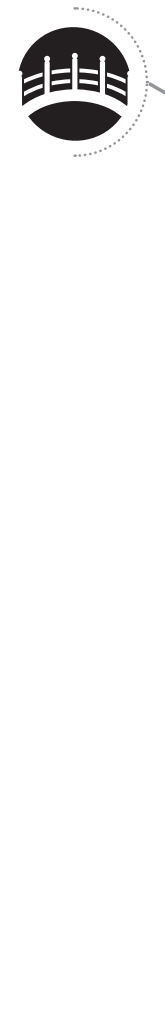

Observemos el esquema llamado Árbol de problemas.

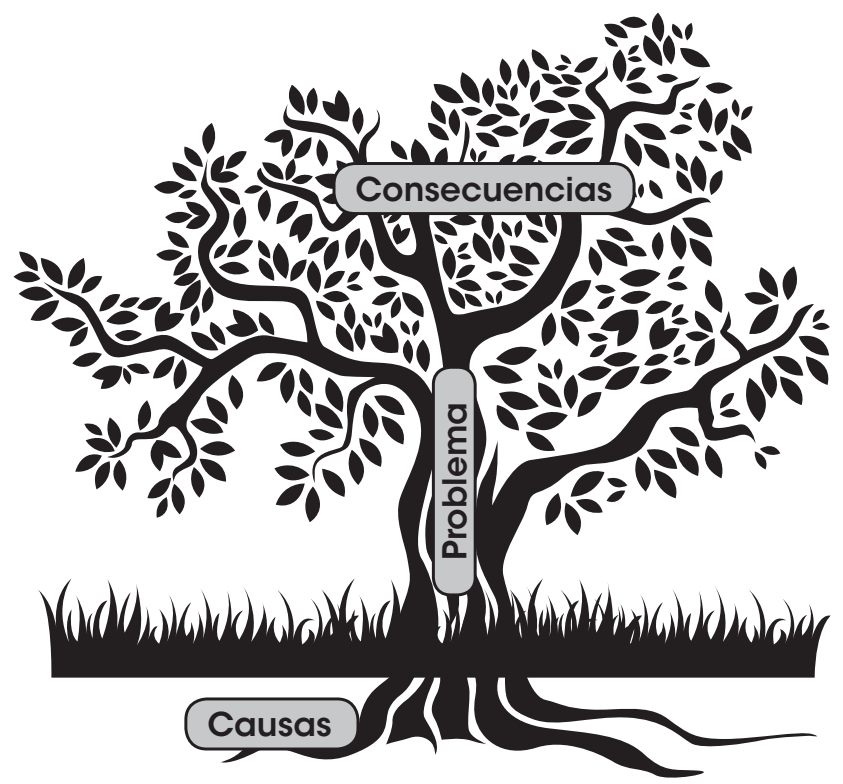

Las Ciencias Sociales plantean que cualquier problema que se da en la comunidad tiene varias causas y provoca consecuencias. En algunas ocasiones puede haber una causa principal y varias secundarias o terciarias. A veces, las principales causas pueden ser más de dos. El árbol de problemas es una herramienta conceptual para analizar las causas y consecuencias de los problemas Elegimos un problema de nuestra comunidad. Por ejemplo: escasez de agua.

\begin{tabular}{|c|c|c|c|c|c|c|}
\hline Consecuencias & $\begin{array}{l}\text { No se lavan } \\
\text { adecuadamente } \\
\text { los alimentos }\end{array}$ & $\begin{array}{l}\text { Se bebe agua } \\
\text { contaminada }\end{array}$ & $\begin{array}{c}\text { El agua } \\
\text { para } \\
\text { bañarse es } \\
\text { escasa }\end{array}$ & $\begin{array}{c}\text { La ropa } \\
\text { se lava } \\
\text { con agua } \\
\text { contaminada }\end{array}$ & $\begin{array}{l}\text { Se invierte } \\
\text { mucho } \\
\text { tiempo } \\
\text { para } \\
\text { obtener } \\
\text { agua } \\
\end{array}$ & $\begin{array}{l}\text { El precio del } \\
\text { agua es muy } \\
\text { elevado }\end{array}$ \\
\hline & \multicolumn{2}{|c|}{ Salud de las personas } & \multicolumn{2}{|c|}{ Higiene personal } & \multicolumn{2}{|c|}{ Economía familiar } \\
\hline & \multicolumn{6}{|c|}{ Problema: escasez de agua potable en las casas de la comunidad } \\
\hline & \multicolumn{2}{|l|}{ Culturales } & \multicolumn{2}{|l|}{ Económicas } & \multicolumn{2}{|l|}{ Jurídicas } \\
\hline Causas & $\begin{array}{l}\text { Hábitos de } \\
\text { consumo } \\
\text { excesivo del } \\
\text { agua. }\end{array}$ & $\begin{array}{c}\text { Falta de } \\
\text { conocimiento } \\
\text { del manejo } \\
\text { apropiado } \\
\text { del agua } \\
\text { potable }\end{array}$ & $\begin{array}{c}\text { Una } \\
\text { industria } \\
\text { cerca } \\
\text { desvía } \\
\text { la fuente } \\
\text { de agua } \\
\text { hacia sus } \\
\text { terrenos de } \\
\text { producción } \\
\end{array}$ & $\begin{array}{l}\text { No hay } \\
\text { recursos para } \\
\text { financiar } \\
\text { proyectos de } \\
\text { agua potable }\end{array}$ & $\begin{array}{l}\text { No existe } \\
\text { una ley } \\
\text { nacional } \\
\text { que regule } \\
\text { el uso del } \\
\text { agua }\end{array}$ & $\begin{array}{c}\text { La } \\
\text { municipalidad } \\
\text { no reglamenta } \\
\text { el uso del agua }\end{array}$ \\
\hline
\end{tabular}

Elaboremos, en equipo, un árbol de problemas como el anterior para algún otro problema de la comunidad. 


\section{Propuestas para solucionar problemas}

En las Ciencias Sociales se sabe que para resolver problemas hay que transformar sus causas, de esta manera las consecuencias desaparecen o disminuyen y el problema queda resuelto o mejora la condición de la comunidad.

Observemos el siguiente esquema.

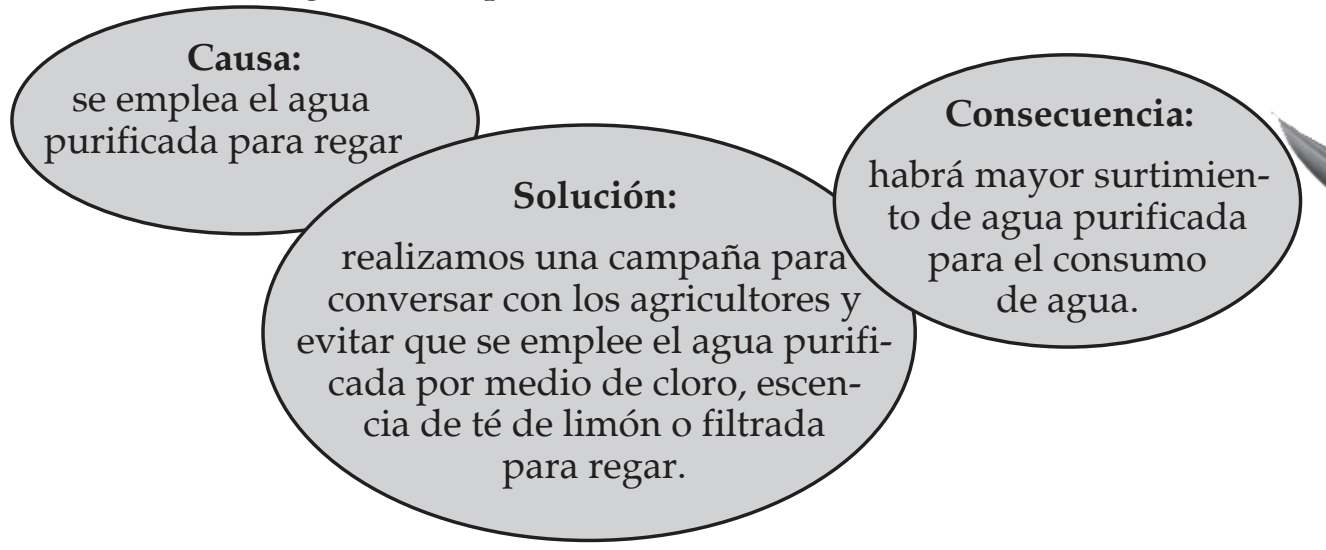

Elegimos una causa del árbol de problemas que elaboramos y hacemos un esquema con propuestas de solución y consecuencias.

Dibujamos o tomamos fotografías de la especie animal y vegetal que más nos agradan del ambiente natural de nuestra comunidad.

- Intercambiamos los dibujos y fotografías con las y los integrantes de nuestro equipo de trabajo.

- Describimos el ambiente natural en el que viven las especies.

- Analizamos si este ambiente tiene potencial para desarrollar actividades productivas sostenibles o es atractivo para el turismo.

- Determinamos si alguna de estas especies está en peligro de desaparecer o podría estarlo al iniciar una actividad productiva en el entorno.

- Elaboro una lista de lugares de interés para promover a la comunidad.

- Dibujo las especies animales y vegetales más bellas de mi comunidad.

- Determino si algunas están en peligro de extinción.

- Elaboro un árbol de problemas para analizar causas y consecuencias de una especie en peligro de extinción.

- Propongo soluciones para el problema de la especie en peligro de extinción.

- Elaboro un esquema de causa, solución y consecuencia.

- Luego redacto un párrafo explicando el esquema usando mi idioma materno.

Estas especies, símbolos nacionales están en peligro de extinción.

- Determino algunas causas de este problema.

- Enumero las consecuencias.

- Propongo soluciones. 


\section{Redes tróficas en ecosistemas terrestres y acuáticos}

La cadena trófica o cadena alimentaria describe el proceso de transferencia de sustancias nutritivas a través de las diferentes especies de una comunidad biológica. Cada elemento de la cadena se alimenta del anterior y es alimento del siguiente. Es la corriente de energía y nutrientes que se establece entre las distintas especies de un ecosistema en relación con su nutrición.

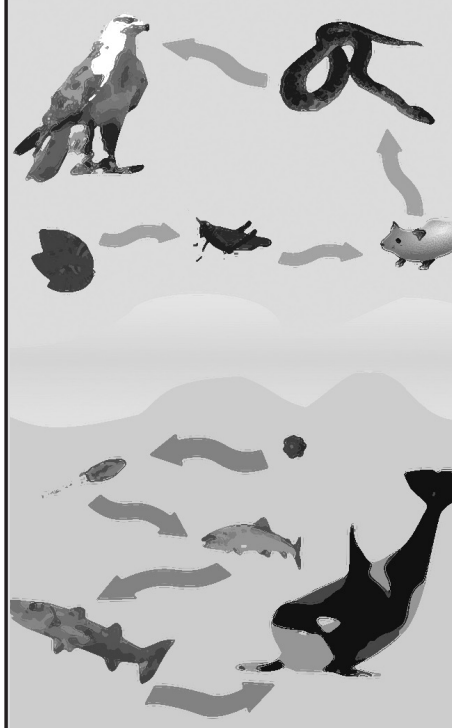

Ejemplos de cadena trófica terrestre y marina.

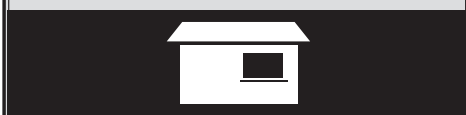

Consulto con abuelas y abuelas y otras personas adultas acerca de animales y plantas que han disminuido o desaparecido en la localidad. Pido su opinión acerca de las posibles causas. Agrego al árbol de problemas la información obtenida.
Observamos el siguiente esquema y lo comentamos en grupo.

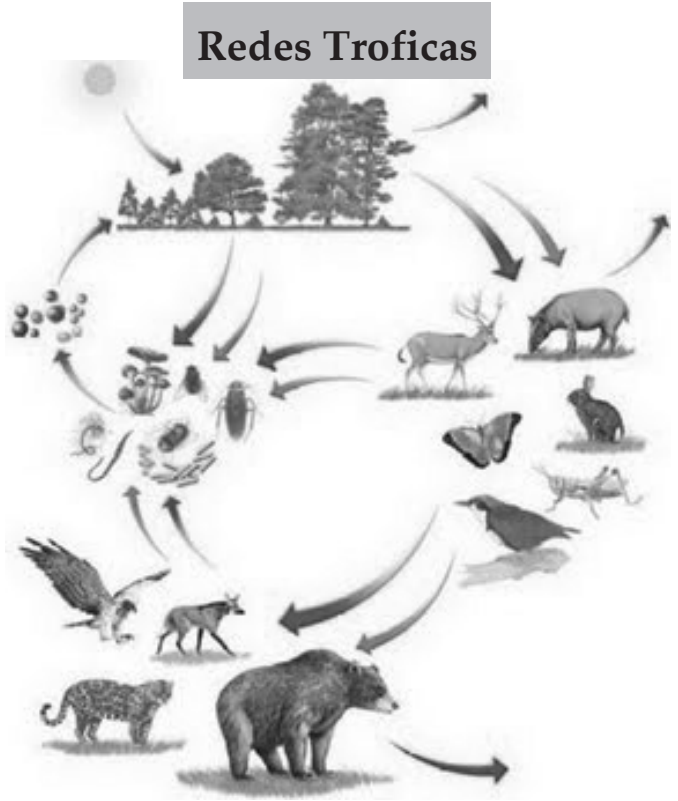

Referencia: https://bioygeodivinapastora.wikispaces.com/7.2. + Cadenas+y+redes+tr\%C3\%B3ficas

Una red alimenticia o trófica (o ciclo alimenticio) es la interconexión natural de las cadenas alimenticias y generalmente es una representación gráfica de cuál especie se alimenta de otra en una comunidad ecológica.

Recuperado de: https://www.google.com.gt/search?q=redes+tr\%C3\%B3fica $\mathrm{s}+\mathrm{en}+\mathrm{los}+\mathrm{ecosistemas}+$ terrestres $+\mathrm{y}+\mathrm{acu} \% \mathrm{C} 3 \% \mathrm{~A} 1 \mathrm{ticos} \& \mathrm{espv}=2 \& \mathrm{biw}=1280 \&$ $\mathrm{bih}=711 \& \mathrm{tbm}=\mathrm{isch} \& \mathrm{tbo}=\mathrm{u} \&$ source $=$ univ\&sa $=\mathrm{X} \& v e d=0 \mathrm{ahUKEwiCp} 8 \mathrm{jWnvn}$ MAhXJbiYKHVFQDUsQsAQIKQ\&dpr=1

Describimos algunas cadenas alimenticias descubiertas en los ecosistemas de nuestra comunidad. Elaboramos un cartel con imágenes para representar la red trófica.

\section{Interrelaciones e interdependencia de los organismos en los ecosistemas}

En grupo leemos el siguiente texto

Dentro de cada ecosistema los organismos y poblaciones mantienen un complejo conjunto de relaciones con otros individuos de su propia especie o con los de otras especies. Estas interacciones, pueden resultar favorables, desfavorables o indiferentes a la supervivencia de las especies afectadas. Pueden determinar su área de distribución a la vez que desempeñar un papel esencial en su evolución. Muchas especies han desaparecido de una u otra región como consecuencia directa de la extinción de otras. 


\section{La simbiosis}

Consiste en la existencia de una relación permanente y muy estrecha entre individuos de distintas especies ("simbiontes"). Al menos uno de los individuos obtiene beneficio de la relación. En muchos casos, gozan de mutuas ventajas y obtienen beneficios recíprocos de la vida en común. Ejemplos de simbiosis son los siguientes:

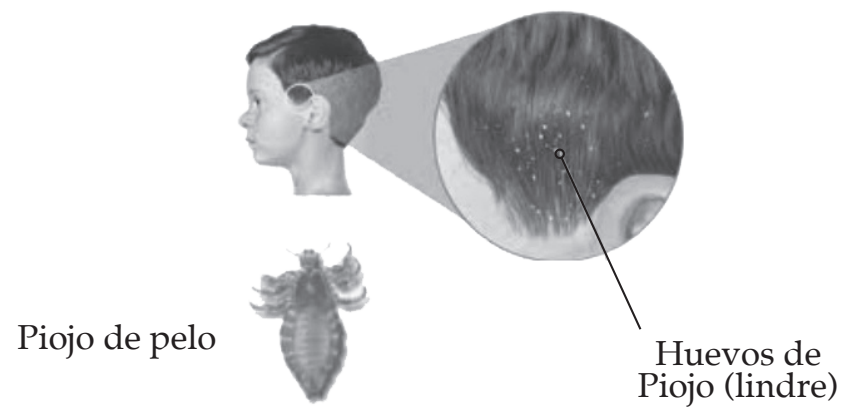

El parasitismo, uno de los actores (el "parásito") se alimenta o reproduce a costa de otro (el "hospedador") o vive en el interior de su organismo.

Si vive dentro del hospedero se le llama endoparásito, por ejemplo la tenía o solitaria. Si vive fuera de su hospedero es llamado ectoparásito, por ejemplo el piojo y la pulga.

El mutualismo, los individuos de dos o más especies implicadas obtienen beneficio. A veces se trata de una relación simbiótica, aunque no siempre es así.

No necesariamente es permanente. Un ejemplo de mutualismo es el de las abejas, que dependen de las flores para su alimentación y las flores de las abejas para su polinización.

Comensalismo, es beneficiosa para uno de los intervinientes pero indiferente para el otro. Puede adquirir diversas formas y en ocasiones es próximo a la explotación, cómo: aprovechamiento de los restos de comida abandonados por un depredador, fijación sobre otro animal para dejarse transportar o, incluso, utilización de los restos de un organismo muerto por parte de otro.

Elaboramos un organizador gráfico acerca de los tipos de simbiosis identificados en los ecosistemas locales.

Realizamos un foro para presentar las principales interrelaciones observadas en los ecosistemas locales. Analizamos el esquema causa, solución y consecuencia de especies de animales y plantas que han disminuido o desaparecido en la región. Discutimos acerca del tipo de relación que tienen las personas de la comunidad con las demás especies, vegetales y animales con las cuales comparte el espacio y el tiempo.

- ¿Son perjudiciales para alguna especie? ¿De qué manera pueden cambiar?
Una población es un grupo de organismos de la misma especie que comparten el mismo espacio y tiempo. Estas poblaciones interdependientes forman una comunidad biológica.

Los grupos de poblaciones de un ecosistema interactúan de varias formas.

Depredación, es un tipo de relación que se produce principalmente entre los animales en la que una especie caza a otra para alimentarse o desarrollar alguna de las etapas de su ciclo vital.

Inquilinismo, se produce cuando un organismo se instala para vivir en otro. En general, los inquilinos pertenecen a especies de pequeñas dimensiones $y$ se benefician mientras que a los hospedadores les resulta indiferente.

Competencia, se produce entre especies de requerimientos similares y que causa un enfrentamiento o un reparto de recursos para todas las partes implicadas. Puede producirse entre individuos de una misma especie o entre especies distintas.

Recuperado de

http:/ / ocw.unican.es/ciencias-sociales-y-juridicas / biogeografia/materiales/tema-2/2.2.1-las-interaccionesbiologicas 


\section{¿Cómo y qué hacemos al bailar en grupo?}

Las danzas tradicionales se asocian a ritos o ceremonias espirituales de la comunidad. "El torito", "El Paabank", son tradicionales.

Son danzas populares las que se presentan en actos solemnes, no religiosos. Ejemplo: coreografías de "El Ferrocarril de los Altos".

Bailes sociales son los que se usan en cualquier fiesta. Cumbias, quebradita, reguetón, salsa, corrido; son comunes en las fiestas.
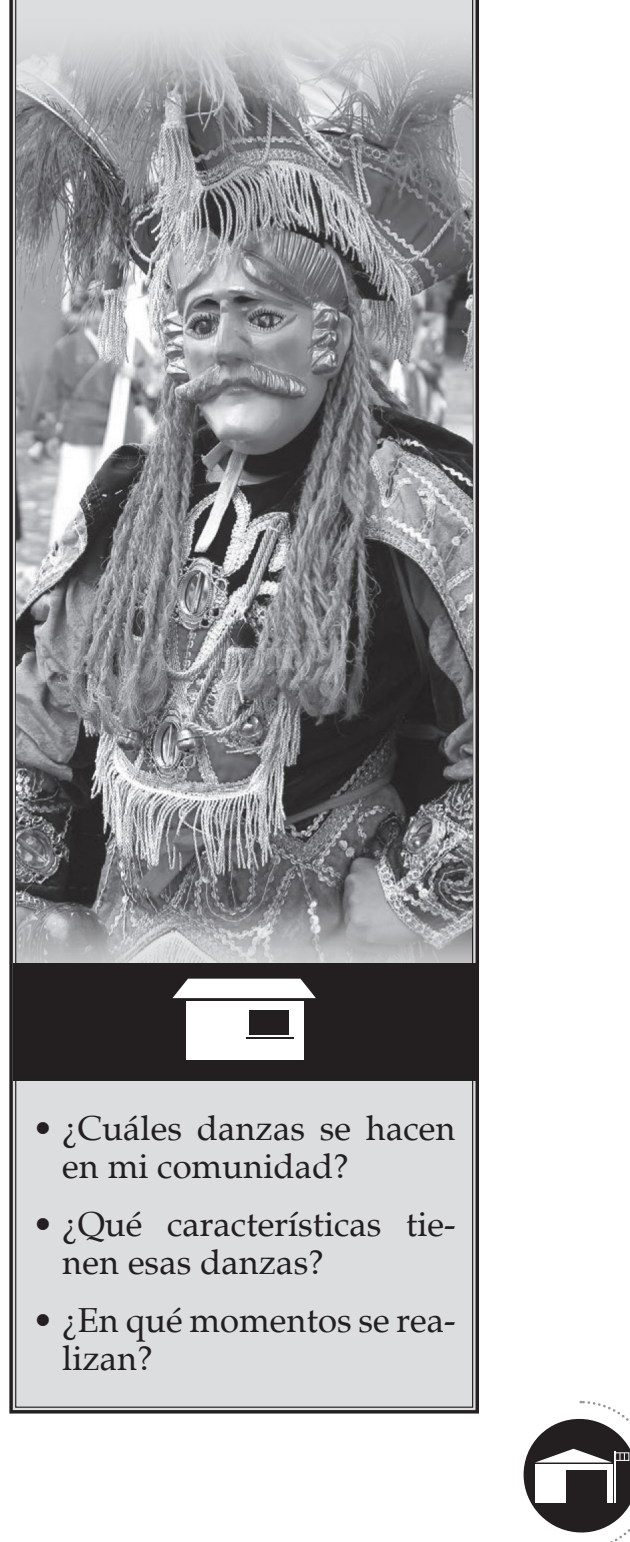

Observemos el esquema de una danza

(3)

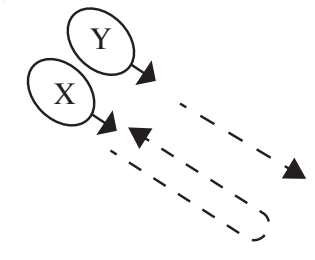

(4)

(2)
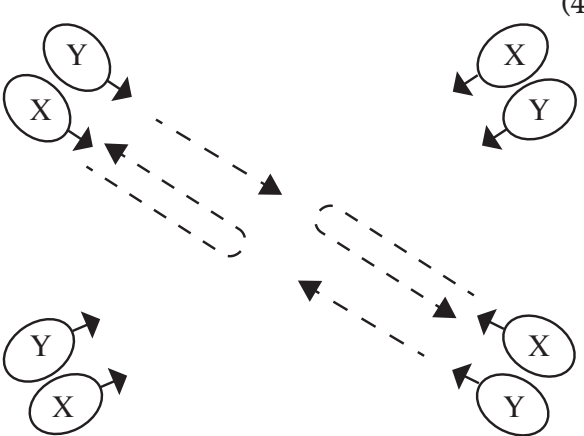

(1)

Cuando danzamos, todo nuestro cuerpo entra en acción. Bailar solos implica realizar varios movimientos de piernas, brazos y cabeza. Al bailar en pareja se requiere de mucha coordinación para no colisionar o golpearse entre sí. También se puede bailar en grupos mayores o con varias parejas. El esquema de arriba muestra la dirección que pueden tomar los bailarines mientras realizan una danza en grupo.

Observemos el cuadro siguiente:
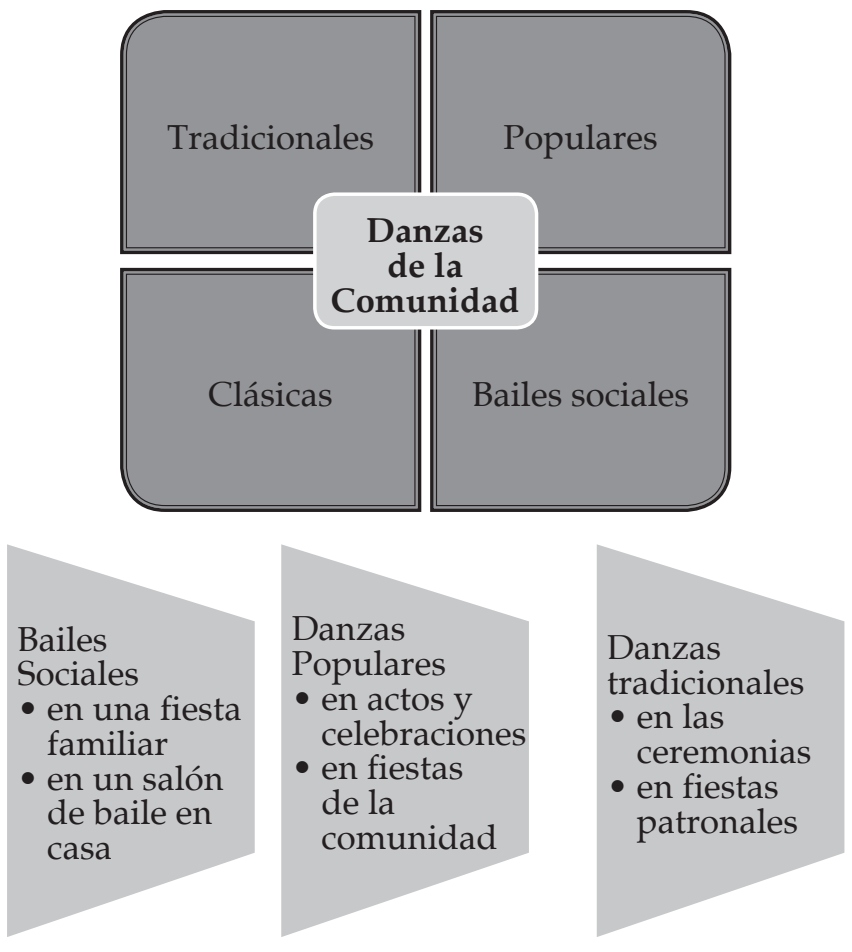

En grupo elaboramos un esquema con la información del cuadro anterior.

- En el ladillo leemos sobre el funcionamiento de las danzas

- Seleccionamos las que se realizan en nuestra comunidad. 


\section{Propuestas para ejecutar una danza}

Para que una danza grupal pueda funcionar es necesario plantear el orden en que se realizarán los pasos. Cada formación implica una rutina en la que hay que contar para hacerlo con exactitud.

Observemos el siguiente esquema.

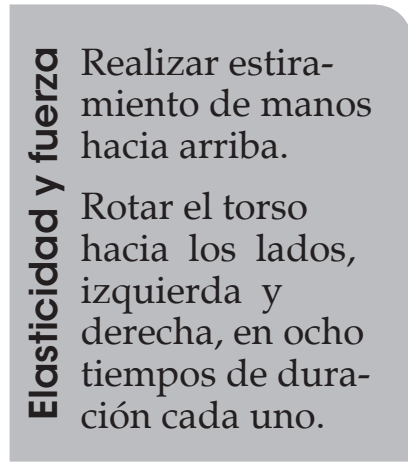

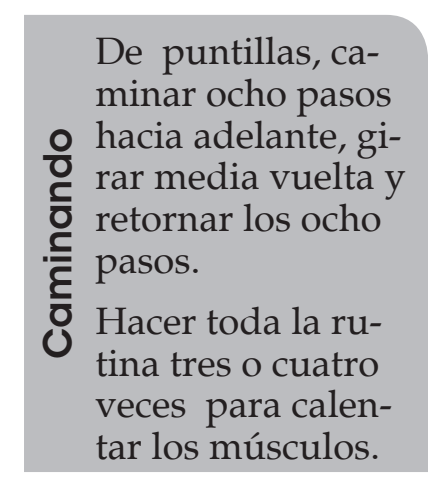

Elegimos una de las danzas de la comunidad y planteamos una rutina de movimientos para realizarla en grupos.

\section{Realizamos el esquema de una coreografía}

Haciendo uso de líneas y formas, describimos los pasos para bailar una danza de nuestra comunidad.

- Ordenamos y dibujamos los pasos y las rutinas a realizar

- Describimos cada paso y movimiento según los participantes

- Elegimos una música que se adapte a la danza, de acuerdo a sus características.

- Determinamos la ocasión en que queremos presentar nuestra danza a la comunidad.

- Investigo con mis vecinas, vecinos, amigas y amigos acerca de las danzas tradicionales y populares de la comunidad.

- Escribo una lista de tres de esas danzas.

- Dibujo una serie de pasos que formen dos rutinas para realizar una de ellas.

- Determino si algunas danzas están en peligro de extinción.

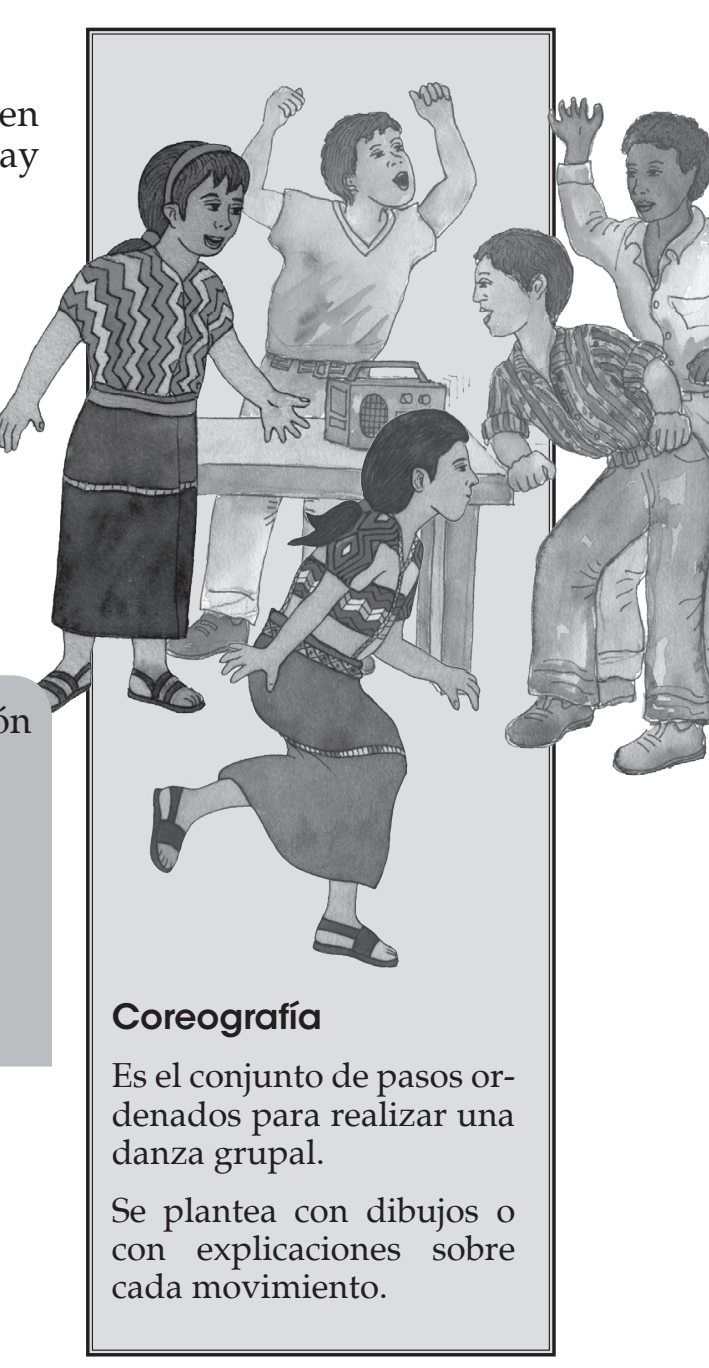

Es el conjunto de pasos ordenados para realizar una danza grupal.

Se plantea con dibujos o con explicaciones sobre cada movimiento. 


\section{Escribir, ¿un reto?}

Para muchas personas, escribir constituye un reto. Las dificultades surgen debido a la falta de un método ágil y adecuado para redactar. Es muy importante contar con un procedimiento para organizar un escrito y su redacción porque nos da seguridad para escribir. Los pasos a seguir son:

Elegir sobre qué vamos a escribir.

Determinar a quién va dirigida la redacción.

Saber qué se quiere lograr. Saber con cuánto espacio se cuenta para escribir.

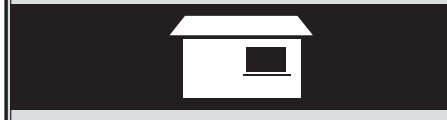

Imagino que necesito escribir un texto para fomentar el cuidado del agua en mi comunidad. Su extensión debe ser de dos páginas. Organizo en un esquema las ideas para mi texto antes de escribirlo, en mi cuaderno. Respondo las siguientes preguntas con respecto al tema: ¿Cuál es el reto, en dónde, cuándo, cómo y por qué?
Manejar nuestro idioma correctamente resulta indispensable para poder expresar nuestras ideas y sentimientos; además de conocer nuestros derechos y obligaciones. Podemos expresarnos de dos maneras, principalmente: de forma oral y de forma escrita.

La elaboración de un texto escrito es el último paso de un proceso que primero pensamos, mediante estos pasos: búsqueda de ideas o "lluvia de ideas", ordenamiento de ideas en un esquema, en orden de importancia. Y, finalmente, desarrollo de cada idea en un párrafo. El párrafo final debe ser una conclusión o reflexión valorativa.

Un párrafo se forma de varias oraciones breves. Generalmente, la primera contiene la idea principal y las demás, la desarrollan o apoyan con ideas secundarias.

Reflexionemos sobre el cuidado de nuestro entorno. ¿Cómo podemos cuidarlo? ¿Cómo afecta la tala inmoderada de los árboles en la escasez de agua? ¿Cuáles son los colores naturales de nuestro entorno y cómo cambian cuando hay una sequía? ¿Qué responsabilidad tenemos para que las futuras generaciones tengan acceso a recursos naturales?

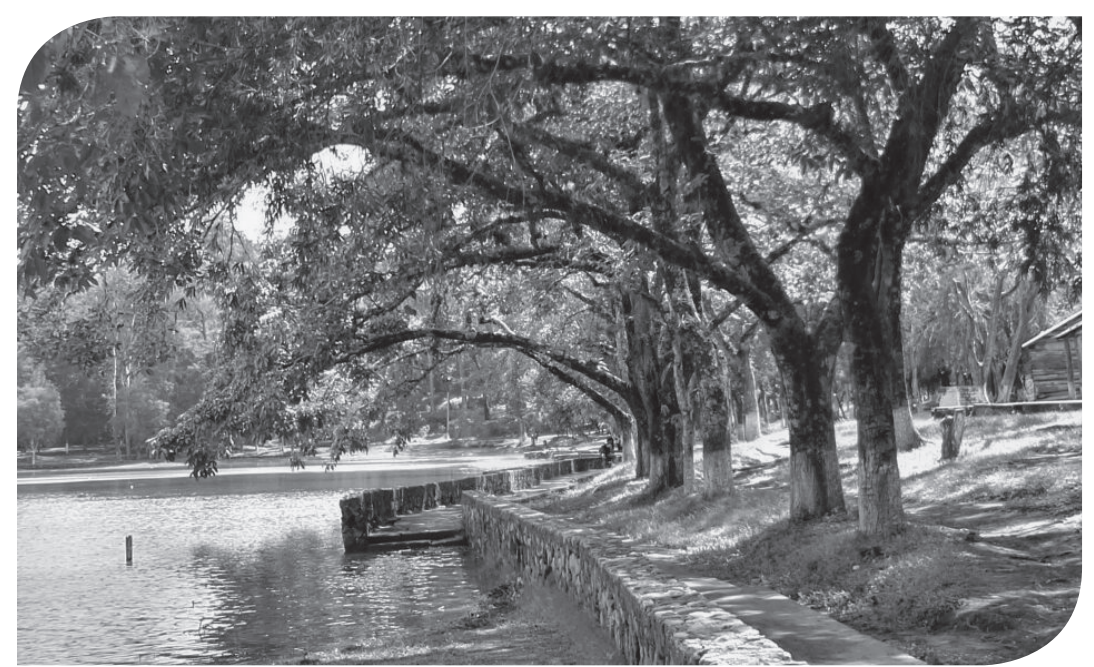

Foto: Laguna del Pino, Fraijanes, Guatemala

Seleccionamos una oración del prisma y la traducimos al inglés, con ayuda del diccionario español-inglés.

- Elaboro un anuncio de convocatoria en el idioma de mi comunidad para la presentación del prisma publicitario.

- Envío por teléfono, mensaje de texto o correo electrónico, la convocatoria elaborada a tres personas para que vengan a la presentación del prisma. 


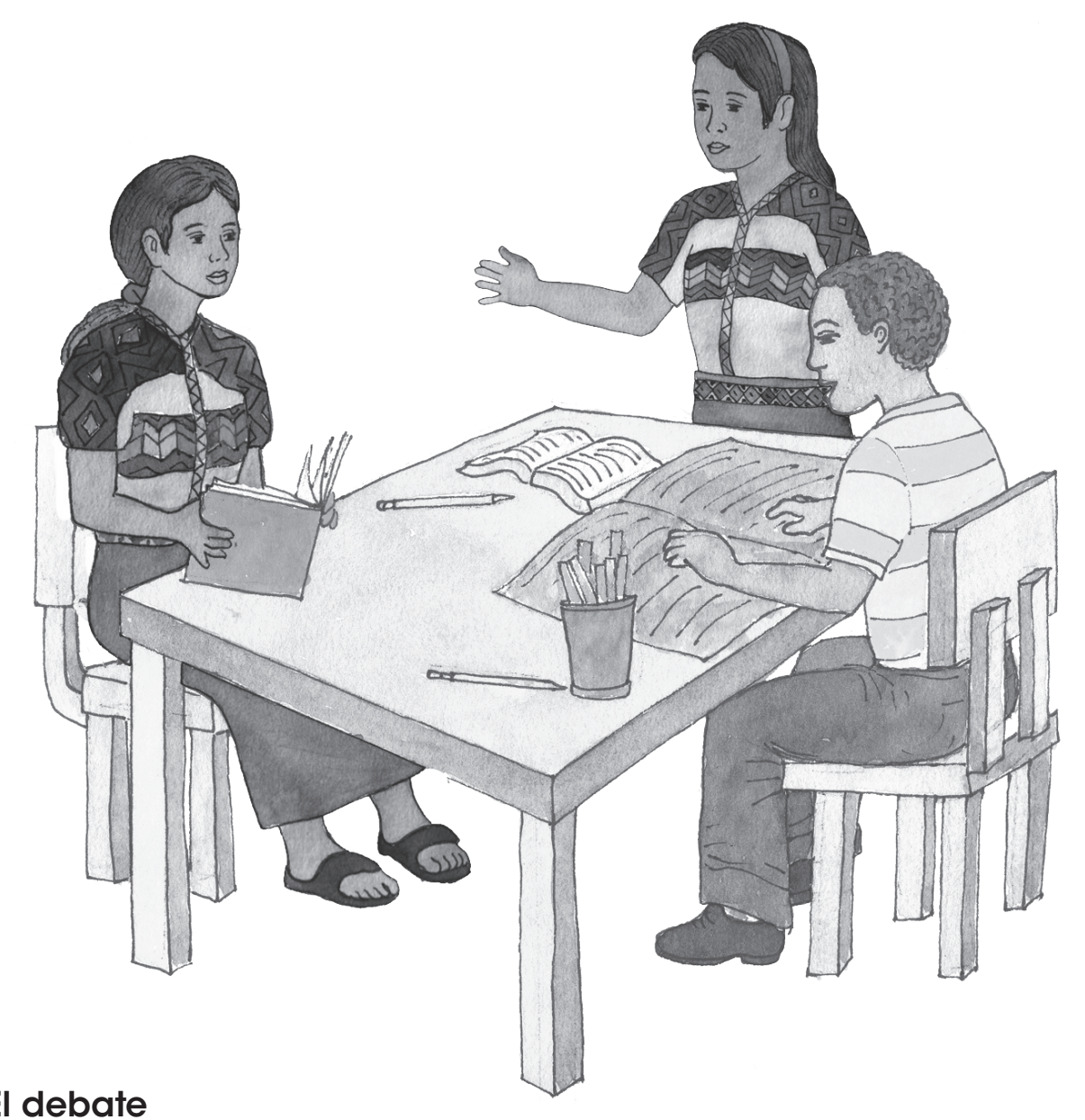

Uno de los medios más efectivos para compartir ideas y reflexionar sobre un tema es el debate: dos o tres personas discuten sus opiniones acerca de un asunto y son moderadas por otra. Los participantes deben investigar el tema y poseer argumentos válidos que respalden su postura, para convencer al público. La persona que modera debe limitar el tiempo de participación de cada integrante del debate y dirigir las preguntas del público.

Un elemento esencial para que nuestro mensaje sea comprendido con claridad y seriedad es su corrección. Para que un texto escrito esté bien escrito debe atenerse a las reglas de redacción y ortografía:

El punto nos ayuda a separar ideas. Un consejo sano para redactar es el de usar una oración para cada idea y terminar con punto. Ejemplo: Los árboles son fuente importante de oxígeno.

Los dos puntos nos ayudan a anunciar una enumeración. La coma nos ayuda a separar los elementos de una enumeración. Ejemplo:

Algunos elementos de mi entorno son: el agua, los árboles, los animales, los sonidos y el viento.

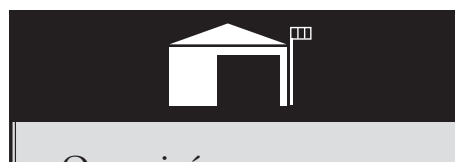

- Organicémonos en grupos de dos a tres personas. Distribuyámonos equitativamente, en mujeres y hombres en cada grupo. Dialoguemos sobre cada uno de nuestros recursos naturales y elaboremos un texto escrito. ¿Cuáles son nuestros recursos naturales? ¿Qué riesgos corren estos recursos? ¿Cómo nos afecta su pérdida? Utilicemos carteles que ilustren nuestras ideas.

- Organicemos un debate en nuestra escuela o en nuestra comunidad. Elijamos a una persona de cada uno de los grupos de investigación. Integremos uno o dos grupos de debate con temas específicos. Tenemos el cuidado que haya participación equitativa de mujeres y hombres. Los participantes deben poseer un plan de trabajo con objetivos bien definidos. La tutora o tutor puede moderar.

- Terminemos el debate con la reflexión sobre estos pensamientos:

"Salvaje no es quien vive en medio de la Naturaleza, salvaje es quien la destruye".

Mahatma Gandhi Cuidar a la Naturaleza es cuidarnos a nosotros mismos. 


\section{Fracciones algebraicas}

Para simplificar fracciones algebraicas nos será útil recordar las propiedades de las potencias.

$$
\begin{array}{r}
\frac{a^{m} \cdot a^{n}=a^{n+m}}{a^{m}} a^{n}=a^{m-n} \\
\frac{\left(a^{m}\right)^{n}=a^{n \cdot m}}{(a \cdot b)^{n}=a^{n} \cdot b^{n}} \\
\hline\left(\frac{a}{b}\right)^{n}=\frac{a^{n}}{b^{n}}
\end{array}
$$
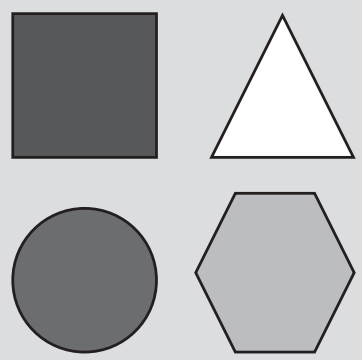

Para simplificar, multiplicar y dividir fracciones algebraicas el procedimiento es igual al que se lleva a cabo con las fracciones aritméticas.

Simplificación:

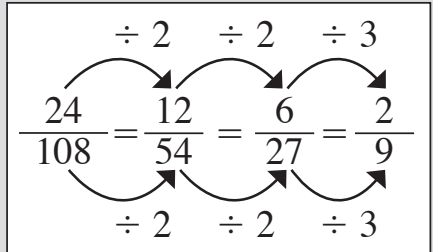

Multiplicación:

$$
\frac{1}{2} \times \frac{1}{3}=\frac{1 \times 1}{2 \times 3}=\frac{1}{6}
$$

\section{División:}

$$
\frac{3}{4} \div \frac{2}{5}=\frac{3 \cdot 5}{4 \cdot 2}=\frac{15}{8}
$$

Utilicemos expresiones algebraicas para plantear la siguiente situación.

Debido a la abundancia de lluvias y a la gran cantidad de cosechas, este año, la caja de tomate bajó su precio. Si el precio original era "x", ¿cuánto valdrá ahora la caja si el nuevo precio es una cuarta parte del original, más Q15.00?

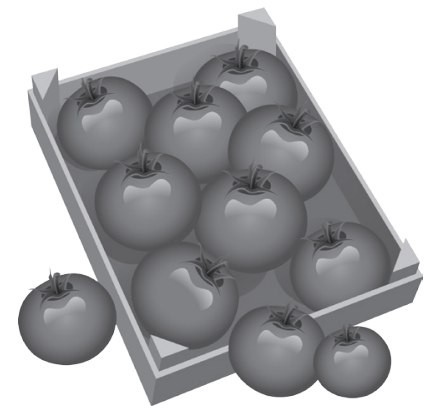

Escribimos la expresión anterior en nuestro cuaderno y discutimos acerca de lo siguiente: ¿Es una fracción algebraica? ¿Cuáles son las características de las fracciones algebraicas? ¿Para qué son útiles las fracciones algebraicas?

Las fracciones algebraicas, al igual que las fracciones aritméticas, pueden simplificarse y operarse. Observamos las analogías en la simplificación de ambos tipos de fracciones:

\begin{tabular}{|c|c|}
\hline Fracción aritmética & Fracción algebraica \\
\hline$\frac{4}{12}=\frac{1}{3}$ & $\frac{4 x}{12}=\frac{x}{3}$ \\
\hline$\frac{5}{30}=\frac{1}{6}$ & $\frac{5 x^{3}}{30 x}=\frac{x^{2}}{6}$ \\
\hline$\frac{21}{7}=\frac{3}{1}=3$ & $\frac{21 x y}{7 x^{2} y}=\frac{3}{x}$ \\
\hline
\end{tabular}

- ¿Cómo simplificaríamos fracciones algebraicas que contienen polinomios?

Observemos el siguiente ejemplo y comentemos cómo se simplificó la fracción.

$$
\frac{x^{2}-9 x+20}{x-5}=\frac{(x-4)(x-5)}{x-5}
$$

Recordamos: Solo se simplifican factores, nunca términos que pertenezcan a una suma o resta. Factores son los números que se multiplican o los que se operan en una multiplicación. Por ejemplo, en la multiplicación: $4 \times 5=20.4$ y 5 son los factores a multiplicar. 
Para operar fracciones algebraicas el proceso es el mismo que se lleva a cabo al operar fracciones aritméticas.

Observemos los siguientes ejemplos y escribamos en nuestro cuaderno, cómo se llevó a cabo cada operación.

\begin{tabular}{|l|l|}
\hline \multicolumn{1}{|c|}{ Multiplicación } & \multicolumn{1}{c|}{ División } \\
\hline$\frac{3 x y}{5} \times \frac{x^{2}}{4 x}=\frac{(3 x y)\left(x^{2}\right)}{(5)(4 x)}=\frac{3 x^{3} y}{20 x}=\frac{3 x^{2} y}{20}$ & $\frac{x^{2}}{y^{3}} \div \frac{2 x}{3 x y}=\frac{x^{2}}{y^{3}} \times \frac{3 x y}{2 x}=\frac{\left(x^{2}\right)(3 x y)}{\left(y^{3}\right)(2 x)}=\frac{3 x^{3} y}{2 x y^{3}}=\frac{3 x^{2}}{2 y^{2}}$ \\
\hline$\frac{x^{2}+10 x+25}{x+1} \times \frac{x^{2}-1}{x+5}=$ & $\frac{x^{2}+5 x+6}{(x+3)} \div \frac{(x+2)}{x^{2}+3 x+2}=$ \\
$\frac{(x+5)^{2}(x+1)(x-1)}{(x+1)(x+5)}=(x+5)(x-1)$ & $\frac{(x+2)(x+3)}{x+3} \times \frac{(x+2)(x+1)}{x+2}=\frac{(x+2)^{2}(x+3)(x+1)}{(x+3)(x+2)}=$ \\
& $(x+2)(x+1)$
\end{tabular}

En el caso de la suma y resta el proceso también es similar al de las fracciones aritméticas. Vemos el siguiente enlace y comentamos.

https://es.khanacademy.org/math/algebra-basics/core-algebra-expressions / $\mathrm{al} / \mathrm{v} /$ algebraic-expression-adding-fractions

Escribo en mi cuaderno los procesos para sumar y restar fracciones de igual y distinto denominador. Practico con los ejemplos que me proporcionó mi tutor o tutora.

Expreso el área de la siguiente figura. Simplifico si es posible.

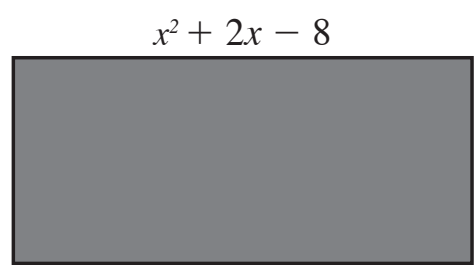

$$
\frac{49-4 x^{2}}{(x+4)(x-2)}
$$

Simplifico y resuelvo las siguientes operaciones con fracciones algebraicas

$$
\begin{aligned}
& -\frac{32 a^{2} b}{4 a b^{5}} \\
& -\frac{x^{2}+9 x+20}{x^{2}+1} \div \frac{x+5}{x-1} \\
& -\frac{4 y}{y^{2}-1}+\frac{3 y+5}{y+1}
\end{aligned}
$$

Recuerdo que las fracciones inconsistentes son aquellas que tienen denominador cero.

Para hallar el área de un cuadrilátero se deben multiplicar las longitudes de los lados que lo conforman. Si las expresiones que representan los lados pueden factorizarse se debe hacer antes de representar el producto. 


\section{Investigación acción participativa}

Reflexiono y respondo.

- ¿Cómo fue mi participación en estas etapas de la Investigación acción participativa?

- ¿Prestaron atención a lo que opiné?

- ¿Respetaron mi punto de vista?

- ¿Cómo me siento al estudiar de esta manera?

Toda persona tiene derecho a ser tomada en cuenta por los miembros de su grupo o comunidad en toda actividad que se realice. También sus opiniones deben ser respetadas por el resto del grupo o comunidad. Estos son parte de nuestros derechos humanos.

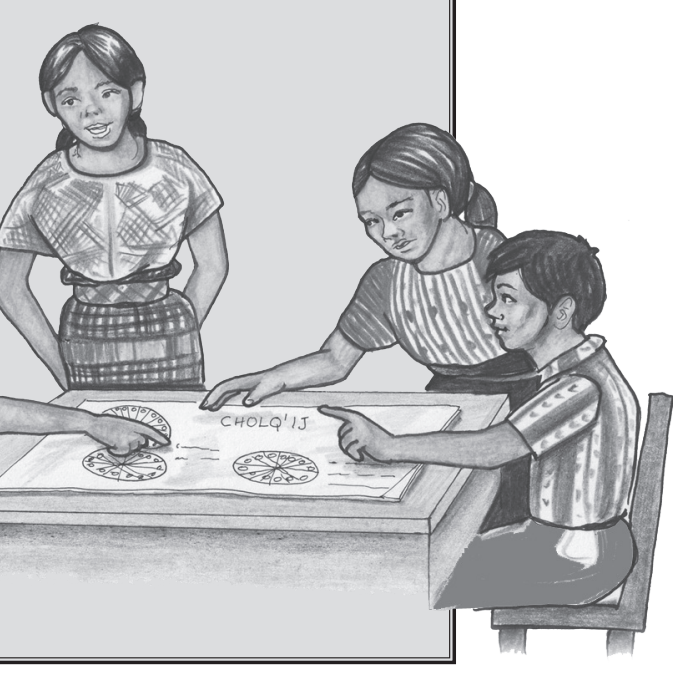

Observemos el esquema.

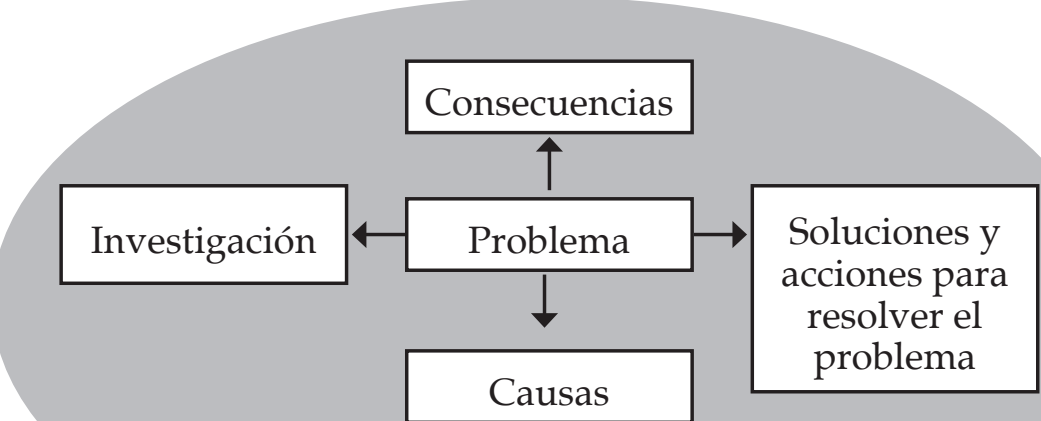

Participación de miembros de la comunidad en todos los procesos

El esquema representa uno de los diseños para investigar en la comunidad: Investigación acción participativa.

Nos reunimos en equipo y analizamos lo que representa el esquema.

- ¿Qué similitud le encontramos con el árbol de problemas?

- ¿Cómo interpretamos el óvalo en el que se encierra el esquema?

La investigación acción es participativa porque un grupo de personas de la comunidad participan en la investigación, en la búsqueda de soluciones y en las acciones para resolver el problema.

\section{Elegimos, con nuestro equipo, un problema del centro educativo}

- Cada integrante del equipo expresará la forma en que ve el problema, su opinión acerca de las causas de dicho problema y las consecuencias que tiene para la comunidad educativa.

- El resto de integrantes anotaremos las opiniones de nuestra compañera o compañero.

- Cuando todas y todos hayamos opinado, procederemos a buscar las similitudes en las respuestas.

- Dialogaremos en torno a las diferencias de opinión y trataremos de llegar a consensos.

- Las opiniones similares y los consensos obtenidos, los ordenaremos en un cuadro como el siguiente.

\begin{tabular}{|c|c|c|}
\hline $\begin{array}{c}\text { ¿Cómo vemos el } \\
\text { problema? }\end{array}$ & Causas & Consecuencias \\
\hline & & \\
\hline & & \\
\hline
\end{tabular}




\section{Transformar las causas de un problema}

Recordemos que para resolver un problema debemos transformar sus causas. Podemos seguir los siguientes pasos.

Primero. Las y los integrantes del grupo nos reuniremos para analizar de qué forma podemos transformar las causas del problema.

- Anotaremos las propuestas de toda y todo integrante del equipo.

- Analizaremos cada propuesta y elegiremos las que consideremos más exitosas.

- Para elegir las propuestas debemos tomar en cuenta las que tengamos capacidad para realizar.

Segundo. Nos organizamos, antes de realizar las acciones que transformarán las causas del problema.

- Comencemos por asignar los cargos más adecuados para realizar las tareas propuestas.

- Distribuimos las funciones que cada quién cumplirá.

Tercero. Cada semana, fijaremos un día y hora para reunirnos y analizar los resultados que hemos obtenido.

- Si valoramos que estamos cumpliendo con lo que nos propusimos, continuaremos con nuestra labor.

- Cuando apreciemos que no lograremos lo propuesto, debemos acordar nuevas medidas, reorganizar o modificar las funciones de los miembros del equipo.

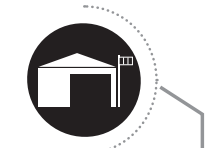

Apliquemos algunos procedimientos de la Investigación acción participativa para revisar la lista de los lugares que pueden ser de interés económico, social, cultural y turístico para la comunidad y que nos servirán para desarrollar el Proyecto 1.

Propongo algunas estrategias para integrar al Prisma publicitario, la información obtenida por el grupo de los lugares de posible interés de la comunidad.

Analizamos, con nuestro equipo de trabajo, la importancia de la organización cuando realizamos tareas en grupo.

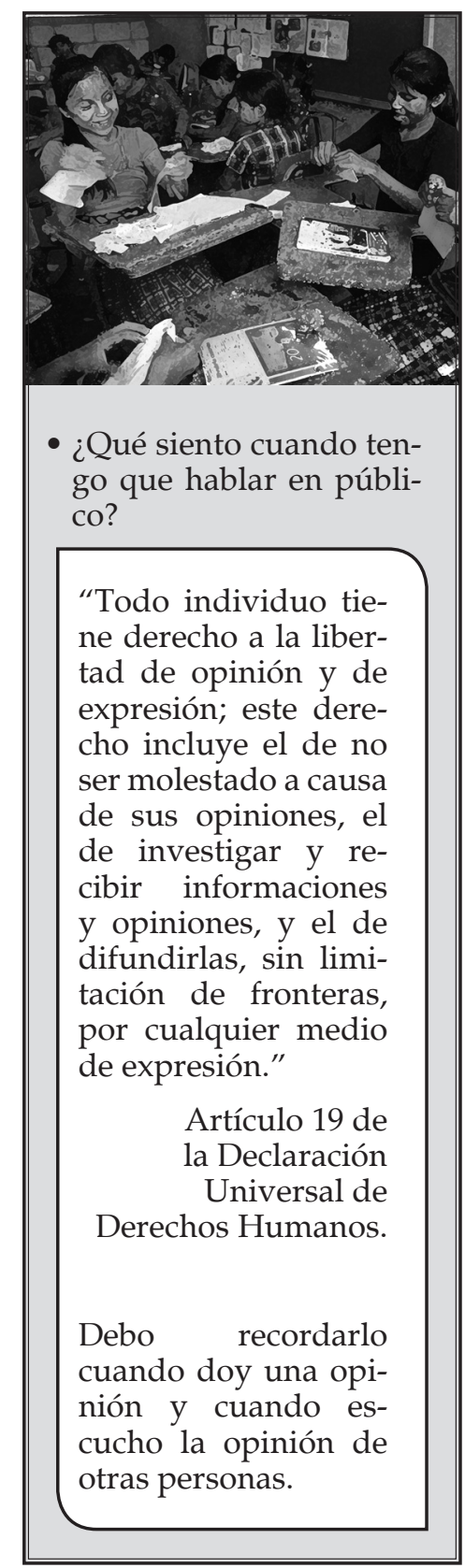

Debo recordarlo cuando doy una opinión y cuando escucho la opinión de otras personas. 


\section{Crecimiento de poblaciones y su autorregulación}

Las relaciones entre los miembros de una comunidad pueden verse afectadas cuando una especie desaparece o crece en demasía. Es lo que pasó en Tacaná en el siglo $X X$. Los pinabetes estaban desapareciendo. Al buscar la causa, resultó que las personas se dedicaban al pastoreo libre de ovejas, las cuales se alimentaban de las semillas del pinabete. Así, se alteró el crecimiento normal de esa población. La solución fue el pastoreo controlado mediante corrales.

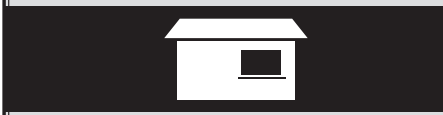

Con respecto a la desaparición del pinabete en Tacaná, respondo en mi cuaderno:

- ¿Qué acciones humanas contribuyeron a la desaparición de gran parte de la población de pinabetes?, ¿qué efectos negativos habría tenido la disminución del pinabete?, ¿qué fenómeno natural contribuyó a este hecho? ¿Cuáles derechos se lesionan cuando un ecosistema se daña por acción humana?

La historia de los lobos que cambiaron el rumbo de un río en Yellowstone, en Estados Unidos de Norteamérica, ilustra este fenómeno. Lo podemos ver en: https://www.youtube.com/ watch? $\mathrm{v}=\mathrm{nHdBB} 9 \mathrm{zTuNA}$

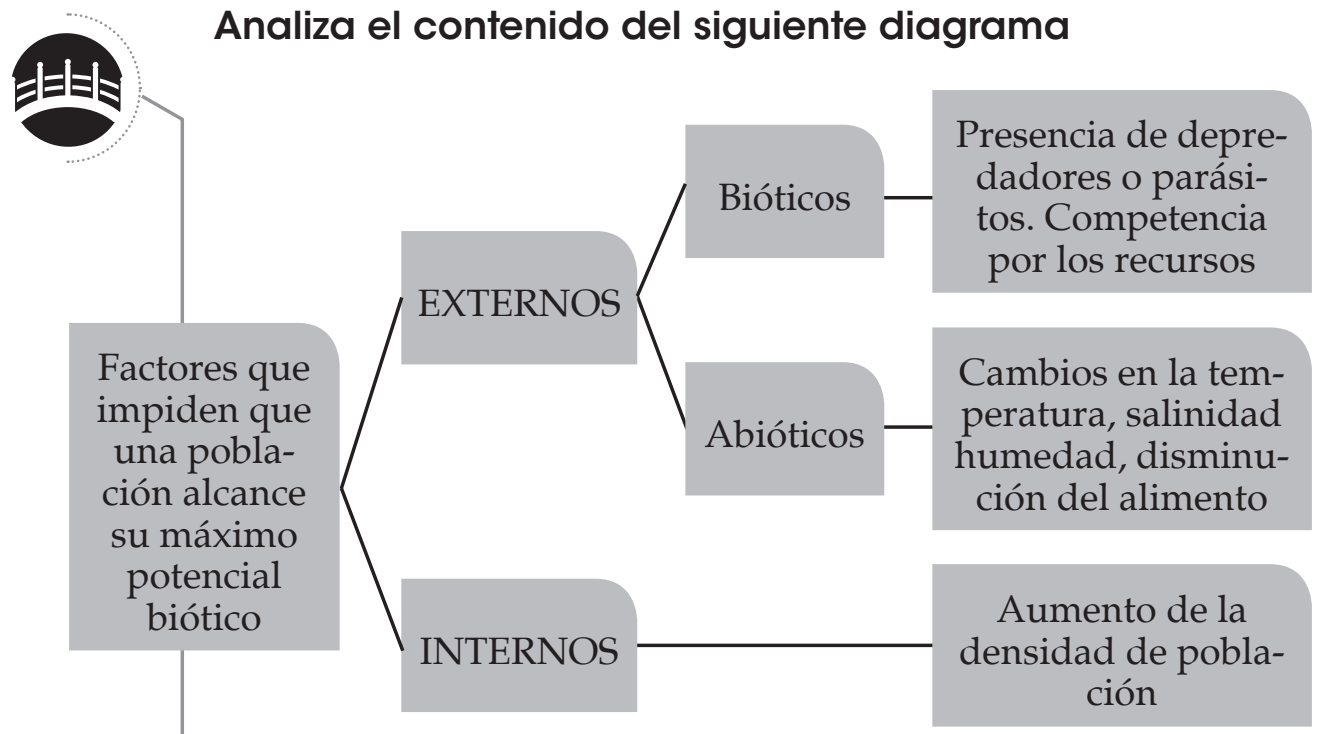

Los ecólogos de poblaciones tratan de determinar los procesos comunes a todas las poblaciones.

Estudian el modo en que una población interactúa con su medio. Por ejemplo, cómo los individuos de una población, compiten por el alimento y otros recursos. También cómo la depredación y otras presiones ambientales afectan a la población.

El principal agente de crecimiento de una población es la natalidad o número de nacimientos. El principal agente de descenso de la población es la mortalidad. También, como factor del crecimiento, se debe tener en cuenta la migración. Las emigraciones y las inmigraciones, son los movimientos de dispersión más importantes.

El crecimiento de una población ha sido favorecida por el avance de la medicina que ha logrado erradicar muchas enfermedades que en el pasado ocasionó numerosas muertes. Como también el acceso de conocimientos de como tener a una mejor calidad de vida, aumentando la etapa productiva del ser humano.

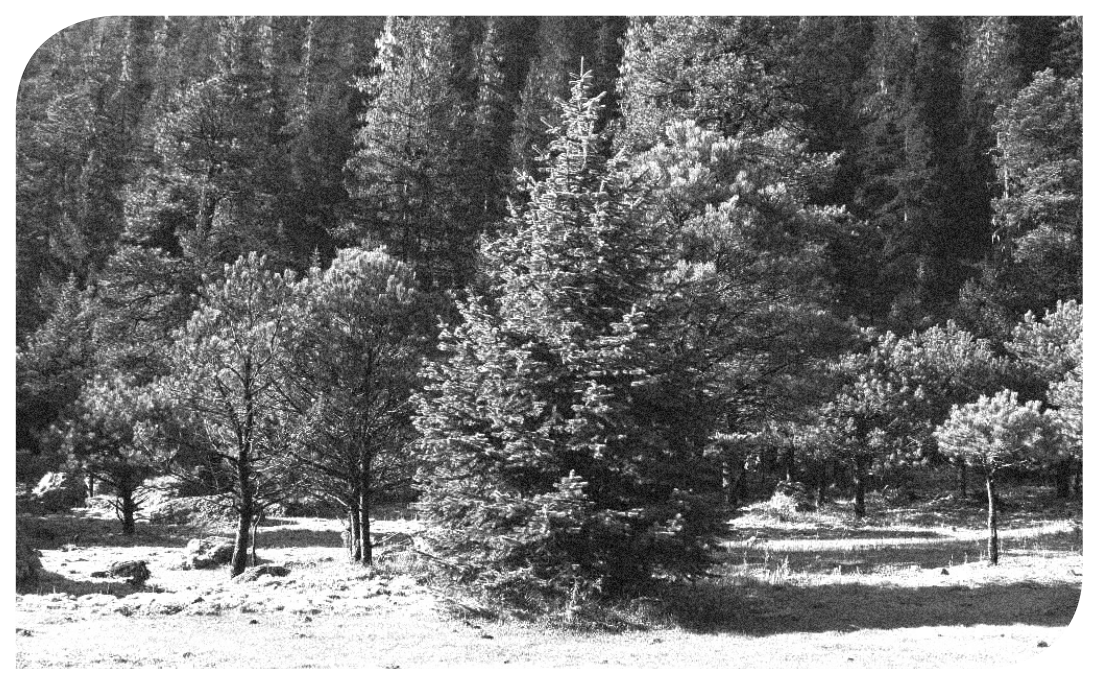

Semana 4 
Observemos la siguiente gráfica:

Proyecciones de la población de Guatemala del 2002 al 2020

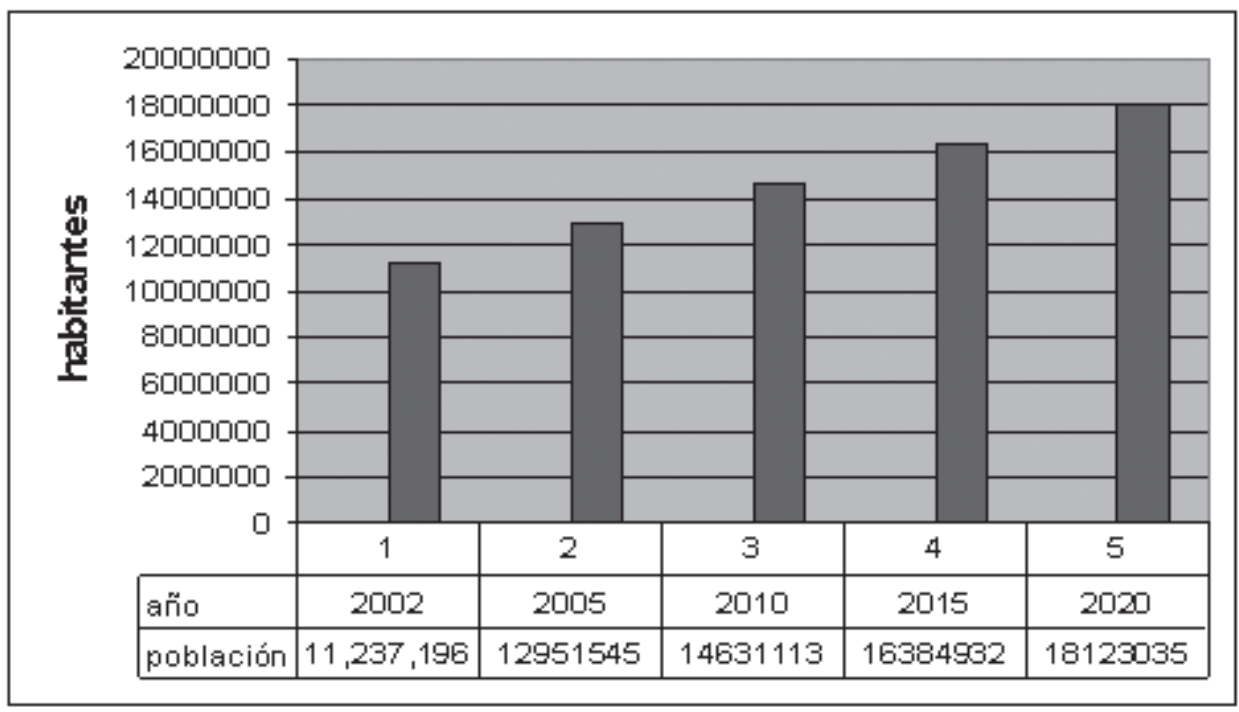

Foto: Estimaciones y Proyecciones de población 1950-2050, INE 1997.

Elaboremos en equipo una interpretación de la información proporcionada por la gráfica.

Organizamos un proyecto de investigación para consultar con expertos de la salud, otras personas y datos relacionados con la autorregulación de la población humana de Guatemala. Tomamos en cuenta los factores externos e internos que pueden incidir en que esta predicción sea una realidad.

Para realizar el proyecto sigamos los siguientes lineamientos:

- Planificamos qué se va a hacer para obtener la información.

- Organizamos comisiones para distribuir el trabajo y decidir cómo lo vamos a hacer.

- Ejecutamos el proyecto. Visitamos las instituciones y las personas a las que vamos a consultar.

- Elaboramos un instrumento para llevar el control de las acciones realizadas.

- Elaboramos un informe con los datos obtenidos.

Elegimos una de las poblaciones vegetales o animales de la comunidad. Indagamos con personas de la comunidad acerca de cómo se regula su crecimiento poblacional. Averiguamos tipos de variación poblacional frecuentes en la comunidad: causas y efectos.
Emigración. Integrantes de una población cambian su lugar de hábitat hacia otro, sin la intención de retornar al lugar original.

Inmigración. Integrantes de una población que se han movilizado de su lugar original, llegan a una nueva ubicación en donde se establecen.

Migración. El traslado que realizan algunas poblaciones en determinadas épocas del año. Suelen ser por ciclos, van y retornan.

Densidad poblacional. La cantidad promedio de integrantes de una población que ocupan un espacio de superficie determinado. Se estima dividiendo la cantidad total de población entre la extensión del área que ocupan. Ejemplo: número de personas por kilómetro cuadrado. Se calcula:

Densidad = Población / $\mathrm{km}^{2}$

Respondemos:

- ¿Qué migraciones de las especies animales que viven en la comunidad observamos? ¿Cómo han afectado los factores abióticos la densidad poblacional de alguna especie vegetal o animal local?

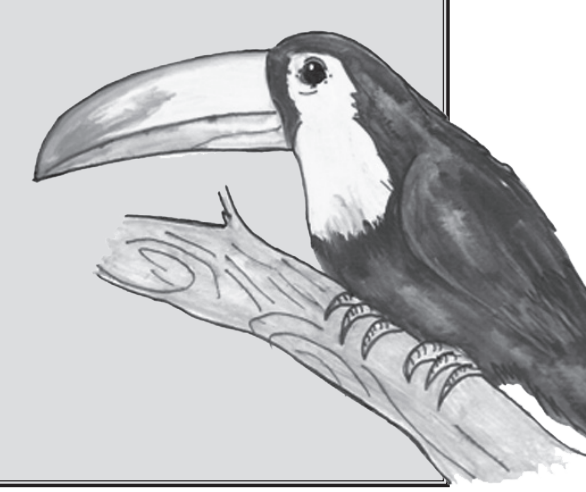




\section{Las etapas de un proyecto}

Un proyecto es un conjunto de actividades que realiza una persona para lograr un resultado u objetivo. Anticipar posibles dificultades y soluciones significa planificar la forma y los medios para alcanzar los objetivos. El plan es una herramienta como el machete que nos ayuda a quitar la maleza para llegar más rápido a nuestro destino.

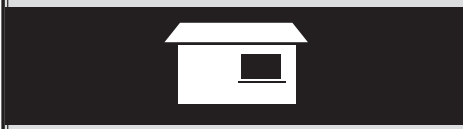

Cuando decidí continuar estudiando, me propuse terminar los estudios de secundaria. ¿Qué planes hice? ¿Los he modificado en estos años? ¿Cómo me organicé para cumplir con mis responsabilidades como estudiante además de las responsabilidades como persona adulta, en el trabajo o como madre o padre? Además de tiempo, ¿qué otros recursos he necesitado? ¿Estoy alcanzando las metas propuestas?

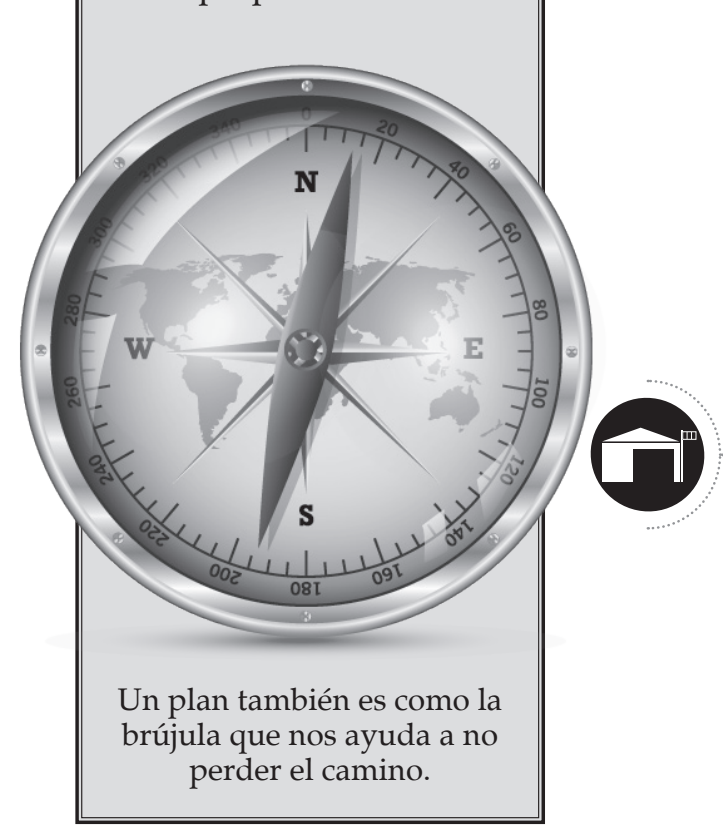

Un plan también es como la brújula que nos ayuda a no perder el camino.
Al igual que con el método científico, los proyectos son el resultado de observar y analizar la realidad y luego, seleccionar un problema que podemos solucionar. Cuando se formula un proyecto de cierta manera se tienen planteadas algunas soluciones, pero se necesita flexibilidad para ajustar el plan a la realidad.

Constantemente estamos planificando eventos en nuestra vida. Desde planear qué vamos a hacer al día siguiente hasta una fiesta familiar: con anticipación pensamos sobre la fecha, la hora, a quiénes invitar, la comida, las bebidas, la música, las mesas, las sillas, las personas que ayudarán y cuánto costará. No hacemos una fiesta de un día para el otro porque para realizar un proyecto exitoso necesitamos tiempo, recursos, información, organización y supervisión.

Analicemos cómo organizamos una fiesta y veremos qué en forma empírica, seguimos el ciclo de un proyecto:

- Diagnóstico. Observamos y estudiamos la realidad para identificar el o los problemas más importantes, sus causas, consecuencias y alternativas de solución. En esta etapa utilizamos las herramientas que ya aprendimos, el árbol de problemas y la investigación participativa.

- Plan del proyecto. Seleccionamos un problema, determinamos los objetivos (resultados o cambios esperados), las actividades a realizar, el presupuesto o costo de cada actividad y el tiempo esperado para alcanzar el objetivo final (cronograma).

- Organización y administración del proyecto. Selección de personas responsables de cada actividad y ejecución de las mismas con los recursos asignados en el tiempo esperado.

- Monitoreo y evaluación. La supervisión constante ayuda a ver los avances, corregir los errores a tiempo y modificar el plan para ajustarlo a la realidad.

- Proyecto revisado y nuevos proyectos. Lecciones aprendidas. Analizamos lo que realizamos y cómo lo realizamos para incorporarlo a los nuevos proyectos y evitar caer en los mismos errores.

En grupo, analizamos el avance del proyecto de promoción de nuestra comunidad.

\begin{tabular}{|l|l|}
\hline \multicolumn{1}{|c|}{ Preguntas } & \multicolumn{1}{|c|}{ Análisis } \\
\hline ¿Cuál fue nuestro diagnóstico? & \\
\hline $\begin{array}{l}\text { ¿Seguimos las indicaciones para el } \\
\text { plan del proyecto? }\end{array}$ & \\
\hline $\begin{array}{l}\text { ¿Seleccionamos responsables de } \\
\text { cada actividad? }\end{array}$ & \\
\hline $\begin{array}{l}\text { ¿Monitoreamos y supervisamos } \\
\text { los avances de cada responsable? }\end{array}$ & \\
\hline
\end{tabular}




\section{Ciclo de un proyecto}

\section{Diagnóstico \\ (Análisis de los problemas)}
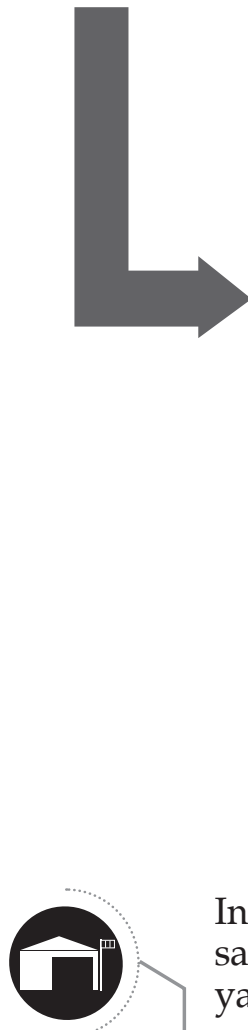

Invitamos a una o un integrante del Consejo Comunitario de Desarrollo (COCODE) para que comparta sobre un proyecto que hayan ejecutado para la comunidad y la experiencia de ejecución del mismo. Algunas preguntas que podemos hacer:

- ¿Cómo decidieron que la solución que están planteando al problema era la más adecuada? ¿Qué factores tomaron en cuenta?

- ¿Cuál es el procedimiento para gestionar un proyecto en el Consejo Municipal de Desarrollo (COMUDE)?

- ¿Quién está a cargo del monitoreo del proyecto? ¿Qué hacen si un proyecto no se está ejecutando como se desea?

Conversemos en familia. Es posible que en casa uno o varios miembros de la familia tenga planes a futuro. Pidamos que nos lo comparta, analicemos con crítica constructiva para que pueda hacer realidad su plan:

- ¿Cuál es el objetivo principal? ¿Cuándo piensa alcanzarlo? Si es a largo plazo, ¿tiene considerado lograrlo por etapas?

- ¿Qué recursos necesita y cómo los va a obtener? ¿Podemos ayudarle? ¿A dónde y a quién necesita acudir para obtener guía y consejo?
Proyecto revisado y nuevos proyectos
Nos rodean problemas que deseamos resolver pero a veces no sabemos cómo o cuál es el más importante. A veces nos abruman, son tantos que no sabemos por dónde empezar. Pero un buen proyecto inicia con un problema bien definido. Antes de iniciar un proyecto, hagámonos estas preguntas:

- ¿Qué factores mantienen o agravan el problema?

- ¿Se ha hecho algo por resolver ese problema? ¿Por qué no se ha podido resolver?

- ¿Qué tan grande es el problema? ¿Se puede resolver inmediatamente o es necesario hacerlo en etapas?

- ¿Podemos solucionar las causas del problema o solo sus síntomas?

- ¿Qué consecuencias estamos viviendo por no solucionar el problema? ¿Cuáles de estas consecuencias podremos solucionar? 


\section{Nuestro patrimonio}

Dentro de nuestro derecho a la educación, se contempla el dominio del idioma español. Observemos nuestra manera de hablar e identifiquemos algunos usos incorrectos para corregirlos.

\begin{tabular}{|c|c|}
\hline Incorrecto & Correcto \\
\hline media vez & una vez \\
\hline andara & anduviera \\
\hline antier & anteayer \\
\hline empedido & impedido \\
\hline saludes & saludos \\
\hline trompezar & tropezar \\
\hline demen & denme \\
\hline delen & denle \\
\hline $\begin{array}{l}\text { desdioy/ } \\
\text { disdioy }\end{array}$ & desde hoy \\
\hline pior & peor \\
\hline querramos & queramos \\
\hline haiga & haya \\
\hline $\begin{array}{l}\text { estudiastes, } \\
\text { comistes }\end{array}$ & $\begin{array}{l}\text { estudiaste, } \\
\text { comiste }\end{array}$ \\
\hline polvazón & polvareda \\
\hline trastes & trastos \\
\hline garraspera & carraspera \\
\hline narizón & narigón \\
\hline $\begin{array}{l}\text { Escribo una } \\
\text { cinco de las } \\
\text { rrectas del lis } \\
\text { en mi cuader }\end{array}$ & $\begin{array}{l}\text { oración con } \\
\text { palabras co- } \\
\text { tado anterior, } \\
\text { to. }\end{array}$ \\
\hline
\end{tabular}

\section{Las tres clases de párrafos}

(ii) Un párrafo es un texto que expone un argumento, describe algo o narra alguna situación. Puede ser argumentativo, descriptivo y narrativo. Un párrafo básico suele estructurarse en tres partes $\mathrm{u}$ oraciones diferentes, separadas por un punto y seguido.

\begin{tabular}{|c|c|c|c|}
\hline $\begin{array}{l}\text { Partes de un } \\
\text { párrafo }\end{array}$ & Argumentativo & Descriptivo & Narrativo \\
\hline Oración 1 & $\begin{array}{l}\text { Idea principal o } \\
\text { tesis }\end{array}$ & $\begin{array}{l}\text { Definición } \\
\text { ¿qué es? }\end{array}$ & $\begin{array}{l}\text { Acción } \\
\text { ¿qué pasa? }\end{array}$ \\
\hline Oración 2 & $\begin{array}{l}\text { Ideas argumen- } \\
\text { to o } \\
\text { ideas de apoyo }\end{array}$ & $\begin{array}{l}\text { Explicación } \\
\text { ¿por qué? }\end{array}$ & $\begin{array}{l}\text { Personajes } \\
\text { ¿quiénes? }\end{array}$ \\
\hline Oración 3 & $\begin{array}{l}\text { Confirmación de } \\
\text { la tesis } \\
\text { o síntesis }\end{array}$ & $\begin{array}{l}\text { Ejemplo } \\
\text { ¿cómo es? }\end{array}$ & $\begin{array}{l}\text { Ambiente } \\
\text { ¿dónde y cuán- } \\
\text { do? }\end{array}$ \\
\hline Ejemplo: & $\begin{array}{l}\text { El patrimonio es } \\
\text { la suma de los } \\
\text { valores de los } \\
\text { recursos dispo- } \\
\text { nibles en una } \\
\text { comunidad (1). } \\
\text { Estos recursos } \\
\text { debieran usar- } \\
\text { se para la vida } \\
\text { económica y en } \\
\text { beneficio de los } \\
\text { habitantes de ese } \\
\text { grupo humano } \\
\text { (2). Por ello, es } \\
\text { importante iden- } \\
\text { tificarlo, valorar- } \\
\text { lo y defenderlo } \\
\text { (3). }\end{array}$ & $\begin{array}{l}\text { Los derechos } \\
\text { son reglas o } \\
\text { normas que fija } \\
\text { una autoridad y } \\
\text { que son propie- } \\
\text { dad del pueblo } \\
\text { (1). Los merecen } \\
\text { todas las perso- } \\
\text { nas, sin importar } \\
\text { su origen, su } \\
\text { género, su edad } \\
\text { o su religión (2). } \\
\text { Por ejemplo, } \\
\text { el derecho a la } \\
\text { educación (3). }\end{array}$ & $\begin{array}{l}\text { Una tradición } \\
\text { consiste en una } \\
\text { acción que se re- } \\
\text { pite para celebrar } \\
\text { algo (1). Gene- } \\
\text { ralmente, en esta } \\
\text { celebración par- } \\
\text { ticipa la mayoría } \\
\text { de habitantes de } \\
\text { una comunidad } \\
\text { (2). Puede llevar- } \\
\text { se a cabo en una } \\
\text { plaza, la calle o } \\
\text { un lugar específi- } \\
\text { co, para celebrar } \\
\text { una fecha im- } \\
\text { portante como la } \\
\text { navidad (3). }\end{array}$ \\
\hline
\end{tabular}

- Identificamos las partes de cada párrafo, en la tabla anterior. Escribimos un párrafo relacionado con el patrimonio de nuestra comunidad.

- Revisamos y corregimos los borradores de los artículos que in-

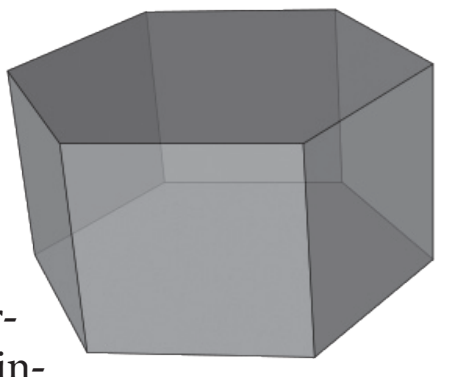
cluiremos en el prisma.

- Elaboramos un boceto de los elementos que incluirá el prisma publicitario.

- Cuidamos el uso adecuado del vocabulario, conforme lo aprendido. 


\section{Los lenguajes de la publicidad}

La publicidad es una herramienta de persuasión. Esto significa que busca convencer al mayor número de personas, en el menor tiempo posible, para impulsarlas a que adquieran los productos o servicios anunciados. La publicidad tiene aspectos negativos y positivos.
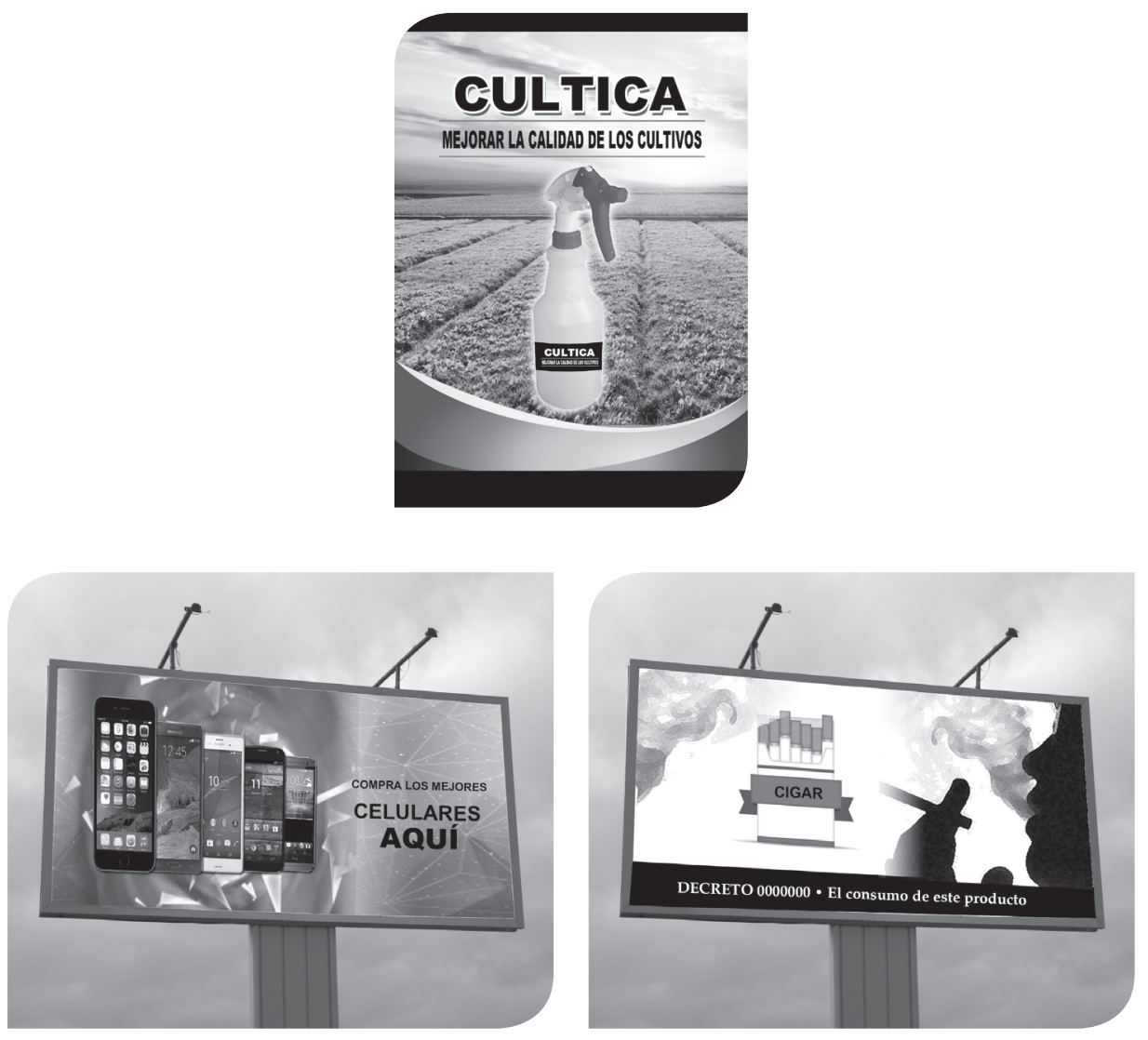

\begin{tabular}{|c|c|c|}
\hline Ventajas & Desventajas & Tipos \\
\hline $\begin{array}{l}\text { Permite a quien consu- } \\
\text { me establecer compara- } \\
\text { ciones entre los produc- } \\
\text { tos, informa a las y los } \\
\text { consumidores acerca } \\
\text { de la existencia de nue- } \\
\text { vos productos, educa e } \\
\text { informa sobre temas de } \\
\text { interés nacional. }\end{array}$ & $\begin{array}{l}\text { Crea necesidades fal- } \\
\text { sas; presenta al dinero } \\
\text { como el valor por ex- } \\
\text { celencia; establece mo- } \\
\text { delos que pueden ser } \\
\text { irreales de la belleza, } \\
\text { la felicidad o el éxito; } \\
\text { apela más a los sentidos } \\
\text { que a la razón de quien } \\
\text { consume; puede orien- } \\
\text { tar a adquirir hábitos } \\
\text { nocivos para su salud y } \\
\text { bienestar. }\end{array}$ & $\begin{array}{l}\text { La publicidad puede } \\
\text { ser de tipo comercial, } \\
\text { política, social, educati- } \\
\text { va y deportiva. } \\
\end{array}$ \\
\hline
\end{tabular}

- Organicemos varias investigaciones en grupos de dos a tres personas sobre cada uno de nuestros derechos, nuestras tradiciones y los elementos de nuestro patrimonio.

- Elaboremos un texto escrito sobre cada uno y empleemos los párrafos que sean necesarios. Podemos usar los que ya empezamos a redactar en la actividad anterior.

- Pensemos, ¿cómo nos afecta su pérdida? ¿Cómo podemos lograr que todas y todos los integrantes de nuestra comunidad los conozcan?

- Utilicemos carteles publicitarios que ilustren nuestras ideas.

- Concluyamos esta actividad con la reflexión sobre la importancia de conocer nuestras riquezas naturales, culturales y sociales.

La conciencia es como el sol; cuando brilla sobre las cosas, estas se transforman. Así, tengamos conciencia de nosotros mismos. 


\section{Simbología y expresividad del color, mezcla de colores}

El color es una sensación óptica provocada por el reflejo de la luz. La ausencia total de luz es el color negro. En el siglo XVII, Isaac Newton descubrió que la luz blanca es el producto de la combinación de todos los tonos de color. Si se ponen todos los colores en un prisma y este se hace girar se obtiene el color blanco.

En el siglo XVI, Sofonisba Anguisola, una pintora italiana, pintó retratos y escenas aplicando con maestría las técnicas de la luz reflejada por el color.

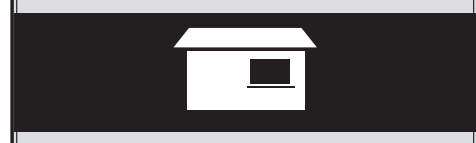

Respecto del uso de los colores en pinturas, fotografías, anuncios publicitarios, películas, revistas y periódicos, respondo en mi cuaderno:

- ¿Con qué propósito usan los colores en sus obras de arte? Imagino ¿cómo sería un mundo sin colores tan variados? ¿Cómo me influyen a mí los colores?

Pausa pedagógica: Hace-
mos una coreografía de una
canción popular guatemal-
teca que nos identifique.

Analicemos el contenido del siguiente diagrama

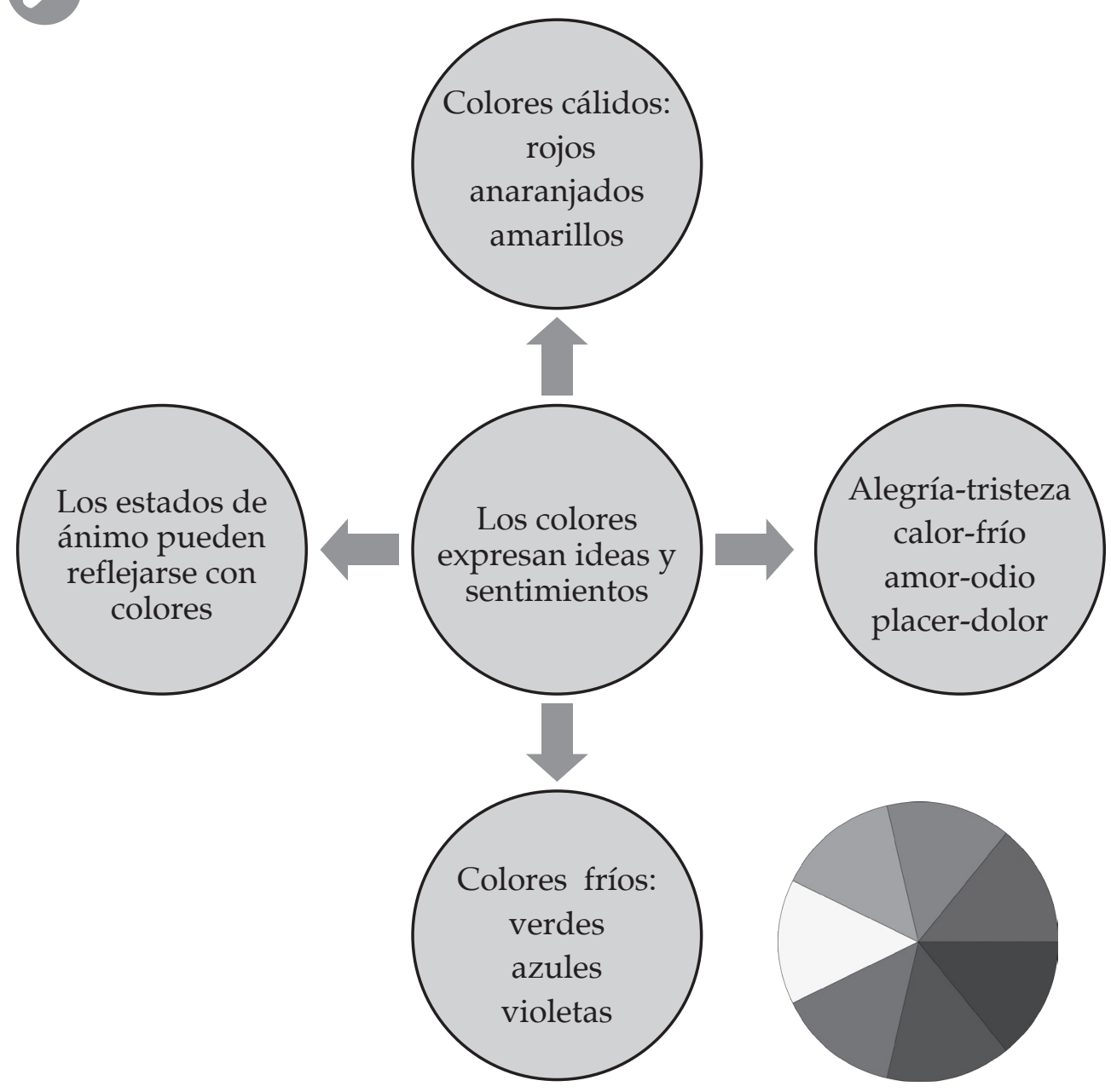

Quienes se dedican a la pintura y al diseño han clasificado los colores según los estados de ánimo que provocan. Los colores fríos y cálidos proyectan la sensación de temperatura que su nombre indica. Un cuadro realizado con colores rojos, anaranjados y amarillos fácilmente se relaciona con el calor del día. En cambio, un cuadro realizado con colores verdes, azules y violetas puede relacionarse con el frío de la noche.

El mismo cuadro pintado con ambas combinaciones de colores puede relacionar diversos estados de ánimo. También expresa ideas y sentimientos que las y los artistas quieren transmitir.

Foto: Autorretrato de Sofonisba Anguissola.

Fuente: http:/ / uncajonrevuelto.com/ ?p=786 


\section{Pinturas murales}

Observemos las siguientes imágenes
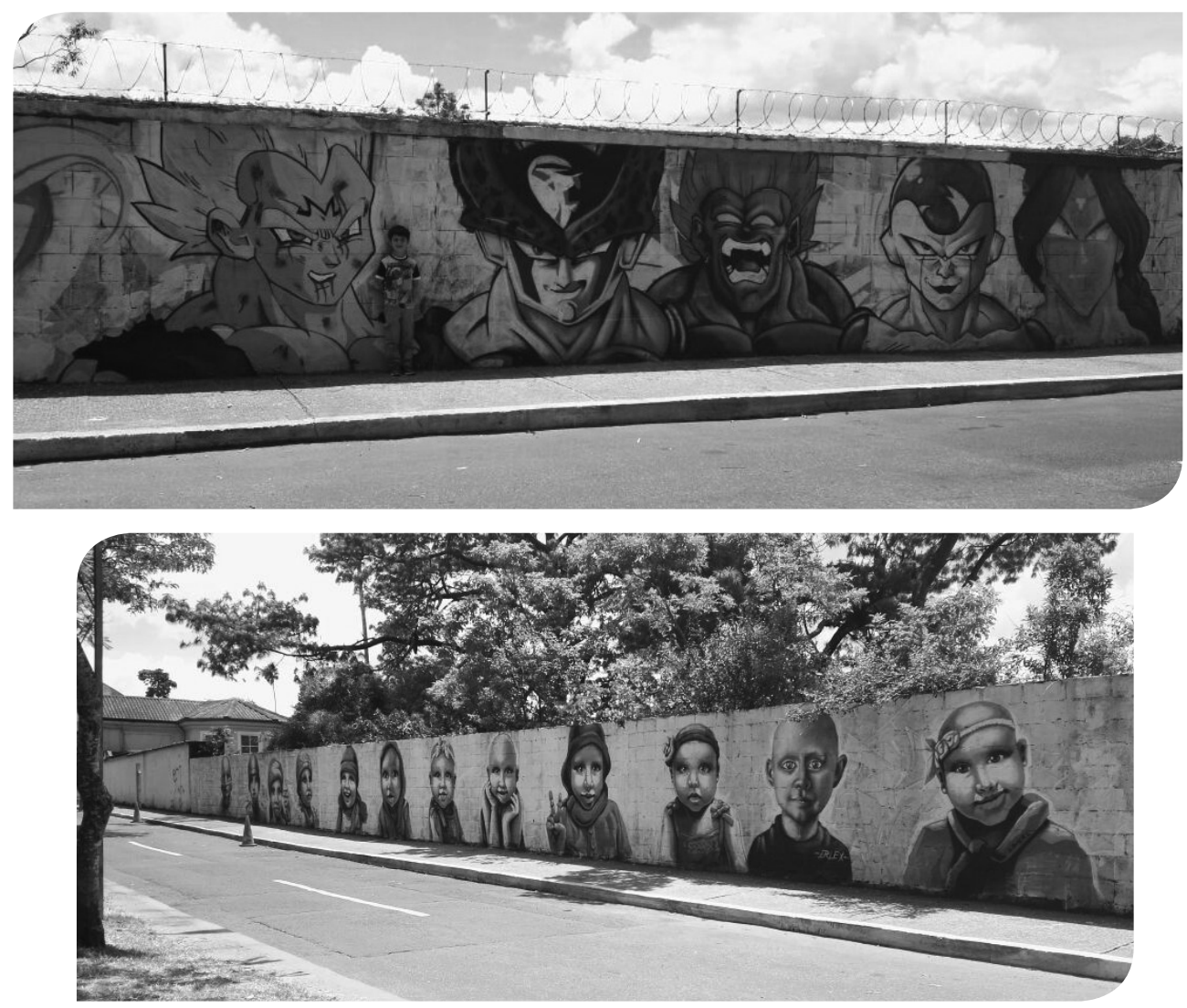

Fotos: Graffitis ubicados en la Avenida Simeón Cañas, zona 2 Ciudad de Guatemala.

En grupos, discutimos sobre la imagen y leemos el texto:

¿En dónde hemos visto este tipo de arte?, ¿quiénes realizan estas pinturas?, ¿para qué puede servir una pintura como esta?, ¿cómo se combinan allí los tonos cálidos y fríos?

La pintura mural es una técnica que se realiza sobre paredes o muros. Su práctica generalmente es un acuerdo entre el o la artista y el espacio donde se realiza. Todas las pinturas sirven para expresar ideas y sentimientos. Algunas son famosas porque retratan la forma en que viven las personas. A veces, sus condiciones de vida son difíciles. Su arte lleva un mensaje social importante.

Busco información sobre las personas que realizan pintura en mi comunidad. Consulto con las personas mayores, abuelas y abuelos sobre la historia de esas personas. Escribo una lista de las mujeres y los hombres que utilizan la combinación de colores para expresar sus ideas y sentimientos.
El graffiti también es una técnica de pintura realizada sobre paredes en lugares públicos. Su principal característica es que puede parecer ilegal o prohibido si se realiza en espacios privados. Sin embargo, si se realiza en espacios que no son de uso estatal, residencial o comercial, pueden aportar a la estética de una calle o espacio abandonado. O bien, ser un medio que promueve el derecho a la libertad de expresión.

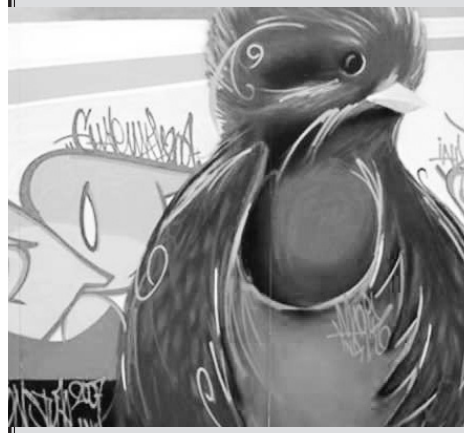

Fuente: http:/ /brujula.com. gt/grafiti-en-guatemala-moda-o-arte/

En grupos, realizamos un diseño para realizar nuestro prisma como proyecto. Realizamos tres propuestas, una utilizando solo colores fríos, otra utilizando solo colores cálidos, y otra combinando ambos tonos de una manera estética y agradable. 


\section{Técnicoss para representar imágenes}

Observemos el siguiente diagrama

\begin{tabular}{|c|c|c|}
\hline \multicolumn{3}{|c|}{$\begin{array}{c}\text { Cómo trabajar imágenes } \\
\text { artísticas }\end{array}$} \\
\hline $\begin{array}{l}\text { Dibu- } \\
\text { jamos } \\
\text { con } \\
\text { líneas } \\
\text { y for- } \\
\text { mas }\end{array}$ & $\begin{array}{l}\text { Pinta- } \\
\text { mos y } \\
\text { deco- } \\
\text { ramos } \\
\text { nues- } \\
\text { tros } \\
\text { dibu- } \\
\text { jos }\end{array}$ & $\begin{array}{l}\text { Organi- } \\
\text { zamos } \\
\text { imáge- } \\
\text { nes pre- } \\
\text { diseña- } \\
\text { das en } \\
\text { collages }\end{array}$ \\
\hline
\end{tabular}

Podemos dibujar usando únicamente líneas y creando imágenes de la comunidad, de las personas y de los espacios sociales.

También podemos agregar color a los dibujos y utilizar técnicas de pintura con acuarela, óleo, crayón de cera o pastel, los dedos o graffitti. Podemos usar tintes naturales.

Al organizar las imágenes podemos usar la técnica del collage, que combina dibujo, pintura y fotografía para integrar imágenes ya trabajadas. También se puede usar la técnica para combinar hojas, tierra u otro material del entorno.

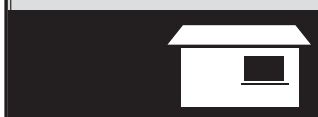

Busco fotografías en periódicos, revistas, otros medios impresos y material de desecho. Recorto y colecciono 20 imágenes. Las organizo y pego en una hoja, dando forma de collage y lo presento al grupo.

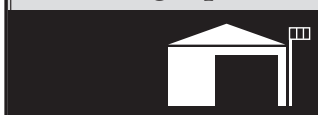

En equipo: analizamos el tipo de mensaje de las imágenes. Identificamos si muestran problemas poblacionales, estereotipos, cosificación de la mujer, discriminación u otro.
En grupos, discutimos la construcción artística del prisma:

¿Cuáles imágenes de la comunidad nos gustaría divulgar en el prisma de nuestro proyecto?, ¿Cómo organizamos artísticamente las imágenes? ¿Qué recursos necesitamos?, ¿Cómo podemos visualizar nuestros problemas usando el arte plástico?

\section{El collage}

Es una técnica plástica mixta que combina el manejo de dibujos, pinturas y fotografías. Cualquier imagen puede sobreponerse a otra parcialmente, es decir, una sobre otra, tapándole una parte; para formar una composición visual o grupo de imágenes relacionadas entre sí con un mensaje común. Formas de letras, figuras de todo tipo, cualquier forma con color, pueden servir para componer una imagen más grande.
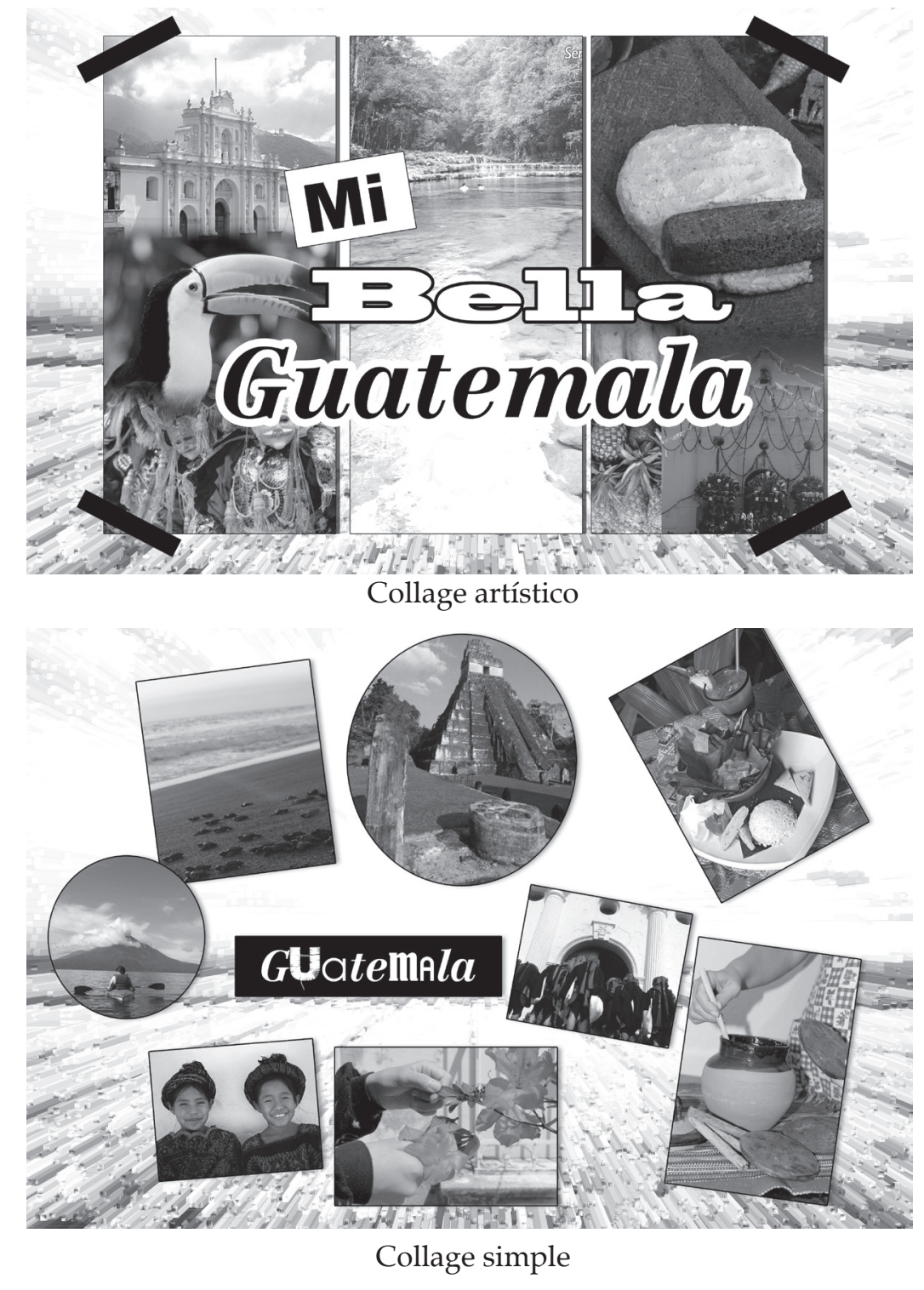


\section{El arte aplicado a la vida de la comunidad}

\begin{tabular}{|c|c|c|c|}
\hline Música & Teatro & Danza & Artes Plásticas \\
\hline $\begin{array}{l}\text { Los materiales con los } \\
\text { que se realiza la música } \\
\text { son: } \\
\text { sonidos, instrumentos, la } \\
\text { voz, madera, lámina, so- } \\
\text { nidos de la Naturaleza. } \\
\text { También con aparatos } \\
\text { electrónicos y reproduc- } \\
\text { tores de audio, teléfonos, } \\
\text { computadoras, ipods, } \\
\text { etc. } \\
\text { Se transmite a través de } \\
\text { los medios de comunica- } \\
\text { ción: radio, radio comu- } \\
\text { nitaria, presentaciones } \\
\text { en vivo en asambleas } \\
\text { comunitarias y fiestas } \\
\text { patronales, televisión, in- } \\
\text { ternet. }\end{array}$ & $\begin{array}{l}\text { Utiliza los siguientes re- } \\
\text { cursos: } \\
\text { movimiento escénico, } \\
\text { actuación, } \\
\text { escenografía, } \\
\text { Iluminación. } \\
\text { Se expresa a través de es- } \\
\text { cenas y obras de teatro. }\end{array}$ & $\begin{array}{l}\text { Utiliza como recursos: } \\
\text { movimientos, expresión } \\
\text { corporal, } \\
\text { ritmo y coordinación. } \\
\text { Se expresa a través de } \\
\text { escenas de movimientos } \\
\text { articulados y bailes. }\end{array}$ & $\begin{array}{l}\text { Utiliza estos recursos: } \\
\text { líneas, colores, formas y } \\
\text { texturas. } \\
\text { Se expresan a través de } \\
\text { composiciones como } \\
\text { pinturas, esculturas, } \\
\text { collages, murales. }\end{array}$ \\
\hline
\end{tabular}

\section{¿Cómo los usamos?}

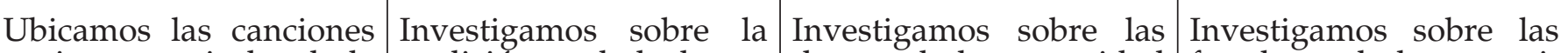
y piezas musicales de la tradición oral de la co- danzas de la comunidad comunidad y las divul- munidad y sus obras tea- y promovemos su difugamos.

Ubicamos los materiales y medios disponibles para divulgar nuestra música regional. trales o juegos de repre- sion. sentación.

Participamos en obras que visibilicen los problemas de la comunidad. fortalezas de la comunidad que podemos visibilizar mediante el arte.

Bailamos y participamos en bailes colectivos. decoramos, organizamos collages y pinturas murales.

Tenemos varios proyectos que realizar en este ciclo de estudio. En cada proyecto podemos utilizar una o varias de las expresiones artísticas para desarrollarlo mejor. Esto evidencia que el arte es una parte importante en la vida de las personas y de toda la comunidad. Podemos incluir otras expresiones de la cultura guatemalteca, como los convites y los murales de algunas comunidades. En el proyecto actual, para elaborar el prisma usamos más las artes plásticas, aunque podemos pensar en actividades que usen las otras expresiones artísticas. Además, podemos analizar el mensaje de toda expresión del arte. Por ejemplo: el mensaje de una canción de moda y los roles o estereotipos que identificamos.

- Busco información sobre las posibilidades del collage artístico usando diversos materiales.

- Busco materiales que encuentre en casa: tela, granos o semillas, fotografías o imágenes de la comunidad. Planteo una composición de collage que muestre los problemas que queremos resolver. Lo hago con las ideas artísticas que aprendí.
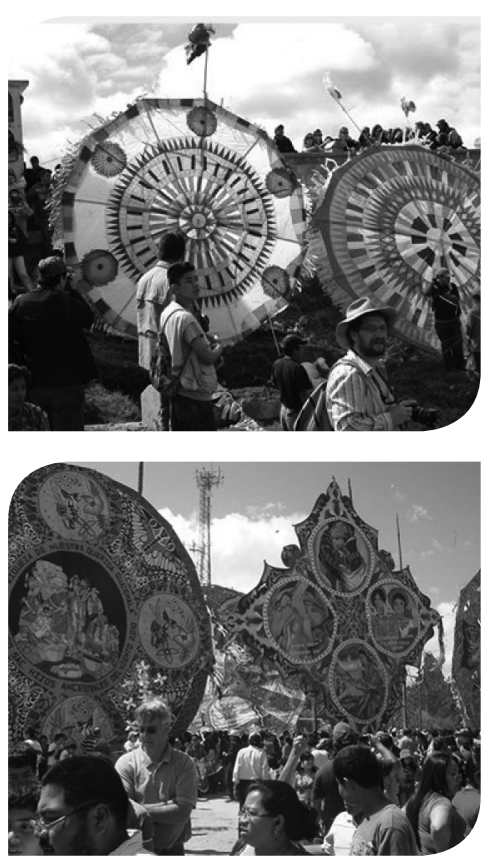


\section{Operaciones básicas con fracciones algebraicas}

El área o superficie de una figura geométrica puede hallarse utilizando las siguientes fórmulas:

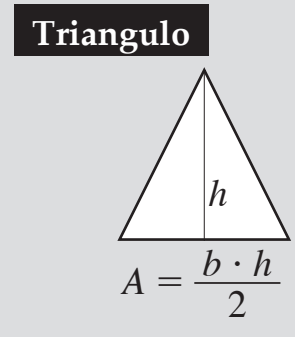

\section{Cuadriláteros}

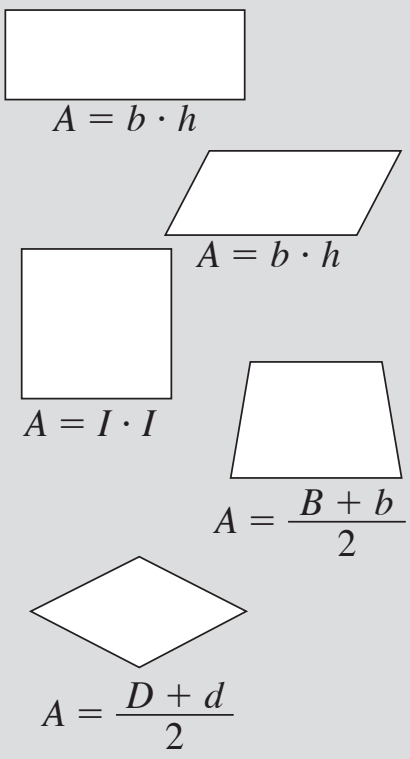

Poligonos

regulares

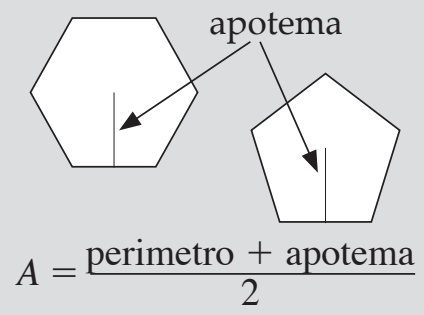

El perímetro de una figura geométrica es la suma de las longitudes de todos los lados que la conforman.

- Investigo y propongo cómo hallar el área y perímetro de un círculo.
¿Qué lugares turísticos conocemos en la comunidad? Representamos las formas de algunos de ellos con un dibujo. ¿Averiguamos las dimensiones, en metros, de algunos de esos lugares? Colocamos las medidas conocidas o estimadas en los dibujos que realizamos.

¿Qué figura se asemeja más al espacio que estamos ocupando?
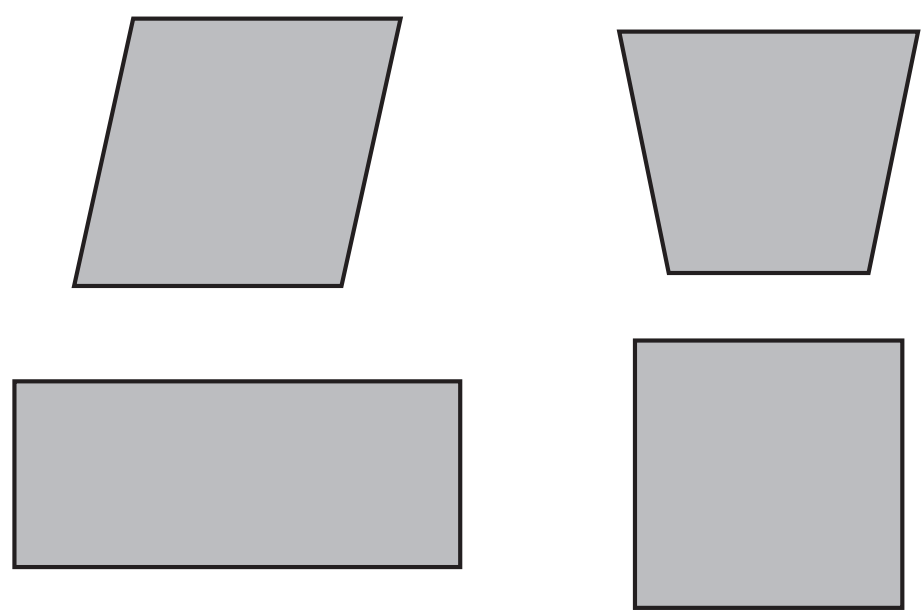

Discutimos nuestras respuestas y comentamos cómo podríamos determinar el área del lugar dónde nos encontramos. ¿Necesitaríamos algún instrumento para efectuar el cálculo?

Investigamos qué es densidad de población. Anotamos las ideas principales y comentamos: ¿podemos representar la densidad de población como una fracción? ¿Cuál es la densidad de población del área que ocupamos en este momento? ¿Cómo se compara con la densidad de población de toda la comunidad?

Formamos grupos de 4 personas para calcular el área y perímetro de los lugares que dibujamos. Comentamos cómo hallamos dichas medidas y compartimos con los otros grupos nuestros procedimientos y respuestas. ¿De qué forma nos sirven estos cálculos en la comunidad?

En los mismos grupos, utilizamos los dibujos de los lugares turísticos y escribimos expresiones algebraicas que representen las longitudes de los lados de las figuras. Cada 3 metros corresponderán a la letra $X$; por ejemplo: si una longitud es de 11 metros, la expresión será: $3 x+2$. Escribimos dichas expresiones a la par de cada lado de nuestras figuras. Averiguamos cuántas visitas, en promedio, reciben el fin de semana estos lugares turísticos. Escribimos una expresión para representar la densidad de población de dichos lugares.

¿Cuál es la densidad de población de nuestro país? ¿Es parecida o distinta a la densidad poblacional de los lugares de nuestra comunidad? Comentamos nuestras respuestas. 
- Utilizamos nuestras figuras algebraicas para hallar el perímetro de las figuras que dibujamos.

- Hallamos una expresión algebraica para el área de las mismas. También podemos utilizar nuestras figuras algebraicas.

- Escribimos, y simplificamos si es posible, fracciones algebraicas que relacionen:

a) Las longitudes de los lados de una misma figura.

b) El perímetro y el área de una misma figura.

c) Las longitudes de los lados de dos figuras distintas.

d) ¿Cuál es el área de los siguientes cuadriláteros formados con fichas algebraicas? Escribo los factores que forman la figura y el producto.

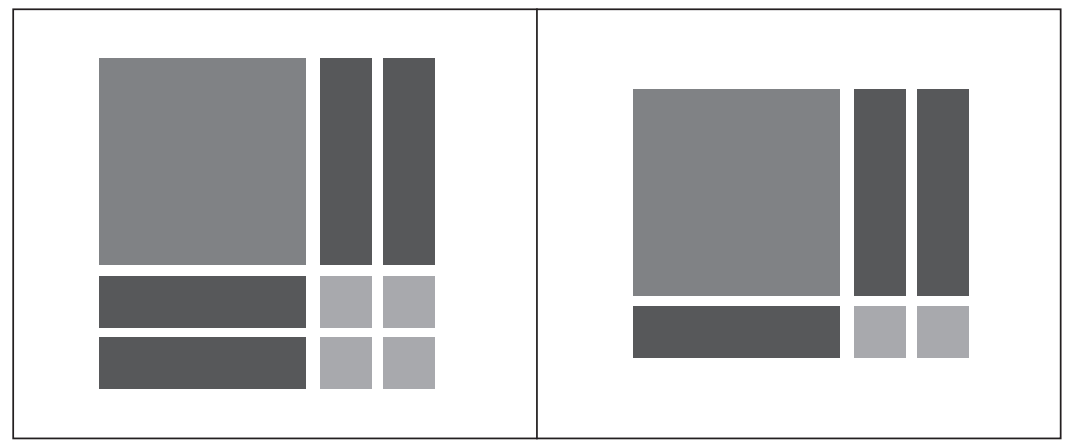

En mi cuaderno, escribo dos ejemplos de cada operación con fracciones algebraicas. Explico el procedimiento que debe hacerse para resolver cada una de ellas. Anoto en tarjetas distintas los procedimientos para efectuar las operaciones.

Comparto la información de mis tarjetas con el resto del grupo. Analizamos aciertos y errores en las mismas y luego presentamos al resto de compañeras y compañeros. Discutimos si fue posible utilizar las figuras algebraicas para resolver operaciones con fracciones algebraicas.

Sumo las fracciones
a) $\frac{3}{x-1}+\frac{x}{x+1}+\frac{4}{x^{2}+1}$
b) $\frac{x-1}{x+2}+\frac{3}{x-2}-\frac{3 x+4}{(x+2)^{2}}-\frac{x+2}{x^{2}-4}$

Simplifico
a) $\frac{x^{3}+x}{x^{4}-1}$
b) $\frac{m^{2}-9}{9 m-m^{3}}$
c) $\frac{a x+b y}{a x^{2}+b x y}$

Las fracciones complejas son fracciones que constan de una o más fracciones en el numerador, en el denominador o en ambos. Observo algunos ejemplos:

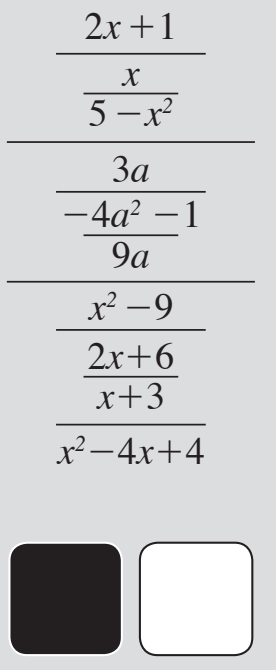




\section{Planificación; organización y administración}

Muchos proyectos necesitan de varias personas para ejecutarse de manera rápida y eficiente. El trabajo en equipo no es fácil, pero si se logra es muy satisfactorio. Fomenta la amistad, el rendimiento y la solidaridad. La organización y distribución equitativa de las tareas es importante para que cada integrante del equipo aporte según sus habilidades y responsabilidades.

\section{$\square$}

¿Trabajo en equipo con $\mathrm{mi}$ familia? Elaboro un cuadro comparativo de las tareas que cada integrante realiza y reflexiono sobre la distribución de tareas. Agrego columnas o filas según las y los integrantes y sus tareas. Ejemplo:

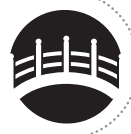

\section{Planificar para alcanzar metas}

Para alcanzar una meta, es necesario planificar las actividades. Esto implica prever cómo, dónde, cuándo, con quién y con qué realizaremos las actividades. También se requiere de una adecuada organización y administración. Organizar los recursos y actividades significa que anticipamos qué necesitamos hacer en cada paso de nuestra planificación con qué recursos y en qué momento. Administrar los recursos significa utilizarlos en el momento justo de manera eficiente.

Antes de realizar una tarea, es conveniente planificarla. También se requiere adecuada organización y administración. Así por ejemplo, preparar el almuerzo de la familia, requiere organización y administración. Estudiemos el proceso.

Planificamos el menú según la ocasión, calculamos la cantidad de los ingredientes según el número de personas, algunas veces ajustamos el menú para no desperdiciar ingredientes, preparamos un presupuesto y, posiblemente, ajustamos el menú para adaptarlo a nuestras posibilidades económicas. Hacemos esto con anticipación, pues comidas, como los tamales, requieren varios días de preparación y, según la cantidad preparada, también de varias personas que ayuden en distintos momentos y en diferentes actividades.

Este ejemplo muestra la organización y administración de recursos. Estos pueden ser económicos, materiales y humanos. Los recursos económicos se refieren al dinero que necesitamos. Los recursos materiales, son, entre otros, los ingredientes, ollas, cuchillos, paletas, leña o gas para cocinar. Recursos humanos, son, por ejemplo, cocineras, cocineros y ayudantes. Pasos similares se utilizan para realizar cualquier otra labor, ya sea de carpintería o de construcción o incluso de un proyecto social o productivo.

Selecciono una tarea productiva y pido permiso a la persona que la realiza para entrevistarla y acompañarla durante la ejecución de la tarea. Elaboro un diagrama mostrando las actividades que realiza, el tiempo y los recursos utilizados.

$\circ$

\begin{tabular}{|l|c|l|l|l|l|l|l|}
\hline Horario & Tareas & \multicolumn{5}{|c|}{ Miembros de la familia } \\
\hline & $\begin{array}{c}\text { Levantarse } \\
\text { a preparar } \\
\text { el } \\
\text { desayuno }\end{array}$ & Mamá & Papá & Hija & Hijo & Abuela & Abuelo \\
\hline & & & & & & & \\
\hline & & & & & & & \\
\hline
\end{tabular}


También organizamos y administramos nuestras expectativas de trabajo, estudios y otras metas que forman parte de nuestro proyecto de vida. Cualquier meta individual requiere tiempo y recursos. También, la vida en pareja implica compaginar aspiraciones de dos personas en una misma línea de tiempo, es una de las planificaciones importante de la vida. Conlleva decidir sobre recursos limitados en un tiempo definido. Las hijas y los hijos necesitan recursos, cantidad y calidad de tiempo durante un período prolongado de nuestras vidas. La familia utiliza sus recursos para satisfacer las necesidades de todos los miembros. Por eso es importante prever cómo, cuándo, cuánto y cuáles recursos necesitaremos.

Planificar significa tomar decisiones sobre nuestras vidas. Una decisión puede marcar el curso de nuestras vidas, por eso si hemos decidido tener una pareja para consolidar nuestra familia es importante conocerle, respetar y pedir respeto a nuestras opiniones y decisiones, alejarnos ante la primera señal de violencia física, sicológica o emocional, apoyar nuestras metas y sueños individuales y de pareja, dialogar abierta y libremente sobre temas sensibles como religión, política, sexo, economía y relaciones familiares, entre otros y llegar a un acuerdo sobre el número de hijos e hijas que deseamos tener.

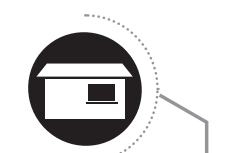

Investigamos sobre el acceso a los servicios de salud reproductiva en nuestra comunidad y reflexionamos cómo la toma de decisiones del hombre y la mujer influye en la administración de los recursos del hogar.
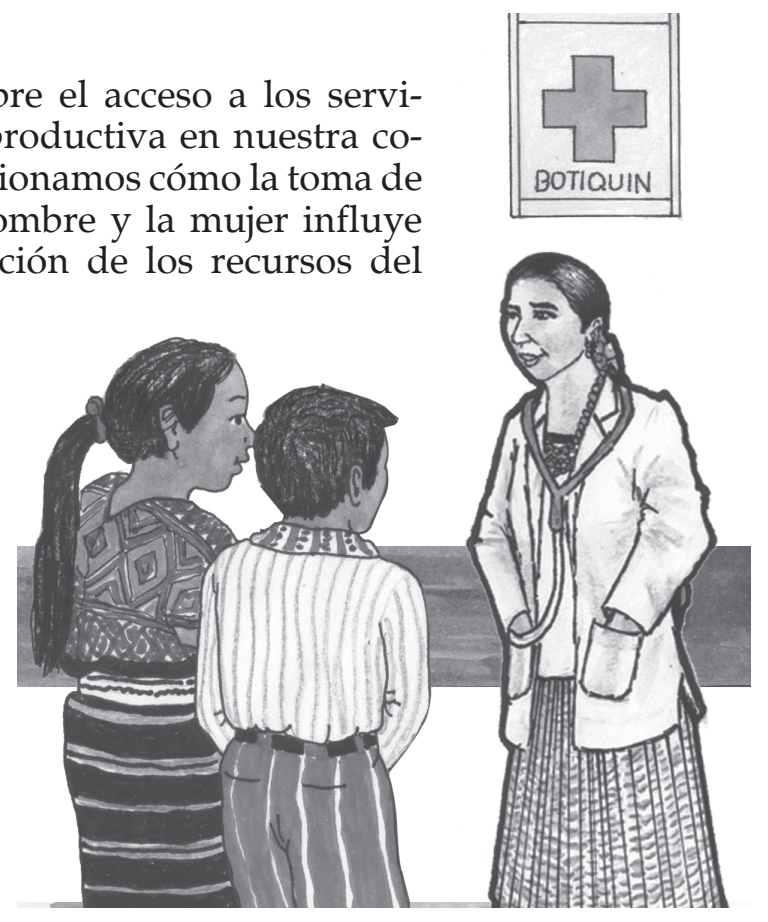

- Revisamos el avance de nuestro proyecto para promover a la comunidad.

- Evaluamos si el proyecto avanza según lo planificado.

- Verificamos que se hayan conseguido los recursos previstos en la organización de la presentación del proyecto.

- Cuidamos que la administración del proyecto esté funcionando y preparada para la presentación final.
El embarazo pone en peligro a niñas y adolescentes (10 a 17 años) porque sus cuerpos todavía están en crecimiento y desarrollo. No están preparadas sicológicamente para criar a un nuevo ser y las nuevas responsabilidades las obligan a dejar de estudiar violando su derecho a una vida digna.

Por ley, la edad mínima para casarse es 18 años. Sostener relaciones genitales con menores de 14 años es delito de violación. Violación es forzar a una persona a tener relaciones genitales contra su voluntad. No importa si es fuera o dentro del matrimonio o en unión de hecho.

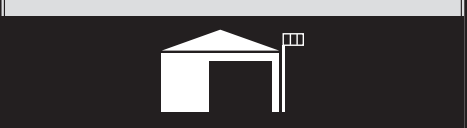

Solicitamos al comité de la niñez y adolescencia del COCODE que comparta los mecanismos de denuncia por maltrato y abuso físico, sicológico y sexual de niñas y niños. 


\section{Equilibrio y desequilibrio en los ecosistemas locales}

Un ecosistema está en equilibrio cuando presenta determinadas condiciones ambientales, en las que los diferentes organismos que allí habitan mantienen un tamaño y unos hábitos alimenticios constantes en el transcurso de su existencia. Esta situación de estabilidad y armonía se denomina equilibrio ecológico. El ecosistema tiene la capacidad de conservar y mantener el equilibrio.

Un ecosistema se equilibra con la circulación de materia y energía a través de las cadenas y redes alimenticias. Puede almacenar y proporcionar alimento para los seres vivos mediante la circulación permanente de nutrientes. El oxígeno y el carbono, son algunos nutrientes fundamentales para los seres vivos.

Los árboles, son productores de oxígeno, modifican el clima al reducir la temperatura a su alrededor, ayudan a la humedad del ambiente, retienen agua en el subsuelo, reducen la velocidad del viento, impactan el estado de ánimo de las personas, mitigan los efectos de desastres naturales, son el hábitat de flora y fauna, reducen la erosión del suelo y dan identidad al lugar. Cuidemos y conservemos los bosques de la comunidad.
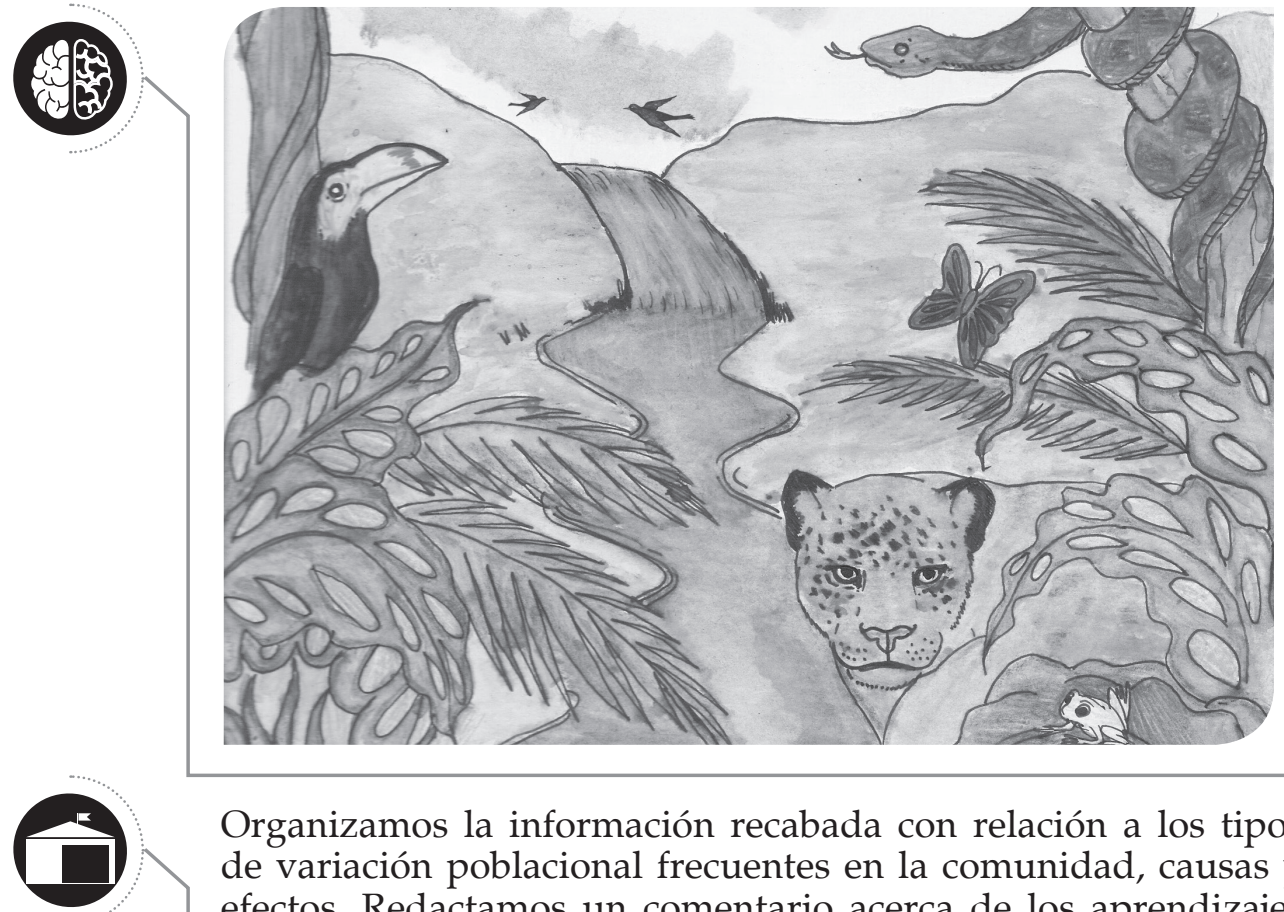

Organizamos la información recabada con relación a los tipos de variación poblacional frecuentes en la comunidad, causas y efectos. Redactamos un comentario acerca de los aprendizajes alcanzados. Exponemos ante la clase.

Observamos el siguiente esquema y respondemos:
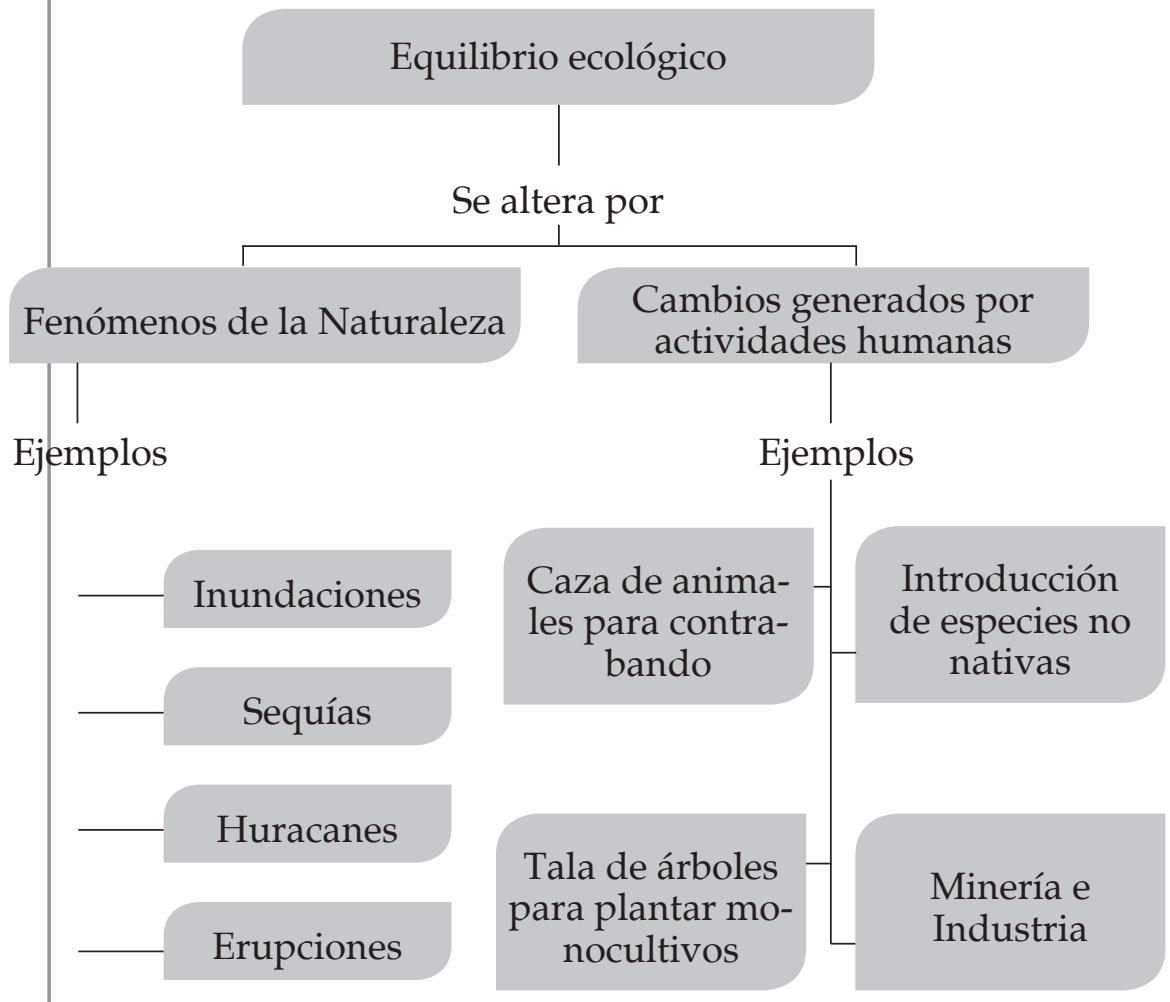

- ¿Cuáles de estos hechos se han producido en nuestra comunidad y han provocado desequilibrio ecológico? 


\section{La comunidad y las ciudades como ecosistemas.}

Algunos cambios provocados por actividades humanas han dado como resultado la creación de nuevos ecosistemas, por ejemplo las ciudades, que son ecosistemas urbanos. Las granjas y los cultivos, son ecosistemas agrícolas o agroecosistemas.

Acciones como la deforestación, expansión de las poblaciones humanas, construcción de viviendas, utilización de tierras para pastoreo de ganado, cultivos extensivos y monocultivos, entre otros, producen la desaparición de especies que no son capaces de adaptarse a las nuevas condiciones del ecosistema.

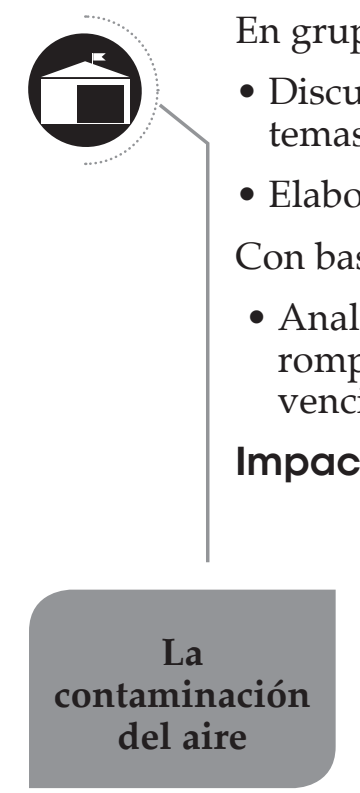

- Natural: Debido a incendios forestales, corrientes de vientos, erupciones volcánicas.

- Artificial: Debido a partículas y gases tóxicos, quema de cultivos, desechos de las actividades industriales y domésticas y al funcionamiento de vehículos automotores

La contaminación del suelo

\section{La} contaminación del agua
- Natural: Por la erosión, que implica desgaste de la superficie terrestre, especialmente la capa vegetal, rica en sustancias nutritivas, debido al viento, corrientes de agua, cambios de temperatura.

- Artificial: Se debe a la tala indiscriminada de árboles, el uso inadecuado de prácticas agrícolas, la aplicación de plaguicidas y fungicidas y la eliminación de desechos domésticos e industriales.

- Se produce por desechos provenientes de actividades domésticas, los desechos industriales y los derrames de petróleo.
Causas de extinción de especies. Deforestación, caza indiscriminada, pesca indiscriminada, desastres naturales, pérdida de hábitat, sobreexplotación $\mathrm{y}$ bosques nativos reemplazados por cultivos, pastizales y potreros para ganado.

Mantenimiento del equilibrio en los ecosistemas. Depende de tres aspectos: la cantidad de energía disponible, las condiciones del medio ambiente y las interacciones entre las especies.

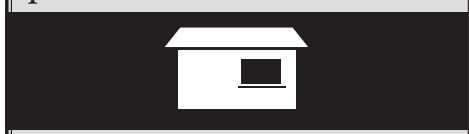

Reflexiono acerca de los aprendizajes logrados en relación con el equilibrio en los ecosistemas locales.

Identifico lugares de mi comunidad que requieren protección y defensa de las actividades industriales, que podrían estar en riesgo.

Escribo una propuesta para el rescate de las especies en peligro de extinción en mi comunidad. 


\section{Pensamiento lógico}

La Declaración Universal de los Derechos Humanos dice: "Toda persona tiene todos los derechos y libertades proclamados en esta Declaración, sin distinción alguna".

Aplico el pensamiento lógico para responder:

- ¿Qué condiciones o normas vulneran los derechos de las niñas y las mujeres?

- ¿Por qué no se puede negar el derecho a la libre expresión a una persona que está en desacuerdo con las autoridades?

- ¿Cuánto deben variar los derechos de una persona si su cultura es diferente a la de la mayoría?

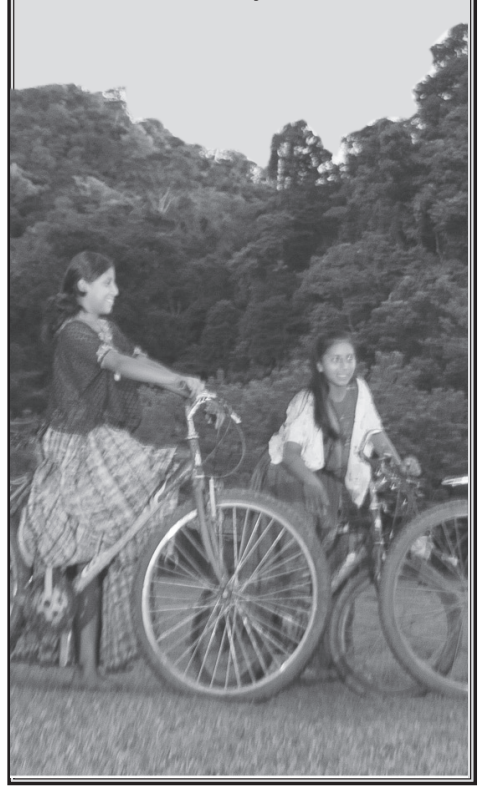
Interpretamos el esquema.

(iii)
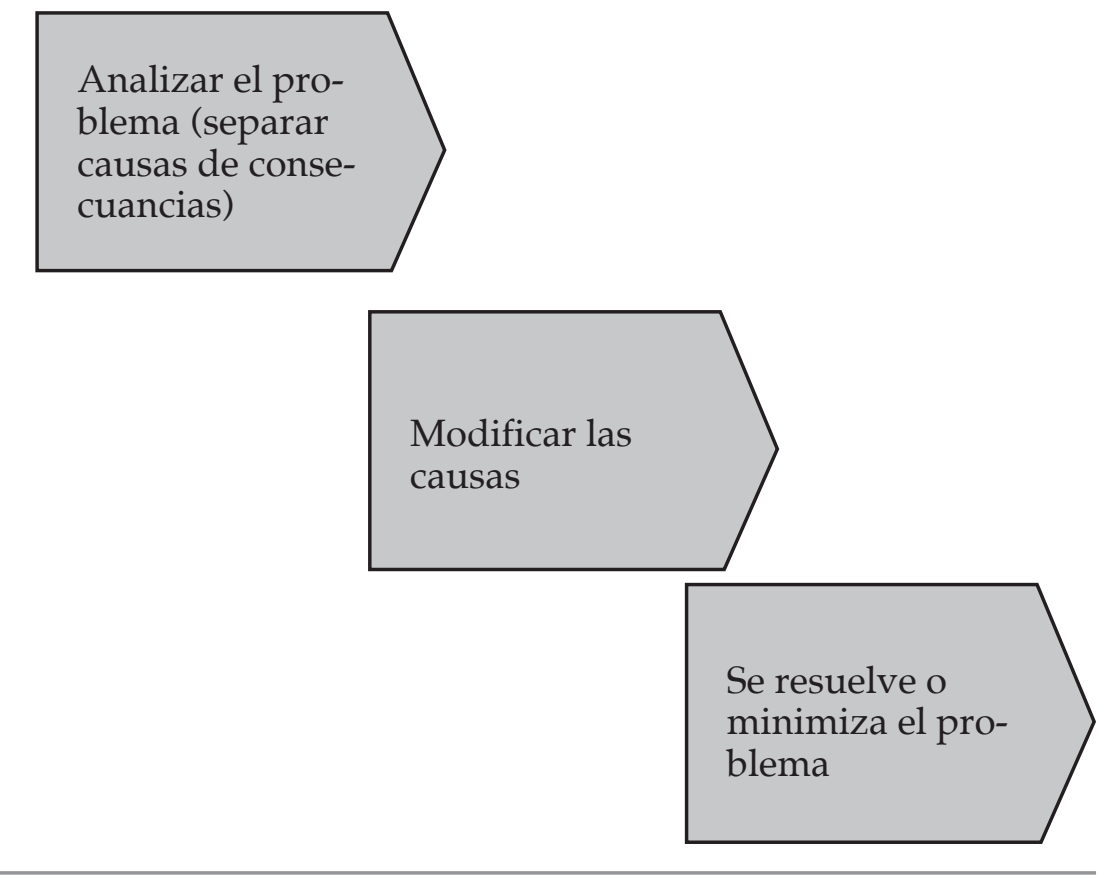

\section{Redactamos la interpretación del esquema}

El esquema y lo que hemos redactado corresponde con el pensamiento lógico.

Reunámonos en equipo y respondamos.

- ¿Cómo ayudan estas ideas a resolver un problema?

- ¿Es suficiente esto para resolver un problema?

El pensamiento lógico también dice que: para resolver un problema lo primero que debemos hacer es seleccionarlo.

¿Cuál es el problema que deseamos resolver con el Proyecto 1?

Reunámonos con nuestro equipo de trabajo y recapitulemos el análisis que hemos hecho del problema que deseamos resolver con el Proyecto 1.

Podemos aplicar los siguientes aportes del pensamiento lógico:

- Ordenemos cronológicamente lo que ha sucedido.

- Organicemos las ideas que tenemos del problema.

- Enumeremos los conocimientos científicos que se relacionan con el problema.

- Contemos o midamos algunos elementos que se relacionan con el problema.

- Separemos las causas de las consecuencias. 
Apliquemos, con nuestro equipo, algunos criterios del pensamiento lógico para verificar lo que hemos avanzado en la elaboración del prisma publicitario.

Respecto de los lugares de interés económico, social, cultural o turístico de la comunidad que divulgaremos:

- ¿Según sea la característica, ordenamos la información?

- ¿Están organizadas las ideas que tenemos?

- ¿Hemos registrado los conocimientos científicos que tenemos del tema?

- ¿Qué elementos hemos contado o medido?

- ¿Hemos diferenciado causas de consecuencias?

También nos conviene evaluar lo que hemos aprendido y aportado.

Discutamos acerca de los criterios con los que autoevaluaremos en casa. Estos criterios deben ir en dos direcciones:

1. Evaluar las experiencias adquiridas de trabajar en parejas o equipo.

2. Los beneficios de promocionar la comunidad por diferentes medios publicitarios.

Analizo la forma en que mi equipo ha organizado la información que presentaremos en el prisma publicitario.

- ¿Motiva a las personas a continuar con la lectura? ¿Por qué? ¿Se puede mejorar?

- ¿Contiene todos los aspectos importantes? ¿Sobra algo? ¿Falta algo?

- ¿Está bien ordenada toda la información?

Analizamos cuánto ha crecido en diez años, la población humana en el lugar de interés de la comunidad que divulgaremos.

Ordenamos las ideas que tenemos acerca de la relación entre la población y el lugar de interés que divulgaremos.

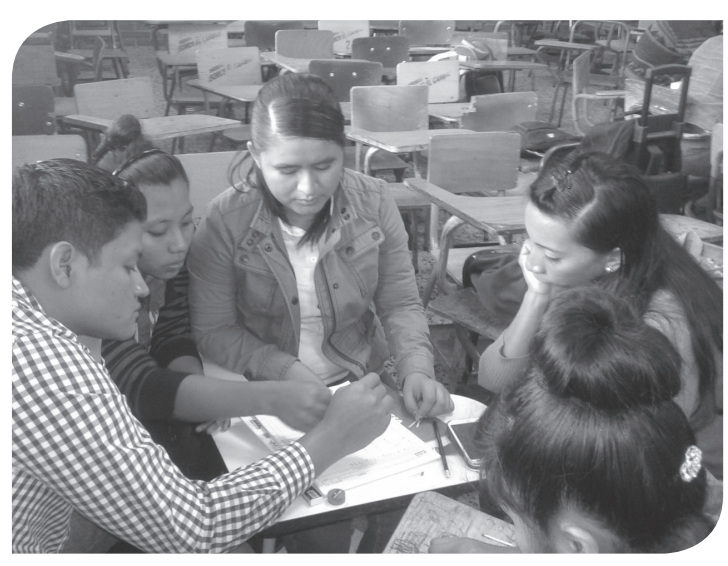

De acuerdo a los conocimientos científicos que tenemos, ¿causa problema el crecimiento poblacional en el lugar de interés? Argumentamos nuestra respuesta.

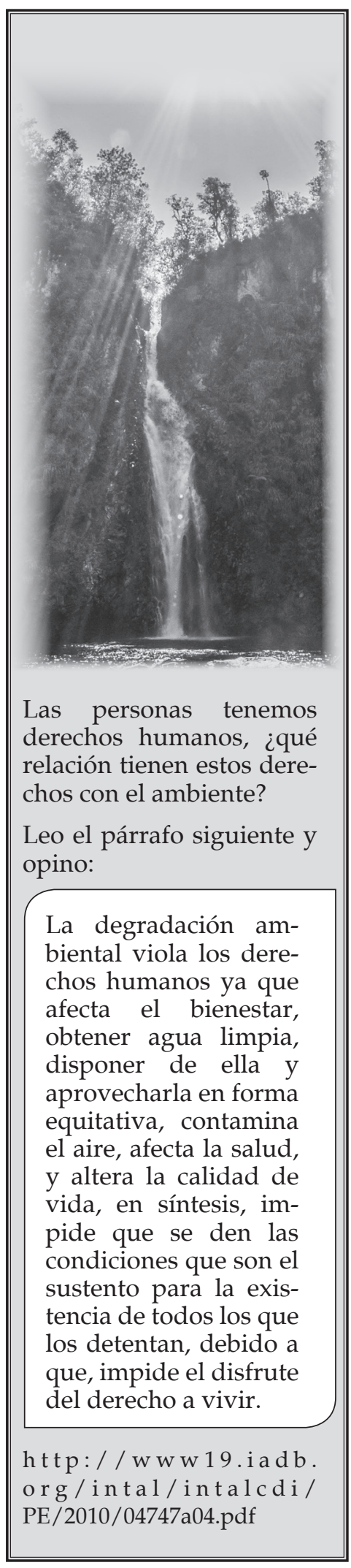

Las personas tenemos derechos humanos, ¿qué relación tienen estos derechos con el ambiente?

Leo el párrafo siguiente y opino:

La degradación ambiental viola los derechos humanos ya que afecta el bienestar, obtener agua limpia, disponer de ella y aprovecharla en forma equitativa, contamina y altera la calidad de vida, en síntesis, impide que se den las condiciones que son el sustento para la existencia de todos los que que, impide el disfrute del derecho a vivir.

http: / / w w w 19.iadb org / in tal/in ta lcdi / PE/2010/04747a04.pdf 


\section{Diferentes maneras de comunicarnos}

\begin{tabular}{|c|c|}
\hline \multicolumn{2}{|c|}{$\begin{array}{l}\text { Algunas veces, usamos } \\
\text { expresiones con palabras } \\
\text { innecesarias, porque ya } \\
\text { están contenidas en otro } \\
\text { elemento de la oración. } \\
\text { Estas se llaman pleonas- } \\
\text { mos o redundancias. } \\
\text { Las más frecuentes son: }\end{array}$} \\
\hline Incorrecto & Correcto \\
\hline $\begin{array}{l}\text { El día de } \\
\text { hoy }\end{array}$ & Hoy \\
\hline $\begin{array}{l}\text { Lapso de } \\
\text { tiempo }\end{array}$ & Lapso \\
\hline $\begin{array}{l}\text { Prever de } \\
\text { antemano }\end{array}$ & Prever \\
\hline $\begin{array}{l}\text { Vuelvo a } \\
\text { repetir }\end{array}$ & Repetir \\
\hline Salir afuera & Salir \\
\hline Bajar abajo & Bajar \\
\hline $\begin{array}{l}\text { Volar en el } \\
\text { aire }\end{array}$ & Volar \\
\hline $\begin{array}{l}\text { Hija mujer, } \\
\text { hija hembra }\end{array}$ & Hija \\
\hline $\begin{array}{l}\text { Recordar } \\
\text { de memoria }\end{array}$ & Recordar \\
\hline $\begin{array}{l}\text { Cállate la } \\
\text { boca }\end{array}$ & Cállate \\
\hline Cita previa & Cita \\
\hline $\begin{array}{l}\text { Mas sin } \\
\text { embargo }\end{array}$ & $\begin{array}{l}\text { Sin embar- } \\
\text { go }\end{array}$ \\
\hline Ambos dos & Ambos \\
\hline $\begin{array}{l}\text { Proseguir } \\
\text { adelante }\end{array}$ & proseguir \\
\hline $\begin{array}{l}\text { - Reviso qué } \\
\text { utilizo en } \\
\text { oral. }\end{array}$ & $\begin{array}{l}\text { redundancias } \\
\text { mi expresión }\end{array}$ \\
\hline $\begin{array}{l}\text { Preparamos } \\
\text { los problem } \\
\text { tantes de nu } \\
\text { dad. }\end{array}$ & $\begin{array}{l}\text { un listado de } \\
\text { as más impor- } \\
\text { estra comuni- }\end{array}$ \\
\hline
\end{tabular}

Desde: una de las formas de comunicación más usadas en nuestra época es la exposición oral. Nos sirve para presentar un tema o un punto de vista y para que tenga éxito, debemos cuidar: el mensaje, la corrección y fluidez del lenguaje, nuestros ademanes y nuestros gestos.
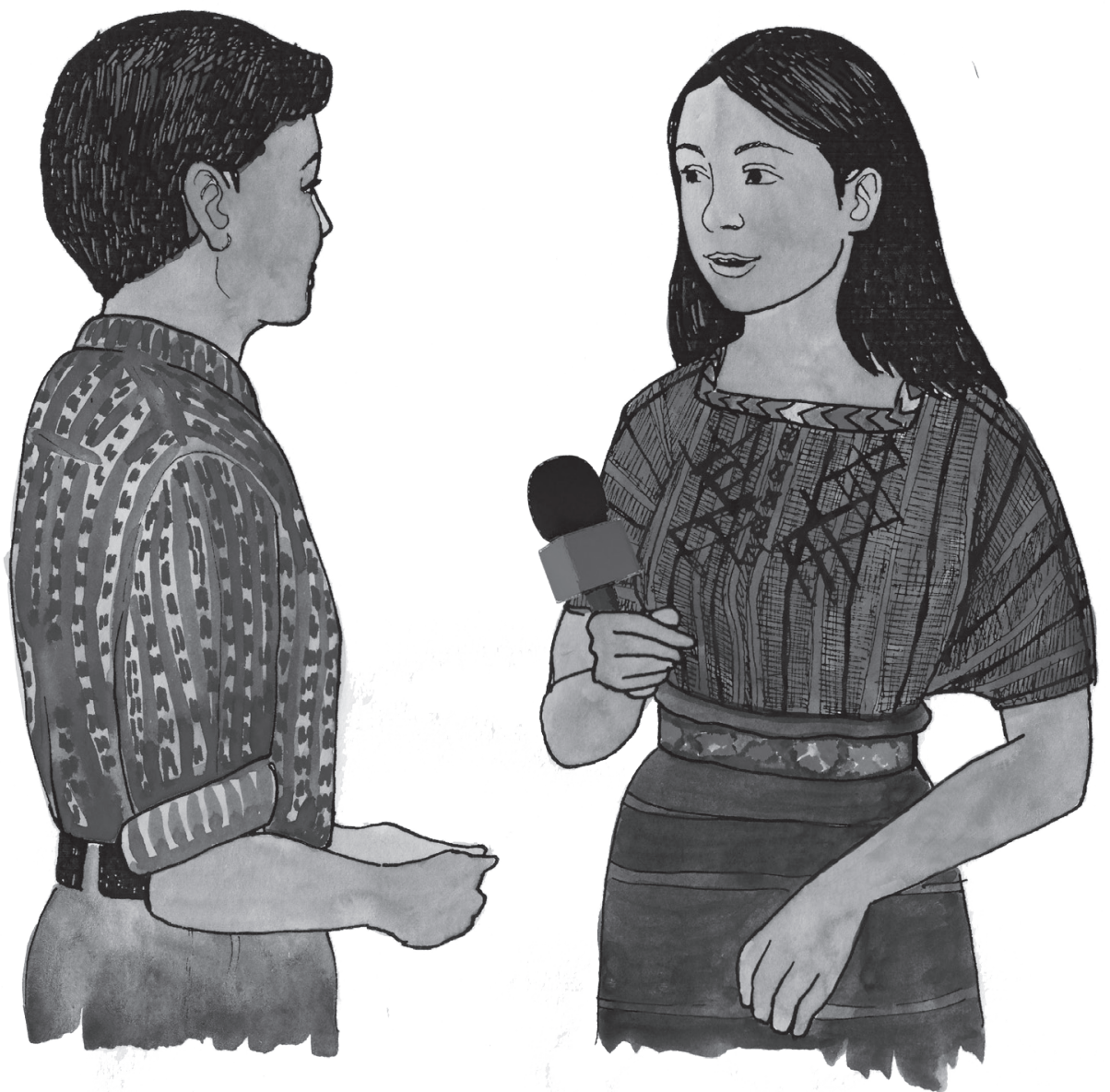

La entrevista es una conversación oral o escrita entre dos personas. Se realiza con el fin de conocer las ideas, experiencias y sentimientos de una persona. Según el fin que se persigue, puede estar estructurada por medio de un cuestionario previamente elaborado. Por ejemplo, podemos entrevistar a una maestra de escuela para conocer algo de su experiencia docente.

La encuesta es una técnica de adquisición de información. Se trabaja por medio de un cuestionario preparado con anterioridad. Sirve para valorar la opinión y valoración de varias personas seleccionadas sobre un asunto dado. Se diferencia de la entrevista en que es más impersonal.

Los recursos audiovisuales son apoyos gráficos que sirven para reafirmar de manera instantánea el mensaje que se está exponiendo, en quienes escuchan. Algunos de estos son carteleras, diapositivas, videos y rotafolios.

Prepararemos un texto escrito sobre uno de los problemas de nuestra comunidad. Usemos los elementos que se describen arriba para reforzar nuestro trabajo. 


\section{La literatura en nuestras vidas}

La creatividad y la imaginación son cualidades importantes para el desarrollo de las personas. Nos permite realizarnos, obtener beneficios económicos, resolver problemas personales, familiares y sociales. Nos da felicidad y plenitud. En literatura, son valiosas cuando hacemos:

\section{Oralidad}

Esta comprende todo juego de palabras que nos ayuda a aprender nuevos vocablos y a experimentar el placer del lenguaje. Nos transmite también el ritmo y la musicalidad. Al conocer este juego de palabras podemos disfrutar mejor de la poesía.

Adivinanzas, rimas, canciones de cuna, trabalenguas, retahílas, dichos, coplas, refranes.

\section{Poesía}

Es una aventura hacia el interior de la persona. Es la impresión o efecto estético que produce en el poeta y la poetisa el mundo que le rodea. El poema es el objeto verbal. Es la poesía hecha forma en el lenguaje. Al dominar la poesía, el teatro deviene natural. Coplas, redondillas, canciones, odas, elegías, sonetos, madrigales, entre otros.

\section{Teatro}

El teatro se caracteriza por usar el diálogo y por ser representado por actores y actrices. Pertenece al género dramático. Luego de dominar el lenguaje y la representación pasamos a conocer historias más complicadas.

Comedia, tragedia, tragicomedia, monólogo.

\section{Relatos}

Los relatos son narraciones que nos transportan a otras situaciones en el tiempo y en el espacio. Nos permiten conocer el mundo. Es parte de la narrativa, la cual nos prepara para la gran literatura.

Anécdotas, chistes, mitos, fábulas, leyendas o crónicas familiares.

\section{Literatura}

La literatura es el arte de la palabra. Su propósito es conmover por medio de las combinaciones diversas del lenguaje. La literatura comprende todas las anteriores manifestaciones hasta llegar a la literatura en general.

Novela, crónicas de viajes, poesía, teatro, ensayo, biografías, memorias.

Uno de los beneficios de la literatura lo representa la memoria ortográfica o sea la grabación de las palabras bien escritas, en nuestra mente. Por ejemplo, aprendemos que las mayúsculas se utilizan al principio de una oración; en los nombres propios: Ana, Petén; en los títulos de publicaciones, en la palabra inicial: Cien años de soledad; y los tratamientos, si están en abreviatura: Sr. Luna, Licda. Güit.

- Organicemos varias exposiciones orales sobre nuestras investigaciones y usemos recursos audiovisuales. Utilicemos dramatizaciones en una de ellas para hacer más evidente el problema, sus efectos en nuestra comunidad y sus posibles soluciones. Podemos escenificar la situación en dos momentos: "antes de reflexionar sobre el tema" y "después".

- Concluyamos esta actividad con un festival literario en el cual hayamos escrito diferentes ejemplos de la tradición oral y de la poesía que se manejen en nuestra comunidad, en carteles que colocaremos en la pared. 


\section{Operaignes con fracciones algebraicas. operaciones con numeros redies.}

Un prisma es un cuerpo geométrico de tres dimensiones. Sus caras son polígonos y sus partes principales son:

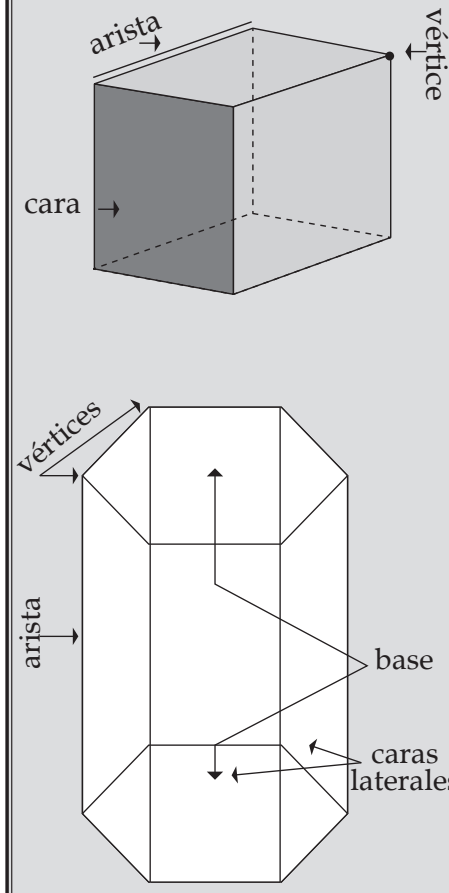

Prisma Hexagonal

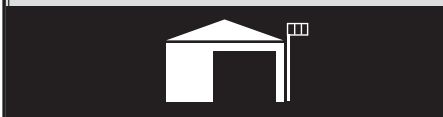

- Revisamos en grupo las medidas de los terrenos de los lugares de la comunidad que promocionamos en el prisma publicitario.

- Calculamos el perímetro y el área de los lugares de interés.

- Incluimos esa información en el prisma publicitario.

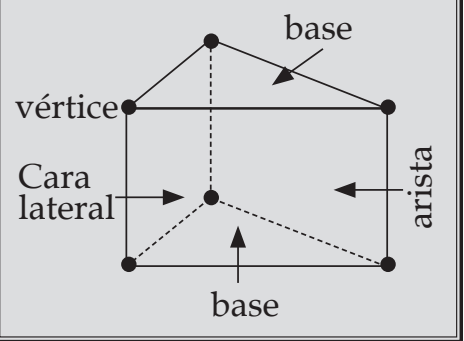

Una caja de tomate tiene las siguientes dimensiones:

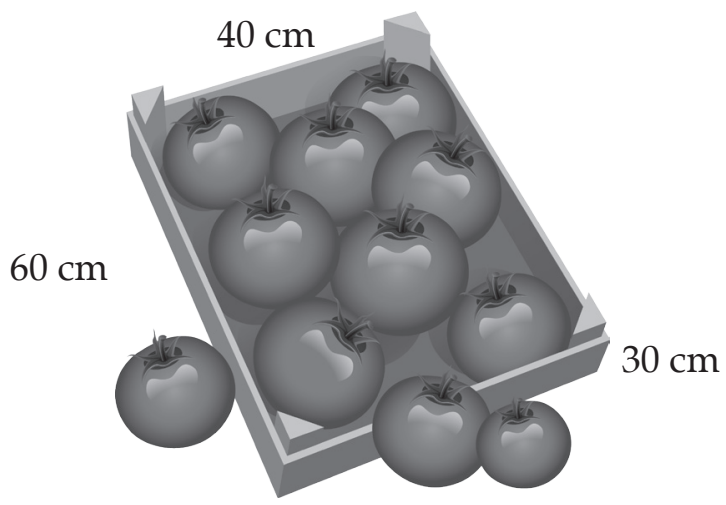

Un agricultor que cosecha tomates desea reforzar las juntas de la caja. Decide colocar cinta adhesiva en cada arista $u$ orilla que limita cada cara de la caja. ¿Qué longitud mínima, de cinta adhesiva, necesita? ¿Cómo lo supimos?

Comentamos: ¿Qué productos de nuestra comunidad son vendidos en cajas parecidas a esta?

Utilizamos una hoja de papel de tamaño carta y la dividimos horizontalmente en seis partes iguales, como se muestra en la figura:

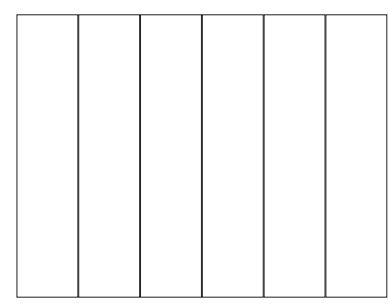

Doblamos cada división del papel y, unimos los extremos de la hoja. Formamos una figura de tres dimensiones. La base y la tapadera quedarán abiertas.

¿Qué forma tiene el cuerpo que formamos? Este cuerpo se denomina prisma. ¿Qué forma tiene la base del prisma? Según el número de los lados de la base, ¿cómo podemos nombrar a la figura?

Utilizando una regla graduada, relacionamos las medidas del ancho de cada parte con el alto de la hoja. Por ejemplo: si el ancho de cada parte mide $4 \mathrm{~cm}$ y el alto de la página mide $21 \mathrm{~cm}$ significa que cada división horizontal; $4 \mathrm{~cm}$ equivalen a $x$ y el alto entonces será igual a $4 x+1$.

Escribimos una expresión algebraica que relacione el alto de nuestra hoja en función de su ancho. 
Recién hemos formado un prisma. Utilizamos nuestras figuras y las expresiones algebraicas que formulamos antes, para hallar una expresión que represente el perímetro de los lados del prisma y de las bases.

Escribimos en nuestro cuaderno el proceso o la norma que utilizamos para hallar perímetros de cuerpos sólidos.

Utilizando las dimensiones reales, en $\mathrm{cm}$, hallamos el perímetro de los lados del prisma y de las bases.

¿De qué forma las expresiones algebraicas nos pueden ayudar a calcular volumenés de las producciones agrícolas de nuestra comunidad? ¿Qué otros cuerpos sólidos, con forma de prisma, encontramos en nuestro entorno? ¿Por qué nos sería útil conocer su volumen? Compartimos las respuestas con el resto del grupo.

- Un agricultor empaca naranjas en cajas cerradas de cartón, cuyas dimensiones son: ancho $35 \mathrm{~cm}$, largo $45 \mathrm{~cm}$ y alto $20 \mathrm{~cm}$. Desea amarrar un lazo para asegurarlas de la siguiente forma:

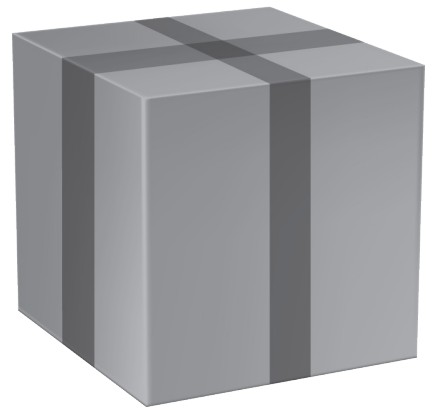

¿Cuántos metros de lazo, como mínimo, necesitará para amarrar 20 cajas?

¿Cuál es el perímetro, en metros, de cada caja?

- Encuentro el perímetro de los siguientes sólidos:
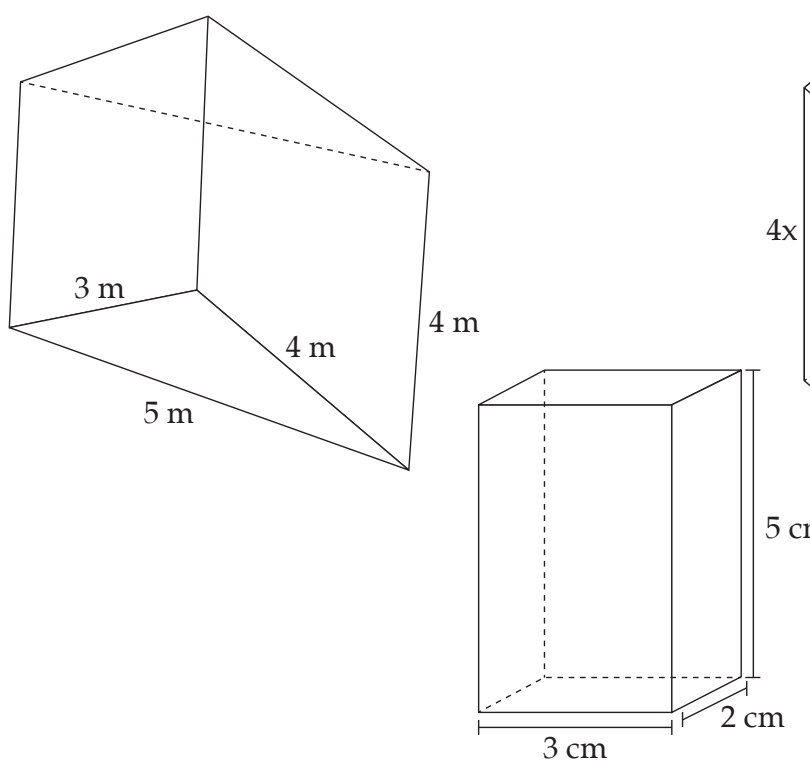

Según la forma de su base, los prismas pueden ser:

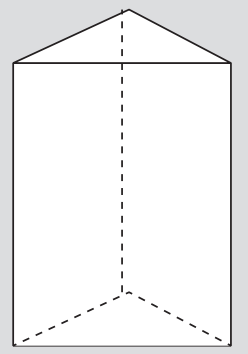

Prisma triangular

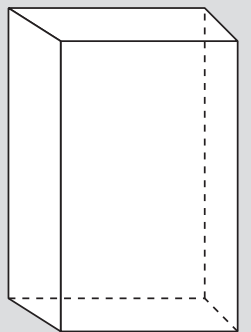

Prisma cuadrangular

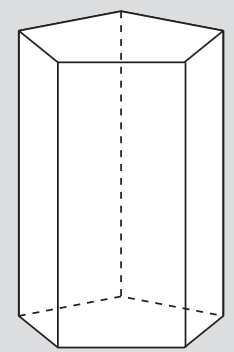

Prisma pentagonal

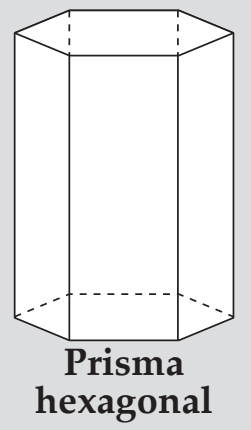




\section{Protección del medio ambiente}

\section{El pensamiento cosmo-} céntrico

"Muy diferente al pensamiento antropocéntrico que considera a las personas como el centro de la creación, el pensamiento cosmocéntrico, considera al Cosmos como el centro de la vida y de todo lo existente. En virtud de ese pensamiento, las personas no somos ni más ni menos que otro elemento integrante del Cosmos, con derecho de existir y con la responsabilidad de cuidar el tejido de la vida.

Dentro del tejido, todo lo que existe tiene un valor en función de la integralidad: las personas, los animales, las plantas, los elementos fundantes de la vida, los cuerpos celestes, las distintas formas de energía, el espíritu de los abuelos y el nuestro, todo es importante y se encuentran a un mismo nivel.

Las personas no hicimos el tejido y por lo tanto no tenemos derecho a destruir$10^{\prime \prime}$.

Recuperado de: Módulo 1, Ciencias Naturales desde la cosmovisión de los pueblos y su aprendizaje. USAC-EFPEM/PACE-GIZ. Primera edición. 2014.

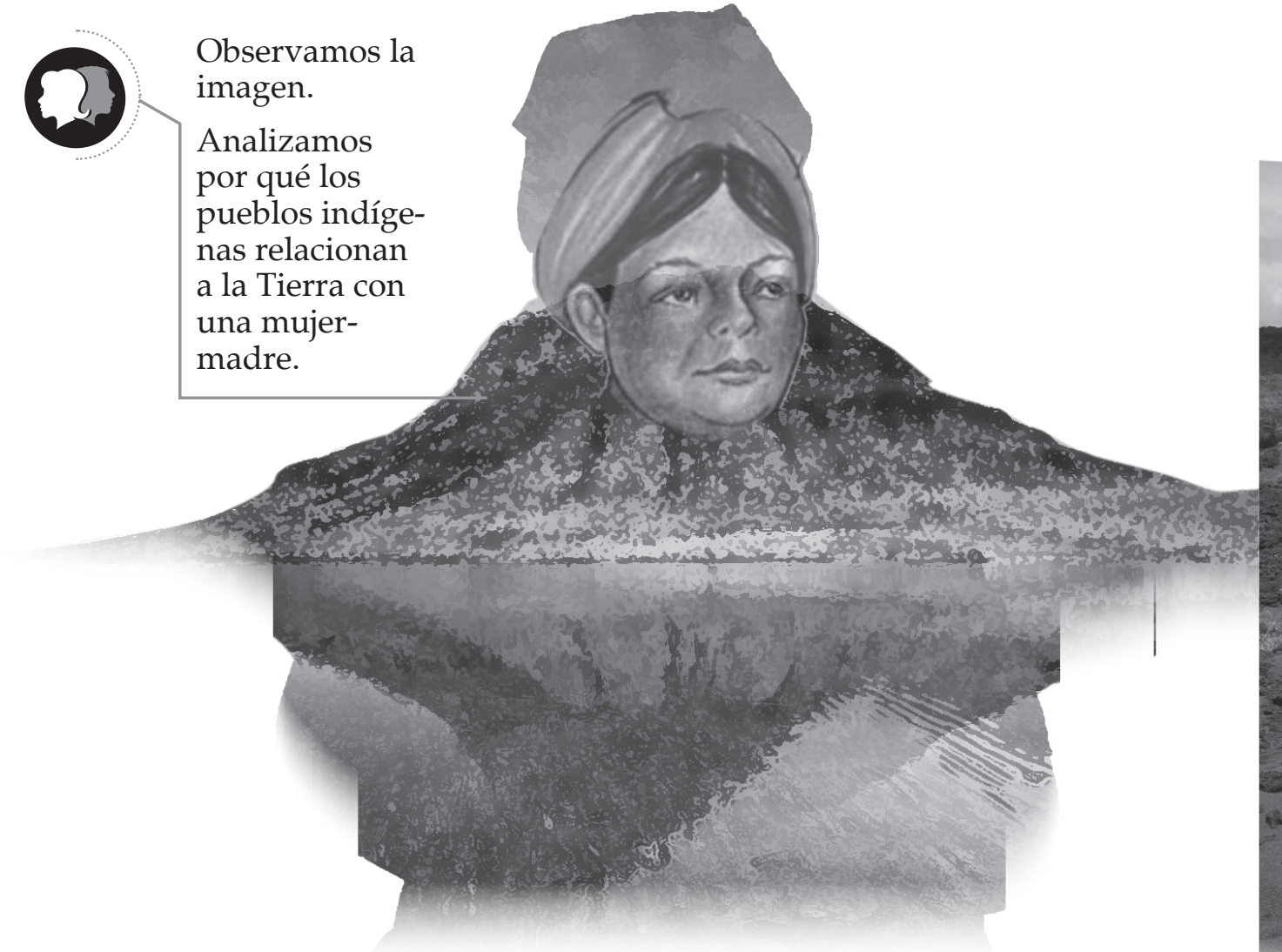

Algunos nombres de la Madre Tierra, son: $Q t x u^{\prime} T x^{\prime}$ otx $x^{\prime}$ en maya mam y $Q a-$ nan Ulew en maya k'iche'. Otros nombres, son: Gea, Gaia o Pachamama. Es quien nos provee de todos los recursos para mantener la vida y es en este ciclo de vida donde se puede observar que tanto las plantas como los animales están en una perfecta simbiosis con su medio. ¿El hombre también lo esta?

Es por eso que se debe cuidar y conservar para bien de la humanidad para evitar desastres, la destrucción de la capa de ozono, contaminación

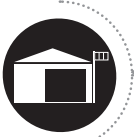

\section{Respeto por la Madre Tierra.}

En grupos:

- Encontramos evidencias del pensamiento cosmocéntrico a partir de las propias vivencias.

- Explicamos por qué proteger el entorno es proteger la vida

- Diseñamos una representación creativa de la Madre Tierra; incluimos las especies silvestres en peligro de extinción en nuestra comunidad.

- Incluimos en el prisma los mejores diseños y explicamos la idea que representa nuestro trabajo.
}

Investigo en la comunidad, cómo se trasmite el valor y conocimiento de la Naturaleza. Con esa información escribo un ensayo de una página. 


\section{○}

- ¿Existe el ecoturismo en la comunidad?

- ¿Qué organizaciones se encargan de promocionar el turismo local?

- ¿Cuáles son los fines que motivan la actividad turística?

El ecoturismo o turismo ecológico es la actividad turística que se desarrolla sin alterar el equilibrio del medio ambiente y evitando los daños a la Naturaleza. Se trata de una tendencia que busca compatibilizar la industria turística con la Ecología.

Incluimos en el prisma un lugar de la comunidad para promover el ecoturismo.

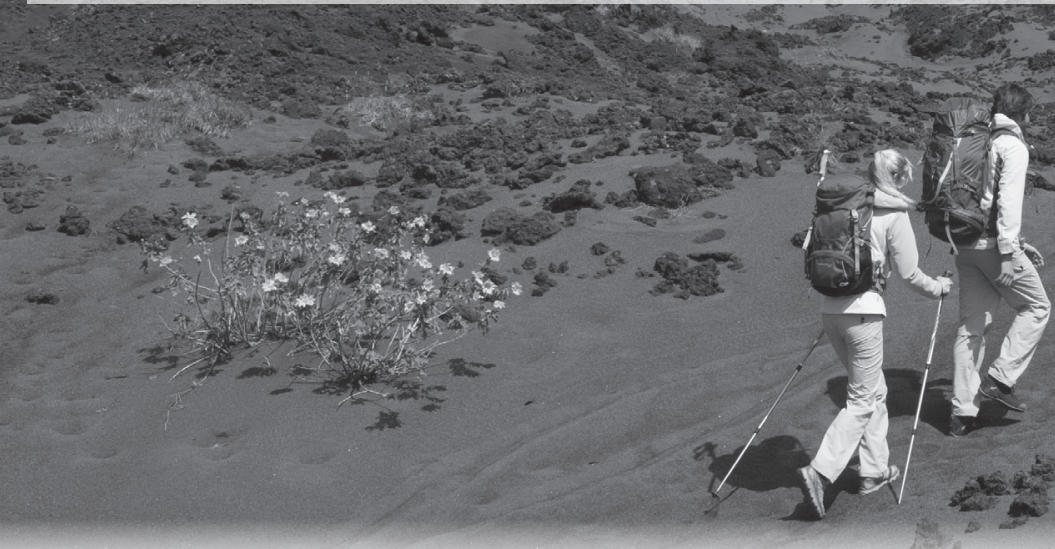

- Analizamos uno de los siguientes objetivos de desarrollo sostenible, promovido por la Organización de las Naciones Unidas.

- Relacionamos el objetivo con los problemas de extinción de especies silvestres y contaminación.

- Elaboramos una propuesta para contribuir con el cumplimiento de ese objetivo.

\begin{tabular}{|l|l|}
\hline \multicolumn{2}{|c|}{ Objetivos de Desarrollo Sostenible } \\
\hline Objetivo 11 & $\begin{array}{l}\text { Lograr que las ciudades y los asentamientos } \\
\text { humanos sean inclusivos, seguros, resilientes y } \\
\text { sostenibles. }\end{array}$ \\
\hline Objetivo 12 & $\begin{array}{l}\text { Garantizar modalidades de consumo y } \\
\text { producción sostenibles. }\end{array}$ \\
\hline Objetivo 13 & $\begin{array}{l}\text { Adoptar medidas urgentes para combatir el } \\
\text { cambio climático y sus efectos. }\end{array}$ \\
\hline Objetivo 15 & $\begin{array}{l}\text { Promover el uso sostenible de los ecosistemas } \\
\text { terrestres, luchar contra la desertificación, } \\
\text { detener e invertir la degradación de las tierras y } \\
\text { frenar la pérdida de la diversidad biológica. }\end{array}$ \\
\hline
\end{tabular}

Desertificar, convertir en desierto grandes extensiones de tierra fértil.
Los siguientes son principios a seguir por quienes llevan a cabo actividades de ecoturismo:

Minimizar los impactos ambientales y sociales.

Aumentar la conciencia y el respeto por el ambiente y la cultura

Ofrecer experiencias positivas tanto para visitantes como para la comunidad.

Ofrecer beneficios financieros directos para la conservación.

Proveer beneficios financieros y participación real para la población local.

Aumentar la sensibilidad de los turistas hacia la comunidad anfitriona en su contexto político, cultural y social.

Recuperado y adaptado de:

https://www. ecotourism.org/book/ definicion-y-principiosdel-ecoturismo 


\section{Monitoreo de proyectos}

El monitoreo de los proyectos, es la supervisión de la ejecución de un proyecto. Permite asegurarnos que va bien encaminado y logrará los resultados deseados según el presupuesto estimado y el tiempo programado. Así cualquier problema o retraso podrá solucionarse inmediatamente para evitar que el proyecto se desvíe de sus objetivos.

A mitad y al final del proyecto hacemos la evaluación que determinará si hemos logrado los objetivos planteados inicialmente o cuánto nos falta para alcanzarlos. El análisis y reflexión sobre los resultados nos brindan lecciones aprendidas que sirven de guía para rectificar el avance de un proyecto o iniciar un nuevo proyecto.

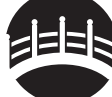

Cuando alguien cocina, no coloca la olla al fuego y regresa cuando cree que ya está lista la comida. Una persona que se considere buena cocinera estará al tanto de la comida que prepara para evitar que los líquidos se derramen de la olla. Cuidará que los alimentos no se peguen a la olla, que la comida no quede seca o no se queme. Es decir, estará atenta, monitoreando el proceso.

Madres y padres se preocupan por el crecimiento y desarrollo de sus hijas e hijos. El cerebro se desarrolla más rápidamente desde el embarazo hasta los dos años. Por eso es importante que las mujeres embarazadas, así como las niñas y niños pequeños reciban todos los nutrientes necesarios para que su cuerpo y su cerebro se desarrollen adecuadamente. Una baja estatura que no sea la esperada para la edad, es señal de desnutrición crónica. Significa que el cuerpo y el cerebro de la niña o el niño no están recibiendo los nutrientes que necesita debido a una mala dieta. Esto puede ocurrir porque no come lo suficiente o no come los alimentos importantes. Es vital que la mujer embarazada asista mensualmente al puesto de salud para su control prenatal, siga las instrucciones del personal de salud que le atiende y tenga acceso a alimentos, hierro y vitaminas. Posteriormente: debe llevar a su hija o hijo mensualmente al control y monitoreo de crecimiento y de su salud. Así se asegurará que está creciendo adecuadamente.

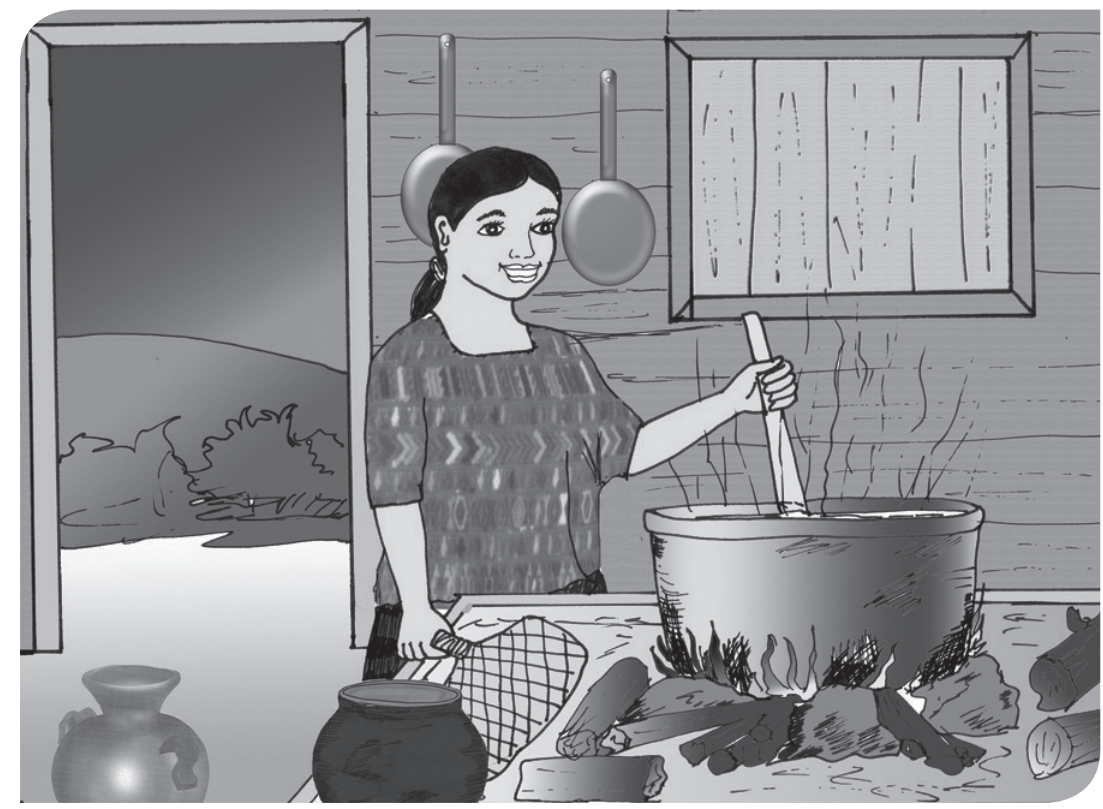

Evaluamos nuestro proyecto, Determinamos si logramos los objetivos planteados. ¿Hubo algún objetivo trazado que no cumplimos? Anotamos el objetivo u objetivos no alcanzados. Determinamos las causas de haber cubierto todos los objetivos o no haber alcanzado alguno. Analizamos las lecciones aprendidas. 


\section{Monitoreo e indicadores}

Los proyectos son como nuestros hijos e hijas. En ellos tenemos orientados nuestros propósitos e ideales. Anhelamos que se desarrollen fuertes para soportar cualquier problema que se avecine. El monitoreo nos ayudará a conocer si nuestro proyecto avanza en la dirección adecuada. Para ello debemos determinar claramente cuáles son nuestros objetivos y cómo los mediremos. Estos reciben el nombre de indicadores. Por ejemplo: tenemos como objetivo la introducción de agua entubada. Un indicador será la toma de muestra de agua y aseguramiento de su potabilidad durante el primer mes. El monitoreo verificará que se han llevado a cabo las pruebas de agua y tendrá a la vista los resultados de los análisis. Si el análisis muestra que el agua no es adecuada para consumo, se evaluará la posibilidad de tomar muestras de agua de otro nacimiento. Esto significaría reestructurar el proyecto, verificando los nuevos costos y tiempos.

Algunos proyectos que se realizan en nuestras comunidades son llevados a cabo por empresas contratadas por el gobierno, la municipalidad u organizaciones no gubernamentales (ONG). El COCODE, en nuestra representación, debe tener una copia de esos proyectos y realizar monitoreo de las obras. Alertar a las autoridades cuando en los proyectos no se esté cumpliendo con las actividades trazadas, no se estén respetando a las personas de la comunidad o los acuerdos alcanzados, no se usen materiales de calidad, la obra no esté bien hecha o no avance como debería hacerlo. Recordemos que nosotros somos quienes sufrimos las consecuencias de un proyecto mal ejecutado.

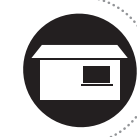

¿Se está llevando a cabo algún proyecto en nuestra comunidad? ¿Qué tipo de proyecto es? ¿A quién beneficia? ¿Quién lo supervisa y cómo? ¿Tenemos copia de ese proyecto? Preguntemos a los y las integrantes del COCODE o la organización que esté llevando a cabo ese proyecto en nuestra comunidad y aseguremos que la comunidad participa en el monitoreo y evaluación del mismo.
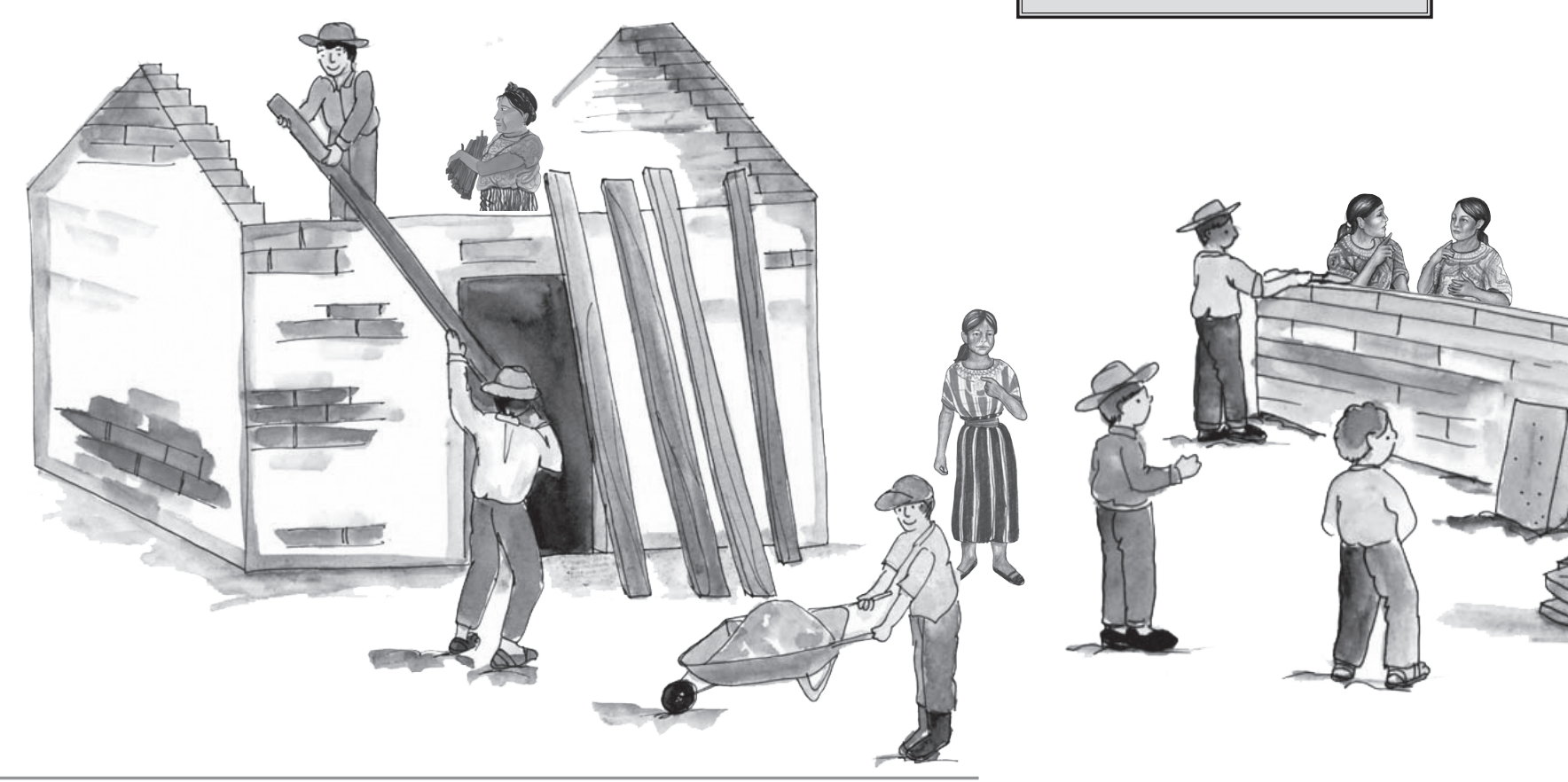

La Ley de acceso a la información pública (Decreto 57-2008) garantiza el derecho a conocer el actuar de nuestras autoridades e instituciones públicas. Es nuestro deber monitorear los proyectos para asegurarnos que persigan el desarrollo sustentable y respeten nuestra identidad y cultura, como también que los fondos públicos no se desvíen para satisfacer intereses privados $\mathrm{O}$ personales.

El buen vivir significa vivir en armonía con nosotros mismos, nuestra sociedad y la Naturaleza. Está en nosotros restaurar y mantener esa armonía con nuestros pensamientos, actitudes y acciones.

Visitemos el puesto de salud y conozcamos acerca del avance de las metas propuestas y las dificultades para alcanzarlas.

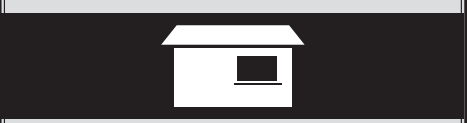




\section{Propuestas para solucionar problemas}

El pensamiento crítico busca la razón de los hechos, en dónde se originan y cómo evolucionan. Para encontrar la razón se basa en la reflexión individual y colectiva. Se emplea para resolver problemas individuales, familiares y comunitarios. El pensamiento creativo es la capacidad de idear formas diferentes o innovadoras de hacer las cosas. El pensamiento propositivo busca la mejor manera de comunicar y argumentar las ideas críticas e innovadoras para que sean apoyadas por las demás personas.

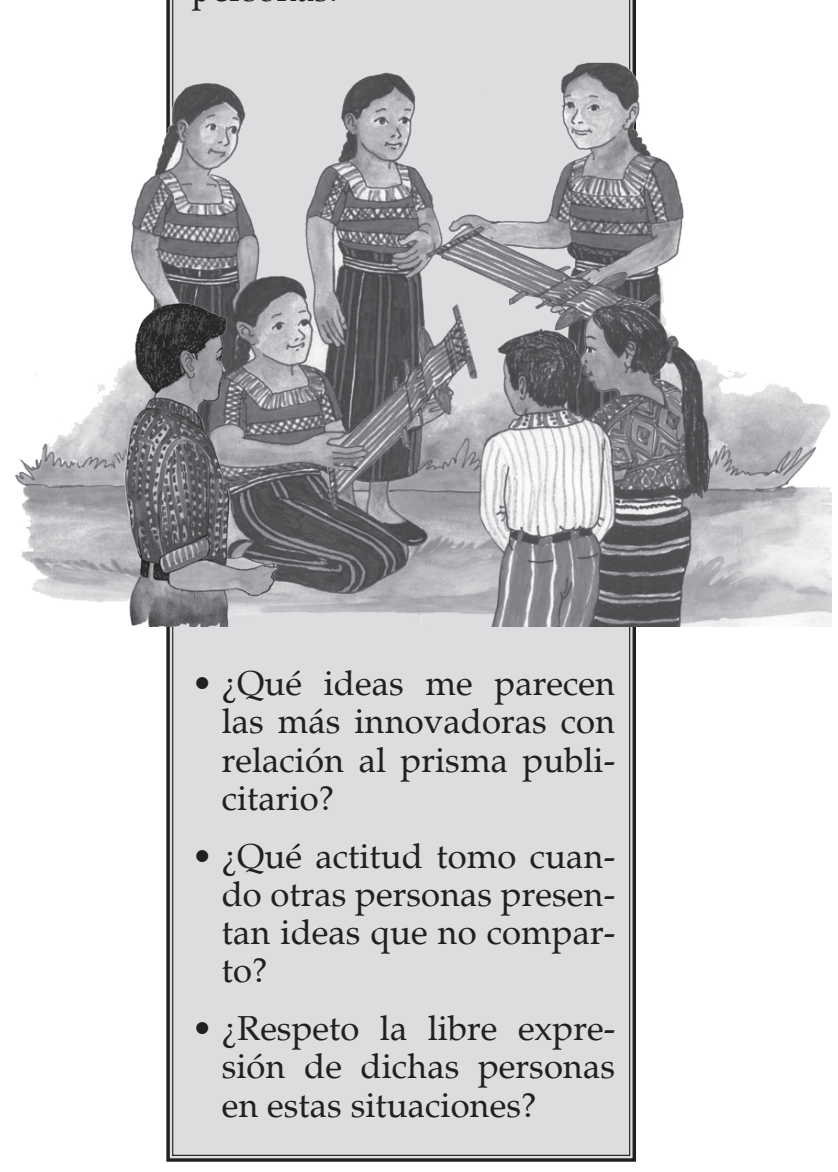

¿Qué ideas me parecen las más innovadoras con relación al prisma publicitario?

¿Qué actitud tomo cuando otras personas presentan ideas que no comparto?

¿Respeto la libre expreen estas situaciones?

\section{Leamos las oraciones:}

"Si se sigue el algoritmo dos veces, se obtendrá el mismo resultado"

http://ing.unne.edu.ar/pub/informatica/Alg_diag.pdf

De esta característica de un algoritmo, surge una frase, que se le atribuye a Albert Einstein: "Si quieres resultados distintos, no hagas siempre lo mismo"

Nos reunimos en equipo y discutimos el significado de la segunda frase. Podemos guiarnos con las preguntas:

- ¿Qué significado tiene esta oración?

- ¿Qué coincidencias y diferencias hay en nuestros significados?

- ¿Qué conclusiones podemos formular?

Parte del pensamiento lógico es repetir las rutinas que nos han dado buenos resultados. Pero muchos problemas se generan porque las condiciones cambian y las personas continúan repitiendo las mismas rutinas. Para buscar soluciones, se necesita cambiar rutinas. Pensar y actuar de otra forma. A esto se le llama pensamiento crítico, creativo y propositivo.

\section{Analicemos un caso en la agricultura}

Desde tiempos ancestrales, quien siembra comienza a preparar la tierra antes de mayo y espera el inicio de la época lluviosa para que su siembra reciba suficiente agua y pueda cosechar.

- ¿En qué mes se siembra en la región donde vivimos?

Las alteraciones que los seres humanos hemos causado en el ambiente natural, han modificado el ciclo de la lluvia.

- Describamos, con nuestro equipo de trabajo, cómo ha sido la época lluviosa en nuestra comu-

nidad durante los últimos dos años.

- ¿Qué diferencias hay respecto del ciclo de lluvia de hace 10 años?

- ¿Cuál ha sido la influencia de este ciclo de lluvia en las cosechas?

- ¿Cómo se puede aprovechar mejor la lluvia en la agricultura?

- ¿Qué puede hacerse para que las lluvias tengan la misma regularidad?

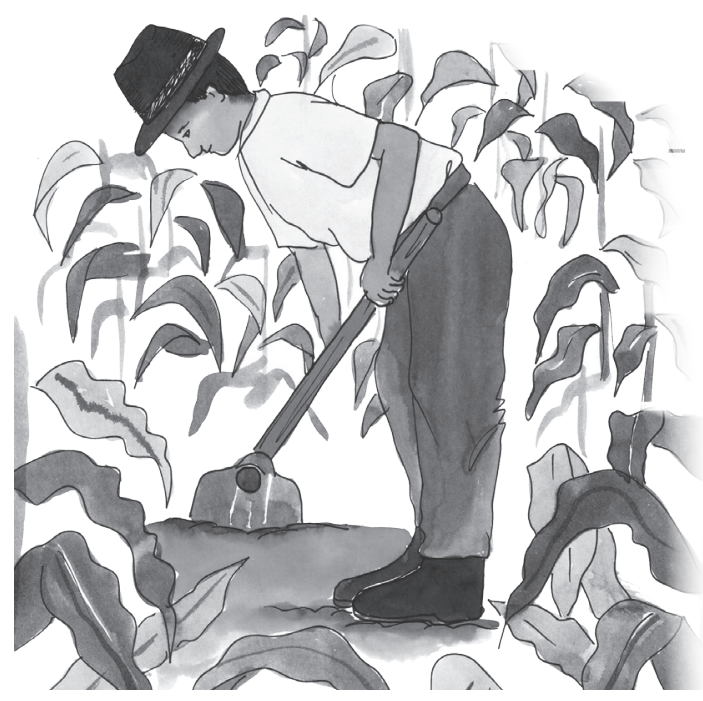




\section{El buen vivir}

Una propuesta crítica, creativa y propositiva ante los grandes problemas de la sociedad y la Naturaleza es el buen vivir o vida en plenitud. La esencia de esta propuesta es vivir en armonía en la comunidad y con la Naturaleza.

Para vivir armónicamente en la comunidad social se practica la democracia comunitaria, es decir, el ejercicio diario de consulta y participación permanente. También es fundamental reconocer la diversidad de pueblos, que además somos diversidad de culturas.

- ¿Qué derechos humanos tienen relación con estas ideas del buen vivir?

Para vivir en armonía con la Naturaleza, se reconoce que ella tiene derechos. Además que la comunidad es unidad de vida, es decir que está conformada por seres humanos y por toda forma de vida o de existencia. Por esto, todo se encuentra interconectado y es interdependiente; el sufrimiento de un individuo o especie lleva al deterioro de la comunidad.

De acuerdo con este criterio del buen vivir:

- ¿Qué sucede cuando se contamina un vecindario? ¿Por qué?

- ¿A quiénes afecta el hecho de que una familia sufra pobreza? Argumentamos nuestra respuesta.

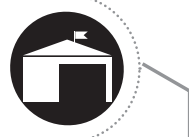

Reunámonos en equipo y pensemos cómo podemos incorporar algún criterio del buen vivir en nuestra propuesta para aprovechar y promover los lugares con potencial para el desarrollo económico, social, cultural y turístico de la comunidad.

Formulo algunas estrategias para presentar el prisma publicitario y que esto sea de utilidad para la comunidad.

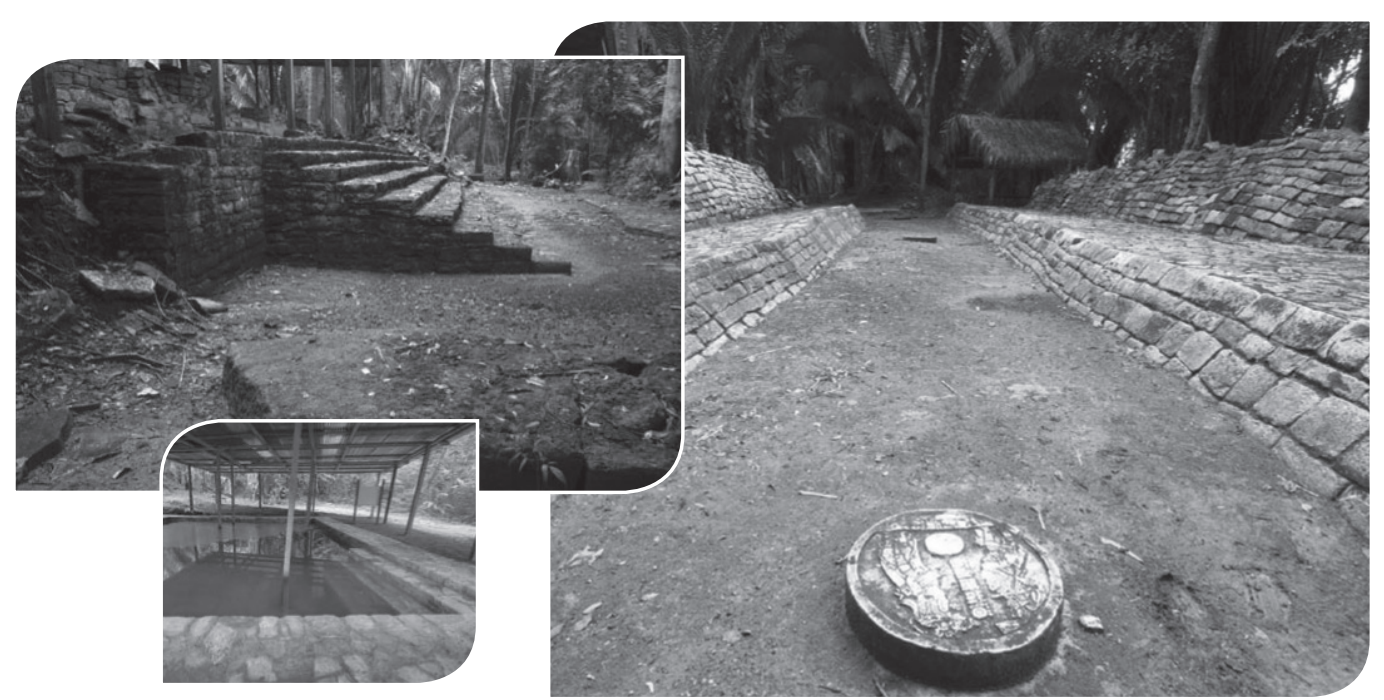

Foto: Parque Nacional Cancuen

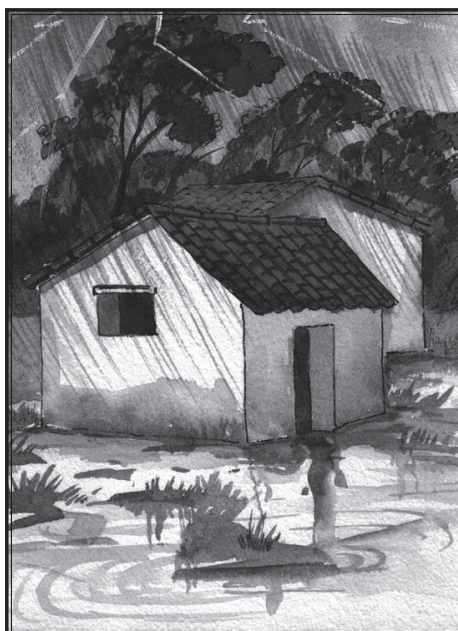

Perspectiva climática de junio 2016

Hay condiciones favorables para "...el desarrollo de un posible fenómeno de La Niña en los siguientes meses. Sin embargo, la atmósfera tardará aproximadamente un mes en responder a estos cambios. Estas condiciones favorecen el desarrollo de lluvias, motivo por el cual, esperamos que la canícula que se presenta en el mes de julio, no sea tan intensa comparada con los años 2014 у 2015."

http:/ / www.insivumeh.gob. gt/meteorologia/boletin_climatico/Boletin_climatico. pdf

- ¿Qué evidencia hay en este párrafo de que el ciclo de lluvia está alterado?

- ¿La propuesta de El buen vivir mejoraría esta situación? ¿Por qué?

- ¿Cómo contribuye al disfrute de los derechos humanos la propuesta del buen vivir?

Argumento mi respuesta. 


\section{Integramos las artes para proteger la vida}

\begin{tabular}{|l|l|l|}
\hline Música & Poemas y canciones & Buscar canciones de la comunidad \\
\hline Teatro & Escenas de problemas ecológicos & $\begin{array}{l}\text { Representar problemas sociales y } \\
\text { naturales }\end{array}$ \\
\hline Danza & Coreografías con movimientos de animales & Realizar danzas propias de la comunidad \\
\hline Artes Plásticas & Dibujos de plantas y animales & $\begin{array}{l}\text { Pintar las especies de la flora y fauna de } \\
\text { la comunidad }\end{array}$ \\
\hline
\end{tabular}

En las semanas anteriores hemos estudiado música, danza y artes plásticas, pensando en la construcción de nuestro proyecto. Al integrar todas las expresiones artísticas podemos crear mejores mensajes para la comunidad. Podemos también integrar lo aprendido con otras áreas del conocimiento.

Podemos dibujar y pintar la Naturaleza o cantar un poema a la belleza e importancia del ecosistema. También podemos representar escenas de un problema ecológico o social. Incluso, podemos bailar una danza que asemeje los movimientos de la fauna que nos rodea.

Veamos algunas de estas sugerencias para realizar:

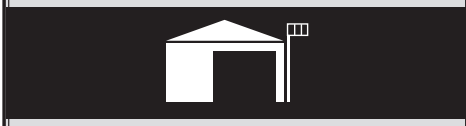

Identificamos dos canciones de la comunidad o región donde vivimos. Las escribimos en nuestro cuaderno. Las socializamos con el resto de la clase.

\section{Cantamos en compañía}

Cantar es una de las actividades más interesantes de la música. Todos y todas podemos cantar. Es muy fácil seguir la melodía con la voz y unirnos como un coro. La mayor parte de música que escuchamos en la radio, son canciones que tratan diversos temas. Las personas cantan en muchos lugares: en el parque, en la iglesia, en los anuncios publicitarios. Y para cantar mejor, se puede acompañar con el cuerpo llevando el ritmo con las palmas o con los pies. Pero cuando agrego un instrumento, puede sonar aún mejor. Presentamos una opción para acompañar nuestras canciones con guitarras o teclados. Para hacerlo únicamente conseguiremos un instrumento entre las y los integrantes de la comunidad y practicaremos bastante las posiciones. En cada acorde suenan varias notas juntas. Por eso se llaman así, pues es como si se pusieran de acuerdo para sonar bien.

\section{Lección de guitarra y teclado en La mayor}

Puedo acompañar una canción con solo 2 o 3 acordes. En esta ocasión usaré La, Re y Mi. Las letras indican el acorde que toco:

$\mathrm{A}=$ La mayor; $\mathrm{D}=$ Re mayor; $\mathrm{y} \mathrm{E}=$ Mi mayor
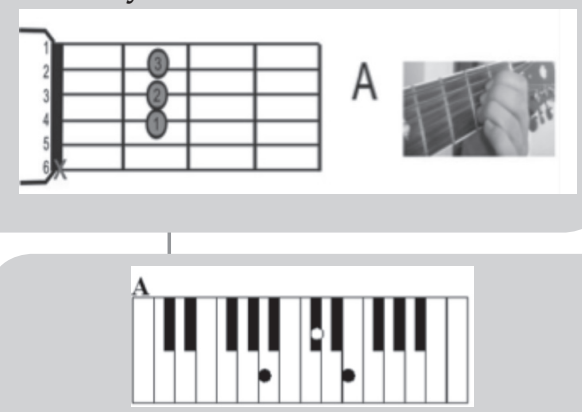

Los acordes en teclado funcionan tocando las teclas que están marcadas con un punto. Pruebo cada acorde por separado y luego toco una secuencia de 4 tiempos para cada uno.

Así: 4 tiempos de La mayor, $\mathrm{A}$ 4 tiempos de Re mayor, D Luego 4 tiempos de Mi mayor, E
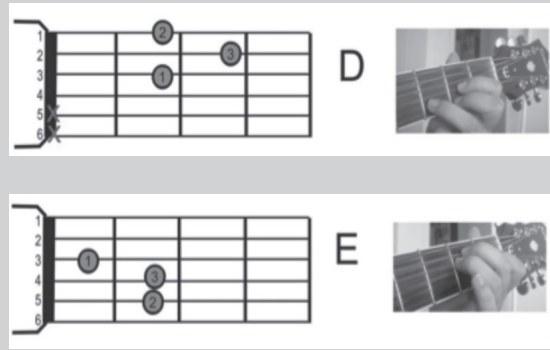

Las cuerdas que tienen una " $X$ " no deben sonar

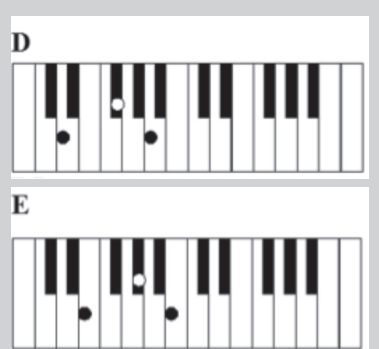

Al final regreso a La mayor $\mathrm{y}$ vuelvo a comenzar.

Estos acordes forman el círculo de La mayor. 


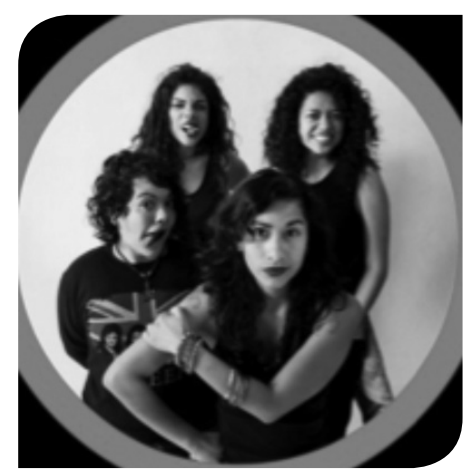

Miss Lilith

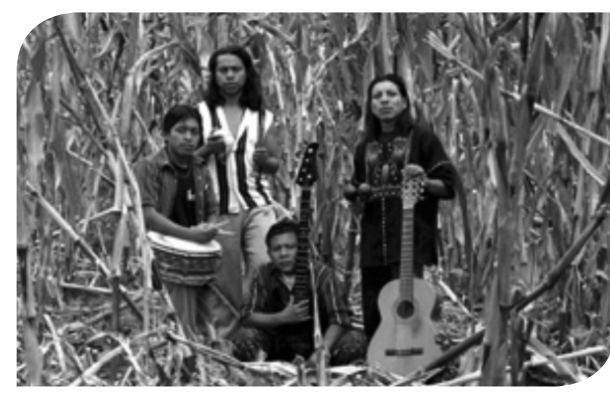

Sobrevivencia

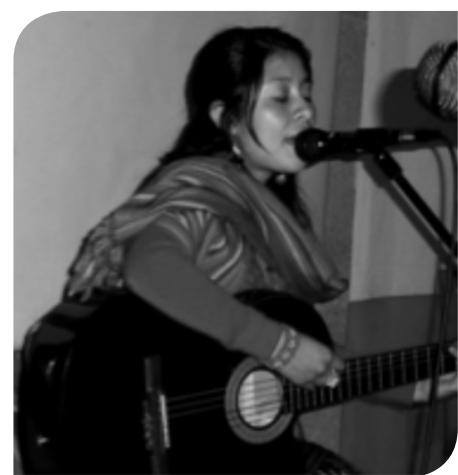

Ch'umilkaj Curruchiche
Qatinamït (Ch'umilkaj Curruchiche)

Cuando regreso a mi tierra

Veo los colores del cielo ocultando al padre sol detrás de las montañas.

Y Cuando cae la noche

Veo a mis hermanas estrellas

engalanando el cielo

junto a la abuelita Ixchel, la luna.

Quiero tejer las vivencias de mi tierra

de múltiples colores

que reflejen su belleza

y su armonía.

Nuestra tierra es ensamble de artes

y en tus venas fluye la inspiración.

Cuando veo en tus galerías

plasmas tus sentimientos de mi pueblo

y puedo escuchar tus voces

en las melodías de tus sierras.
Rub'ix ri ya' (En el canto del agua)

Rub'ix juyu' (En el canto de los cerros)

Rub'ix chikopi' (En el canto de las aves) //2

Quiero tejer las vivencias de mi tierra de múltiples colores que reflejan su belleza y su armonía.

Cuando veo a los abuelos por las calles caminar me inspiran esperanzas de vida me inspiran esperanzas de vida mMe inspiran esperanzas de vida...

Qa tinamÏt yalan yoj kikot awik'in Matyox chawe Ruma ri ak'ojlem Matyox chawe//2

Fuente: Ch'umilkaj Curruchiche, entrevista con J. Flores H. Para escucharla puedes ir al link: https:/ / www.youtube.com/watch?v=VERBl2ckMQM

Muchos y muchas jóvenes en Guatemala se reúnen para tocar y cantar música de diversos estilos, crean sus propias canciones y las presentan al público. Por ejemplo: la banda de metal y rock progresivo Miss Lilith, reúne a cuatro muchachas metaleras. Sobrevivencia es un grupo de Rock en Mam, Achí y Kaqchikel. También hay solistas que cantan en sus propios idiomas, canciones de su comunidad o sus propias creaciones. En ellas expresan la cosmovisión de sus ancestros. Sara Curruchich y $\mathbf{C h}^{\prime}$ umilkaj Curruchiche han llegado a participar en eventos nacionales e internacionales con su música en Kaqchikel.

Para usar nuestros acordes en La mayor, podemos buscar en youtube la canción "Qatinamït" de Ch'umilkaj Curruchiche. Luego, a cantar todos juntos.

- Buscamos las canciones de la comunidad que nos gusten. De preferencia, canciones que hablen de la Naturaleza o describan aspectos de la realidad. Probamos cantarlas acompañándonos solo de palmas y pies. Buscamos guitarras o teclados. Las acompañamos usando los acordes de La mayor. Buscamos más acordes para cantar. Presentamos las canciones junto con el prisma de nuestro proyecto. 


\section{Panes para mi matate... de identidad}

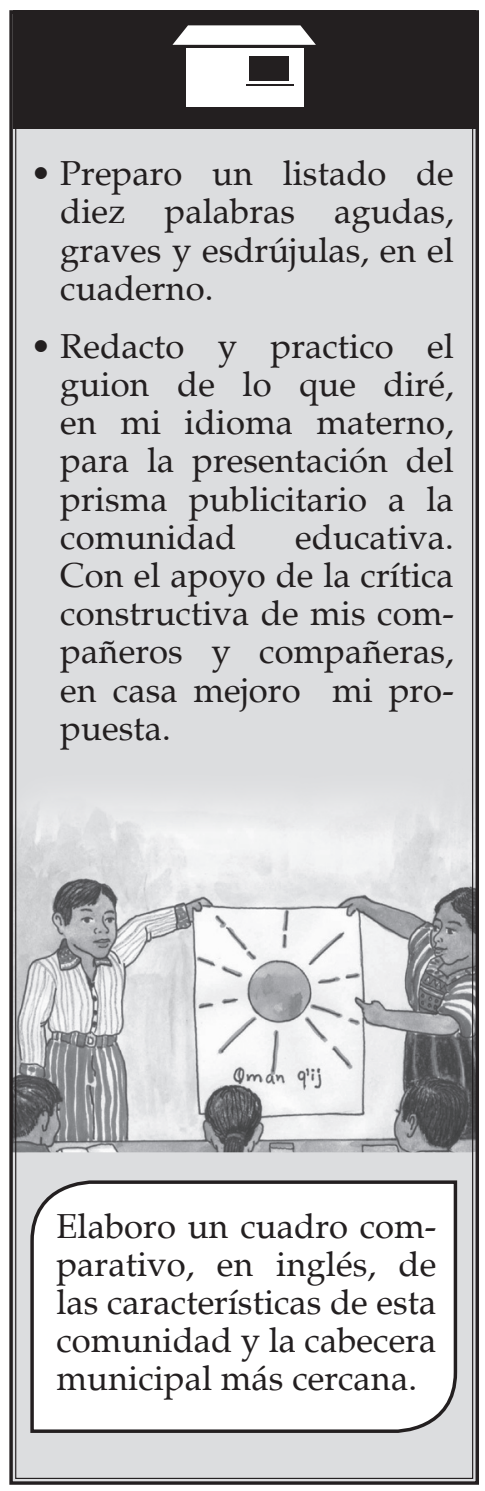

Todas las palabras tienen una sílaba que al pronunciarla suena más fuerte que las otras. Esa sílaba acentuada se llama tónica. Llamamos acento al mayor esfuerzo de voz en una sílaba. El acento puede ser fonético o prosódico, cuando únicamente se marca con la voz, por ejemplo: casa, pared. Y ortográfico, cuando esa fuerza se marca gráficamente con una tilde ('). Según la ubicación de la sílaba tónica, las palabras son:

\begin{tabular}{|l|l|l|}
\hline Agudas & última sílaba: & revés, canción, reloj \\
\hline Graves & penúltima sílaba: & tecolotes, luna, poesía \\
\hline Esdrújulas & antepenúltima sílaba & luciérnagas, murciélagos \\
\hline
\end{tabular}

Recuerdo que las palabras esdrújulas llevan siempre el acento ortográfico o tilde. Pero, ¿cuándo se tildan el resto de palabras?

- Cuando son agudas y terminan en n, s o vocal.

- Cuando son graves y No terminan en n, s o vocal.

- En Guatemala existen condiciones que facilitan la formación de palabras propias: el clima, la herencia cultural indígena y española y la existencia de varios idiomas en el país. A las palabras cuyo origen y uso se limitan a Guatemala se les llama guatemaltequismos y son parte importante de nuestra identidad. ¿Entendemos la siguiente oración? Estás muy chispuda, patoja, dale a la chamba y ponete pilas. Pues, si la entendimos, es porque compartimos la nacionalidad y estamos acostumbrados a nuestros modismos, pero un joven peruano o una joven cubana seguramente no hubieran comprendido el mensaje. ¿Qué otros guatemaltequismos recordamos?

- "El ser es lo auténtico, lo real en nosotros y urge aprender a desarrollarlo. Para saber ser, hay que conocerse. En la medida que alguien se conoce, puede transformarse y realizarse. En ese proceso de conocerse, transformarse y realizarse, el ser humano, descubre lo que es auténtico o real en su vida y a distinguirlo de lo ilusorio, la falsedad y lo irreal. Es preciso encontrar la forma de desarrollar valores y actitudes, entre ellas: solidaridad, creatividad, responsabilidad cívica, sentido crítico, asertividad, capacidad de resolver problemas y transformar positivamente conflictos por métodos no violentos; pero todo desarrollado desde la perspectiva del saber ser". Jorge Galindo

- Los nombres de nuestros panes son muy chapines: cachitos, molletes, churros, lenguas de gato, campechanas, conchas, champurradas, shecas, franceses y pirujos. Unos se refieren a su forma, como los cachitos o las conchas. Otros, como el mollete, tienen su historia: su nombre proviene del latín mollis que significa tierno; así que, de todos los personajes en la panera, es el más emparentado con la ternura. Los churros y champurradas tienen su origen en la prisa con que se hicieron: churro significa algo mal hecho y champurrada se deriva de la palabra champurreada, hecha con descuido y de prisa. Dicen que alguien campechano o campechana tiene disposición al chiste. ¿Será que la campechana con su forma enrollada hacia arriba es la broma de algún panadero o de alguna panadera? 


\section{Mímica y lenguaje gestual y corporal}

Comunicamos más allá de las palabras: lo hacemos también a través de nuestros gestos y de los movimientos de nuestro cuerpo. Por ello, estos influyen en los mensajes que transmitimos. Nuestros gestos y movimientos también delatan sentimientos y/o percepciones.

En la presentación dramática, esta comunicación no verbal cobra mucha más importancia. Quien actúa debe comunicarse con el público y hacerle llegar lo que siente y piensa su personaje y, así, conmover, enojar, hacer reír o llorar a su público. Cada movimiento de los actores y actrices sobre un escenario, cada gesto, cada postura, su andar, su forma de expresarse con las manos al hablar, sus tics, su manera de reír o de llorar, su postura al sentarse... todo forma parte del trabajo de interpretación a la hora de elaborar un personaje. Si se unen a estos elementos, otros signos como la escenografía, la música y el vestuario, entre otros, comprendemos por qué el teatro está considerado como un arte total porque utiliza todos los lenguajes.

\section{Poesía y narración}

¿Cuál es la forma de cada uno de estos fragmentos? ¿Cuál es poesía y cuál, narración?

Yo pienso en ti, tú vives en mi mente, sola, fija, sin tregua, a toda hora, aunque tal vez el rostro indiferente no deje reflejar sobre mi frente

la llama que en silencio me devora.

(José Batres Montúfar)

Así fue la creación de la tierra, cuando fue formada por el Corazón del Cielo, el Corazón de la Tierra, que así son llamados los que primero la fecundaron, cuando el Cielo estaba en suspenso y la tierra se hallaba sumergida dentro del agua. Así fue como se perfeccionó la obra, cuando la ejecutaron después de pensar y meditar sobre su feliz terminación.

Popol-Vuh (versión de Adrián Recinos)

- Escribamos situaciones graciosas de la vida diaria y nuestro ecosistema. Representémoslas frente a nuestros compañeros y compañeras. Tomemos en cuenta la personalidad de los personajes. Recordemos que la clave es evidenciar, no denunciar.
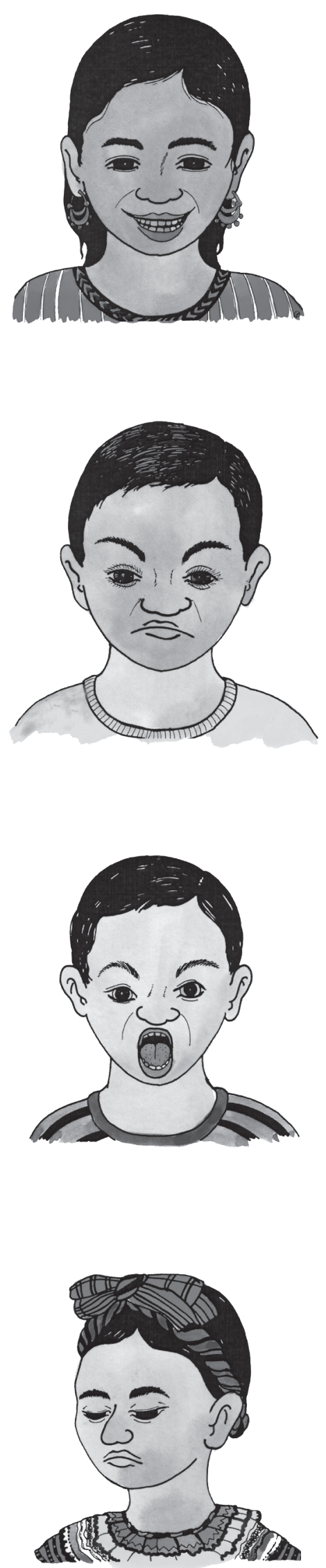


\section{PROYECTO No. 1. Promoción de mi comunidad.}

\section{Reflexión sobre mi participación en el desarrollo del proyecto}

Marco $\boldsymbol{X}$ en las casillas que considero corresponden a mis actitudes en relación con mi participación y aprendizaje.

\begin{tabular}{|c|c|c|c|}
\hline Actitud & Siempre & Casi siempre & Nunca \\
\hline $\begin{array}{l}\text { Reconozco que en cada actividad realizada mi pro- } \\
\text { pósito fue aprender para la vida. }\end{array}$ & & & \\
\hline $\begin{array}{l}\text { Me interesé por profundizar lo aprendido en clase } \\
\text { y realicé las investigaciones propuestas. }\end{array}$ & & & \\
\hline $\begin{array}{l}\text { Relacioné la información vista en clase con la cultu- } \\
\text { ra, salud, recreación, deporte, ambiente, producti- } \\
\text { vidad y economía de mi comunidad. }\end{array}$ & & & \\
\hline $\begin{array}{l}\text { Los conocimientos recibidos en clase me parecen } \\
\text { importantes para valorar y mejorar el ambiente na- } \\
\text { tural, la salud, el intercambio cultural, la economía } \\
\text { y productividad de mi comunidad. }\end{array}$ & & & \\
\hline $\begin{array}{l}\text { Cada semana, asigné un horario específico a mis } \\
\text { estudios }\end{array}$ & & & \\
\hline Realicé a tiempo las tareas asignadas. & & & \\
\hline $\begin{array}{l}\text { Evité copiar las tareas de mis compañeros porque } \\
\text { les faltaría el respeto y porque limitaría mi apren- } \\
\text { dizaje. }\end{array}$ & & & \\
\hline $\begin{array}{l}\text { En mis investigaciones elegí, analicé y sinteticé la } \\
\text { información y evité copiar la información. }\end{array}$ & & & \\
\hline $\begin{array}{l}\text { Reconozco que mi realidad inmediata puede cam- } \\
\text { biar al utilizar mis nuevos conocimientos. }\end{array}$ & & & \\
\hline $\begin{array}{l}\text { Reconozco las acciones que promueven la salud, re- } \\
\text { laciones entre culturas, producción, el trabajo digno } \\
\text { y la mejora de la economía de mi comunidad. }\end{array}$ & & & \\
\hline $\begin{array}{l}\text { Colaboro a mis compañeros y compañeras en el } \\
\text { proceso de su aprendizaje. }\end{array}$ & & & \\
\hline $\begin{array}{l}\text { Me intereso por aplicar las normas de redacción y } \\
\text { ortografía en los textos que escribo. }\end{array}$ & & & \\
\hline
\end{tabular}




\section{Evaluación por Competencias}

\begin{tabular}{|c|c|c|c|}
\hline Actitud & Siempre & Casi siempre & Nunca \\
\hline $\begin{array}{l}\text { Demuestro respeto a mí persona, compañeros(as), } \\
\text { docentes y centro educativo. }\end{array}$ & & & \\
\hline $\begin{array}{l}\text { Propongo soluciones y aporto ideas cuando partici- } \\
\text { po en equipos de trabajo. }\end{array}$ & & & \\
\hline $\begin{array}{l}\text { Expreso mis sentimientos y pensamientos con res- } \\
\text { peto, sin ofender a otras personas en el momento } \\
\text { oportuno. }\end{array}$ & & & \\
\hline $\begin{array}{l}\text { Respeto la participación, ideas, diferencias físicas, } \\
\text { intelectuales, religión, idioma, cultura y género de } \\
\text { quienes conforman mi clase. }\end{array}$ & & & \\
\hline $\begin{array}{l}\text { Me intereso por hablar y escribir en mi idioma ma- } \\
\text { terno. }\end{array}$ & & & \\
\hline $\begin{array}{l}\text { Utilizo diferentes estrategias para solucionar pro- } \\
\text { blemas. }\end{array}$ & & & \\
\hline $\begin{array}{l}\text { Analizo y utilizo conceptos importantes de ecosis- } \\
\text { temas, economía, productividad, interculturalidad, } \\
\text { salud, deportes y otros. }\end{array}$ & & & \\
\hline $\begin{array}{l}\text { Comparo conceptos y distingo sus diferencias y si- } \\
\text { militudes. }\end{array}$ & & & \\
\hline $\begin{array}{l}\text { Observo fenómenos de la Naturaleza y realizo ex- } \\
\text { perimentos para comprobar aprendizajes. }\end{array}$ & & & \\
\hline $\begin{array}{l}\text { Utilizo las herramientas tecnológicas como apoyo } \\
\text { para mi aprendizaje. }\end{array}$ & & & \\
\hline $\begin{array}{l}\text { Utilizo el arte para expresar mis ideas y sentimien- } \\
\text { tos. }\end{array}$ & & & \\
\hline $\begin{array}{l}\text { Aprecio las diferentes expresiones artísticas (músi- } \\
\text { ca, plásticas, teatro, danza) como desarrollo perso- } \\
\text { nal y social. }\end{array}$ & & & \\
\hline
\end{tabular}

\section{Anecdotario:}

Lleno los espacios para contar mi experiencia con las actividades del proyecto

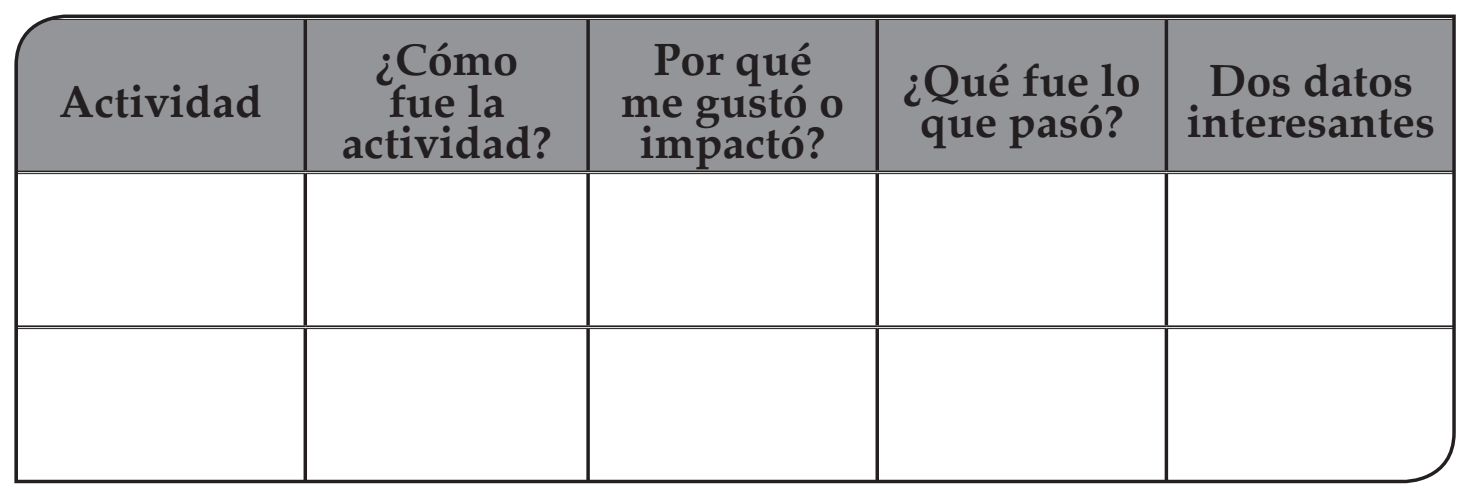

(77) $\cdots \cdots \cdots \cdots$ 


\section{Productos y servicios de nuestra}

Lo que produce nuestra comunidad es muy importante para lograr el bienestar de sus integrantes. La producción de los bienes y los servicios es fuente de ingresos económicos para las familias que participan en la misma. Quienes participan en la producción también obtienen la satisfacción de saber que contribuyen al bienestar de las personas. Los productos y servicios que se producen también son elementos de identidad para nuestra comunidad. Por eso es importante conocer qué se produce, cuáles son los procesos de producción, qué tipo de recursos se emplean, cómo se comercializa y de qué manera se distribuyen los beneficios.

\section{¿Qué deseamos?}

Identificar los productos y servicios que se elaboran y ofrecen en la comunidad, los procesos ancestrales y actuales que se siguen para obtenerlos, la infraestructura y recursos utilizados, la oferta y la demanda de esos productos; y cómo y a quiénes se distribuyen. También dialogaremos sobre cómo el proceso de producción impacta el entorno de la comunidad y su relación con el desarrollo humano.

\section{¿Qué haremos?}

Elaboraremos un catálogo que contenga los productos y servicios de la comunidad. Nos organizaremos en grupos de trabajo según los tipos de productos y servicios locales. Clasificaremos los productos y servicios de acuerdo con la actividad productiva. Puede ser agrícola, pecuaria, industrial, artesanal, turística o de otra naturaleza. El número asignado de páginas del catálogo estará de acuerdo con lo investigado por cada equipo.

\section{¿Con quiénes trabajaremos?}

Decidiremos si continuamos con los mismos grupos o formamos nuevos. Respetaremos la decisión personal de quien quiera cambiarse de grupo. Cada grupo debe elegir, al menos, una persona como coordinadora y otra, como relatora. La designación de responsabilidades en el grupo debe ser representativa, facilitar la participación de las mujeres y dar oportunidad a la rotación de cargos. Asimismo es recomendable evitar algún tipo de sexismo en la elección de cargos, por ejemplo: asignar la secretaría siempre a una mujer o la presidencia a un hombre.

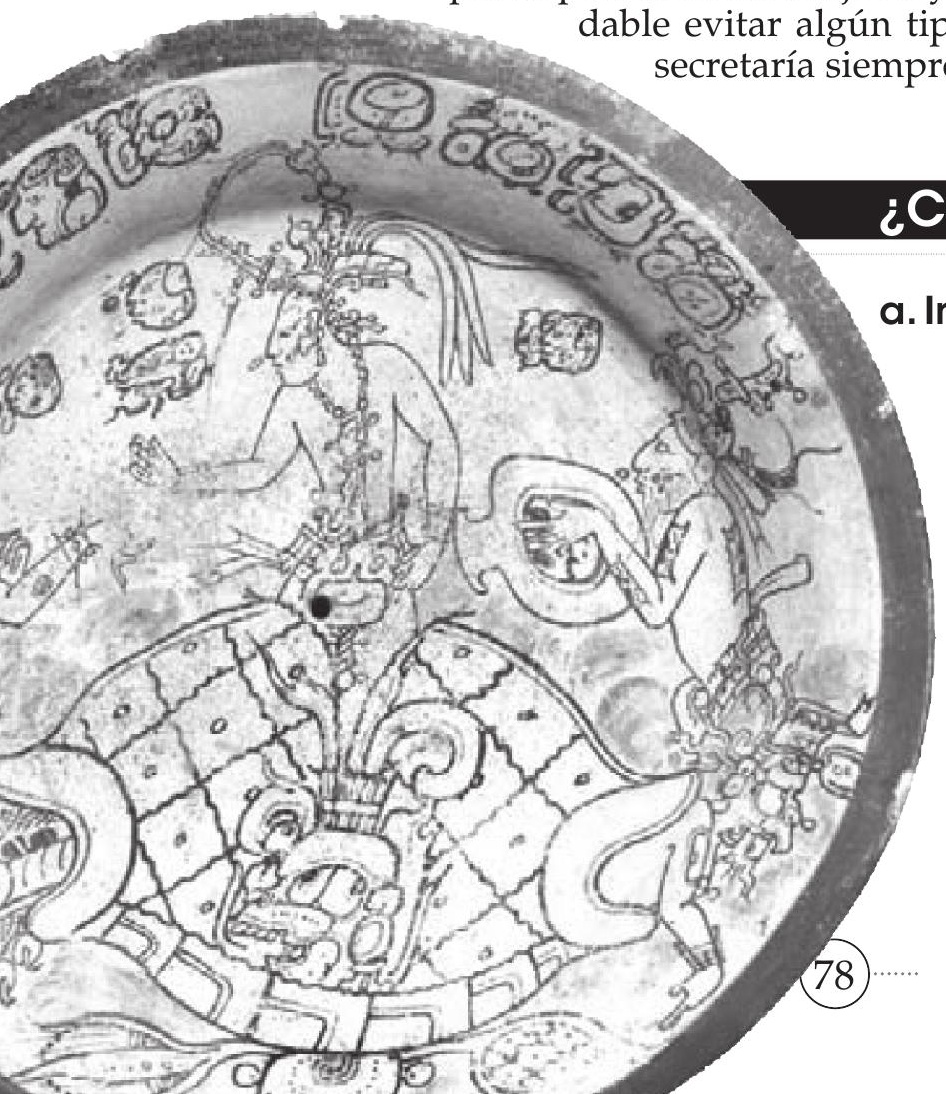

Investigamos acerca de los productos y servicios de la comunidad y los clasificaremos según el tipo de actividad económica a la que correspondan. Por ejemplo, productos agrícolas: hortalizas, granos o frutos, entre otros; productos pecuarios: cría de vacas, cerdos, aves u otros; productos industriales: transformación o embazado de alimentos, textiles, medicinas, químicos, joyería, orfebrería, entre otros; servicios: relacionados con el turismo, la recreación, el comercio, entre otros. 


\section{comunidad}

\section{b. Organización}

Cada grupo elegirá, por consenso, el tipo de producto o productos en los que enfocará su investigación. Visitaremos los lugares de producción, promoción, comercialización y distribución del tipo de producto elegido y nos entrevistaremos con personas responsables de esa producción. Obtendremos información del tipo de producto, técnicas empleadas para obtenerlo, mercado, oferta, demanda, formas de promocionar, comercializar y distribuir la producción, recursos e infraestructura utilizada.

En un cuadro, resumimos la información de los productos investigados, según la categoría a la que pertenecen y la información obtenida de cada producto.

- Después de consultar con su grupo, las personas coordinadoras acordarán las características del catálogo y recursos necesarios: formato, título, créditos, número total de páginas y cantidad destinada para cada producto o actividad económica; tipo de papel o material de los exteriores y de los interiores, colores, tipo de imágenes; útiles de escritorio o recursos tecnológicos disponibles, etcétera.

- Consolidamos, clasificamos, ordenamos y seleccionamos la información obtenida.

- Redactamos la información, elegimos los elementos gráficos que emplearemos (fotografías, dibujos, esquemas, etc.) y elegimos la distribución de texto e imágenes del catálogo.

- Colaboramos en el diseño del catálogo.

\section{¿A quién presentaremos nuestro producto?}

Con nuestra tutora o tutor, acordaremos a quiénes les presentaremos nuestro catálogo. Puede ser a quienes estudian en el centro de educación extraescolar y demás tutoras o tutores; a madres y padres de familia, las personas que participan en la producción de bienes y servicios, entre otras.

\section{¿Cómo distribuiremos el tiempo?}

\section{,}

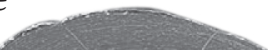


Los prismas son cuerpos sólidos cuyas secciones transversales paralelas a las caras son iguales. Existen otros cuerpos geométricos como las pirámides, cilindros, esferas y conos:

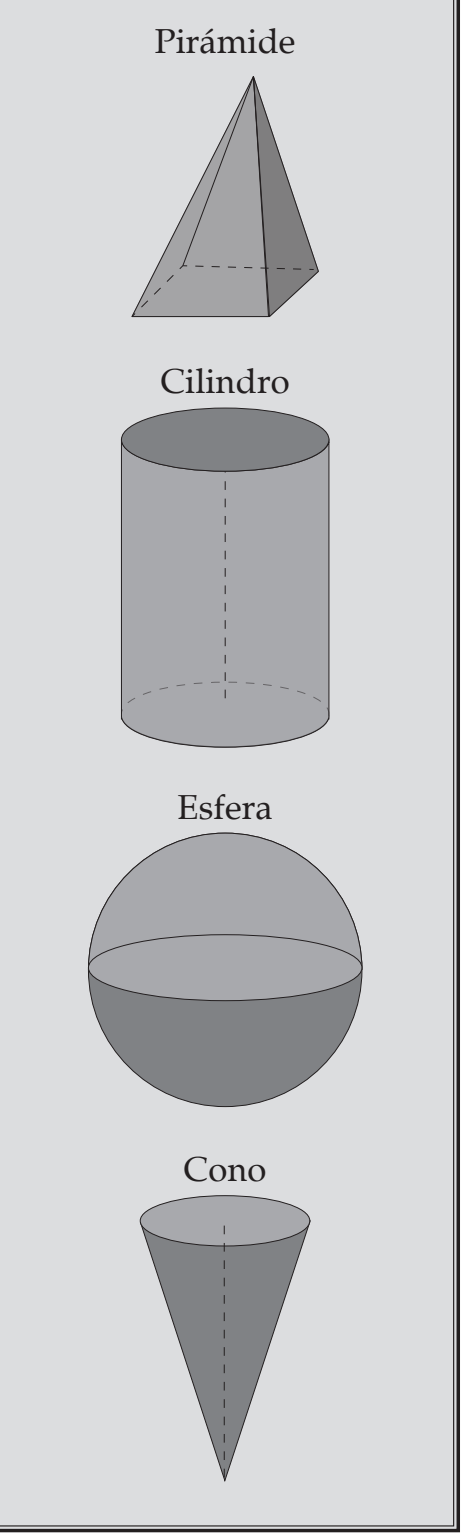

Visitamos la tienda o abarrotería más cercana y observamos los productos que ahí se venden. Respondemos y comentamos: ¿Qué productos originarios de nuestra comunidad se venden en el lugar? ¿De dónde vienen el resto de productos? ¿Cuáles productos tienen empaque? ¿Qué formas tienen los productos que se venden empacados? Copiamos las formas de algunos productos empacados.

Encontramos productos de la tienda que tengan forma de prismas. Estimamos las dimensiones de algún producto con forma de prisma y estimamos su perímetro. Compartimos con el resto del grupo la estrategia que utilizamos.

Escribimos en una tarjeta la estrategia que utilizamos para hallar el perímetro de un cuerpo sólido. La presentamos oralmente al resto de compañeros y compañeras. Comparamos las estrategias y observamos si algunas de ellas coinciden.

Con apoyo de nuestra tutora o tutor, encontramos fórmulas

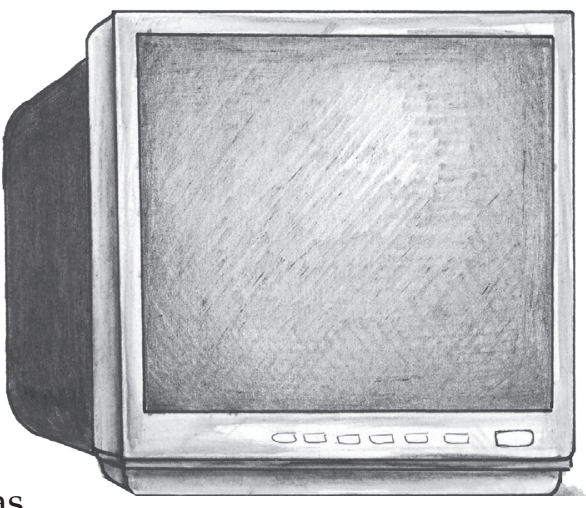
para hallar perímetros de cuerpos sólidos.

En grupo, elegimos cinco objetos con forma de prisma $y$ determinamos el perímetro de cada objeto. ¿Cuántas dimensiones tienen los objetos elegidos? ¿Todos los objetos elegidos tienen el mismo número de dimensiones? ¿Qué nombre

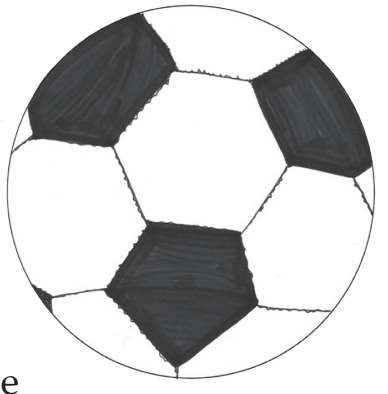
asignamos a cada dimensión? Medimos las dimensiones de cada objeto. Con estos datos, fácilmente obtendremos el perímetro de cada objeto seleccionado.
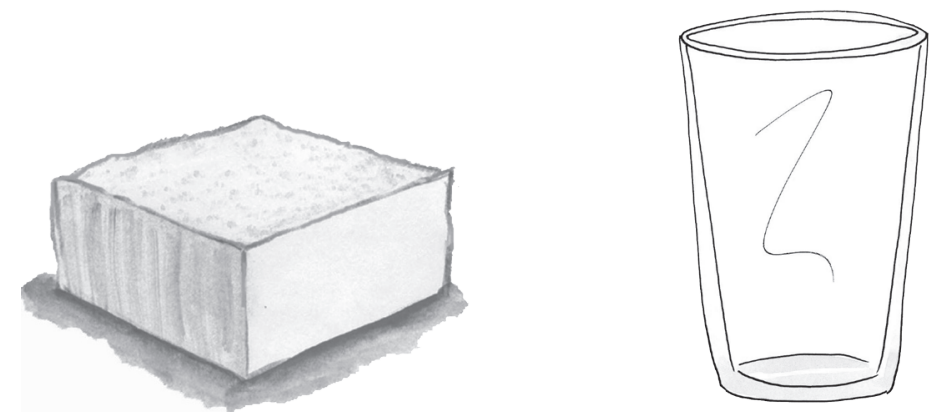
Utilizamos palillos de madera y plasticina, arcilla u otro material adecuado para representar los siguientes cuerpos sólidos. Luego los representamos gráficamente en el cuaderno.

$$
\begin{aligned}
& \text { - Cubo - Pirámide - Cono } \\
& \text { - Cilindro - Esfera }
\end{aligned}
$$

¿Qué sólidos pudimos representar con facilidad? ¿Por qué? Discutimos las respuestas con el resto de compañeras y compañeros.

Utilizamos media cartulina para copiar y completar la información de los siguientes cuerpos geométricos.

\begin{tabular}{|c|l|l|l|l|}
\hline Nombre & Dibujo & Características & $\begin{array}{c}\text { Forma de } \\
\text { hallar su } \\
\text { perímetro }\end{array}$ & $\begin{array}{c}\text { Objetos } \\
\text { cercanos } \\
\text { que tienen } \\
\text { forma } \\
\text { similar }\end{array}$ \\
\hline Prisma & & & & \\
\hline Pirámide & & & & \\
\hline Cilindro & & & & \\
\hline Cono & & & & \\
\hline
\end{tabular}

¿Cómo son empacados los productos que se producen en la comunidad? ¿Es importante la forma que tienen los empaques de los productos que se venden y producen en mi comunidad? ¿Qué cuerpos sólidos son los que más se observan en los productos de la comunidad?

Para cada uno de los productos que incluiremos en el catálogo, recomendaremos el cuerpo sólido y tipo de empaque más apropiado para promocionarlo en el catálogo.

Utilizo una cinta métrica para hallar perímetros de los siguientes cuerpos. Comparo mis resultados con los que obtengo utilizando la fórmula.

- Lata de frijoles

- Crema dental

- Paquete de servilletas de papel

¿Puedo hallar el área de los empaques de los productos anteriores utilizando únicamente una cinta métrica? ¿Por qué?
Los poliedros regulares están formados únicamente por polígonos regulares:

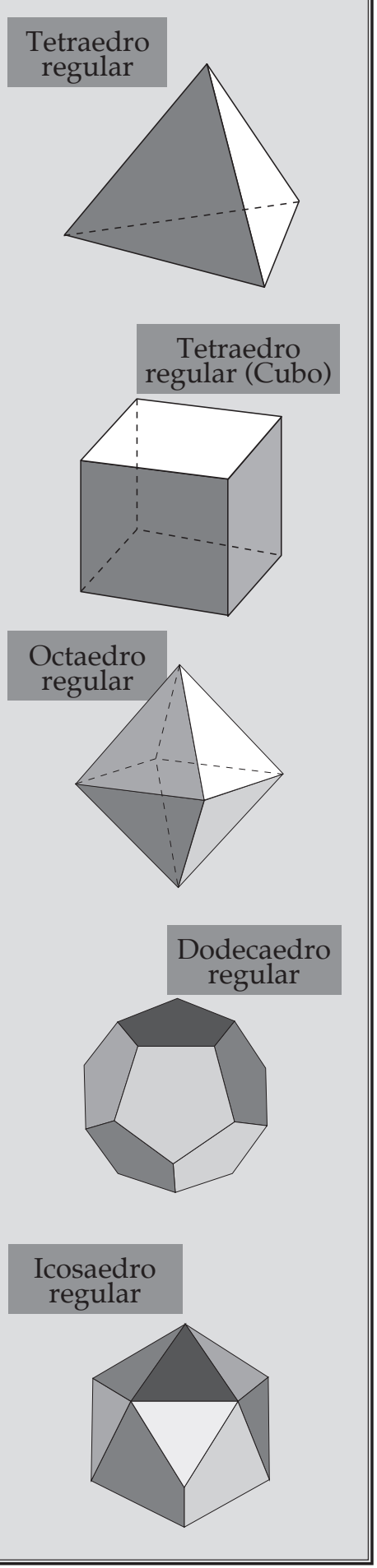




\section{El arte como herramienta para el desarrollo humano}

El psicólogo estadounidense Howard Gardner propuso en 1983 una teoría sobre la inteligencia humana. Sostiene que la inteligencia no es una sola, ni que corresponde a un solo tipo de capacidades; sino que es un conjunto de capacidades. Cada una diferente y útil para un aspecto de la vida humana. Según Gardner, existe una inteligencia para cada actividad que realizamos o sentimos. Estas inteligencias son: lingüística, lógico-matemática, espacial o visual, musical, kinéticacorporal, intrapersonal, interpersonal y naturalista.

Las inteligencias que se asocian a las artes son:

Musical, para los aspectos de la música

Kinético-espacial, para los aspectos de la danza, el teatro y la música

Espacial o visual, para los aspectos de las artes plásticas.

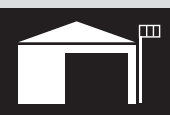

Comentamos sobre el uso de las inteligencias asociadas al arte. Buscamos ejemplos de cada una al realizar los productos artísticos.

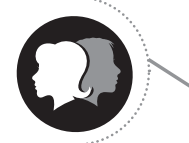

Reunidos en grupo, recordamos las emociones que nos provocan la música, la danza, el teatro y la plástica. Respondemos las siguientes preguntas y las discutimos.

- ¿Qué tipo de arte producimos en nuestra comunidad?

- ¿Por qué la música nos hace sentir emociones intensas de gozo, alegría, tristeza o paz?

- ¿Qué emociones sentimos al escuchar música de nuestra comunidad?

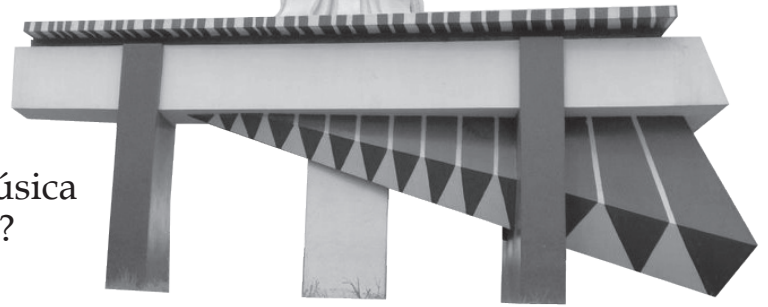

Imagen: Monumento a la marimba por Rodolfo Galeotti Torres, 1975.

Observemos el esquema:

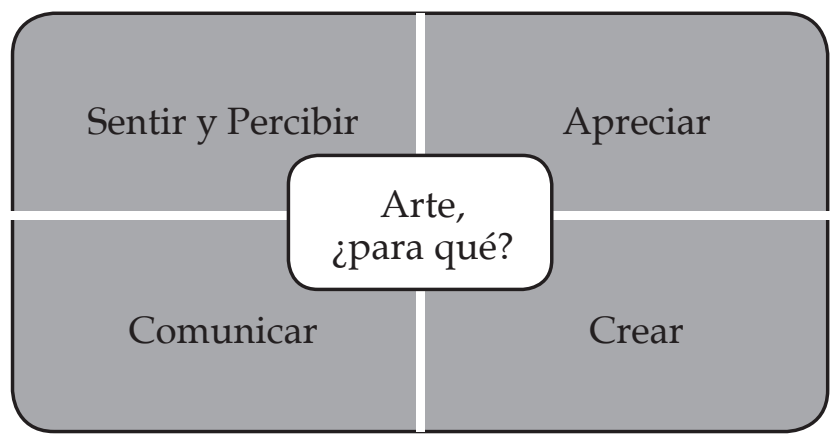

En grupo interpretemos el esquema.

Compartamos ejemplos de cada aspecto que nos propone lo que podemos hacer con el arte

Relacionemos, ¿Cómo nos ayuda el arte para tener un mejor desarrollo humano?

El arte es una capacidad que todas las personas tenemos y podemos desarrollar. La inteligencia se desarrolla mejor cuando pintamos, esculpimos, bailamos, cantamos o tocamos instrumentos. El hemisferio izquierdo de nuestro cerebro se activa con el arte en los aspectos analíticos y racionales; mientras que el hemisferio derecho desarrolla la sensibilidad y las emociones que el arte nos proporciona.

La imaginación es muy importante, pues en el arte las ideas son infinitas. Los productos del arte tocan nuestros sentidos, los disfrutamos y los apreciamos. Luego, con ellos podemos comunicar nuestras ideas y sentimientos. Y aún más, podemos crear y producir obras de gran calidad artística y ejercemos nuestra libertad de expresión.

Cantemos una canción de nuestra comunidad que exprese nuestra identidad. 


\section{Arte y bienestar}

El arte produce bienestar. Como parte de la cultura también brinda identidad y permite que los seres humanos expresen sus ideas y sentimientos. Muchas obras de arte también pueden llegar a ser productos de intercambio y de mercado. Incluso, el o la artista que las produce puede vivir de su trabajo pintando o esculpiendo, haciendo música, danzando o actuando.

Muchas personas, a veces creen que solo las obras hechas por artistas de renombre son arte, lo cual no es así. Al observar el trabajo que hacen las tejedoras al formar un güipil, o las alfareras y alfareros al darle forma al barro, también puede apreciarse la creatividad y la imaginación. Únicamente las piezas que son realizadas con moldes o en serie pueden reconocerse como artesanías, pues no son piezas únicas, en tanto que las obras de arte sí lo son. La alfarería, es el arte u oficio de hacer vasijas y otros objetos de barro.

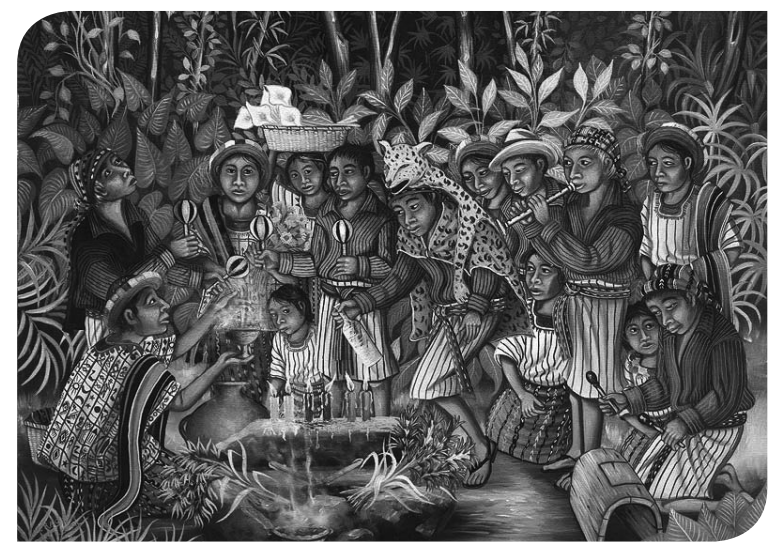

Fuente: www.artemaya.com
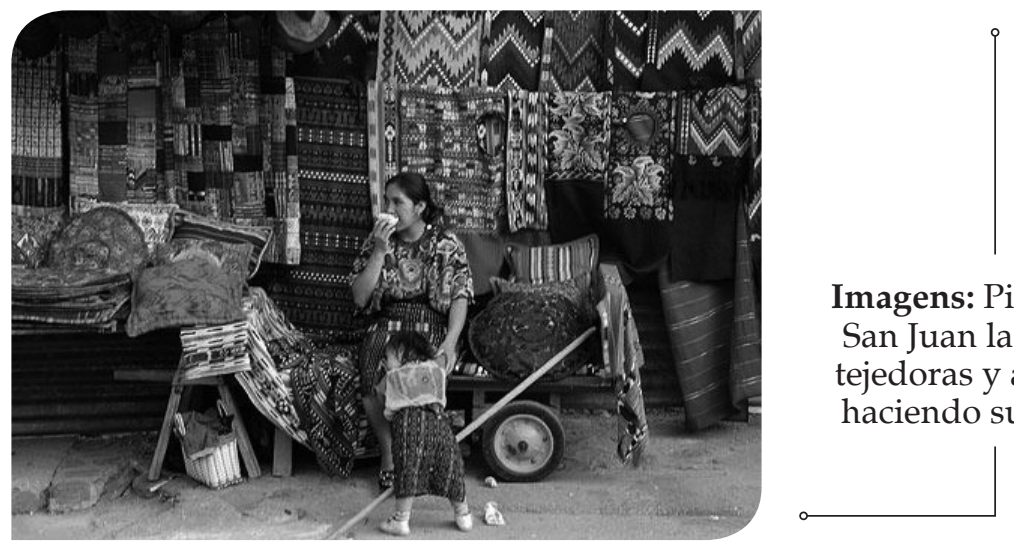

Fuente: http:/ / atitlan-guatemala.blogspot.com/
Imagens: Pinturas de

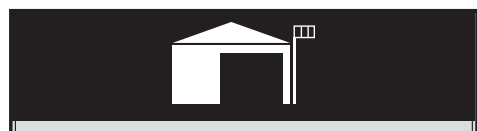

Durante 20 minutos, con música de diversos ritmos, realizamos la siguiente exploración de nuestro estado interior. De preferencia buscamos música que sea muy tranquila, sin letra, solo instrumental.

- En una superficie limpia colocamos una alfombra, petate, tela o papel para recostarnos y escuchar la música

- Realizamos respiraciones lentas, llevando el pulso largo de las piezas. Sentimos la respiración en nuestras vías respiratorias y sentimos todo nuestro cuerpo.

- Seguimos respirando, agregamos movimiento de brazos levantados según el pulso musical y la respiración.

- En la misma sintonía y sintiendo nuestro cuerpo, respiramos agregando movimiento de pies levantados con el pulso musical

- Cambiamos de música y realizamos toda la rutina San Juan la Laguna, tejedoras y artesanos haciendo su trabajo. de relajación con la nueva
pieza musical. de relajación con la nueva
pieza musical.

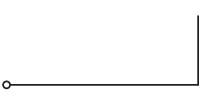

\section{(1)}

- Buscamos información sobre los recursos musicales que realizamos en nuestra comunidad y departamento.

- Investigamos sobre las mujeres artistas de la comunidad.

- Identificamos cuáles productos son arte y cuáles son artesanías para su inclusión en el catálogo.

- Destacamos si hay instrumentos musicales entre los productos.
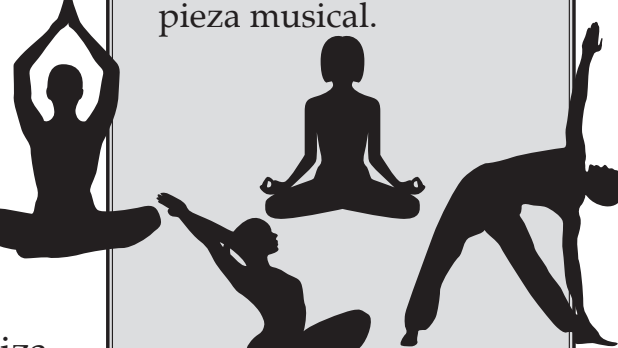

- ¿Pudimos relajarnos completamente?

- ¿Es posible hacer este mismo ejercicio con música muy movida, como rock, salsa o merengue? 


\section{Herencia, ciencia y tecnología}

Gen. Es la unidad de almacenamiento de los datos hereditarios. Se encuentran en los cromosomas, contienen la información hereditaria que poseen los seres vivos, y que van a transmitir a su descendencia.

Genoma. El conjunto de genes de un organismo, por lo tanto es toda la información que puede ser transmitida de una generación a otra.

Genotipo. Es la información genética contenida en los cromosomas, que pueden manifestarse o no. Por ejemplo, si los progenitores de una persona, uno tiene ojos azules y el otro ojos café, el descendiente puede tener ojos azules o cafés, porque en sus genes tiene la información de los dos colores de ojos. Ese es su genotipo.

Fenotipo. Es el conjunto de rasgos de un organismo, siguiendo con el ejemplo anterior, si el descendiente tiene ojos cafés, ese es su fenotipo, pero sigue teniendo la información de los ojos azules en sus genes.

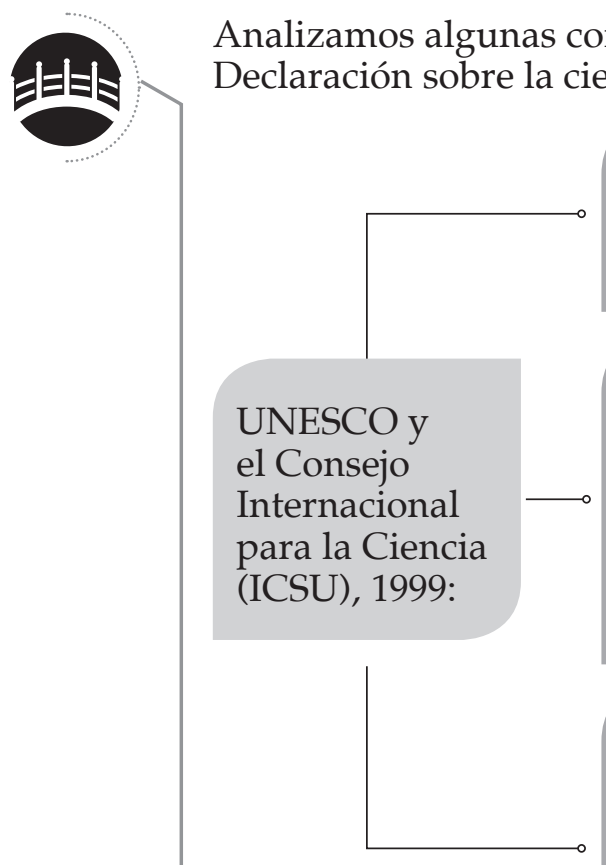

"En el siglo XXI la ciencia debe convertirse en un bien compartido solidariamente en beneficio de todos los pueblos..."

"La investigación científica y el uso del saber científico deben respetar los derechos humanos y la dignidad de los seres humanos,[....] a la luz de la Declaración Universal sobre el Genoma Humano y los Derechos Humanos"

"Incumbe a los científicos, junto a otros importantes agentes, una responsabilidad especial para evitar las aplicaciones de la ciencia que son éticamente erróneas o que tienen consecuencias negativas"

Recuperado de: https://es.khanacademy.org/math/algebra-basics/ core-algebra-expressions/al/v/algebraic-expression-adding-fractions

La ciencia es el conjunto de conocimientos obtenidos mediante la observación y el razonamiento, sistemáticamente estructurados y de los que se deducen principios y leyes generales.

La tecnología es el conjunto de teorías y técnicas que permiten el aprovechamiento práctico del conocimiento científico.

Mediante entrevistas averiguo si en la comunidad se producen o comercializan plantas modificadas genéticamente.

Mediante visita a centros productivos observo el trabajo que desarrolla la maquinaria que se implementa para producir en la comunidad. Registro en una ficha: los movimientos, las fases del proceso y grafico los movimientos que emplea la maquinaria.

\section{Respondemos}

1. ¿Qué aspectos de la vida han mejorado por la aplicación de la ciencia?

2. ¿Cuáles recursos tecnológicos benefician la calidad de vida de las personas en la comunidad?

3. ¿Cuáles recursos tecnológicos perjudican la calidad de vida de las personas en la comunidad?

- Exponemos nuestras respuestas en una mesa redonda. 


\section{Cromosoma humano y avances en la genética humana}

Comentamos los caracteres hereditarios de nuestro grupo, tanto genotípicos como fenotípicos (por ejemplo el color de cabello, de ojos y piel).
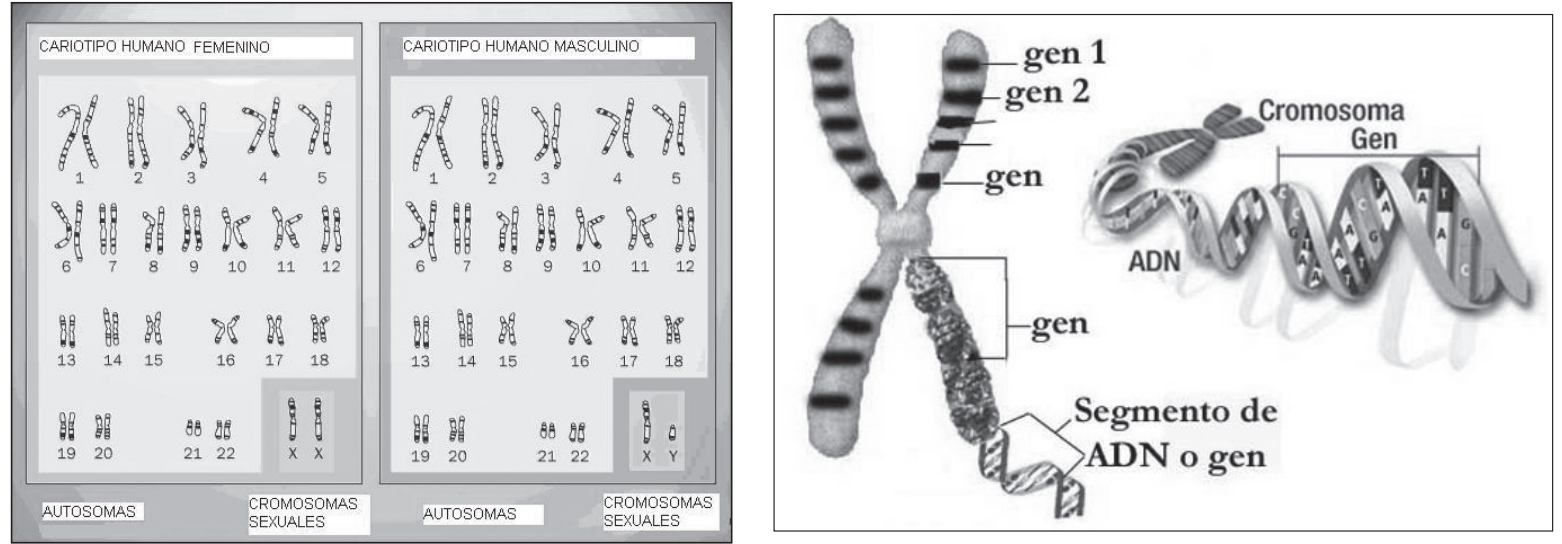

Recuperado en: http:/ / www.quimicaweb.net/Webalumnos/GENETICA\%20Y\%20HERENCIA/Paginas/3.htm

Los cromosomas son cuerpos en forma de bastoncillos que se encuentran en el interior del núcleo de la célula. Está constituido de ácido desoxirribonucleico $(\mathrm{ADN})$. Contiene el material bioquímico que determina toda la información genotípica y fenotípica, que la persona hereda de sus padres y la transmite a sus hijos. Cada ser humano, tanto hombres como mujeres tenemos 23 pares de cromosomas; pero el último par se diferencia en la mujer por ser par XX y en el hombre XY. Con la ayuda de la tecnología moderna y con una pequeña muestra de tejido humano se realizan pruebas de paternidad, de enfermedades hereditarias, pruebas forenses y otras. Mediante la prueba de paternidad, se compara la huella o mapa genético del presunto padre o madre con la del niño o niña. La huella genética es un marcador único característico de cada persona. Las pruebas forenses permiten resolver casos de criminalidad, abusos y violaciones sexuales e identificación de cuerpos.

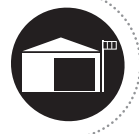

Realizamos una experiencia para extraer ADN de una muestra de saliva.

Necesitamos: agua, jabón líquido de lavatrastos, sal común ( $\mathrm{NaCl}$ ), alcohol $96 \%$ y 2 vasos.

Procedimiento:

1. En un vaso con la mitad de agua añadimos media cucharadita de sal y jabón líquido. (El jabón descompone la célula y liberara el ADN).

2. Colocamos un poco de agua en la boca limpia y enjuagamos por 30 segundos (procuramos no hacer espuma), Soltamos el agua en el vaso que contiene el jabón y la sal.

3. Movemos la solución sin generar espuma y agregamos una o dos cucharadas de alcohol (frio) de manera que resbale por las paredes del vaso.

4. Observamos que se forma un hilo de ADN como filamentos nubosos blanquecino. ¡Allí está el ADN! Tiene que formarse una pequeña bola de hilo blanco.
Con la ayuda de la tecnología, el análisis de ADN, se utiliza para desarrollar nuevos métodos médico preventivos, frente a aquellas enfermedades que se heredan. Puede contribuir a conocer, anticipadamente, si un niño nacerá con características genéticas especiales, identificar los genes que causan enfermedades y conocer los que han mutado. Por este método se confirma o descarta la paternidad, maternidad o relación biológica entre las personas motivo de estudio. Es un recurso legal importante cuando el presunto padre de un niño o niña se niega a cumplir con sus obligaciones económicas familiares. En demandas judiciales son ordenadas por juez competente y las realiza el Instituto Nacional de Ciencias Forenses -INACIF-

¿Qué importancia tienen los genes en la trasmisión de caracteres hereditarios entre los individuos de una misma especie?

Mutación: es un cambio en la estructura del ADN. 


\section{Desarrollo humano}

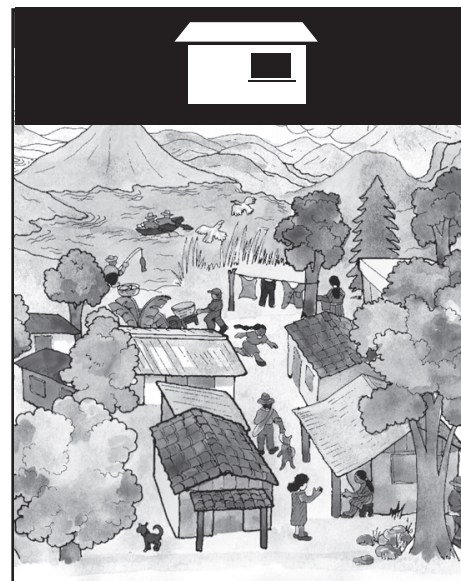

Establezco la relación entre desarrollo humano y derechos humanos.

Tomo en cuenta cuatro condiciones favorables para el desarrollo humano y evalúo su situación en mi comunidad.

Hago una comparación entre los conceptos de desarrollo humano y buen vivir.

"El Programa de Naciones Unidas para el Desarrollo (PNUD) alerta sobre el incremento de la población vulnerable, que podría recaer en la pobreza si no se cambian las políticas públicas actuales. La advertencia se hace a pesar de que el número de personas sin recursos se redujo en los últimos diez años en casi todos los países de América Latina y el Caribe. Sólo uno incumplió las metas fijadas, se quedó atrás y reporta cifras en aumento: Guatemala."

https:/ / www.plazapublica. com.gt/content/guatemalael-unico-pais-latinoamericanoen-el-que-aumento-la-pobreza

Escribo mi opinión sobre la cita anterior
Observemos el esquema.
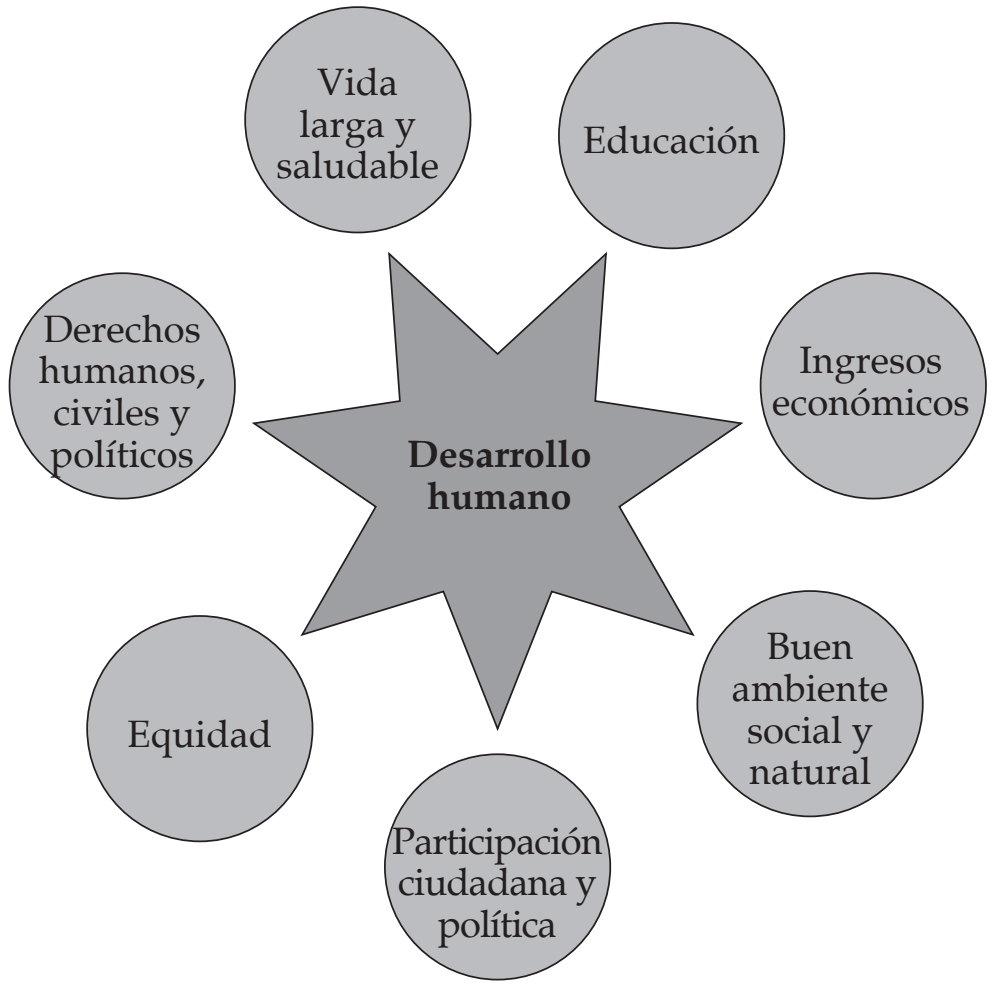

Reunámonos en grupo para interpretar el esquema.

Redactemos una definición de desarrollo humano.

Respondamos, ¿qué falta en nuestra comunidad para alcanzar un alto desarrollo humano?

Según el Programa de las Naciones Unidas para el Desarrollo -PNUD- el desarrollo humano requiere que en una comunidad se brinden condiciones favorables para que las personas desarrollen sus potencialidades y puedan crear y producir todo lo que necesitan y corresponda con sus intereses. Dentro de esas condiciones favorables está la vida saludable y prolongada, la educación, los ingresos satisfactorios, el ambiente natural y social adecuado, entre otras.

Analizamos la definición anterior y la comparamos con la que redactó nuestro grupo. Podemos hacerlo en un cuadro como el siguiente.

\begin{tabular}{|c|c|c|}
\hline Definición & Similitudes & Diferencias \\
\hline PNUD & & \\
\hline Nuestra definición & & \\
\hline
\end{tabular}

- ¿Cómo inciden las formas de producción y distribución de bienes y servicios de la comunidad en el índice desarrollo humano de nuestra comunidad? 

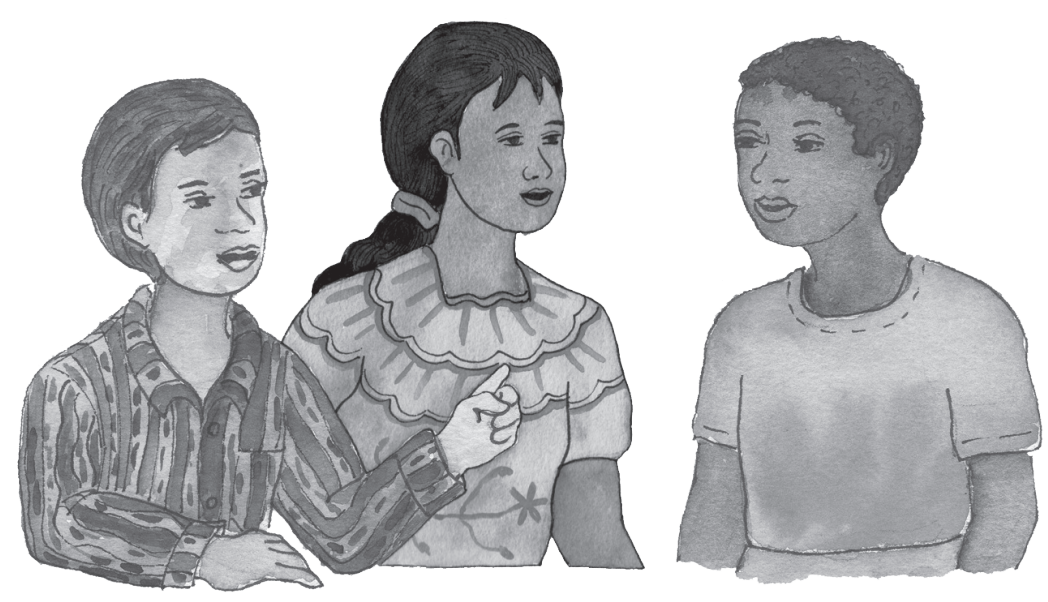

\section{Índice de desarrollo humano}

El PNUD creó una forma de medir el desarrollo humano. Para hacerlo se basó en los tres componentes que presentan menos dificultades para medirlos: vida larga y saludable, educación y nivel de vida digno. El índice de desarrollo humano, IDH, tiene base estadística y es una suma proporcional de promedios de las mediciones de los tres factores; no es exacto, pero sí refleja tendencias aceptables. En 2015, el índice de Guatemala fue de 0.627. De acuerdo con el mismo, es un país de mediano desarrollo a nivel mundial.

La canasta básica de alimentos es la cantidad suficiente de un conjunto de alimentos que satisfacen los requerimientos de calorías y proteínas que necesita una familia de cinco integrantes. Según el Instituto Nacional de Estadística, los ingresos familiares para comprar estos alimentos son de Q 3700.00 mensuales. A las familias que tienen ingresos menores al precio de la canasta básica se les considera extremamente pobres. Esto puede variar en una comunidad, por ejemplo si destinan parte de su cosechas para consumir, baja el costo; también puede subir si muchos productos son más caros que en los mercados de las ciudades.

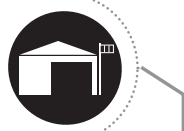

Usemos Microsoft Excel para hacer una tabla en la que ingresamos por cada producto de la canasta básica el costo de producción y el costo de venta. En nuestra comunidad, ¿es más alto o más bajo el precio de la canasta básica? Argumentamos la respuesta. El costo de la canasta básica, ¿cubre a la mayoría de familias? ¿Por qué?

El índice de desarrollo de Guatemala es un promedio, hay departamentos donde es más alto y otras donde está por debajo.

El IDH por departamentos se encuentra en esta dirección: http:/ / desarrollohumano.org.gt/wp-content/uploads/2016/04/ INDH_2011-2012_2-Sintesis-Espan\%CC\%83ol.pdf

Averiguamos cuál es el IDH en nuestro departamento.

Analizamos si en nuestra comunidad el IDH es más alto o más bajo que el departamental. Exponemos nuestros argumentos en plenaria.
Esperanza de vida al nacer. Es una estimación de la cantidad de años que vivirá un recién nacido o nacida, siempre que las condiciones que determinan su salud y vida no cambien. Este indicador es el que se emplea para representar la vida larga y saludable del IDH.

Ingreso nacional bruto per cápita. Suma de ingresos de los habitantes de un país, más los impuestos a los productos, más los envíos de los residentes en el extranjero; todo dividido entre el total de habitantes de dicho país. Dicha estimación se emplea como representativo del nivel de vida digno en el IDH.

Años de escolaridad por adulto. Es el promedio de años que las personas adultas de un país han estudiado.

Escolaridad esperada. Es el promedio de años que se espera que los y las menores de edad estudien, si las condiciones del sector educativo no cambian.

Los años de escolaridad por adulto y la escolaridad esperada son los indicadores que se emplean en el IDH para determinar el componente de educación.

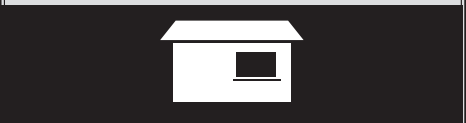

- ¿Qué importancia tienen los ingresos familiares para el desarrollo humano?

- ¿Habrá desarrollo humano con altos ingresos, pero sin salud ni educación?

- ¿Qué efecto tiene la forma de producción de nuestra comunidad sobre nuestra oportunidad de vivir, estudiar y tener buenos ingresos? 


\section{Comercio justo y desarrollo humano}

Las personas que se dedican a los negocios aseguran la venta de su producto con un estudio de mercado. Este incluye conocer en qué dirección se mueve el mercado, cuáles son los productos que se están vendiendo, cuáles no y conocer a los futuros clientes para estimar el volumen de ventas. Han de tomar en cuenta que posiblemente no serán los únicos que tendrán a la venta ese producto. Además, deberán conocer a fondo a la competencia para buscar nuevos "nichos" de mercado, es decir, clientes cuyas necesidades aún no han sido atendidas.

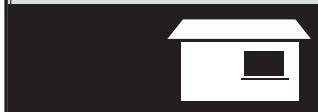

Estudio las similitudes y diferencias entre un tipo de negocio o servicio que se ofrece en mi comunidad, ya sean productos, clientes, ubicación, volumen de venta $\mathrm{u}$ otros.

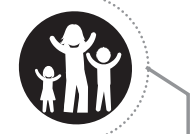

El ser humano es el centro del desarrollo humano. Busca su bienestar al obtener los bienes y servicios necesarios para desarrollar las capacidades, habilidades y destrezas que le permitan llevar una vida digna. Para alcanzar su bienestar, debe respetar los derechos de las demás personas y los de la Madre Tierra. Debe tener una fuente de ingresos de forma lícita, ya sea por medio del empleo, la propia producción o negocio. Así podrá satisfacer las necesidades básicas de su familia y promover el desarrollo en su comunidad.

La mayor parte de familias rurales ponen su máximo empeño en la producción de maíz y frijol para asegurar su sustento entre cosecha y cosecha. También producen en pequeñas cantidades otros cultivos, como hortalizas y frutos, ya sea para el consumo familiar o el mercado local. Los pequeños productores venden directamente o a través de intermediarios; pero estos últimos generalmente tienen mejores ganancias que los propios productores. En ocasiones los productores y productoras optan por vender al intermediario ante la escasez de transporte. El intermediario compra a varios pequeños productores para tener un mayor volumen de producto por el cual puede obtener un mejor precio al vender en mayor cantidad. La intermediación corre con los gastos de transporte y la inversión de compra, pero no corre con los riesgos de la producción.

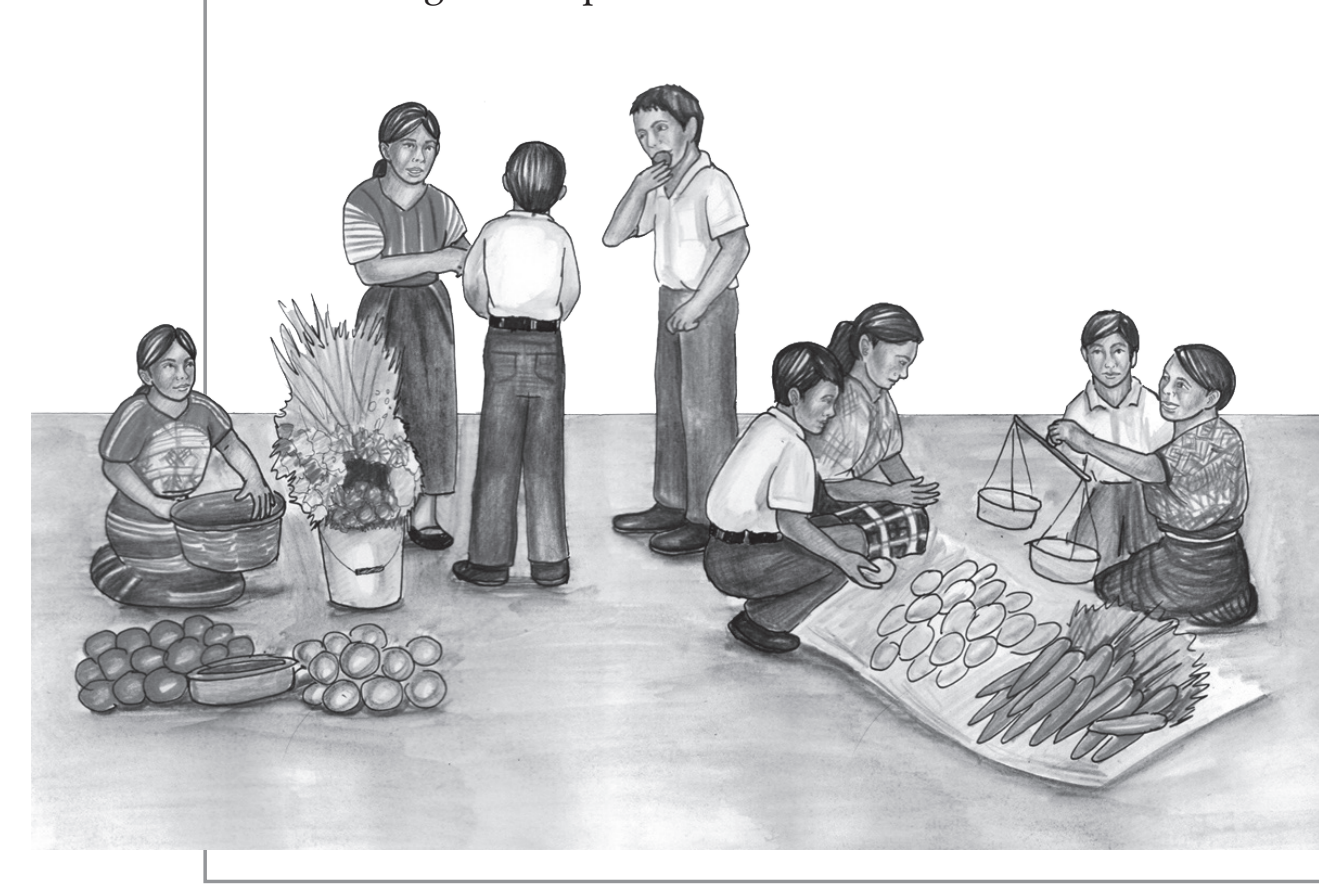

Conversamos con personas productoras de la comunidad sobre sus costos de producción y venta. ¿Cuál es el margen de ganancia que obtienen? ¿Obtienen lo suficiente para alcanzar sus metas personales y familiares? ¿Obtienen los suficiente para aumentar su capital? Investiguemos sobre estrategias de mercadotecnia y publicidad que favorecerán el comercio de estos productos.

Busquemos en un sitio web cómo se realiza un estudio de mercado. 
Para que quienes se dedican a la producción obtengan mejores ingresos, se ha creado un modelo de comercio alternativo llamado "comercio justo"; que fortalece a las y los pequeños productores para mejorar la calidad de su producto. Se vinculan directamente con mercado de compradores, a quienes pueden vender a precios justos y obtener ganancias que les permitan mejorar sus condiciones de vida.

Para participar en el comercio justo y recibir una certificación, se requiere participación equitativa de hombres y mujeres, que no se emplee a niñas o niños, se proteja el medio ambiente y se brinden condiciones apropiadas de trabajo. Productoras y productores tienen que organizarse en asociaciones o cooperativas. Pagan a una empresa certificadora para que supervise una o dos veces al año los campos de cultivo y las instalaciones de trabajo, entre otros. A cambio, al precio establecido se le agrega un porcentaje o pequeña cantidad de dinero como incentivo, especialmente, si la producción es orgánica.

Se espera que los beneficios se distribuyan a nivel personal y comunitario. El esfuerzo rinde, pues se estima que los productores obtienen hasta un cuarto más de ganancias en comparación al mercado tradicional. En Guatemala por el sistema de comercio justo se producen café, miel, y artesanías, entre otros productos.

Una empresa certificadora, es la que, a pedido de productoras o productores, se dedica a comprobar que la elaboración de alimentos u otros productos y servicios de quien produce esos bienes o servicios; se realiza de acuerdo con prácticas aceptadas legalmente y conforme a normas internacionales. Las normas a cumplir se orientan a prácticas higiénicas, de salud alimentaria y no contaminante. Ya sea en el producto o servicio, en sus procesos de cultivo o elaboración, así como en su empaque, distribución y comercialización.

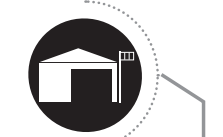

Informémonos sobre productores de comercio justo, cooperativas, asociaciones de comerciantes existentes en nuestra región u otros de comercio alternativo. Planificamos incluir en el catálogo una estrategia de promoción de comercialización de estos productos.
Guatemala cuenta con un Código de Trabajo (Decreto 1441 del Congreso de la República) que regula los derechos y obligaciones de trabajadores y patronos. Allí se establecen los horarios, tarifas de horas extra, las condiciones de pago y trabajo, el pago de salarios, prestaciones y razones de despido justificado. La Constitución de la República y el Código de Trabajo protegen la maternidad de la mujer trabajadora, quien gozará de 89 días de descanso durante el final del período prenatal e inicios del postnatal. También tiene el derecho de una hora de lactancia materna durante el primer año de vida del bebé. El embarazo no es justificación de despido. Las faltas de respeto a los derechos de las y los trabajadores pueden ser denunciadas a la Inspección General de Trabajo.

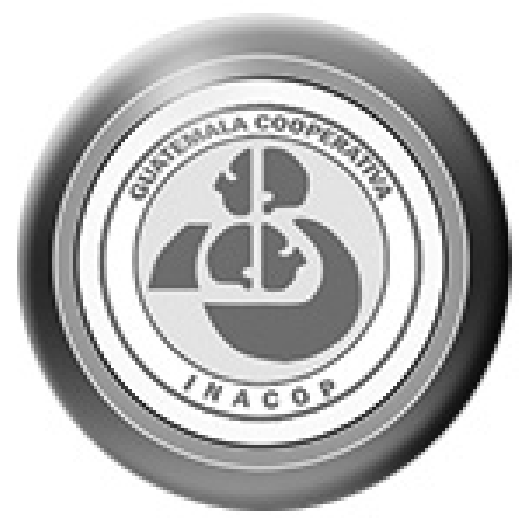




\section{Sintagmas de la oración}

\section{Usemos B}

- En las palabras que empiezan con las sílabas bu-, bur-, bus-: búho, burla, buscar.

- En las terminaciones-aba, -abas, -ábamos, -aban, de algunos verbos: jugaba, esperabas, platicábamos, paraban. Y las formas del verbo ir: iba, ibas, íbamos, iban.

Usemos V

- En las palabras que empiezan por eva-, evi-, eve, evo-, excepto, ébano: evaluar, evitar, evento, evolucionar.

- En las que empiezan por di-, excepto, dibujo: diversión, dividendos.

Usemos J

- En las palabras que empiezan o terminan con -aje, -eje, excepción: agencia, agenda, agente y ambages: ajetreo, ejercitó, paisaje.

- En los verbos terminados en -jear: cojear, homenajear.

\section{Usemos G}

- En las palabras que empiezan por geo-, gest- y legis-: geología, gesticular, legislación.

- En las que terminan en gia, gio, gión, logia, lógico, lógica: magia, prodigio, región, biología, sicológica, ecológico.
Un sintagma es una agrupación de palabras alrededor de un núcleo que desempeña una función sintáctica (como sujeto, predicado, complemento u otro), dentro de la oración. De acuerdo con la naturaleza de su núcleo, el sintagma puede ser:

Sintagma nominal: el núcleo es siempre un sustantivo (Juan, María, perro, madrina); un pronombre (él, eso, ella); o un elemento sustantivado (el alto, la chispouda, la pilas).

Ejemplo: Juana es alta. / Él es alto./ El alto te vino a buscar.

Sintagma verbal: el núcleo es siempre un verbo. Ejemplo: Mis amigas estudian a diario.
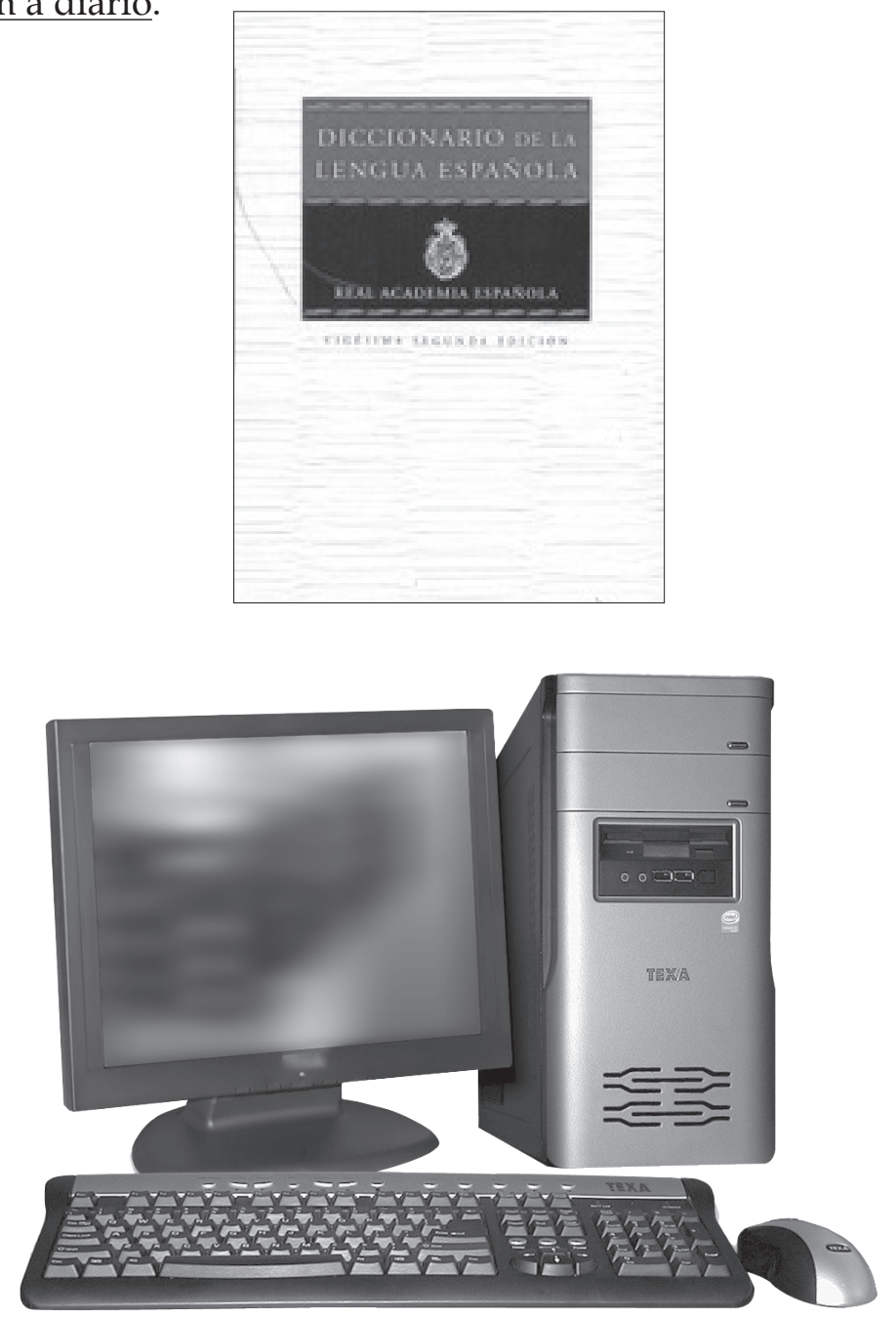

Escribo una oración con algunas de las palabras listadas arriba, en mi cuaderno.

Hablo con personas de mi comunidad sobre sus estrategias de mercadeo y promoción de sus productos. Escribo las principales respuestas en mi idioma materno.

Busco los nombres de los productos del catálogo en el diccionario de inglés y los preparo para incluir en el catálogo. 
La literatura y el arte se sirven de situaciones imaginarias para plantear los problemas fundamentales de la esencia humana. Por esta razón, no debemos descuidar las grandes expresiones artísticas de la humanidad. Una de ellas es la gran obra El ingenioso hidalgo don Quijote de La Mancha, considerada como la primera novela de la modernidad. Fue publicada por primera vez el $16 \mathrm{de}$ enero de 1605 y su contenido y sus reflexiones continúan siendo valorados en nuestros tiempos. Miguel de Cervantes Saavedra, su autor, pone en boca de don Quijote, su personaje inmortal, la frase siguiente:

"La libertad, Sancho, es uno de los más preciosos dones que a los hombres dieron los cielos; con ella no pueden igualarse los tesoros que encierran la tierra y el mar; por la libertad, así como por la honra, se puede $y$ debe aventurar la vida.

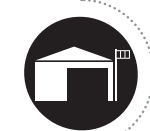

1. Ahora que sabemos lo anterior, planificamos un texto escrito sobre la libertad y respondemos:

- ¿Cuál es la idea central de este pensamiento?

- ¿Qué es la libertad?

- ¿Qué elementos son necesarios para que las personas gocemos de ella?

- ¿Qué responsabilidades implica ser libre?

- ¿Son igualmente libres las mujeres y los hombres?

- ¿Cómo fortalece la libertad al desarrollo humano?

- ¿Hasta dónde llega la libertad en la ciencia, la tecnología y el comercio?

2. Investiguemos en internet, en libros, revistas, periódicos u otros medios a nuestro alcance sobre el tema; así como entrevistar a personas de mayor edad.

3. Escribamos una composición de cinco párrafos: el primero de introducción, los tres siguientes de análisis sobre las preguntas planteadas arriba y el último de conclusiones. Todos los párrafos deben englobar nuestra reflexión acerca de la libertad.

Aprendamos que una mesa redonda es un espacio en el cual se presentan diferentes puntos de vista sobre uno o varios temas relacionados. Sus integrantes toman turnos para comunicar su mensaje al público y están dirigidos por un moderador.

- Pongámosla en práctica con nuestros compañeros y compañeras.

- Expongamos las conclusiones de nuestros textos sobre la libertad.

- Reflexionemos, además, sobre el bienestar de nuestra comunidad, su desarrollo y los bienes de consumo. ¿Se encuentra nuestra comunidad en su mejor condición? ¿Cuáles aspectos deben desarrollarse? ¿Son los bienes de consumo elegidos por nuestras necesidades o impuestos por la publicidad? ¿Qué tiene todo esto qué ver con la libertad?

¿De qué manera incide la situación económica con la libertad?
Las personas de mayor edad, generalmente, conservan en su memoria muchos acontecimientos de su historia personal, familiar, comunitaria y nacional. Poseen muchos saberes ancestrales, que pasan por tradición oral de una generación a otra.

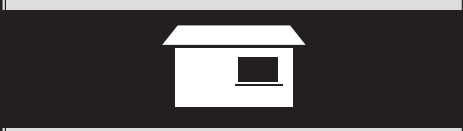

Pido a las personas de mayor edad que narren alguna leyenda o historia que haya vivido o aprendido por tradición oral. Si su idioma materno es distinto al español, le pido que me hable en su idioma materno. Dialogo con una persona que vende productos en el mercado. Averiguo el nombre de los productos que vende. Escribo palabras en el idioma de la comunidad y que correspondan a productos de la comunidad. En cada una de ellas uso, al menos, una de las letras: $b, v, j, g$.

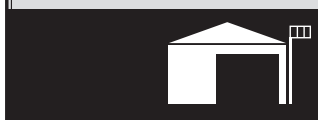

Mediante un organizador gráfico iniciamos la planificación del catálogo. Redactamos lineamientos para hacer un estudio de mercado de los productos de la comunidad que incluiremos en el catálogo. 


\section{Área y volumen de poliedros y}

Cuando las superficies de los cuerpos sólidos son poligonales, se llaman cuerpos poliedros y cuando las superficies son curvas, se llaman cuerpos redondos.

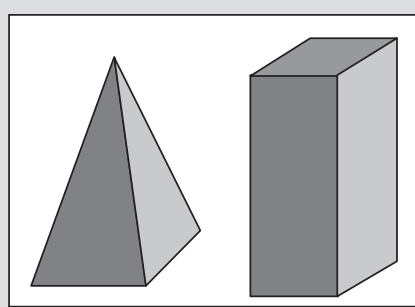

Poliedros

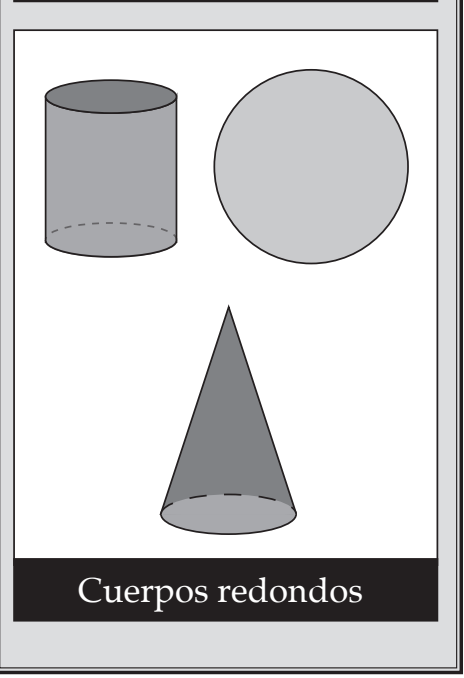

En equipos, recolectamos objetos y productos de la comunidad que tengan la forma de cilindro, pirámide, prisma y cono. Si no nos es posible hallar un objeto con determinada forma lo dibujamos o buscamos una fotografía que lo represente. Observamos los hallazgos de los demás grupos y comentamos acerca de la similitud entre las formas de los cuerpos.

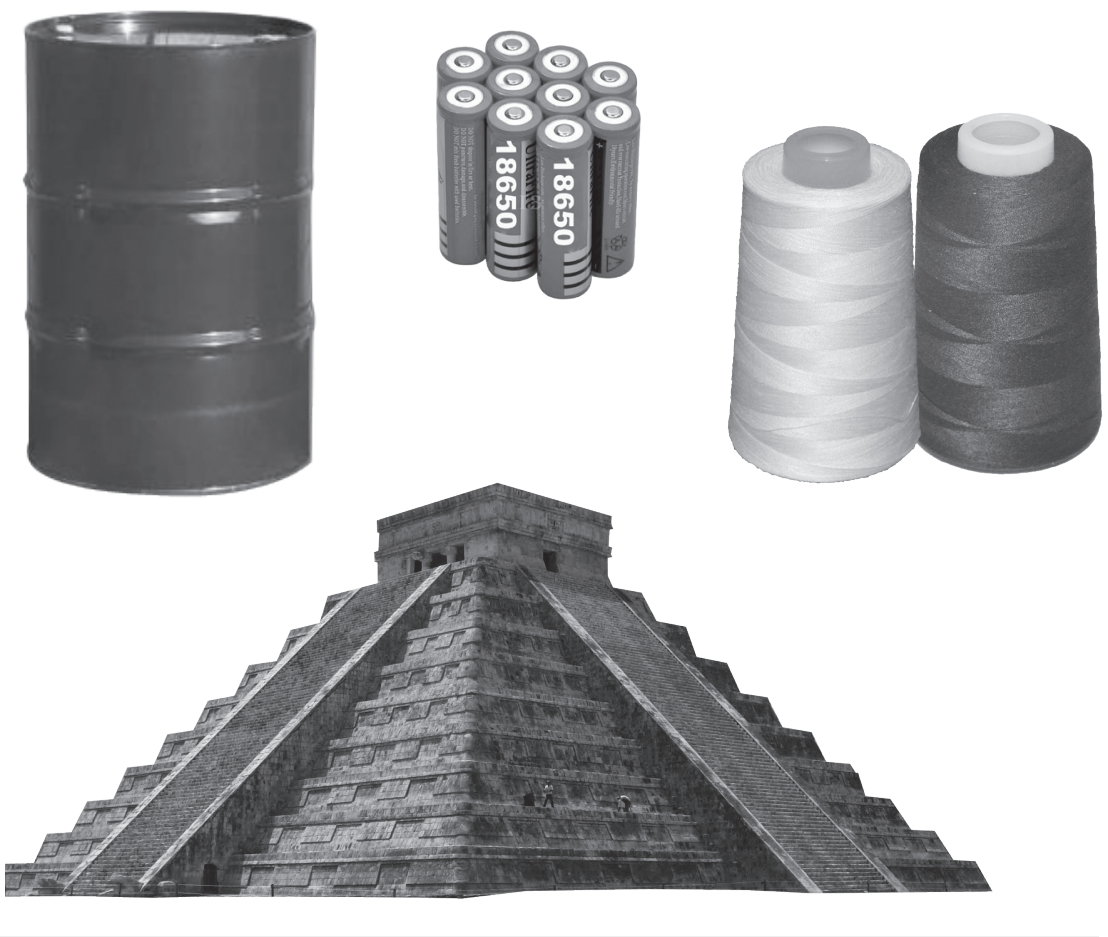

Presentamos el cartel, que realizamos en la clase anterior, al resto de compañeros y compañeras. Cada persona explicará las características de un tipo de cuerpo y demostrará cómo halló su perímetro. Comentamos: ¿Cómo podemos hallar el área de cada cara de los objetos? ¿Existe alguna relación entre el área total del cuerpo y su perímetro? ¿Qué es el volumen de un cuerpo?

Completamos, en el cuaderno, el siguiente cuadro con la información que hace falta:

\begin{tabular}{|c|c|c|c|}
\hline $\begin{array}{c}\text { Tipo de } \\
\text { medida }\end{array}$ & $\begin{array}{c}\text { ¿Puede } \\
\text { medirse } \\
\text { con algún } \\
\text { instrumento? }\end{array}$ & $\begin{array}{c}\text { ¿Cuántas } \\
\text { dimensiones } \\
\text { abarca? }\end{array}$ & $\begin{array}{c}\text { ¿En qué } \\
\text { unidades } \\
\text { se puede } \\
\text { expresar? }\end{array}$ \\
\hline Perímetro & & & \\
\hline Área & & & \\
\hline Volumen & & & \\
\hline
\end{tabular}

Comentamos y discutimos nuestras ideas. Luego elaboramos conclusiones. 
Utilizamos media cartulina más para completar el cuadro que realizamos la semana anterior. Esta vez agregamos dos columnas que contendrán los procesos para hallar áreas y volúmenes de cuerpos sólidos. Agregamos un ejemplo resuelto en dónde encontremos perímetro, área y volumen.

Enumeramos algunos de los productos que se producen en la comunidad. Por grupos escogemos un producto distinto y diseñamos una propuesta innovadora de empaque. Asumimos que cada empaque debe contener una libra de producto. Comparamos nuestras propuestas y contestamos: ¿Qué forma de empaque resulta más económica, es decir, que empaque emplea menos material y es más durable? ¿Cuál empaque resulta más atractivo para la venta del producto? ¿Qué empaque preserva mejor la integridad de su contenido? ¿Qué empaque es más amigable con el entorno natural? ¿De qué manera contribuye al desarrollo humano la innovación en los productos de la comunidad? Discutimos y justificamos nuestras respuestas. Prevemos incluir nuestras recomendaciones en el catálogo.

Resuelvo en mi cuaderno las siguientes situaciones, explico cómo lo hice.

- Un zapatero desea empacar, en cajas rectangulares los zapatos que produce. Estima que el volumen de cada par de zapatos es de $6000 \mathrm{~cm} 3$. La caja que le ofrecen mide $29 \mathrm{~cm}$ de largo, $16 \mathrm{de}$ ancho y 14 de ancho. ¿Le conviene o no comprar ese tipo de caja? Justifico mi respuesta.

- El productor de las cajas de cartón para los zapatos desea fabricar 500 unidades, si no desperdicia nada al fabricarlas ¿cuánto cartón necesitará?

- Para trasladar las cajas de zapatos a la capital se contrató un pequeño camión que tiene un tanque de gasolina en forma de cono. Las dimensiones del cono son: altura $12 \mathrm{~cm}$ y radio 12 $\mathrm{cm}$. Si un litro tiene $1000 \mathrm{~cm} 3$ ¿cuántos litros de gasolina cabrán en el tanque? ¿A cuántos galones equivale?

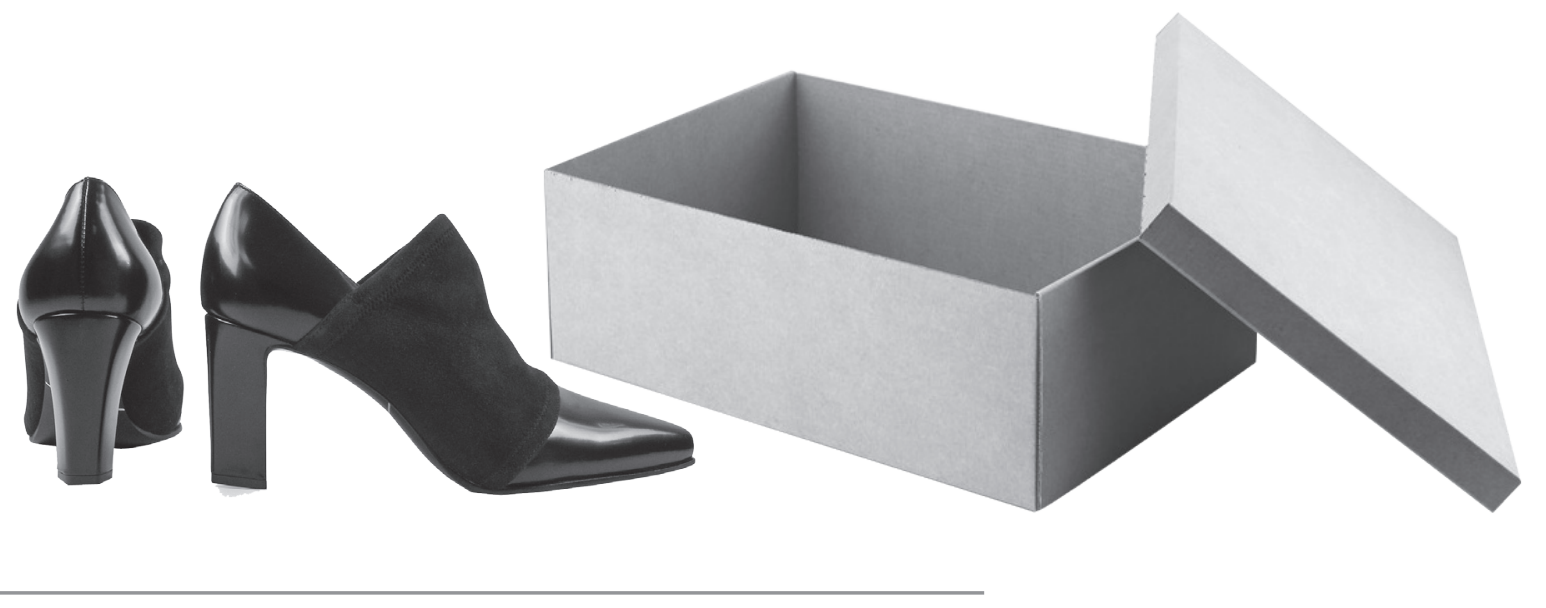

En un cono se llama generatriz a la longitud que se genera al unir el radio con la altura del mismo.

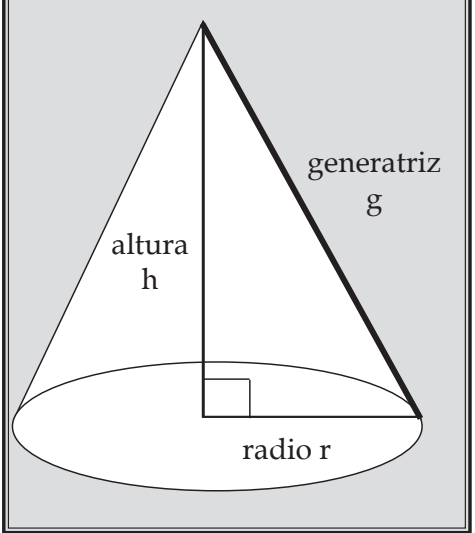




\section{Sustancias aulimicas y calidad de vida humana}

La contaminación química altera nuestro entorno $y$ pone en riesgo el desarrollo sostenible. Afecta el desarrollo humano, económico y social de las personas, comunidades, pueblos y países. La elaboración de sustancias químicas presentes en productos de consumo cotidiano es fuente importante de ingresos económicos, su producción debe hacerse de manera responsable y amigable con el ambiente. Es indispensable desarrollar una cultura de seguridad química, para prevenir riesgos a la salud y al ambiente. Los productos que contienen sustancias corrosivas, tóxicas o inflamables dejan residuos peligrosos. Su uso y desecho debe hacerse responsablemente: almacenarse en recipientes adecuados y en recintos apropiados, debidamente resguardados $y$ alejados del alcance de niñas y niños.

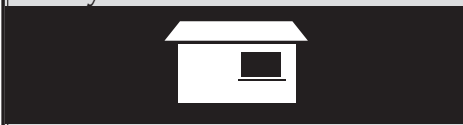

Investigo qué productos químicos o naturales se producen y comercializan en la comunidad.

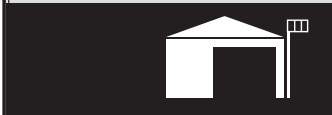

Compartimos los resultados con el grupo. Seleccionamos los que incluiremos en el catálogo.

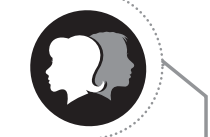

Observamos las imágenes y relacionamos con que se produce, comercializa y consume en la comunidad.

- Elaboramos una lista de los productos que conocemos y que son similares a los de las imágenes. ¿Cuáles de estos consumimos? ¿Cuáles se producen en la comunidad?

- Analizamos los efectos positivos y negativos que tienen esos productos químicos y naturales en nuestra salud y en nuestro desarrollo humano.

- Comentamos la información de la tabla.

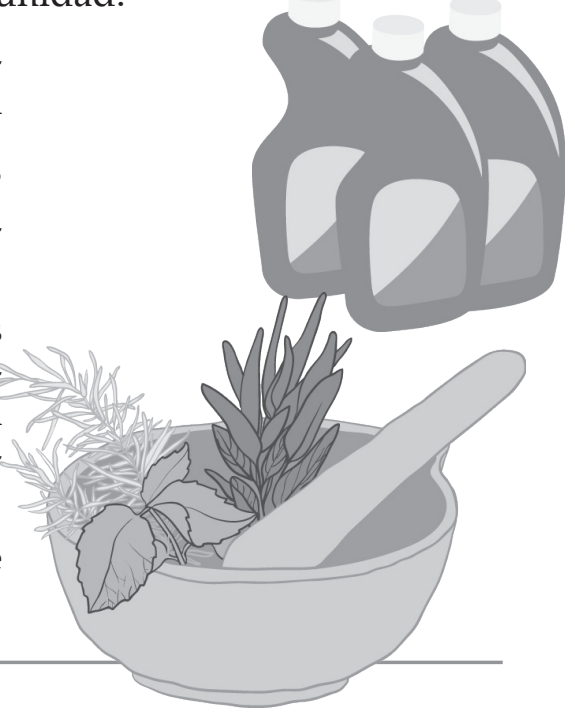

\begin{tabular}{|c|c|c|c|}
\hline $\begin{array}{l}\text { Producto } \\
\text { químico }\end{array}$ & $\begin{array}{c}\text { Sustancias químicas } \\
\text { que contiene }\end{array}$ & $\begin{array}{l}\text { Efecto sobre la } \\
\text { salud }\end{array}$ & $\begin{array}{c}\text { Efecto sobre } \\
\text { el ambiente } \\
\text { natural }\end{array}$ \\
\hline Sosa cáustica & Hidróxido de sodio & $\begin{array}{l}\text { Causa daños } \\
\text { permanentes a } \\
\text { la piel }\end{array}$ & $\begin{array}{l}\text { Su uso } \\
\text { excesivo } \\
\text { daña los } \\
\text { suelos. }\end{array}$ \\
\hline $\begin{array}{l}\text { Insecticidas y } \\
\text { raticidas }\end{array}$ & $\begin{array}{l}\text { Talio, cianuro, } \\
\text { carbonatos, } \\
\text { organofosforado, } \\
\text { estricnina }\end{array}$ & $\begin{array}{l}\text { Cáncer, } \\
\text { problemas en los } \\
\text { pulmones y vías } \\
\text { respiratorias. } \\
\text { Envenenamiento } \\
\text { y muerte. }\end{array}$ & $\begin{array}{l}\text { Contamina } \\
\text { la capa de } \\
\text { ozono }\end{array}$ \\
\hline Shampoo & $\begin{array}{c}\text { Amoniaco, } \\
\text { nitratos, naftalina } \\
\text { y percloroetileno y } \\
\text { fragancias sintéticas }\end{array}$ & $\begin{array}{l}\text { Cáncer, mareos, } \\
\text { sueño y nauseas }\end{array}$ & $\begin{array}{l}\text { Sus ácidos } \\
\text { contaminan } \\
\text { la capa de } \\
\text { ozono } \\
\end{array}$ \\
\hline Baterías (Pilas) & $\begin{array}{l}\text { Mercurio, zinc, litio, } \\
\text { cadmio, carbono, plata }\end{array}$ & $\begin{array}{c}\text { Cáncer, } \\
\text { irritación de } \\
\text { la piel, posible } \\
\text { envenenamiento. }\end{array}$ & $\begin{array}{c}\text { Sus } \\
\text { compuestas } \\
\text { pueden } \\
\text { contaminar el } \\
\text { agua, la tierra } \\
\text { y el aire }\end{array}$ \\
\hline Blanqueadores & $\begin{array}{l}\text { Hidróxido de potasio o } \\
\text { de sodio, peroxido de } \\
\text { hidrógeno, hipoclorito } \\
\text { de sodio o de calcio }\end{array}$ & $\begin{array}{l}\text { Causa daños } \\
\text { permanentes a } \\
\text { la piel }\end{array}$ & $\begin{array}{c}\text { Su uso } \\
\text { excesivo } \\
\text { daña a los } \\
\text { suelos. } \\
\end{array}$ \\
\hline $\begin{array}{l}\text { Detergente } \\
\text { sólido }\end{array}$ & $\begin{array}{l}\text { Alquilbencensulfonatos } \\
\text { de sodio (LAS) }\end{array}$ & $\begin{array}{l}\text { Irritante de la } \\
\text { piel }\end{array}$ & $\begin{array}{c}\text { Contamina el } \\
\text { agua. }\end{array}$ \\
\hline
\end{tabular}

Recuperado de: http://www.uaeh.edu.mx/scige/boletin/prepa3/n1/m13.html 


\section{Modelo atómico}

La diversidad de materiales presentes en la Naturaleza y sus variadas propiedades han llevado a la humanidad a buscar una explicación y comprensión de la materia. Para explicar su estructura interna se ha recurrido a modelos mentales como los del átomo.

Sugerencia video: https:/ /www.youtube.com/watch?v=qzXvNh-mwys

Representación de átomos de elementos esenciales de la vida:

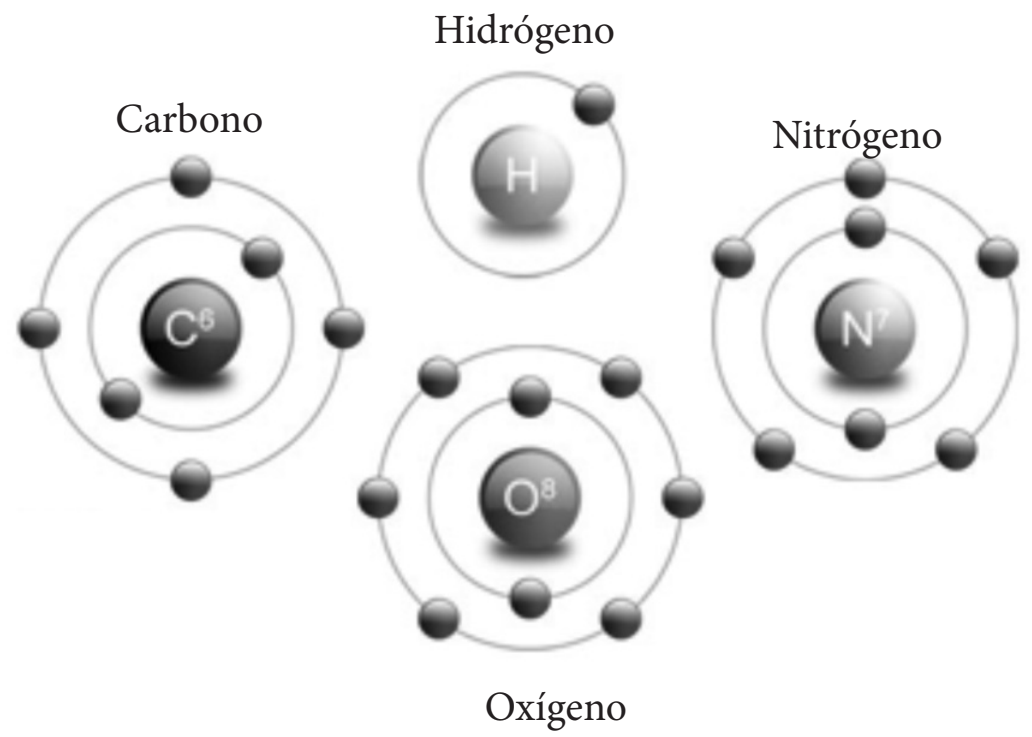

$\mathrm{Al}$ igual que el resto de materia, nuestro cuerpo está conformado por diversos elementos que aportan características únicas a los seres humanos. Algunos elementos que nos componen son fundamentales para el funcionamiento de:

- Huesos y dientes formados por calcio $(\mathrm{Ca}, 20)$

- Las células reciben energía del fósforo $(\mathrm{P}, 51)$ que también se encuentra en la estructura ósea.

- El corazón y los nervios se benefician en su regulación y actividad del potasio $(K, 19)$.

- El cuerpo necesita mucha agua, y el sodio $(\mathrm{Na}, 11)$ ayuda en su regulación.

- Los músculos y muchas reacciones metabólicas usan el magnesio (Mg, 12).

- La sangre, que transporta el oxígeno a todo nuestro cuerpo, lo hace gracias a la presencia del hierro (Fe, 26).

También gozamos de la presencia de más elementos químicos como el cobre, el zinc, selenio, molibdeno, flúor, yodo.
Sustancia pura. Se caracteriza por su composición definida y constante cuando están bajo una serie de condiciones determinadas. Ejemplos: la sal, el azúcar, el oro, el hierro y el aluminio.

Compuesto. Cualquier sustancia pura que se puede descomponer por medios químicos en dos o más sustancias diferentes y más simples.

Son compuestos químicos: el agua, que es una combinación de hidrógeno y oxígeno; así también, la sal común que resulta de la combinación de cloro y sodio.

Elemento. Cualquier sustancia pura que no se puede descomponer por medios químicos ordinarios en dos o más sustancias diferentes y más simples.

Átomo. La parte más pequeña de un elemento que puede existir y exhibir las propiedades de ese elemento, incluida la capacidad de reaccionar con otros átomos.

Algunos elementos son: oro, plata, plomo y mercurio.

\begin{tabular}{||c|c|}
\hline Nivel & $\begin{array}{c}\text { Número } \\
\text { máximo de } \\
\text { electrones que } \\
\text { puede contener }\end{array}$ \\
\hline 1 & 2 \\
\hline 2 & 6 \\
\hline 3 & 18 \\
\hline 4 & 32 \\
\hline
\end{tabular}

$\underset{\square}{\square}$

Consulto en la tabla periódica de los elementos la ubicación y propiedades químicas de los elementos estudiados en clase. 


\section{Hi desarrollo humano y sus niveles}

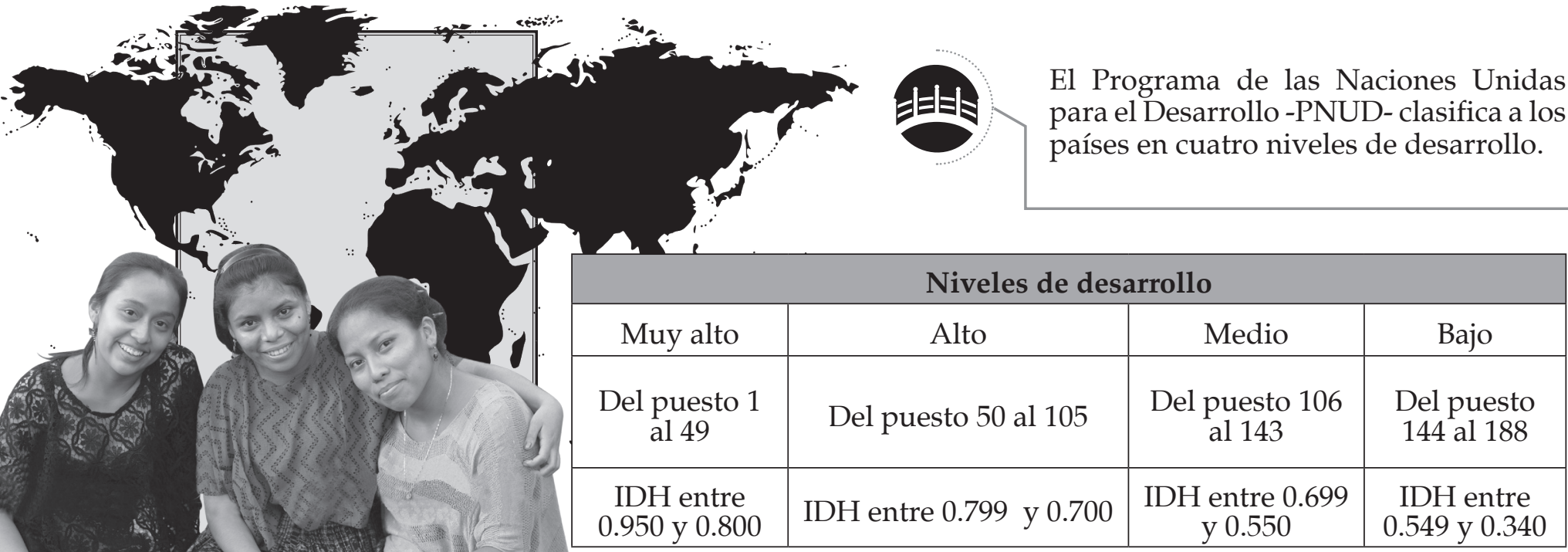

Ya sabemos que el IDH mide aspectos como ingresos económicos, esperanza de vida y nivel de escolaridad. La comparación del indicador entre diversos grupos permite entrever las condiciones de equidad, libertades, vigencia de derechos humanos y el grado de participación cívica y política de una sociedad. Dentro de los países de desarrollo muy alto están Noruega, Australia y Chile; desarrollo alto: Rusia, Cuba y Túnez; desarrollo medio: Egipto, Guatemala y Camboya; desarrollo bajo: Angola, Haití y Guinea. Los países con desarrollo muy alto se concentran en el norte de América y Europa. La mayoría de países latinoamericanos tienen desarrollo alto y la mayoría de países africanos y muchos asiáticos tienen desarrollo medio y bajo.

En Guatemala también hay departamentos y municipios con diferentes niveles de desarrollo. El departamento de Guatemala, principalmente los municipios de Guatemala, Santa Catarina Pinula, y San José Pinula poseen índices de desarrollo humano alto. Mientras que varios municipios de Totonicapán, Alta Verapaz y Quiché, poseen índices de desarrollo bajo.

\begin{tabular}{|l|l|}
\hline \multicolumn{2}{|c|}{ Guatemala } \\
\hline Año & IDH \\
\hline 2014 & 0.627 \\
\hline 2013 & 0.628 \\
\hline 2012 & 0.581 \\
\hline 2011 & 0.574 \\
\hline 2010 & 0.560 \\
\hline
\end{tabular}

\section{Analizamos el siguiente texto y respondemos.}

"Ser mujer, afrodescendiente, indígena, LGBTI, joven, persona con discapacidades, todo esto incide en las oportunidades, en la posibilidad de ascenso social y económico y en el acceso a servicios," dijo el principal autor del informe y economista en jefe para América Latina y el Caribe: George Gray Molina. La sigla LGBTI, se refiere a la necesidad de reconocer la diversidad sexual de la población más allá de hombres y mujeres o del género masculino y femenino. Se incluye aquí a lesbianas, gais, bisexuales, transexuales e intersexuales.

http:/ / desarrollohumano.org.gt/noticias/recaida-de-millones-delatinoamericanos-a-la-pobreza-es-evitable-con-politicas-publicas-denueva-generacion-pnud/

- ¿El IDH de un país refleja la condición de las mujeres? ¿Por qué? 


\section{Desarrollo humano sostenible}

Si una comunidad satisface las necesidades que tienen sus integrantes, sin comprometer la capacidad de las futuras generaciones de satisfacer sus propias necesidades, se dice que posee un desarrollo humano sostenible. Para lograr desarrollo humano sostenible se requiere de garantizar la equidad étnica, de género y entre grupos de población de diferentes generaciones; de la reducción de la pobreza, preservación y la restauración del medio ambiente, así como la conservación de recursos naturales y la implementación de la justicia social.

La economía de una comunidad está formada por tres sectores:

- Sector primario es el que toma los productos tal y como la Naturaleza los proporciona, como la agricultura, ganadería y minería.

- Sector secundario es el que transforma los bienes de la Naturaleza antes de consumir, por ejemplo: la artesanía y la industria.

- Sector terciario es el que proporciona los servicios necesarios para las personas o los otros sectores de la economía: educación, salud, comercio, turismo y otros.

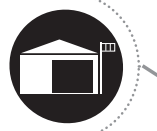

Nos reunimos con el grupo y respondemos:

- ¿Cuál es la diferencia entre desarrollo humano y desarrollo humano sostenible? Tomamos un aspecto social, económico o ambiental. Discutimos en grupo y explicamos qué se necesita en la comunidad para que contribuya a mejorar la calidad de vida de todos y todas.

- Analizamos ¿Qué acciones se realizan en nuestra comunidad para preservar o restaurar el medio ambiente?

- En equipo de trabajo, ejemplificamos los productos de cada sector de la economía de nuestra comunidad. Por cada sector de la economía, elaboramos una lista de productos que es posible producir en la comunidad. Elegimos uno de ellos y planificamos una estrategia para producirlo.

- Clasificamos los productos y servicios de la comunidad según cada sector de la economía. Prevemos incluirlos en el catálogo.

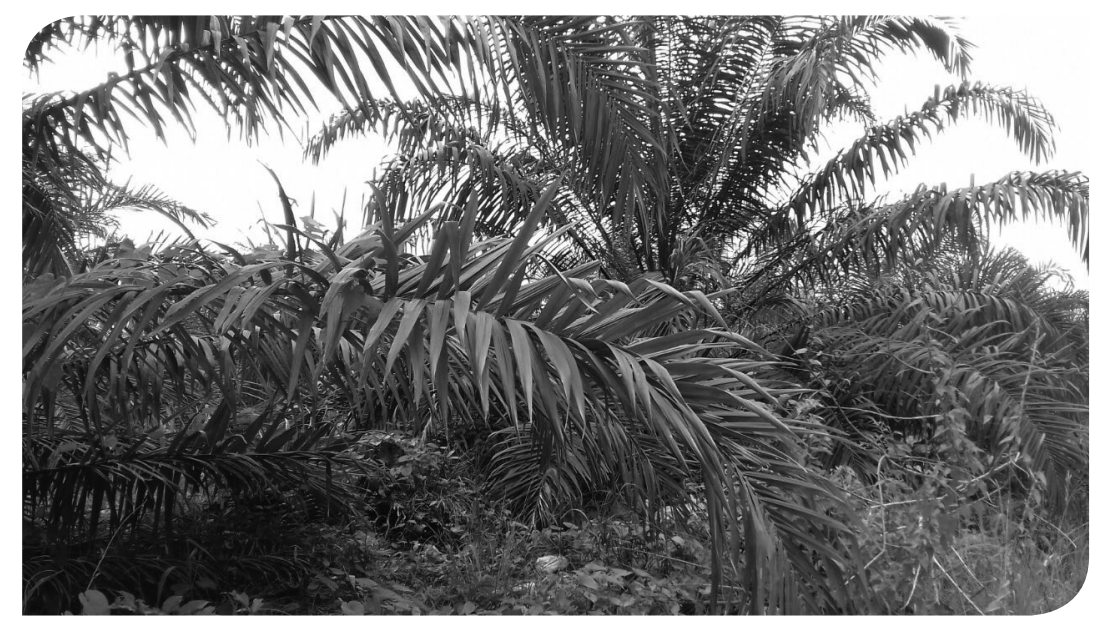

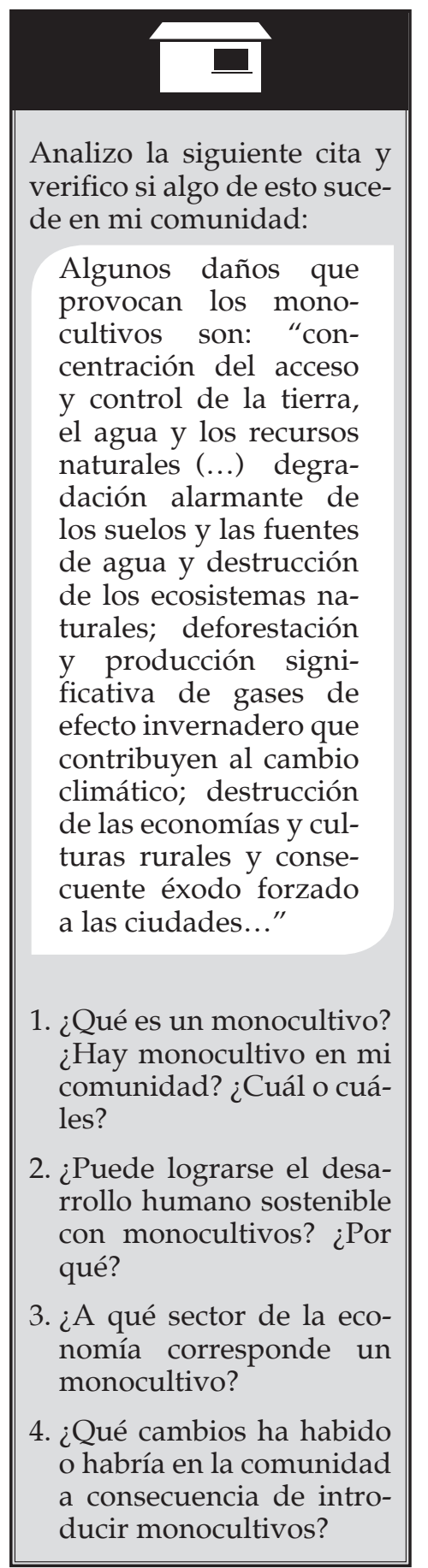




\section{Hacer realidad nuestras metas}

La cultura occidental ve la Tierra como un objeto de uso pero cada vez más necesitamos adoptar el amor de los pueblos originarios hacia la Naturaleza. La Tierra es una madre que nos ofrece alimento y cobijo y los recursos suficientes para que los seres humanos tengamos una vida satisfactoria y digna. Estos recursos pueden ser ilimitados si los manejamos adecuadamente para que se reproduzcan. Al igual que un niño debemos atender y cuidar el planeta para que no se enferme debido a la contaminación que producimos. Nuestro desarrollo y futuro depende de ello.

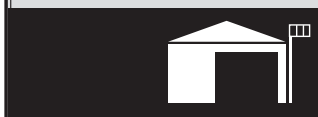

Los proyectos económicos y sociales de la comunidad, deben perseguir el desarrollo sostenible. Miremos a nuestro alrededor. ¿Qué tipo de desarrollo deseamos? ¿Podemos lograrlo en armonía con la Madre Tierra?

Con la orientación de la tutora o tutor, hacemos una pausa pedagógica. Hacemos ejercicios de estiramientos y gimnasia cerebral

Elaboramos una lista de cooperativas, asociaciones de productores y organizaciones de la sociedad civil. ¿Qué productos y servicios brindan? Incluimos en el catálogo fotografías, videos y audios de sus productos, servicios y beneficios.
Las y los pobladores de la aldea Tierra Colorada se reunieron a dialogar para encontrar formas para mejorar su situación económica y elevar su nivel de desarrollo humano. Decidieron que era necesario tener otras fuentes de ingreso y el comercio pareció una buena idea. Visitaron un banco para pedir préstamos individuales para instalar pequeños establecimientos comerciales, cada uno con un particular tipo de negocio.

Después de escuchar su planteamiento, la persona del banco hizo algunas preguntas:

- ¿A qué distancia queda su comunidad del pueblo? ¿Cuántas comunidades quedan cerca y a qué distancia?

- ¿Cuántas personas viven en su comunidad? ¿Cuántos hombres, mujeres y niños?

- ¿Qué desean vender: artículos de consumo diario, productos agrícolas, materiales de construcción...? ¿Cuántas tiendas van a poner?

- ¿Cuál será su clientela?

Después de escuchar las respuestas, la persona del banco dijo:

-Me han contado que su comunidad es lejana y pequeña, si en todas las casas abren una tienda no tendrán suficiente clientela. ¿Por qué no piensan en un artículo que ya producen y que en conjunto podrían vender fuera de su comunidad? Fue así como nació una cooperativa que al paso del tiempo, trabajando en equipo y mejorando sus buenas prácticas agrícolas, ahora exporta sus productos a buen precio.

Hemos hablado de los anhelos y metas. Aunque tengamos elaborado un proyecto, debemos tener cautela antes de invertir tiempo, esfuerzo y dinero. Es importante realizar un estudio de factibilidad. La persona del banco planteó preguntas cruciales que siempre debemos hacernos para asegurarnos que nuestro proyecto no fracase.
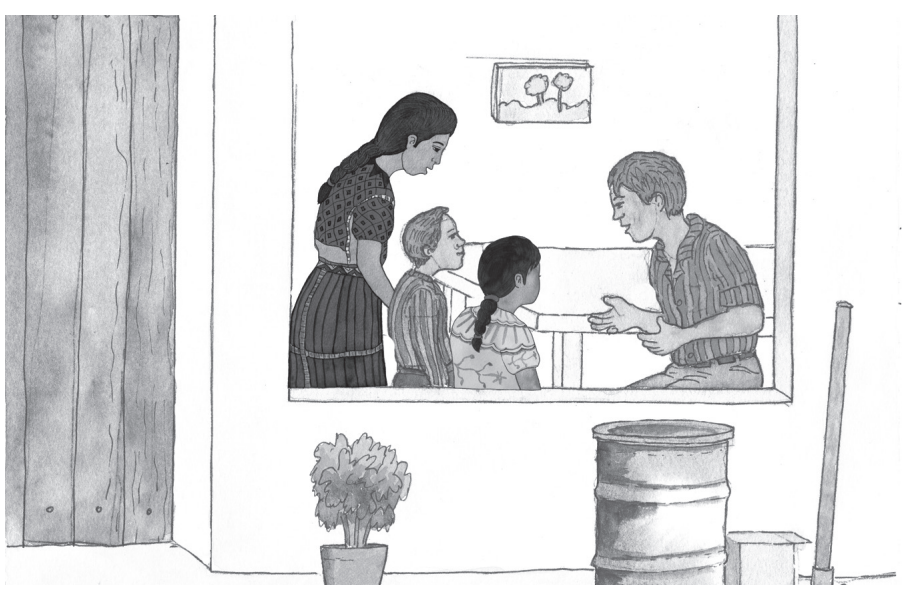

Semana 8

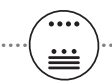




\section{Estudios de factibilidad}

Un proyecto lo iniciamos con entusiasmo y esperanza. Pero si nos dejamos llevar por los deseos sin considerar aspectos técnicos o financieros, tarde o temprano tendremos que pagar. Un estudio de factibilidad reduce este riesgo considerando:

- Estudio de mercado relacionado con el producto o servicio

- Estudio técnico

- Tamaño, lugar y proceso para realizar el proyecto;

- Actividades, calendario, recursos necesarios y disponibles,

- Posibles problemas

- Costos de la obra y su operación y costos unitarios de los productos o servicios

- Estudio financiero

- Recursos financieros disponibles, presentes y a futuro

- Evaluación

- Punto de equilibrio

- Análisis costo-beneficio

Un estudio de factibilidad debe ser objetivo e imparcial, realizarse con ho nestidad. Debe incluir datos y cifras reales para ser evaluado correctamente. La evaluación determinará si es posible ejecutar el proyecto: si habrá un punto de equilibrio, es decir, no perdemos pero no ganamos o, si por el contrario, los beneficios son mayores a los costos.

En grupo analizamos diferentes necesidades de la comunidad. Elegimos un problema a resolver. Por ejemplo, consensuamos que nuestra comunidad debe invertir en un pozo de agua. Un consenso es un acuerdo por consentimiento que apoyan todas las personas involucradas. No necesita de ser sometido a votación. Con base en la información para realizar un estudio de factibilidad, establecemos que podemos encontrar agua a pocos metros de la superficie y que podemos extraerla manualmente; pero, tendremos suficiente agua solo para dos años. Posteriormente, tendremos que hacer más profundo el pozo y comprar una bomba para obtener el agua. Reflexionamos sobre cómo financiar el proyecto a corto y largo plazo, ¿Será

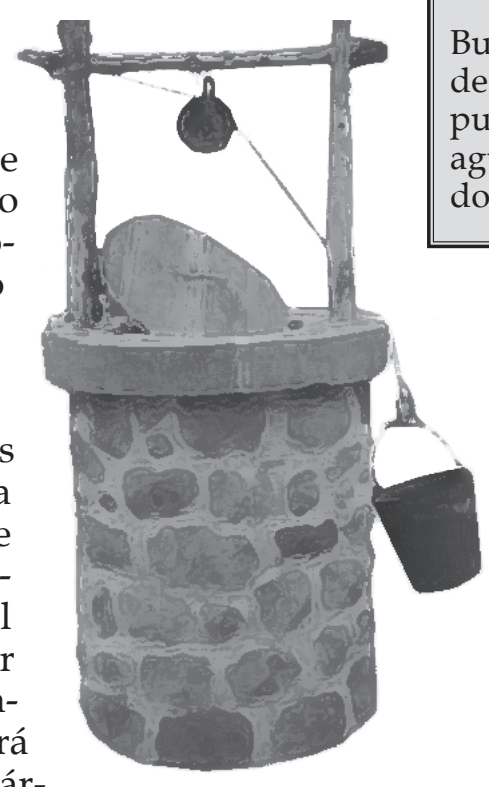
el pozo la mejor solución? Hagamos un árbol de problemas para analizar el problema del agua en esta comunidad, enfoquémonos en las causas del problema y sus efectos sobre los derechos humanos de la población.
El agua es fuente de vida porque constituye el $70 \%$ de nuestro cuerpo. Una pequeña falta de agua produce daños en nuestro cuerpo y al igual sucede con plantas y animales. Un derecho humano fundamental es el acceso al agua potable porque asegura salud y bienestar, ayuda a prevenir enfermedades y contribuye a la higiene $\mathrm{y}$ aseo. Aunque algunas veces tenemos acceso al agua, esta solo es agua entubada, no potabilizada. Es importante que nuestras familias y autoridades aseguren el acceso a agua potable o sea agua que podemos consumir directamente sin enfermarnos. Solo sanos y sanas podemos desarrollar nuestras habilidades, capacidades y potencial.

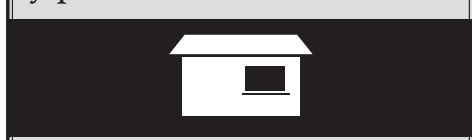

Busco información acerca de diferentes medios para purificar o potabilizar el agua y cuáles son utilizados en mi comunidad. 


\section{Dibujomos pintamos y representamos la vida}

En la historia del arte es notable que las y los artistas busquen algo más que solamente expresar algo bello. La belleza es una parte del arte, pero detrás de lo bello está también la necesidad de expresar ideas y sentimientos. Estas ideas pueden propiciar reflexiones o recuerdos. Los sentimientos pueden ser placenteros o dolorosos, de bienestar o malestar. Lo importante es que pueden trascender su aspecto estético y provocar a quienes observan su obra. Veamos dos ejemplos de arte que provoca reflexión o refleja momentos importantes de la sociedad.

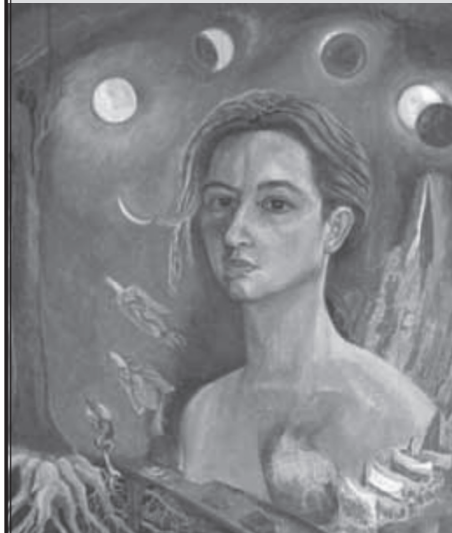

Autorretrato con lunas (¿1963?) Rina Lazo, pintora y muralista guatemalteca.

Tomado de www.revistasunam.mx. No. 50458-1402111 PB pdf p. 249

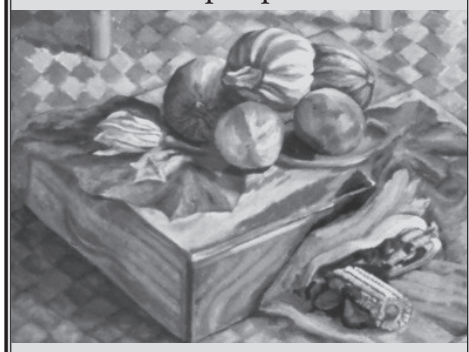

Bodegón, por Rina Lazo Tomada de http:/ / biblio3.url. edu.gt/AGallo/MaVas/05. php

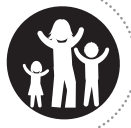

Al integrar líneas con colores se logran imágenes y mensajes más complejos. Al aplicar estas técnicas en la vida cotidiana, podemos usarlos como herramientas para expresarnos ante la comunidad. El prisma que realizamos en el proyecto anterior fue un ejemplo de cómo integrar nuestros conocimientos a la vida diaria. El catálogo que haremos en este proyecto, requerirá de imágenes adecuadas.

Si observamos el siguiente dibujo, encontramos que tiene una integración de líneas con una intención. Puede ser la de rellenar espacios, crear volumen o textura, o provocar la sensación de densidad. Lo mismo puede aplicarse al diseño del catálogo de productos.

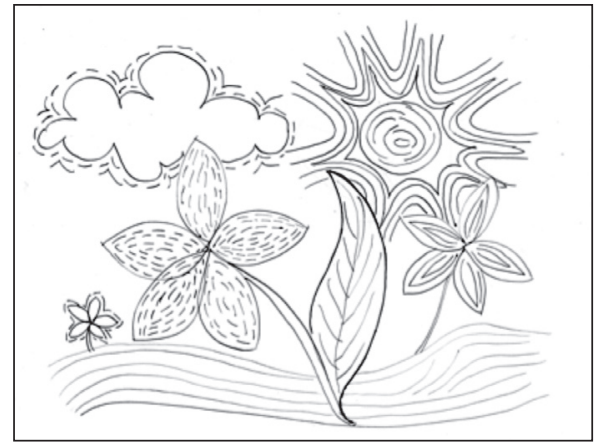

En una hoja de papel dibujamos dos cuadros. Dibujas algunos de los productos que queremos incluir en el catálogo y en ambos cuadros combinamos colores fríos o cálidos. Podremos observar que los dos dibujos expresarán mensajes diferentes, según la temperatura de los colores.

Realizamos un dibujo libre siguiendo los siguientes pasos:

1. Pensamos en un recuerdo que nos llevó a sentir alegría, triste$\mathrm{za}$, enojo, susto, etc.

Temas para recordar: situaciones familiares, igualdad de oportunidades entre hombres y mujeres, respeto a los derechos de todas y todos, uso o abuso de los recursos naturales, desarrollo sostenible, hombres y mujeres que nos inspiran en la vida.

2. En una hoja, dibujamos los rasgos posibles del recuerdo que tuvimos.

3. Socializamos nuestro producto artístico. Lo presentamos al grupo de trabajo. El resto del grupo expresa lo que observa en nuestro dibujo. Si queremos, podemos contarles cuál fue nuestro recuerdo representado en el dibujo.

Discutimos y comentamos con nuestro grupo:

- ¿Qué sentimientos queremos producir con el catálogo de productos?

- ¿Qué técnica deseamos utilizar para su elaboración?

- ¿Puede ser útil el arte para la promoción de lo que produce la comunidad y su relación con el desarrollo humano de personas, comunidades y pueblos? 


\section{Bodegones, Naturaleza muerta y retratos}

En diversas culturas existe la tendencia a representar objetos o espacios de la vida cotidiana. Los paisajes y calles de barrio son quizá los más comunes, aunque también se representan interiores de casas o palacios. Otro de los temas favoritos para pintar son los objetos de la cocina, vasijas, floreros, panes y frutas. A estos temas se les llama bodegones o naturaleza muerta. Sin embargo, el más difícil de todos es sin duda el retrato de personas. Esto se debe a que al realizarse se debe tomar en cuenta que el rostro expresa emociones y se deben cuidar los detalles.

Numerosos artistas han realizado estudios sobre la figura humana, cuidando que lo que se representa sea visto como un reflejo fiel de la realidad. Probaremos el proceso para realizar un retrato. Necesitamos: hojas en blanco, lápiz, regla y borrador. Sigamos los siguientes pasos:
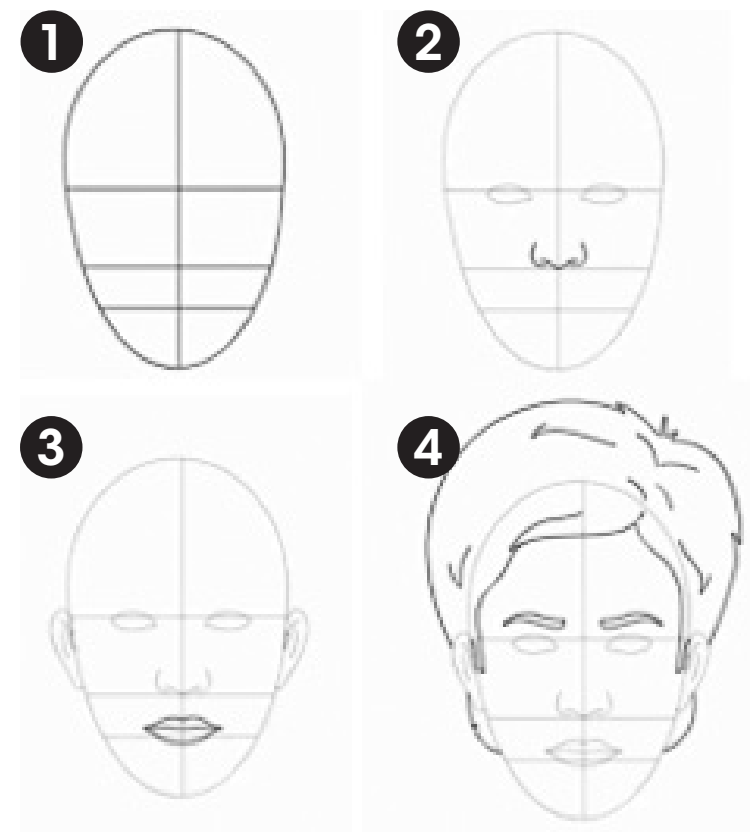

Tomado de http:/ /www.wikihow.com/Draw-Human-Faces

1. El trazo de un óvalo vertical, un poco más ancho por el lado de arriba. 2. Trazo a la medida de las proporciones superior e inferior. 3. Los detalles según el orden: ojos, nariz, orejas, boca, cejas y cabello, cuello y hombros.

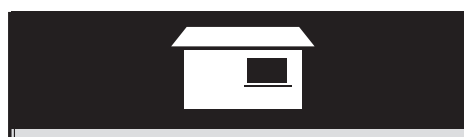

Elaboro una lista de aspectos del desarrollo humano que puedo representar con dibujos, pinturas y otras técnicas plásticas que he aprendido. Selecciono un aspecto y una técnica para representar la relación entre la producción de la comunidad y nuestro desarrollo humano. Elaboro una propuesta de catálogo y la presento ante la clase.

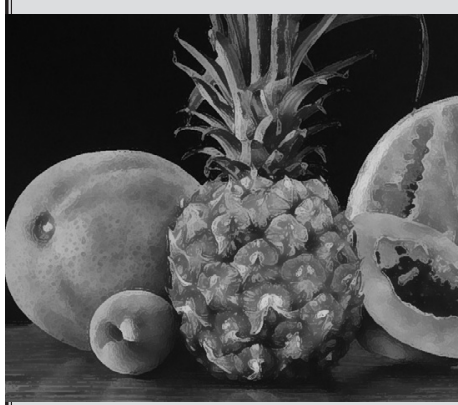

Analizo la pintura y verifico si algo de esto se produce o se comercializa en mi comunidad.

- ¿Qué es un bodegón?

- ¿Puedo hacer un bodegón con productos de mi comunidad para la carátula del catálogo?

- ¿Cómo me siento al representar los productos de $\mathrm{mi}$ comunidad?¿Muestra mi catálogo el aporte de la producción comunitaria al desarrollo humano? 


\section{Comprensión lectora y organizadores gráficos}

Observamos la siguiente manera de presentar la información de un tema. Comentamos en clase.

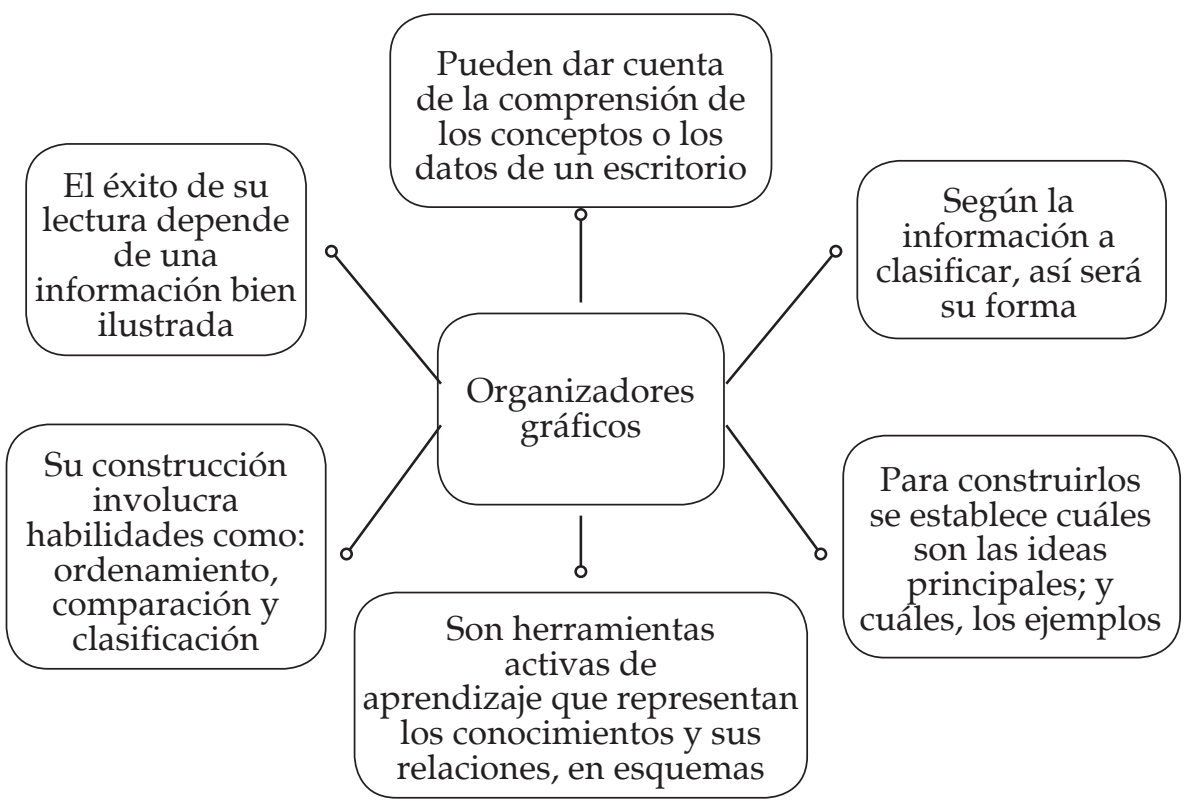

Leemos el siguiente fragmento de un ensayo, del gran escritor guatemalteco Luis Cardoza y Aragón, contenido en su obra "Guatemala, las líneas de su mano":

"No amamos nuestra tierra por grande y poderosa, por débil y pequeña, por sus nieves y noches blancas o su diluvio solar. La amamos, simplemente, porque es la nuestra. En su territorio hay una región que es la región de nuestra infancia. Y en tal región, una ciudad o un pueblecillo. En el pueblecillo, una casa. En la casa, cuatro paredes viejas y manchadas (...). En medio de la casa, una fuente de la cual nunca dejaremos de escuchar el canto. Todo se va replegando hasta llegar de la caja más grande a la más pequeña, del mundo a las cuatro paredes de la infancia, hasta la cuna y el ataúd. La tierra que caerá sobre esas cuatro tablas, cuando estemos de vuelta a geranios y quiebracajetes y nos empinemos en los árboles, es la tierra más dulce que existe."

Leímos dos textos diferentes: uno organizado de manera gráfica y otro, de forma lineal.

En ambos, la primera lectura que hacemos, siempre es literal. Es decir que leemos la superficie del texto. En una segunda lectura o inferencial, podemos relacionar la información con nuestros conocimientos previos y hacer deducciones, incluso, descubrir las intenciones del autor. En una tercera lectura o crítica podemos asumir una posición frente al texto y emitir una opinión.

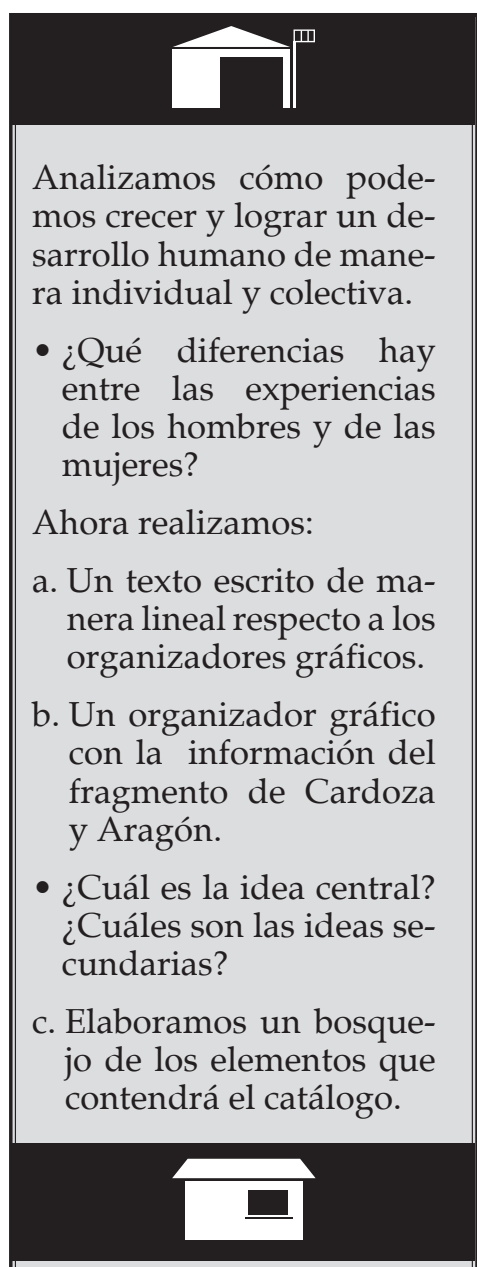

Represento la relación entre las necesidades, las formas de producción, la distribución y el desarrollo humano en mi comunidad.

- Entrevisto a una persona sobre posibles nichos de mercado en mi comunidad.

- Presento sus respuestas mediante un organizador gráfico.

- Elaboro diferentes campos semánticos con los elementos de mi comunidad y entorno. 


\section{Razones trigonométricas}

Las razones trigonométricas son relaciones que expresan el cociente de dos lados de un triángulo rectángulo asociado a los ángulos. Existen seis razones principales:

$$
\begin{aligned}
& \operatorname{sen} B=\frac{\text { cateto opuestro }}{\text { hipotenusa }}= \\
& \cos B=\frac{\text { cateto adyacente }}{\text { hipotenusa }}= \\
& \tan B=\frac{\text { cateto opuestro }}{\text { cateto adyacente }}= \\
& \cot B=\frac{\text { cateto adyacente }}{\text { cateto opuestro }}= \\
& \sec B=\frac{\text { hipotenusa }}{\text { cateto adyacente }}= \\
& \csc B=\frac{\text { hipotenusa }}{\text { cateto opuestro }}=
\end{aligned}
$$
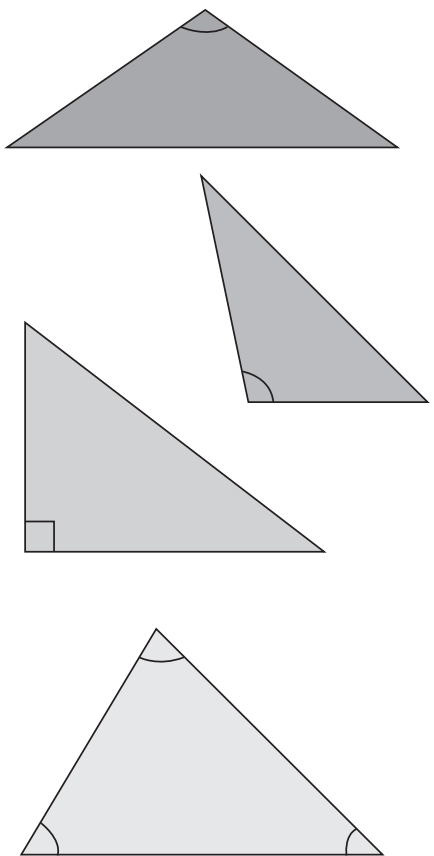

En papel o cartulina, trazamos la figura de un triángulo y determinamos cuál es la suma de sus ángulos internos. Cortamos cada ángulo del triángulo y los colocamos, uno seguido de otro, sobre una línea horizontal, así:
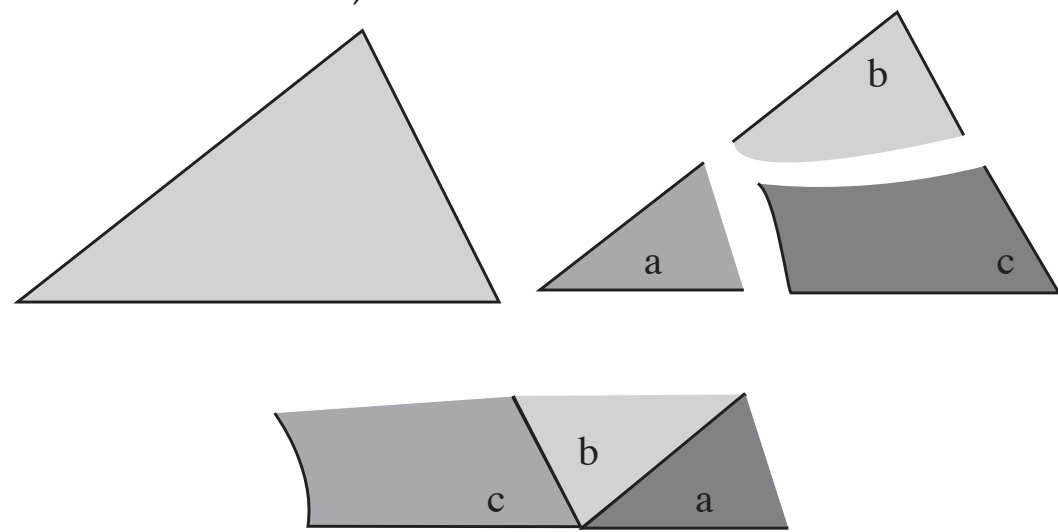

- ¿Qué tipo de ángulo forman? Comprobamos nuestras respuestas midiendo, con un transportador, cada ángulo del triángulo y hallando el total. ¿Qué podemos concluir?

- ¿Qué tipos de triángulos conocemos? ¿Según la medida de sus lados cómo pueden ser? ¿Según la medida de sus ángulos cómo pueden ser? Utilizamos regla y transportador para dibujar, en nuestro cuaderno, un ejemplo de cada tipo de triángulo según la medida de sus lados y de sus ángulos.

Trazamos cuatro triángulos distintos con una característica común. Uno de sus ángulos debe medir 90․ Recordamos que el ángulo de $90^{\circ}$ se denomina ángulo recto. Este tipo de triángulos se denominan triángulos rectángulos. Identificamos la hipotenusa y los catetos de cada triángulo. Nombramos cada uno de sus lados con una letra minúscula y utilizamos la misma letra, en mayúscula, para nombrar el ángulo que se encuentra opuesto a cada lado. Utilizamos un transportador para medir los ángulos internos de cada uno de los triángulos. Comparamos nuestras respuestas.

Junto a una pared de $2.40 \mathrm{~m}$ se pretende hacer un huerto de sombra para hortalizas que no necesitan mucha luz. ¿Qué longitud máxima deberán tener los sembrados si se observó que al medio día el ángulo de elevación entre el suelo y el sol es de $65^{\circ}$ ?

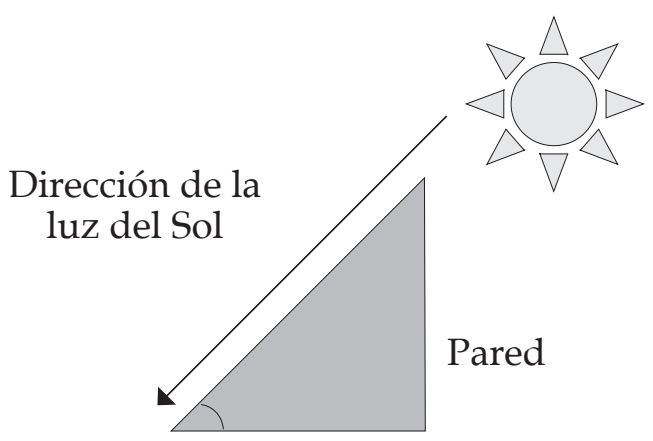

Huerto 
Utilizamos una calculadora científica o una tabla que contenga los valores de las razones trigonométricas. Encontramos los que corresponden a los ángulos de los triángulos que dibujamos. Colocamos nuestras respuestas en una tabla parecida a esta:

\begin{tabular}{|l|l|l|l|}
\hline & \multicolumn{1}{|c|}{ Seno } & Coseno & Tangente \\
\hline Triángulo 1 & & & \\
\hline Ángulo 1 & & & \\
Medida: & & & \\
\hline Ángulo 2 & & & \\
Medida: & & & \\
\hline Ángulo 3 & & & \\
Medida: & & & \\
\hline Triángulo 2 & & & \\
\hline Ángulo 1 & & & \\
Medida: & & & \\
\hline Ángulo 2 & & & \\
Medida: & & & \\
\hline Ángulo 3 & & & \\
Medida: & & & \\
\hline
\end{tabular}

Dibujo otra tabla igual que la anterior y calculo las mismas funciones trigonométricas haciendo uso de las longitudes de los lados de cada triángulo. Para hallar la razón seno, obtendré el cociente, es decir, el resultado de dividir la longitud del cateto opuesto al ángulo que me interesa entre la hipotenusa. Para obtener la razón coseno, divido la longitud del cateto adyacente al ángulo que me interesa entre la hipotenusa. Para encontrar la hipotenusa, obtengo el cociente entre el cateto opuesto y el cateto adyacente al ángulo que quiero encontrar.

Aproximo a las cienmilésimas. Comparamos los resultados de ambas tablas. Comentamos nuestras respuestas. ¿Obtendríamos respuestas similares en ambas tablas? ¿Qué podemos concluir? ¿Podemos utilizar las relaciones trigonométricas para hallar lados o ángulos desconocidos de un triángulo rectángulo?

Hallo las medidas desconocidas de los siguientes triángulos.

\begin{tabular}{|l|l|l|l|l|l|}
\hline $\mathrm{A}=90^{\circ}$ & $\mathrm{B}=$ & $\mathrm{C}=42^{\circ}$ & $\mathrm{a}=5 \mathrm{~m}$ & $\mathrm{~b}=$ & $\mathrm{c}=$ \\
\hline $\mathrm{A}=90^{\circ}$ & $\mathrm{B}=$ & $\mathrm{C}=$ & $\mathrm{a}=12 \mathrm{~cm}$ & $\mathrm{~b}=5 \mathrm{~cm}$ & $\mathrm{c}=$ \\
\hline
\end{tabular}

Las razones trigonométricas solo son válidas para relacionar longitudes de catetos e hipotenusa y los ángulos de los triángulos rectángulos.

Identificamos espacios de la comunidad para ejemplificar triángulos rectángulos. Incluimos en el boceto de catálogo lugares de producción de bienes y servicios donde se observen triángulos rectángulos.

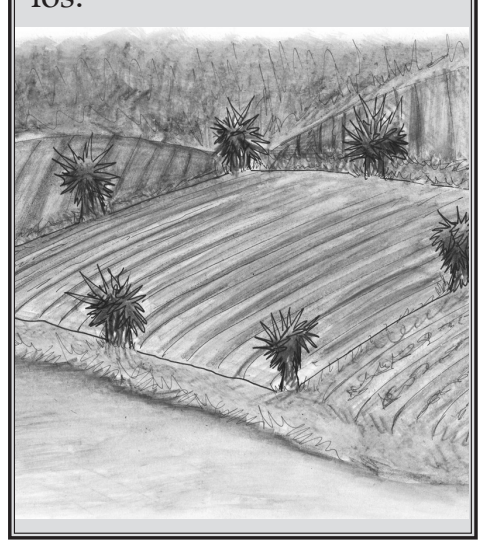




\section{Trabajar juntos para llegar lejos}

Las empresas ya no pueden vivir aisladas de la sociedad que les rodea. Algunas han implementado prácticas éticas y responsables de respeto al medio ambiente, a los derechos de las y los trabajadores y a la comunidad donde están localizadas. Así, se promueve un ambiente agradable de trabajo y lealtad entre la empresa, empleadas, empleados y la comunidad. Se asegura la sostenibilidad, al promover el cuidado de los recursos naturales. Es una forma de devolver parte de lo ganado pero también de resarcir al medio y a la población, por los daños ocasionados durante el proceso de producción. A estas prácticas se les llama responsabilidad social empresarial.

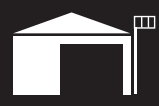

Actualmente, muchas empresas guatemaltecas anuncian ser responsables socialmente. Analicemos sus acciones.

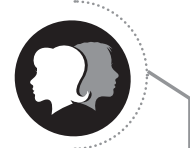

¿A quién no le gusta trabajar en un ambiente sano donde nos traten bien? Este es un principio básico de respeto, pero también de administración; pues las personas felices y satisfechas, son más productivas. Tratar a los trabajadores y trabajadoras como seres humanos con anhelos, metas, necesidades y sentimientos; es más que simplemente cumplir con las leyes, entre ellas, el Código de Trabajo. El recurso humano de una empresa es más que la persona que se presenta a trabajar todos los días: tiene familia y le importa el bienestar de su comunidad y su país. Al mismo tiempo, la empresa necesita personas que no solo trabajen por un pago, sino que se comprometan y crean en lo que hacen ellas y en la organización con la que colaboran.

Las empresas generan inversión, empleo y crecimiento económico y son importantes para la reducción de la pobreza; siempre y cuando cumplan con normas éticas y de cuidado al ambiente. Si una empresa no respeta el medio ambiente está creando problemas para el futuro. Lo mismo ocurre con la ética. Por falta de ética se busca el enriquecimiento personal a costa de la pobreza, salud, seguridad, bienestar del personal, y la comunidad. Una empresa responsable cumple, entre otros, estos principios: proteger, respetar y remediar. Siguiendo estos principios, las empresas confirman su compromiso con el respeto, la protección de la libertad, el bienestar y la dignidad

Entrevisto a trabajadores en relación de dependencia, para conocer su ambiente de trabajo y si la institución o empresa para la que laboran cumplen con las normas de ética y responsabilidad social empresarial.

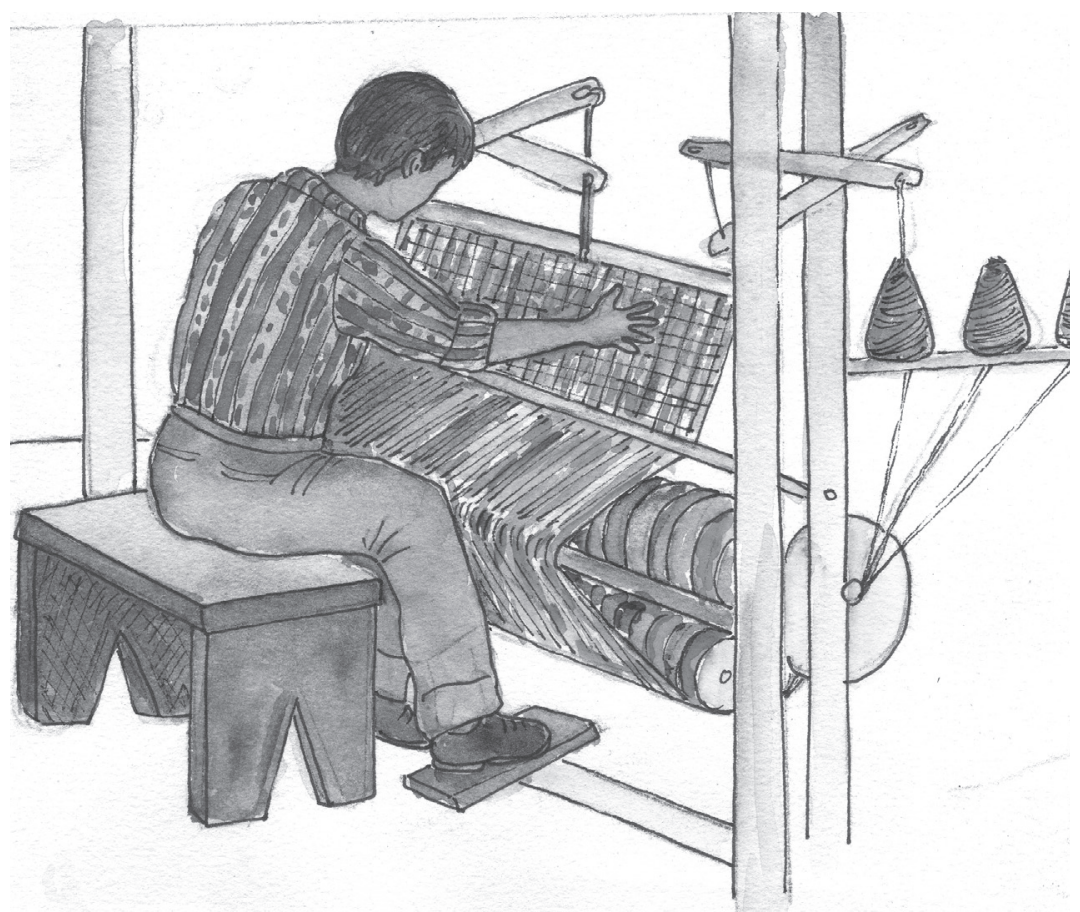


Todas y todos queremos mejorar nuestras condiciones de vida, por eso emprendemos proyectos productivos. Este es un derecho humano fundamental, siempre y cuando respetemos los derechos colectivos. Los derechos colectivos protegen los intereses y la identidad de un grupo social y buscan garantizar la identidad cultural, el medio ambiente, el desarrollo y la autodeterminación. El gobierno de Guatemala se comprometió a respetar los derechos colectivos del Pueblo Maya al ratificar, en 1996, el Convenio 169 de la Organización Internacional del Trabajo $\left(\mathrm{OIT}_{1}\right)$.

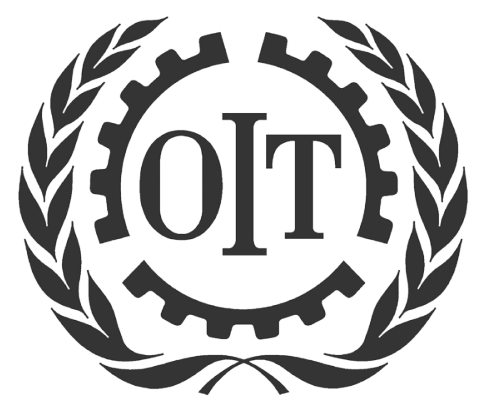

El Convenio 169 establece el mecanismo de consulta para que los pueblos indígenas manifiesten sus decisiones sobre aspectos que afectan su identidad, su ambiente y sus formas de vida. Por eso las comunidades que habitan alrededor de una empresa o de su centro de operaciones, tienen derecho a conocer las implicaciones para su bienestar de la intervención que realiza la empresa y puedan decidir, mediante una consulta, si las aprueban o no.

En años recientes, en Guatemala se ha denunciado los efectos dañinos de empresas que han desviado o contaminado ríos u operaciones mineras que dañan el suelo, el aire, las aguas y la salud de las poblaciones. Las consultas manifiestan la decisión de los pueblos sobre cuál tipo de desarrollo desean.

Todas las empresas deben cumplir con sus obligaciones tributarias, respetar las leyes del país y las consultas populares. Las empresas sociales no tienen por objetivo el enriquecimiento personal. Se sostienen por medio de la venta de un producto o un servicio compitiendo en el mercado al igual que otras empresas. Buscan resolver un problema y tener impacto social.

Antes de iniciar un proyecto debe evaluarse su viabilidad. Mediante una investigación previa es imprescindible establecer la probabilidad que tenemos de realizar o ejecutar un proyecto. Debemos considerar que será de calidad, atractivo, funcional y de beneficio para la comunidad. Estará bien diseñado y contaremos con los recursos para hacerlo. El estudio de viabilidad permitirá tomar decisiones acertadas en el diseño y en la ejecución del proyecto.

\footnotetext{
Trabajamos en grupo para determinar la viabilidad de publicar y divulgar nuestro proyecto de catálogo enumerando:

- Oportunidades

- Necesidades

- Población beneficiaria

- Limitaciones

Buscamos información sobre la forma de realizar una consulta popular y los resultados que las consultas han tenido en Guatemala.
}

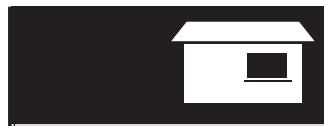

Pienso en un proyecto personal que tengo y abordo a una persona experta en este tipo de proyecto para determinar la viabilidad de lo que me interesa hacer. Preparo preguntas previo a abordarle.

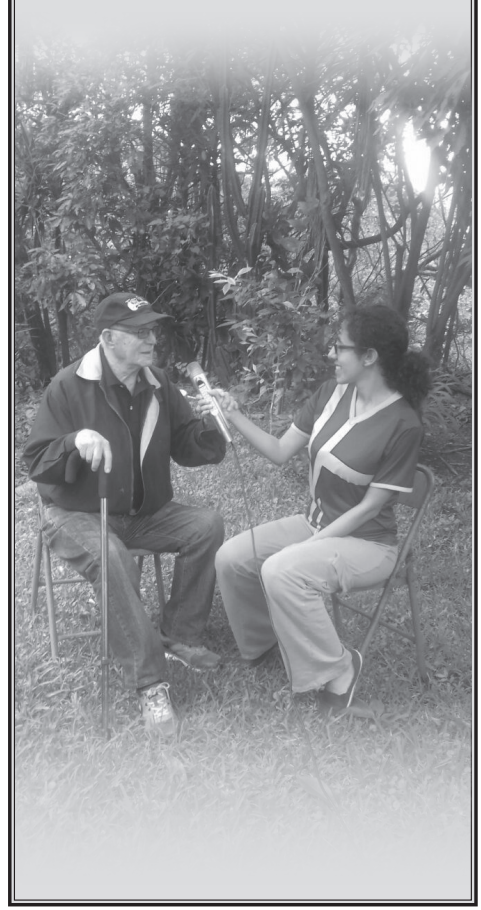




\section{Mejoramiento genético}

\section{Técnicas tradicionales de mejoramiento vegetal}

Injertos: una fracción del tallo de una planta se une a otra que se convierte en su soporte y proporciona alimento necesario para su crecimiento. Termina por convertirse en una sola y única planta.

Selección artificial y cruzamientos selectivos: cruce entre variedades de una misma especie al momento de la polinización. El polen de una variedad de planta, se deposita en los estambres de otra variedad.

Hibridación: cruzamiento entre diferentes especies.

Mutagénesis inducida: mutaciones en el genoma con sustancias químicas o radiaciones.

Cultivo in vitro de células, tejidos y órganos vegetales: la célula viva e íntegra de una planta regenera una planta entera igual a la original.

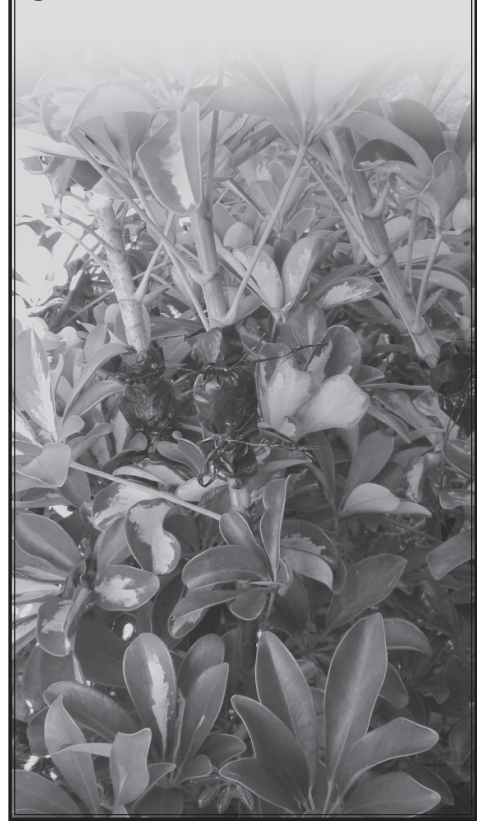

La modificación genética consiste en la selección y cruce de individuos de especies vegetales y animales por parte del ser humano. En plantas, ha ocurrido desde los inicios de la agricultura con la domesticación de especies vegetales comestibles, como el maíz y el trigo. Las nuevas variedades obtenidas varían de las anteriores, por su aspecto, sabor, color, consistencia y tamaño. Hay métodos tradicionales, como los injertos, en los cuales se van cruzando variedades hasta lograr las características deseadas. Actualmente se utilizan métodos de biotecnología a nivel celular y con la información genética. El resultado son organismos genéticamente modificados.

Analizamos el siguiente esquema:
Aplicación de cualquier forma de tecnología en organismos vivos.
Objetivos Aumentar la producción de plantas y crecimiento de animales, desarrollar nuevos organismos, manipular la herencia.

\section{Biotecnología}

Se aplica en agricultura, industria, medicina, producción de energía y combustibles y en el tratamiento biológico de desechos.
Propósitos: cura de enfermedades, control de los síntomas del envejecimiento, disposición de mayor cantidad de productos.
Algunos peligros potenciales de la biotecnología son la creación de nuevos alérgenos y toxinas en el organismo, aparecimiento de maleza agresiva y plantas nocivas resistentes a herbicidas, daño a la vida silvestre y la creación de lugares favorables al crecimiento de moho y hongos.

Con los datos obtenidos en la investigación de la semana anterior, elaboramos y diseñamos para el catálogo el segmento informativo acerca de los productos indagados. Incluimos cómo se utiliza la transmisión de caracteres genéticos en el mejoramiento de alguno de estos productos. 
Mediante la Ingeniería Genética se ha desarrollado la forma de cambiar las características intrínsecas de un ser vivo a través de la manipulación controlada y deliberada de sus genes. En algunas ocasiones se selecciona y elimina un gen determinado, en otras se implanta un nuevo gen que proviene de otro organismo y a veces se hacen modificaciones al gen. Lo que se pretende es adecuar las características del organismo a los propósitos de las personas. Al nuevo gen se le llama: Transgen y al nuevo organismo creado se le llama: Trasngénico u Organismo Géneticamente Modificado (OGM)

Algunas plantas transgénicas han sido provistas de determinados genes de bacterias que las hacen resistentes a ciertos herbicidas, como el glifosato. Otras han recibido genes de una bacteria que produce un pesticida a determinados insectos. Se ha producido variedad de plantas con el gen de la esterilidad para evitar que se cruce con las variedades silvestres. Además se impide que el agricultor seleccione parte de la semilla de la planta cultivada para una futura cosecha. Así tiene que comprar nuevamente la semilla transgénica a quien la comercializa.

En animales el progreso ha sido contraproducente, más lento y menos productivo. Por ejemplo en el intento de crear cerdos más magros, los cerdos crecieron más rápido, pero padecían artritis, úlceras, esterilidad y morían prematuramente. En la industria acuícola, centrada en un crecimiento acelerado, para lograr una rápida producción, se observa que el apetito aumentado de los peces, los hace crecer de 7 hasta 35 veces más. Si estos peces se encontraran libres, podrían exterminar otras especies al competir por el alimento.

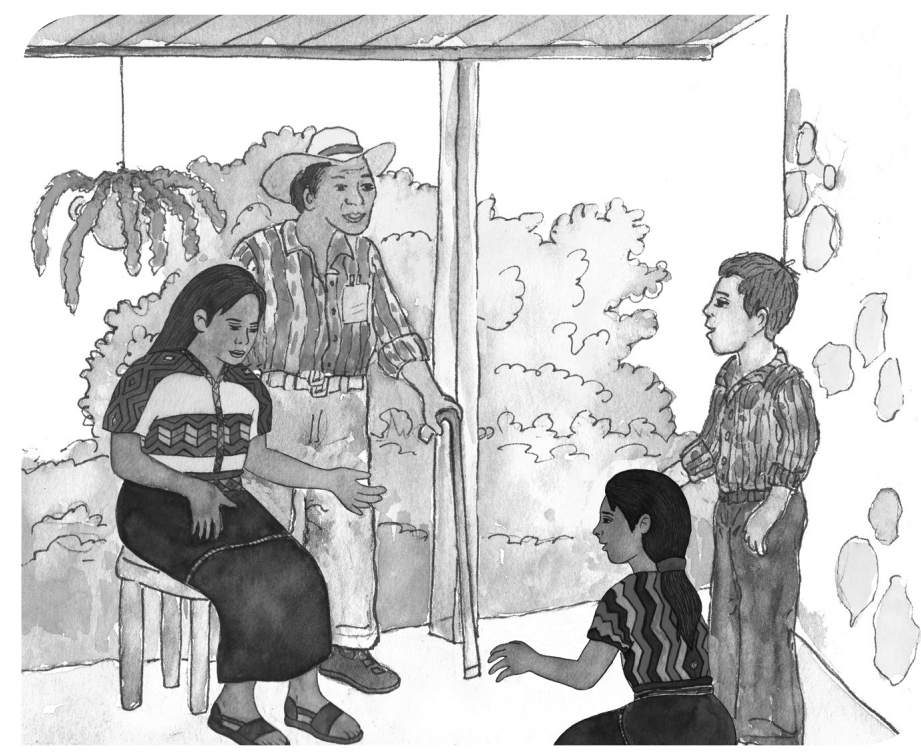

Investigo si en la comunidad se realizan cultivos que se hayan modificado genéticamente: injertos, cruzamientos selectivos $\mathrm{u}$ otros. Incluyo en la propuesta de catálogo a dichos productos.

Incluyo en mi investigación si en la comunidad se cultivan productos transgénicos y qué incidencia socioeconómica y socioambiental ha tenido su cultivo en la comunidad. Analizo si cumple con principios de responsabilidad social y del buen vivir.
El trigo OMG que se cultiva en la actualidad, tiene tantas modificaciones que dista mucho del que se comía décadas atrás. Actualmente está en debate los efectos perjudiciales para la salud humana del consumo de alimentos transgénicos. En el caso del trigo, existe la enfermedad celiaca. Cada año, más personas no toleran el gluten presente en el trigo actual. El debate más grande es el de la ingeniería genética humana y la creación de armas biológicas a través de la manipulación genética.

Gluten. Una de las proteínas del trigo y otros cereales, entre ellos, la cebada y la avena. Responsable de la elasticidad de la masa de harina. Es esencial para darle volumen, consistencia elástica y esponjosa al pan. No es indispensable para el ser humano, por lo que las personas pueden alimentarse de otras comidas y vivir sin comer pan con gluten.

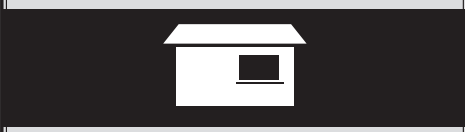

Si conozco una persona con alergia o sensibilidad al gluten. La entrevisto para que me comente sus síntomas.

- ¿Si tengo acceso a internet, sigo el siguiente enlace:

https:/ / noticiasdeabajo.wordpress.com / 2012/06/20 / lo-que-se-oculta-tras-los-ensayos-del-nuevo-trigo-transgenico/ 


\section{Organismos del Estado}

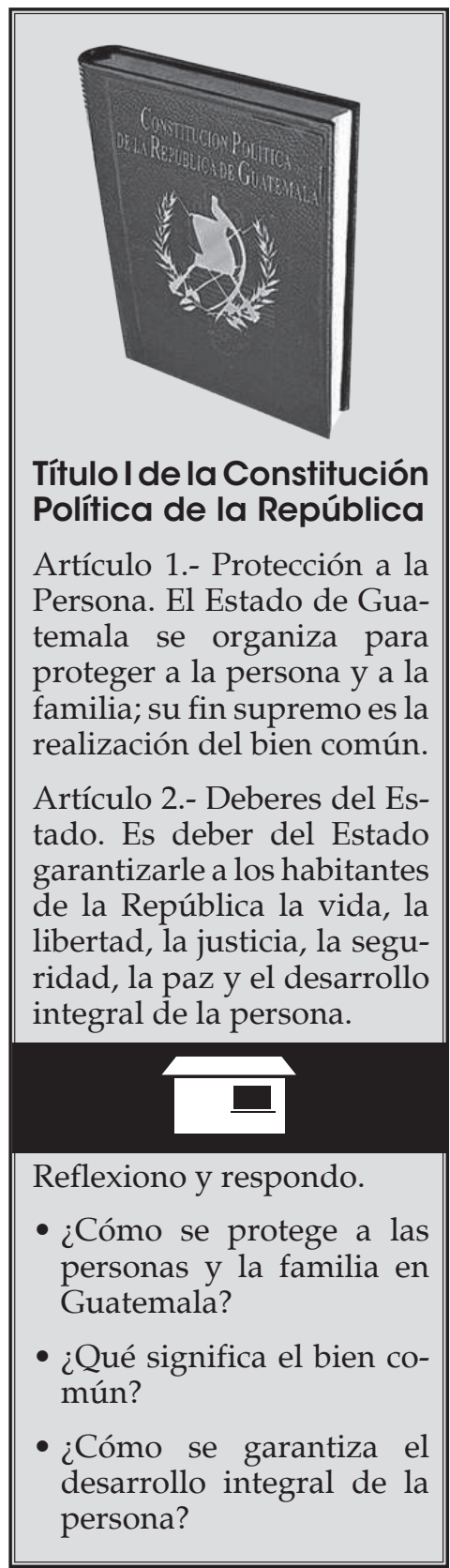

\begin{abstract}
El Estado guatemalteco se compone por tres organismos:

El Legislativo. Está representado por el Congreso de la República, integrado por diputados

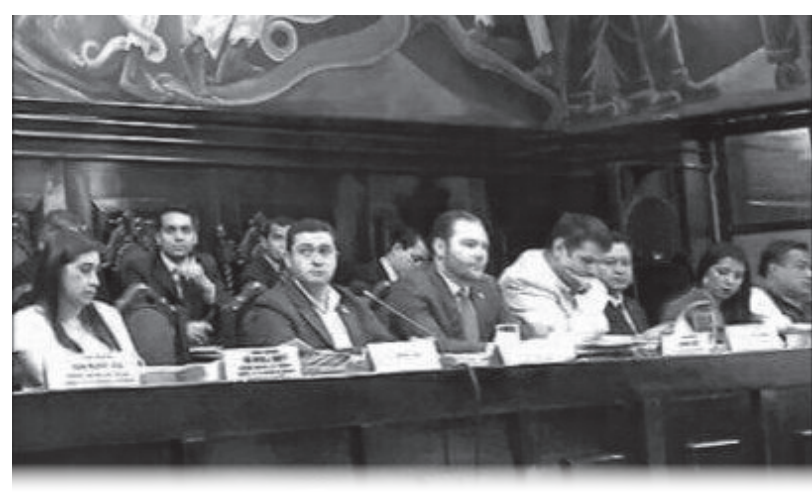
y diputadas electas popularmente para un período de cuatro años. Decreta, reforma o deroga leyes y da posesión a la persona electa para la Presidencia y la Vicepresidencia de la República. Tiene autoridad para auditar a los otros organismos del Estado, interpelar ministros y ministras y aprobar causas legales contra Presidentes y Vicepresidentes de la República, entre otras atribuciones.
\end{abstract}

Analizamos y respondemos en grupo.

- ¿Qué importancia tienen las leyes para una comunidad?

- Mencionamos otras dos atribuciones que tiene el poder Legislativo. Podemos investigar en la Constitución Política de la República.

El Ejecutivo. Lo representan quienes han sido electos y electas democráticamente para desempeñarse como Presidente o Presidenta de la República, y quien ocupará la Vicepresidencia, para un período de cuatro años. Para el desempeño de sus funciones se auxilia de varios equipos de trabajo organizados en Ministerios que asumen la implementación de políticas para atender las necesidades y los derechos de la población. Por ejemplo el Ministerio de Educación tiene la responsabilidad de asegurar el derecho a la educación; de la seguridad ciudadana se encarga la Ministra o Ministro de Gobernación; para velar por la garantía de los derechos laborales está el Ministro o Ministra de Trabajo.

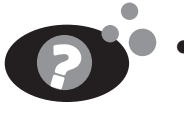

- ¿Debe tener mayor poder el Ejecutivo que los otros poderes? Argumentamos nuestra respuesta.

El Organismo Judicial. Se encarga de la aplicación de la justicia siguiendo lo establecido en la Constitución y las leyes del país. La Corte Suprema de Justicia es el órgano principal y está integrada por magistrados y magistradas que elige el Congreso de la República para un período de cinco años. Este organismo goza de independencia absoluta y no debe ser sujet de presión por ninguno de los otros organismos de Estado.

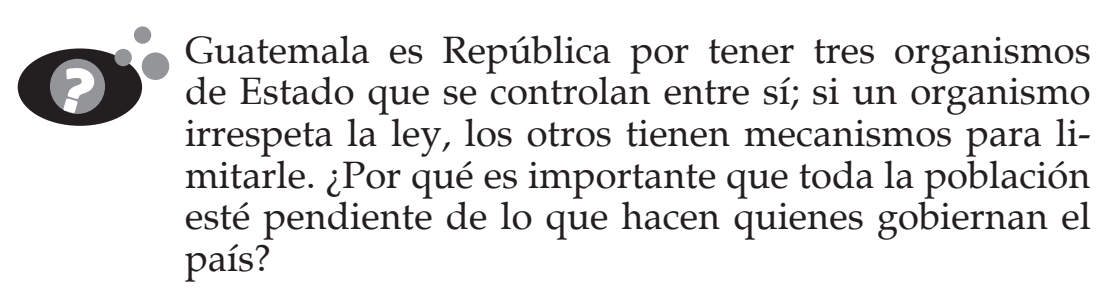




\section{Responsabilidades del Estado}

El Estado es el responsable de garantizar los derechos individuales, sociales, cívicos y políticos de las y los habitantes de la república de Guatemala. También es su responsabilidad mantener las garantías constitucionales y el orden constitucional.

Discutimos en equipo.

- ¿Cómo se le pide al Estado que cumpla con sus responsabilidades?

Las autoridades municipales y la comunidad también tienen responsabilidades. En equipo de trabajo:

Determinamos qué responsabilidades tienen las autoridades municipales.

Elaboramos una lista de responsabilidades que tiene la comunidad.

Cada integrante de la comunidad también tiene responsabilidades individuales. Con el grupo:

Discutimos cuáles son las responsabilidades de cada integrante de la comunidad con el medio ambiente.

Compartimos nuestras conclusiones con los otros grupos.

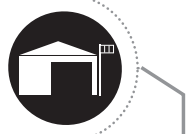

Infraestructura productiva son todas las construcciones y sistemas que se crean para favorecer la producción material y de servicios o su intercambio en un país o comunidad. Por ejemplo: mercados, carreteras, caminos, puentes, energía eléctrica y medios de comunicación. El Estado también tiene responsabilidad en garantizar la existencia y buenas condiciones de dicha infraestructura. Son esenciales también la participación democrática de la comunidad, asistencia en salud, educación y seguridad ciudadana; así como la conservación del ambiente, entre otros.

Trabajamos en grupo y analizamos: ¿qué actividades, servicios e infraestructura de la comunidad inciden en el nivel de educación, los años de vida y los ingresos de las familias?

Busquemos en el diccionario inglés-español para escribir en inglés los nombres de la infraestructura productiva que existe en la comunidad. Puedes investigar sobre su historia con tu familia.

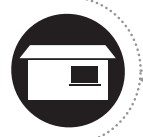

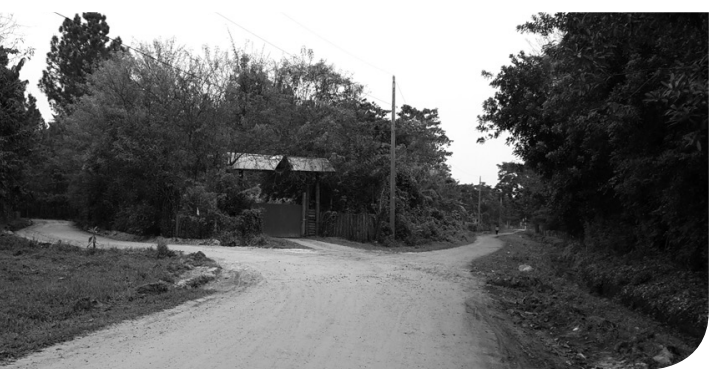

Visitamos, en parejas, los lugares de la comunidad donde hay infraestructura productiva.

Elaboramos un informe que describa cómo es la infraestructura, en qué estado se encuentra, cuál es su utilidad y en qué contribuye al desarrollo humano de la comunidad. Incluyo esos lugares en el boceto de catálogo.

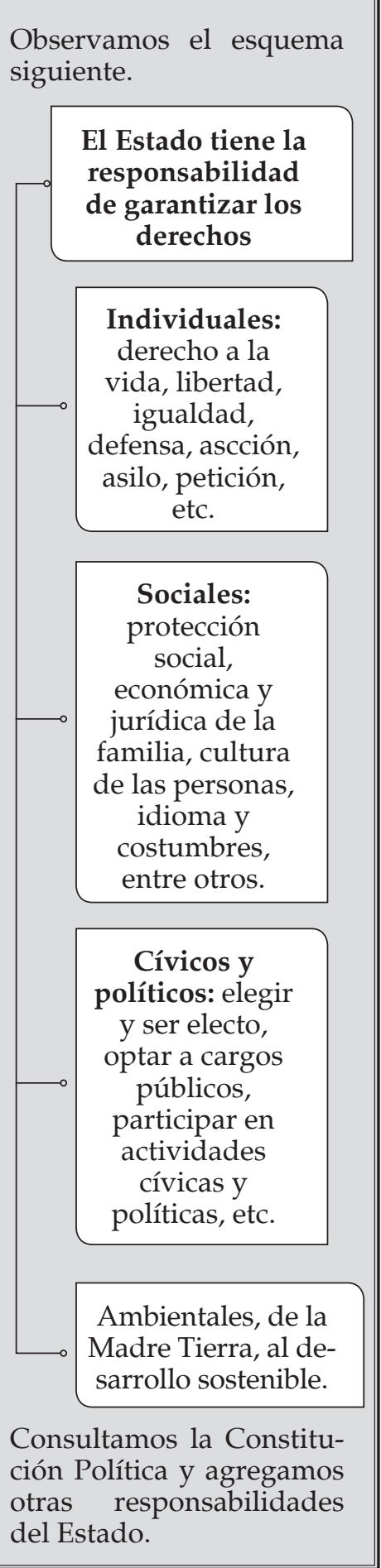

Observamos el esquema siguiente.

responsabilidad

de garantizar los

derechos

Individuales:

derecho a la

vida, libertad,

igualdad,

defensa, ascción,

asilo, petición, etc.

\section{Sociales: \\ protección \\ social,}

económica y

amilia, cultura

las personas,

idioma

costumbres,

entre otros.

Cívicos y

políticos: elegir

y ser electo,

optar a cargos

públicos,

participar en

actividades

cívicas y

políticas, etc.

Ambientales, de la Madre Tierra, al desarrollo sostenible.

Consultamos la Constitución Política y agregamo del Estado. 


\section{eódịos iconográficos en publicidad}

Juez: -¿Quién mató, villano, al señor Comendador?

Mengo: -¡Ay, yo lo diré, señor!

Juez: -Afloja un poco el castigo.

Frondoso: - ¡Ay, va a confesar!

Juez: $-¿$ Vas al fin a cantar?

Mengo: -Quedo; que ya lo diré...

Juez: -¿Quién lo mató? Mengo: - ¡El pueblo, señor; Fuenteovejuna, señor!

Observemos los signos resaltados en este fragmento de la obra Fuenteovejuna, del dramaturgo español Félix Lope de Vega. Estos nos ayudan a expresar cómo debemos pronunciar las oraciones.

Las oraciones que preguntan algo se llaman interrogativas y las encerramos entre signos de interrogación, así: i ?

Las oraciones que exclaman algo se llaman exclamativas y las encerramos entre signos de admiración, así: i!

Cuando queremos indicar una pausa que exprese duda, vacilación o suspenso en una oración, usamos puntos suspensivos y son solo tres: ...

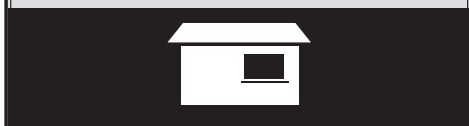

Escribamos dos oraciones con cada uno de los signos anteriores, en el cuaderno.

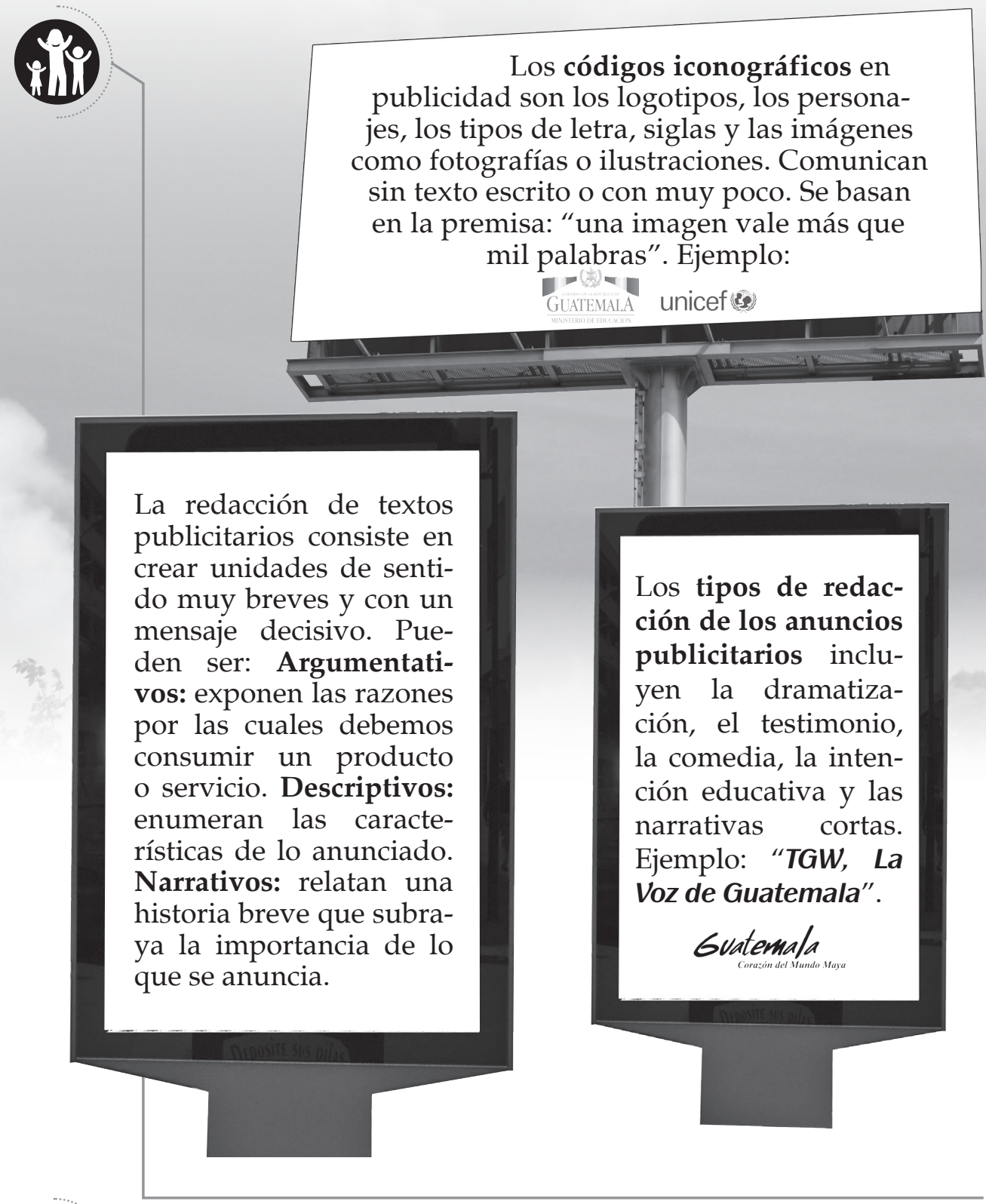

En grupos, anotamos ejemplos de códigos publicitarios de empresas y productos que reconozcamos fácilmente.

Consultemos el sitio dedicado al desarrollo sostenible de las Naciones Unidas: http://www.un.org/sustainabledevelopment/es/ infrastructure/

Publicidad y responsabilidad social: es muy importante estar alerta a los mensajes de los anuncios publicitarios que se instalan en nuestra comunidad. Comprendamos que son poderosas herramientas de dirección de nuestra conducta y manera de pensar. Muchos anuncios publicitarios nos orientan a consumir productos que son necesarios o que son perjudiciales para la salud. Por ejemplo: cigarros, licores, comida chatarra. Favorezcamos la publicidad social sobre la comercial. Ejemplo: Invirtamos en el desarrollo de nuestra comunidad para evitar la emigración. 


\section{Organicemos nuestras ideas}

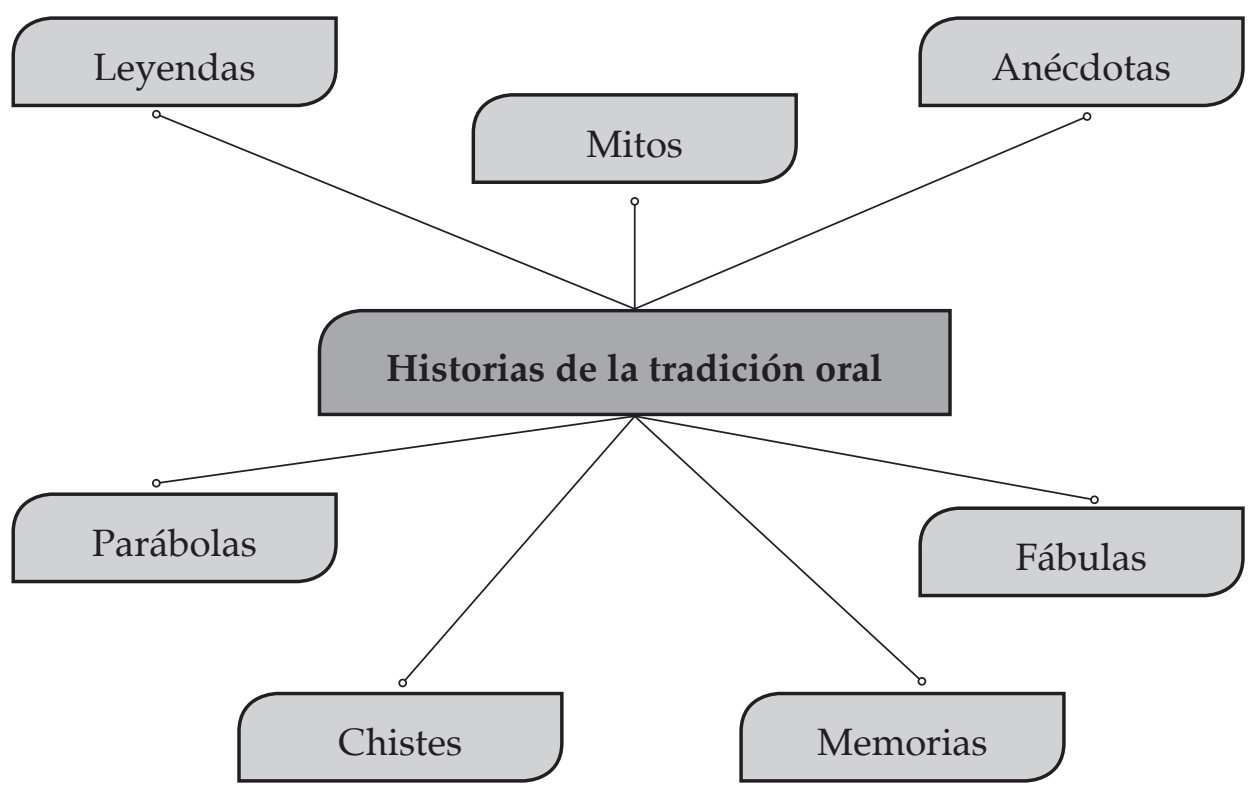

Un esquema es parte de los organizadores gráficos. Es un conjunto de datos ordenados por orden de importancia que se relacionan por medio de líneas, de manera horizontal o vertical. El anterior es un ejemplo de los tipos de historias de la tradición oral.

Organicemos una dinámica de trabajo en equipo nueva para seleccionar el bosquejo de catálogo que mejor incluya a los demás y tenga potencial de demostrar el vínculo entre la productividad y el desarrollo humano de la comunidad: la Phillips 66 o Discusión 66. ¿En qué consiste? Se basa en dividir un grupo de personas en subgrupos de 6 personas y hacerlas conversar sobre un tema específico, durante 6 minutos. Finalmente, se obtiene una idea general de las conclusiones de cada grupo. Por esta razón es importante que usemos un esquema para sintetizar nuestras ideas en el tiempo límite que tenemos.

Cuando tengamos el bosquejo seleccionado, podemos reforzarlo con la integración de iconografía de la comunidad, con información que obtengamos con entrevistas. Desarrollemos preguntas para una entrevista sobre la iconografía de la comunidad.

La iconografía es la representación gráfica de un elemento. Puede aplicarse a una comunidad, a un derecho, a un producto, a una meta.

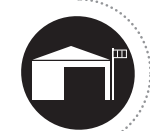

Revisamos los bosquejos producidos para el catálogo de productos enfocándonos en:
1. La redacción
2. La ortografía
3. La veracidad de la información

Desarrollamos lemas y un ícono que represente a nuestra comunidad para en el catálogo. Entrevistamos a personas de la comunidad para obtener información que nos permite desarrollarlos.

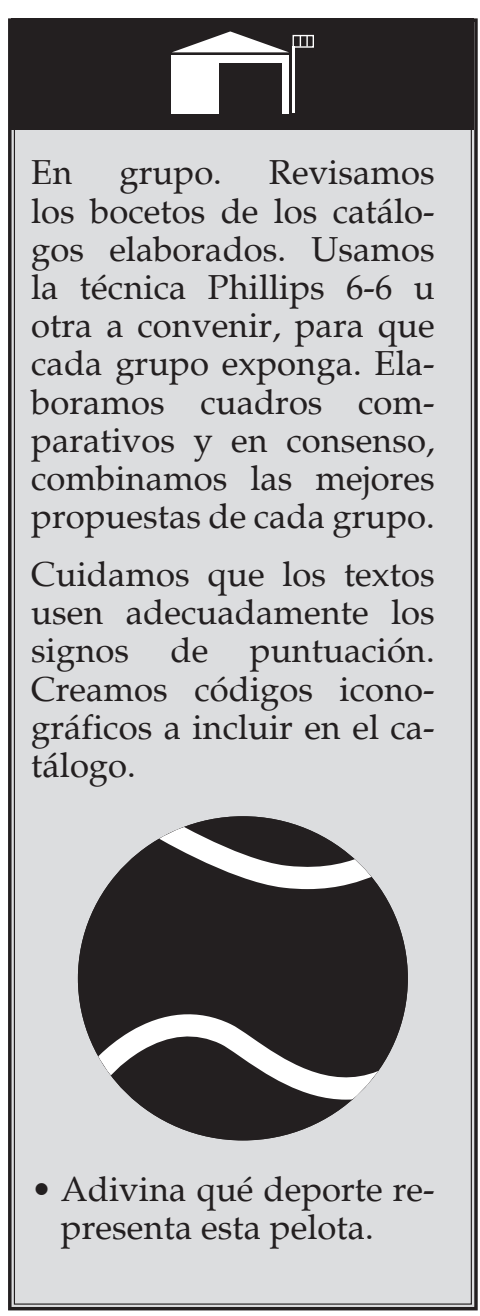

En grupo. Revisamos los bocetos de los catálogos elaborados. Usamos la técnica Phillips 6-6 u otra a convenir, para que cada grupo exponga. Elaboramos cuadros comparativos y en consenso, Cuidamos que los textos usen adecuadamente los signos de puntuación Creamos códigos iconográficos a incluir en el catálogo. 


\section{Teatro para nuestro desarrollo}

\section{Juego dramático:}

Es el juego teatral que combina la expresión corporal con la expresión lingüística. Partiendo del interés por el juego, pueden explorarse las destrezas expresivas del movimiento. Este movimiento conlleva los elementos propios de la expresividad del cuerpo: muecas, gestos, ruidos, ademanes, sonidos, entre otros.

Al hacer juegos dramáticos o escénicos se fortalece la capacidad lúdica, la destreza de imitación y la memoria. Además, se desarrolla el dominio personal.

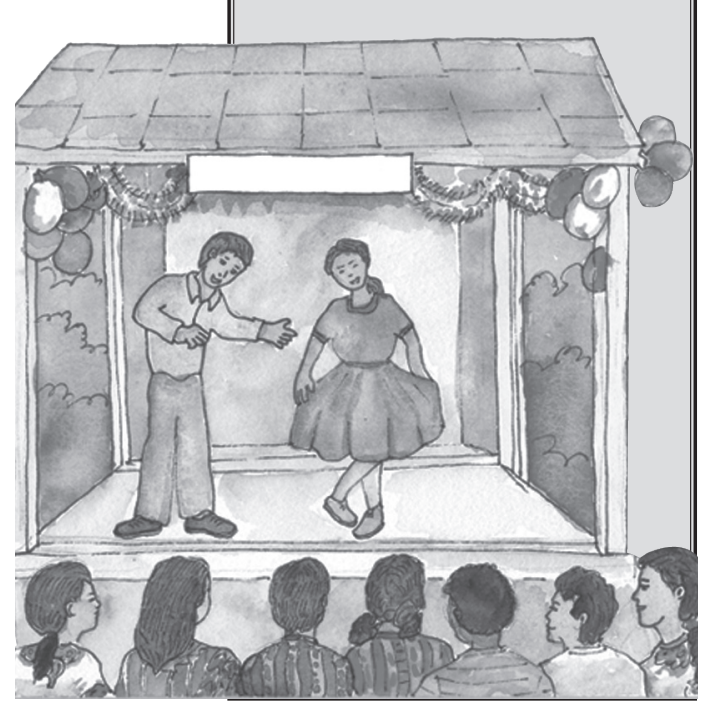

Discurso: "En nuestra comunidad todos somos responsables de hacer el bien. Ella necesita de nuestro trabajo conjunto para salir adelante. Juntos, hombro con hombro, podemos hacer que el desarrollo sea para todos. Construyamos juntos un mejor país."
Hacer teatro es expresar nuestras ideas y sentimientos por medio de la actuación. Para actuar se necesita imaginar cómo siente y piensa un personaje, imaginar cómo sería "estar en sus zapatos". Por ejemplo, si pensamos lo que experimenta una persona Cuando tiene pasión por su trabajo, seguramente podemos actuar como si nos pasara a nosotros. Lo mismo aplica para otras situaciones cotidianas que pueden ser agradables o desagradables.

Hacemos teatro todos los días ante las personas que nos rodean. Cada acto de nuestra vida reviste una parte teatral que nos muestra ante las y los demás según lo que queremos mostrar. Esto quiere decir que podemos mostrar una parte de nuestro ser y otras partes las podemos ocultar. Es importante actuar con sinceridad ante quienes nos observan o interactúan con nosotros, aunque a veces mostramos lo contrario de lo que realmente somos. También podemos usar el teatro para reforzar nuestra manera de ser.

Realicemos los siguientes ejercicios de preparación teatral. Cada nivel implica un compromiso más profundo con las acciones o los personajes.

\section{Nivel básico. Sintiendo el espacio}

1. En grupos, formamos círculos y prestamos atención a lo que nos rodea. Percibimos colores, sonidos, olores, nuestra respiración y nuestro cuerpo. Realizamos movimiento circular de cabeza, cerrando los ojos, imaginamos que nuestra cabeza es el planeta que gira alrededor del sol, a la derecha y luego a la izquierda.

2. Giramos brazos imaginando que giramos una rueda, luego dibujando en el aire un espiral hacia fuera y hacia dentro.

3. De puntillas, estiramos los brazos imaginando que alcanzamos una fruta que está en alto, incluso, saltamos para alcanzarlo. La alcanzamos y la comemos.

\section{Nivel intermedio. Imitando con mímicas}

1. Cada integrante del grupo elige un oficio o trabajo. Por turnos y sin anunciarlo, cada cual va representando los movimientos propios del oficio ante las y los demás.

2. El resto del grupo debe descubrir qué oficio está representando quien actúa.

\section{Nivel avanzado. Imitando con gestos y voz}

1. De la siguiente lista, elegimos un personaje que representaremos: agricultor/agricultora, vendedora/vendedor, tejedor/ tejedora, empresaria/empresario, presidente/presidenta, ingeniera, ingeniero $u$ otros que el grupo elija.

2. El trabajo teatral consiste en imitar los gestos, la voz, la actitud y la manera de ser del personaje.

3. Leemos en conjunto, el discurso que está en el ladillo. Luego cada integrante del grupo lo debe decir como lo diría el personaje que le toca representar.

4. Al finalizar, discutimos en conjunto, ¿Por qué muchos discursos emplean solo artículos y sustantivos masculinos?, ¿Quiénes quedan fuera del discurso por esta razón? 


\section{Representamos las necesidades de la comunidad}

Hacer juegos dramáticos y representar escenas puede ayudarnos a mejorar nuestras destrezas expresivas, comunicarnos mejor y desarrollar nuestra personalidad. Estos juegos también se han usado para hacer notar los problemas sociales que nos afectan. Una manera de usarlos es representando sociodramas. Con ellos, se pueden plantear las problemáticas que enfrenta la comunidad. A veces quienes integran la comunidad encuentran difícil enfrentarlos abiertamente; pero a través de esta herramienta abren una puerta de comunicación para buscar soluciones.

Pueden representarse acciones de responsabilidad social empresarial y respeto a los derechos humanos que conozcamos, factores de riesgo o problemas socioambientales. Seleccionamos representaciones positivas de esos productos y bienes de servicio. Mediante imágenes los incluimos en el boceto de catálogo. La extracción minera, la recuperación del cauce natural de los ríos, la tala inmoderada de árboles, la equidad de género, la migración pueden ser otros temas a representar.

Conozcamos las propuestas de catálogos producidas por la clase, mediante una presentación. Planteemos tres situaciones comunitarias y representémoslos:

Con toda la clase formamos tres grupos.

1. Un grupo representará el efecto de las migraciones.

2. El otro grupo representará a jóvenes que no encuentran un trabajo digno.

3. El último grupo dramatiza la comercialización de los productos de la comunidad.

Al final, realizamos un foro sobre la responsabilidad de todos y todas en el bienestar de la comunidad. Si bien estos pueden ser problemas que afectan a todas las personas, el reto es buscar soluciones que permitan responder a las preguntas: ¿afectan estos dos problemas a mi comunidad?, ¿conozco casos parecidos a los que se representan?, ¿qué soluciones podemos plantear como posibilidad ante este fenómeno?

Al plantearnos algunos de los problemas que nos afectan, hemos pasado por el proceso de reconocerlos e identificarlos. Corresponde evaluar si hemos abarcado los problemas identificados en cada área de estudio. Clasifiquemos cómo podríamos representar estos problemas.
Un sociodrama o psicodrama es una técnica de representación teatral con fines educativos que busca el planteamiento de los problemas sociales desde un enfoque crítico y sociológico. Su impulsor fue el dramaturgo brasileño Augusto Boal, en 1971, mediante lo que él denominó Teatro del Oprimido.

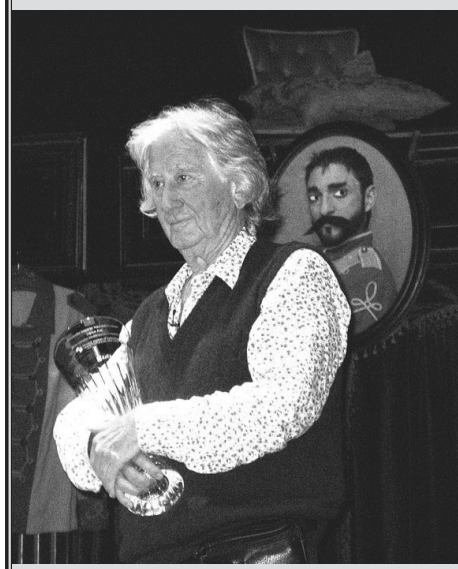

Augusto Boal, (1931-2009)

Fuente: https:/ / es.wikipedia. org/wiki/Archivo:Augusto Boal.jpg

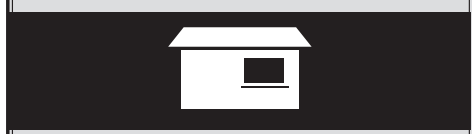

Dibujo un servicio que se provee en la comunidad que respeta los derechos humanos para incluir en el catálogo.

\begin{tabular}{|c|c|c|c|c|}
\hline $\begin{array}{c}\text { Comunicación } \\
\text { y Lenguaje }\end{array}$ & $\begin{array}{c}\text { Productividad } \\
\text { y Desarrollo }\end{array}$ & Matemática & $\begin{array}{c}\text { Ciencias } \\
\text { Naturales }\end{array}$ & $\begin{array}{c}\text { Ciencias } \\
\text { Sociales }\end{array}$ \\
\hline $\begin{array}{c}\text { Sociodrama } \\
\text { sobre: }\end{array}$ & $\begin{array}{c}\text { Sociodrama } \\
\text { sobre: }\end{array}$ & $\begin{array}{c}\text { Sociodrama } \\
\text { sobre }\end{array}$ & $\begin{array}{c}\text { Sociodrama } \\
\text { sobre: }\end{array}$ & $\begin{array}{c}\text { Sociodrama } \\
\text { sobre: }\end{array}$ \\
\hline
\end{tabular}




\section{Lè de los senos de los triángulos}

Los triángulos no rectángulos son llamados triángulos oblicuos. Un triángulo oblicuo tiene tres ángulos agudos o dos ángulos agudos y un ángulo obtuso.

Recuerdo que: Los ángulos agudos miden menos de 90․․ Los ángulos obtusos miden más de $90^{\circ} \mathrm{Y}$ menos de $180^{\circ}$. La suma de los ángulos internos de un triángulo es $180^{\circ}$.

\section{Triángulos oblicuos}
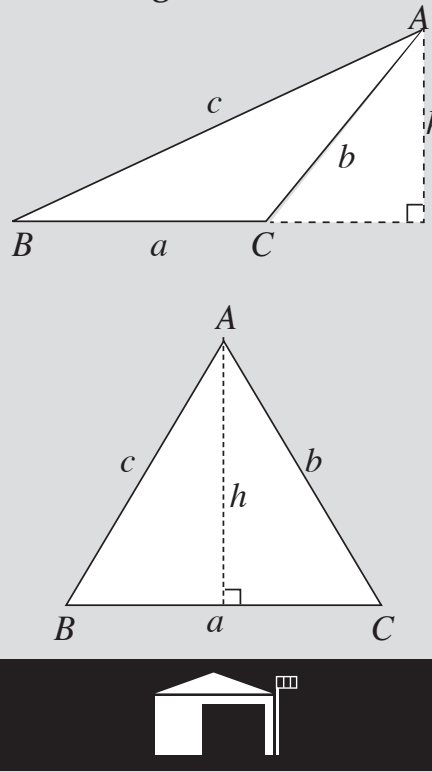

Averiguamos si en la comunidad, existen bifurcaciones de caminos o lugares de producción agrícola o industrial, con terrenos o construcciones con formas triangulares. Determinamos el beneficio que tienen o pueden tener esos espacios triangulares. Incluimos una que las represente, en el boceto de catálogo.

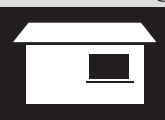

Diseño un modelo de empaque de un producto de la comunidad con forma de prisma triangular.
- ¿Cuántos triángulos observamos en la figura? ¿Qué tipos de triángulos encontramos en ella? ¿Cuántos triángulos rectángulos encontramos? ¿Cuántos agudos? ¿Cuántos obtusángulos? Comentamos nuestras respuestas.

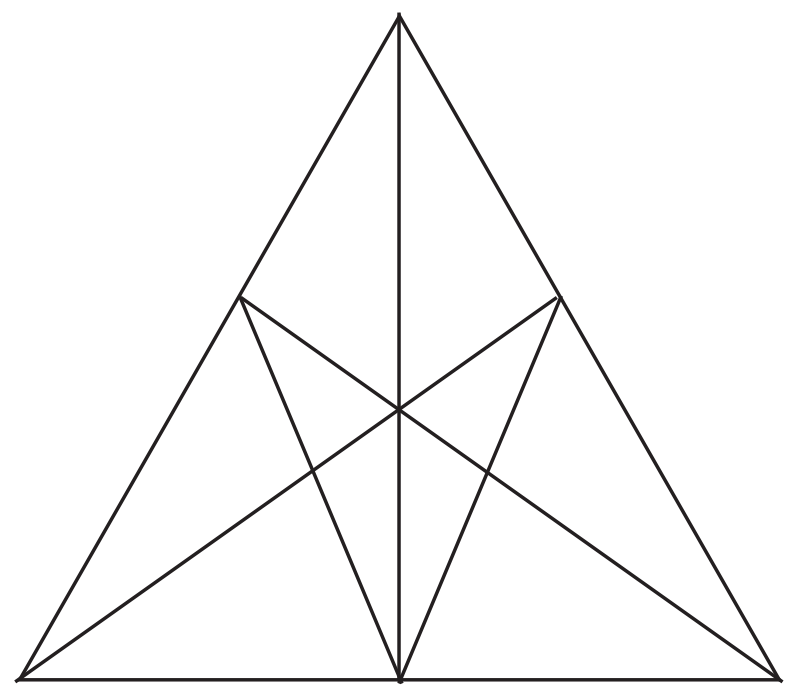

Utilizamos regla para dibujar tres triángulos distintos sobre papel periódico. Un triángulo rectángulo, uno agudo y uno obtuso. Verificamos la suma de sus ángulos internos, tal como lo hicimos la semana pasada. ¿Qué observamos? ¿Sucede lo mismo en todos los casos? Compartimos nuestras respuestas.

¿Qué tipos de triángulos, según la medida de sus ángulos, se pueden construir con las siguientes longitudes de lados? Utilizamos papel y regla para comprobarlo.

- $5 \mathrm{~cm}, 5 \mathrm{~cm}$ y $5 \mathrm{~cm}$

- $17 \mathrm{~m}, 15 \mathrm{~m}$ y $8 \mathrm{~m}$

- $45 \mathrm{~cm}, 2 \mathrm{~cm}$ y $4 \mathrm{~cm}$

- $3 \mathrm{~cm}, 2 \mathrm{~cm}$ y $4 \mathrm{~cm}$

- Utilizamos los triángulos que ya usamos la semana pasada. y los clasificamos en rectángulos, agudos y obtusos. Medimos la longitud de sus lados y sus ángulos. Anotamos las respuestas.

- Empleamos la ley de senos para verificar esa información. ¿Se comprobó la información para todos los tipos de triángulos?

- Usamos razones trigonométricas (seno, coseno y tangente) para verificar la información. ¿Se logró comprobar para todos los tipos de triángulos? ¿Qué podemos concluir? Intercambiamos nuestros triángulos con los de nuestros compañeros y compañeras y repetimos la actividad. 
En fichas de papel escribo toda la información que tengo acerca de la ley de senos. Agrego tres ejemplos. Dibujo los triángulos que utilizo para cada ejemplo. Con apoyo de mi tutora o tutor, investigo en libros, internet $\mathrm{u}$ otras fuentes, las aplicaciones de la ley de los senos. Si tengo acceso a internet puedo consultar esta lección:

https:/ / es.khanacademy.org/math/trigonometry/trig-with-generaltriangles/law-of-sines/v/law-of-sines

¿Es posible utilizar siempre la ley de senos para hallar longitudes de lados o medidas de ángulos en un triángulo? ¿Qué ocurre si solo conozco la longitud de los lados del triángulo, pero no la medida de algún ángulo? ¿Puedo utilizar la ley de senos si conozco la medida de los tres ángulos de un triángulo, pero no la longitud de algún lado? Discutimos nuestras respuestas.

Resolvemos utilizando ley de senos:

Tres estudiantes están colocados sobre un campo de futbol. Entre Andrés y Briseida hay 25 metros y entre Briseida y Carla, 12 metros. El ángulo que se forma en la esquina de Carla es de $20^{\circ}$. Calcula la distancia entre Andrés y Carla.

Encontramos la longitud del lado desconocido:

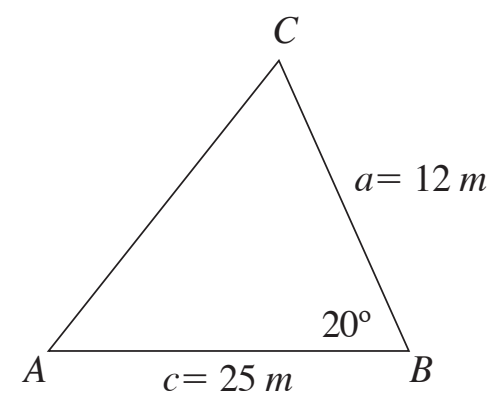

Para encontrar la respuesta, sustituimos las letras por los números conocidos, en la ley de senos, anotada líneas abajo. Formamos una proporción con las razones que tengan, al menos un dato conocido. Encontramos el valor de los tres ángulos. Hacemos una proporción con la razón que tiene el lado desconocido y cualquiera de las otras razones. Resolvemos la proporción.

Utilizando la ley de senos hallamos las medidas de los ángulos y de los lados desconocidos en los siguientes triángulos $\mathrm{ABC}$ :
1) $m<A=60^{\circ}$
$m<B=70^{\circ} \quad b=20 m$
2) $m<A=30^{\circ}$
$a=6 \mathrm{~cm}$
$c=9 \mathrm{~cm}$
3) $m<A=131^{\circ}$
$m<C=23^{\circ}$
$b=10 m$
4) $m<A=170^{\circ}$
$b=100 m$
$c=75 \mathrm{~m}$
5) $m<A=54^{\circ}$
$b=7 \mathrm{~mm}$
$c=18 \mathrm{~mm}$

La ley de senos es útil para resolver problemas de triángulos oblicuos. Permite encontrar las longitudes de los lados de un triángulo no rectángulo y las medidas de sus ángulos. Es útil, si se conoce un lado y dos ángulos o dos lados y el ángulo opuesto a uno de esos lados. Establece que la relación de la longitud de un lado de un triángulo con seno del ángulo opuesto a ese lado, es igual para todos los lados y ángulos en un triángulo dado.

$$
\begin{aligned}
& \frac{a}{\operatorname{Sen} A}=\frac{b}{\operatorname{Sen} B}=\frac{c}{\operatorname{Sen} c} \\
& \frac{\operatorname{Sen} A}{a}=\frac{\operatorname{Sen} B}{b}=\frac{\operatorname{Sen} c}{c}
\end{aligned}
$$




\section{Mạfertiales fecnológicos de difusión y transmisión sonora}

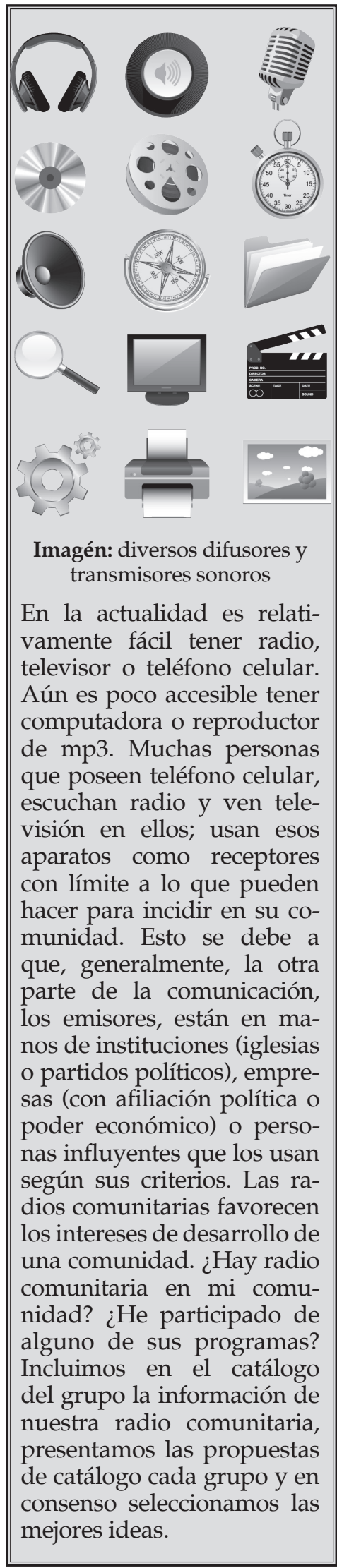

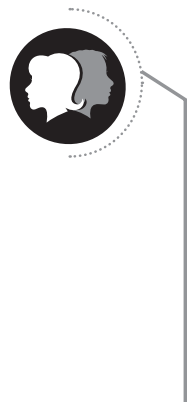

En grupos respondemos las siguientes preguntas:

- ¿Por qué medios escuchamos música?

- ¿Dónde y cómo se produce la música que escuchamos?

- ¿Qué necesitamos para producir y difundir nuestra propia música?

\section{Tecnología de comunicación sonora}

\begin{tabular}{|c|c|c|c|c|}
\hline $\begin{array}{l}\text { Radio- } \\
\text { receptores }\end{array}$ & Televisión & $\begin{array}{l}\text { iPods y } \\
\text { mp3 }\end{array}$ & Computadoras & Celulares \\
\hline $\begin{array}{l}\text { Recibe la } \\
\text { señal por } \\
\text { ondas } \\
\text { electromag- } \\
\text { néticas que } \\
\text { viajan en } \\
\text { el espacio } \\
\text { aéreo. }\end{array}$ & $\begin{array}{l}\text { Igual que el } \\
\text { radio, recibe } \\
\text { las ondas } \\
\text { electromag- } \\
\text { néticas, } \\
\text { que además } \\
\text { de sonido } \\
\text { también } \\
\text { transmiten } \\
\text { imágenes. }\end{array}$ & $\begin{array}{l}\text { Son dis- } \\
\text { positivos } \\
\text { de almace- } \\
\text { namiento } \\
\text { y repro- } \\
\text { ducción } \\
\text { de sonido } \\
\text { y video. } \\
\text { También } \\
\text { almacenan } \\
\text { datos. }\end{array}$ & $\begin{array}{l}\text { Máquinas } \\
\text { electrónicas } \\
\text { procesadoras } \\
\text { de datos. Entre } \\
\text { sus múltiples } \\
\text { funciones, } \\
\text { permiten alma- } \\
\text { cenar y repro- } \\
\text { ducir música y } \\
\text { videos. }\end{array}$ & $\begin{array}{l}\text { Los teléfo- } \\
\text { nos celula- } \\
\text { res, la radio } \\
\text { y la TV fue- } \\
\text { ron creados } \\
\text { para la co- } \\
\text { municación } \\
\text { a distancia. } \\
\text { Los celula- } \\
\text { res llegaron } \\
\text { a funcionar } \\
\text { como com- } \\
\text { putadoras } \\
\text { personales, } \\
\text { son exce- } \\
\text { lentes para } \\
\text { almacenar y } \\
\text { reproducir } \\
\text { música. }\end{array}$ \\
\hline
\end{tabular}

Estos aparatos facilitan la comunicación en todo el planeta, al difundir música y otros mensajes audiovisuales. Los medios tradicionales de comunicación sonora incluyen: el teléfono, la radio y la televisión. Con el surgimiento del internet, se facilitó la divulgación de todo lo que hoy conocemos de las redes y la comunicación virtual.

Elaboramos una presentación sobre los usos que damos a estos aparatos en la comunidad

- Generamos ideas de cómo se pueden aprovechar para el desarrollo de la comunidad. Incluimos las propuestas en el catálogo.

- Obtenemos conclusiones acerca de cómo usarlos para usar nuestro derecho a la libertad de expresión.

Escuchamos la música que nos traen a la clase y realizamos movimientos con todo nuestro cuerpo. 


\section{Canales de difusión}

En todo proceso de comunicación existen al menos tres elementos:

\begin{tabular}{|c|l|l|}
\hline \multicolumn{1}{|c|}{ Emisor } & \multicolumn{1}{c}{ Mensaje } \\
$\begin{array}{l}\text { Emisor, el que emite un } \\
\text { mensaje }\end{array}$ & $\begin{array}{l}\text { Mensaje, lo que se quie- } \\
\text { re transmitir }\end{array}$ & $\begin{array}{l}\text { Receptor, el que recibe } \\
\text { el mensaje }\end{array}$ \\
\hline
\end{tabular}

Pero el receptor o receptora no es alguien que solo recibe el mensaje y se queda de brazos cruzados. Siente, piensa, sufre y disfruta los mensajes, y luego reacciona ante ellos. Los mensajes artísticos permiten:

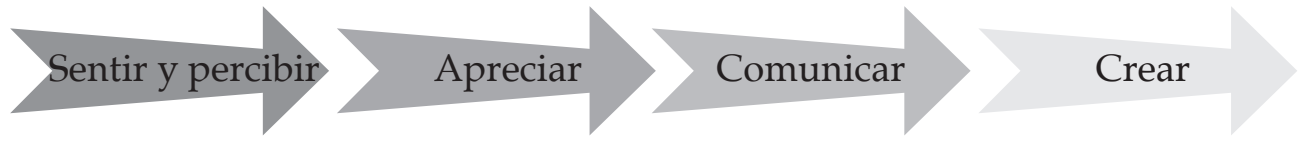

Si la música nos hace sentir, apreciar, comunicar y crear, entonces el proceso de comunicación está completo. Lo mismo sucede con otros mensajes que nos llegan por ese medio. Al hacer uso de los receptores sonoros podemos reaccionar sintiendo, apreciando, comunicando y creando. Podemos usarlos para provocar sentimientos y apreciación en otras personas.

- ¿Pero cuáles son esos canales de difusión y transmisión que nos envían los mensajes?

\begin{tabular}{|c|c|c|}
\hline Bandas de onda & Frecuencias radiales & Sistemas de red \\
\hline $\begin{array}{l}\text { Son enviadas por una } \\
\text { antena de radio o tele- } \\
\text { visión. Se clasifican en: } \\
\text { - AM= amplitud mo- } \\
\text { dulada } \\
\text { - FM= frecuencia mo- } \\
\text { dulada } \\
\text { - UHF= Frecuencia Ul- } \\
\text { tra Alta (en inglés) } \\
\text { - VHF= Frecuencia } \\
\text { muy Alta (en inglés) }\end{array}$ & $\begin{array}{l}\text { Las emisiones de radio, } \\
\text { viajan a través de la } \\
\text { banda AM o FM. } \\
\text { Cada emisor de radio } \\
\text { tiene su propia "Fre- } \\
\text { cuencia". }\end{array}$ & $\begin{array}{l}\text { El internet es una red } \\
\text { Internacional de comu- } \\
\text { nicación. } \\
\text { A través de computa- } \\
\text { doras o teléfonos, se } \\
\text { accede a redes sociales, } \\
\text { blogs, páginas electró- } \\
\text { nicas, correo electróni- } \\
\text { co o videoconferencias. }\end{array}$ \\
\hline
\end{tabular}

Las bandas y frecuencias de radio, televisión y teléfono son parte importante del desarrollo humano. El contacto con el mundo ayuda en muchos aspectos de la vida cotidiana. Sin embargo, sus efectos en el tejido social también pueden ser nocivos. Si la radio o la televisión no transmiten la música o la cultura que se produce en el país o en la comunidad, el efecto sobre la cultura es devastador.
Parte de los programas de radio y tv están destinados a las y los jóvenes. Incluyen música y noticias de la farándula. Muchas personas aspiran a ser como sus ídolos, que son promocionados en los medios. Es importante que las y los jóvenes de la comunidad se expresen con libertad mediante cualquiera de las expresiones artísticas y desarrollen sus talentos.

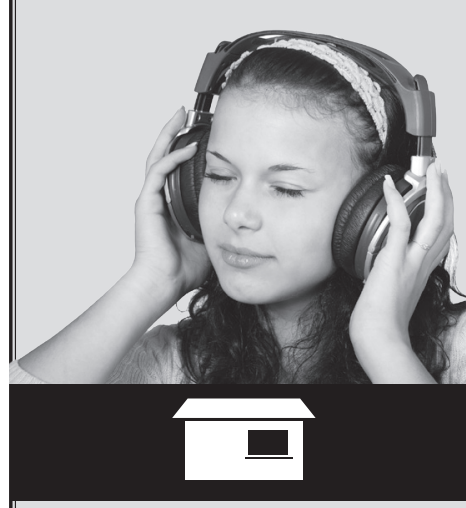

Sintonizo una hora diaria de radio o televisión. Averiguo la influencia de los medios en mi comunidad. Para cada día, anoto los aspectos de mi comunidad reflejados en la programación y respondo.

- ¿Cuánta presencia tiene mi comunidad y mi país en los medios de comunicación?

- ¿Qué se necesita para que los medios reflejen lo que somos y vivimos como comunidad?

- ¿Cómo me siento al recibir lo que transmiten los medios?

- ¿Cuánta variedad de música puedo elegir en las transmisiones de estos medios? 


\section{Compuestos químicos, formación y estructura de compuestos}

Para que pueda formarse un compuesto químico debe realizarse un enlace químico.

Enlace químico Unión de dos o más átomos por acción de fuerzas de atracción electrostática.

Reacción química es un fenómeno químico en el cual dos sustancias o más, denominadas reactivos, se convierten en nuevas sustancias denominadas compuestos.

El oxígeno del aire reacciona con el hierro y forma el óxido de hierro. El carbono, hidrógeno, oxígeno, nitrógeno, fosforo y azufre son elementos con los que se forman compuestos como los carbohidratos, lípidos, proteínas y ácidos nuclei$\cos (\mathrm{ADN})$.

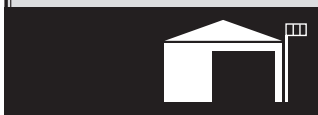

Identificamos reacciones químicas en el entorno. Las escribimos en el cuaderno. Compartimos la información con compañeros y compañeras.

Observamos el video y en grupo elaboramos comentarios. Exponemos en el aula.

https: / / www.youtube.com/ watch? $\mathrm{v}=\mathrm{q} 4 \mathrm{~g} 8$ frrICJk

- ¿Qué productos agropecuarios y forestales que produce la comunidad, incluimos en el catálogo? Pensemos también en los que se producen en forma orgánica o sustentable.
Observamos la siguiente secuencia de imágenes. Interpretamos la información que muestra.

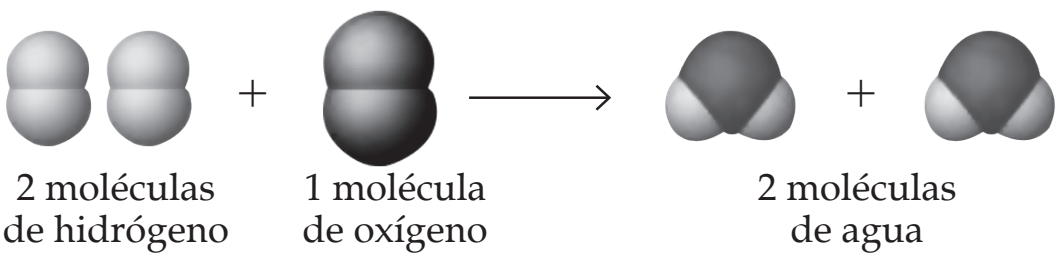

Un compuesto químico es la combinación de dos o más elementos que reaccionan entre sí para formar una nueva sustancia. El agua, la sal de mesa y el azúcar son ejemplos de compuestos. Otros ejemplos de compuestos químicos aparecen en la siguiente tabla:

\begin{tabular}{|l|l|l|}
\multicolumn{1}{|c|}{$\begin{array}{c}\text { Nombre } \\
\text { químico }\end{array}$} & \multicolumn{1}{|c|}{$\begin{array}{c}\text { Nombre } \\
\text { común }\end{array}$} & \multicolumn{1}{|c|}{ Propiedades y usos } \\
\hline Ácido acético & Vinagre & Aditivo de los alimentos \\
\hline Etanol & $\begin{array}{l}\text { Alcohol de } \\
\text { grana }\end{array}$ & $\begin{array}{l}\text { Cerveza, vinos, aguardien- } \\
\text { te, combustible }\end{array}$ \\
\hline Metanol & $\begin{array}{l}\text { Alcohol de } \\
\text { madera }\end{array}$ & $\begin{array}{l}\text { Disolvente, combustible, } \\
\text { plásticos, fibras }\end{array}$ \\
\hline Sacarosa & Caña dulce & Endulzante \\
\hline $\begin{array}{l}\text { Cloruro de } \\
\text { vinilo }\end{array}$ & PVC & Mangueras, tuberías \\
\hline Poliamida & Nailon & Medias, hilos, telas \\
\hline Glucógeno & $\begin{array}{l}\text { Almidón ani- } \\
\text { mal }\end{array}$ & Combustible celular \\
\hline Retinol & Vitamina A & $\begin{array}{l}\text { Buena visión, construcción } \\
\text { de células epiteliales }\end{array}$ \\
\hline Ácido leico & Aceite de oliva & Aceite de cocina \\
\hline
\end{tabular}

Algunos compuestos químicos presentes en los alimentos procesados son nocivos para la salud. El jarabe de maíz, presente en refrescos y postres, provoca resistencia a la insulina, incrementa la grasa en abdomen y provoca enfermedades del corazón.

El glutamato de sodio presente en comidas saladas como papas fritas, puede provocar taquicardias, dolor de cabeza y dolor de pecho. Colorantes artificiales, en golosinas, galletas y postres; provocan alergias, congestión nasal, hiperactividad y trastornos de atención. El benzoato de sodio puede provocar alergias, ataques de asma y cáncer. La adecuada o inadecuada selección de las comidas es causa de buena o mala salud. Los alimentos naturales, preferentemente orgánicos, libres de fertilizantes, herbicidas y pesticidas, son más saludables y fortalecen el sistema inmunológico. Su consumo no origina efectos secundarios por la ausencia de tóxicos. Son más amigables y sustentables con el medio, respetan y protegen a la Madre Tierra. Su producción y consumo es ejemplo de vida digna. 


\section{Compuestos binarios}

Los compuestos binarios son aquellos que están formados por átomos de solo dos elementos. Son compuestos binarios, los óxidos, peróxidos, hidruros y las sales binarias.

Los óxidos que se forman por la combinación del oxígeno más un metal o no metal; según sea el caso, los óxidos serán básicos o ácidos respectivamente. Ejemplos: óxido de aluminio $\left(\mathrm{Al}_{2} \mathrm{O}_{3}\right)$, óxido de sodio $\left(\mathrm{Na}_{2} \mathrm{O}\right)$, óxido de calcio $(\mathrm{CaO})$, dióxido de carbono $\left(\mathrm{CO}_{2}\right)^{2}$. Los peróxidos son resultado de la combinación de oxígeno y no metal. Ejemplo: peróxido de hidrógeno o agua oxigenada $\left(\mathrm{H}_{2} \mathrm{O}_{2}\right)$, se utiliza como decolorante y desinfectante.

Los hidruros están formados por un elemento metal o no metal y el hidrógeno. El amoníaco $\left(\mathrm{NH}_{3}\right)$ es un hidruro volátil utilizado comúnmente en los productos de limpieza.

En la siguiente tabla se observan algunos ejemplos:

\begin{tabular}{|l|l|l|l|l|l|}
\hline \multicolumn{3}{|c|}{$\begin{array}{l}\text { Hidruros } \\
\text { Metal + hidrógeno }\end{array}$} & \multicolumn{3}{c|}{$\begin{array}{c}\text { Hidrácidos } \\
\text { No metal + hidrógeno }\end{array}$} \\
\hline Fórmula & \multicolumn{1}{|c|}{ Nombre } & \multicolumn{1}{c|}{ Utilidad } & \multicolumn{1}{c|}{ Fórmula } & Nombre & Utilidad \\
\hline $\mathrm{CaH}_{2}$ & $\begin{array}{l}\text { Hidruro } \\
\text { de calcio }\end{array}$ & $\begin{array}{l}\text { Como } \\
\text { deshidra- } \\
\text { tador }\end{array}$ & $\mathrm{NH}_{4}$ & Amonio & $\begin{array}{l}\text { Como } \\
\text { fertilizan- } \\
\text { te }\end{array}$ \\
\hline $\mathrm{NiH}_{2}$ & $\begin{array}{l}\text { Hidruro } \\
\text { de níquel }\end{array}$ & $\begin{array}{l}\text { Como } \\
\text { pila re- } \\
\text { cargable }\end{array}$ & $\mathrm{ClH}$ & $\begin{array}{l}\text { Ácido } \\
\text { clorhídri- } \\
\text { co }\end{array}$ & $\begin{array}{l}\text { Limpiar } \\
\text { baños }\end{array}$ \\
\hline $\mathrm{LiH}$ & $\begin{array}{l}\text { Hidruro } \\
\text { de litio }\end{array}$ & $\begin{array}{l}\text { Con agua } \\
\text { hace } \\
\text { funcionar } \\
\text { motores }\end{array}$ & $\mathrm{HF}$ & $\begin{array}{l}\text { Ácido } \\
\text { Fluorhí- } \\
\text { drico }\end{array}$ & $\begin{array}{l}\text { Prepara- } \\
\text { ción de } \\
\text { vidrio }\end{array}$ \\
\hline $\mathrm{NaH}$ & $\begin{array}{l}\text { Hidruro } \\
\text { de sodio }\end{array}$ & $\begin{array}{l}\text { Inflama- } \\
\text { ble }\end{array}$ & $\mathrm{BrH}$ & $\begin{array}{l}\text { Ácido } \\
\text { Bromhí- } \\
\text { drico }\end{array}$ & $\begin{array}{l}\text { Medica- } \\
\text { ción vete- } \\
\text { rinaria }\end{array}$ \\
\hline
\end{tabular}

Las sales binarias son la combinación de un metal + no metal. Ejemplo de ello es el cloruro de plata $(\mathrm{AgCl})$, útil para revelado impreso de fotografías. Otras sales binarias son el cloruro de sodio $(\mathrm{NaCl})$ o sal común, carburo de magnesio $\left(\mathrm{Mg}_{2} \mathrm{C}\right)$ y sulfuro de plomo $\left(\mathrm{PbS}_{2}\right)$.

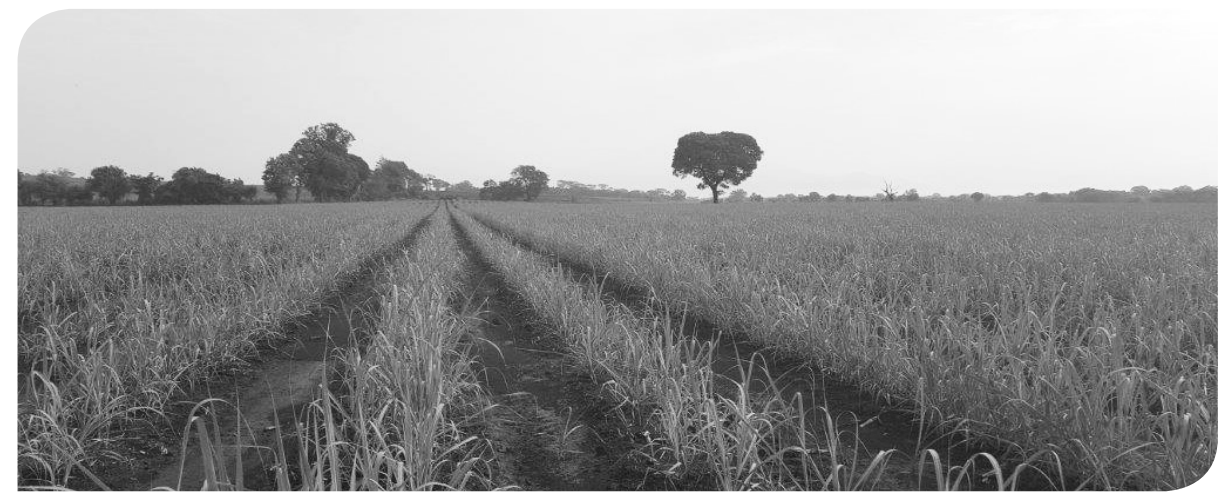

Plantación de caña de azúcar.
Clasificación de los compuestos binarios

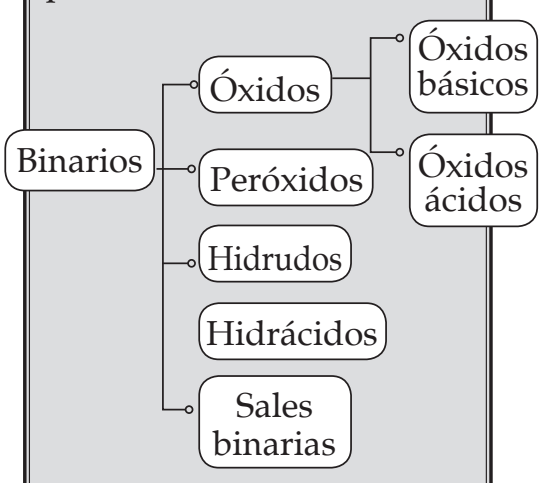

La sal yodada, es cloruro de sodio, reforzado con yoduro potásico que tiene como finalidad prevenir el déficit de yodo en la población. De esta forma se pretende evitar trastornos como pérdida del coeficiente intelectual, retraso mental, problemas tiroideos o bocio entre otros.

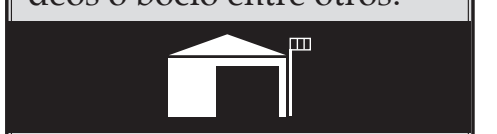

Incluimos en el catálogo la lista de productos químicos producidos en la comunidad o de sustancias químicas que se encuentran en nuestro entorno. Con apoyo de carteles, modelos tridimensionales o multimedia, representamos los niveles de energía atómica de algunos elementos y compuestos binarios más comunes.

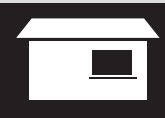

Determino el nombre para los siguientes óxidos básicos: $\mathrm{CuO}, \mathrm{Li}_{2} \mathrm{O}, \mathrm{FeO}$, $\mathrm{Fe}_{2} \mathrm{O}_{3}, \mathrm{BeO}, \mathrm{K}_{2} \mathrm{O}, \mathrm{PbO}_{2}$, $\mathrm{MgO}$. Observo en mi casa o en tiendas, los nombres de los compuestos químicos que contienen diferentes productos procesados. Los anoto en mi cuaderno. Comparto la información en clase. 


\section{Culfivos organicos y manejo integrado de plagas}

La deficiencia de vitamina A produce ceguera, la de zinc aumenta el riesgo de infecciones, problemas en la piel y retraso de crecimiento, la de hierro, anemia y la de yodo, problemas en la tiroides. La carencia se debe al bajo consumo de carne, pescado, productos lácteos $\mathrm{y}$ vegetales verdes. Para evitar esta deficiencia, en Guatemala se fortifica el azúcar con vitamina $A$, la sal con yodo y algunas harinas con hierro.

El Instituto de Ciencia y Tecnología Agrícolas ICTA- produce diversas semillas mejoradas, como el frijol ICTA Ligero, resistente a la sequía y a algunas plagas; el maíz ICTA Maya, con más proteína y el frijol ICTA Superchiva con más hierro y zinc. Su consumo disminuye la desnutrición.

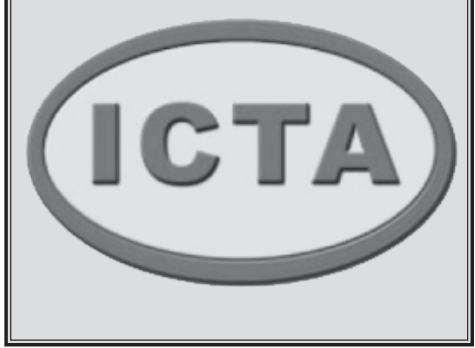

Actualmente, muchos agricultores se quejan de que sus tierras ya no producen como antes. Dicen que las tierras están cansadas y quemadas por los fertilizantes, herbicidas y plaguicidas químicos. Los productos químicos pueden ayudar a mejorar la producción agrícola, pero deben usarse con cuidado y adecuadas dosis, siguiendo las instrucciones del fabricante y los consejos del personal a cargo de los técnicos y técnicas agrícolas.

Las enfermedades de las plantas son iguales a las de las personas. Si tomamos más antibióticos de los necesarios, las bacterias se hacen resistentes y cada vez necesitaremos un antibiótico más fuerte. De manera similar, las plagas cada vez son más potentes.

Es importante mantener nuestros suelos sanos para que tengan "alimento" y estén bien nutridos. Solo así podremos tener buenas cosechas. Necesitamos:

- Cultivar en un mismo terreno variedad de plantas y especies (cultivo en asocio) y rotar los cultivos.

- Usar semillas de buena calidad y variedades adaptadas al clima, suelo y altura.

- Manejar de forma integrada plagas, enfermedades y malas hierbas.

- Usar eficientemente el agua.

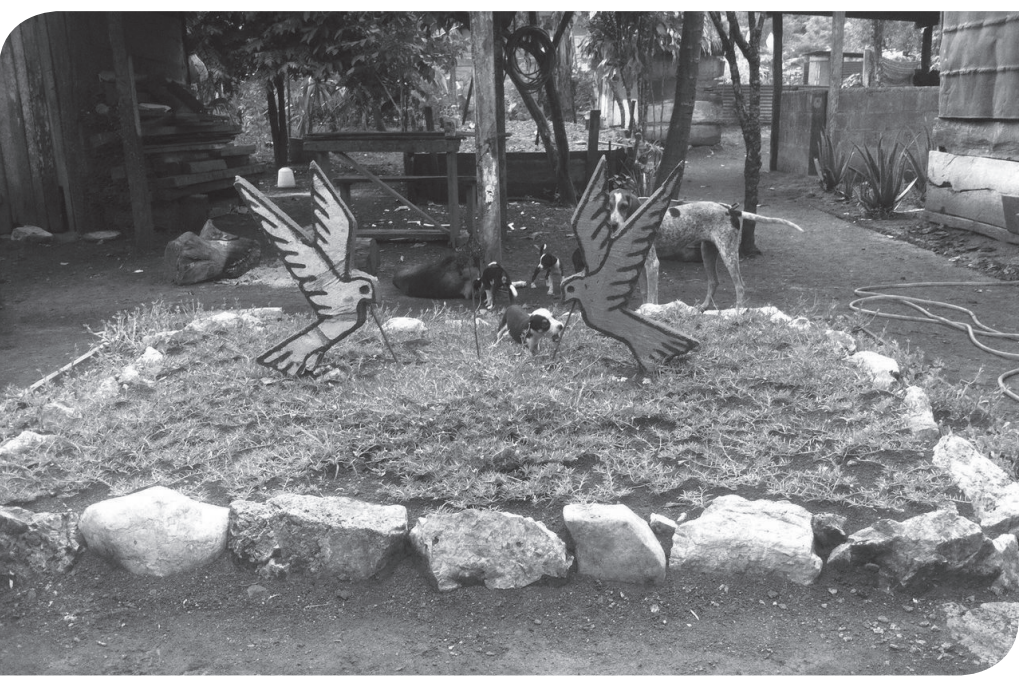

Visitemos un campo de cultivo de la comunidad. Damos preferencia a los sistemas de cultivo orgánico y sustentable. Observemos y hablemos con la persona responsable de la producción del cultivo, para conocer cuáles son sus prácticas agrícolas y qué medidas toma para proteger el suelo y las aguas. Averiguamos acerca de los métodos que utilizan para el control de plagas, qué tipo de fertilizantes usa y la calidad de las aguas para el riego. 


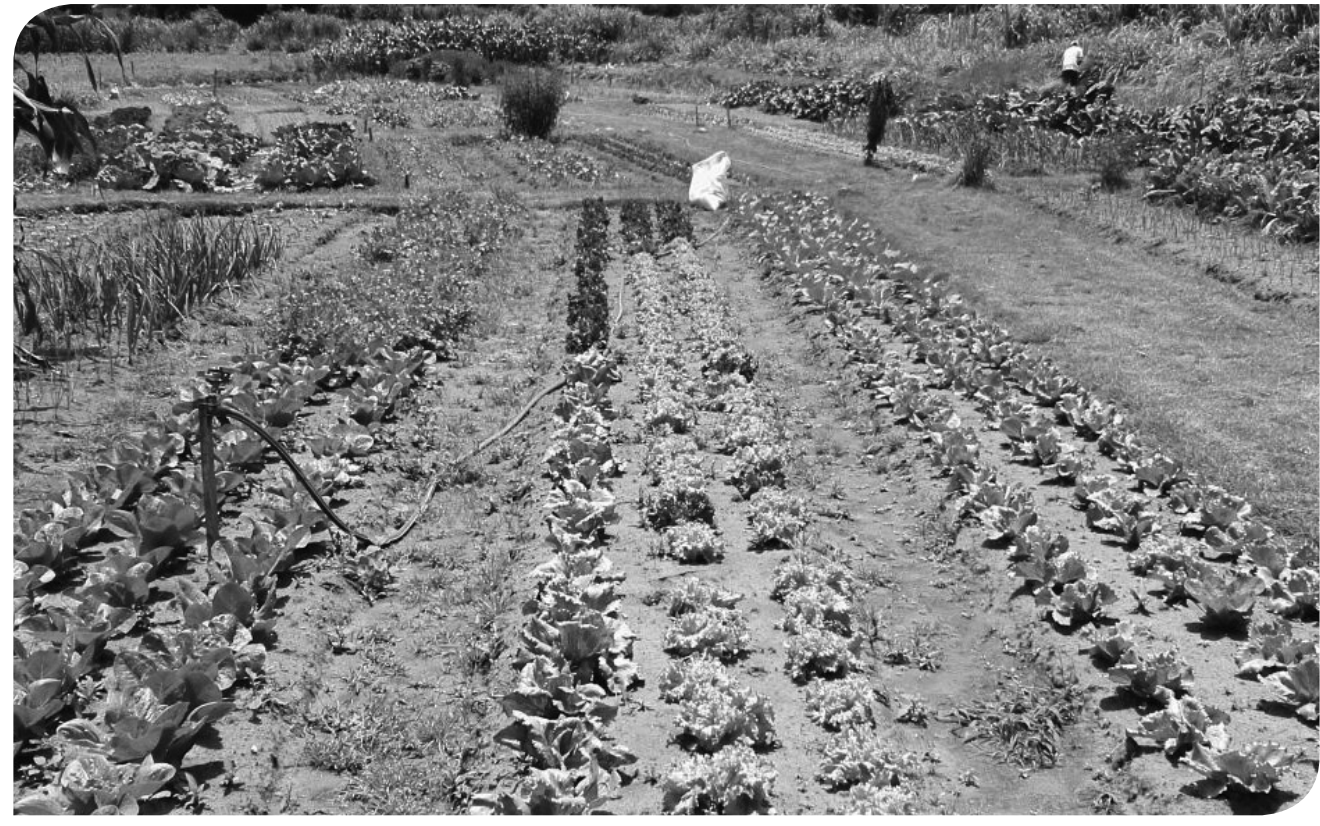

Muchas personas prefieren alimentos orgánicos, son producidos por pequeños agricultores con métodos no industriales y sin utilizar productos químicos industriales, como plaguicidas, herbicidas o fertilizantes. Un cultivo orgánico no se descuida, ni se deja al natural, si ningún tipo de control. Necesita cuidados especiales para producir cosechas sanas y fuertes.

Quienes practican la agricultura orgánica, producen su propio abono utilizando estiércol, humus de lombriz, vegetales en descomposición, restos de alimentos orgánicos, ceniza, entre otros. Cuidan los cultivos de plagas y enfermedades sin utilizar químicos. Los plaguicidas y los herbicidas matan sin distinción a los insectos y hierbas beneficiosas. El uso de herbicidas químicos provoca que muchas plantas comestibles, no retoñen en forma natural y su rendimiento sea menor. Los plaguicidas naturales, como hongos $u$ otros insectos, evitan que las plagas depositen sus huevos en las plantas, utiliza repelentes, hacen resbalosa la superficie donde se asientan, se alimentan de la plaga, la parasitan o la contagian de alguna enfermedad.

La agricultura orgánica ayuda a proteger los suelos, evita la contaminación del agua, no utiliza elementos industriales por lo que ayuda a disminuir la contaminación del aire y a proteger la capa de ozono. Conserva la biodiversidad utilizando variedad de semillas criollas y mejoradas. Rescata conocimientos tradicionales y, sobre todo, ofrece salud y bienestar.

Un medio eficaz de agricultura sustentable, son los bancos de semillas comunitarios. Estos se organizan para guardar en bodegas especiales las mejores semillas de la comunidad. Ayudan a conservar la biodiversidad y aseguran la soberanía alimentaria. Facilitan el acceso de semillas para los cultivos de los miembros de la comunidad. Suministran semillas de emergencia, si se han perdido sus cosechas, ya sea por sequía, inundaciones u otras causas. Evitan que incurran en gastos cada año para comprar nueva semilla.
Quien tiene experiencia en la agricultura, selecciona las mejores semillas de sus cultivos. Almacena convenientemente la semilla seleccionada para sembrarla en la siguiente época de cosecha. Así prevé la mejor calidad de sus cultivos. Las semillas criollas y naturales, necesitan muchos cuidados, pues no son resistentes a plagas, ni a la sequía. Al cosechar la planta, su sabor es más agradable que los cultivados en la agricultura intensiva.

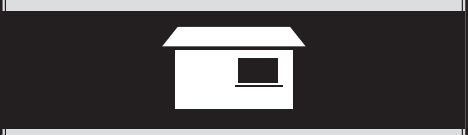

Entrevistamos a las abuelas y abuelos acerca de los métodos de cultivo, abonos y plaguicidas tradicionales. Les pedimos ejemplos de cultivos orgánicos y agricultura en armonía con la Madre Tierra. Averiguamos si en la comunidad existe un banco comunitario de semillas y lo incluimos en el catálogo. Si no existe, incluimos en el catálogo, la propuesta a la comunidad.

Escribo un correo electrónico a personas que conozco que podrían interesarse en los cultivos orgánicos de mi comunidad para contarles lo que he investigado. 


\section{Formas de producción}

Una forma de producción es la manera en que se combinan aspectos económicos, tecnológicos y culturales para satisfacer las necesidades de bienes y servicios. Analicemos el siguiente cuadro comparativo.

\begin{tabular}{|l|l|l|l|}
\hline Forma de producción & \multicolumn{1}{|c|}{ Aspectos económicos } & \multicolumn{1}{|c|}{ Aspectos tecnológicos } & \multicolumn{1}{|c|}{ Aspectos culturales } \\
\hline Artesanal & $\begin{array}{l}\text { Pequeñas propiedades } \\
\text { familiares, poca contra- } \\
\text { tación de mano de obra } \\
\text { y las personas participan } \\
\text { en todo el proceso pro- } \\
\text { ductivo. }\end{array}$ & $\begin{array}{l}\text { La materia prima tiene } \\
\text { poca transformación in- } \\
\text { dustrial, las herramientas } \\
\text { son simples y la principal } \\
\text { energía que se emplea, es } \\
\text { la humana. }\end{array}$ & $\begin{array}{l}\text { El aumento de la pro- } \\
\text { ducción y el consumo es } \\
\text { limitado y el impacto al } \\
\text { ambiente natural es bajo. }\end{array}$ \\
\hline De gran escala & $\begin{array}{l}\text { Grandes propiedades de } \\
\text { sociedades o consorcios, } \\
\text { mucha contratación de } \\
\text { personal y las personas } \\
\text { se reparten las tareas del } \\
\text { proceso productivo. }\end{array}$ & $\begin{array}{l}\text { Materia prima industrial, } \\
\text { maquinaria sofisticada, } \\
\text { muchos procesos es- } \\
\text { tán automatizados y se } \\
\text { emplea energía eléctrica, } \\
\text { solar, eólica, atómica, } \\
\text { etc. }\end{array}$ & $\begin{array}{l}\text { Persigue el aumento in- } \\
\text { cesante de la producción } \\
\text { y consumo y, cuando no } \\
\text { respeta los derechos de } \\
\text { la Madre Tierra deteriora } \\
\text { el ambiente natural. }\end{array}$ \\
\hline
\end{tabular}

Entre la producción artesanal y la de gran escala está la producción de mediana escala. Nos reunimos en equipo y establecemos las características de la producción de mediana escala.

No importa la forma de producción, siempre se puede encontrar una manera de hacerla sustentable. Para lograrlo, se requiere apreciar la Naturaleza, pensar en las generaciones futuras y destinar esfuerzos por desarrollar tecnología que sea amigable con la Naturaleza.

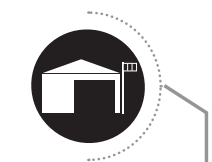

Con nuestro grupo, elaboramos una presentación de las formas de producción que se observan en la comunidad.

- Generamos ideas de cómo se pueden transformar en formas sustentables de producción.

- Incluimos en el catálogo las conclusiones y propuestas del grupo.

Si una persona dedicada a la agricultura trabaja artesanalmente, pero derriba árboles, emplea abono inorgánico, emplea semillas transgénicas y los desechos los vierte en un río, ¿está aportando al desarrollo humano y el desarrollo sustentable de su comunidad? ¿Qué puede hacer una empresa con producción a escala para ser sustentable?

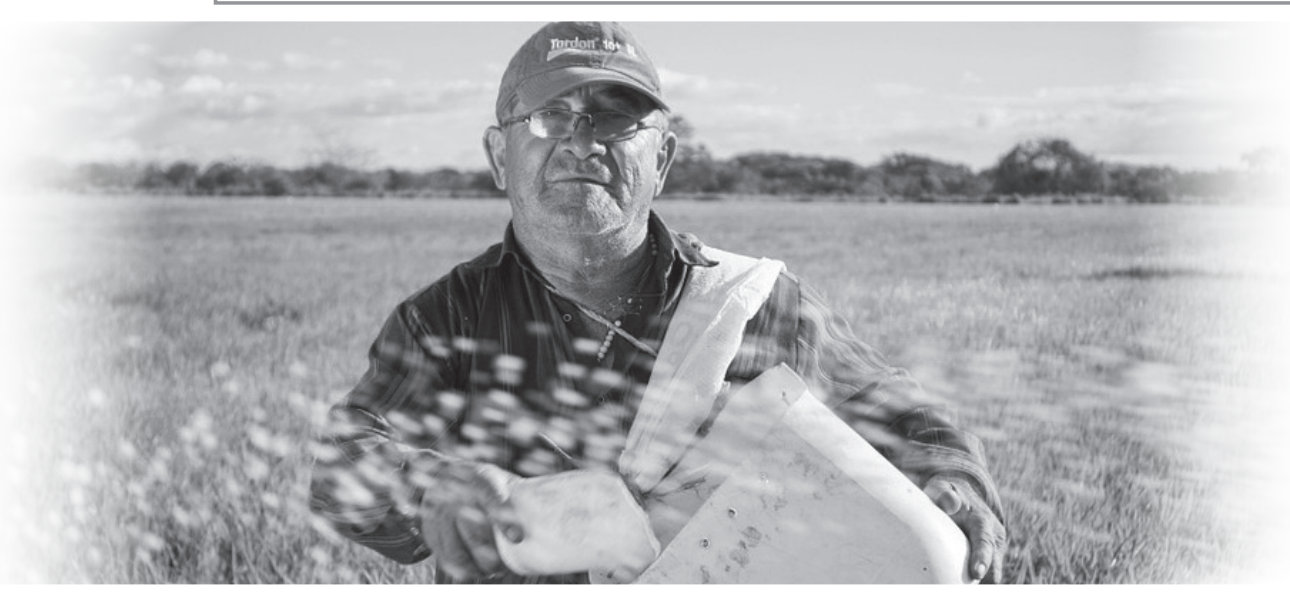

124....... Semana 10

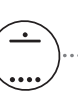




\section{Niveles socioeconómicos de la población}

Existen varias formas para establecer si una familia vive o no en pobreza, pero por lo general se tiene en cuenta el ingreso familiar. Cuando un grupo familiar recibe cada mes menos del costo de la canasta básica vital se considera que vive en pobreza, pues apenas alcanza a cubrir el costo de lo que necesitan para vivir dignamente: alimentos, vestuario, salud, vivienda, educación entre otros bienes y servicios esenciales. Si la familia recibe ingresos mínimos se considera que vive en pobreza extrema. Las familias guatemaltecas que tienen un ingreso superior al costo de canasta básica vital se considera que no viven en pobreza. En Guatemala, como resultado de la desigualdad, 6 de cada 10 personas viven en condiciones de pobreza. Pero no somos un país pobre, la mitad de la riqueza de todo el país está concentrada en el $20 \%$ de la población total.

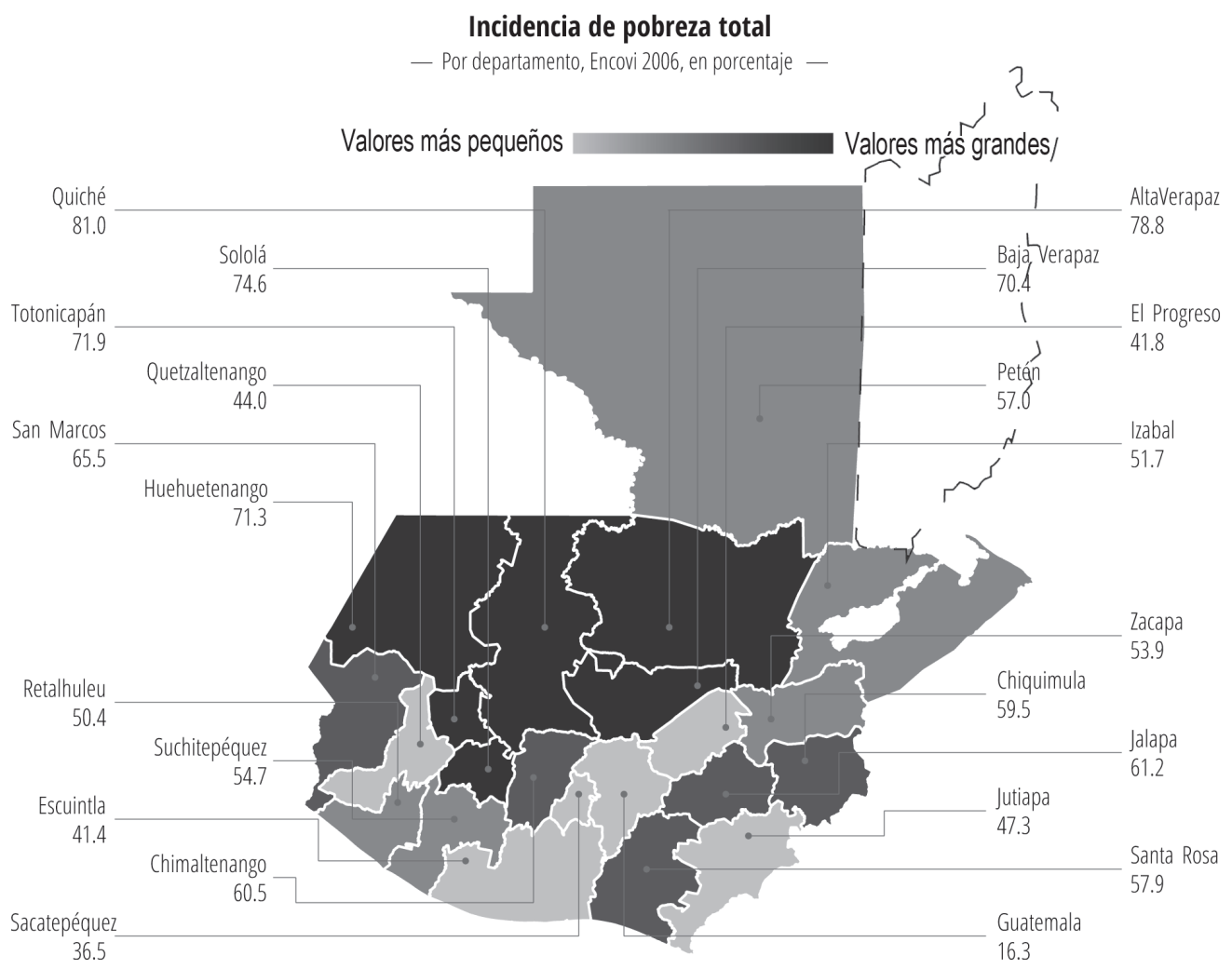

Foto: ENCOVI 2014 INE Guatemala

Fuente: Instituto Nacional de Estadística

Respondemos en equipo, de acuerdo con la información anterior:

- ¿En qué departamentos viven más familias que se encuentra en condiciones de pobreza?

- ¿Qué porcentaje de la población vive en pobreza en tu departamento?

- ¿Qué dificultades confrontan las personas que viven en pobre$\mathrm{za}$ ?

- Si se desea mejorar el desarrollo humano, ¿los servicios esenciales deben ser públicos o privados?, ¿por qué?

- ¿Qué relación tiene la desigualdad con el cuidado del medio ambiente? Razonamos nuestra respuesta.

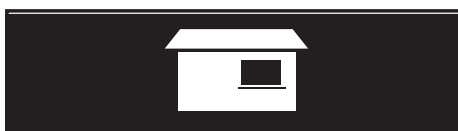

Selecciono la información que emplearía para escribir un informe acerca de la producción y el desarrollo humano en la comunidad. Para ello, puedo seguir las pautas:

- Estimo la cantidad de integrantes de mi comunidad que son clasificados como extremadamente pobres, pobres y no pobres.

- Argumento cómo repercuten los ingresos en el desarrollo humano de mi comunidad.

- Describo de qué forma los principales procesos productivos de la comunidad se relacionan con el nivel de pobreza. Incluimos en el catálogo la información obtenida. Hacemos una propuesta para elevar el IDH de cada familia mediante la promoción y mejora de los productos y servicios de la comunidad.

"Según un estudio presentado por la Comisión Económica para América Latina y el Caribe (CEPAL), en países como Brasil, Chile, Honduras, Paraguay y Guatemala, el 10\% de los hogares más ricos, en promedio, concentran el $40 \%$ de los ingresos totales de esas naciones."

http: / / w w w .estrategiaynegocios.net/ i n i cio/ $824984-330 /$ cepal-hogares-ricos-concentran-40-de-riqueza

- ¿Qué repercusiones tiene la desigualdad de ingresos para la niñez y la juventud? 


\section{Mejoremos nuestra capacidad de expresión}

\section{Fenómenos semánticos}

Son los cambios de significado que sufren las palabras, de acuerdo con las circunstancias en que se usen. Veamos algunos:

Sinónimos: representan una idea similar a la palabra original: alfabeto y abecedario.

Antónimos: indican la idea contraria a la palabra original: seco y mojado.

Parónimos: tienen pronunciación y escritura parecida: actitud y aptitud.

Homónimos: tienen igual pronunciación, pero distinto significado y origen. Pueden ser:

Homófonos: de pronunciación igual y escritura parecida, pero con diferente significado: cien y sien, haya y halla, tú y tu.

Homógrafos: se escriben y se pronuncian igual, pero su significado depende de las circunstancias en las que se utilicen: río (de reír) y río (de agua), traje (de traer) y traje (de vestir).

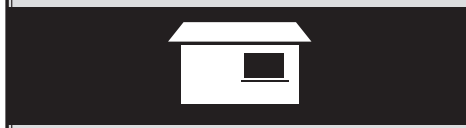

Con ayuda del diccionario: encontremos los sinónimos y los antónimos de las siguientes palabras: taciturna, sabia, emoción, alegría, niño. Luego, encontremos los significados de los parónimos: ratificar y rectificar, sinónimo y seudónimo, actitud y aptitud. Por último, busquemos los significados de estos homónimos: haz, has y as; cima y sima; honda y onda; azar y asar; dé y de; sé y se.
La argumentación consiste en el ejercicio de exponer las ideas propias con el fin de convencer a otras personas. Puede realizarse de manera oral o escrita y debe tener un orden lógico. Esto significa presentar nuestras ideas principales en primer lugar y luego apoyarlas con nuestras ideas secundarias y/o ejemplos.

Ya hemos visto cómo se estructuran los párrafos. Sin embargo, un escrito puede mejorar por medio de los marcadores textuales: frases acuñadas para relacionar párrafos entre sí. Los hay de dos clases:

1. Los que relacionan párrafos, apartados o grupos de oraciones. Enlazan fragmentos relativamente extensos de un texto y establecen el orden y las relaciones de significado entre los bloques que conectan o enlazan: Este texto trata de..., En otras palabras..., Finalmente..., En resumen..., etc.

2. Los que estructuran las ideas al interior de una oración: ....aunque,... ... de modo que, ... .... antes bien, ... sin embargo, ... pero,... Estos conectan dos ideas entre sí en el interior de una oración o de un párrafo.

Los más usuales son: para terminar..., por otro lado..., por ejemplo..., en consecuencia..., de cualquier modo..., asimismo..., entre tanto..., en resumen..., no obstante..., por consiguiente..., por otra parte..., en efecto..., en conclusión..., sin embargo..., a pesar de lo anterior...

Leamos diferentes textos de las páginas de opinión de un periódico. Luego, subrayemos los marcadores textuales que encontremos y analicemos la importancia que tienen en el momento de argumentar, por escrito $u$ oralmente.

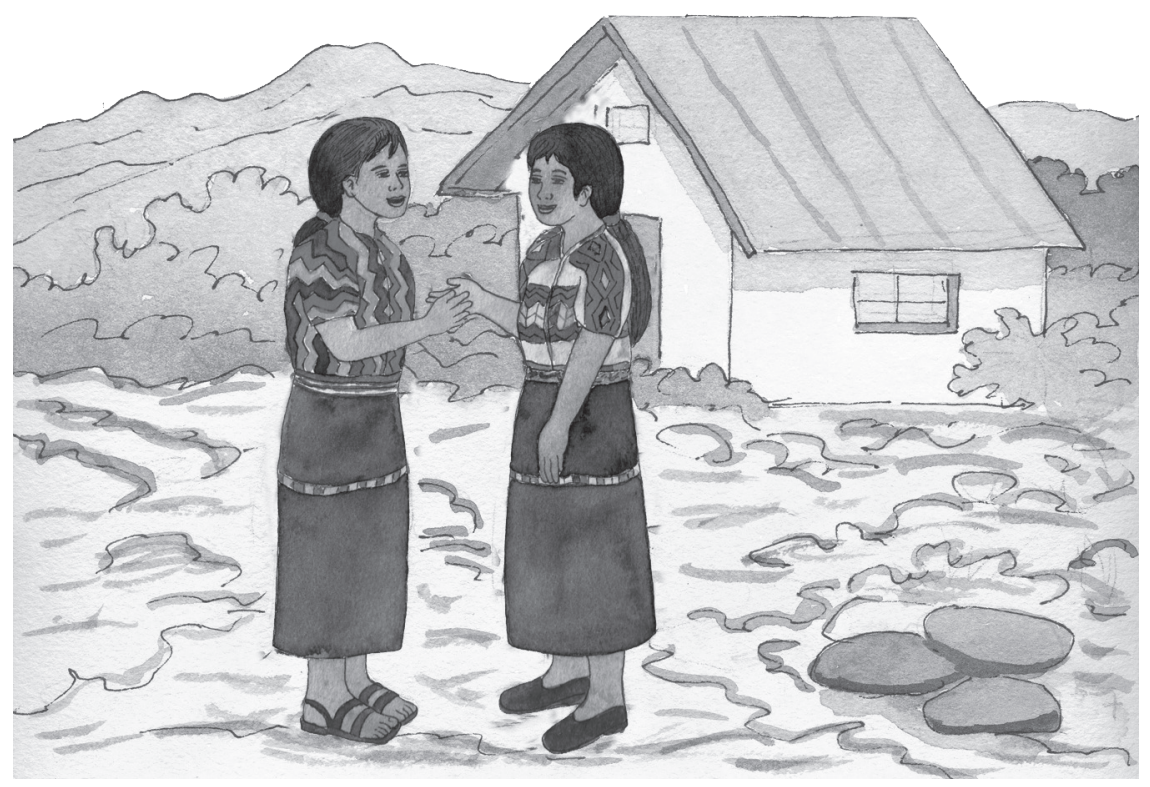




\section{El poema}

Emoción, sentimiento o deseo: el mundo interior del o de la poeta se vuelca en su creación. En la poesía domina el subjetivismo de quien escribe, o sea, que él o de ella se refiere a personas, objetos o hechos con una visión muy personal. Cualquier hecho de la vida diaria puede convertirse en un poema si se traslada a un lenguaje literario.

En un principio, la poesía se acompañaba con música de lira y, por ello, es que aún se conoce la poesía como el género lírico. Es una forma literaria que se caracteriza por estar escrita en versos y estar distribuida por estrofas. El verso es cada una de las líneas del poema y la unión de varios versos hacen una estrofa.

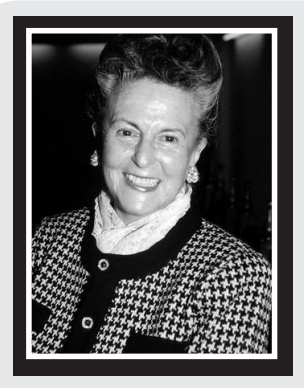

Te he buscado

en la entraña de tu nombre

Guatemala.

He buscado

tu génesis

y tus dioses de maíz

$\mathrm{y}$ de vegetales alientos.

$$
\begin{array}{r}
\text { Margarita Carrera } \\
\text { (guatemalteca) }
\end{array}
$$

Fuente: http://guatemalainmortal.blogspot.com/2013/05/margarita-carrera.html

$$
\begin{aligned}
& \text { La lección del árbol } \\
& \text { Al manantial que brota, da su sombra; } \\
& \text { al cansado viajero, da su alfombra; } \\
& \text { su fruto, al paladar, que dulcifica; } \\
& \text { su ramaje frondoso, al blando nido; } \\
& \text { y cuando en su vejez, cae vencido, } \\
& \text { se da en leño: ¡Y así se glorifica! } \\
& \text { Gerardo Díaz } \\
& \text { (guatemalteco) }
\end{aligned}
$$

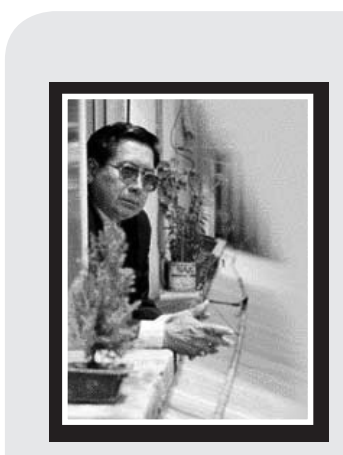

\section{Adiós al día}

A lomo de loma

se está yendo el sol,

mientras lo despido

con un girasol.

$\mathrm{Y}$ a lomo de mulo

--do re mi fa sol--,

vuelvo a casa envuelto

por el arrebol.

$$
\begin{array}{r}
\text { Francisco Morales Santos } \\
\text { (guatemalteco) }
\end{array}
$$

Fuente: https://sammymilan.wordpress.com/biografia/

Uso mi imaginación y escribo un poema que tenga seis versos. Utilizo de inspiración los siguientes versos iniciales:

Una niña brilla como el sol

Un niño ilumina con su luz

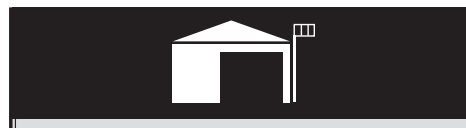

Redactemos un texto sobre los temas siguientes y usemos un párrafo para cada uno de ellos. Utilicemos los marcadores textuales para apoyar nuestra argumentación:

1. Describamos qué es la seguridad alimentaria.

2. Describamos en qué consiste la producción y el consumo de productos orgánicos.

3. Analicemos la razón por la cual es más beneficioso para la salud consumir estos productos.

4. Razonemos por qué la comida chatarra y los productos preparados con sustancias perjudiciales no son saludables.

5. Redactemos una conclusión sobre nuestras ideas.

Leemos al grupo nuestras propuestas y debatimos para encontrar puntos de vista comunes y diferentes.

Revisamos la redacción y ortografía del catálogo.

Elaboramos en el idioma de la comunidad, la convocatoria para la presentación del catálogo.

Ensayamos la presentación oral del catálogo. 


\section{Ley de cosenos}

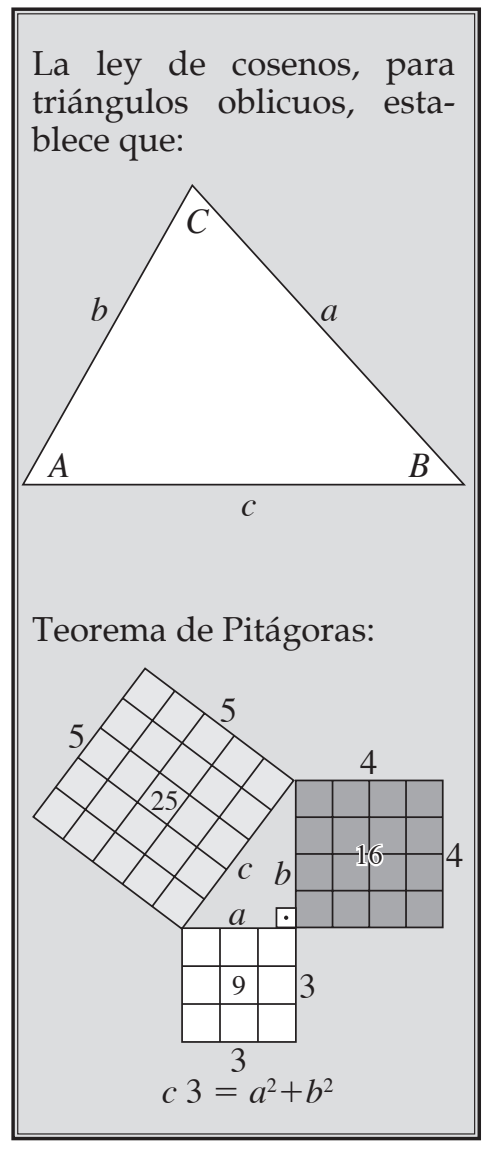

Utilizamos regla y transportador para dibujar la siguiente situación:

- Se necesita terminar de cercar un gallinero de forma triangular. Se sabe que uno de sus lados mide $11 \mathrm{~m}$ y el otro mide $5 \mathrm{~m}$. También se conoce que el ángulo que forman ambos lados es de $20^{\circ}$.

Si dibujamos a una escala apropiada, ¿Cuál es la longitud aproximada del lado que falta? ¿Cuáles son las medidas de los ángulos restantes? Comparamos y discutimos respuestas.

¿Qué tipo de triángulo, según sus lados y ángulos, dibujamos? ¿Todos los triángulos que se dibujaron son iguales? ¿Puedo utilizar también razones trigonométricas o ley de senos para hallar el lado que falta? ¿Por qué? Compartimos nuestras respuestas y escribimos una conclusión al respecto.

Investigamos sobre el teorema de Pitágoras. Podemos utilizar el recurso de Khan Academy ya utilizado. Anotamos en nuestro cuaderno cómo y cuándo utilizarlo y buscamos algunos ejemplos de su aplicación. Comentamos y discutimos: ¿Existe alguna relación entre el teorema de Pitágoras y lo que expresa la ley de cosenos?

El teorema de Pitágoras es útil para determinar la medida de uno de los lados de un triángulo rectángulo. Para ello, deben conocerse los valores de los otros dos. Ya sabemos que el lado opuesto al ángulo recto o que está enfrente del ángulo recto, se denomina hipotenusa. Los lados que forman el ángulo recto, son los catetos. El teorema de Pitágoras, explica que: en todo triángulo rectángulo, el cuadrado que se forma sobre la hipotenusa es igual a la suma de los cuadrados de los catetos.

La ley de los cosenos establece que el cuadrado de un lado de un triángulo oblicuo es igual a la suma de los cuadrados de los otros dos, menos el doble de su producto, multiplicado por el coseno del ángulo conocido.

Al operar la ley de cosenos, debemos tomar en cuenta el principio de jerarquía operacional: realizar primero las operaciones con potencias, luego obtener productos y cocientes $y$, finalmente, sumas $\mathrm{y}$ restas.

Un conductor de camioneta viaja hacia el este, en línea recta, 10 $\mathrm{km}$. De pronto se da cuenta que ha olvidado una encomienda y decide regresar por otro camino; gira $45^{\circ}$ y recorre $6 \mathrm{~km}$, vuelve a girar en dirección al punto de partida y recorre una distancia desconocida $\mathrm{x}$. Las y los pasajeros le reclaman al conductor pues consideran que han recorrido mayor distancia al regresar. El conductor les afirma que no. ¿Quién tiene razón? Explico.

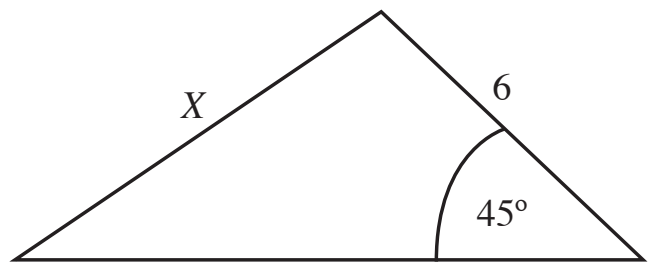

10

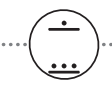


Utilizamos una calculadora científica o la tabla de razones trigonométricas y aplicamos la ley de cosenos para verificar la longitud del lado que hace falta al gallinero. ¿Cuánto alambre se necesitará para cercar todo el gallinero? Comparamos y discutimos respuestas. ¿Hubo alguna dificultad al realizar este cálculo? ¿Qué diferencia existe al encontrar longitudes de triángulos y al encontrar ángulos?

Encontramos la longitud de los lados y la medida de los ángulos desconocidos:

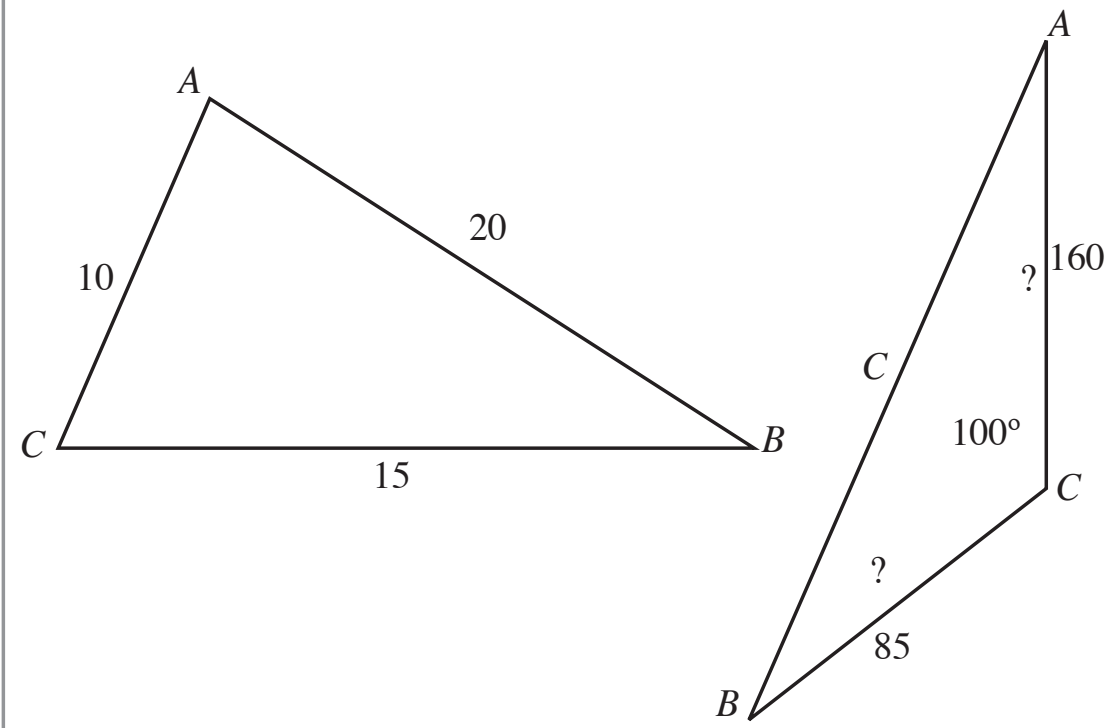

Contestamos y discutimos:

- ¿En qué otras situaciones cotidianas nos es útil la ley de cosenos?

- ¿Qué problemas puede traer un mal cálculo de la longitud o de algún ángulo en una superficie?

- ¿Por qué es importante tener cuidado y exactitud al momento de medir o de realizar cálculos geométricos?

Resuelvo:

Utilizando la ley de cosenos hallamos los valores de los ángulos internos de los siguientes triángulos $\mathrm{ABC}$ :
1) $a=2.2 \mathrm{~m}$
$b=4.1 \mathrm{~m} \quad c=2.4 \mathrm{~m}$
2) $a=22 \mathrm{~cm}$
$b=22 \mathrm{~cm}$
$c=35 \mathrm{~cm}$
3) $a=4 \mathrm{~km}$
$b=6 \mathrm{~km}$
$c=7 \mathrm{~km}$

Utilizando la ley de cosenos hallamos las medidas de los ángulos y de los lados desconocidos en los siguientes triángulos $\mathrm{ABC}$ :
1) $m<B=115^{\circ}$
$a=24 m$
$c=32 m$
2) $m<A=133^{\circ}$
$b=12 \mathrm{~cm}$
$c=15 \mathrm{~cm}$
3) $m<C=135^{\circ}$
$a=6 \mathrm{~km}$
$b=7 \mathrm{~km}$

Para encontrar los valores de las razones trigonométricas en la calculadora utilizamos las teclas: sin, cos y tan. Si deseamos hallar el valor de un ángulo utilizamos la función inversa presionando la tecla shift.

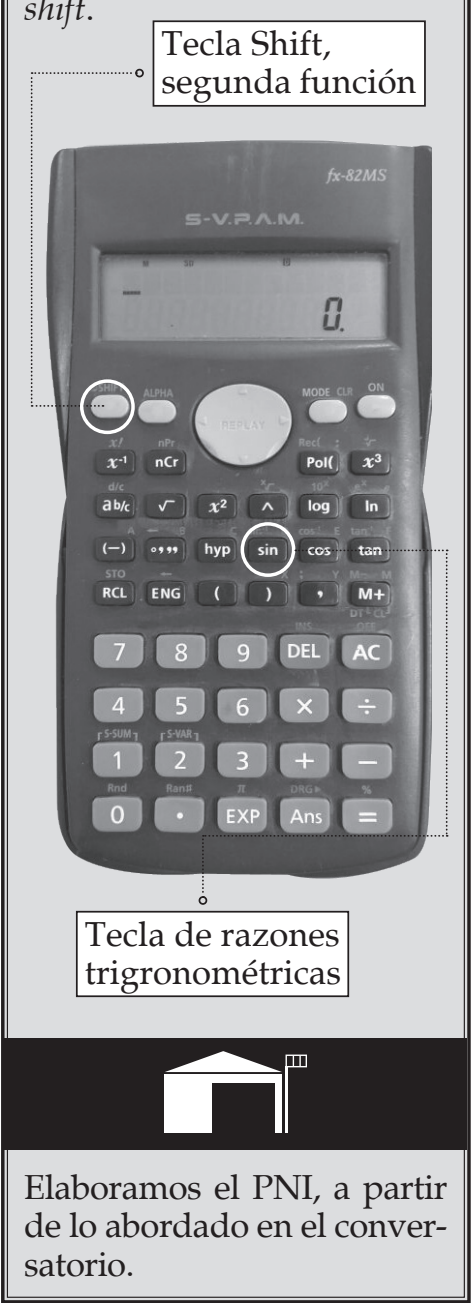

\section{satorio.}




\section{Ideas y frases musicales}

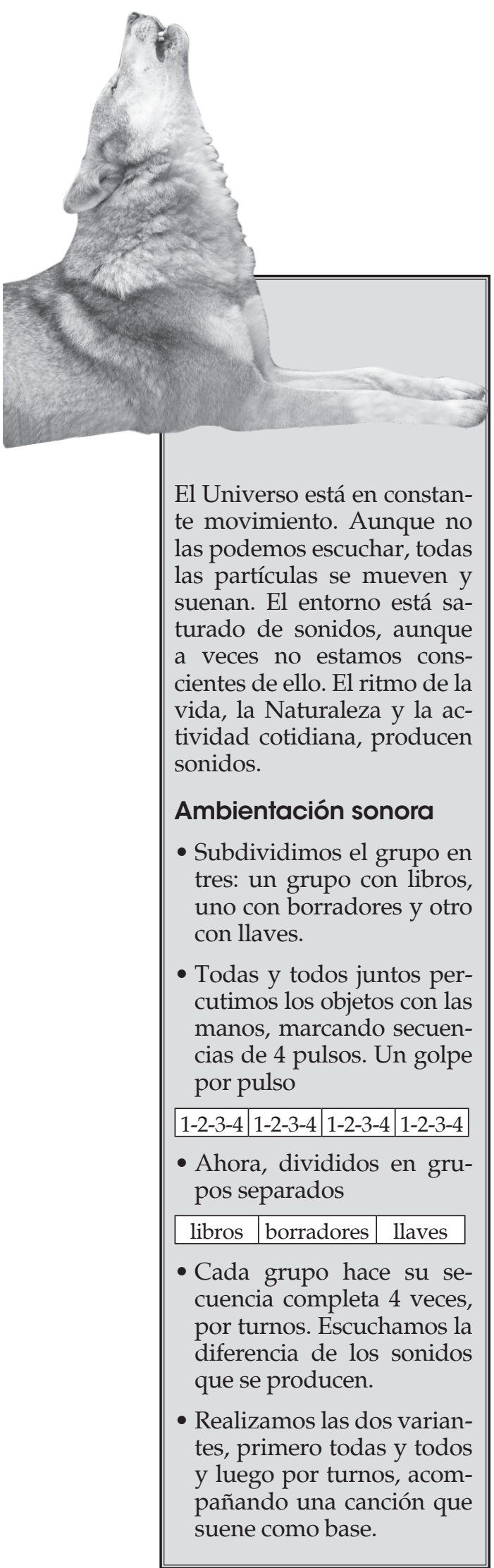

En grupos, respondemos las siguientes interrogantes:

- ¿Por qué la música tiene un ritmo ordenado y coherente?

- ¿Cómo se forman las ideas musicales?

- ¿Por qué se dice que la música es un lenguaje que permite la comunicación con sonidos?

Las palabras clave para responder estas preguntas son:

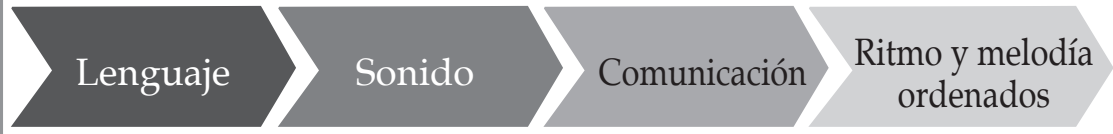

Esto quiere decir que el ritmo y la melodía de la música realizan un proceso que nos permite comunicarnos con sonidos, por eso la música es un lenguaje.

\section{Procesos de expresión musical}

La música es un lenguaje que utiliza los sonidos para expresar ideas, sentimientos y estados de ánimo. Así como nos expresamos por medio de palabras formando frases y oraciones, con la música nos expresamos formando motivos y frases musicales. Esto quiere decir que nos comunicamos hablando, cantando o tocando instrumentos.

Observa el siguiente esquema:

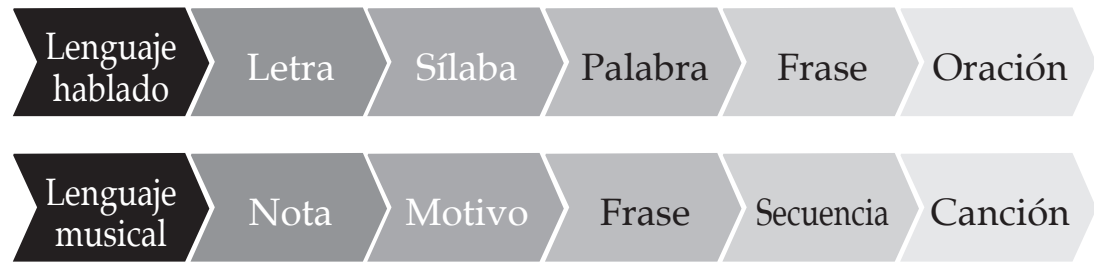

Cuando nos comunicamos hablando, producimos sonidos. Al pronunciar el sonido de cada letra, nos damos cuenta que el habla es musical porque usa los sonidos que produce nuestro aparato fonador. Luego, con los sonidos de cada letra formamos palabras. Con las palabras formamos frases y con ellas construimos ideas completas, o sea, oraciones.

Al cantar o tocar un sonido se consigue una nota o un pulso. La unión de notas forma motivos, los motivos forman frases. Las frases forman secuencias y estas completan una pieza, que puede ser una canción. 


\section{Sonidos y Vida en armonía}

La música es el resultado de un ordenamiento con que se producen los sonidos. Este orden abarca a las tres dimensiones de la música:

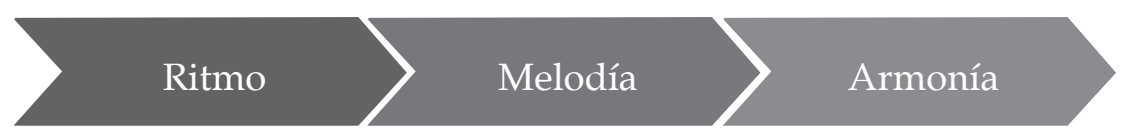

Con ese ordenamiento se pueden estructurar las frases y secuencias musicales. En encuentros anteriores realizamos secuencias rítmicas de 4 pulsos, también se puede hacer en orden de 2 o 3 pulsos. Este orden no solo es parte de la música sino de todas las expresiones artísticas. En esa sintonía, es importante que quienes participan de la música lleguen a acuerdos para que las frases que se tocan sean coherentes. Al coordinar la producción de los sonidos se logra una armonía musical que se escucha en los resultados sonoros. Para hacer mejor los ritmos grupales, aprendamos acerca del compás en la música.

\section{El compás de 4/4}

Podemos tocar, leer y escribir ritmos. En clase hemos percutido y acompañado canciones con palmadas, hemos sentido el ritmo. Ahora aprendamos a leerlo y escribirlo.

El compás de 4/4 significa que hay que leer 4 figuras negras $\downarrow$ por cada compás. También existe el compás de 3/4 y el de 2/4.

El silencio $\{$ también es importante y se debe hacer una pausa cuando aparece, pero se debe seguir contando los tiempos.

Ejemplo de escritura rítmica en 4/4: cada compás está dividido por una barra I. Es la línea vertical que divide los compases, cada cuatro figuras negras II.

Al final la doble $\mid$ barra indica el final de un fragmento rítmico o musical. Practiquemos esta lectura diciendo la sílaba ta, cada vez que aparece una figura negra, ya que valen un tiempo cada una:

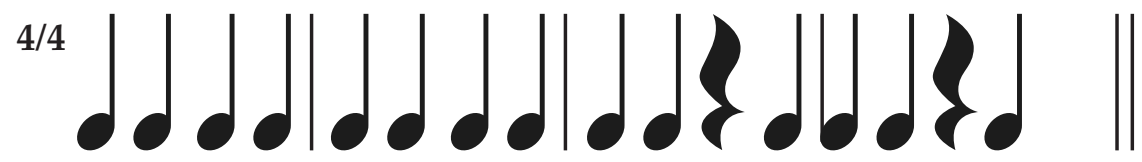

$\begin{array}{llllllll}1 & 2 & 3 & 4 & 1 & 2 & 3 & 4\end{array}$

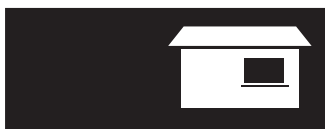

Realizo la lectura de 4 compases en $4 / 4$ con negras y silencios, usando objetos de mi casa: ollas, sartenes, cucharas, tenedores, paletas, etc.

Escribo una secuencia de 4 compases usando solo 3 negras y/o silencios.

Escribo una secuencia de 4 compases usando solo 2 negras y silencios.

Practico tocar las secuencias que escribí y las comparto con mi clase.

Corregimos el diseño e imágenes del catálogo según observaciones dadas, inserto más fotografías y otros recursos si mi catálogo es digital.

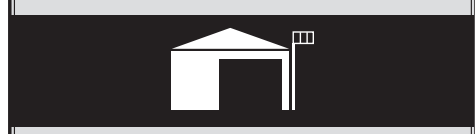

Elegimos una canción popular guatemalteca en la que estén presentes cuatro compases y la interpretamos en coro a la comunidad educativa.

Aprovechamos a presentar también las escenas de teatro preparadas en el encuentro anterior.

Antes y después de cada acto podemos acompañar con producción musical siguiendo secuencias de 4 compases usando solo 3 negras y/o silencios. 


\section{Símbolos y estructura de Lewis. Enlace iónico y covalente}

Los grupos son familias de elementos que tienen características en común.

Los períodos representan los niveles energéticos que tiene un átomo. Así, como el hierro $(\mathrm{Fe})$ tiene cuatro niveles energéticos, pertenece por lo tanto al cuarto período.

Los bloques indican el orbital o nivel de energía que están ocupando los electrones más externos.

El número atómico indica el número de electrones que posee un elemento.

El número de oxidación es el número de electrones que un átomo ha ganado, perdido o compartido cuando forma un compuesto. Puede ser positivo y negativo.

El número de electrones que permite cada nivel de energía son:

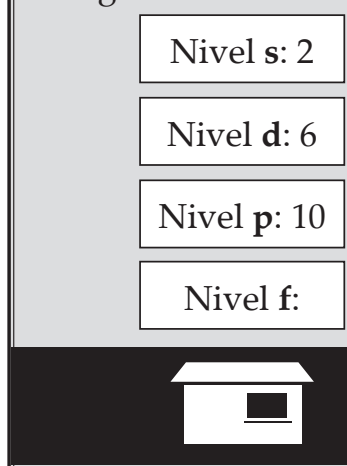

En la tabla periódica busco el símbolo de diez elementos simples que me indique mi tutura o tutor.

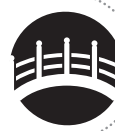

Observamos la tabla periódica y descubrimos información de los elementos químicos.

Consultamos con la tabla periódica y anotamos en el cuaderno, el nombre, el número atómico y el número de oxidación de los elementos: N, B, F, Mg, Al, P, Cl, Cr, Zn, Br, La, Au, Y, Hg, Pb, Fr.

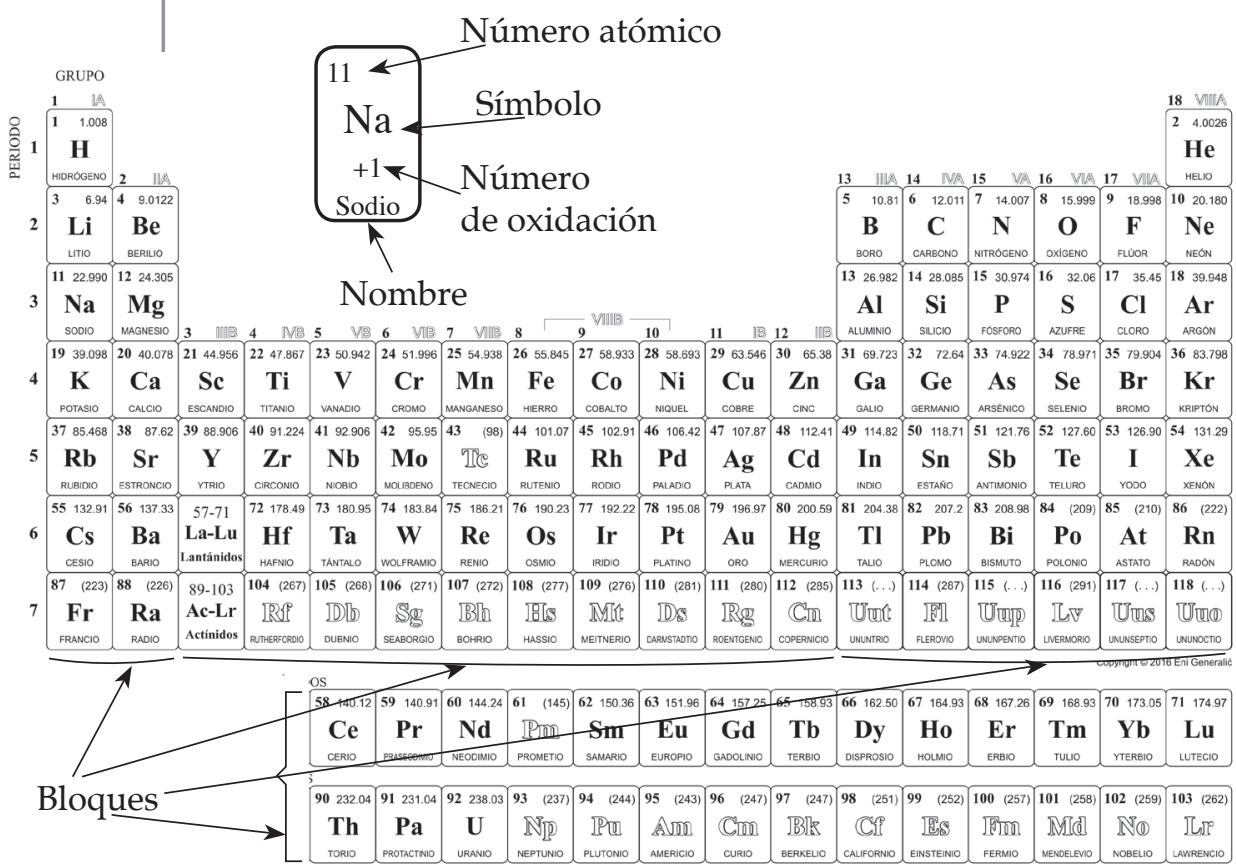

Tomado de: http://www.periodni.com/gallery/tabla_periodica-negro.png

Regla del octeto. Los átomos tienden a tener ocho electrones en su nivel de energía más externo. La excepción es el hidrógeno que completa con 2 electrones, lo cual proporciona la misma configuración electrónica que la del helio.

Enlace químico. Ocurre cuando dos átomos se unen para formar un compuesto.

Con la estructura de Lewis se representa gráficamente los electrones de enlaces entre los átomos de una molécula.

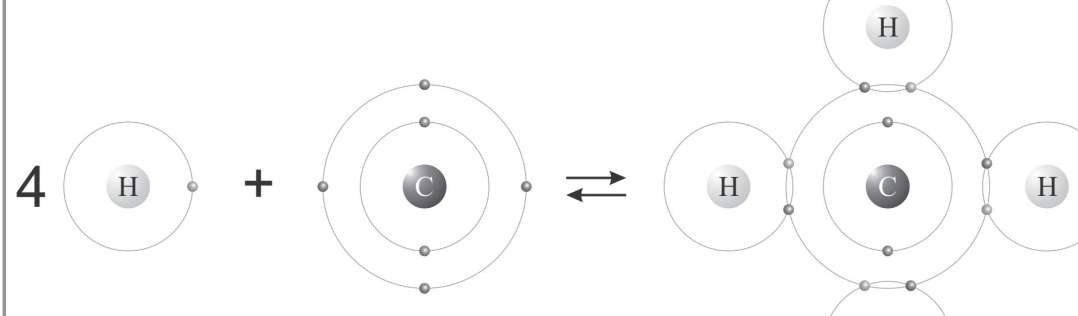

H

Tomado de: http:/ / www.periodni.com/gallery/covalent_bond.png 


\section{Enlace iónico, isótopos, número de valencia}

Ion es un átomo que ha ganado o perdido un electrón. Ejemplo. El sodio pierde un electrón y el cloro gana un electrón. ( $\mathrm{Na}+$ y $\mathrm{Cl}$-)

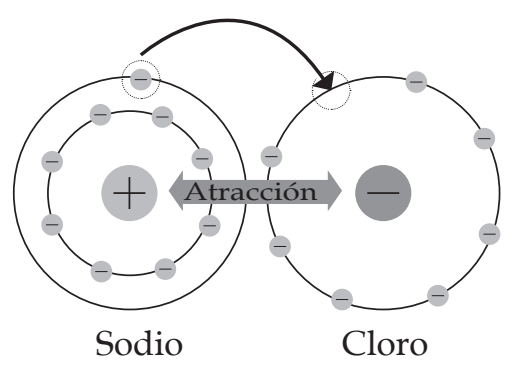

\section{Tipos de enlaces químicos}

\begin{tabular}{|l|l|l|}
\hline \multicolumn{1}{|c|}{ Enlace } & \multicolumn{1}{c|}{ Descripción } & \multicolumn{1}{c|}{ Ejemplos } \\
\hline Iónico & $\begin{array}{l}\text { Unión entre iones de distin- } \\
\text { to signo. Uno de los átomos } \\
\text { capta los electrones del otro. }\end{array}$ & $\begin{array}{l}\text { La sal común: } \\
\mathrm{Na}^{+}+\mathrm{Cl}^{-} \rightarrow \mathrm{NaCl}\end{array}$ \\
\hline Covalente & $\begin{array}{l}\text { Enlace en el que se compar- } \\
\text { ten los electrones del último } \\
\text { nivel. Así alcanzan el octeto } \\
\text { estable. }\end{array}$ & $\begin{array}{l}\text { El gas cloro: } \\
\mathrm{Cl}^{-}+\mathrm{Cl}-\rightarrow \mathrm{Cl}_{2}\end{array}$ \\
\hline
\end{tabular}

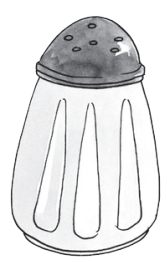

El consumo de la sal es esencial para mantener la presión adecuada y evitar la pérdida excesiva de agua. Los elementos cloro, sodio e hidrógeno benefician al cuerpo para mantener un equilibrio de ácido-básico en los fluidos corporales importantes para la nutrición, respiración, eliminación de desechos y reproducción celular.

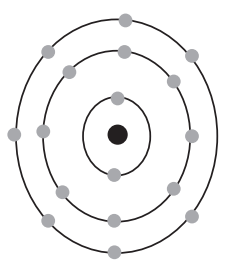

Átomo de CI Átomo de $\mathrm{H}$

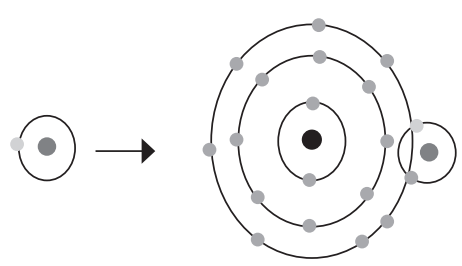

Molécula de $\mathrm{HCI}$

$$
\begin{aligned}
& \text { Cloro } 1 S^{2} 2 S^{2} 2 p^{6} 3 S^{2} 3 p^{5} \\
& \text { Hidrógeno } 1 S^{1}
\end{aligned}
$$

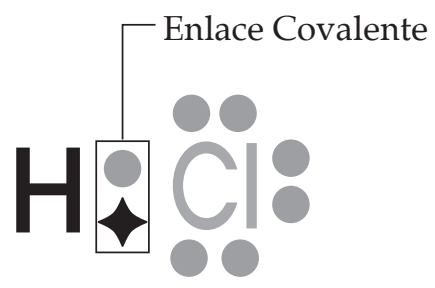

El ácido clorhídrico que se forma entre un átomo de cloro y un átomo de hidrógeno mediante el enlace covalente forman un compuesto que se encuentra en el estómago. Es un ácido que favorece la descomposición de los alimentos como también eliminar organismos enfermizos que se encuentran en la comida en proceso de digestión.
Número de valencia es la cantidad de electrones que se encuentran en el último nivel de energía más externo.

Isótopo es un elemento que contiene mayor o menor cantidad de neutrones. Ejemplo. C12 posee 6 neutrones y es Isótopo del carbono terrestre; C13 posee 7 neutrones Se utiliza en las pruebas de diagnóstico médico, como la prueba de aliento para detectar el helicobacter pylori; y el C14 con 8 neutrones, que se utiliza para determinar la edad de un esqueleto prehistórico, madera o restos de tejidos; basado en la cantidad de carbono radiactivo.

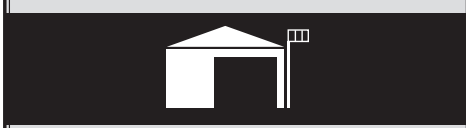

Presentamos y describimos por equipo los segmentos informativos relacionados con productos químicos y agroforestales que se producen o comercializan en la comunidad. Incluimos aspectos beneficiosos o perjudiciales de su uso o consumo según los principales compuestos químicos que constituyen las sustancias químicas que se producen.

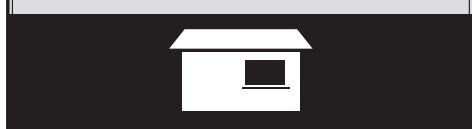

Elaboro el PNI a partir de la información contenida en el catálogo. 


\section{Valores para la convivencia}

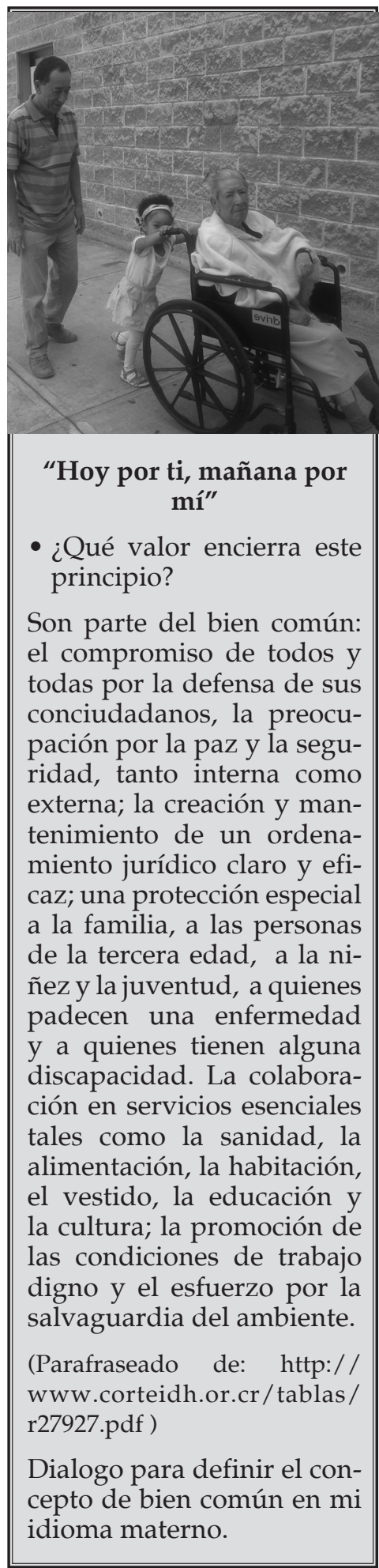

Reunámonos en equipo y relatemos acciones en donde una o más personas ayudaron a otras $\mathrm{u}$ otra.

Cuando una persona sufre un contratiempo y le ayudamos, sin esperar que en otra ocasión ella nos ayude o nos dé una compensación estamos actuando según el principio de solidaridad. La persona solidaria no espera que le den las gracias ni tampoco una compensación por apoyar a otros y otras.

Enlistemos acciones propias de la comunidad que son solidarias. Argumentamos nuestras respuestas.

Si un grupo de personas tienen un problema en común y todas participan para resolverlo, se practica la cooperación.

Determinamos acciones propias de la comunidad que son prácticas de cooperación.

Respondemos: ¿se practica la cooperación en las cooperativas?

Hay otros valores que se practican cuando ayudamos a una persona o a un grupo. Por ejemplo: la reciprocidad y la caridad.

¿Qué valores se practican en el resto de acciones que relatamos? Argumentamos nuestras respuestas.

Todas las acciones que se realizan para ayudar a otras personas contribuyen al bien común. Este concepto está relacionado con las condiciones que debe tener una comunidad para que sus integrantes alcancen el bienestar. Se refiere a normas, instituciones, valores, actitudes, acciones que garanticen una vida de calidad para todas y todos. El bien común es un principio fundamental del Estado que establece la Constitución.

Establecemos la relación del bien común con los aspectos:

- Derechos humanos

- Buen vivir

- Desarrollo humano
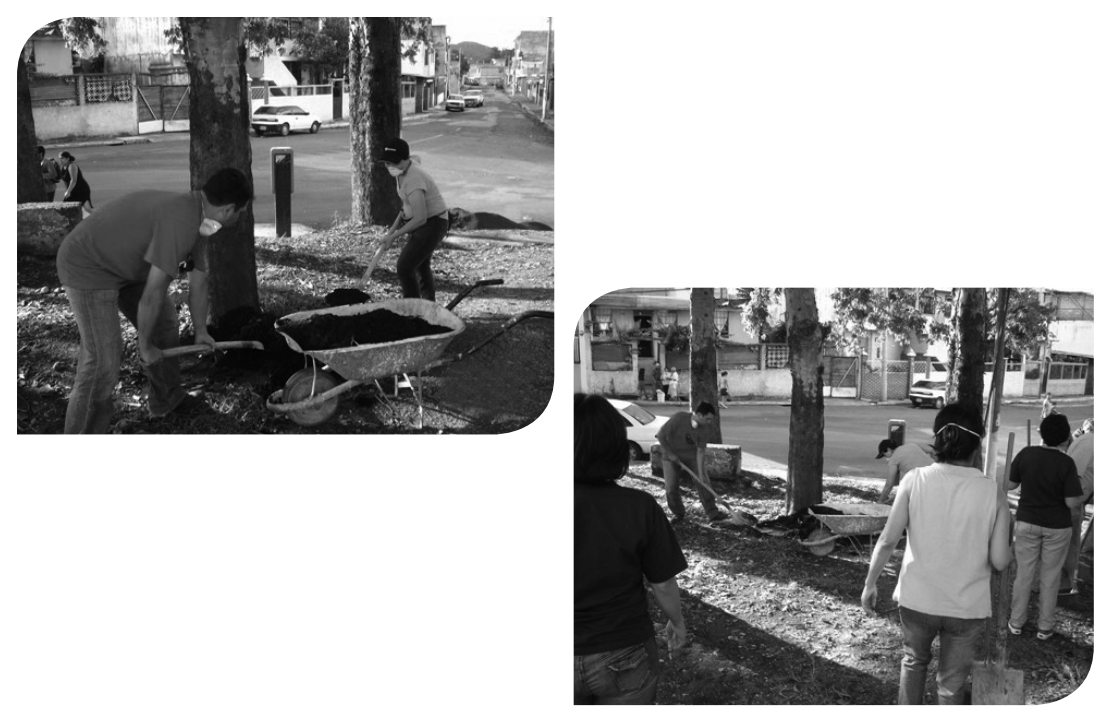


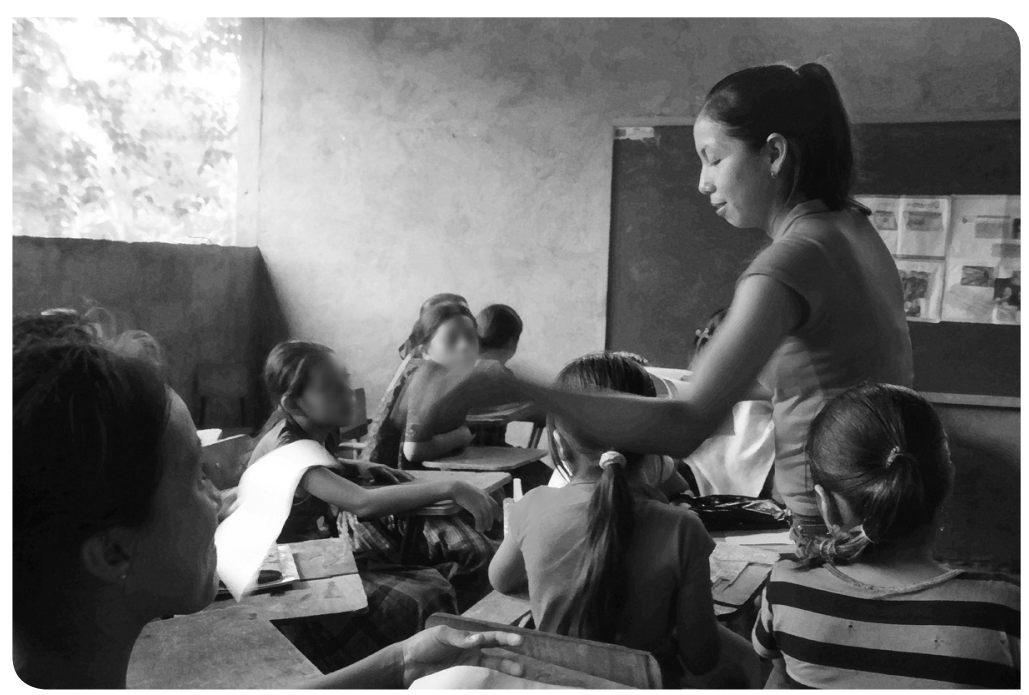

\section{Coordinación social}

Cuando las personas practican la solidaridad, la cooperación o buscan el bien común; necesitan coordinar sus acciones. Pueden coordinar de manera individual, por medio de grupos organizados, de manera espontánea, una institución estatal, estructura municipal, organización no gubernamental, entre otras. Cuando las acciones que se realizan son de gran dimensión, también se necesitará coordinar entre instituciones u organizaciones. Hay personas que por su liderazgo, sabiduría o el cargo que ocupan en determina institución, son fundamentales para coordinar acciones. A estas personas se les conoce como actores o actoras clave.

- ¿Qué personas son clave para coordinar acciones de cooperación de carácter productivo en la comunidad?

- ¿A qué actores y actoras clave se toma en cuenta en la elaboración del catálogo?

Presentamos el catálogo de la producción a nuestra comunidad, enfatizando en lo siguiente:

- Nuestra apreciación acerca del desarrollo humano de la comunidad.

- Los procesos productivos más desarrollados que se realizan en la comunidad.

- Los actores y actoras clave en los procesos productivos más desarrollados.

- Características de la infraestructura productiva del municipio.

Elaboro un cuadro sinóptico que me permita reflexionar acerca de los siguientes aspectos de mi comunidad:

- El desarrollo humano

- Procesos productivos

- Infraestructura

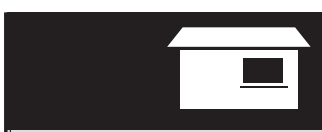

- ¿Quién es el actor o actora clave para desarrollar la educación de mi comunidad?

Describo las características de una actora o actor clave que sea ideal para promover los derechos humanos de mi comunidad.

Proyecto en qué asuntos de mi comunidad podría aportar yo como actor o actora clave en el futuro. 


\section{La agricultura de hoy}

El calendario agrícola es importante para la producción. Nos indica cuáles son los cultivos que mejor se dan en cierta época, de acuerdo a los requerimientos de temperatura y lluvia según el lugar donde se cultiven. Por ejemplo, en el altiplano solo se da una cosecha de frijol mientras que en oriente, en lugares con adecuado régimen de lluvias, se dan dos e incluso una tercera, llamada de verano. Algunas hortalizas se pueden cultivar varias veces al año, mientras que otras como el maíz de occidente solo una vez al año. En comparación, el cafeto necesita tres a cuatro años para dar sus primeros frutos, lo cual continúa haciendo por unos 15 años.

\section{$\square$}

Entrevisto a mis familiares sobre el tipo de maíz y frijol que prefieren cultivar o consumir y por qué.

Elaboro un cuadro el que anoto mis reflexiones de los aprendizajes en el curso, mediante el PNI. Elaboro carteles o diapositivas de Power point con información del manejo integrado de plagas, de cultivos y de agricultura orgánica.

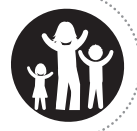

Muchas familias del área rural guatemalteca procuran producir sus propios alimentos. Sembrar maíz significa continuar la tradición de la familia, pero también asegurar el alimento familiar. Existen muchas variedades de maíz; en oriente se prefiere el maíz blanco; mientras en occidente, el maíz amarillo. Algunas familias prefieren el maíz de la costa, otras el de occidente. El ICTA ha introducido diversas variedades de maíz mejorado, pero existen productores y productoras que prefieren cultivar maíz criollo. Las variedades de maíz y frijol producidas por el ICTA son más resistentes a sequías y plagas mientras que las variedades criollas requieren mayor cuidado pero su sabor es exquisito, dicen quienes las siembran.

El maíz criollo tiene varas altas. Para fortalecerlas, se siembran dos semillas en vez de tres. Los troncos más fuertes permiten que el frijol criollo se enrede en sus varas sin temor a ser doblado por el viento. Las variedades mejoradas de maíz son más bajas y si bien son más fáciles de doblar se debe tener cuidado de que la mazorca no toque el suelo al hacerlo. El frijol mejorado es de "suelo" por lo que necesita más espacio.

La producción de alimentos va más allá de sembrar lo que se desea consumir. Las decisiones sobre cuestiones agrícolas toman en consideración: el tipo de alimentos que se desea producir, el tamaño de la parcela, el tipo de suelo, los costos de producción (compra de semilla, y fertilizantes y plaguicidas orgánicos o químicos), jornales de trabajo, rendimiento de la cosecha y precio de venta final. Quienes se dedican a la agricultura, además, saben que corren riesgos debido a los fenómenos atmosféricos, que cada vez se producen en patrones menos esperados.

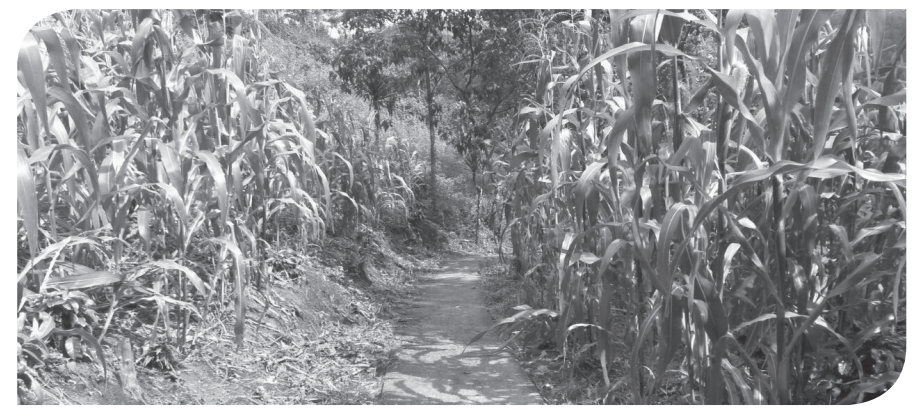

Consultemos en la comunidad y elaboremos un calendario agrícola. Veamos el ejemplo.

Elaborar un calendario con los y las agriculturas de la comunidad nos ayudará a visualizar ciclos laborales. Habrá meses en los que se necesita mayor mano de obra y épocas que podríamos cultivar otros productos o realizar otras labores. Así aprovecharemos de mejor manera los recursos.

\begin{tabular}{|l|l|l|l|l|l|l|l|l|l|l|l|l|} 
Producto & Enero & Febrero & Marzo & Abril & Mayo & Junio & Julio & Agosto & Septiembre & Octubre & Noviemvre & Diciembre \\
\hline Banano & & & & \multicolumn{2}{c|}{ Siembra } & & & \\
\hline
\end{tabular}


Además de producir alimentos para consumo, algunas familias cultivan con el objetivo de vender su cosecha. No importa el tamaño de su parcela. Algunas familias tienen bastantes cuerdas que cultivan con fines comerciales, pero otras, dividen sus parcelas para cultivos de consumo y cultivos comerciales. De esta manera, las familias aseguran alimento e ingresos económicos.

En el área rural, muchas familias se dedican al cultivo de diversas hortalizas, como tomate, cebolla, zanahoria y hierbas que venden en los mercados. Algunos agricultores y agricultoras se organizan en cooperativas o asociaciones agrícolas. Venden su producción a supermercados o agroexportadoras. Para ello han incorporado buenas prácticas agrícolas, que incluyen el uso limitado de herbicidas y plaguicidas, uso de agua no contaminada para riego, recolección de la cosecha en momentos óptimos y de manera adecuada para evitar la contaminación de suelo y agua, limpieza con agua clorada, uso de guantes y mantillas de cabello para la limpieza y embalaje del producto. Posiblemente, la inversión sea mayor pero los ingresos son mejores.

Para practicar la agricultura comercial, lo más importante no es el tamaño de la tierra sino la capacidad de organización. Pequeños productores y productoras asociados pueden ofrecer a sus clientes un mayor volumen de producto, lo cual les permite negociar precios de mejor manera. El trabajo asociado, además, permite reducir costos de producción al comprar insumos y pagar transporte. Los productores y productoras asociados legalmente, además, pueden emitir facturas lo cual les permite ofrecer directamente sus productos a empresas evitando los intermediarios. Además, pueden tener un sistema contable que les ayuda a determinar sus costos y ganancias; a cambio, reciben acompañamiento y asistencia técnica.

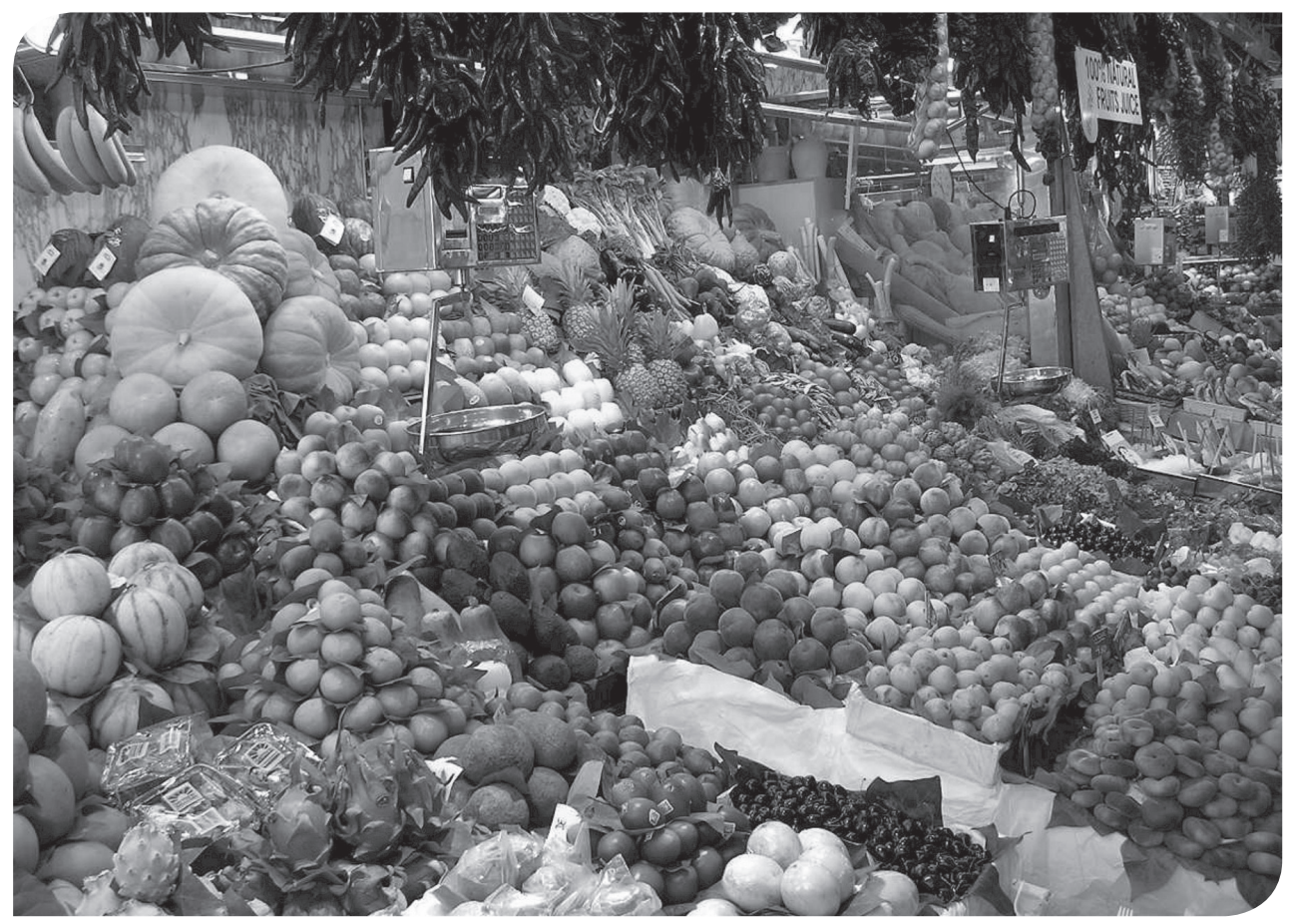

La producción es importante para el desarrollo de una comunidad. Los ingresos que producen los cultivos, las artesanías, y otras actividades, como las turísticas; generan ingresos para las familias. Estos ingresos pueden ser invertidos en alimentación, salud, educación y bienestar en general. Sin embargo, estamos en un mundo competitivo, por lo que nuestros productos o servicios deben tener la más alta calidad y con entregas puntuales. Asimismo deben darse a conocer para que el público los adquiera. La publicidad es importante y una manera de hacerlo es a través de la creación de un nombre o una marca, tarjetas de presentación, folletos de información y un catálogo de productos agrícolas o artesanales.

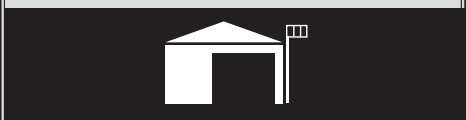

Dialogamos en torno de los aprendizajes del área en esta semana e integramos reflexiones del PNI. Revisamos el catálogo. ¿Incluimos cultivos de maíz, frijol u hortalizas? ¿Qué tipo de semilla de maíz se utilizan? ¿Están incluidas en el catálogo y las razones de la preferencia? Integramos los carteles o diapositivas para la presentación de manejo integrado de plagas, cultivos y agricultura orgánica.

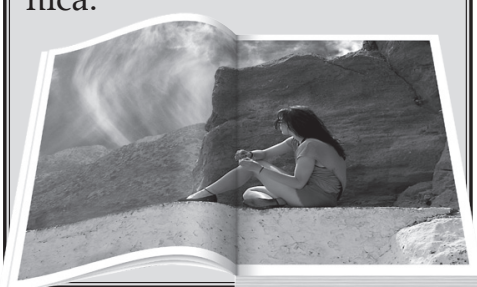




\section{Normas parlamentarias}

\section{Uso de mayúsculas}

Se escribirán con letra inicial mayúscula:

1. Nombres de persona, animal o cosa singularizada: Cecilia, Rocinante, Programa Abriendo Oportunidades.

2. Nombres geográficos: América, Quetzaltenango, Petén, Usumacinta. Cuando el artículo forme parte oficialmente del nombre propio, ambas palabras comenzarán por mayúscula: El Salvador, La Antigua Guatemala, El Progreso.

3. Nombres de obras de arte (libros, música, pinturas, etc.): La mansión del pájaro serpiente, Las meninas, El Mesías.

4. Al empezar una oración y al escribirla, después de un punto: Llegamos al lago. Nunca pensamos que sería tan hermoso.
Las normas parlamentarias son el conjunto de normas empleadas por las organizaciones sociales para la toma de decisiones en forma ágil, ordenada y democrática. Surgieron con la finalidad de organizar las juntas deliberativas a fin de ahorrar tiempo y llegar a soluciones contundentes. Sus principios fundamentales son:

1. Se trata un solo asunto cada vez.

2. Toda propuesta presentada para su consideración merece pleno y libre debate.

3. Cada quien tiene iguales derechos que los demás.

4. La decisión de la mayoría debe llevarse a cabo y respetar la posición de la minoría.

5. La personalidad de cada persona de la organización debe fortalecer al grupo.

\section{Técnica PNI}

PNI Es una estrategia que permite el mayor número de ideas que se generan sobre un tema o acontecimiento. Permite determinar lo positivo, lo negativo y lo interesante del mismo, por lo que se le considera de un alto valor educativo. Es útil para lograr un equilibrio en nuestros juicios valorativos $\mathrm{y}$, por lo tanto, para tomar decisiones fundamentales. Además, fortalece el pensamiento crítico y reflexivo. Cada persona expresa una idea de cada aspecto:

$\mathrm{P}=$ positivo. Los aspectos positivos de una idea.

$\mathrm{N}=$ negativo. Los aspectos negativos de una idea.

I = interesante. Los aspectos interesantes en una idea.

\section{Códigos de la publicidad}

La publicidad se vale de diferentes códigos para transmitir mensajes de manera más contundente. Los más usados son: gestual: los gestos de las personas o animales; escenográfico: comprende el montaje, el vestuario y la utilería; simbólico: usa símbolos reconocidos como la lealtad del perro; lumínico: uso de la luz para acentuar un aspecto determinado.

En nuestro cuaderno, hagamos una tabla como la que se ilustra a continuación y completémosla con ejemplos de los usos de las mayúsculas que se han empleado en el catálogo:

\begin{tabular}{|c|c|c|c|}
$\begin{array}{c}\text { Uso 1: } \\
\text { nombre } \\
\text { propio }\end{array}$ & $\begin{array}{c}\text { Uso 2: } \\
\text { nombre } \\
\text { geográfico }\end{array}$ & $\begin{array}{c}\text { Uso 3: } \\
\text { nombre de } \\
\text { obra de arte }\end{array}$ & $\begin{array}{c}\text { Uso 4: Inicio } \\
\text { de la oración }\end{array}$ \\
\hline & & & \\
\hline & & & \\
\hline
\end{tabular}




\section{Distribución lingüística en Guatemala}

En Guatemala existen 25 comunidades lingüísticas: el español, el xinka, el garífuna y veintidós idiomas que pertenecen a la familia lingüística maya: achí, akateko, awakateko, chalchiteko, chorti', chuj, itza', ixil, jakalteco (popti), kaqchikel, $k^{\prime} i c h e^{\prime}$, mam, mopan, poqomam, poqomchi', q'anjob'al, q'eqchi', sakapulteko, sipakapense, tektiteko, tz'utuji y uspanteko. El español se usa en la mayoría de las actividades educativas, económicas, políticas y sociales en Guatemala. Esto significa una gran desventaja comunicativa interétnica para quienes no lo dominan. Esta situación ha favorecido las desigualdades, pues durante años se ha desestimado los idiomas de los pueblos indígenas como herramientas para el aprendizaje, entre otras actividades sociales, culturales y políticas.

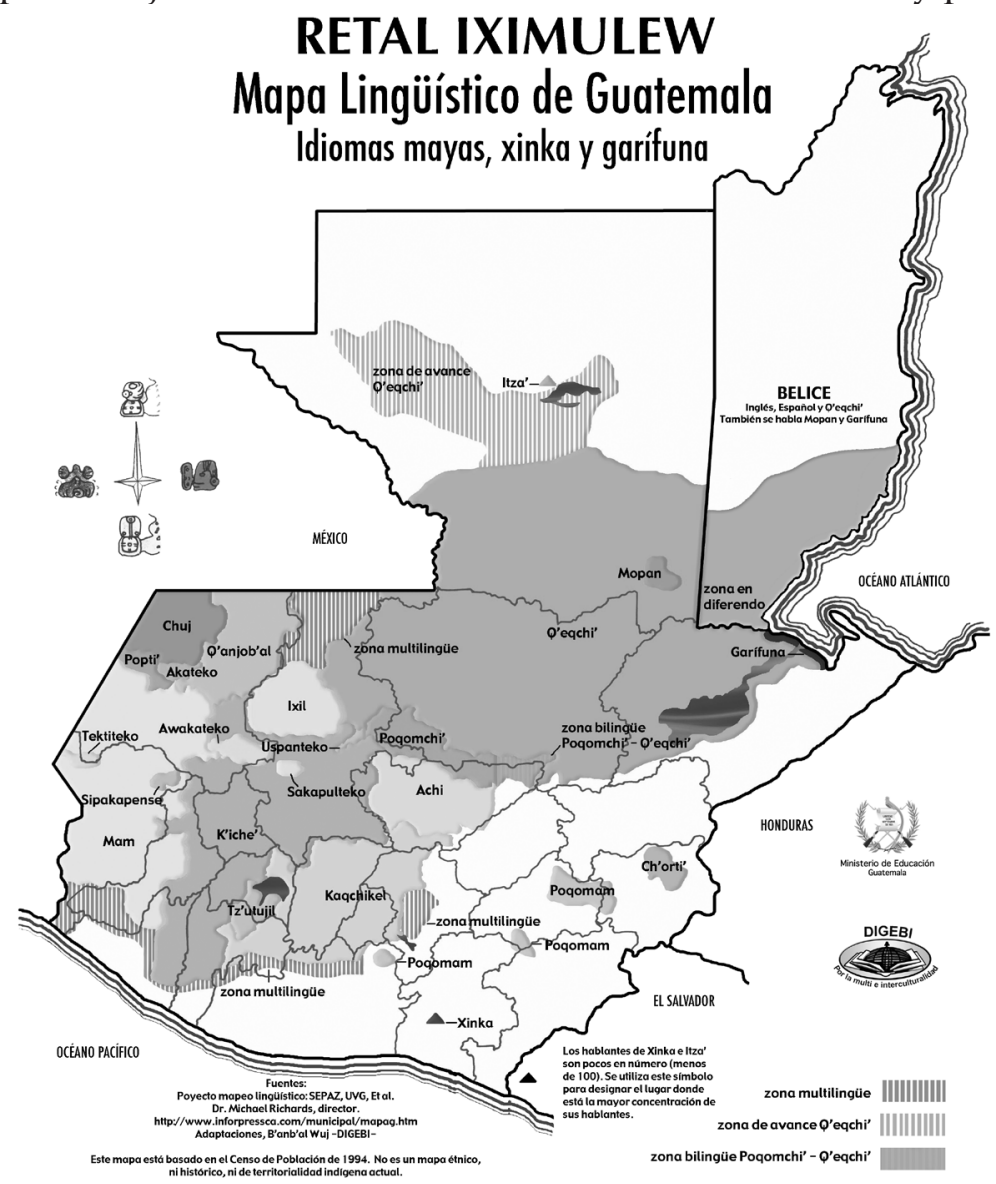

Fuente: http://www.mineduc.gob.gt/digebi/documents/mapaLinguistico.pdfpng

- Copiemos este mapa lingüístico en un cartel, en la clase. Luego, hagamos una tabla en la parte inferior del mapa con los nombres de los departamentos de Guatemala, los idiomas que se hablan en cada lugar y, si es posible, investiguemos algunas palabras en cada lengua.

- Organicemos un conversatorio sobre la comunicación interétnica y la dificultad que significa el monolingüismo en castellano que predomina en Guatemala: las lenguas no solo son medios para la comunicación, sino las expresiones de su cultura, las diversas formas de pensar y visiones del mundo que nos enriquecen como nación.

- Realicemos una presentación sobre la diversidad idiomática en nuestro país que incluya una descripción de lo investigado y el ejercicio de la técnica de PNI.

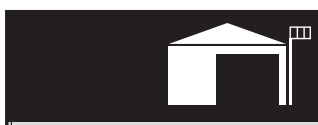

- Preparamos y realizamos tres diferentes conversatorios, por medio de estrategias publicitarias que utilicen diferentes códigos, sobre los temas siguientes en nuestra comunidad:

1. La producción agropecuaria

2. La salud y sus problemas

3. La coordinación óptima de las personas de nuestro grupo social.

- En consenso, establecemos las normas parlamentarias para las presentaciones.

- Realicemos los conversatorios y ejercitemos la técnica PNI en los mismos.

- Después de informarnos sobre cada uno de estos temas, tomemos decisiones que incidan en el mejoramiento de nuestra vida en común, por medio del ejercicio de las normas parlamentarias.

- Presentamos el catálogo a la comunidad.

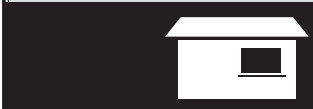

Busco información acerca de las variantes regionales en mi idioma materno en otras comunidades. Hago lo mismo con el español, en otros departamentos y regiones del país. Encuentro ejemplos de palabras y expresiones distintas o de significado distinto en una región u otra.

Realizo una propuesta de afiche publicitario para el catálogo. 


\section{Razones frigonométria as. Leyes de senos y de cosenos}

Para hallar la longitud de un lado o ángulo desconocido de un triángulo rectángulo lo más sencillo es utilizar razones trigonométricas. Aparte de las razones de seno, coseno y tangente existen otras llamadas inversas o recíprocas. También son tres y se denominan: cosecante, secante y cotangente. A continuación, se expresan matemáticamente, cada una de estas razones:

$$
\begin{aligned}
& \operatorname{cosec} \alpha=\frac{\text { hipotenusa }}{\text { cateto opuesto }}=\frac{1}{\operatorname{sen} \alpha} \\
& \sec \alpha=\frac{\text { hipotenusa }}{\text { cateto adyacente }}=\frac{1}{\cos \alpha} \\
& \operatorname{cotg} \alpha=\frac{\text { cateto adyacente }}{\text { cateto opuesto }}=\frac{1}{\operatorname{tag} \alpha}
\end{aligned}
$$

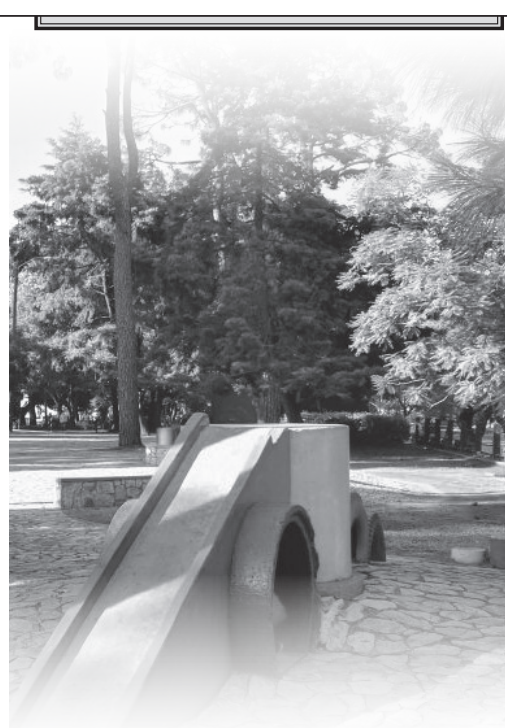

\section{Resolvemos la siguiente situación:}

En un parque infantil se desea construir un resbaladero para niñas y niños, como el que aparece en la figura:

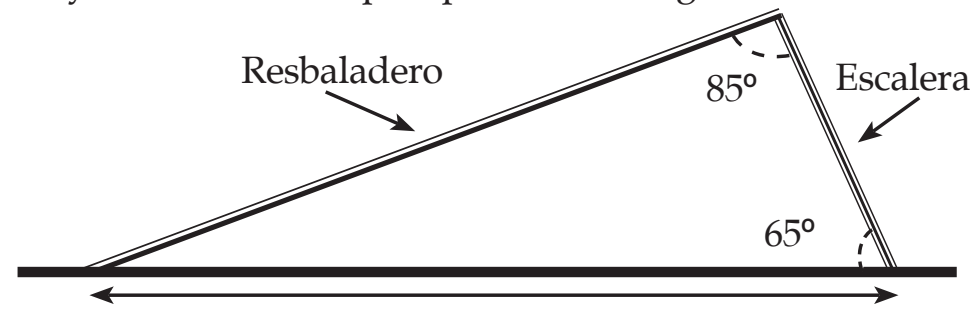

7 metros

- ¿Con estos datos, se podrá calcular la longitud del resbaladero? ¿Y el largo de la escalera?

- ¿Qué proceso utilizamos para llegar a la respuesta? Comentamos y discutimos nuestras respuestas.

Escribimos en tarjetas las razones trigonométricas seno, coseno y tangente. En otras tarjetas escribimos las leyes de senos y de cosenos. Expresamos oralmente dentro de nuestro grupo qué diferencias y similitudes encontramos en la aplicación de cada relación.

- ¿Es posible utilizar la ley de senos y de cosenos para resolver situaciones en dónde se involucran triángulos rectángulos? Utilizamos el siguiente triángulo para justificar nuestra respuesta y encontramos los valores desconocidos.

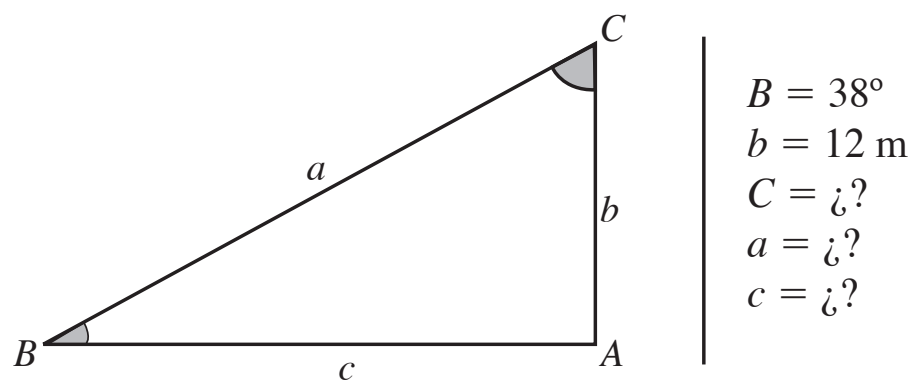

En mi cuaderno encuentro los valores desconocidos y, con regla y transportador, trazo los triángulos.
1) $A=90^{\circ} \quad B=30^{\circ}$
$C=i ? \quad a=5 \mathrm{~cm}$
$b=i ?$
$c=i ?$
2) $A=i ? \quad B=45^{\circ}$
$C=90^{\circ} a=i$ ?
$b=8 \mathrm{~cm} \quad c=i$ ?
3) $A=i ? \quad B=90^{\circ}$
$C=25^{\circ} a=i$ ?
$b=i$ ?
$c=7 \mathrm{~cm}$
4) $A=40^{\circ} \quad B=45^{\circ}$
$C=i ? a=i$ ?
$b=i$ ?
$c=i$ ?
5) $A=i ? \quad B=110^{\circ}$
$C=i ? \quad a=6 \mathrm{~cm}$
$b=i$ ?
$c=4 \mathrm{~cm}$ 
En grupos de trabajo, copiamos en una cartulina el siguiente cuadro. Lo completamos con la información necesaria.

\begin{tabular}{|l|l|l|l|}
\hline & $\begin{array}{c}\text { ¿Cuándo } \\
\text { podemos } \\
\text { aplicarlo? }\end{array}$ & $\begin{array}{c}\text { ¿Cuándo no } \\
\text { podemos } \\
\text { aplicarlo? }\end{array}$ & $\begin{array}{c}\text { Ejemplo de } \\
\text { aplicación. (Incluir } \\
\text { dibujo) }\end{array}$ \\
\hline $\begin{array}{l}\text { Razones trigo- } \\
\text { nométricas }\end{array}$ & & & \\
\hline Ley de senos & & & \\
\hline Ley de cosenos & & & \\
\hline
\end{tabular}

Encontramos el valor de la longitud de los lados y ángulos desconocidos en cada triángulo. Indicamos qué relación utilizamos.

Resolvemos en grupos las siguientes situaciones:

- Por la tarde, un árbol proyecta una sombra de $60 \mathrm{~m}$. Se conoce que la distancia entre la copa del árbol y el lugar donde termina su sombra, a esa hora de la tarde es de 90 metros. ¿Cuál es el ángulo de elevación, desde el suelo, del sol en ese momento de la tarde?

- Dos autos parten del mismo punto con trayectorias rectilíneas y formando entre sí un ángulo de $65^{\circ}$. ¿A qué distancia se encontrarán luego de dos horas si uno viaja a $60 \mathrm{~km} / \mathrm{h}$ y el otro a $70 \mathrm{~km} / \mathrm{h}$ ?

- Una antena de teléfonos se encuentra en la cima de una colina. El ángulo de inclinación de la colina es de $20^{\circ}$. Se colocará un cable que irá desde el punto más alto de la antena hacia el suelo, a 100 metros de dónde se ubica la antena. El ángulo que forma el cable con el suelo es de $40^{\circ}$ ¿Cuál debe de ser la longitud mínima del cable requerido?

- La sede del ECA mide una distancia de 500 metros con la casa de Ana y 700 metros de distancia con la casa de Bernardo. El ángulo de separación entre la ECA y ambas casas, es de 120 metros. ¿Qué distancia separa la casa de
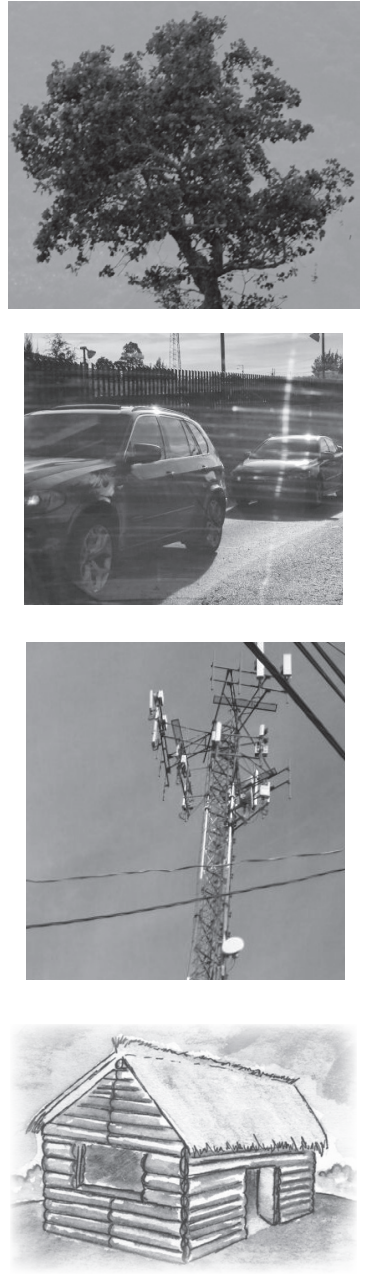

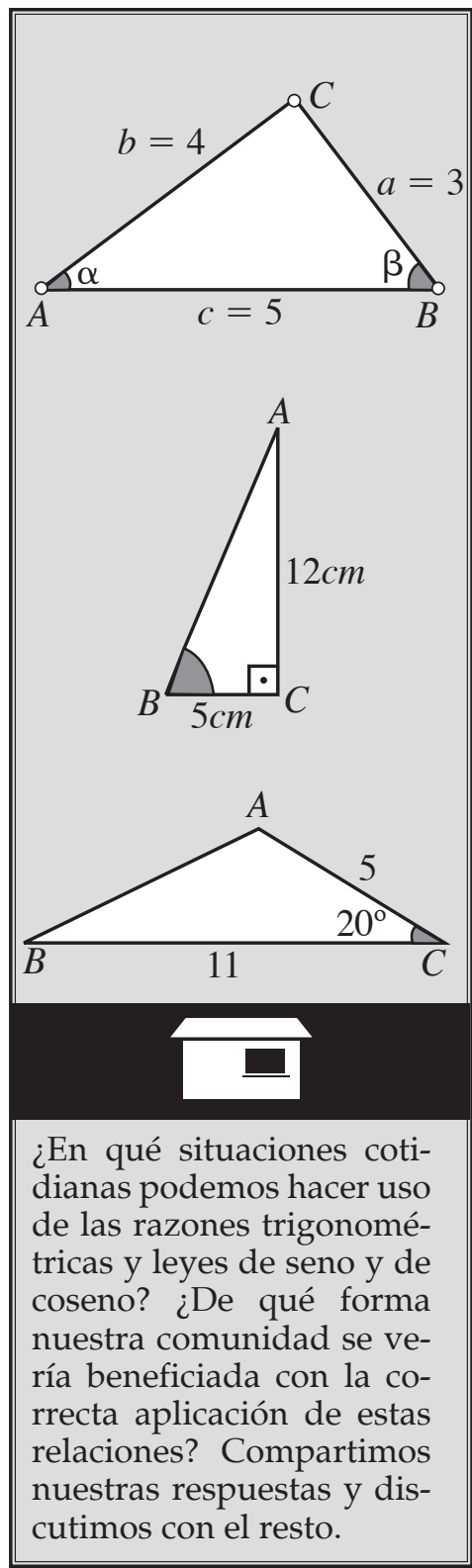

¿En qué situaciones cotidianas podemos hacer uso de las razones trigonométricas y leyes de seno y de coseno? ¿De qué forma nuestra comunidad se vería beneficiada con la correcta aplicación de estas relaciones? Compartimo cutimos con el resto. 


\section{Productos agroforestales y químicos}

Existe una tendencia en la actualidad de migrar hacia la agricultura sostenible, que busca mitigar los efectos negativos de los agroquímicos en el ambiente y las comunidades. Asimismo, se busca la autosuficiencia de las unidades de producción, por medio del uso de insumos locales como los rastrojos de cosecha y estiércol animal para reducir el uso de insumos externos.

La agricultura sostenible permite, en el largo plazo, mejorar la calidad ambiental y los recursos básicos de los cuales depende la agricultura. Satisface las necesidades básicas de fibra y alimentos humanos, es económicamente viable y mejora la calidad de vida de quien produce y de la sociedad.

Recuperado de: http:// www.cricyt.edu.ar/enciclopedia/terminos/AgriSos.htm

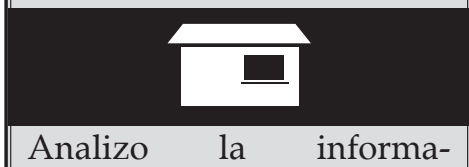
ción del video: https:// w w w. you t u b e.com / watch?v=iYKlrbzQcmY

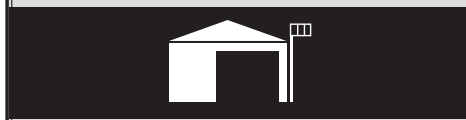

Revisamos el PNI y establecemos las fortalezas y debilidades en relación con los aprendizajes logrados.
- En grupo comentamos las prácticas agrícolas en nuestra comunidad y qué tipo de químicos son utilizados para mejorar la producción de alimentos.

- Elaboramos un cuadro comparativo de los alimentos naturales y procesados que incluimos en la alimentación. Comparamos la información con otros grupos.

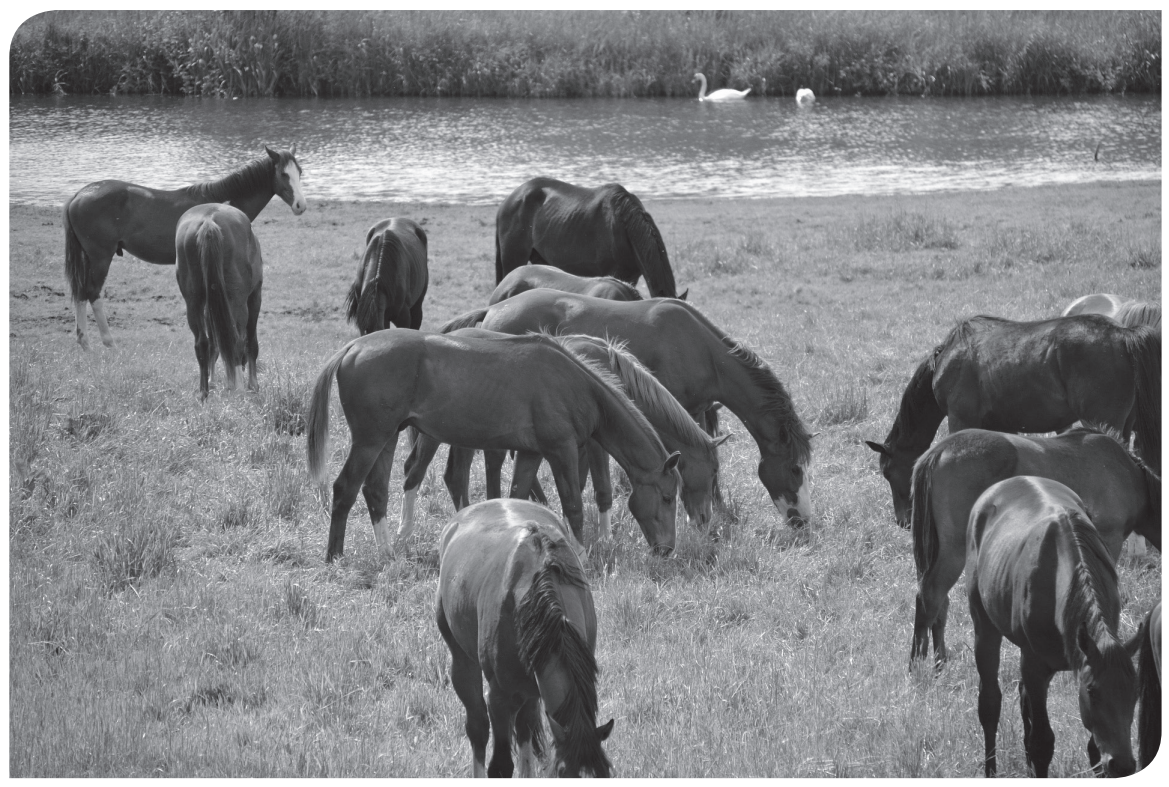

Los productos agroforestales se relacionan con la producción de materias primas por medio del cultivo de plantas. Su campo de aplicación es el uso de la tierra, donde la productividad dependerá de adecuados manejos técnicos, selección de semillas, aplicación de fertilizantes, manejo integrado de plagas y el equilibrio con la Naturaleza. De allí que debe procurarse armonía en la sostenibilidad, adaptabilidad y productividad.

En las plantaciones puede encontrarse cultivos, como frijol, maíz, papa, caña de azúcar, entre otros; o también especies forestales como la Teca. Es posible integrar ambos sistemas: cultivos y árboles frutales o maderables, a lo cual se le conoce como sistemas agroforestales. Ejemplo de producción agroforestal, es el asocio de árboles frutales o maderables con cultivos de ciclo corto.

En la agricultura se usan productos fitosanitarios (insecticidas, herbicidas y fungicidas), fertilizantes sintéticos, orgánicos y fitohormonas de crecimiento. Los agroquímicos se clasifican en categorías de acuerdo a su grado de toxicidad para las personas y para el medio ambiente. Para el control integrado de plagas se usa el conocimiento sobre los hábitos, el ciclo de vida, las necesidades de las plantas, así como sus aversiones a ciertas plagas y capacidad de tolerar otras plagas que son inofensivas.

La producción más limpia es una estrategia ambiental preventiva integrada que se aplica a los procesos, productos y servicios a fin de aumentar la eficiencia y reducir los riesgos para las personas y el ambiente. Un ejemplo es la agricultura orgánica, como en el caso del café, algunas frutas, entre otros. 
- Comentamos en clase si existe en la comunidad el intercambio de nutrientes como práctica tradicional. Por ejemplo: al utilizar restos de vegetales, como alimento para animales (gallinas y cerdos) y sus desechos como abono.

\section{Compuestos químicos nocivos en alimentos naturales}

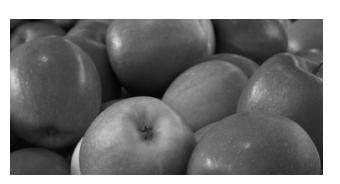

Glucósidos cianogénicos son precursores de hidrógeno de cianuro que es letal cuando lo procesa el cuerpo. Se encuentra en semilla de la manzana (en pequeñas cantidades no afecta), el interior carnosos de las semillas de ciruela, melocotones, durazno y cerezas.

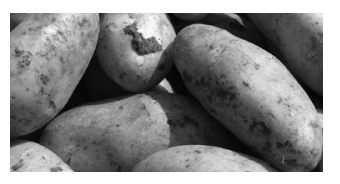

Solanina: es una toxina que se encuentra en la papa cruda. Actúa como pesticida o fungicida contra insectos. Puede causar malestares desde síntomas gastrointestinales, hasta alucinaciones, parálisis o muerte.

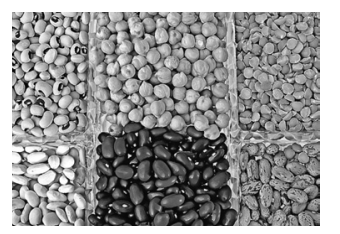

Lectinas. El frijol, lenteja, garbanzos, arvejas, maní, soja contiene glucosa, hierro, acido fólico y magnesio. La lecitina esta relacionada con el síndrome de colón irritable, alergias, úlceras pépticas y artritis. Se recomienda que antes de la cocción, se remoje el frijol y se tire el líquido . Con el primer hervor, retirar la espuma superficial.

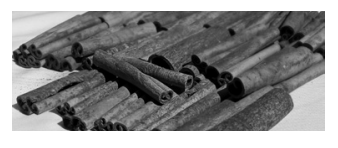

Cumarina. Esta contenido en la canela. En altísimas cantidades puede dañar el hígado.

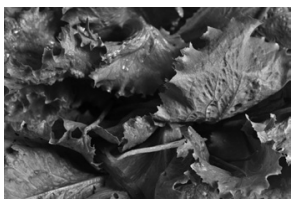

Nitratos: Entre las que tienen un alto contenido de nitratos están la lechuga, remolacha, zanahoria, espinaca, perejil, repollo, rábanos, apio y col. Evitan formación de coagulos. Con altos niveles, puede ser tóxico.

Los huertos familiares mixtos son prácticas agroforestales donde se presentan múltiples cultivos. Existen diferentes asociaciones de cultivos, siendo algunas desfavorables o no recomendables y otras favorables. El ajo, al asociarlo en parcelas, cerca de rosas y frambuesas; ayuda a potenciar el crecimiento y el sabor. La albahaca, asociada al tomate mejora el crecimiento y el sabor de las plantas. Es un excelente repelente para moscas y mosquitos.

El bledo o amaranto, contiene minerales, vitaminas (A, C, B1, B2, B3). Es rico en ácido fólico, niacina calcio, hierro y fósforo. Contiene carbohidratos y fibra. El componente principal del amaranto es el almidón. Contiene también lisina- aminoácido esencial para el crecimiento. Es recomendable para evitar la desnutrición. Tiene la característica de producirse todo el año.

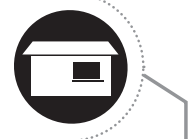

Observo el video y elaboro conclusiones. https:/ /www.youtube. com/watch?v=5Nn-s_HpR8A .

Revisamos el catálogo y recomendamos con especial énfasis los productos y servicios químicos y agroforestales más sustentables y respetuosos de la Madre Tierra y el buen vivir.
Ya que se conoce mejor cuáles son los efectos negativos de los agroquímicos, sobre el ambiente y las comunidades que los utilizan, muchas personas están optando por emplear prácticas de agricultura sostenible. Sustituye los elementos nocivos por otros naturales como los rastrojos de cosecha, el estiércol animal y además tiene como meta alcanzar la autosuficiencia en la producción. Algunos beneficios aportados por la agricultura sostenible son:

- Mejorar la calidad ambiental.

- Disminuir la contaminación al agua, la tierra y los alimentos.

- Reduce los costos de producción.

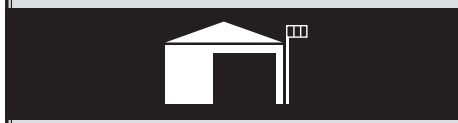

Formamos equipos para hacer la representación de átomos, isótopos, números de valencia, enlaces químicos y órbitas electrónicas con materiales naturales que tenemos al alcance.

- ¿Podemos seguir la propuesta de la estructura de Lewis? 


\section{Problemática social}

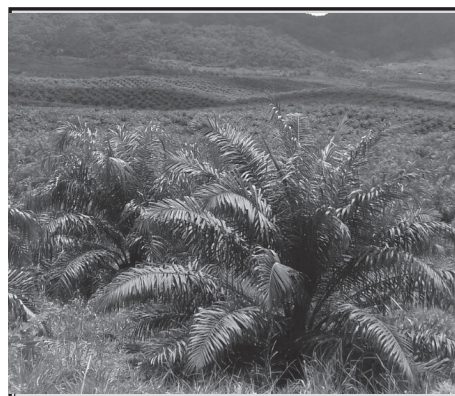

- ¿Qué problemática social genera este cultivo?

Clasifico los problemas que genera el cultivo en coyunturales y estructurales.

“... a) el capital social y humano se ve afectado al percibir que se violan los derechos humanos de las poblaciones en donde se asienta la mina; b) los impactos sobre el capital natural son elevados, acumulativos y diferenciados durante todo el ciclo del proyecto y existe la posibilidad de que dichos impactos sean irreversibles, imposibilitando la compensación; c) el Gobierno fomenta las actividades mineras sin un análisis amplio y multisectorial de los costos y beneficios de largo plazo..."

http:/ /icefi.org/wp-content/ uploads / 2014/03/mineriaimpresion.pdf

\section{$\square$}

- ¿De qué problemática habla este párrafo?

Clasifico los problemas que se mencionan en dicho párrafo.

- ¿Qué industrias de la localidad producen problemas sociales?

- ¿Qué modificaciones podrían hacer estas industrias en su forma de organizar y funcionamiento para no generar problemas sociales?

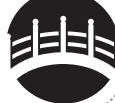

Nos reunimos en equipo y respondemos.

- ¿Qué problemas afectan a más integrantes de nuestra comunidad?

A los problemas que afectan a muchas personas o a la mayoría de integrantes de la comunidad, se les llama problemas sociales. En su conjunto constituyen la problemática social. Casi todos los problemas sociales tienen un componente económico significativo y por ello se les llama problemas socioeconómicos.

Analizamos en equipo:

- ¿Qué problemas sociales de nuestra comunidad tienen un componente económico?

- ¿Cuáles problemas sociales de la comunidad no tiene un componente económico significativo?

Los problemas sociales que surgen por un período relativamente corto se les llama problemas coyunturales; mientras que a los que permanecen por muchos años se les denomina problemas estructurales. Por ejemplo: si los precios del azúcar bajan a nivel mundial, los ingresos de los azucareros bajan. Esto hará que baje el empleo en algunas comunidades cercanas a los ingenios. Este es un problema coyuntural porque cuando los precios del azúcar mejoren, el empleo también debiera mejorar.

En una comunidad agrícola, si no hay suficiente tierra laborable o las fincas contratan a pocas personas, el pago a los y las trabajadores son menores al costo de la canasta básica alimenticia y la canasta básica vital, y hay mucha pobreza. Estos son problemas sociales de carácter estructural porque sus causas están enraizadas en la forma de organizarse de la sociedad, duran décadas y hasta siglos sin resolverse.

- Elaboramos un cuadro para clasificar los problemas sociales de nuestra comunidad. Podemos emplear el siguiente diseño.

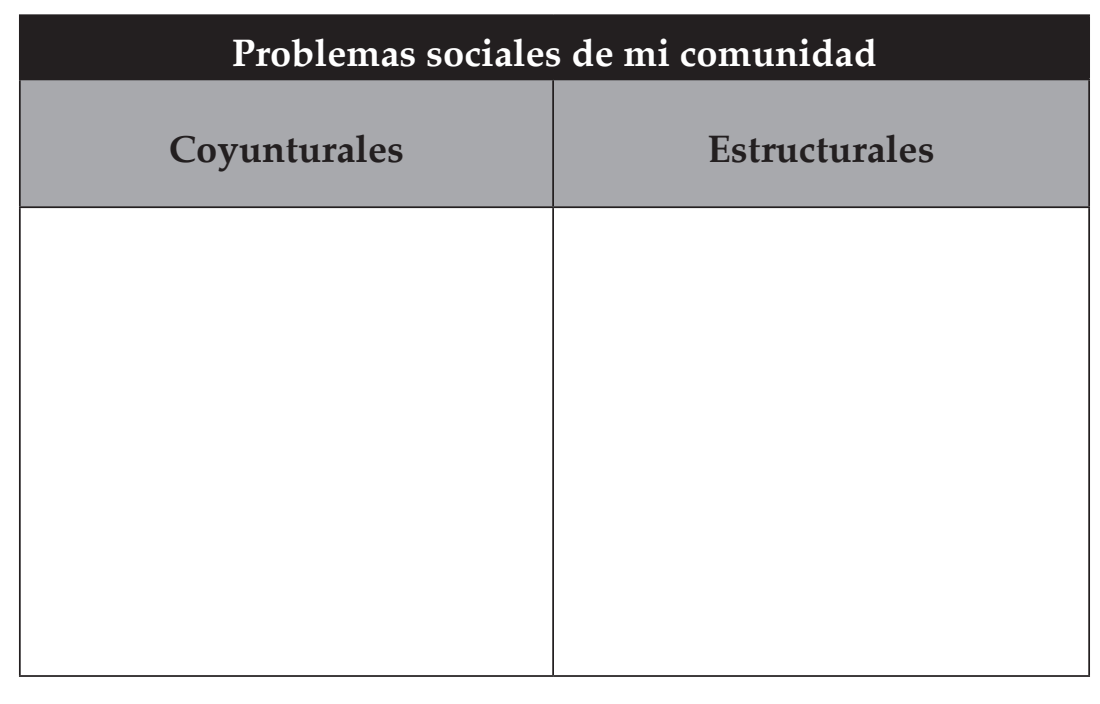

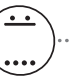




\section{Participación ciudadana}

Cuando las personas deciden apoyar a una institución estatal, municipal o no gubernamental para realizar acciones de beneficio para la comunidad o cuando deciden exigir a las instituciones que cumplan con sus responsabilidades o piden cuenta de lo actuado, realizan participación ciudadana.

Reunámonos en equipo y realicemos lo siguiente.

- Mencionamos cinco ejemplos de participación ciudadana.

- Explicamos qué limitantes tienen las y los jóvenes para realizar participación ciudadana en la comunidad.

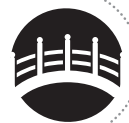

Uno de los principales problemas sociales de las comunidades en Guatemala es la alimentación, porque la cantidad de personas que no tienen posibilidades de nutrirse adecuadamente es muy grande.

\section{Analicemos:}

- ¿Qué sucede con la salud de las personas cuando no se alimentan bien?

- ¿Qué relación tiene la alimentación adecuada con el nivel de desarrollo humano?

Enriquezcamos el catálogo de la producción de nuestra comunidad.

- Verifiquemos que el catálogo incluye las temáticas de desarrollo humano, procesos productivos e infraestructura necesaria del municipio.

- Especifiquemos qué producción contribuye a la alimentación de la comunidad y de qué forma esto incide en el desarrollo humano.

- Describamos qué procesos productivos e infraestructura están orientados a la producción de alimentos y a la educación.

- Realizo una autoevaluación mediante un PNI. Puedo guiarme con el modelo siguiente.

\begin{tabular}{|l|l|l|l|}
\hline \multicolumn{1}{|c|}{ Criterios } & Problemas & Necesidades & Intereses \\
\hline $\begin{array}{l}\text { En los aprendizajes } \\
\text { que logré. }\end{array}$ & & & \\
\hline $\begin{array}{l}\text { Aportes que brindé } \\
\text { al catálogo de pro- } \\
\text { ductos. }\end{array}$ & & & \\
\hline
\end{tabular}

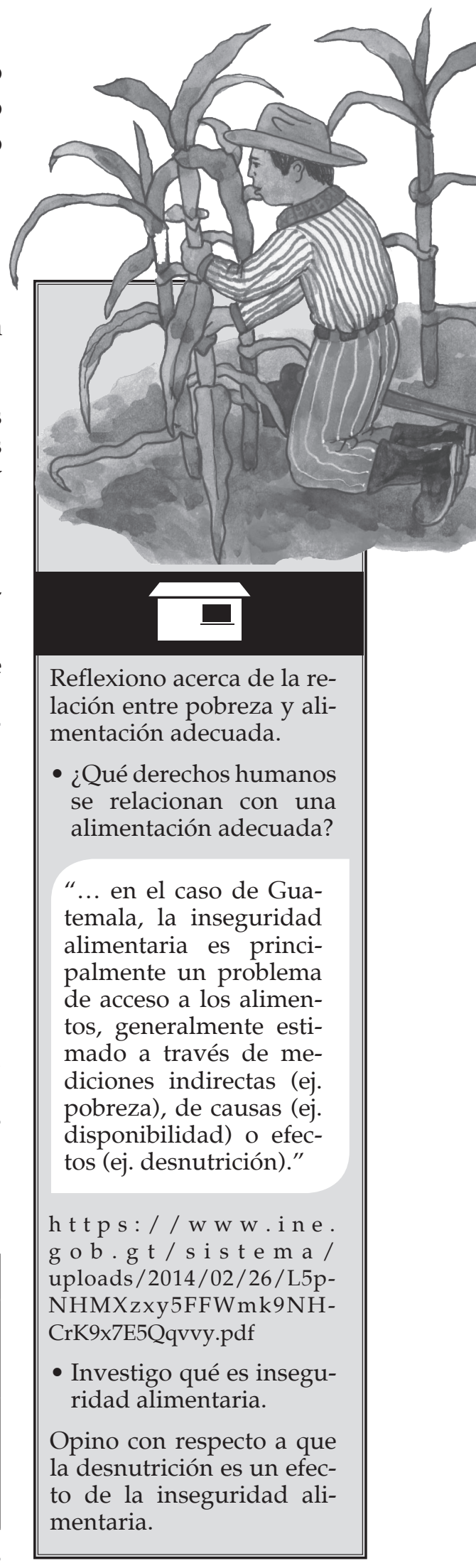


Las estufas ahorradoras de leña permiten reducir la deforestación, facilitan la limpieza e higiene para la cocción de alimentos y mejoran la salud expulsando el humo de la casa mediante una chimenea. Diferentes tipos de estufas ahorradoras comparten ser de aproximadamente un metro de alto y encerrar el calor con una pequeña abertura para introducir la leña y encender el fuego. El calor se distribuye y mantiene caliente una plancha con hornillas sobre las cuales se pueden colocar ollas, jarros o comales de distintos tamaños para calentar varios alimentos al mismo tiempo con poca leña.

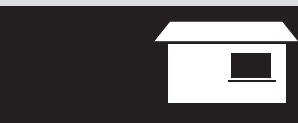

Investigo si hay una o persona dedicada a la albañilería que me explique cómo se construye una estufa ahorradora de leña. Si no hay, busco las instrucciones en internet.

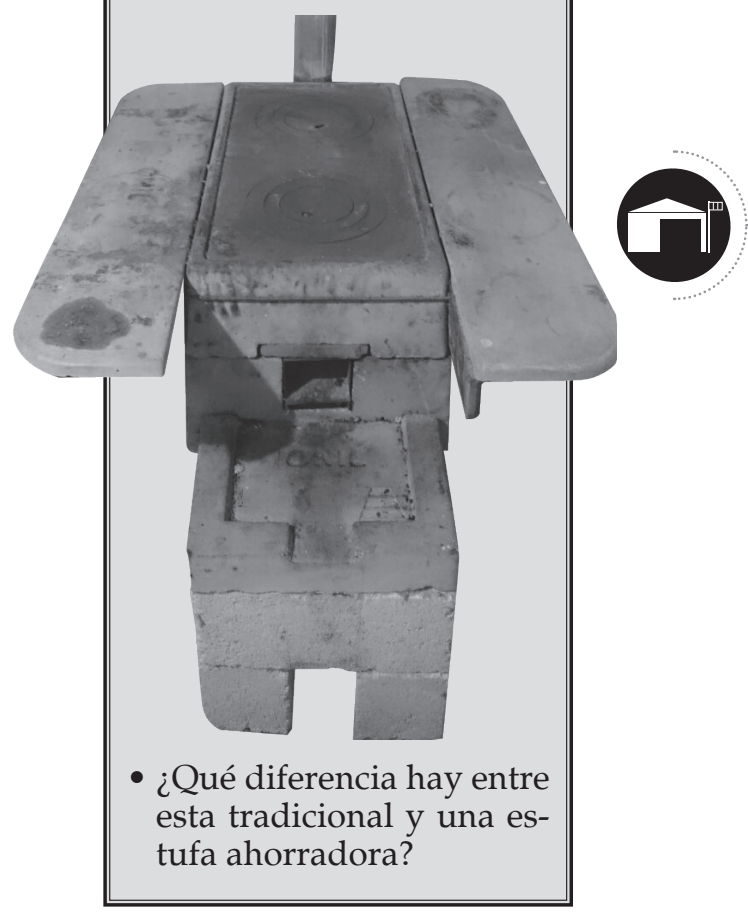

La gastronomía estudia los componentes culturales relacionados con la preparación de alimentos: conocimientos, ingredientes, recetas y técnicas culinarias. La gastronomía guatemalteca es rica en sabores de diferente procedencia: maya, hispana, garífuna, xinka y otros. La comida es más que alimento para satisfacer el hambre. También tenemos comidas especiales, como las que se preparan durante la época de Cuaresma y Semana Santa, para el primero de noviembre, para Navidad, las bodas, las velaciones y aniversarios; así como para otras ocasiones importantes. Son tan importantes los ingredientes como su preparación. Vestigios arqueológicos mayas muestran fogones colectivos donde se preparaban alimentos para muchas personas, para ocasiones especiales. Muchas familias se reúnen para preparar tamales $\mathrm{u}$ otros alimentos, pasando recetas de generación en generación por medio del ejemplo y la práctica.

El maíz tiene un lugar principal en la gastronomía guatemalteca. Alimento que, en la cosmovisión maya y según el Popol Wuj, dio origen al ser humano. Está presente tanto en la comida diaria como la ceremonial. El Popol Wuj narra cómo Tepew y Q'ukumatz se pusieron contentos "al encontrar un lugar de abundancia lleno de fragancias, abundante en mazorcas amarillas y mazorcas blancas, abundante también en pataxte y cacao; de incontables zapotes, anonas, jocotes, nances, matasanos y miel". También se refiere a pequeños alimentos, grandes alimentos, pequeñas plantas y grandes plantas en relación a la fauna y flora comestibles.

En nuestro país, crecen diversas plantas alimenticias, que forman parte de la dieta alimenticia tradicional. El bledo o amaranto, la chaya, el ramón; son ejemplos de plantas altamente nutritivas y que deben formar parte de la dieta cotidiana. En tiempos más recientes se ha incorporado al consumo tradicional de atoles, propio del área maya, la Incaparina de alto valor nutritivo, inventada por el bioquímico Ricardo Bressani y desarrollada por el Instituto de Nutrición de Centroamérica y Panamá.

Investigamos y rescatamos la siembra y preparación de plantas que consumían las y los abuelos.

Elaboramos una lista de los productos alimenticios que consumimos diariamente. Los clasificamos en comida chatarra y comida tradicional. Analizamos nuestros hábitos alimenticios.
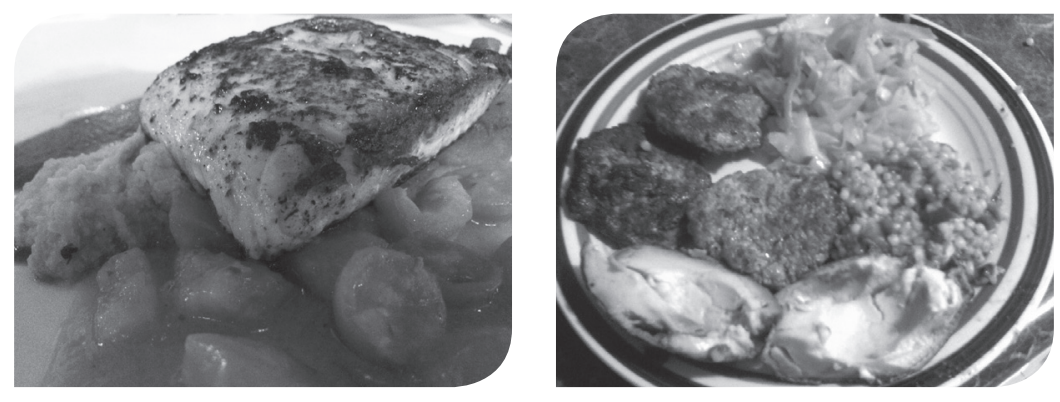
El secreto de una dieta nutritiva es la variedad: alimentos verdes, rojos, amarillos; entre más colorida nuestra comida mayor valor nutricional tendrá. Sembrar un huerto en casa ayuda a tener alimentos de bajo costo al alcance de la mano. Un caldo de hierbas con verduras (güisquil, papa, zanahoria, chile pimiento, cebolla, ajo) es un gran alimento y más si agregamos huevo o carne. En la dieta diaria es importante incluir abundante consumo de frutas frescas, propias de nuestra región. Mejor si son frutas de traspatio que se han cultivado de manera orgánica. Incluir frutas y vegetales frescos en la dieta, fortalece el sistema inmunológico y evita enfermedades. Si cada comida tiene un poquito de cada alimento damos fuerza a nuestro cuerpo y cerebro. Un niño o niña que come diferentes alimentos rinde más en la escuela.

El maíz es un alimento muy importante y combina bien con otros, por ejemplo, las tortillas de maíz con frijol y pepitoria, es una comida muy nutritiva. Es importante seleccionar y combinar adecuadamente los alimentos para que sean más provechosos, saludables y nutritivos.

Hagamos cuentas, ¿cuántos huevos podemos comprar con lo que cuesta un agua gaseosa? El agua gaseosa y las chucherías nos dan energía vacía, nos sentimos con sensación de llenura y fuerza pero solo por un momento y pueden dañar nuestro cuerpo permanentemente, por eso es mejor tomar un vaso de Incaparina.

Tener una dieta sana, variada y balanceada es salud porque nos mantiene bien y evita que nos enfermemos. Importante es recordar que la higiene y el aseo en la cocina, utensilios y al preparar los alimentos; evita que nos enfermemos.

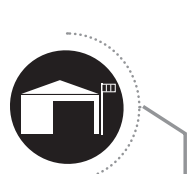

A partir de los productos que hemos incluido en nuestro catálogo preparamos cinco menús variados y nutritivos utilizando alimentos tradicionales $y$ de bajo precio. ¿Qué aprendimos sobre el valor alimenticio de lo que producimos en la comunidad y nuestra condición nutricional? Preparamos un menú en casa.
Desde la época prehispánica, la sal ha sido importante para la conservación de alimentos. Se utilizó la sal marina además de sal de minas de Sacapulas, Quiché; San Mateo Ixtatán, Huehuetenango y Salinas de los Nueve Cerros, Alta Verapaz. Ejemplos de comida conservada son: el patín, pescaditos salados y secos que se preparan en salsa de tomate; tiras de carne salada que se colocan a más de un metro encima del fogón para que se ahumen y se preparen en caldo; los chiles guaque y pasa que se colocan maduros sobre láminas y se exponen al sol durante 15 días para que se sequen y se utilicen para preparar diferentes recados.

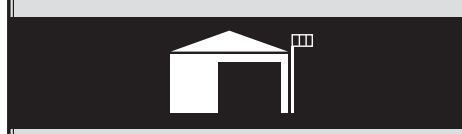

Identifiquemos técnicas antiguas y modernas de conservación de alimentos.

Miremos videos que muestran estas técnicas. 


\section{Diseños Creativos: Exposición con enfogue artístico}

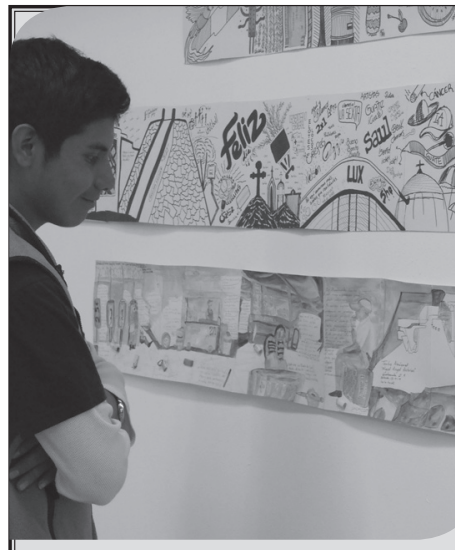

Composición de Arte Plástico

Al unir el resultado de varias ideas que han quedado plasmadas en dibujos o pinturas, puede realizarse una composición temática. Ya estudiamos la técnica del "bodegón" y realizamos uno con los productos de la comunidad y lo incluimos en el catálogo. En él se conjugan ya las ideas de una composición con la finalidad de expresar un tema. Al revisar el catálogo, podemos ampliar el tema utilizando nuestros dibujos y pinturas de productos locales y agregarlos.

\section{Ideas para exhibir} y divulgar nuestro catálogo

1. Conseguimos cajas grandes de cartón

2. Reunimos herramientas y materiales, goma, tijeras, cuchillas, pinturas, etc. Es importante tener a la mano nuestros dibujos y pinturas realizados en clase.

3. Con las ideas de todos, elaboramos afiches $y$ otros exhibidores, para divulgar el catálogo en la comunidad.
Para mostrar los productos y servicios que produce nuestra comunidad podemos usar lo que hemos aprendido sobre líneas y colores. Agregaremos algunas técnicas para conseguir texturas y lo integraremos en la preparación de nuestro catálogo. Utilizaremos materiales de reciclaje y otros que puedan conseguirse en la comunidad. Luego, agregaremos los productos artísticos que hayamos elaborado en las clases anteriores o realizaremos los que falten.

\section{Texturas con líneas y colores}

La textura es uno de los elementos visuales más completos de las artes plásticas. El uso de la línea definiendo direcciones y contornos, es un ejemplo de esta técnica. En un espacio cuadrado se pueden aplicar distintas direcciones de líneas y el efecto de textura es muy efectivo. También se logran efectos interesantes aplicando puntos de colores. Observo estos ejemplos:
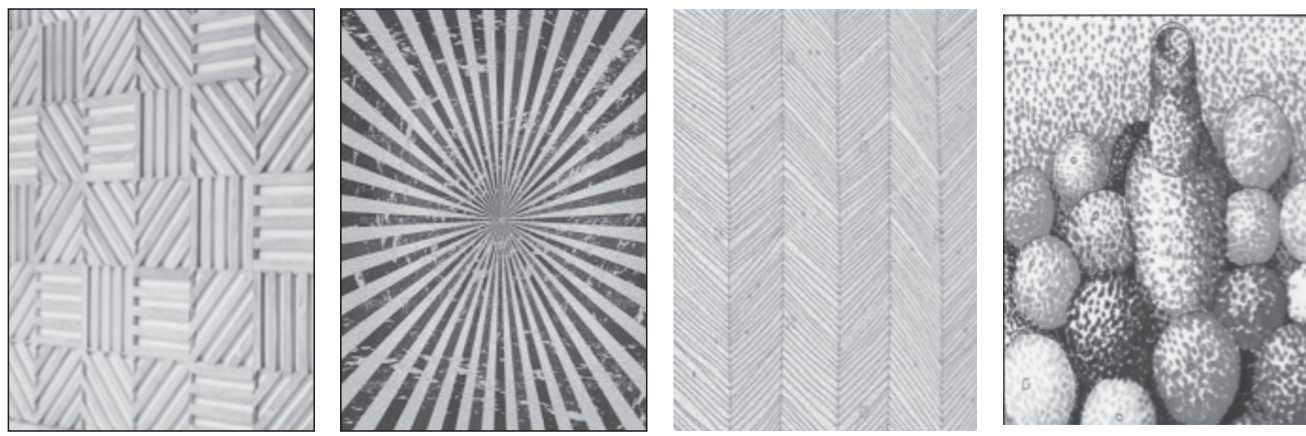

Las líneas se aplican en diferentes direcciones. Se pueden hacer utilizando crayones o marcadores de colores. La aplicación de puntos se hace según la concentración de ellos en una forma. A mayor densidad de puntos, menos luz. Si se separan los puntos, se logra mayor concentración de luz.

La importancia de las texturas es el efecto visual que provocan, pues la vista crea la ilusión que al tocar, hay algo más que solo líneas. Esta ilusión provoca la sensación de superficies ásperas, lisas, rugosas, raspadoras, estriadas o irregulares.

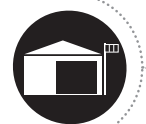

Realizamos tramas con líneas de diversos colores en distintas direcciones:

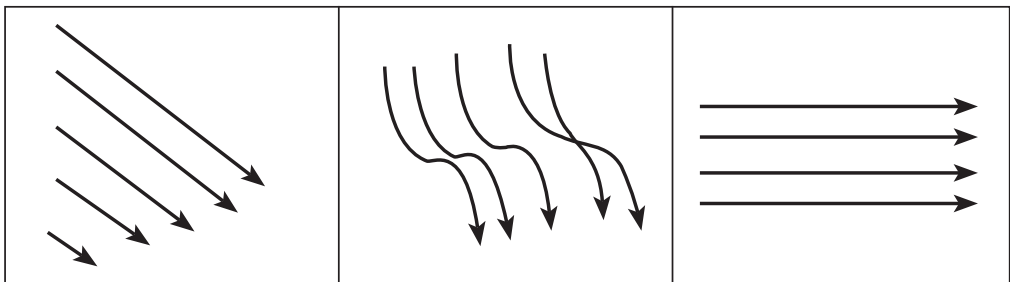

En cartulinas, realizamos dibujos de los productos de la comunidad que queremos destacar más de nuestro catálogo. Los decoramos con la técnica de líneas y texturas. Podemos usar también pliegos de papel bond, periódico o cartulina, para hacer dibujos más grandes. 


\section{Las etapas finales de la redacción}

\section{Un fenómeno de nuestra época}

La comunicación masiva se da entre un emisor, el comunicador, y un receptor numeroso, la audiencia. "Masiva" se refiere entonces al número de personas que van a recibir la información y que debe cumplir con tres condiciones: ser grande, ser heterogéneo o variado y ser anónimo. Se da por medio de la televisión, la radio, los periódicos, la internet y otros.

La comunicación incide directamente en las sociedades y por ello la publicidad y la política, se han servido de ella. Sin embargo, tiene su costo en la vida de las personas que pueden ser desinformadas y manipuladas. Sus funciones son: 1. Formar o educar, 2. Informar, 3. Entretener y 4. Formar opinión (persuadir y orientar).

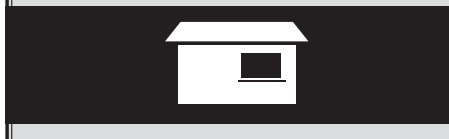

- Investiguemos las palabras nuevas o desconocidas.

- Revisemos diferentes programas de radio y televisión y de revistas y periódicos. Luego, clasifiquémoslos por su función.
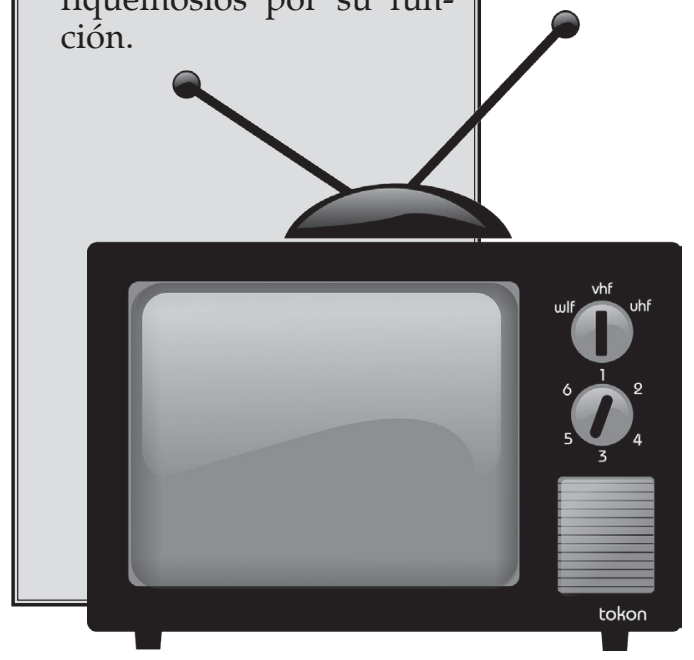

(150)
Hemos aprendido a generar un ensayo a partir de mapas conceptuales, redacción de párrafos y pequeños escritos. Ahora, aprenderemos cómo darle una estructura lógica y revisarlo para que sea más eficaz, por medio de los siguientes pasos:

1. Estructura: debe tener un párrafo de introducción que lleve una o dos oraciones con la descripción del tema y dos o tres, con la justificación o importancia de escribir sobre eso. Luego, irán varios párrafos con el desarrollo del tema. Y, por último, uno, con las conclusiones finales.

2. Lectura de revisión: ¿Puede comprobarse lo que se está afirmando? ¿La descripción y la narración corresponden con la realidad? ¿Se relacionan las conclusiones con la introducción y el desarrollo del texto? ¿El texto está claro y correctamente escrito (ortografía y redacción)?

3. Publicación o presentación: la manera estándar comprende la impresión del trabajo en páginas con el formato siguiente: márgenes de una pulgada, letra del tipo de fuente times de doce puntos y espacio de uno y medio renglones. Este tipo de letra es aconsejable porque facilita la lectura. Depende del uso que vayamos a darle a nuestro ensayo, podemos presentarlo en un fólder o carpeta y empastarlo.

\section{Concordancia gramatical}

Observemos en las siguientes oraciones que los artículos (La, Los) y los adjetivos (distante, susurrantes) tienen el mismo género gramatical del sustantivo que acompañan. De igual manera, los verbos varían del singular al plural (brilla, guardan). Esta armonía se llama concordancia gramatical y es muy importante porque le da coherencia y claridad al lenguaje:

La estrella distante brilla en la noche.

Los árboles susurrantes guardan mil secretos.

Retomamos un ensayo que hayamos escrito antes, le aplicamos los pasos de la revisión final y lo corregimos hasta su versión para publicar. Aplicamos estos criterios en la revisión de la redacción final del catálogo.

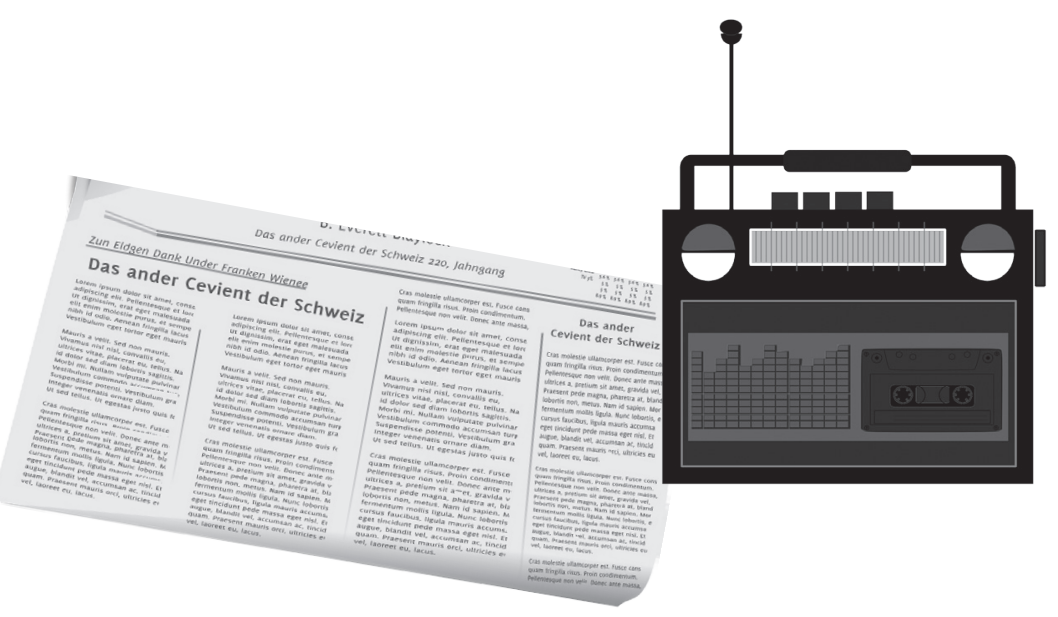

Semana 12

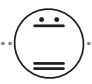




\section{La narración}

Esta manifestación del arte también se conoce como Género Épico. La palabra Epos significa "narración" en griego. Se deriva del poema épico de la antigüedad que consistía en un poema narrativo extenso, de estilo elevado, personajes heroicos, grandes hazañas e intervenciones mágicas o sobrenaturales. Un ejemplo clásico de poema épico es La Eneida de Virgilio. Poco a poco, esta relación de hechos fue conformando un relato o narración con características similares: acción, descripción, personajes, ambientes, drama. Las diferencias esenciales son que el poema épico está escrito en verso y que la narración tiene diálogos.

Dentro de la narración encontramos variantes como: crónica de viajes, autobiografía, leyenda, fábula, cuento y novela. También aquí podemos incluir la historieta y la novela gráfica.

\section{El cuento y la novela}

Tanto el cuento como la novela están escritos en prosa y en ella se narran acciones reales y ficticias. Contienen los mismos elementos: tema o asunto; argumento, o encadenamiento de las acciones; personajes o actores; tiempo o duración del argumento; espacio o escenario donde sucede las acciones; y narrador, un personaje bajo cuya perspectiva o punto de vista se va contando lo que sucede en el relato. La diferencia entre ambos géneros es esencialmente la extensión, aunque hay rasgos estilísticos propios de cada uno. El cuento, generalmente, puede leerse de una sola vez. La novela, por su parte, puede estar dividida en capítulos o episodios y su argumento es más complejo.

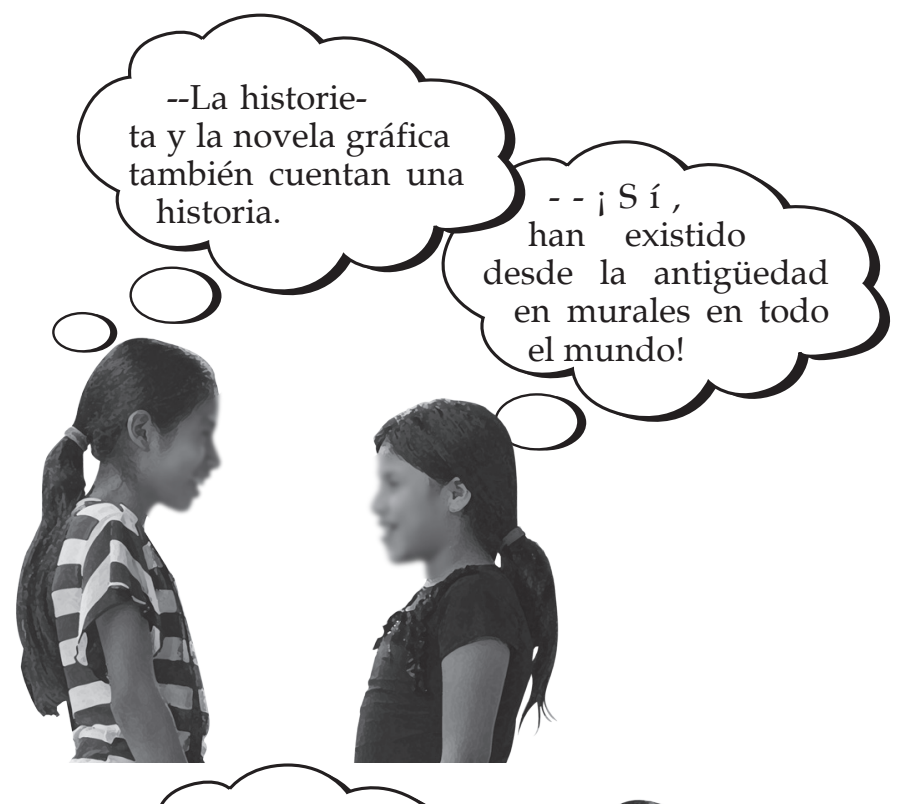

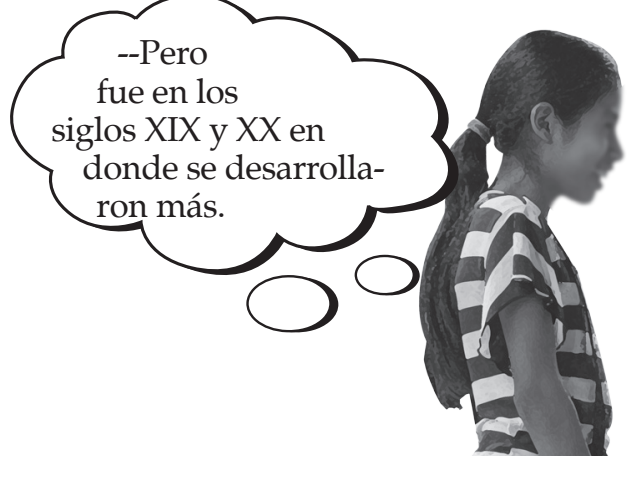

(151)

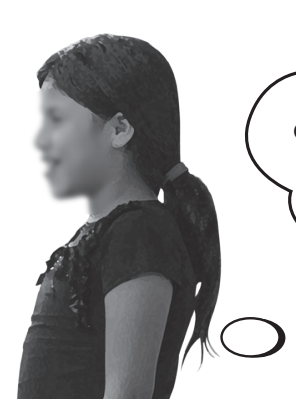

Semana 12
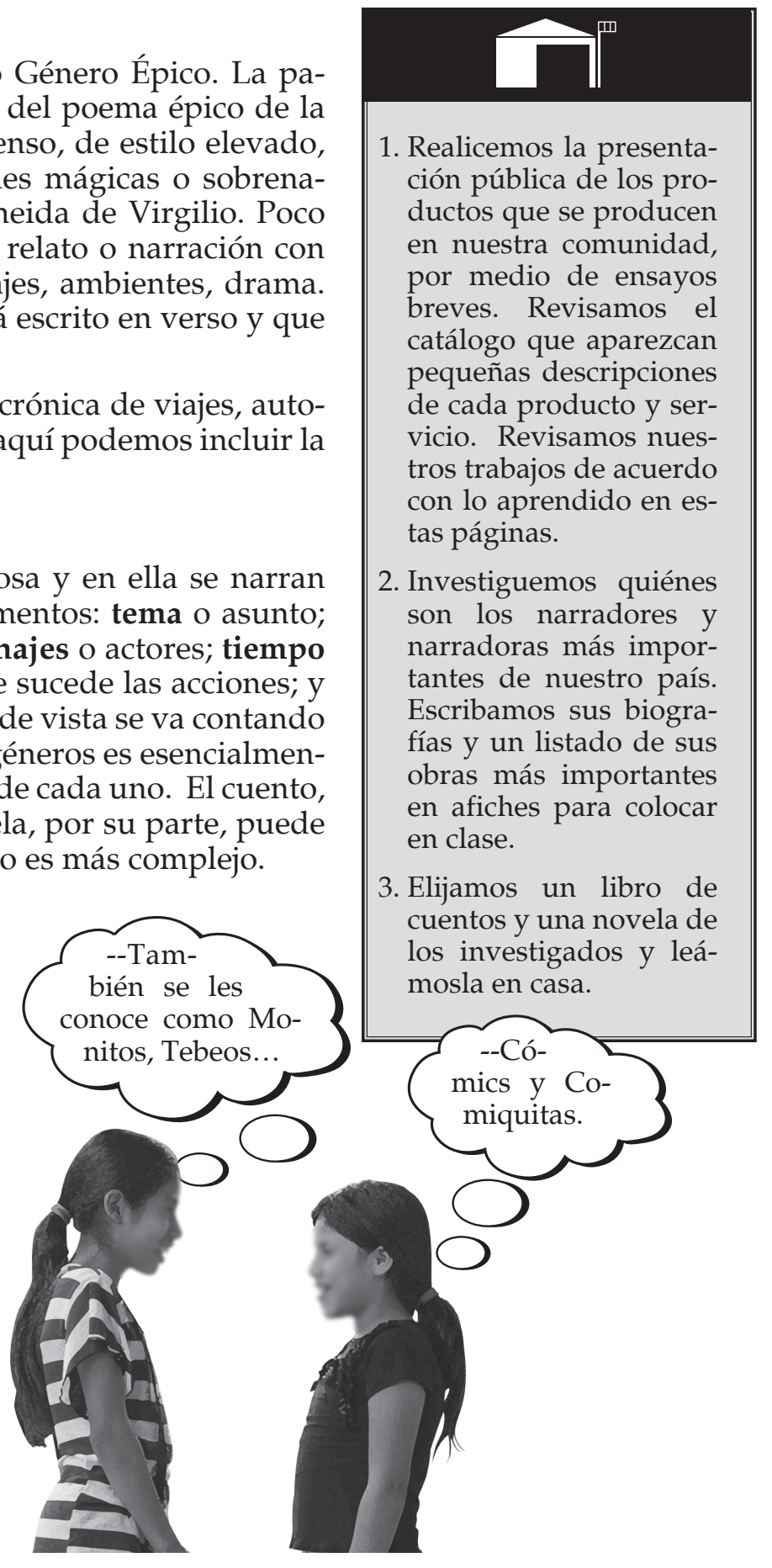

1. Realicemos la presentación pública de los productos que se producen en nuestra comunidad, por medio de ensayos breves. Revisamos el catálogo que aparezcan pequeñas descripciones de cada producto y servicio. Revisamos nuestros trabajos de acuerdo con lo aprendido en estas páginas.

2. Investiguemos quiénes son los narradores y narradoras más importantes de nuestro país. Escribamos sus biografías y un listado de sus obras más importantes en afiches para colocar en clase.

3. Elijamos un libro de cuentos y una novela de los investigados y leámosla en casa.

\section{bién se les}

conoce como Monitos, Tebeos...

to! Y fueron

orientadas más hacia lo cómico para aparecer en los periódicos.

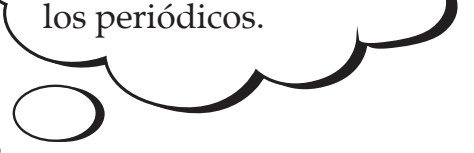


PROYECTO No. 2. Producción de mi comunidad.

Reflexión sobre mi participación en el desarrollo del proyecto

Marco $\boldsymbol{X}$ en las casillas que considero corresponden a mis actitudes en relación con mi participación y aprendizaje.

\begin{tabular}{|c|c|c|c|}
\hline Actitud & Siempre & Casi siempre & Nunca \\
\hline $\begin{array}{l}\text { Reconozco que en cada actividad realizada mi pro- } \\
\text { pósito fue aprender para la vida. }\end{array}$ & & & \\
\hline $\begin{array}{l}\text { Me interesé por profundizar lo aprendido en clase } \\
\text { y realicé las investigaciones propuestas. }\end{array}$ & & & \\
\hline $\begin{array}{l}\text { Relacioné la información vista en clase con la cultu- } \\
\text { ra, salud, recreación, deporte, ambiente, producti- } \\
\text { vidad y economía de mi comunidad. }\end{array}$ & & & \\
\hline $\begin{array}{l}\text { Los conocimientos recibidos en clase me parecen } \\
\text { importantes para valorar y mejorar el ambiente na- } \\
\text { tural, la salud, el intercambio cultural, la economía } \\
\text { y productividad de mi comunidad. }\end{array}$ & & & \\
\hline $\begin{array}{l}\text { Cada semana, asigné un horario específico a mis } \\
\text { estudios }\end{array}$ & & & \\
\hline Realicé a tiempo las tareas asignadas. & & & \\
\hline $\begin{array}{l}\text { Evité copiar las tareas de mis compañeros porque } \\
\text { les faltaría el respeto y porque limitaría mi apren- } \\
\text { dizaje. }\end{array}$ & & & \\
\hline $\begin{array}{l}\text { En mis investigaciones elegí, analicé y sinteticé la } \\
\text { información y evité copiar la información. }\end{array}$ & & & \\
\hline $\begin{array}{l}\text { Reconozco que mi realidad inmediata puede cam- } \\
\text { biar al utilizar mis nuevos conocimientos. }\end{array}$ & & & \\
\hline $\begin{array}{l}\text { Reconozco las acciones que promueven la salud, re- } \\
\text { laciones entre culturas, producción, el trabajo digno } \\
\text { y la mejora de la economía de mi comunidad. }\end{array}$ & & & \\
\hline $\begin{array}{l}\text { Colaboro a mis compañeros y compañeras en el } \\
\text { proceso de su aprendizaje. }\end{array}$ & & & \\
\hline
\end{tabular}




\section{Evaluación por Competencias}

\begin{tabular}{|c|c|c|c|}
\hline Actitud & Siempre & Casi siempre & Nunca \\
\hline $\begin{array}{l}\text { Demuestro respeto a mí persona, compañeros(as), } \\
\text { docentes y centro educativo. }\end{array}$ & & & \\
\hline $\begin{array}{l}\text { Propongo soluciones y aporto ideas cuando partici- } \\
\text { po en equipos de trabajo. }\end{array}$ & & & \\
\hline $\begin{array}{l}\text { Expreso mis sentimientos y pensamientos con res- } \\
\text { peto, sin ofender a otras personas en el momento } \\
\text { oportuno. }\end{array}$ & & & \\
\hline $\begin{array}{l}\text { Respeto la participación, ideas, diferencias físicas, } \\
\text { intelectuales, religión, idioma, cultura y género de } \\
\text { quienes conforman mi clase. }\end{array}$ & & & \\
\hline $\begin{array}{l}\text { Me intereso por hablar y escribir en mi idioma ma- } \\
\text { terno. }\end{array}$ & & & \\
\hline $\begin{array}{l}\text { Utilizo diferentes estrategias para solucionar pro- } \\
\text { blemas. }\end{array}$ & & & \\
\hline $\begin{array}{l}\text { Analizo y utilizo conceptos importantes de ecosis- } \\
\text { temas, economía, productividad, interculturalidad, } \\
\text { salud, deportes y otros. }\end{array}$ & & & \\
\hline $\begin{array}{l}\text { Comparo conceptos y distingo sus diferencias y si- } \\
\text { militudes. }\end{array}$ & & & \\
\hline $\begin{array}{l}\text { Observo fenómenos de la Naturaleza y realizo ex- } \\
\text { perimentos para comprobar aprendizajes. }\end{array}$ & & & \\
\hline $\begin{array}{l}\text { Utilizo las herramientas tecnológicas como apoyo } \\
\text { para mi aprendizaje. }\end{array}$ & & & \\
\hline $\begin{array}{l}\text { Utilizo el arte para expresar mis ideas y sentimien- } \\
\text { tos. }\end{array}$ & & & \\
\hline $\begin{array}{l}\text { Aprecio las diferentes expresiones artísticas (músi- } \\
\text { ca, plásticas, teatro, danza) como desarrollo perso- } \\
\text { nal y social. }\end{array}$ & & & \\
\hline
\end{tabular}

\section{Anecdotario:}

Lleno los espacios para contar mi experiencia con las actividades del proyecto.

\begin{tabular}{|l|c|c|c|c|}
\hline Actividad & $\begin{array}{c}\text { ¿Cómo } \\
\text { fue la } \\
\text { actividad? }\end{array}$ & $\begin{array}{c}\text { Por qué } \\
\text { me gustó o } \\
\text { impactó? }\end{array}$ & $\begin{array}{c}\text { iQué fue lo } \\
\text { que pasó? }\end{array}$ & $\begin{array}{c}\text { Dos datos } \\
\text { interesantes }\end{array}$ \\
\hline & & & & \\
\hline & & & & \\
\hline
\end{tabular}




\section{Uso sustentable de los recursos}

Aprendemos sobre algunos procesos físicos, químicos y biológicos que intervienen en el origen de los recursos naturales que posee el país y nuestra comunidad. Estos recursos son medios que permiten satisfacer necesidades humanas, pero son escasos. Por consiguiente, es necesario su uso sustentable para preservar su valor social, económico y ambiental. Para profundizar en nuestros conocimientos, organizaremos una feria científica, en donde presentaremos propuestas de solución a la problemática socio ambiental de la comunidad.

\section{¿Qué deseamos?}

Formular propuestas de solución a la problemática socioambiental de la comunidad y presentarles en una feria científica.

\section{¿Qué haremos?}

Planificaremos y organizaremos una feria científica en la que se expongan los hallazgos, experiencias e inventos que muestren propuestas de solución a la problemática socioambiental de la comunidad y región. Para ello, emplearemos herramientas tecnológicas, recursos físicos y, preferentemente, materiales reciclados o de fácil acceso.

Prepararemos el lugar de exposición con los elementos esenciales. Utilizaremos términos científicos apropiados para explicar los fenómenos y procesos físicos, químicos y biológicos relacionados con los recursos naturales y el uso racional de los mismos.

Propondremos acciones realizables para mejorar el ambiente ecológico, lo haremos en cuatro ámbitos: individual, familiar, vecinal y comunitario. Finalmente, realizaremos acciones esenciales de desmontaje y limpiaremos el lugar utilizado. En todo el proceso manifestaremos habilidades comunicativas.

\section{¿Con quiénes trabajaremos?}

Participaremos en equipos, contaremos con la orientación de nuestra tutora o tutor y la colaboración de tutores y tutoras, padres y madres de familia y autoridades educativas o de la comunidad. Es importante que, en la designación de responsabilidades, el grupo fomente la participación de diversas personas lo que dé oportunidad a todas para aportar.

\section{¿Cómo procedemos?}

\section{a. Investigación}

Comenzamos por realizar una investigación acerca de las experiencias o inventos realizados por mujeres y hombres que aportan a la solución de la problemática socio ambiental. Por ejemplo, los recursos tecnológicos que se aplican para mejorar los productos agrícolas, sin dañar el ambiente. Cada grupo acordará, por consenso, la experiencia que quiere presentar en la feria científica.

\section{b. Organización}

Analizamos la viabilidad de presentar los inventos o experiencias relacionadas con los recursos naturales y el uso sustentable de los mismos. Luego elegimos los más relevantes. 


\section{naturales}

\section{PROYECTO}

c. Producto

- Después de consultar con su grupo, las coordinadoras o coordinadores se reúnen para acordar los elementos que se exhibirán en la feria científica. Además asignarán las experiencias o inventos para que cada grupo elabore sus materiales y diseñe su exposición.

- Elaboramos las presentaciones de las experiencias o inventos que se expondrán en la feria científica.

- Colaboramos en el diseño y la organización del montaje de la feria científica.

- Participamos en la feria científica.

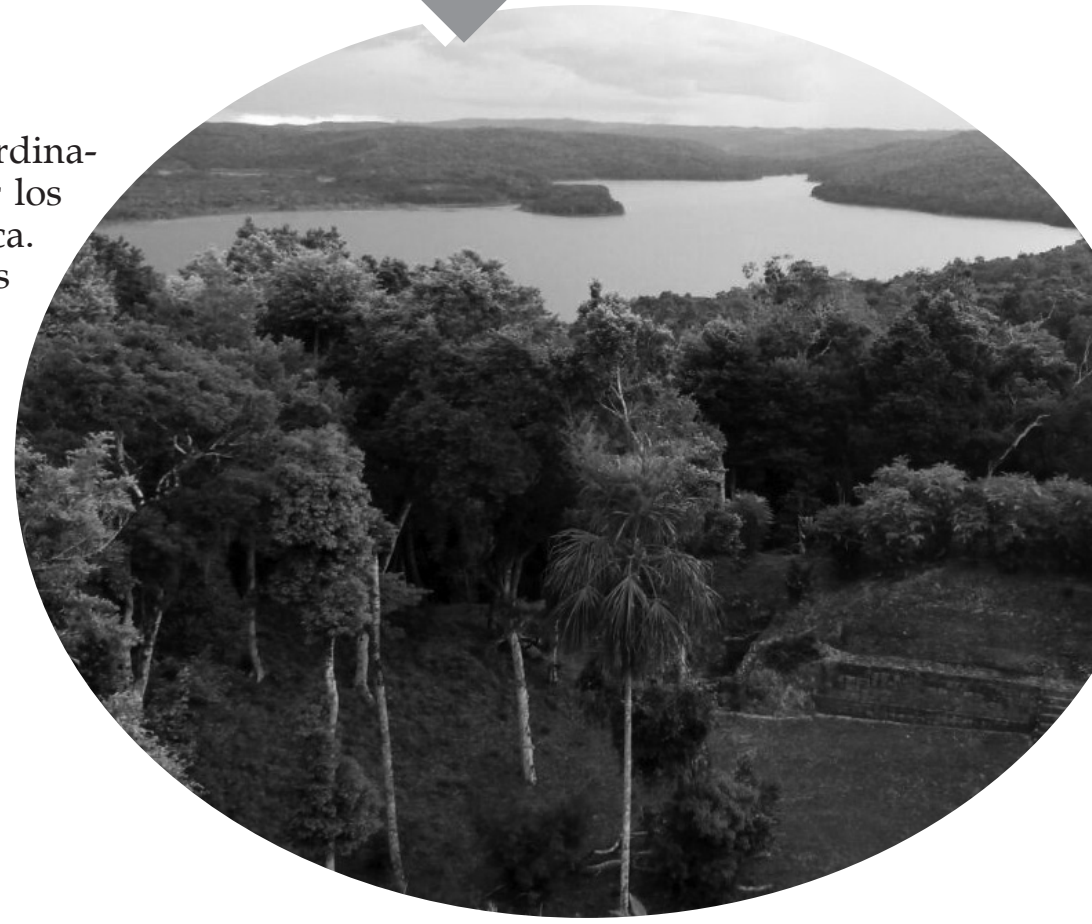

\section{¿A quién presentaremos nuestro producto?}

Con nuestra tutora o tutor, acordamos a quiénes invitaremos a la feria científica. Puede ser a quienes estudian en el centro educativo y demás tutoras o tutores, madres y padres de familia, autoridades, líderes y lideresas de la comunidad. Las personas relatoras pueden organizar una presentación ante quienes muestren interés en las experiencias e inventos que se presentarán.

\section{¿Cómo distribuiremos el †iempo?}

\begin{tabular}{|l|l|l|l|l|l|l|}
\hline \multicolumn{1}{|c|}{ ACTIVIDAD } & $\mathbf{1}^{\mathbf{a}}$ & $\mathbf{2}^{\mathbf{a}}$ & $\mathbf{3}^{\mathbf{a}}$ & $\mathbf{4}^{\mathbf{a}}$ & $\mathbf{5}^{\mathbf{a}}$ & $\mathbf{6}^{\mathbf{a}}$ \\
\hline $\begin{array}{l}\text { Investigación de inventos y experiencias } \\
\text { científicas del mundo y de Guatemala que } \\
\text { estén relacionadas con el uso sustentable de } \\
\text { los recursos naturales que aportan a solu- } \\
\text { cionar la problemática socio ambiental. }\end{array}$ & & & & & & \\
\hline Planificación de la feria científica. & & & & & & \\
\hline $\begin{array}{l}\text { Análisis y selección de las experiencias } \\
\text { o inventos a presentar. }\end{array}$ & & & $\checkmark$ & & & \\
\hline $\begin{array}{l}\text { Elaboración de las presentaciones de } \\
\text { experiencias o inventos que se expon- } \\
\text { drán en la feria científica }\end{array}$ & & & & & & \\
\hline $\begin{array}{l}\text { Diseño para el montaje de la feria } \\
\text { científica }\end{array}$ & & & & & $\checkmark$ & \\
\hline Organización de la feria científica & & & & & & $\checkmark$ \\
\hline
\end{tabular}




\section{Los sonidos de la vida cotidiana}

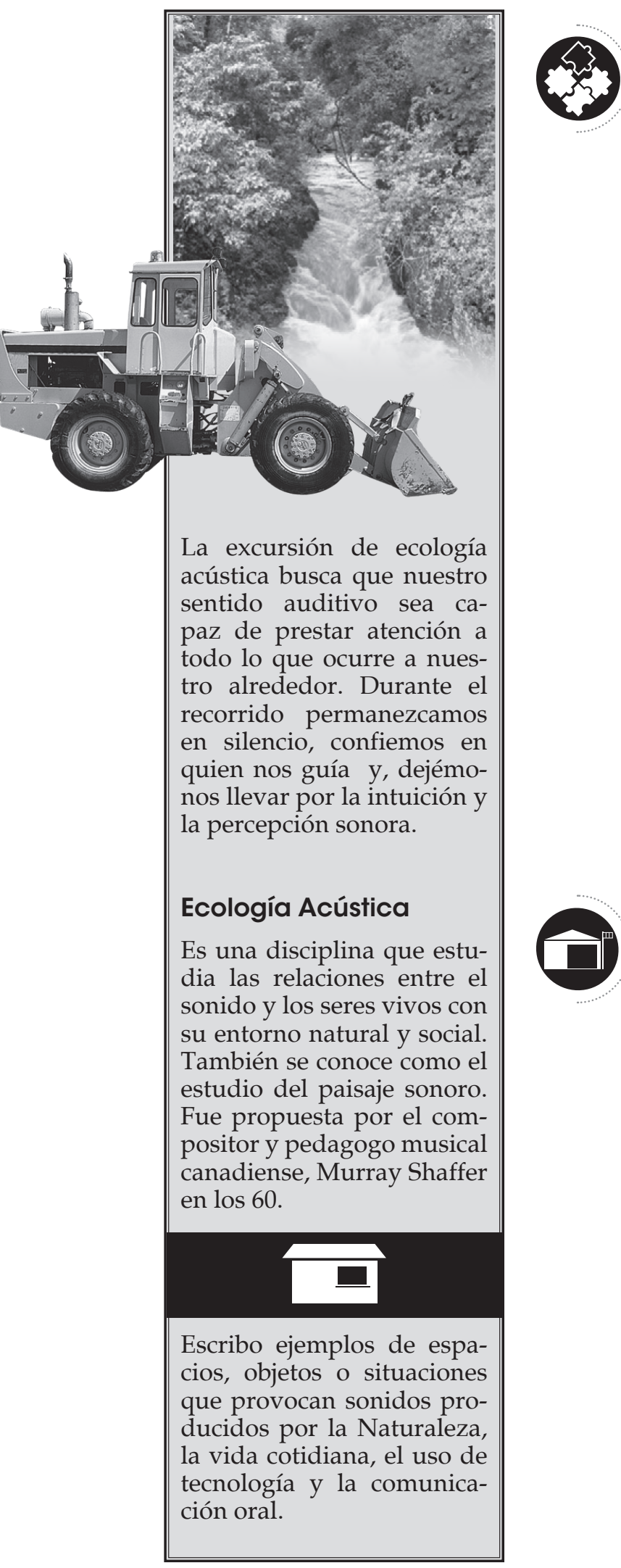

La excursión de ecología acustica busca que nuestro tro alrededor. Durante el recorrido permanezcamos en silencio, confiemos en quien nos guía $\mathrm{y}$, dejémola percepción sonora.

\section{Ecología Acústica}

Es una disciplina que estulas relaciones entre el canadiense, Murray Shaffer en los 60 .

Escribo ejemplos de espacios, objetos o situaciones que provocan sonidos procidos por la Naturaleza, ción oral.
Reflexionemos y opinemos en equipo.

- ¿La Naturaleza y todo lo que nos rodea emite un tipo de música?

- ¿Qué factores sociales pueden incidir en que se pierdan los sonidos de la Naturaleza?

- ¿Cómo podemos evitar este problema en nuestra comunidad?

- ¿Qué elementos producen sonidos en la comunidad que llegan a generar problemas?

\section{Acústica y Ecología}

Los sonidos que se producen dentro del orden natural del universo son parte de lo que estudia la ecología acústica. Entre ellos están los sonidos:

- De la Naturaleza, la flora, la fauna y los ecosistemas,

- producidos por la humanidad en su quehacer diario,

- de la tecnología en un espacio de convivencia social o de producción,

- resultantes de la comunicación oral entre las personas.

En algunas comunidades se ha vuelto familiar el sonido de los teléfonos, el transporte y las computadoras; pero se ha dejado de apreciar el sonido de nuestra propia respiración o el canto de los pájaros. La ecología acústica estudia esta situación y propone soluciones a este problema.

\section{Excursión de ecología acústica}

- Nos organizamos en grupos y elegimos a alguien que nos guie.

- Nos vendamos los ojos, solo quien guía podrá ver el camino.

- Salimos al patio, o a la calle, quien guía nos llevará por varios espacios para escuchar los sonidos cercanos y lejanos.

- Regresamos y registramos la experiencia, podemos emplear el formato siguiente:

\section{Cuadro de hallazgos sonoros}

\begin{tabular}{|l|l|}
\hline \multicolumn{2}{|c|}{ Escuché } \\
\hline $\begin{array}{l}\text { Sonidos más claros y cerca- } \\
\text { nos }\end{array}$ & $\begin{array}{l}\text { Sonidos menos importantes o } \\
\text { lejanos }\end{array}$ \\
\hline & \\
\hline
\end{tabular}

- Comentamos la vivencia y opinamos sobre el origen de los sonidos que escuchamos. 


\section{Para escuchar más y mejor: las características del sonido}

Una de las causas de sordera proviene del contacto directo y la exposición a sonidos demasiado fuertes. Es común observar espacios reducidos en donde se escucha música o discursos a muy alto volumen. Al escuchar sonidos con altas intensidades durante períodos de tiempo prolongados, el oído va perdiendo su capacidad de escuchar sonidos con bajas intensidades. Esto se debe a que el oído se adecúa al nivel de volumen con que se perciben los sonidos, de tal forma que cada vez es necesario hacerlo con más intensidad.

Algunas condiciones en las que esto ocurre pueden llegar a parecer normales por el tipo de espacio o actividad que las provoca, entre ellas: manejo de maquinaria industrial en espacios cerrados o abiertos, la alta densidad del tránsito en calles o avenidas, uso de amplificadores de sonido en espacios reducidos o muy cercanos y uso de audífonos.

El sonido es producto del impacto de la vibración de ondas sobre los materiales del entorno en que nos encontramos. Según las condiciones de estas ondas, se asigna al sonido cuatro características:

Intensidad: los sonidos pueden ser fuertes o pueden ser débiles

Tono: puede ser agudo o bajo

Timbre: varía según la fuente de la que proviene

Duración: el tiempo que permanece un sonido

Con nuestro grupo escribimos tres sonidos que por su nivel alto de intensidad pueden afectar nuestra salud auditiva. Proponemos una lista de normas a seguir para proteger el ambiente sonoro de la comunidad, y en consecuencia nuestra salud auditiva.

- Identifico los lugares de mayor contaminación sonora en la comunidad.

- Durante una semana iré disminuyendo la intensidad con que escucho el radio y la música con audífonos o con las bocinas del equipo de audio.

- Anoto los resultados en una bitácora, puedo emplear un formato como este.

\begin{tabular}{|l|l|l|l|}
\hline \multicolumn{1}{|c|}{ Días } & \multicolumn{1}{|c|}{ Niveles } & Resultados & Comentario \\
\hline Día 1 & Relativamente alto, 9 o 10 & & \\
\hline Día 2 & Bajar un nivel, 8 & & \\
\hline$\ldots$ & $\ldots$ & & \\
\hline Día 6 & Bajar un nivel, 3 & & \\
\hline
\end{tabular}

- Comparo los resultados de mi experimento con los de mis compañeros y compañeras.
Hay espacios en donde normalmente nos exponemos a altas intensidades de sonido, como las fiestas, reuniones o rituales de cualquier religión que usan altavoces.

- ¿Cómo afectan estos espacios a mi comunidad?

- ¿Qué soluciones propongo para este problema de contaminación sonora?

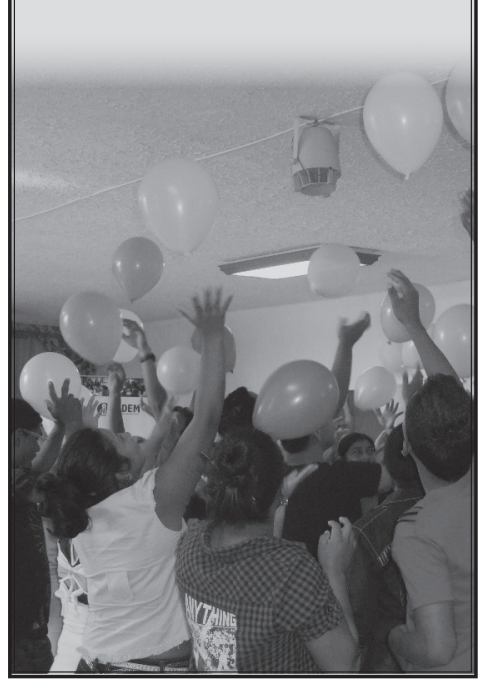




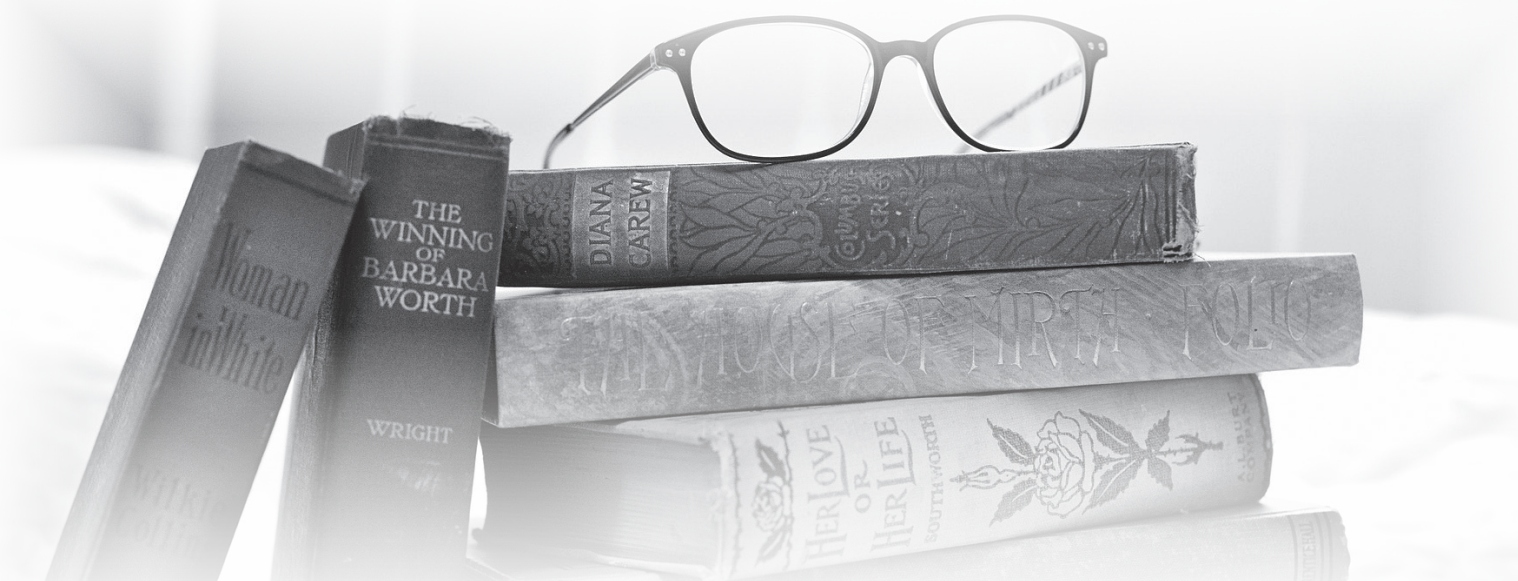

\section{Los recursos de la literatura}

Las figuras literarias son empleadas para transmitir ideas y sensaciones. Existen más de trescientas figuras, pero algunas de las más usadas son:

Comparación o símil. Establece una semejanza directa entre dos cualidades, dos seres o dos hechos. Usa los conectores como, tal como, igual que: "Tus ojos son como dos luceros".

Personificación. Atribuye cualidades o acciones humanas a seres que no lo son, como las plantas, los animales o los objetos: "Lloran las rosas porque no estás aquí."

Hipérbole. Exagera lo que se está interpretando: “Eres lo más bello del universo".

Metáfora: designa una realidad con el nombre de otra con la que mantiene alguna relación de semejanza: "Nuestras vidas son los ríos que van a dar al mar que es el morir."

Anáfora: repite una palabra o conjunto de palabras al comienzo de una frase o verso: "Oh luna que me guiaste, oh luna amable compañera, oh luna mi eterna viajera."

Onomatopeya: consiste en escribir el sonido: “El tic-tac del reloj despertó a todos."

Antítesis: es una contraposición de dos palabras o frases de significación opuesta, que adquieren así mayor alcance y viveza: "Es tan corto el amor y tan largo el olvido."

Ironía: es un procedimiento ingenioso por el que se afirma o se sugiere lo contrario de lo que se dice con las palabras. "Yo no sé porque mi dios le regalo con largueza, sombrero con tanta cinta a quien no tiene cabeza."

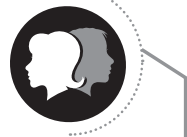

Las figuras literarias se valen de los signos de puntuación y entonación para asegurar que el mensaje está correctamente construido ¿Qué normas conoces sobre el uso del punto, la coma y el punto y coma, signos de exclamación y signos de interrogación?

Organicemos un diálogo sobre los temas ambientales investigados en grupo. Podemos emplear nuestras fichas para apoyar los argumentos.

-Entre tú y yo hay un barranco de diferencia.

- ¿Qué figura literaria se emplea en la oración anterior?

Escribo un párrafo de cinco oraciones usando las palabras de la tabla. Asegúrate de usar las normas correctas de puntuación a lo largo del párrafo e incorporar signos de exclamación e interrogación.

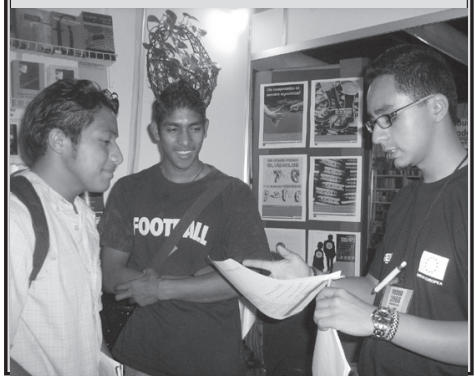




\section{Hipótesis}

\section{Trabajo en grupo}

Escribamos algunas hipótesis o suposición que contesten a algunas de las siguientes preguntas:

- ¿Cuáles son las prácticas de la comunidad más dañinas al entorno natural?

- ¿Qué alternativas están usando las personas para que sus actividades sean menos dañinas al entorno social y ambiental?

- ¿Están más dispuestas las personas jóvenes a modificar acciones que afectan el entorno social y natural?

Ahora establezcan los pasos que seguirán para comprobar si su hipótesis es válida o no.

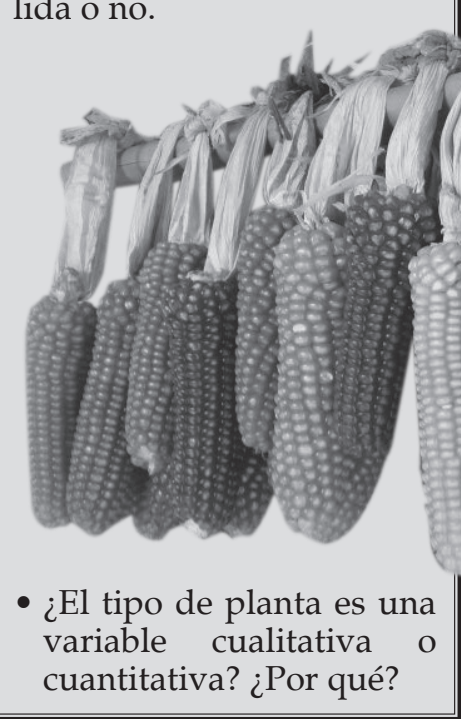

Respondemos con nuestro grupo.

- ¿Qué especies vegetales nativas de nuestra comunidad conocemos?

Si hacemos una investigación sobre dichas especies ¿qué instrumentos de búsqueda de información utilizaríamos? ¿Por qué?

- ¿A quién podríamos entrevistar para obtener información certera?

Recolectamos información sobre 20 plantas que encontramos en nuestra comunidad. Las clasificamos en ornamentales, medicinales y alimenticias. Para registrar la información, podemos emplear una tabla como esta:

\begin{tabular}{|l|l|}
\hline \multicolumn{1}{|c|}{ Tipo de planta } & \multicolumn{1}{c|}{ Frecuencia } \\
\hline Medicinal & \\
\hline Alimenticia & \\
\hline Medicinal y alimenticia & \\
\hline Ornamentales & \\
\hline
\end{tabular}

Compartimos la información de nuestra tabla y comparamos con el resto de equipos.

- ¿Qué tipo de planta es más común en nuestra comunidad? ¿Es más importante cultivar plantas medicinales o alimenticias? Discutimos.

A partir de la información anterior ¿es posible elaborar una suposición o hipótesis acerca de las plantas de nuestra región?

- ¿Qué procedimientos seguimos para encontrar la información que colocamos en la tabla?

- ¿Qué uso le podemos dar a la información que encontramos?

- ¿Qué conclusión podemos obtener a partir de los datos anteriores?

- ¿Qué otro tipo de información podríamos colocar en una tabla de frecuencias? 
Observamos gráficos que muestran información sobre los tipos de especies animales de una región de Guatemala:
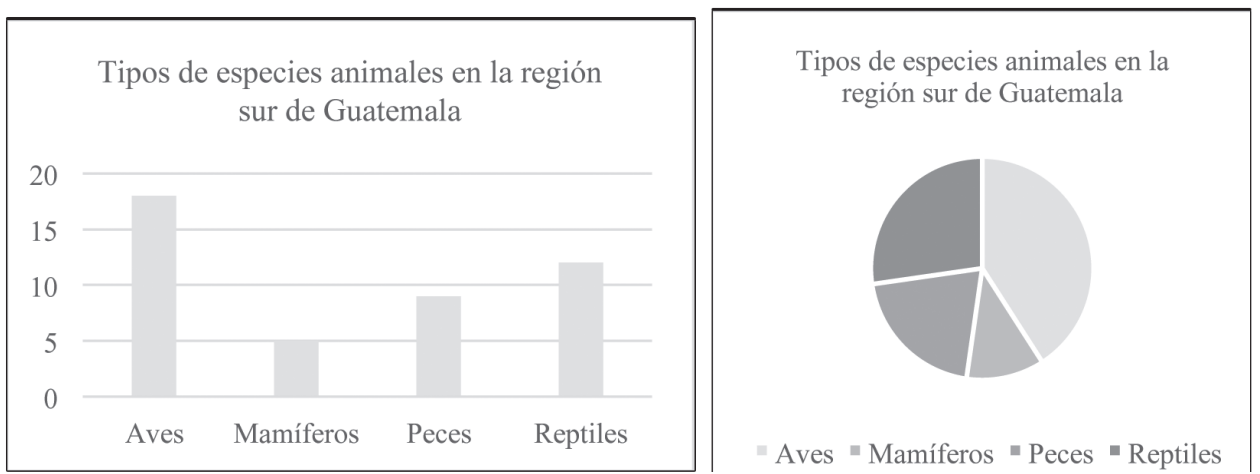

- ¿Qué diferencias observamos entre los dos gráficos? ¿Ambos gráficos representan la misma información? Discutimos en equipo.

Investigamos cómo elaborar gráficos de barras o columnas y circulares. Representamos la información sobre las especies vegetales de nuestra comunidad en un gráfico de barras y en un gráfico circular. ¿Con esta información verificamos la hipótesis que planteamos anteriormente?

- ¿Es más fácil interpretar la información de un gráfico que de una tabla? Explicamos.

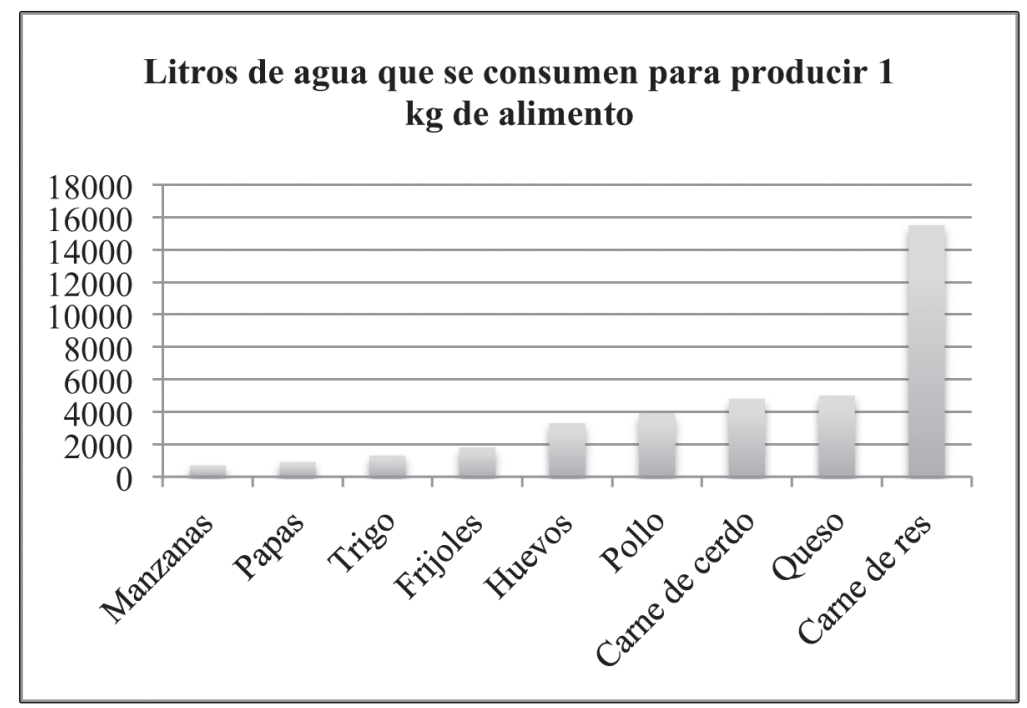

Fuente: http:/ /www.waterfootprint.org/?page=files/productgallery

Interpretamos la información del gráfico anterior.

- ¿Cuántos litros más de agua se consumen al producir $1 \mathrm{~kg}$ de carne de pollo que al producir $1 \mathrm{~kg}$ de frijoles?

- ¿Cuántos litros de agua se utilizarán si se producen $18 \mathrm{~kg}$ de carne de res?

- ¿Cuántos kg de queso se lograrán producir con 78 mil litros de agua?

- Si una libra equivale a 460 g, ¿cuántos litros de agua se utilizarán para producir 5 libras de carne de cerdo?

En casa elige una de las hipótesis que tu grupo ha redactado. Realiza los pasos necesarios para ponerla a prueba. 


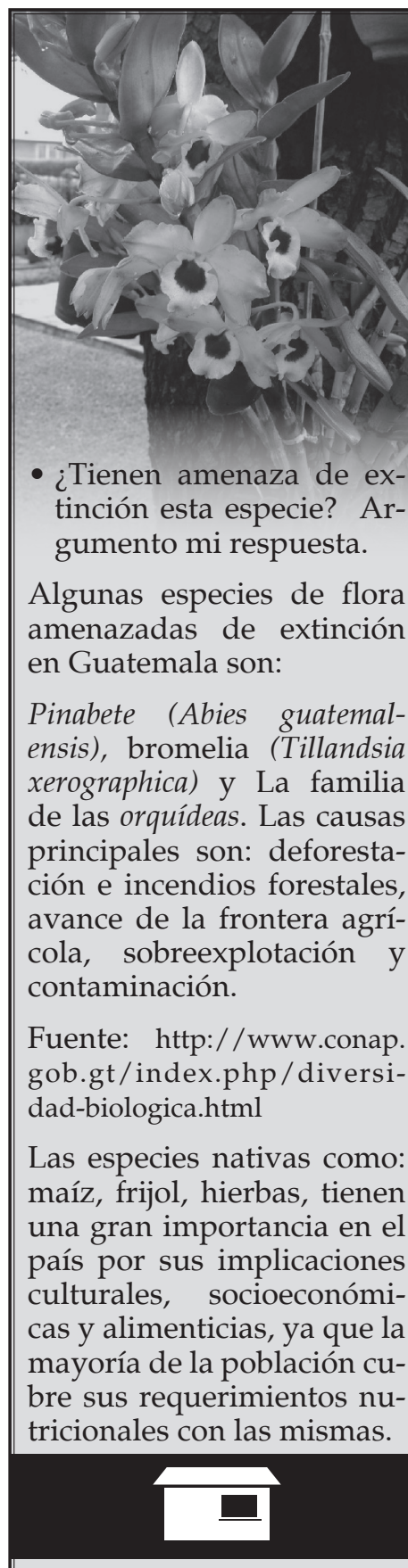

Investigo si en la comunidad existen litorales marítimos, bosques, fuentes de agua natural, plantas representativas, animales silvestres y de crianza, tipos de suelo.

Elaboro un comentario personal acerca de la importancia de proteger los recursos naturales de la comunidad. Incluyo las especies silvestres de fauna y flora.
Trabajamos en equipo.

- Escribimos una lista de las especies silvestres de fauna y flora de la comunidad. Incluimos las plantas que se utilizan con fines medicinales y las que se emplean para la sostenibilidad económica familiar.

- Compartimos nuestro trabajo con otros grupos y enriquecemos nuestra información.

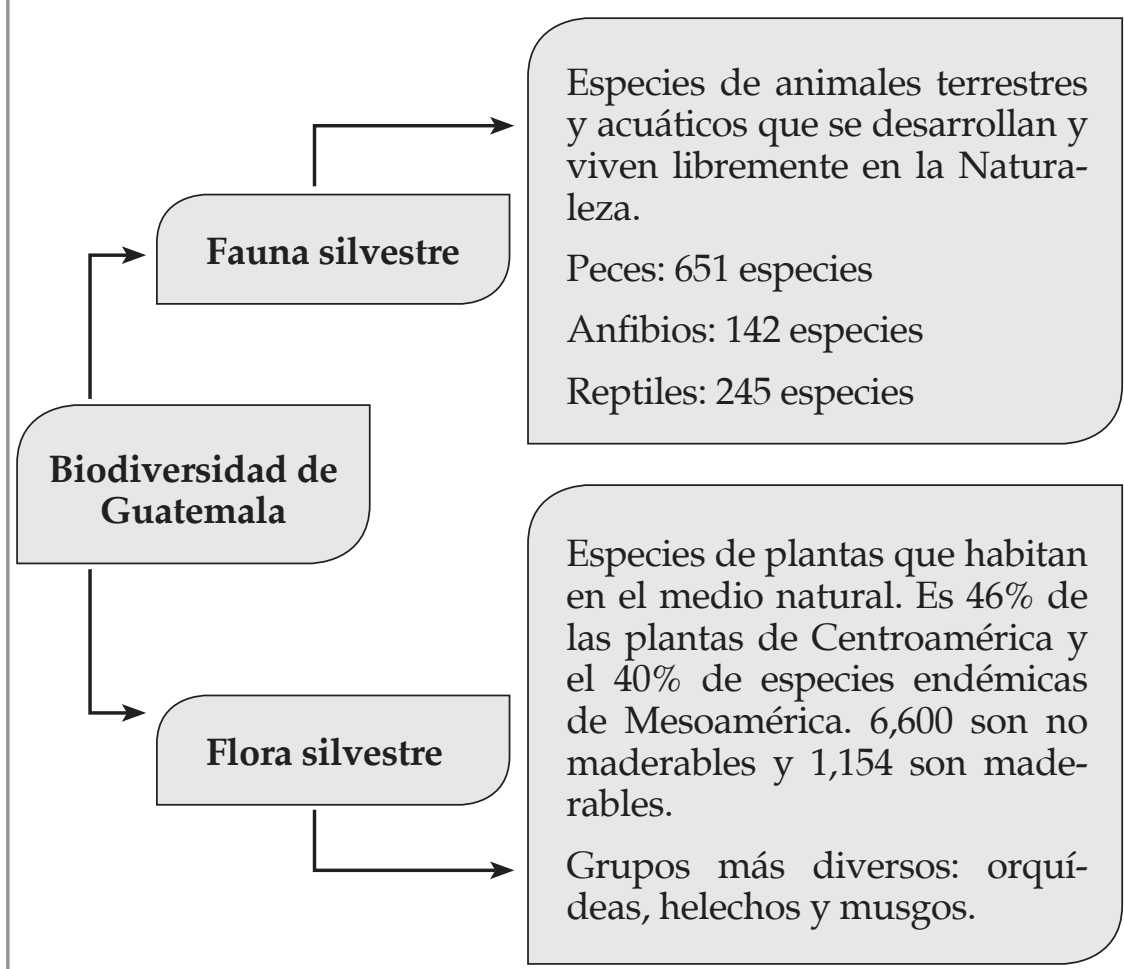

Los países con mayor índice de biodiversidad de la Tierra se denominan megadiversos, nueve de estos se encuentran en América, Guatemala entre ellos, cuatro en África y seis en Asia. Se estima que en conjunto albergan más del $70 \%$ de la biodiversidad del planeta y sus territorios abarcan el 10\% de la superficie del planeta.

Nos organizamos en grupos para investigar sobre los tipos de recursos naturales, las fuentes naturales de agua y de oxígeno y los minerales que se extraen del suelo de la comunidad. Si tenemos posibilidad, compartimos resultados en una presentación multimedia.

- Dialogamos acerca de la caracterización del equilibrio del medio ambiente, la importancia de la conservación sustentable de los recursos naturales y el respeto por la madre Tierra: litorales marítimos, bosques, fuentes de agua natural, plantas representativas, animales silvestres y de crianza. 


\section{Producción, consumo y transferencia de energía en los ecosistemas}

Interpretamos la información del siguiente esquema.

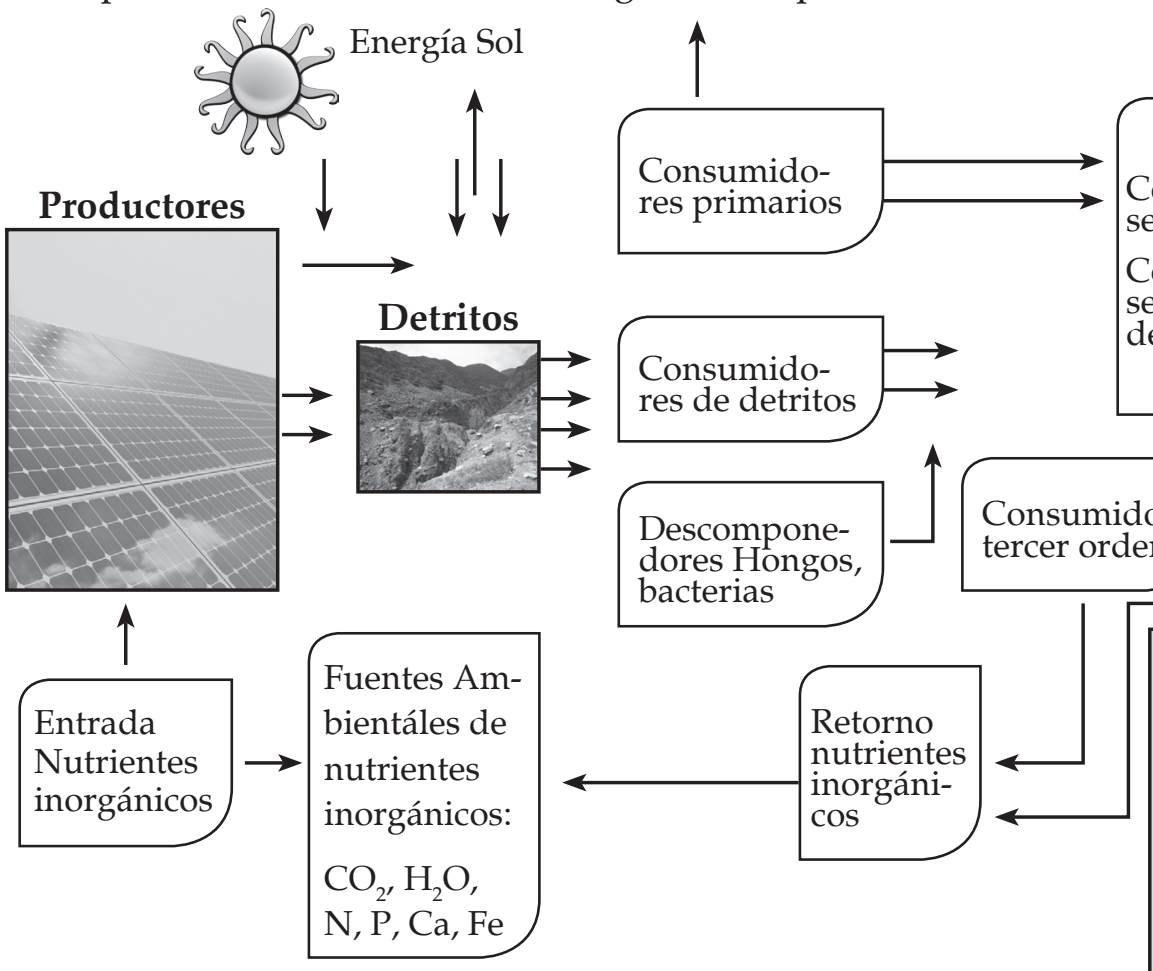

- ¿Qué compuestos químicos se pueden identificar en la transferencia e intercambio de materia y energía en un ecosistema?

La materia y la energía circulan a través de la biosfera y los ecosistemas en forma de relaciones tróficas. Dichas relaciones se representan mediante cadenas, cada organismo puede ser alimento de otros. Las cadenas tróficas están formadas por niveles: productores, consumidores y descomponedores.

Productores. Son organismos que captan y transforman la energía luminosa en energía química mediante la fotosíntesis. Constituyen el primer nivel trófico.

$\mathrm{CO}_{2}+\mathrm{H}_{2} \mathrm{O} \rightarrow \quad$ Materia orgánica $+\mathrm{O}_{2}$

La materia orgánica fabricada es utilizada por los organismos productores para mantener sus procesos vitales mediante la respiración. Después de usarla en los procesos vitales, se transforma en calor.

$$
\text { Materia orgánica }+\mathrm{O}_{2} \rightarrow \mathrm{CO}_{2}+\mathrm{H}_{2} \mathrm{O}+\text { Energía }
$$

La energía restante se acumula en las estructuras vivas y pude ser transferida en forma de alimento a los consumidores.

Consumidores. Forman varios niveles: consumidores primarios o herbívoros, consumidores secundarios o carnívoros, carnívoros finales, omnívoros y detritívoros.

Descomponedores. consumen los restos orgánicos, excrementos o cadáveres. Se clasifican en: necrófagos, saprófagos y coprófagos.

Coprófagos. Seres que se alimentan de excremento, por ejemplo: moscas y escarabajos.

Detritívoros. Seres que obtienen su alimentación de la materia orgánica en descomposición, puede ser excremento, animales muertos o vegetales en descomposición. También se les llama descomponedores.

Necrófagos. Se alimentan de cadáveres que inician su proceso de descomposición, como los zopilotes y las hienas.

Omnívoros. Son animales que se alimentan de otros animales y de plantas, como el cerdo y los ratones.

Saprófagos. Se alimentan de cadáveres y restos de vegetales con un proceso avanzado de descomposición, por ejemplo: lombrices y cangrejos.

Trofos. En griego significa comer.

Ejemplifico cada tipo de ser vivo según su alimentación y desarrolla un glosario en inglés que incluya cada uno de los animales. 


\section{Comunidad y cambio climático}

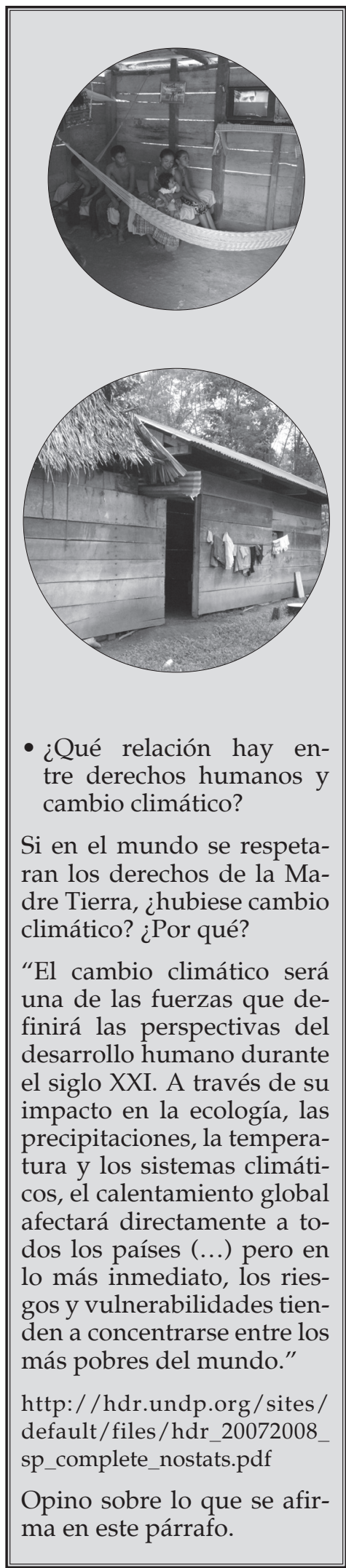

(ii)

A todas las comunidades les ha interesado determinar el comportamiento de algunos elementos del ambiente natural. Por ejemplo, en la época prehispánica, la cultura maya desarrolló la Astronomía porque uno de sus principales objetivos era determinar los factores del clima. Determinar en qué época hará calor y en qué época se sentirá mucho frío, cuándo comenzará a llover y por cuánto tiempo, cuándo soplará más fuerte el viento, permite a las comunidades realizar algunas actividades con anticipación y aprovechar las condiciones del tiempo o prepararse para que no le afecten.

Las comunidades podían prepararse porque había regularidad en la variación temporal de los factores del clima. En las últimas décadas esta regularidad se viene alterando, a esto se le llama cambio climático.

Nos reunimos en equipo y argumentamos nuestras respuestas:

- ¿Cómo ha cambiado la temperatura de nuestra comunidad en los últimos 10 años?

- ¿Cómo afectan las variaciones de la temperatura a nuestra comunidad?

- ¿Ha cambiado el ciclo de lluvia en nuestra comunidad?

- ¿En qué nos afecta que llueva más o que baje la cantidad de lluvia?

Compartimos nuestras respuestas con los demás grupos. Al finalizar las presentaciones nos reuniremos en grupos para enumerar las consecuencias del cambio climático en nuestra comunidad. Podemos preparar una dramatización para compartir con la clase después.

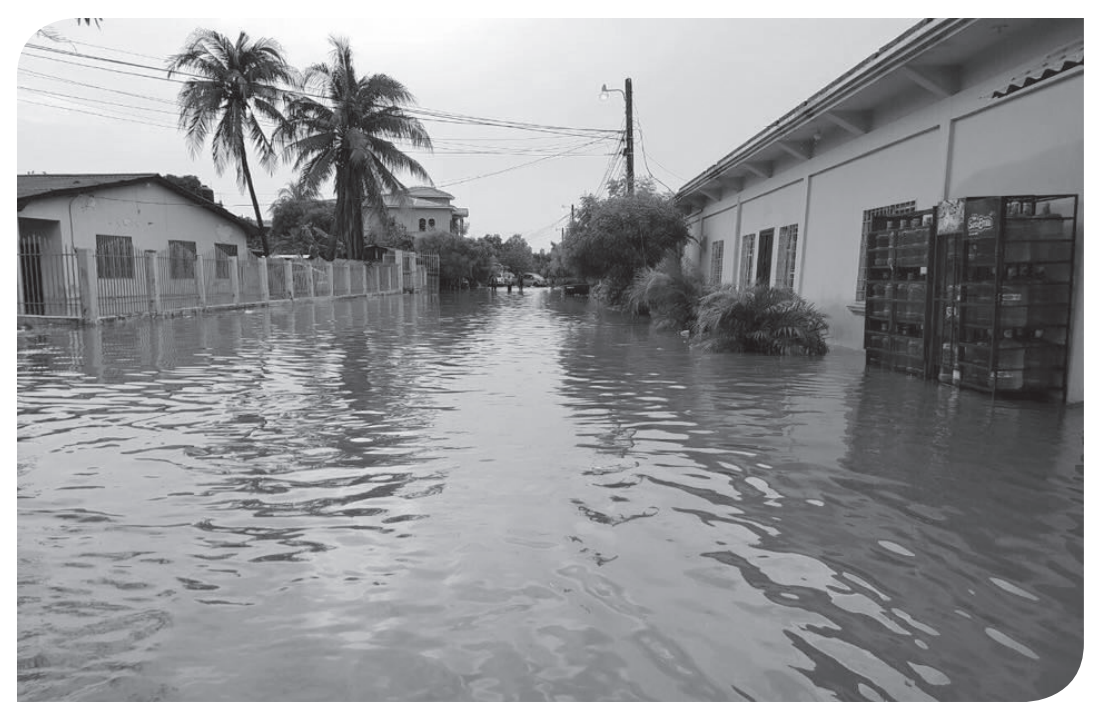




\section{Acciones ante el cambio climático}

El cambio climático es provocado por la comunidad mundial, principalmente por los países que son grandes consumidores de combustible y derivados del petróleo, así como también los que emplean excesivamente el aire acondicionado y los sistemas de refrigeración. Nuestra comunidad contribuye a generar gases que provocan el cambio climático y, aunque no sea de las principales productoras, sí podemos contribuir a evitar dicho cambio.

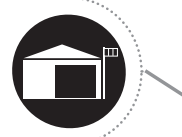

- ¿Cómo contribuyen las selvas y bosques a evitar el cambio climático?

- ¿Qué tipos de energía contribuyen a que no aumente el cambio climático?

- ¿Qué acciones podemos hacer para contribuir a evitar el cambio climático?

En Guatemala, el cambio climático ha hecho que muchas personas no tengan acceso al agua, padezcan enfermedades respiratorias e intestinales, pierdan cosechas, se hayan quedado sin vivienda y no puedan alimentarse adecuadamente. También los desastres ocasionados por el cambio climático han afectado la salud física y mental de las personas.

Antes de separarnos en grupos nos colocamos en círculo y realizamos ejercicios de rotación de hombros, rotación de torso y estiramientos.

- Determinemos cómo ha afectado a nuestra comunidad el cambio climático.

- Propongamos algunas medidas para solventar estas afecciones y prevenir futuros problemas.

- Ubicamos los lugares en donde se encuentra la mayor cantidad de recursos naturales de nuestra comunidad y elegimos algunos para visitarlos.

- Elaboramos una guía de observación para determinar cuánto los ha afectado el cambio climático.

- Visito un lugar de los que elegimos con el equipo y lleno la guía de observación que elaboramos.

- Entrevisto a las personas que encuentro en el lugar sobre el efecto del cambio climático en el mismo.

- Realizo cinco minutos de ejercicio físico en este lugar. Si llevo compañía me pueden grabar realizando esta actividad. Veo la grabación para identificar cómo puedo mejorar.
- ¿Cómo afecta el cambio climático a la seguridad alimentaria de las personas?

"Evaluaciones e informes del Ministerio de Agricultura, Ganadería y Alimentación (MAGA) han incluido apreciaciones sobre los efectos del deterioro ambiental y el cambio climático sobre los derechos humanos, pero el abordaje ha sido muy limitado."

http: / / www.ohchr.org / Documents/Issues/ClimateChange/Submissions/Guatemala.pdf

Reflexiono acerca del cambio climático y cómo afecta los derechos humanos de las y los integrantes de mi comunidad. 


\section{Producir mejor sin dañar el ambiente}

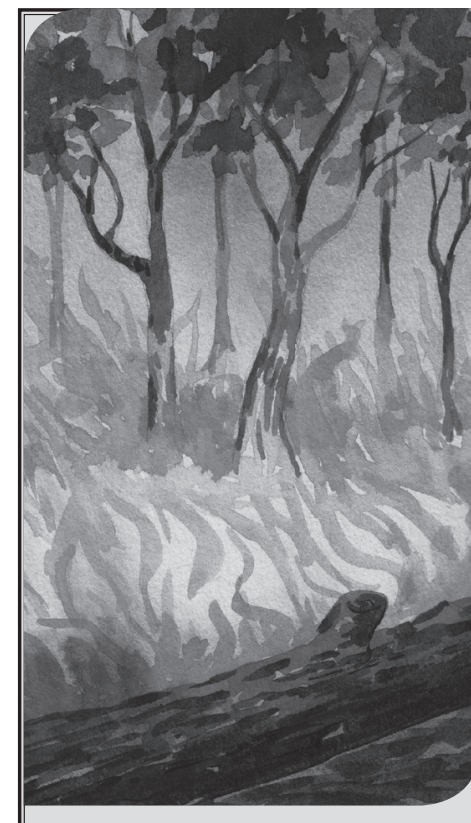

Escribo una lista de daños que puede causar este hecho a las personas.

Muchas enfermedades que hacen peligrar la vida de las personas se deben a factores ambientales y a lo que comemos. La diarrea está asociada al consumo de agua no potable y saneamiento e higiene insuficientes. Las infecciones de las vías respiratorias se deben a la contaminación del aire por humo de fábricas, automóviles, tabaco y leña. La difusión del paludismo, dengue y zika se producen por la deforestación, la falta de desagües y la improvisación para ubicar asentamientos humanos. Si nuestra dieta se basa en comida chatarra y aguas gaseosas, con bajo consumo de frutas y vegetales frescos, las posibilidades de enfermarnos, serán altas.

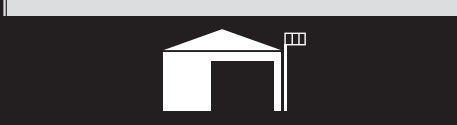

Planificamos una campaña contra el paludismo, zika y dengue o apoyamos una organizada por alguna institución estatal o municipal.
El medio ambiente está formado por bosques y paisajes naturales, pero también por calles, viviendas, fábricas y edificios. Mejorar la calidad del medio ambiente es hacer más sanos los lugares donde vivimos. Cuidar el ambiente nos ayuda a conservar los recursos naturales y nuestra salud, además de protegernos de desastres ambientales.

Mejorar la calidad y rendimiento en los procesos de producción es beneficioso para productores y consumidores. Un producto de calidad y con precio razonable tendrá ventaja sobre sus competidores; también beneficiará a la comunidad si en el proceso de fabricación y distribución se evita dañar al ambiente.

Para ofrecer productos de alta calidad y que no dañen el ambiente, las empresas deben aplicar procesos de mejora continua. Uno de ellos es reunir, discutir y ponderar información que permita eliminar la incertidumbre, tomar buenas decisiones y evitar los daños ambientales. Un principio fundamental es considerar el sistema de producción como un ciclo que se renueva constantemente, las claves son:

- Aprovechar los recursos naturales, materiales, humanos y financieros, además de lograr su interrelación e interdependencia.

- Ajustar las operaciones para reducir costos, aumentar la producción y mejorar la calidad en cada etapa de los procesos.

- Controlar que los procesos, actividades y productos cumplan con los requerimientos en el tiempo estipulado.

Enumero las etapas de producción casera de un producto, por ejemplo: huipil, tortilla o queso. Propongo un proceso de mejora continua para dicho objeto, identifico tres acciones que debieran realizarse en la mejora de producción y calidad para el cuidado del medio ambiente.

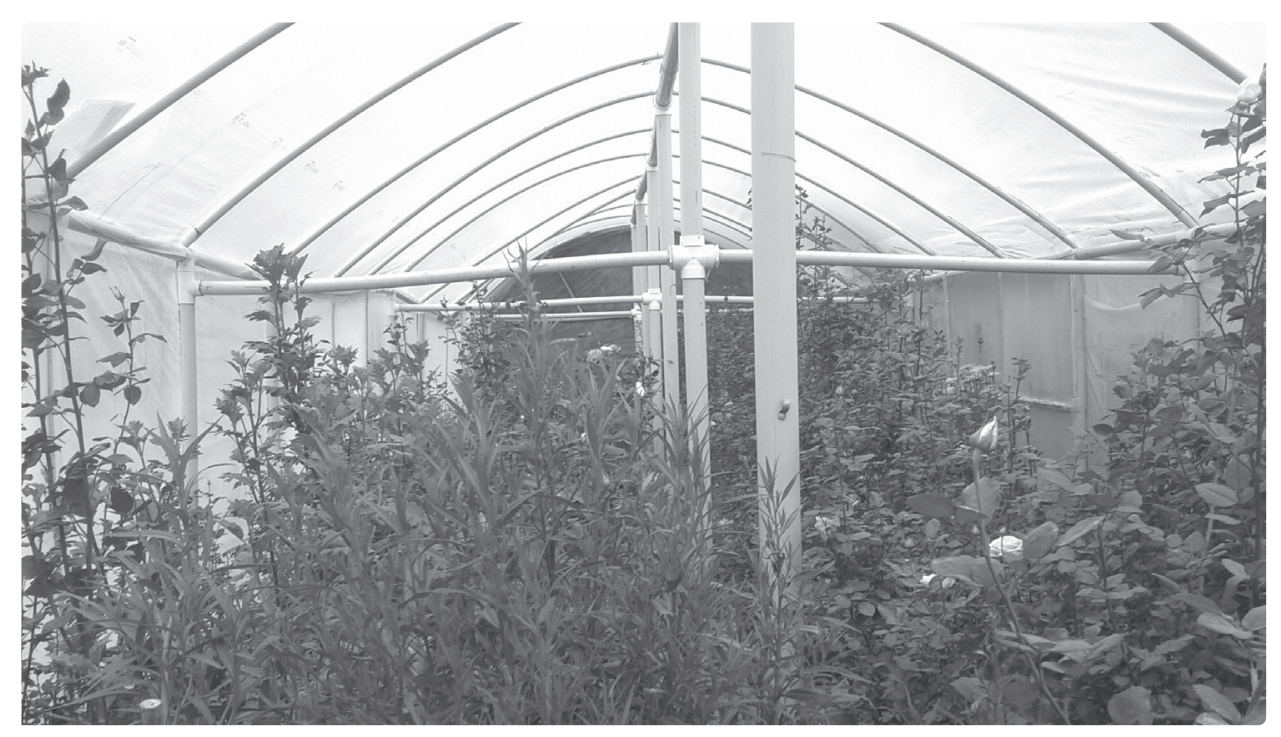


En la tienda venden muchas mercancías, algunas saludables, otras no; unas con empaques biodegradables, otras no. Seleccionemos un producto, puede ser un agua gaseosa, jugo enlatado o sopa instantánea. Analicemos en pareja:

\section{El empaque.}

- Analicemos los elementos visuales del empaque: color, diseño, uso de gráficas, etc. Para ello, aplicamos los conocimientos de Expresión Artística.

- ¿Cuál es el mensaje que transmite? Utilicemos los conocimientos de Comunicación y Lenguaje para analizar el texto.

- ¿De qué material está hecho el empaque? ¿Se puede reciclar o reutilizar?

- ¿Cómo nos deshacemos de ese empaque? ¿Qué daño puede provocar al ambiente?

- Proponemos un empaque más ecológico.

\section{El contenido.}

- ¿Es saludable? ¿Es indispensable? ¿Tiene colorantes o preservantes? ¿Puede ser sustituido por una opción más saludable?

- Escribimos un menú saludable y nutritivo utilizando este ingrediente.

- ¿Cómo se produce? ¿Qué ingredientes tiene?

\section{El precio.}

- ¿Tiene un precio razonable con relación a sus características nutritivas?

- ¿Impacta su compra en nuestro presupuesto?

- ¿Qué otros productos podemos comprar por el mismo precio? ¿Son estos productos más saludables?

Intercambiamos nuestro trabajo y evaluamos si podemos encontrar más respuestas para cada pregunta. Hacemos una propuesta para mejorar nuestra salud y proteger el ambiente.

Elaboro un mapa conceptual sobre el proceso de mejora continua y la preservación del medio ambiente.

Describo algún desastre ambiental que haya afectado mi comunidad.

Explico las consecuencias si el desastre se repitiera.

Si este volcán hace erupción y afecta algunas poblaciones, ipuede considerarse un desastre de origen natural?

La mayoría de desastres ambientales son provocados por los humanos al deforestar, desviar ríos, cazar y pescar descontroladamente y contaminar el aire y los cuerpos de agua. La desertificación, la degradación de la tierra y el cambio climático son algunas de las consecuencias que están provocando la falta de agua y la pérdida de cosechas. Todavía estamos a tiempo de revertir el daño tomando conciencia de nuestro comportamiento y actuando responsablemente hacia la naturaleza y el ambiente. 


\section{Sonidos en decibeles}

\begin{abstract}
El umbral del dolor ante el sonido

Cuando la cantidad de decibeles que el oído humano soporta es traspasado se produce un dolor causado por la presión que ejerce el sonido sobre el oído. A este fenómeno se le conoce como el umbral del dolor. Cantidades de decibeles que producen algunos sonidos:
\end{abstract}

\begin{tabular}{|l|c|}
\hline $\begin{array}{c}\text { FUENTES } \\
\text { DE } \\
\text { SONIDO }\end{array}$ & DECIBELES \\
\hline $\begin{array}{l}\text { Umbral de } \\
\text { audición }\end{array}$ & $\mathbf{0}$ \\
\hline $\begin{array}{l}\text { Susurro, } \\
\text { respiración } \\
\text { normal, } \\
\text { pisadas } \\
\text { suaves }\end{array}$ & 10 \\
\hline $\begin{array}{l}\text { Tránsito } \\
\text { ligero, con- } \\
\begin{array}{l}\text { versación } \\
\text { normal }\end{array}\end{array}$ & 50 \\
\hline $\begin{array}{l}\text { Timbre, ca- } \\
\text { mión pesa- } \\
\text { do movién- } \\
\text { dose }\end{array}$ & 80 \\
\hline $\begin{array}{l}\text { Aspiradora } \\
\text { funcionan- } \\
\text { do, maqui- } \\
\text { naria de } \\
\text { una fábrica } \\
\text { trabajando }\end{array}$ & 90 \\
\hline $\begin{array}{l}\text { Banda de } \\
\text { música rock }\end{array}$ & 100 \\
\hline $\begin{array}{l}\text { Bocina de } \\
\text { un carro, } \\
\text { explosión de } \\
\text { petardos o } \\
\text { cohetes em- } \\
\text { pleados en } \\
\text { pirotecnia }\end{array}$ & 110 \\
\hline \begin{tabular}{l} 
Donal \\
\hline
\end{tabular} & 90 \\
\hline
\end{tabular}

Analicemos y respondamos en equipo.

- ¿Qué sonidos pueden dañar nuestro oído?

- ¿Existen leyes en Guatemala para proteger el ambiente sónico?

Observo el esquema.

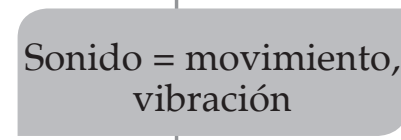
Potencia: ondas sonoras

Se miden en decibeles

Cuando un cuerpo se mueve, produce una vibración en forma de ondas llamada sonido. Las ondas sonoras generan una potencia o presión sobre el medio físico del ambiente en que se producen. El tamaño de estas ondas se conoce como longitud, y mientras más grande es la onda, más fuerte es el sonido que capta el oído. El grado de potencia de las ondas sonoras se mide en decibeles, que son unidades de medida física que la acústica utiliza para medirlas con precisión. Cada decibel mide la potencia con que se manifiesta la intensidad del sonido, para ello emplea una escala logarítmica.

\section{Una exploración de los sonidos que nos rodean}

- Indagamos, con nuestro grupo, sobre los sonidos en nuestra comunidad. Tomamos como referencia el umbral del dolor (120 decibeles) y clasificamos los que pueden estar por debajo o por encima.

- Anotemos nuestros hallazgos, podemos emplear una tabla como esta:

\section{Cuadro de clasificación de decibeles}

\begin{tabular}{|l|l|}
\hline $\begin{array}{l}\text { Por debajo del umbral del } \\
\text { dolor }(-120 \mathrm{~dB})\end{array}$ & $\begin{array}{l}\text { Por encima del umbral del } \\
\text { dolor }(+120 \mathrm{~dB})\end{array}$ \\
\hline & \\
\hline
\end{tabular}

- Discutimos sobre los riesgos que podemos correr si los sonidos sobrepasan el umbral del dolor.

Saldremos del salón a un espacio abierto y con música de fondo realizamos ejercicios de respiración, vocalización y relajamiento. Prestamos atención a lo que nos rodea y a las sensaciones de nuestro cuerpo. Caminamos al entorno de nuestro centro educativo para identificar sonidos naturales que percibimos y sonidos adicionales que no provienen de la Naturaleza. ¿Qué escuchamos más? ¿Qué tipos de sonidos son más propensos a hacernos daño?

Crea un dibujo usando líneas de alguna escena que muestra la producción de diversos tipos de sonidos. Si no terminas en clase, lo puedes continuar en casa. 


\section{Arte y Ecología}

$\mathrm{El}$ arte se hace para expresar las diversas situaciones de la vida. Expresa aspectos como el amor, el bienestar, la paz; también la guerra o la desesperanza. La armonía con el entorno social y natural es uno de los espacios de la existencia que se deben buscar para tener una vida sana y equilibrada. En esta búsqueda ecológica podemos relacionar al arte con el buen vivir.

Las personas que integran una comunidad hacen uso del sonido musical a diario. La música está arraigada en la cultura y se utiliza en diversas actividades. Hay ocasiones en que se abusa del sonido y se vulneran los derechos de las demás personas con sonidos estridentes o con altos rangos de decibeles, por ejemplo, cuando con fines comerciales y de promoción se instalan enormes bocinas.

Escribimos una lista de espacios en los que la música se usa adecuadamente y cuando se abusa de ella con fines que atentan contra los derechos de las personas. Podemos emplear un formato como este.

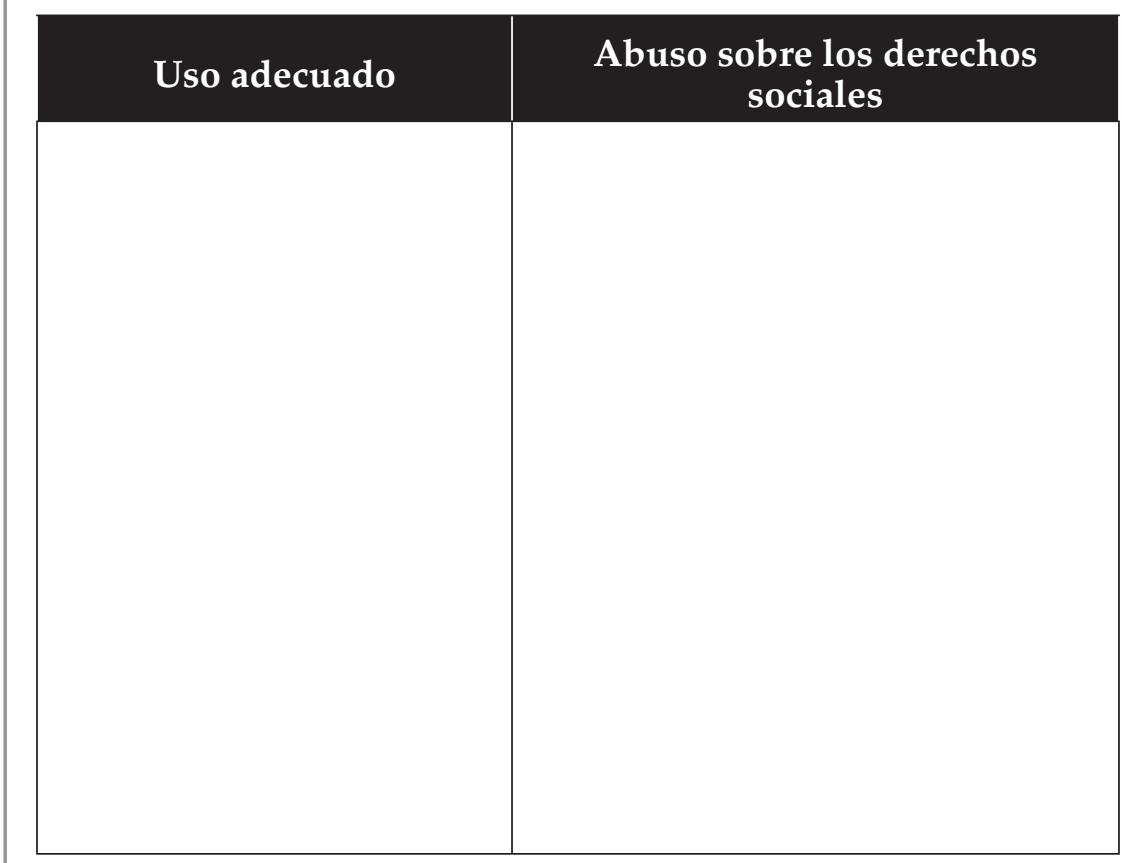

- Busco información sobre algunas normas que se establecieron en mi comunidad para que se respete el ambiente sonoro.

- Acudo a autoridades locales y municipales para saber cómo ejercen control sobre el uso de los sonidos en la comunidad.

- Establezco una propuesta de cómo mejorar la regulación sobre la producción de sonido dañino en mi comunidad para incluir en la feria científica

- ¿Cómo nos protege la ley ante la producción de sonidos dañinos a la salud?

En Guatemala existe una ley que regula los sonidos y las actividades que los provocan, es la Ley de Protección y Mejoramiento del Medio Ambiente, del 5 de diciembre de 1986. En ella, se contempla que el Estado debe formular normas para regular los sonidos. También establece que algunos sonidos "Se consideran actividades susceptibles de degradar el ambiente y la salud, [se trata de] los sonidos o ruidos que sobrepasen los limites permisibles cualesquiera que sean las actividades o causas que los originen."

Discutamos en grupos:

- ¿Protege el Estado a los y las integrantes de nuestra comunidad de los sonidos que atentan contra la salud? 


\section{Estadistica para entender mi comunidad}

Existen 3 datos estadísticos de tendencia central, los cuales miden el centro de un grupo de datos.

Media o promedio Es el total de la suma de los datos, dividido el número de datos (n).

Moda

Es el valor que más se repite.

Mediana.

$\mathrm{Al}$ ordenar los datos de menor a mayor, es el dato que se encuentra justo en el centro. Si la cantidad de datos es par, se halla promediando los dos datos centrales.

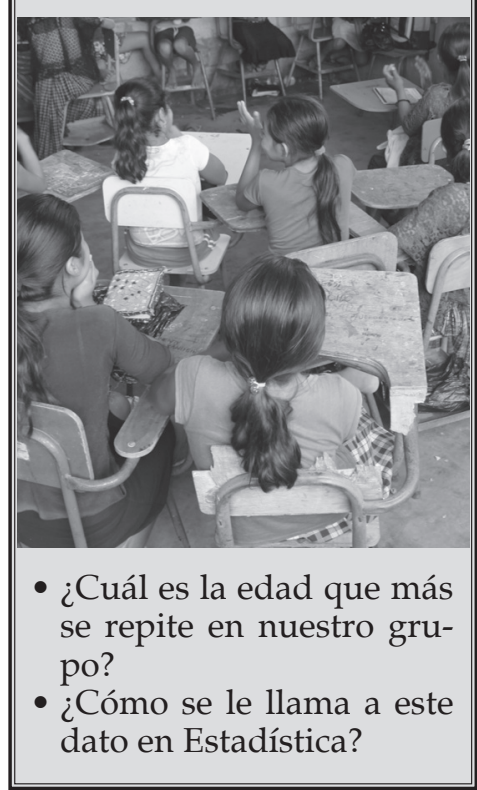

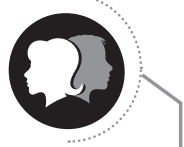

Un grupo de cinco familias fueron seleccionadas en tres comunidades para conocer la cantidad de libras de basura que producían cada semana. Los resultados de las quince familias seleccionadas fueron los siguientes:

\begin{tabular}{|l|l|l|l|l|l|}
\hline $\begin{array}{l}\text { Comuni- } \\
\text { dad A: }\end{array}$ & $\begin{array}{l}\text { Familia 1: } \\
15 \mathrm{lbs}\end{array}$ & $\begin{array}{l}\text { Familia 2: } \\
16 \mathrm{lbs}\end{array}$ & $\begin{array}{l}\text { Familia 3: } \\
12 \mathrm{lbs}\end{array}$ & $\begin{array}{l}\text { Familia 4: } \\
15 \mathrm{lbs}\end{array}$ & $\begin{array}{l}\text { Familia15 } \\
\text { lbs }\end{array}$ \\
\hline $\begin{array}{l}\text { Comuni- } \\
\text { dad B: }\end{array}$ & $\begin{array}{l}\text { Familia 1: } \\
20 \mathrm{lbs}\end{array}$ & $\begin{array}{l}\text { Familia 2: } \\
18 \mathrm{lbs}\end{array}$ & $\begin{array}{l}\text { Familia 3: } \\
13 \mathrm{lbs}\end{array}$ & $\begin{array}{l}\text { Familia 4: } \\
17 \mathrm{lbs}\end{array}$ & $\begin{array}{l}\text { Familia 5: } \\
19 \mathrm{lbs}\end{array}$ \\
\hline $\begin{array}{l}\text { Comuni- } \\
\text { dad C: }\end{array}$ & $\begin{array}{l}\text { Familia 1: } \\
11 \mathrm{lbs}\end{array}$ & $\begin{array}{l}\text { Familia 2: } \\
17 \mathrm{lbs}\end{array}$ & $\begin{array}{l}\text { Familia 3: } \\
17 \mathrm{lbs}\end{array}$ & $\begin{array}{l}\text { Familia 4: } \\
15 \mathrm{lbs}\end{array}$ & $\begin{array}{l}\text { Familia 5: } \\
20 \mathrm{lbs}\end{array}$ \\
\hline
\end{tabular}

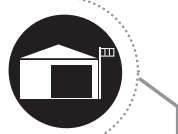

Analizamos los resultados anteriores y los discutimos con el resto del grupo. Identificamos totales por comunidad, las familias con más residuos y las que tienen menos residuos.

- ¿Alguna vez pesamos la basura de nuestra casa?

- ¿Qué acciones inciden en la cantidad de basura que producimos en casa?

- ¿Qué otras formas de medir la basura se nos ocurren?

Las cantidades de basura que se mencionan en el problema, ¿se asemejan a la cantidad de libras de basura que una familia genera semanalmente en nuestra comunidad?

- ¿Cuál es el promedio de libras de basura producidas semanalmente en cada comunidad?

- ¿Cuál es la moda y la mediana de la cantidad de basura producida semanalmente en cada una de las comunidades?

- ¿Qué comunidad tuvo el mayor rango de libras de basura producida?

Trazamos, en nuestro cuaderno, una gráfica de barras que ilustre el promedio de libras de basura que se producen por semana en cada comunidad.

- ¿Qué observamos? Comentemos con nuestro grupo.

- ¿Para qué nos sirve conocer el rango de un grupo de datos?

- ¿Qué tipo de información, sobre un grupo de datos nos da el rango? Explicamos y discutimos nuestras respuestas con nuestro grupo.
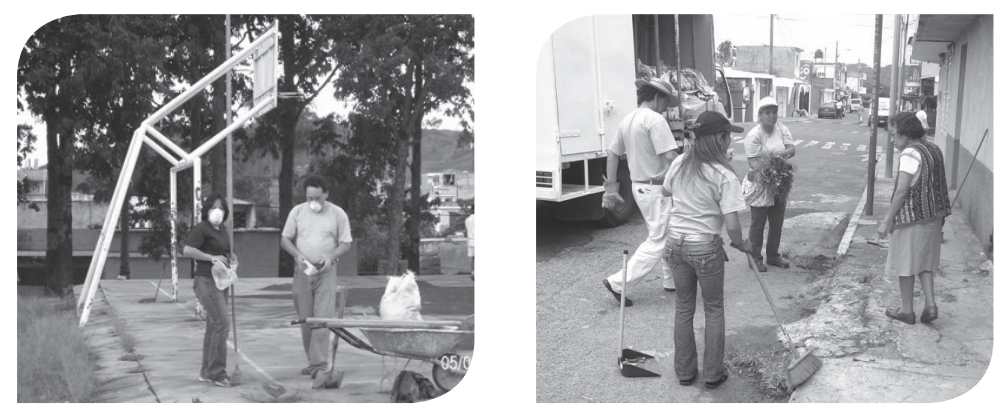
Completamos la tabla con los datos de la comunidad A:

\begin{tabular}{|c|c|c|}
$\begin{array}{c}\text { Libras de basura } \\
\text { semanales (xi) }\end{array}$ & $\begin{array}{c}\text { Desviación } \\
\text { (xi-promedio) }\end{array}$ & $\begin{array}{c}\text { Cuadrado de la } \\
\text { desviación } \\
\text { (xi-promedio) }\end{array}$ \\
\hline 15 & & \\
\hline 16 & & \\
\hline 12 & & \\
\hline 15 & & \\
\hline 15 & & \\
\hline Sumatoria: & & \\
\hline
\end{tabular}

Calculamos la desviación estándar, para ello usamos calculadora. Comparamos nuestros resultados.

Copiamos, en nuestro cuaderno, la tabla anterior y la llenamos con los datos de las comunidades B y C. Calculamos las desviaciones estándar de ambas comunidades.

- ¿Qué significa el valor de la desviación estándar?

Se hizo el mismo estudio en la comunidad D y las libras de basura que se produjeron semanalmente fueron: 10, 21, 30, 9 y 5. Calculamos la desviación estándar y comparamos con las desviaciones que obtuvimos de las tres primeras comunidades. ¿Qué podemos concluir? Comentamos y discutimos los resultados.

Resolvemos. El peso, en $\mathrm{kg}$, de un grupo de pollos cocinados es de: 1.5, 1.8, $1.7,1.4,1.7,1.8,2.0,1.5,1.6,2.1$

- Calculemos la media, mediana y moda de los pesos anteriores.

- Hallamos la desviación estándar del grupo de datos.

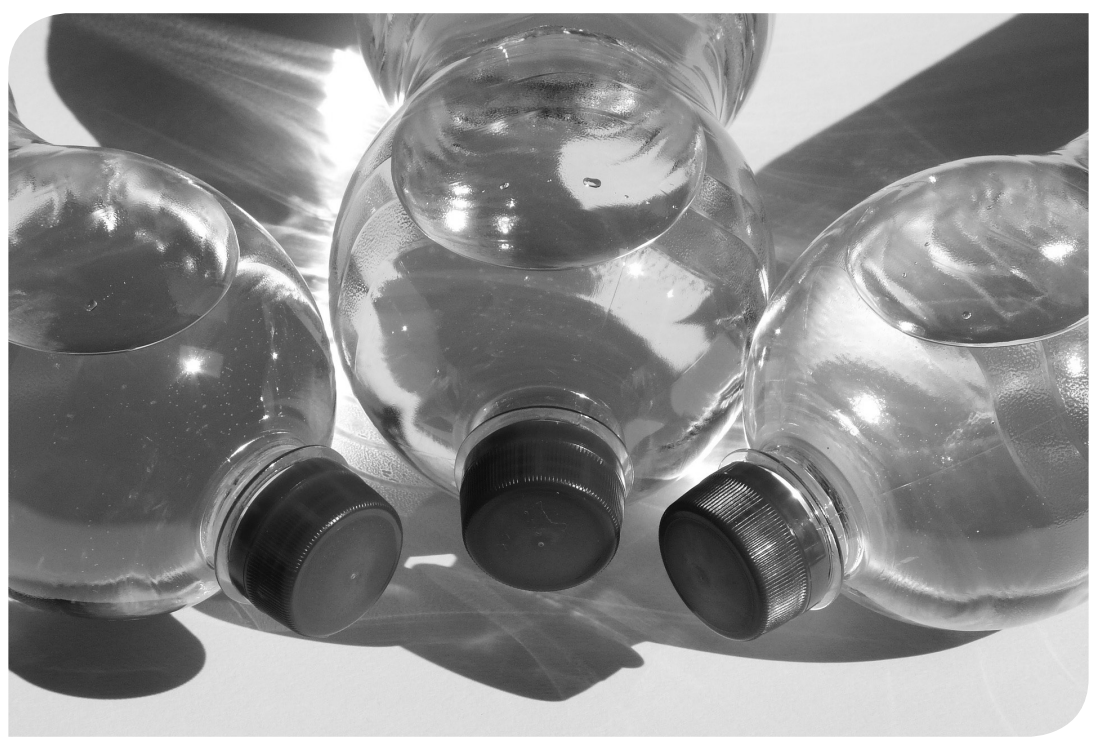

La desviación estándar es una medida estadística que indica cuánto se alejan los datos de la media. Expresa cuán dispersos están los datos. Para calcularla utilizamos la fórmula:

$s=\sqrt{\frac{\sum(X i-\text { promedio })^{2}}{n}}$

Dónde:

$s=$ desviación estándar

$X i=$ cada dato o variable estadística

$n=$ número de datos

$\Sigma=$ sumatoria

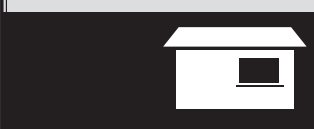

Investigo sobre la redacción de juicios y conclusiones. Redacto una conclusión acerca del manejo del consumo de agua por las familias y por las actividades industriales en la comunidad.

En una comunidad, la desviación estándar de litros de agua que consume cada familia es 3.75; mientras en una comunidad vecina, 2.5 es la desviación estándar. ¿Significa que la primera comunidad consume más agua que la segunda? ¿Cómo se debe interpretar la diferencia en las desviaciones estándar del consumo de agua? ¿Qué acciones pueden realizarse para que las fuentes de agua no se contaminen con los desechos de basura que produce la comunidad? 


\section{Comprensión lectora}

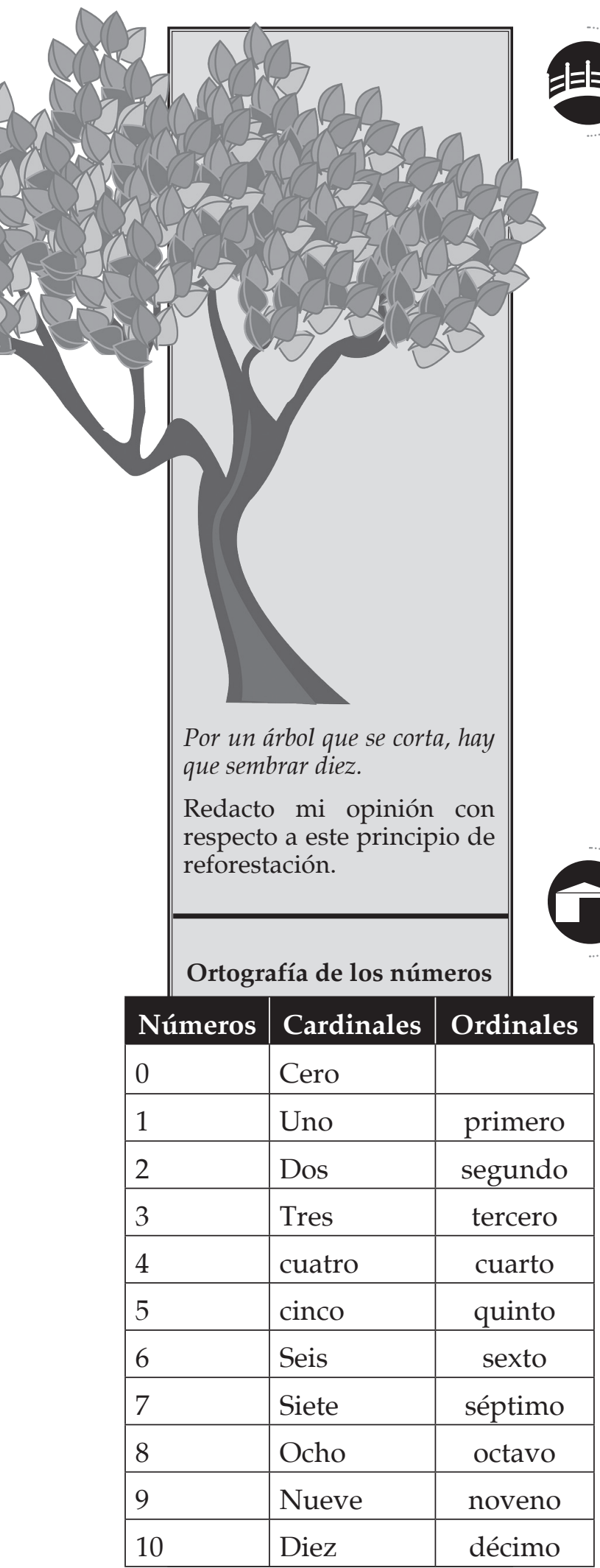

El proceso de comprensión de lectura requiere que sigamos paso a paso su procedimiento. Esto garantiza que comprendamos las ideas del texto, las relacionemos con nuestra experiencia y generemos nuevos pensamientos o criterios. Estos son los pasos del procedimiento.

1. Antes de la lectura

- Plantearnos los objetivos de la lectura

- Recordar los conocimientos previos sobre el tema

- Establecer predicciones sobre el texto

2. Durante la lectura

- Hacer preguntas acerca del contenido

- Buscar los significados del vocabulario nuevo

- Establecer las ideas principales y las secundarias

3. Después de la lectura.

- Aclarar dudas

- Resumir ideas

- Redactar un resumen

- Escribir una conclusión sobre lo leído que sintetice el significado de la lectura y de la interacción con las ideas planteadas.

Escribamos, en el cuaderno, el procedimiento que seguiremos para leer un artículo periodístico que trate un tema ambiental. Podemos tomar como guía la siguiente:

Elegimos el artículo y lo leemos. Luego, respondamos las preguntas, como se indicó en la etapa: Antes de la lectura. En seguida, escuchemos mientras alguien lee en voz alta el artículo. Durante la lectura, anotemos lo que pensamos con relación a las ideas que leemos y escuchamos. Al finalizar la lectura, comparemos notas con nuestros compañeros y compañeras.

Luego, seguimos los pasos de las secciones: Durante la lectura y Después de la lectura.

Divididos en grupos, elaboramos un organizador gráfico con las tres etapas de la comprensión lectora y los pasos que las integran, cada grupo trabajará diferente tipo de relación: secuencia, causa-problema, problema-solución, jerarquía.

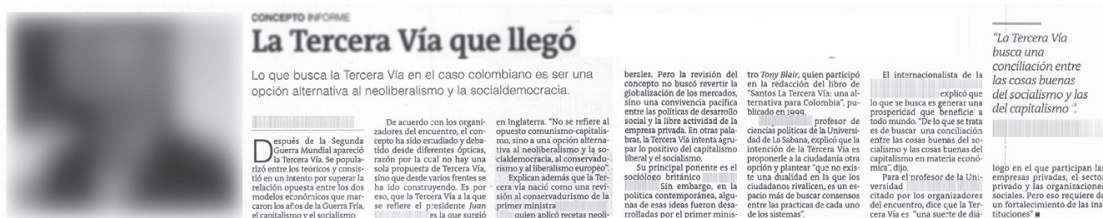




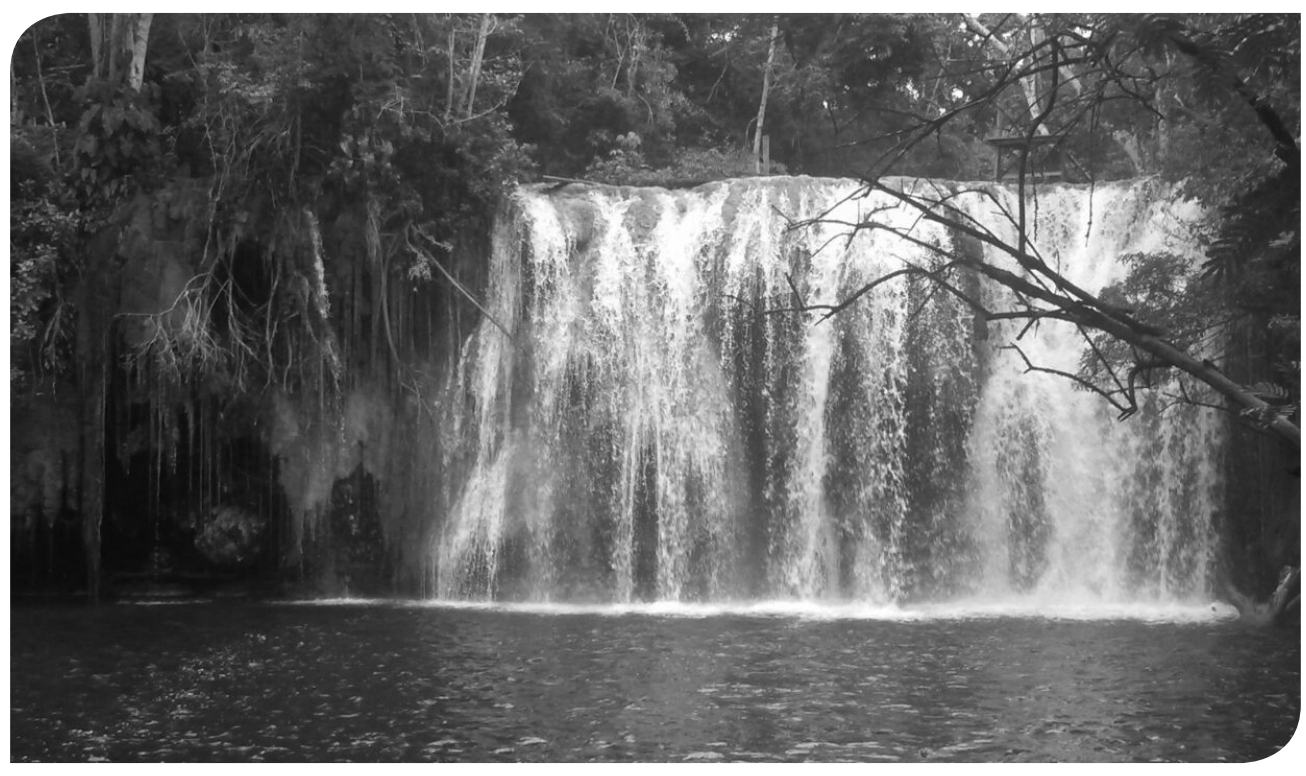

\section{Procesos lógicos del pensamiento y organizadores gráficos}

El proceso del pensamiento lógico para resolver problemas está formado por las etapas: observación, relación con la experiencia propia, comparación, clasificación, análisis, propuesta de solución y toma de decisión final.

La lectura y el análisis de los organizadores gráficos facilitan la práctica del pensamiento lógico. Estos organizadores son herramientas visuales que permiten descubrir la relación entre los conceptos nuevos para comprender y recordar la nueva situación en perspectiva. Mediante estos procesos, se facilita restructurar el pensamiento y la información, analizar los componentes del problema, identificar posibles cambios, ejercer una crítica objetiva y mejorar las habilidades de resolución de problemas.

Trabajemos en equipo.

1. Identifiquemos un problema en el uso de los recursos naturales de nuestra comunidad. Ordenemos los conocimientos que tengamos de dicho problema. Determinemos cuáles conocimientos debemos buscar para comprender mejor el problema.

2. Organicemos la información obtenida, analicémosla y expresémosla por medio de un organizador gráfico.

3. Reconstruyamos los pasos seguidos, sinteticemos la situación y propongamos soluciones viables.

- Organicemos, con nuestro grupo presentaciones dirigidas a los y las integrantes de nuestra comunidad.

- Integremos los temas aprendidos con la identificación de problemas ambientales y propuestas para superarlos inspirándonos en el buen vivir.

- Apliquemos las herramientas aprendidas en esta página.

En el último siglo, el consumo de agua se ha quintuplicado; pero la población solo se ha duplicado. Busco explicaciones al aumento desproporcional del uso del agua.

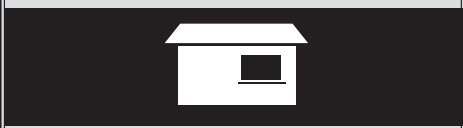

Elaboro fichas bibliográficas con información del agua potable a nivel mundial, nacional y de mi comunidad.

Investigo las propuestas que hay para solventar la problemática de agua potable a nivel mundial.

Ortografía de los números

\begin{tabular}{||c|c|}
\hline Partitivos & Múltiplos \\
mitad & doble \\
\hline tercio & triple \\
\hline cuarto & cuádruple \\
\hline quinto & quíntuplo \\
\hline sexto & séxtuplo \\
\hline séptimo & séptuplo \\
\hline octavo & óctuple \\
\hline noveno & noveno \\
\hline décimo & décuplo \\
\hline
\end{tabular}




\section{Ciclos biogeoquímicos}

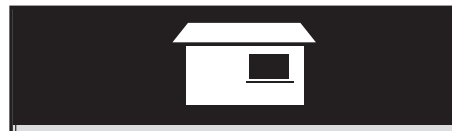

Realizo la siguiente experiencia.

1. Tomo un pedazo de tortilla con unas pinzas y lo quemo con una candela, observo que queda manchado de negro. Anoto lo observado en una hoja de papel. La explicación: queda manchado de negro porque son partículas de carbono.

2. Corto un trozo de una fruta y lo coloco en la llama de una candela. Observo que tarda mucho más en ponerse negro $\mathrm{y}$ arder, es porque tiene mayor cantidad de agua que la tortilla; en el agua, la fruta contiene oxígeno e hidrógeno.

3. Quemo una manía u otro fruto seco, observo que arde debido a que contiene aceite.

Fuente: https://

www.youtube.com/

watch?v=aRSQCiB3wrk

Los ciclos biogeoquímicos son fenómenos naturales que se repiten. En este proceso se transforman en diferentes sustancias químicas. Todo ser vivo está formado por carbono, hidrógeno, oxígeno nitrógeno $\mathrm{y}$ otros elementos químicos. En la Naturaleza existe intercambio de estos elementos o sustancias entre los seres vivos y el ambiente que los rodea. La contaminación tiene efectos secundarios en la Naturaleza. Cuando se alteran los ciclos biogeoquímicos, se incrementan las enfermedades respiratorias y digestivas, entre otras.
Conversamos de lo que sabemos del ciclo del agua. Analizamos la siguiente imagen.

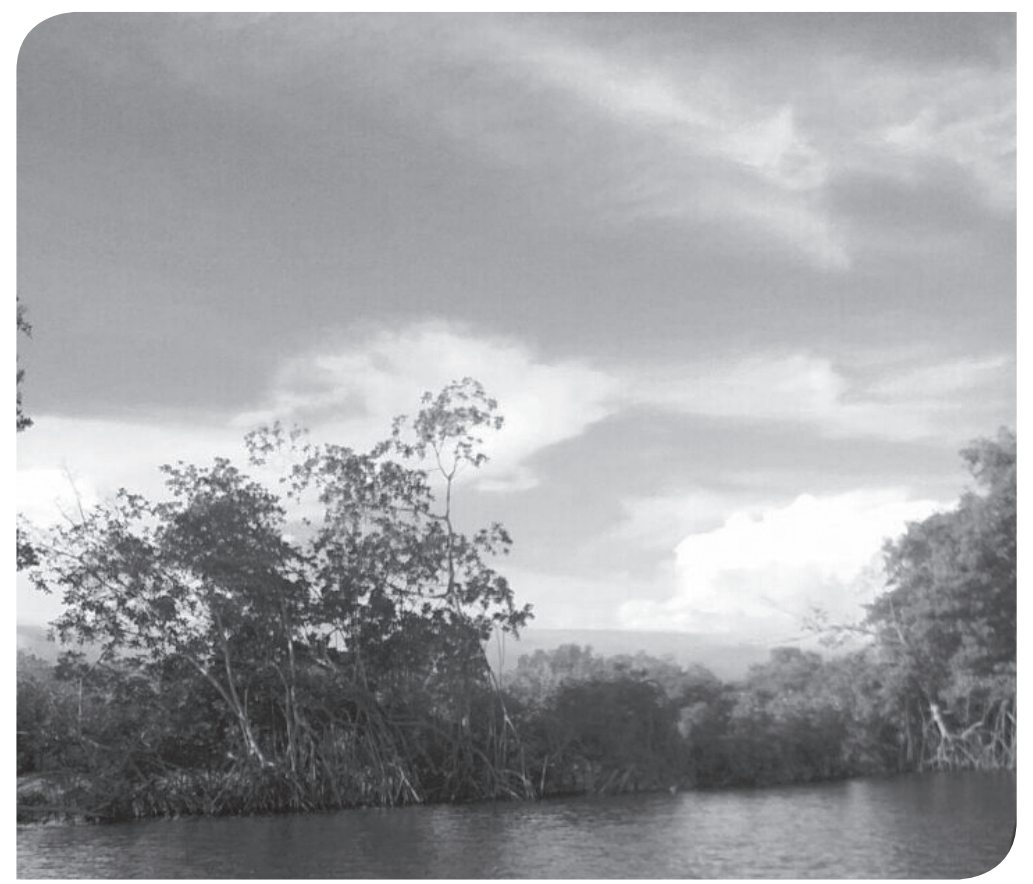

Además del ciclo del agua, existen los ciclos del oxígeno, carbono, nitrógeno, azufre y fósforo. En conjunto, se denominan ciclos biogeoquímicos. Estas sustancias son importantes para el equilibrio de los ecosistemas. El fósforo y el azufre circulan en la corteza terrestre; el carbono, nitrógeno y oxígeno en la atmósfera y seres vivos.

El carbono sube a la atmósfera en forma de dióxido de carbono (C02), el cual es producido por la respiración de animales; humo de fábricas, incendios, descomposición de animales y bacterias. El CO2 y otros gases capturan la radiación solar y se produce calentamiento, es decir que se produce el efecto invernadero.

Los consumidores primarios adquieren el azufre cuando se alimentan de las plantas. El azufre puede llegar a la atmósfera como sulfuro de hidrógeno (H2S) o dióxido de azufre (SO2), ambos gases provenientes de volcanes activos y la descomposición de materia orgánica. La quema de combustibles fósiles y la industria metalurgia producen el $90 \%$ de óxido de azufre en la atmósfera. Al combinarse con el agua, el azufre forma ácido sulfúrico (H2SO4) y cuando se precipita se transforma en lluvia ácida, la cual afecta a varias especies de seres vivos. 
- Observamos la imagen de un ciclo biogeoquímico con nuestro grupo de trabajo y la analizamos mediante un organizador gráfico de secuencias.

- La explicamos a los demás grupos para motivar al diálogo.

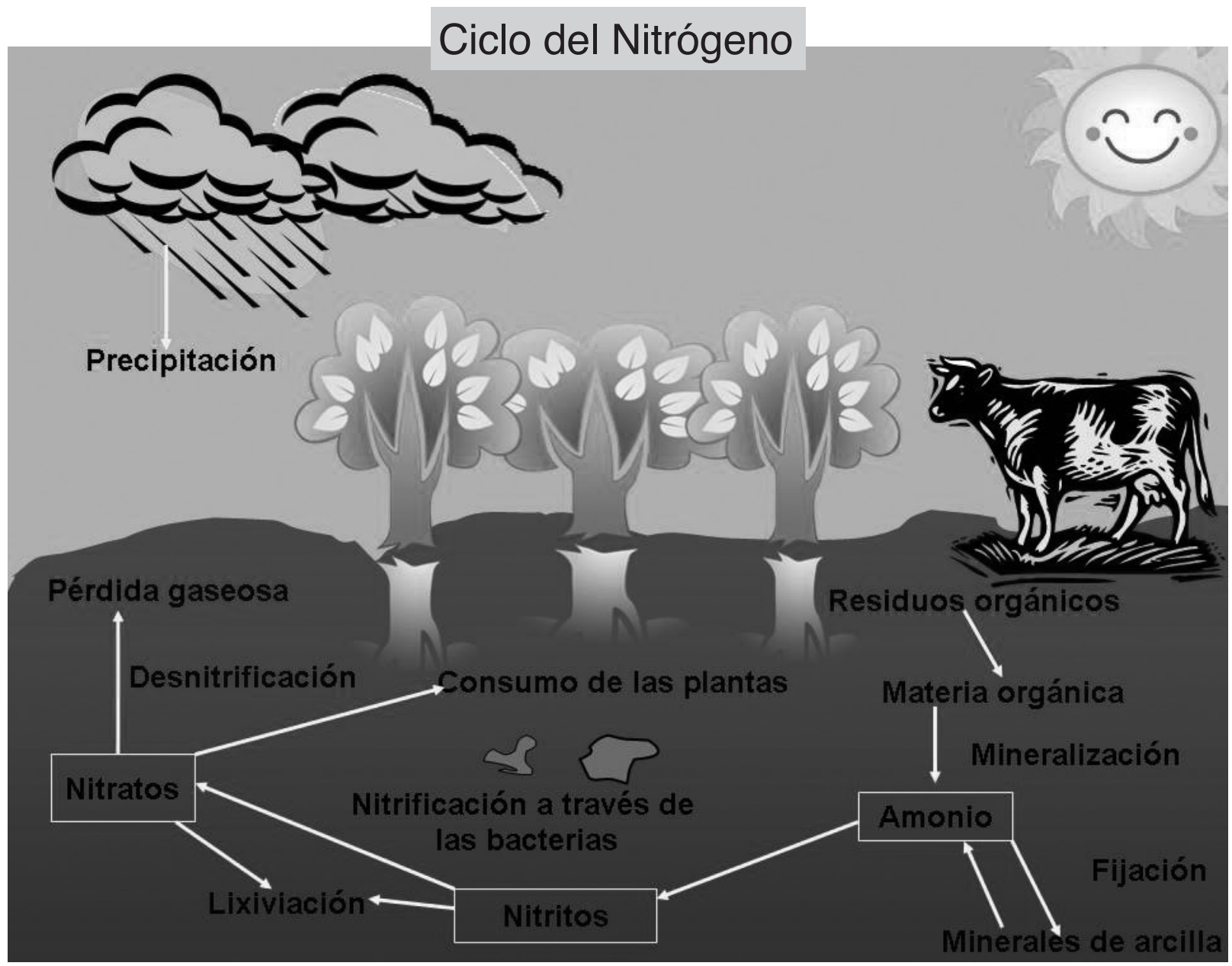

Fuente: http:/ /www.otromundoesposible.net/wp-content/uploads/2013/11/imagenciclo-alimentacion.jpg

El nitrógeno es útil para formar aminoácidos, proteínas y ADN. El exceso de nitrógeno disuelto en la tierra, y arrastrado por las aguas, es descompuesto por las algas que se encuentran en ríos y océanos y lo envían a la atmósfera.

Formamos equipos para enumerar las principales especies animales y vegetales nativas de la comunidad que forman parte de los ciclos biogeoquímicos. Al finalizar discutimos ¿qué importancia tiene el ciclo biogeoquímico en el equilibrio natural? ¿Cómo se puede tener en cuenta en los procesos productivos de la comunidad?

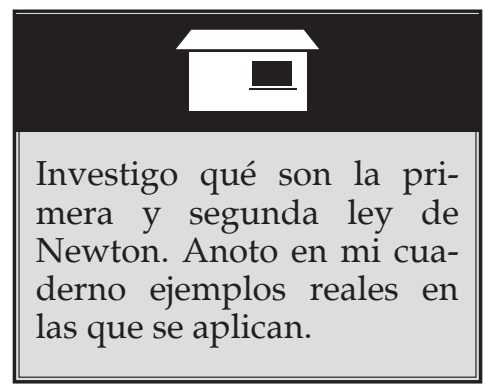




\section{Producir y consumir con desarrollo sostenible}

La naturaleza hace uso pleno de los recursos, es decir que no produce basura. El fin del ciclo de un organismo es el alimento que da vida a otro. Los recursos naturales son enormes si respetamos su ciclo de renovación. Mantener en buen estado el equipo, maquinaria, herramientas y vehículos es otra forma de aumentar su vida útil y ahorrar dinero en su reparación o sustitución. Refabricar, reacondicionar y reciclar son estrategias que disminuyen el uso de energía, agua y transporte, con lo cual se reduce la contaminación.

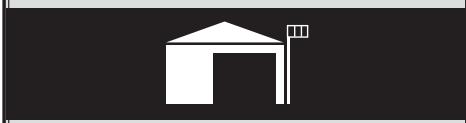

Trabajamos en equipo una propuesta del proceso de mejora continua para el desarrollo sostenible y lo exponemos a nuestra clase. Nos valemos de un organizador gráfico para facilitar la organización de la información.

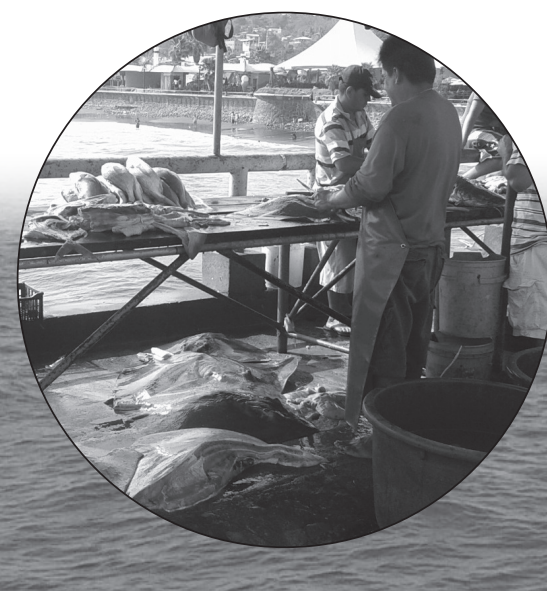

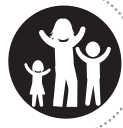

El desarrollo sostenible necesita cambio de actitudes, comportamientos y hábitos de todos nosotros, seamos productores o consumidores. Los consumidores responsables podemos exigir a los productores que cumplan con las normativas medio ambientales, se les puede presionar si seleccionamos o evitamos la compra de sus productos.

El objetivo de la producción y el consumo sostenibles es la minimización del desperdicio, la contaminación y el daño ambiental; a la vez que se optimizan procesos de producción y uso de recursos que reduzcan costos. La revisión de cada etapa del proceso de producción para reducir el desperdicio genera beneficios porque baja los costos de producción y también los de tratamiento y disposición de los residuos. En la actualidad, la falta de tratamiento de estos residuos contamina los ríos, lagos y demás fuentes de agua. La producción sostenible protege al ambiente, además de cuidar el bienestar y salud de los consumidores y trabajadores porque se anticipa y previene cualquier daño antes de que suceda.

Seleccionamos la producción local de un producto agrícola, industrial o artesanal. Analizamos si aplica los principios de la producción sostenible:

1. Uso de materiales reciclados.

2. Empleo mínimo de químicos o residuos peligrosos para el ambiente o la salud humana.

3. Uso reducido de plásticos, duroport u otros objetos no biodegradables.

4. Aplicación de prácticas productivas respetuosas de los derechos humanos (salario, horario y calendario laboral).

5. Empleo racional de agua y energía. 


\section{Contribuir al desarrollo sostenible}

Adquirimos productos y servicios porque no podemos producir todo lo que necesitamos. Podemos consumir lo que producimos y adquirimos sin desperdiciar, con ello ahorramos recursos económicos y recursos naturales. También debemos adquirir productos y servicios de buena calidad y precio razonable; pero que sean producidos respetando el ambiente, a las personas que los producen y a la comunidad que los obtiene.

Es nuestra responsabilidad consumir solo lo necesario, ejercitando nuestro juicio crítico frente a la influencia de la publicidad que promueve comprar artículos novedosos, con la última tecnología, para estar a la moda o porque todos los demás lo adquieren. Antes de comprar, preguntémonos:

- ¿Este producto o servicio es el de mejor calidad y precio?

- ¿Realmente lo necesito y cuánto durará?

- Cuando termine de usarlo, ¿cómo me voy a deshacer de él?

- ¿Está fabricado con materiales reciclables o materia prima renovable?

- ¿Quién y cómo fue producido?

Es importante conocer las condiciones de las y los trabajadores que producen los objetos o servicios que adquirimos, de lo contrario podríamos estar contribuyendo a las formas de esclavitud moderna. La pobreza obliga a muchas personas a aceptar trabajos en condiciones infrahumanas, arriesgan sus vidas por un salario que no les permite una existencia digna; pero producen grandes beneficios económicos para las empresas y sus propietarios. ¿Podemos dejar de adquirir objetos o servicios producidos con estas malas prácticas?

Identifiquemos ejemplos de esclavitud moderna que incluyen: las peores formas de trabajo infantil, explotación sexual, trabajo forzado y trata de personas. ¿Cómo debilitan estas formas los derechos humanos y el buen vivir? ¿Están en riesgo las y los jóvenes de esta comunidad de caer en alguna forma de esclavitud moderna?

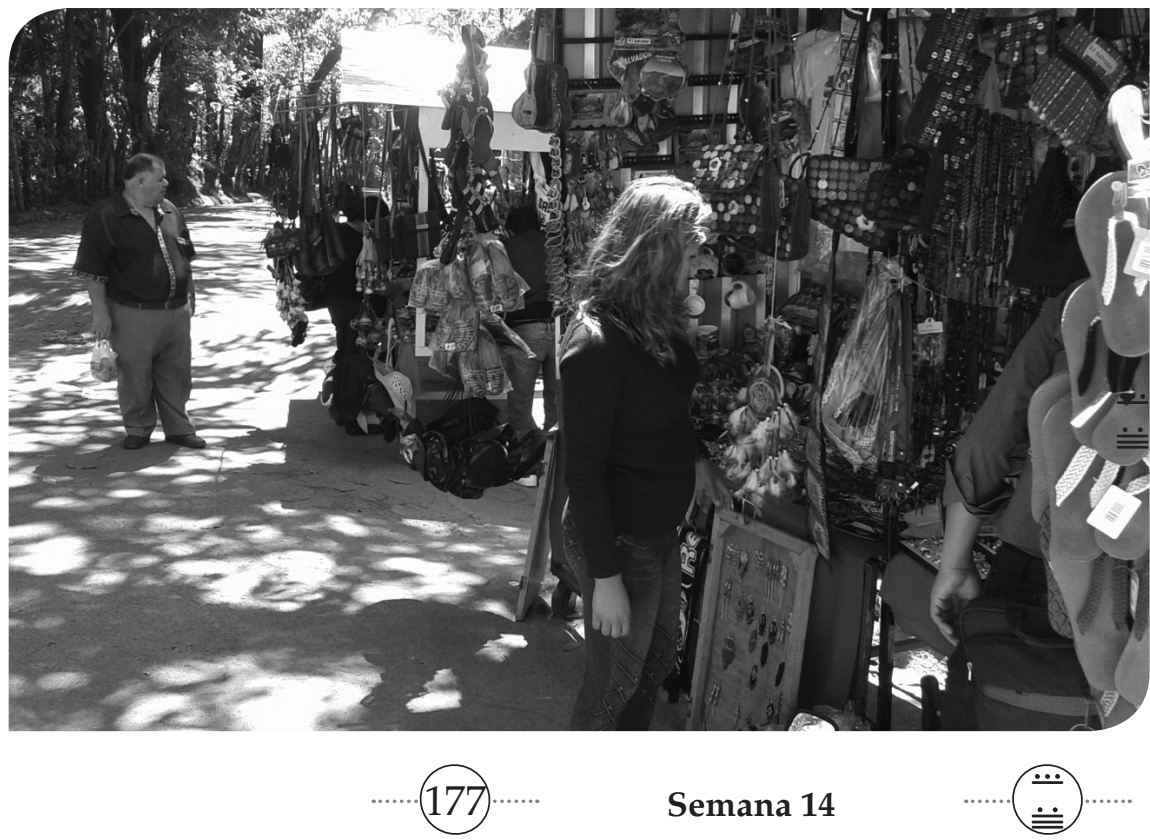

Las energías renovables hacen uso de la fuerza de la naturaleza para activar equipos y maquinaria $y$ producir electricidad. La energía eólica utiliza la fuerza del viento; la energía hidráulica, la del agua y la energía solar, la radiación solar. Estos tipos de energía no producen humo ni gases, evitan el calentamiento de la Tierra y su contaminación.

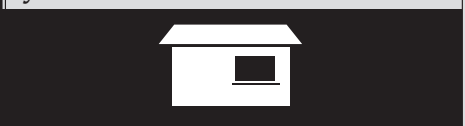

Maya Pedal es una oenegé guatemalteca situada en San Andrés Itzapa, Chimaltenango que recicla bicicletas para producir bicimáquinas. Pienso en formas de aprovechar ese tipo de energía en mi comunidad.

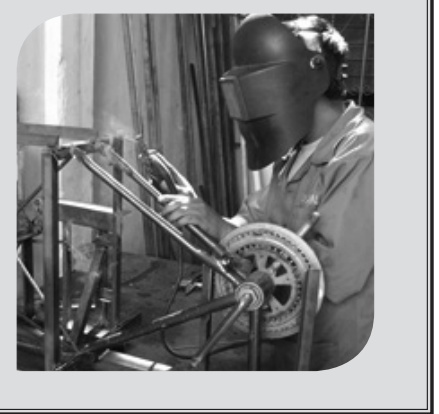




\section{Amenazas naturales}

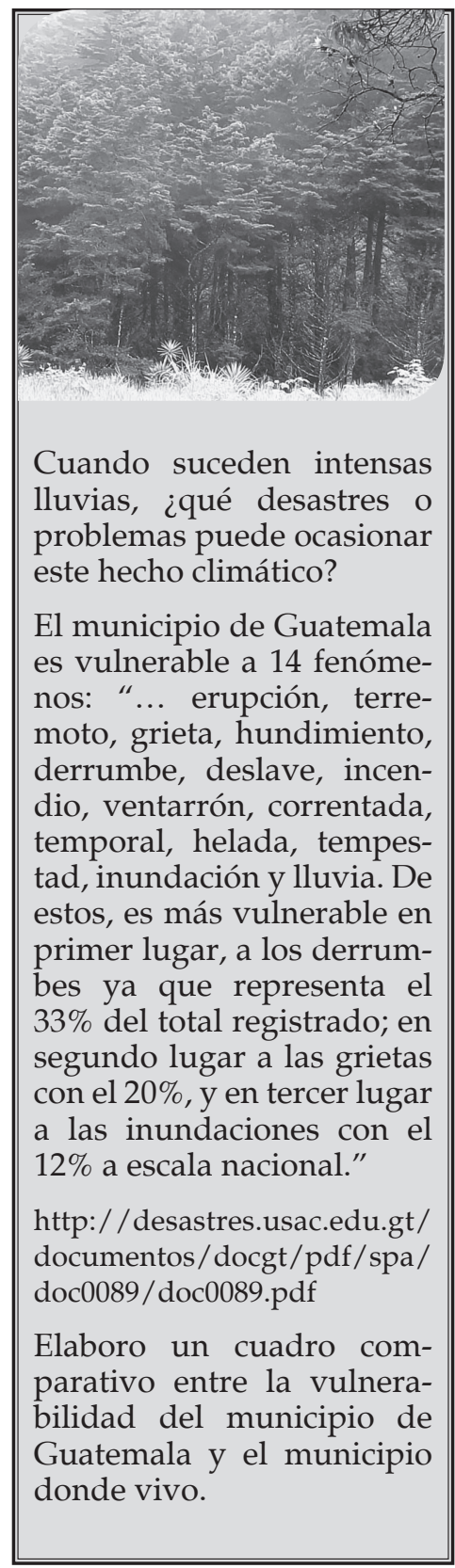

La superficie del territorio guatemalteco es muy irregular debido a que lo atraviesan las cordilleras Septentrional, Central y Volcánica, en esta última se ubican 33 volcanes. También el territorio tiene una gran cantidad de depresiones, con lo cual menos de la tercera parte es terreno plano. Por ser parte del istmo centroamericano, soplan los vientos alisios y contra alisios; en la temporada de huracanes se ve afectada por los que provienen del Atlántico y el Pacífico.

Estas características geográficas hacen que Guatemala tenga varias amenazas naturales cada año, como la posibilidad de que ocurran deslizamientos, avalanchas, derrumbes, hundimientos, desbordamientos, inundaciones, movimientos telúricos, erupciones volcánicas, entre otras. Se les llama amenazas porque existe la posibilidad de que, al ocurrir estos fenómenos naturales, generen desastres para las personas como pérdidas de vidas y bienes materiales.

Trabajamos en equipo.

- Describimos las características geográficas de nuestra comunidad.

- Mencionamos que amenazas naturales han afectado más a nuestra comunidad.

- Narramos cómo sucedieron estas amenazas.

- Explicamos de qué manera fueron afectados los recursos naturales de la comunidad.

- Analizamos cómo actuaron los miembros de la comunidad para solventar los problemas ocasionados.

- Analizamos los aciertos y los errores que se cometieron al solventar los problemas que generaron las amenazas naturales.

- Elaboramos un protocolo para enfrentar desastres sociales o problemas ocasionados por las fuerzas naturales.

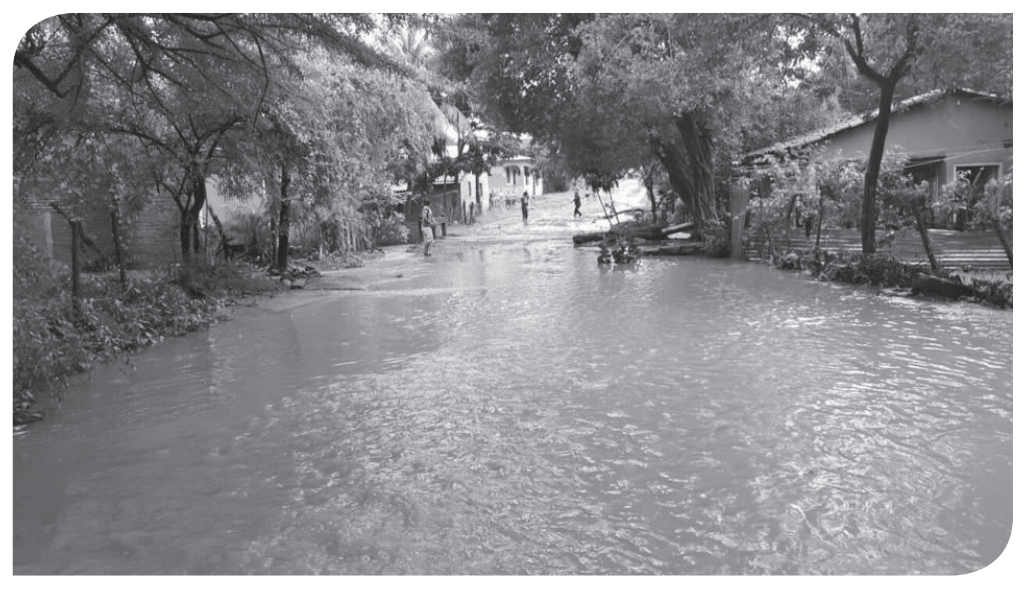




\section{Amenazas socio-naturales}

Cuando en una comunidad hay condiciones adversas para la vida de las personas y se dan fenómenos naturales que pueden causar una catástrofe se denomina amenaza socio-natural. Estas condiciones adversas pueden ser la pobreza, desnutrición, vivir en las laderas de una montaña o a orillas de un barranco. La amenaza es mayor porque si se da una sequía y las personas son pobres se generarán cuadros de desnutrición muy graves. Si se construyen viviendas en la orilla de un barranco y ocurre una gran tormenta, el riesgo de que las viviendas sean arrastradas al barranco y las pérdidas humanas es muy alto.

Escribo en mi idioma materno y en inglés algunas advertencias frente a situaciones de riesgo por amenazas sociales y naturales.

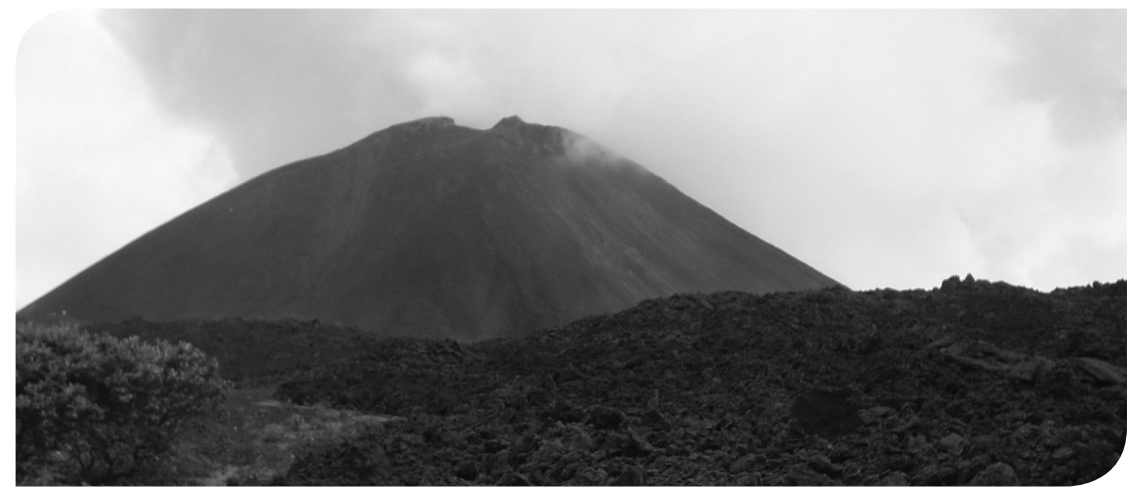

Trabajamos en equipo. Para planificar la feria científica.

- Determinamos cuáles son las amenazas socio-naturales en nuestra comunidad.

- Elaboramos un organizador gráfico que sintetice estas amenazas.

- Formamos en equipos para preparar una propuesta que atienda a cada una de estas amenazas y elaboramos una presentación en Power Point para compartir con el grupo.

Elaboro unas fichas para sintetizar la información relevante sobre los recursos humanos de la comunidad y la posibilidad de emplearlos para prevenir amenazas socio-naturales.

- Mencionamos un uso sostenible de recursos naturales que se practique en nuestra comunidad.

- Analizamos el impacto que tiene la destrucción del ambiente natural en los seres humanos.

- Elaboramos un cuadro comparativo entre el buen vivir y el modelo de desarrollo basado en la libre empresa. Podemos emplear los aspectos siguientes para comparar: respeto por los derechos humanos, los derechos de la Madre Tierra y las amenazas naturales y socio-naturales.
- ¿En qué condiciones este fenómeno natural se convierte en desastre socio-ambiental?

Analizo la cita siguiente.

"No es conveniente seguir refiriéndose a los desastres desencadenados por la acción de eventos naturales como "desastres naturales", ya que en esencia los desastres no son naturales sino acontecimientos sociales causados fundamentalmente por problemas del desarrollo no resueltos. Un desastre ocurre cuando un evento natural encuentra condiciones sociales propicias para causar pérdidas, tales como pobreza, problemas ambientales, ignorancia, desintegración social, entre otras.

Fuente: https://dialnet.unirioja.es / descarga / articulo/4025373.pdf

Emito una opinión personal acerca de lo que se afirma en el texto anterior.

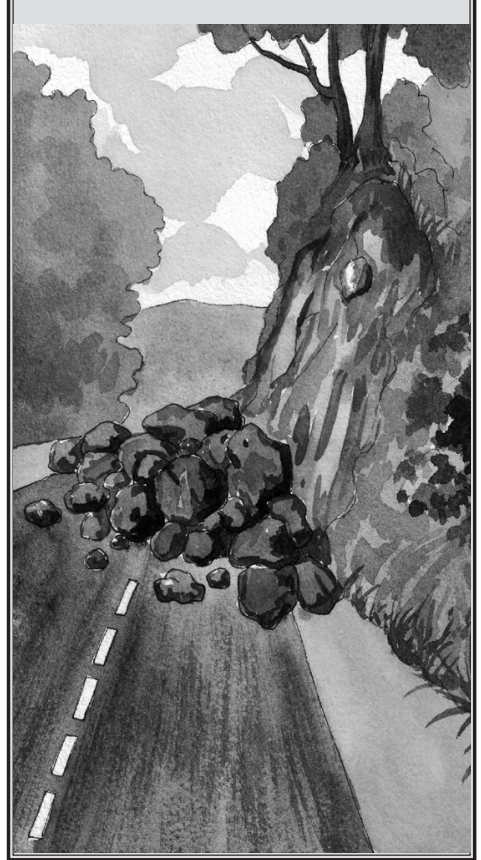




\section{Arte, lenguajes y sentidos}

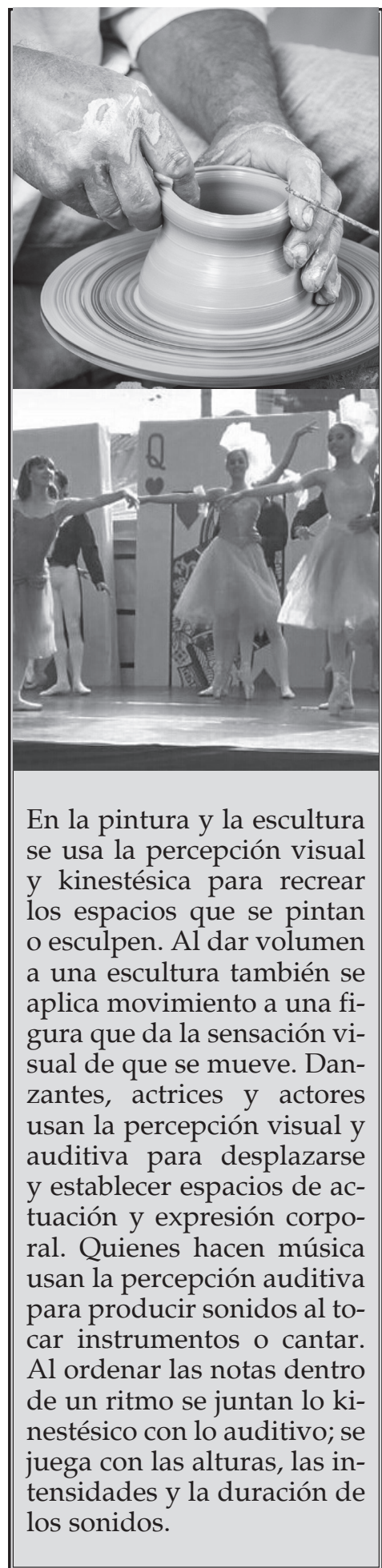

Nos reunimos en equipo y respondemos: ¿se puede usar el arte para expresar problemas o soluciones? Argumentamos nuestra respuesta.

Cada expresión artística utiliza un lenguaje. Los lenguajes son maneras de transmitir mensajes a través de diversos materiales que tienen relación directa con nuestros sentidos con los que captamos la realidad.

La línea, color, forma, volumen, textura y movimiento de las artes plásticas utilizan espacios que son captados por la vista, es el lenguaje visual. Los sonidos de la música, de las voces, de los diálogos y todas las formas de sonar, desde lo natural hasta lo electrónico, constituyen el lenguaje auditivo. Todos los movimientos, gestos y posturas del cuerpo, al desplazarse en un espacio durante un tiempo organizado, integran el lenguaje kinestésico. Los lenguajes se relacionan constantemente, por ejemplo: un dibujo puede tener movimiento y dar origen a los dibujos animados. Para tocar la música hay que moverse y en el teatro los diálogos son acompañados por movimientos del cuerpo y escenografía.

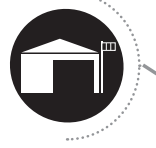

Trabajamos en grupos.

- Leemos cada movimiento en la tabla siguiente.

\begin{tabular}{|l|l|l|l|}
\hline \multicolumn{3}{|c|}{ Movimientos sensoriales que usamos al hacer arte } \\
\hline Danza & Teatro & Música & Artes Plásticas \\
\hline Estiramiento & Tensión & Audición & Percepción \\
Elasticidad & Relajación & Entonación & visual \\
Fuerza & Flotar - deslizar & Interpretación & Trazos de línea \\
Flexibilidad & Tocar - arremeter & Tensión & y color \\
Resistencia & Hendir - presionar & Relajación & Imitación de la \\
Tensión & Hablar & Ejecución de & forma \\
Relajación & Entonar & parámetros: in- & Imitación de la \\
Desplazamiento & improvisar & tensidad, altura, & textura \\
Imitación & Imitación & timbre, duración & \\
\hline
\end{tabular}

- Realizamos los movimientos como un ensayo para hacer arte.

- Discutimos sobre las ocasiones en que usamos combinaciones de movimientos sensoriales, auditivos, visuales, kinestésico y táctiles. 


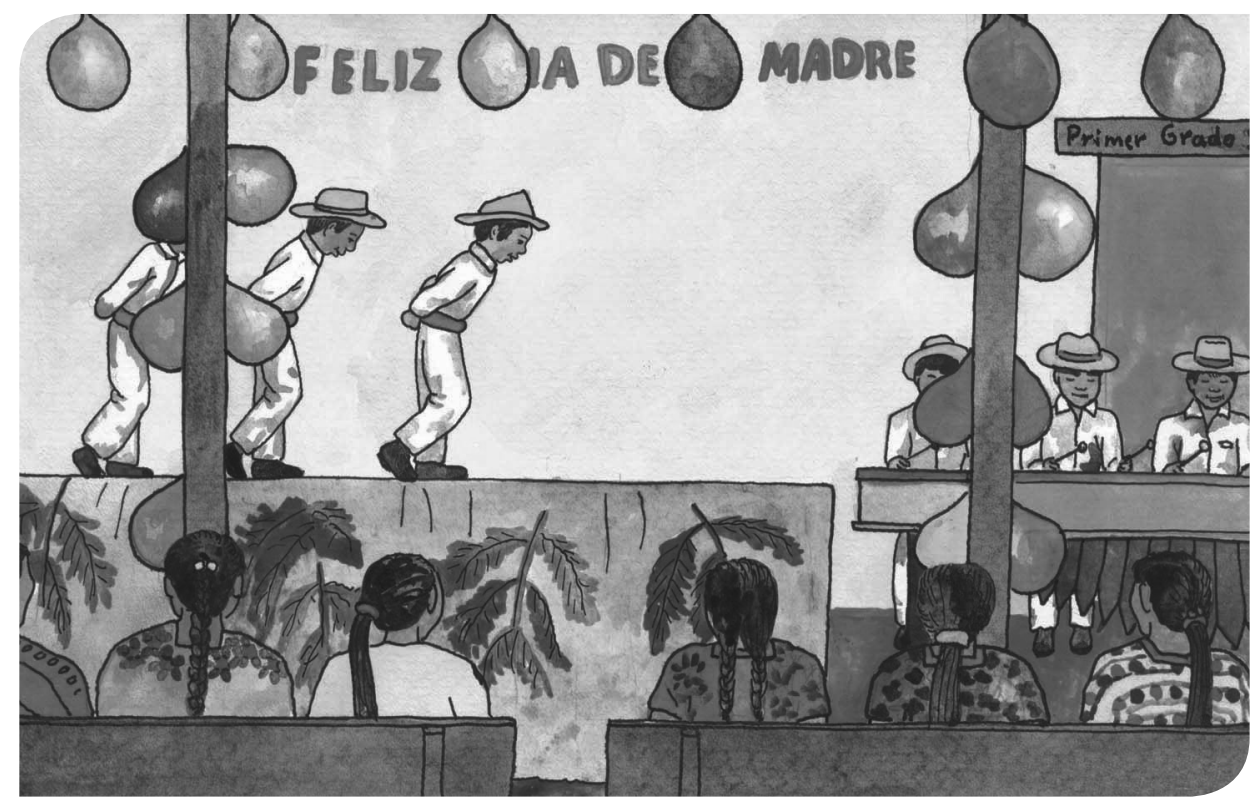

Tres lenguajes integrados

Cuando asistimos a una exposición de artes plásticas, representación teatral, presentación de danza o un concierto de música de cualquier estilo, notamos cómo se integran los tres lenguajes del arte: visual, kinestésico y auditivo. Estas presentaciones tienen un valor artístico por el uso de los lenguajes que allí se muestran.

El teatro y la danza se presentan en escenarios que necesitan de escenografía, y esta es realizada por artistas de la plástica que decoran el ambiente que se quiere recrear en la obra. Si la obra presenta escenas de un barrio, decoran con una calle en perspectiva o casas dibujadas. También puede transcurrir dentro de una casa, entonces la escenografía incluirá paredes y objetos pintados para recrear una sala o un comedor. En conciertos de música popular, a veces también se utiliza escenografía.

Como podemos ver, la forma como se utilizan los tres lenguajes del arte se integran muchas veces en los eventos de cada especialidad. El diálogo teatral permite la integración de los tres lenguajes pues contempla:

- los guiones

- el escenario

- la interpretación

- Pienso en los problemas ambientales que hay en mi comunidad y determino en qué se relacionan.

- Elijo uno de los problemas ambientales para representarlo en una obra de teatro.

- Escribo el guion de la obra.
Personajes: Manuel (hombre, 15 años, ropa deportiva) y Alicia (mujer, 16 años, ropa deportiva)

Escenografía: a medio día, sobre un puente con un río seco al fondo, rodeado por basura.

Manuel: ya te diste cuenta que el río tiene menos agua desde hace un mes.

Alicia: no he podido verlo porque cuando salgo de madrugada está muy oscuro, Manuel. Y ¿por qué será que está pasando eso?

Manuel: dice Juan que es porque allá arriba desviaron el río para las plantaciones.

Alicia: y ¿qué vamos a hacer entonces?

Manuel: vamos a hablar con las autoridades, algo tienen que hacer. 


\section{El gerundio}

Los foros son oportunidad de presentar argumentos y proponer alternativas sobre diversos temas.

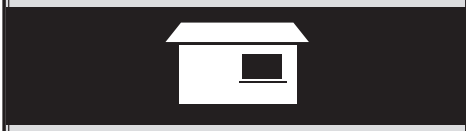

Redacto un texto sobre el derecho al ambiente sano. Para redactar este texto, cumplo con las etapas de la redacción:

1. Establezco el tipo de texto: su destinatario, extensión y objetivo al escribirlo.

2. Investigo acerca del tema. Hago una lluvia de ideas con los datos que obtengo y los que pueda aportar basado en mi experiencia. Trazo un esquema gráfico con la información anterior y escribo el texto organizado en párrafos.

3. Verifico que el texto tenga introducción, desarrollo y conclusión; también que las ideas desarrolladas tengan una base sólida.
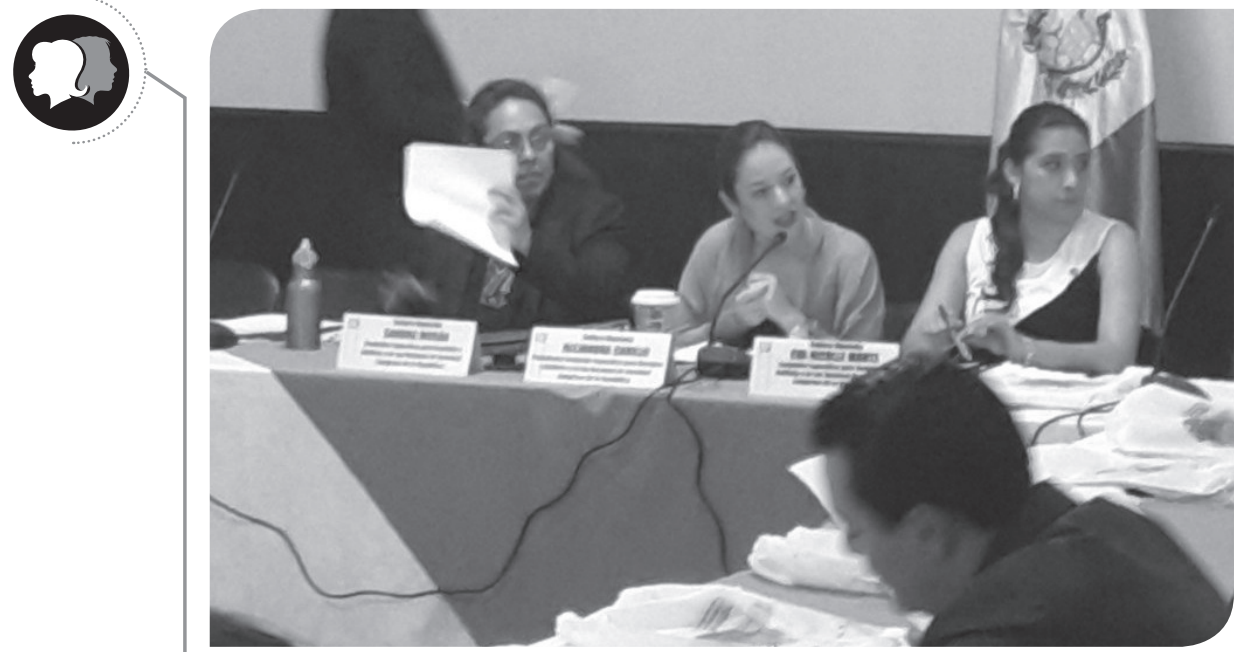

El gerundio es una forma no verbal, al igual que el infinitivo y el participio. En la oración, no adquiere carácter verbal por sí mismo, necesita el apoyo de un verbo. Sus terminaciones son: -ando y-iendo.

El gerundio se usa correctamente:

- Cuando la acción del gerundio es simultánea a la del verbo: Encontré a la niña sembrando árboles y arbustos.

- Si la acción del gerundio es inmediatamente anterior a la del verbo, ejemplo: Terminando la reunión, nos fuimos a casa a buscar una solución.

- Cuando está después del verbo estar porque el gerundio expresa una acción continuada o repetida, ejemplos:

Estaba limpiando la playa. Ella está escribiendo un libro sobre el aporte de algunas mujeres al desarrollo sostenible.

- Si la acción del gerundio sucede inmediatamente después a la acción del verbo: Luis entró proponiendo una gran solución. Eva lo vio pensando en su gran idea.

El gerundio se usa incorrectamente:

- Cuando se usa como adjetivo, porque en el enunciado funciona como adverbio:

Existe una ley reglamentando el tránsito.

Lo correcto: Existe una ley que reglamenta el tránsito.

- Si se usa para indicar una acción posterior a otra:

Ana nació en 1960; muriendo en 1999, en Perú.

Lo correcto: Ana nació en 1960 y murió en 1999, en Perú.

Escribo oraciones y párrafos para presentar argumentos sobre la importancia del desarrollo sostenible, con cada uso correcto del gerundio. 


\section{Tipos de argumentación}

Los argumentos para defender nuestras ideas deben analizarse y adecuarse para lograr un resultado exitoso. Mejoran si los combinamos con estos criterios:

- Persuasivos. Están relacionados con la opinión, ser válidos para generar la conclusión deseada y con solidez para evitar ser rebatidos.

- Funcionales. Apoyan la opinión, ofrecen respuestas para cuestionar la tesis contraria.

- Acordes. Se basan en los temas y los valores para que tengan fuerza.

- Intencionales. Tienen un intención: demostrar, o persuadir por medio de argumentos afectivos o emocionales.

\section{Técnicas de autoevaluación}

Son herramientas para realizar una valoración de nuestro desarrollo educativo; sin embargo, son útiles en todo campo de nuestra vida. Nos ayudan a enfocar nuestro crecimiento, enfatizar en nuestras fortalezas y a considerar nuestros estilos de aprendizaje, capacidad de lenguaje, experiencias y nivel como estudiantes. Algunas de ellas son:

Llaves del pensamiento. Partimos de una lección aprendida o que queramos aprender y realizamos una revisión general del tema; luego sometemos todo a una nueva revisión.

Predicción. Realizaremos una proyección a futuro de los conocimientos y las metas que se alcanzarán.

Comparación. Evaluamos el antes y el después del conocimiento adquirido.

Correlación con conocimientos previos. Establecemos conexiones con información o experiencias adquiridas con anterioridad para su posterior análisis.

Crítica. Analizamos objetivamente el desarrollo individual y grupal.

Organicemos un foro sobre la necesidad de la igualdad en la educación de niños y niñas para alcanzar el desarrollo sostenible. Preparemos diferentes tipos de argumentos para demostrar y persuadir a las personas que invitemos a escucharnos.
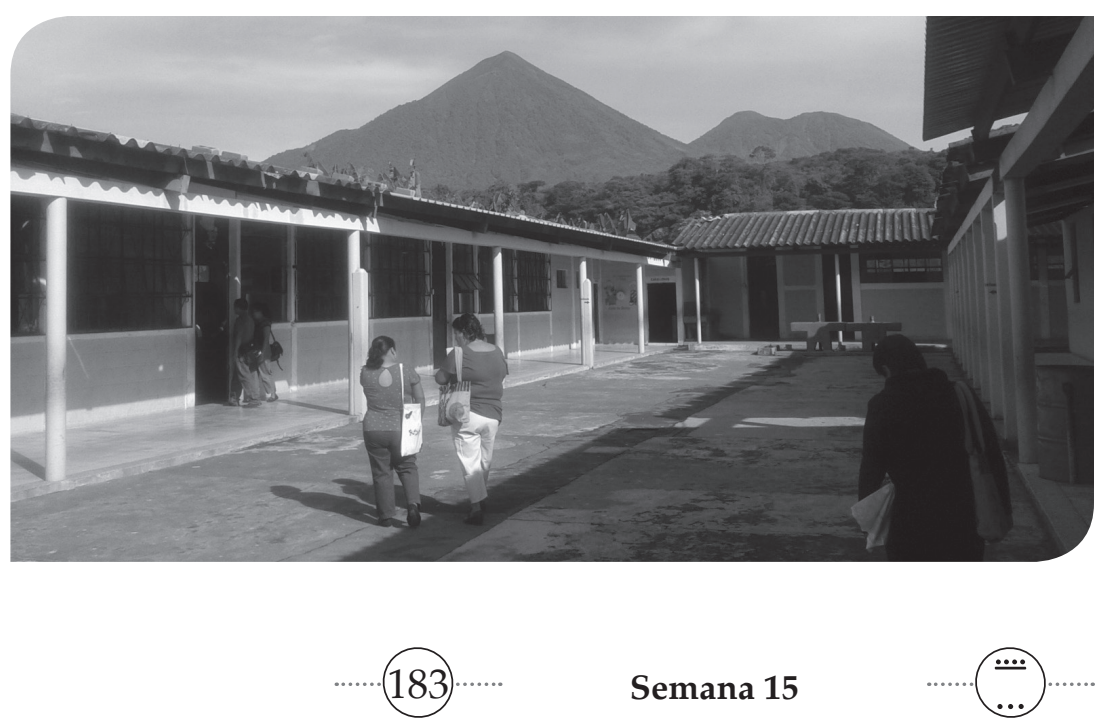

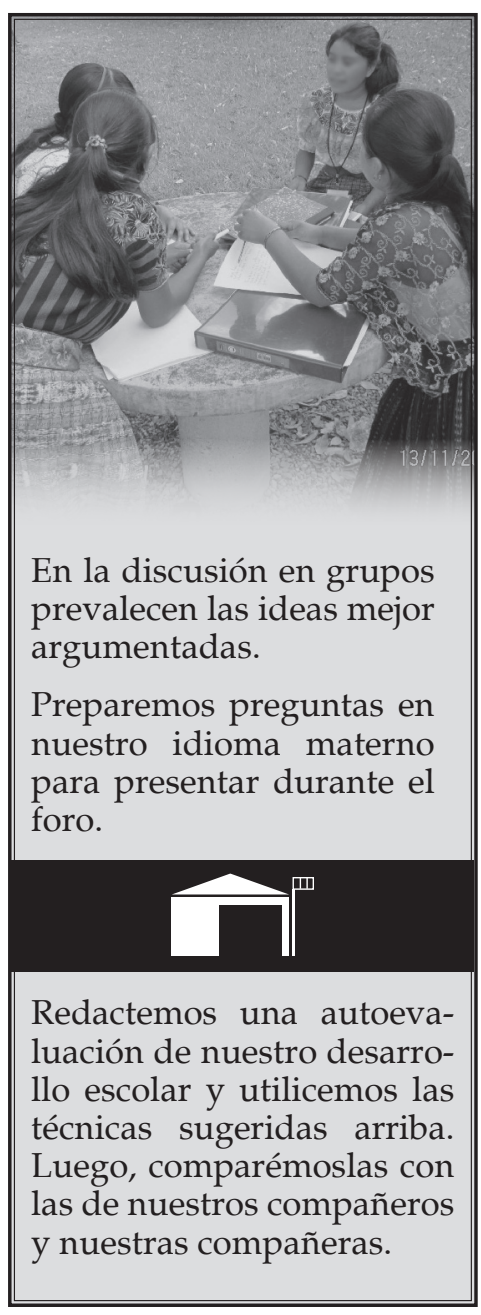

Redactemos una autoevaluación de nuestro desarrollo escolar y utilicemos las técnicas sugeridas arriba. Luego, comparémoslas con las de nuestros compañeros y nuestras compañeras. 


\section{Movimiento}

Un molino de nixtamal, realiza varios tipos de movimiento a la vez. Las poleas, engranajes, discos y ruedas dentadas; realizan movimiento circular, las bandas de las poleas, realizan movimiento rectilíneo y circular. Las quijadas realizan movimiento lineal alternativo y el tornillo sin fin o gusano, realiza movimiento giratorio continuo.

\section{Electrónica y productividad}

La Industria electrónica incluye: desde la obtención de los materiales usados en la fabricación de productos electrónicos, hasta la prestación de servicios basados en el empleo de equipos y sistemas electrónicos.

Fuente: http://www. uba.ar/archivos_secyt / i m a ge / Ind ustria \% 20 Electr\%C3\%B3nica\%20\%20 ANEXOI.PDF

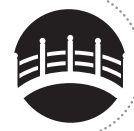

\section{Tipos de movimiento aplicados en maquinarias}

En las máquinas se emplean dos tipos básicos de movimientos:

- Movimiento giratorio. cuando el operador no sigue ninguna trayectoria (no se traslada), sino que gira sobre su eje.

- Movimiento lineal, si el operador se traslada siguiendo la trayectoria de una línea recta (la denominación correcta sería movimiento rectilíneo).

Estos dos movimientos se clasifican en:

- Continuo, si el movimiento se realiza siempre en la misma dirección y sentido.

- Alternativo, cuando el operador está dotado de un movimiento de vaivén, es decir, mantiene la dirección pero va alternando el sentido.

\begin{tabular}{|c|c|c|c|}
\hline \multicolumn{4}{|c|}{ Movimiento en las máquinas } \\
\hline $\begin{array}{l}\text { Giratorio } \\
\text { continuo }\end{array}$ & $\begin{array}{l}\text { Giratorio } \\
\text { alternativo }\end{array}$ & $\begin{array}{l}\text { Movimiento } \\
\text { lineal continuo }\end{array}$ & $\begin{array}{l}\text { Movimiento } \\
\text { lineal } \\
\text { alternativo }\end{array}$ \\
\hline $\begin{array}{l}\text { - Molinos de } \\
\text { viento } \\
\text { - Motores eléc- } \\
\text { tricos } \\
\text { - Motores de } \\
\text { combustión } \\
\text { interna }\end{array}$ & $\begin{array}{l}\text { - Tornos de arco } \\
\text { - Péndulos } \\
\text { - Exprimidores de } \\
\text { cítricos } \\
\text { - Columpio }\end{array}$ & $\begin{array}{l}\text { - Cinta transpor- } \\
\text { tadora } \\
\text { - Lijadoras de } \\
\text { banda } \\
\text { - Sierras de cinta }\end{array}$ & $\begin{array}{l}\text { - Aguja de una } \\
\text { máquina de } \\
\text { coser } \\
\text { - Bombas de } \\
\text { inflar pelotas } \\
\text { - Perforadoras } \\
\text { - Émbolo de las } \\
\text { máquinas de } \\
\text { vapor }\end{array}$ \\
\hline
\end{tabular}

\section{Movimiento giratorio y circular}

El movimiento giratorio se refiere al movimiento del eje, mientras que el movimiento circular, son cuerpos que giran junto con el eje; sus extremos describen una circunferencia. En el molino, los extremos de sus aspas describen una circunferencia; pero, el péndulo del reloj traza un arco de circunferencia. Entonces, las aspas llevan movimiento circular y el péndulo movimiento oscilante, llamado circular alternativo. Este movimiento circular, sea continuo o alternativo, se produce cuando combinamos un eje de giro con una palanca.

Fuente: http://concurso.cnice.mec.es/cnice2006/material107/maquinas/maq_movimientos.htm\#titulo

Dibujamos los diferentes tipos de movimientos. 


\section{Cantidad de movimiento lineal y su conservación}

Observamos la siguiente imagen, representa dos vehículos que se mueven con la misma velocidad, por el mismo camino.

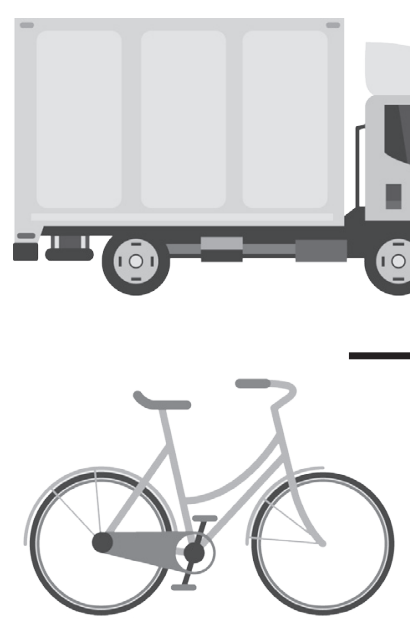

Respondemos con nuestro grupo.

1. Si en el camino hay un derrumbe, ¿a cuál de los dos vehículos le será más fácil detenerse?

2. Argumentemos nuestra respuesta.

3. Propongamos algunas ideas para demostrar la veracidad de la respuesta.

En el movimiento de un objeto o de una máquina intervienen dos cantidades básicas: la cantidad de masa de ese objeto y la velocidad a la que se mueve. De la relación entre estas dos cantidades se obtiene la cantidad de movimiento de un cuerpo. La cantidad de movimiento de un objeto es igual a su masa multiplicada por la velocidad, se expresa en la fórmula:

$p=m v$

En donde $p=$ cantidad de movimiento, $m=$ masa,$v=$ velocidad

\section{Movimiento giratorio y circular}

Muy parecidos, pero también diferentes, son los movimientos giratorio y circular. Estos se encuentran presentes en casi todas las máquinas, sobre todo en aquellas que incluyen tornos y molinos. Cuando un objeto realiza movimiento circular gira junto con el eje mientras que sus extremos marcan una circunferencia. El movimiento giratorio es el movimiento del eje. Por ejemplo, el movimiento de un molino es circular, porque sus aspas marcan una circunferencia.
Máquina simple. Es un dispositivo que solo tiene una, o ninguna, parte móvil, ejemplos: pinza, pala, azadón y alicate.

Máquina compuesta: Resulta de la composición de dos o más máquinas simples, por ejemplo: un motor.

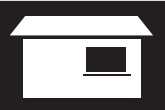

Clasifico las máquinas que hay en mi comunidad, en simples o compuestas.

- Identifico el tipo de movimiento que tienen esas máquinas.

- Describo la utilidad que poseen.

- Elaboro un álbum de las máquinas que se utilizan en las actividades productivas de mi comunidad, como la agricultura y la artesanía.

- Reflexiono sobre la influencia que ha tenido la industria electrónica en la productividad de las empresas de mi comunidad. 


\section{Asentamientos humanos}

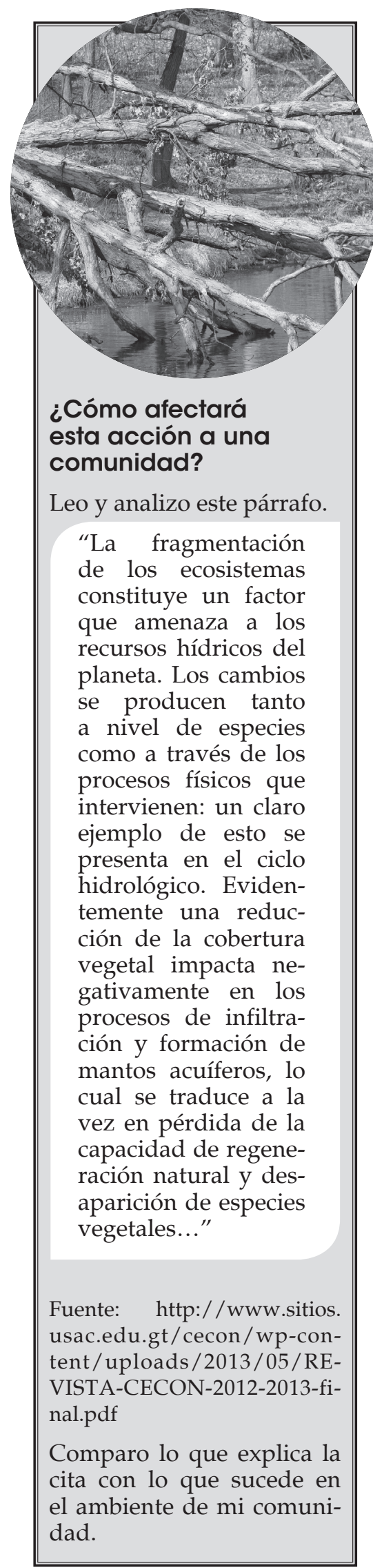

Reunámonos en equipo para hacer lo siguiente:

- Ubiquemos a las personas de mayor edad de nuestra comunidad.

- Diseñemos una entrevista con estas personas para obtener información acerca de la fundación de nuestra comunidad y cuánto ha cambiado el ambiente natural que rodea a la misma.

Cuando un grupo de familias construye sus viviendas en un lugar, establece una relación con el medio que las rodea. También consolidará las relaciones entre sus integrantes y con otros asentamientos humanos. La decisión de construir viviendas en determinado lugar puede estar basada en un estudio técnico que tomó en cuenta las características topográficas del terreno, la existencia de fuentes de agua, impacto que tendría en el ambiente natural, etc. Otra alternativa es que, un asentamiento humano, se desarrolle debido a las necesidades de las personas y porque no hubo otra posibilidad.

- Nos reunimos en equipo para enriquecer nuestra entrevista con otros aspectos, por ejemplo: cómo se eligió el terreno para desarrollar nuestra comunidad o con qué comunidades se establecieron relaciones y de qué tipo eran.

Todo asentamiento humano afecta el ambiente natural que le rodea. Pero hay relaciones con el medio natural que causan contaminación del agua y el aire, reducción de áreas verdes, muerte de animales silvestres, entre otros problemas.

Respondemos en equipo.

- ¿Cuáles son los problemas principales que genera nuestra comunidad en el ambiente natural que la rodea?

- ¿Qué podemos hacer para reducir los impactos que causa nuestra comunidad en el ambienta natural?

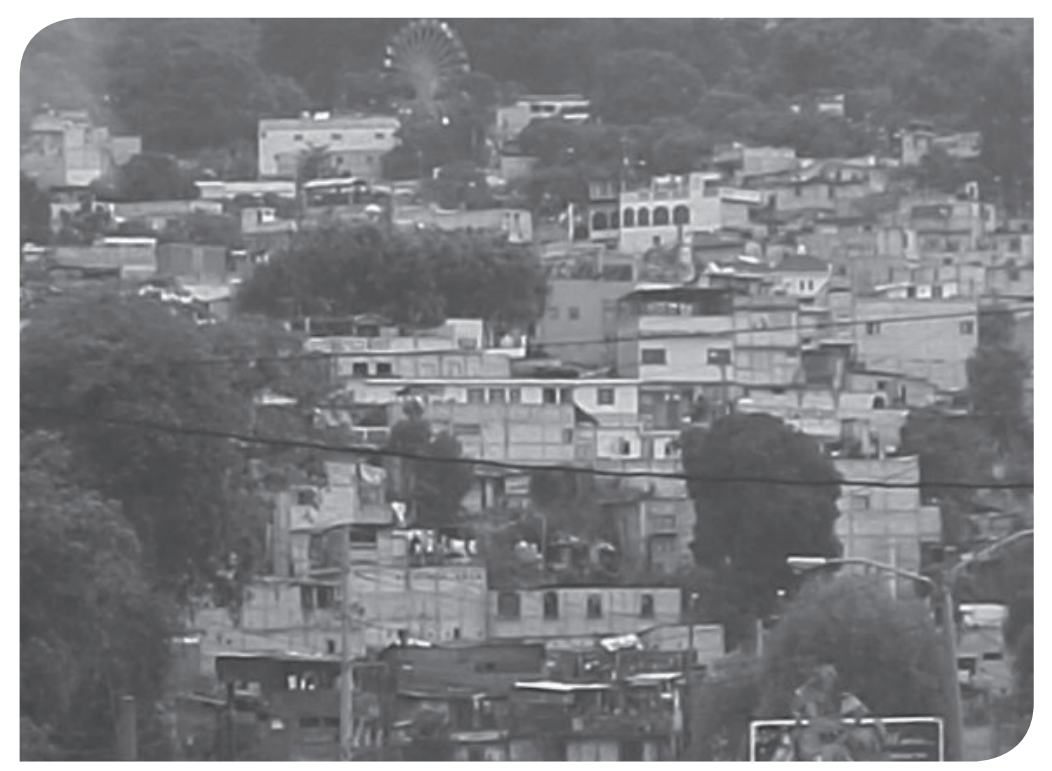




\section{Problemática de los asentamientos humanos}

En los asentamientos humanos se genera una problemática compuesta por dificultades de carácter ambiental y social. A los asentamientos humanos que no poseen servicios básicos mínimos ni condiciones ambientales que brinden una vida digna a sus pobladores se les llama precarios. Dentro de los servicios que no poseen los asentamientos humanos precarios están: energía eléctrica, agua potable, drenajes, extracción de basura, salud y educación. Las condiciones ambientales adversas son: poca área verde, contaminación ambiental, están ubicados en áreas con fallas geológicas, en orillas de barrancos o terrenos con mucha inclinación.

Trabajamos en equipo.

- Analizamos si en nuestra comunidad hay sectores de viviendas que pueden considerarse asentamientos humanos precarios. Argumentamos una respuesta colectiva.

- Opinamos con respecto al mayor riesgo que tienen los asentamientos precarios cuando ocurre un fenómeno natural.

- Determinamos la situación de los derechos humanos en los asentamientos humanos precarios.

\section{Conversamos del foro que se realizará con expertas o expertos ambientalistas.}

- Intercambiamos opiniones acerca de la técnica del foro, explicamos cuáles son las ventajas y desventajas de la misma.

- Definimos detalladamente los roles que cada participante tiene en el foro y cuánto influye el hecho que cada quien cumpla su rol para lograr el éxito de dicha actividad.

Converso con ancianos y ancianas de la comunidad que puedan dar testimonio de los cambios que han observado en el ambiente.

Hago un resumen de los testimonios obtenidos, para ello, elaboro un organizador gráfico con la información recopilada y lo presento usando power point.

- ¿A quién sugiero que pueda participar en el foro?

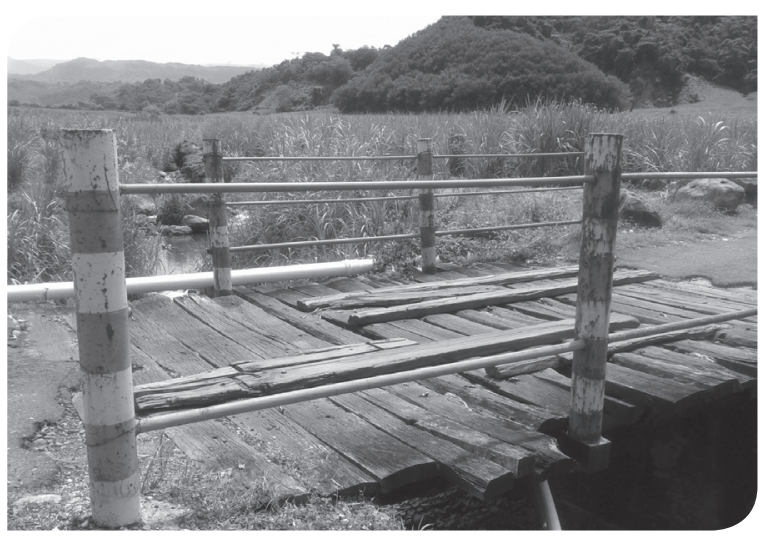

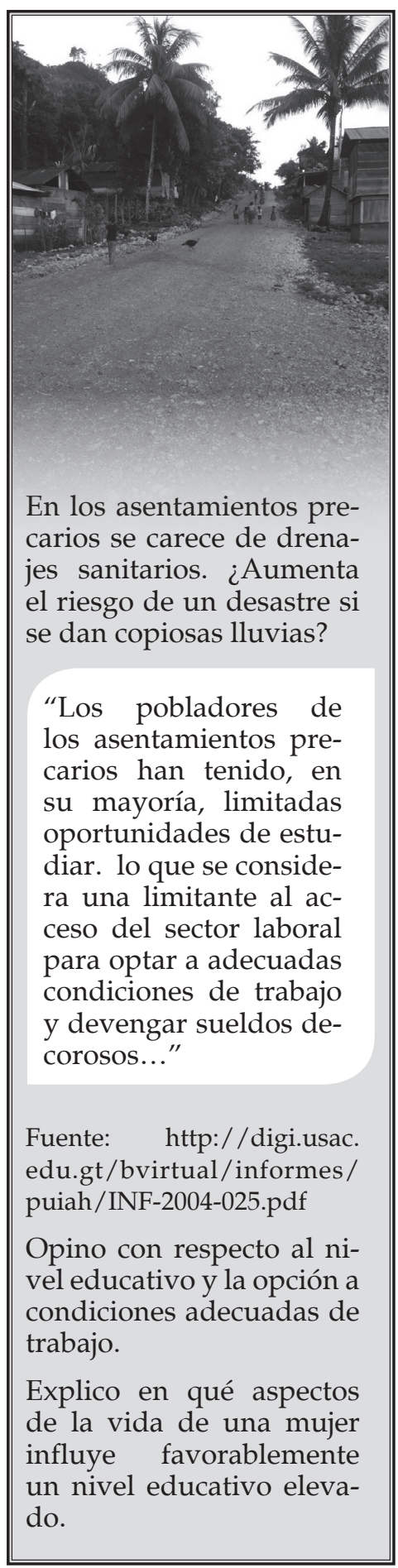

En los asentamientos precarios se carece de drenajes sanitarios. ¿Aumenta el riesgo de un desastre si

"Los pobladores de los asentamientos presu mayoría, limitadas oportunidades de estudiar. lo que se consideceso del sector laboral para optar a adecuadas condiciones de trabajo y devengar sueldos decorosos..."

Fuente: http://digi.usac edu.gt/bvirtual/informes / puiah/INF-2004-025.pd

Opino con respecto al nivel educativo y la opción a condiciones adecuadas de trabajo.

Explico en qué aspectos de la vida de una mujer un nivel educativo elevado. 


\section{Diagramas de flujo}
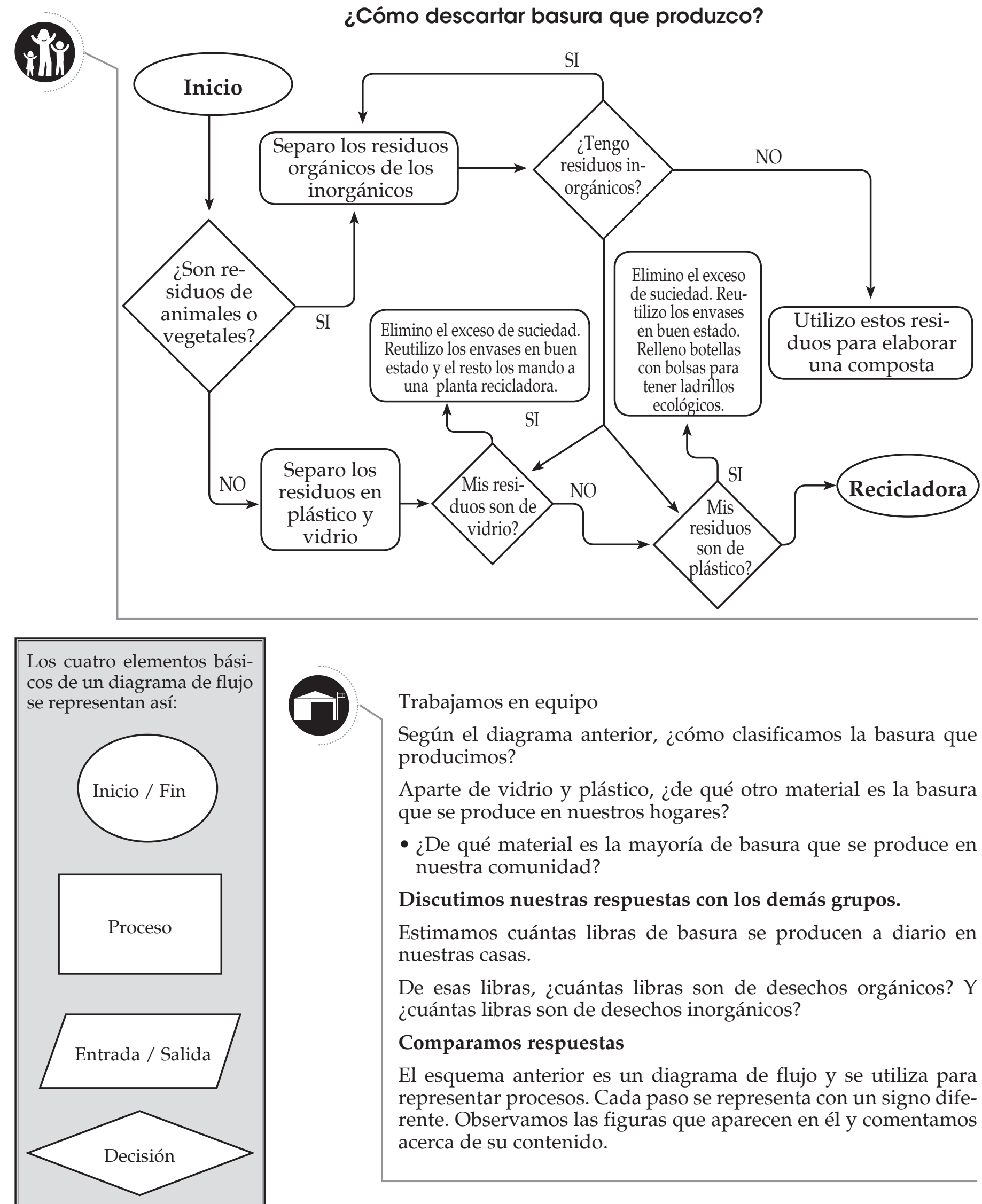

Trabajamos en equipo

Según el diagrama anterior, ¿cómo clasificamos la basura que producimos?

Aparte de vidrio y plástico, ¿de qué otro material es la basura que se produce en nuestros hogares?

- ¿De qué material es la mayoría de basura que se produce en nuestra comunidad?

\section{Discutimos nuestras respuestas con los demás grupos.}

Estimamos cuántas libras de basura se producen a diario en nuestras casas.

De esas libras, ¿cuántas libras son de desechos orgánicos? Y ¿cuántas libras son de desechos inorgánicos?

\section{Comparamos respuestas}

El esquema anterior es un diagrama de flujo y se utiliza para representar procesos. Cada paso se representa con un signo diferente. Observamos las figuras que aparecen en él y comentamos acerca de su contenido. 


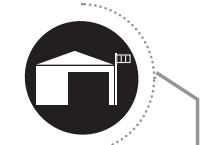

Copiamos y completamos, en nuestro cuaderno, el siguiente esquema con la información del diagrama de flujo anterior.

Escribimos ejemplos conocidos de cada tipo de desecho.

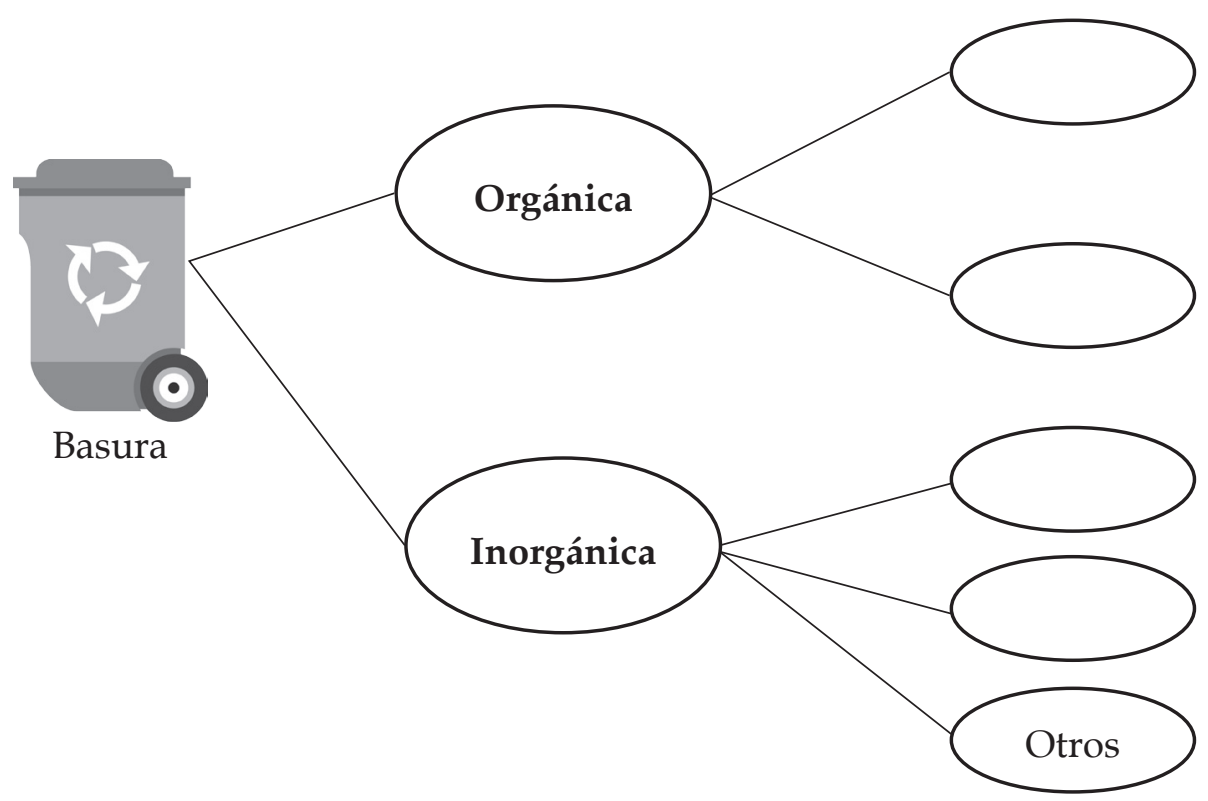

- ¿Qué tipo de basura es una bolsa de papalinas?

- ¿Dentro de qué categoría están las cáscaras de huevo?

- ¿Es el papel un desecho orgánico o inorgánico?

- ¿Podemos elaborar diagramas de decisión a partir de todos los diagramas de flujo?

\section{Explicamos nuestras respuestas.}

Realizamos un diagrama de flujo que represente el proceso de lavado de ropa. Compartimos nuestros diagramas con el resto de compañeras y compañeros. Analizamos diferencias y similitudes.

- ¿Qué hacemos con nuestra basura? ¿A dónde van a parar los desechos de nuestra comunidad? ¿Qué lugares de nuestra comunidad están contaminados por desechos sólidos? ¿De qué forma un diagrama de flujo o un árbol de decisión pueden ayudar a nuestra comunidad con el problema de la basura?

En parejas, en media cartulina, realizamos un diagrama de flujo que represente el proceso de elaboración de tortillas, desde el desgranado del maíz hasta su cocción en el comal. Compartimos con el resto.
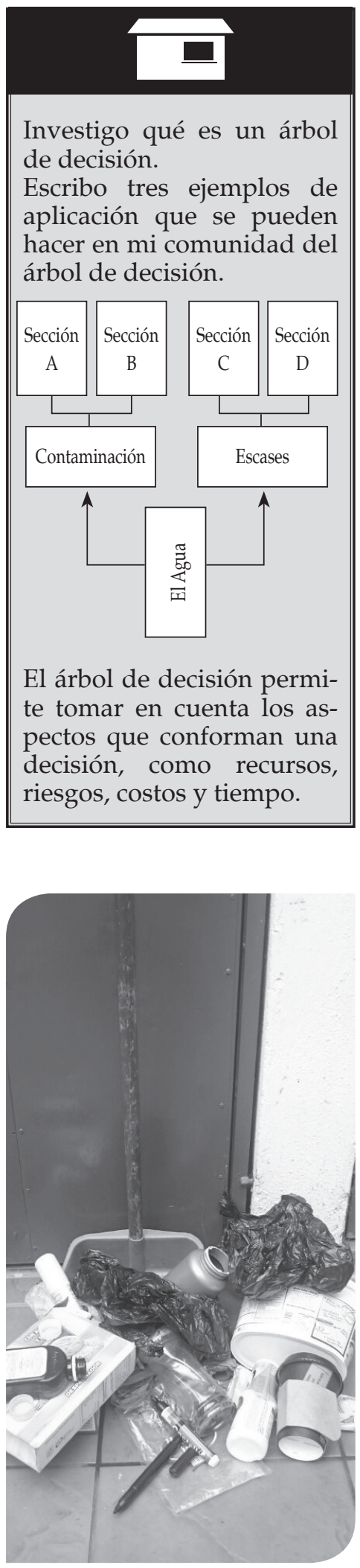


\section{Pican, pican los mosquitos}

La naturaleza nos ofrece algunas plantas cuyo olor funciona como repelente de mosquitos. Para que los mosquitos no entren a una habitación podemos tener ahí una maceta con albahaca fresca; también podemos colocar un vaso con vinagre cerca de las puertas y ventanas.

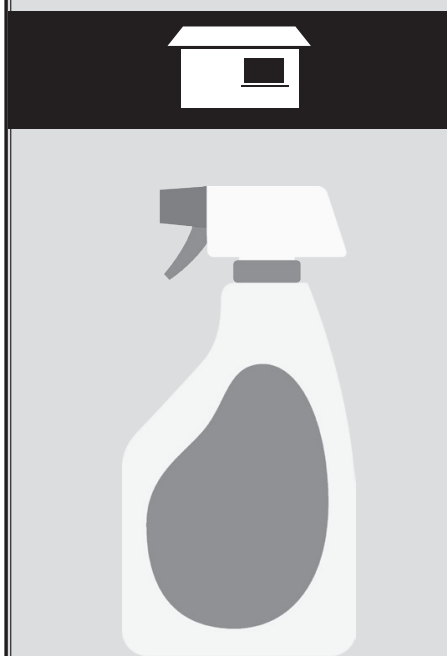

Preparo un spray repelente de mosquitos.

Necesito:

- Una cabeza de ajo

- Un vaso de agua

- Un recipiente

- Un bote atomizador

Procedimiento:

- Corto los dientes de ajo.

- En un recipiente vierto un vaso con agua y el ajo.

- Dejamos reposar la mezcla durante 5 o 6 horas.

- Llenamos el bote atomizador con agua de ajo.

- Echamos el spray de ajo en las esquinas y lugares oscuros, donde los mosquitos se esconden.
Los vectores son microorganismos que, cuando extraen la sangre de una persona o animal afectado por algunas enfermedades, transmiten una enfermedad al picar o morder a una persona o animal sano. La mayoría de vectores son mosquitos que transmiten paludismo, dengue, chikunguya, zika, y fiebre amarilla.

El agua estancada, variaciones en la temperatura y el cambio climático favorecen la expansión de estos insectos y la propagación de las enfermedades que transmiten. El acceso al agua, su saneamiento y la aplicación de medidas de higiene son esenciales para su control ; aunque el mejor método es eliminar los criaderos. Otras medidas preventivas son:

- Podar arbustos y cortar malezas cercanas a la casa.

- Tapar toneles, pilas y depósitos de agua.

- Lavar semanalmente con cloro toneles, pilas y depósitos de agua.

- Recolectar basura en un recipiente tapado.

- Barrer y limpiar los patios para quitar objetos donde se estanque agua, por ejemplo, llantas y botellas.

- Cambiar regularmente el agua de macetas y floreros.

- Revisar regularmente las canaletas de los techos de la vivienda.

Otros insectos que transmiten enfermedades infecciosas son las pulgas, las garrapatas, las moscas y las chinches. Las pulgas nos pueden transmitir peste y tifus. Las garrapatas pueden infectarnos de enfermedad de Lime, fiebre maculosa y tularemia. Las moscas pueden contagiarnos de fiebre tifoidea, disentería y salmonella. Las chinches transmiten la enfermedad de Chagas.

\section{Trabajamos en equipo}

Mencionen casos de la comunidad donde se transmitió una enfermedad por medio de algún insecto.

Expliquen cuál es el tratamiento para estas enfermedades.

Solicitamos a una persona del centro o puesto de salud que nos explique cómo nos afectan las enfermedades infecciosas transmitidas por insectos.

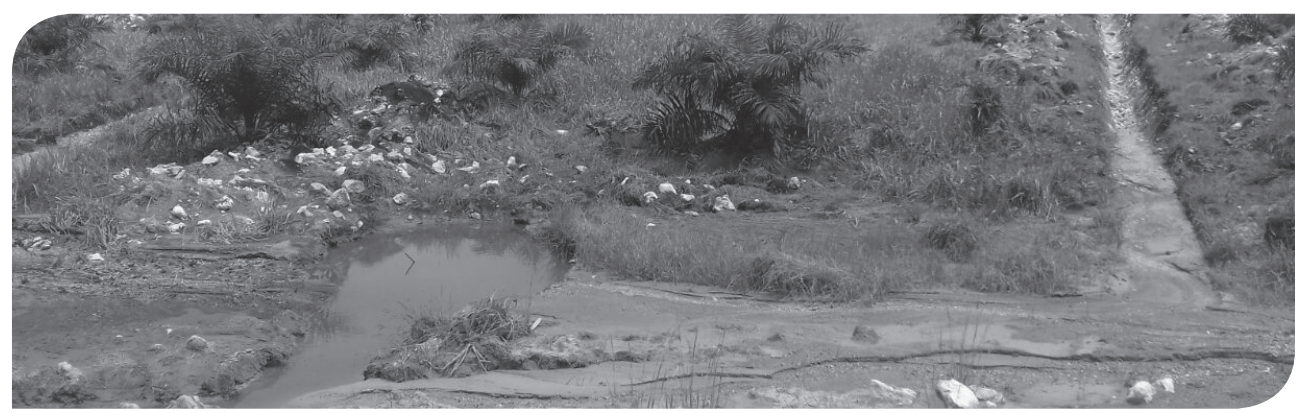




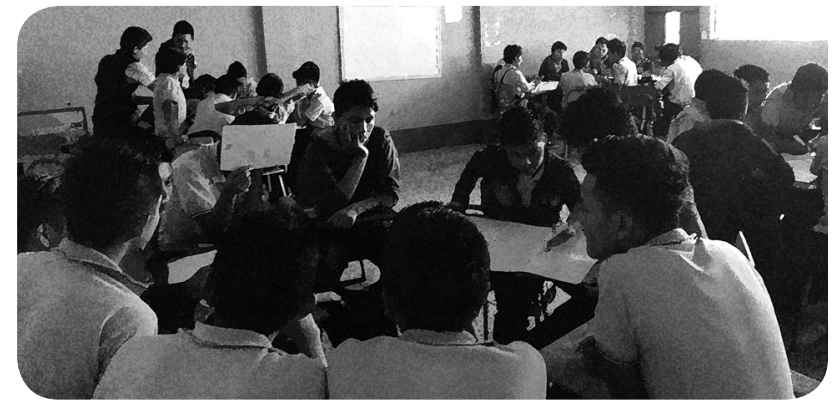

Evaluamos en equipo

- Analizamos la calidad de la información que hemos obtenido para realizar una propuesta en la Feria científica.

- ¿Cuál ha sido el aporte de los y las integrantes de los miembros del grupo?

- ¿Qué propuestas y gestiones hemos hecho para planificar el foro con especialistas ambientales?

\section{Autoevaluación}

1. Explico cada lenguaje que se da en el arte y la Naturaleza.

2. ¿Cómo califico el guion de teatro que escribí?

3. ¿Empleé adecuadamente los gerundios en dicho guion?

4. Redacto un argumento acerca de las ventajas de la autoevaluación.

5. Describo la máquina más compleja que hay en mi comunidad.

6. ¿Qué porcentaje de la población de mi comunidad vive precariamente?

7. ¿Cuáles son los principales riesgos de desastre que tiene mi comunidad?

8. Explico qué tratamiento se le da a la basura en mi comunidad.

9. Redacto una definición de árbol de problemas.

10. Relato mi experiencia en la elaboración del spray repelente de mosquitos o en la aplicación de medidas preventivas contra la proliferación de mosquitos.

Seleccionemos dos ambientes laborales, uno favorable y uno desfavorable. Nos organizamos en dos grupos. Cada grupo discute y organiza un sociodrama representando al menos estos factores:

- Uso de máquinas

- Contaminantes ambientales

- Enfermedades ambientales

Cada grupo finaliza su representación explicando un mapa conceptual previamente realizado.

Evaluamos nuestra actividad evaluándonos a nosotros mismos (nuestro trabajo individual y en equipo), el trabajo que realizamos en equipo y el trabajo de nuestros compañeros y compañeras de equipo y la presentación del otro equipo. Nuestra evaluación final es la ponderación de las cuatro evaluaciones.
No es fácil ni barato entrenar y sustituir a una persona trabajadora. Es importante laborar en un ambiente sano física $y$ emocionalmente, en un espacio adecuado, bien ventilado e iluminado, sin exposición a gases tóxicos o fuentes de contaminación. La ausencia laboral por enfermedad tiene consecuencias para quien se emplea, costos por tratamiento de enfermedades y reducción de salario, y para la empresa, menor productividad y pérdidas económicas.

Actualmente, las enfermedades que más afectan a las y los trabajadores son el estrés, la diabetes y la obesidad. Es importante que las personas trabajadoras gocen de descansos, vacaciones y actividades recreativas para mejorar su estado emocional.

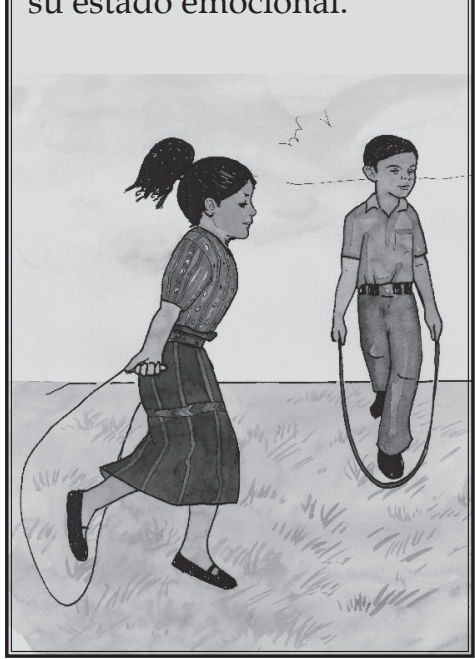




\section{Títeres y marionetas en acción}

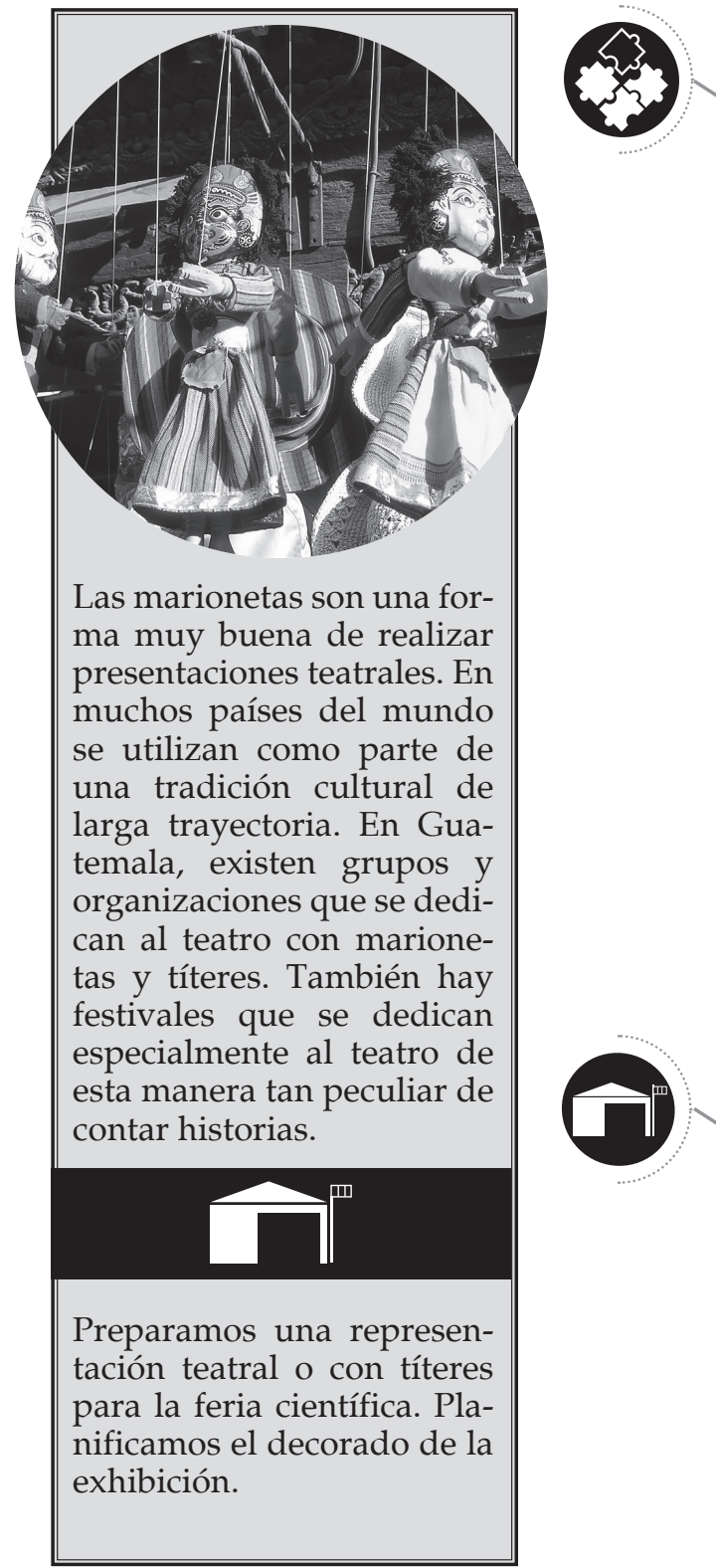

Analizamos con nuestro grupo y respondemos: ¿es posible hacer teatro sin que haya personas reales actuando en el escenario?

Para la representación teatral se pueden usar títeres o marionetas, que son muñecos que actúan movidos por hilos o por el uso de las manos. El teatro de títeres y marionetas puede ser realizado para públicos de todas las edades. Lo importante es que las y los muñecos reúnan características para que el público los relacione con personajes y hechos con los que puedan relacionarse.

Hay maneras diversas de construir títeres y marionetas:

- De guante, la mano entra en el títere como un guante, acciona sus brazos y algunos movimientos de cabeza con los dedos.

- De hilos, es la marioneta, se maniobra desde arriba con hilos articulados a las manos y los pies del títere.

- De varillas, el títere es accionado mediante varillas que lo sostienen y mueven sus brazos.

- De sombras, se proyectan con luz y quien observa solo ve las sombras proyectadas en un plano.

- De siluetas, son formas pintadas sobre una superficie plana que se desplazan por el escenario; también se llaman de paleta.

Elaboraremos títeres para la presentación de una obra sobre los conflictos socio ambientales que afectan a la comunidad o al país.

- Elegimos el tipo de títere que queremos trabajar.

- Pensamos en los personajes que necesitamos para la obra según el guion que escribimos.

- Recolectamos los materiales y comenzamos a trabajar.

- Podemos hacerlos de guante con bolsa de papel.

\section{Materiales:}

- Bolsa de papel manila o periódico

- papeles de china o construcción

- goma

- tijeras y

- marcadores.

\section{Procedimiento:}

1. Se pintan los rasgos del personaje por delante y por detrás de la bolsa de papel.

2. Se forman las ropas con papel china de colores y se agregan las partes como ojos, orejas, boca, cejas, etc.

3. El títere se maniobra con la mano dentro de la bolsa de papel. 


\section{Preparar la presentación de una obra}

Una de las tareas de la semana anterior fue escribir un guion sobre los conflictos socio-ambientales que nos afectan. También leímos un diálogo sobre el problema del cauce del río que se comienza a secar por intervención humana. Sin embargo, existen otros problemas que pueden representarse, como: contaminación acústica, del aire, del agua y del suelo.

\section{Soluciones por medios pacíficos}

Buscamos la armonía con la naturaleza y con las comunidades, por eso debemos pensar en soluciones a nuestros problemas por vía pacífica. Luchamos por la valoración y aplicación de los derechos de todas las personas de nuestra sociedad.

Presentamos nuestro guiones y discutimos, en grupo, sobre la resolución de tres problemas socio-ambientales de la comunidad por medios pacíficos.

Elegimos uno de los guiones y nos aseguramos que la historia incluya una propuesta de problemas.

Escribimos una historia sobre el problema y la solución pacífica al mismo, que aporte al desarrollo sostenible. Preparamos su representación por medio del teatro.

Puede tener diálogos entre personajes, que pueden ser humanos, de animales, de plantas y de otros del entorno que intervienen en la historia. También puede ser mediante la narración de la historia que se interpreta en escena.

\section{Fabrico una marioneta en casa}

Necesitaré: una muñeca o muñeco de juguete, de preferencia que sea de trapo; también puede ser un animalito de peluche. Hilo o lana, aguja, dos cubiertos de metal y tijeras.

\section{Procedimiento:}

- Reúno los materiales.

- Amarro los dos cubiertos formando una cruz, fuertemente para evitar que se suelten. Puede hacerse también con lápices o reglas de madera.

- Amarro una lana a cada punta de la cruz, deben quedar las cuatro lanas colgando.

- Con la aguja, coso los extremos de las lanas a las extremidades del muñeco. Cuido que el largo de los trozos de lana de los pies sea mayor que el de las manos, para que pueda caminar.

- Ensayo cómo manejar mi marioneta para usarla en la presentación de teatro.

\section{Retahílas populares}

Una retahíla es una serie larga de sucesos u objetos que están, suceden o se mencionan. En todas las culturas se construyen juegos en forma de retahílas que se recitan de forma divertida. Se pueden simplemente recitar o bien se pueden actuar. Para usar nuestro títere o marioneta, podemos formar grupos y hacer que los títeres las actúen, jueguen o bailen con ellas. Una dimensión musical surge cuando al recitarlas les agregamos ritmo. Un ejemplo de retahíla es:

\section{La chivita}

Sal de ahí chiva chivita, sal de ahí chiva chivá. $/ /^{*}$

Vamos a llamar al lobo para que saque a la chiva, / /

el lobo no quiere sacar a la chiva, la chiva no quiere salir de ahí.

Sal de ahí chiva chivita sal de ahí chiva chivá. //

Vamos a llamar al palo para que le pegue al lobo, //

el palo no quiere pegarle al lobo, el lobo no quiere sacar a la chiva,

la chiva no quiere salir de ahí...

*// Significa repetir dos veces.

Agregar: fuego par que queme el palo, agua para apagar el fuego, tubo para llevarse al agua, hasta donde llegue la imaginación. 


\section{Transformación de la energía}
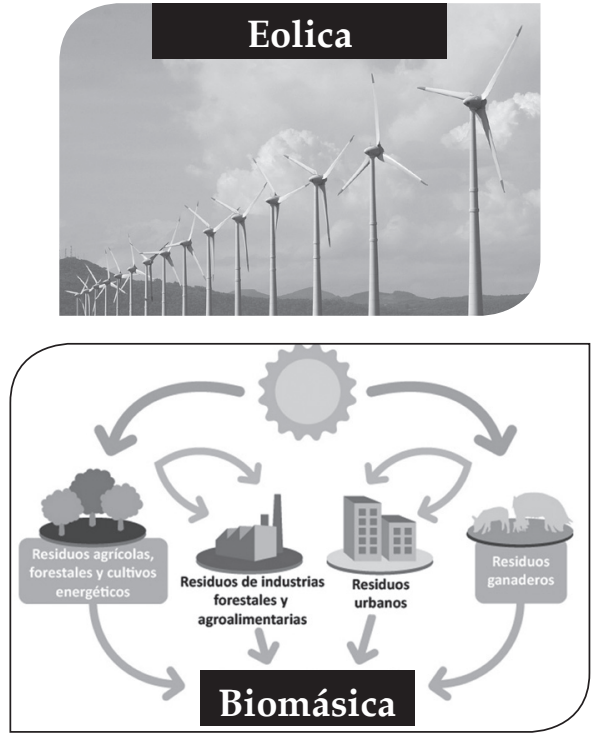

La energía renovable es la que se obtiene de fuentes naturales virtualmente inagotables, ya sea por la gran cantidad de energía que contiene o porque son capaces de regenerarse por medios naturales. Las fuentes de energía renovables se clasifican en: no contaminantes o limpias y contaminantes.

Energía limpia es producida evitando cualquier contaminación o mediante el tratamiento adecuado de todos los residuos peligrosos para nuestro planeta.

Discutimos en grupo ¿qué tipo de energía se produce a partir del petróleo, del carbón y del gas natural que tardan miles de años en regenerarse?

Pongamos a prueba la energía del sol: tomemos un hielo y saquémoslo al sol

- ¿Qué pasa con el hielo? ¿Por qué le pasa eso? ¿Qué variaciones pueden haber según la intensidad del sol?
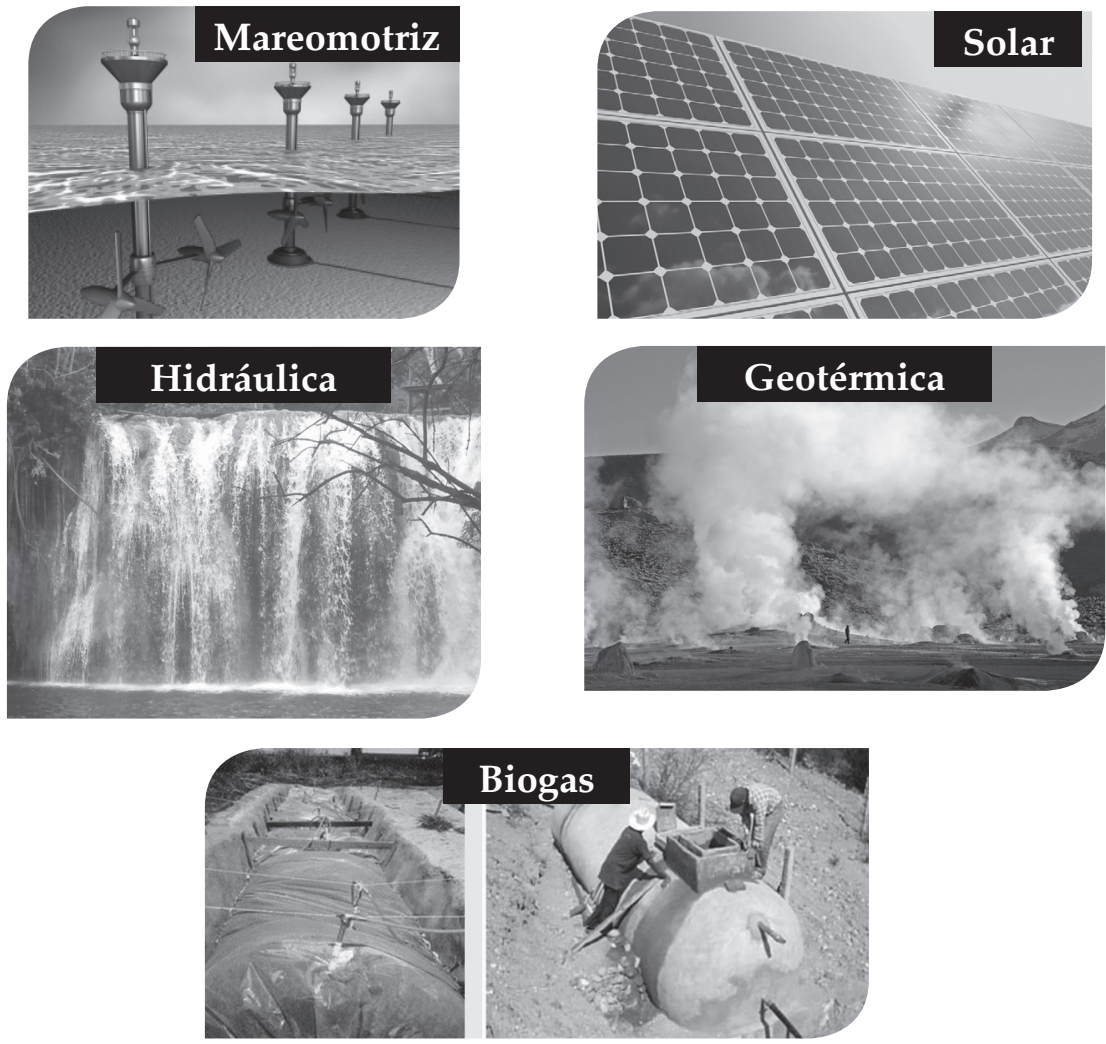

- Observamos las imágenes con los integrantes de nuestro grupo de trabajo y contestamos: ¿Qué recursos naturales están siendo usados para la producción de la energía? ¿Qué efectos tiene el uso de estos recursos sobre el entorno? ¿Cuándo se agotarán cada uno de estos recursos en nuestro planeta?

- Escribimos una definición de los tipos de energía que ilustran según la fuente principal a partir de la que esta se produce.

La energía es la capacidad de producir un trabajo. Es una propiedad que explica los cambios físicos y químicos de los cuerpos al interactuar entre sí. Por ejemplo, la energía que proveen los alimentos se activa gracias a su interrelación con enzimas, flora intestinal y jugos digestivos.

La energía eléctrica se obtiene de otra energía que puede ser térmica, lumínica, química, mecánica, entre otras. Una forma usual de transformar energía en electricidad es el movimiento de una turbina que activa un generador eléctrico. En Guatemala, las turbinas se mueven por medio de combustibles como el bunker y el diésel, pero principalmente con el agua de los ríos (hidroeléctrica).

La ley de la conservación de la energía explica que la energía no se crea ni se destruye, solo se transforma. Ejemplo: en la hidroeléctrica de Chixoy, el agua se encuentra a cierta altura y al desplazarse hacia abajo adquiere energía cinética que provoca el trabajo de la maquinaria generadora de electricidad. La energía hidráulica se convierte en energía cinética y luego esta se convierte en energía eléctrica. 


\section{Energía mecánica}

Cuando se hace una fuerza sobre un objeto y este se mueve o se desplaza se realiza un trabajo. Se calcula así: trabajo realizado = fuerza por desplazamiento en la dirección de la fuerza, $\mathbf{W}=\mathbf{F} \mathbf{d}$, donde $\mathbf{W}$ es el trabajo, $\mathbf{F}$ es la fuerza sobre el cuerpo que se desplaza y d es el desplazamiento.

Todos los cuerpos tienen energía potencial cuando están en reposo. La energía potencial que tiene un cuerpo se convierte en cinética cuando una fuerza lo mueve. Tanto la energía potencial como la energía cinética son formas de energía mecánica. En este caso el trabajo se calcula: trabajo realizado es igual al cambio de energía mecánica, $\mathbf{W}=\Delta \mathbf{E m}_{\mathrm{m}}$ donde $\Delta$ significa cambio y $\mathbf{E m}$ representa la energía mecánica.
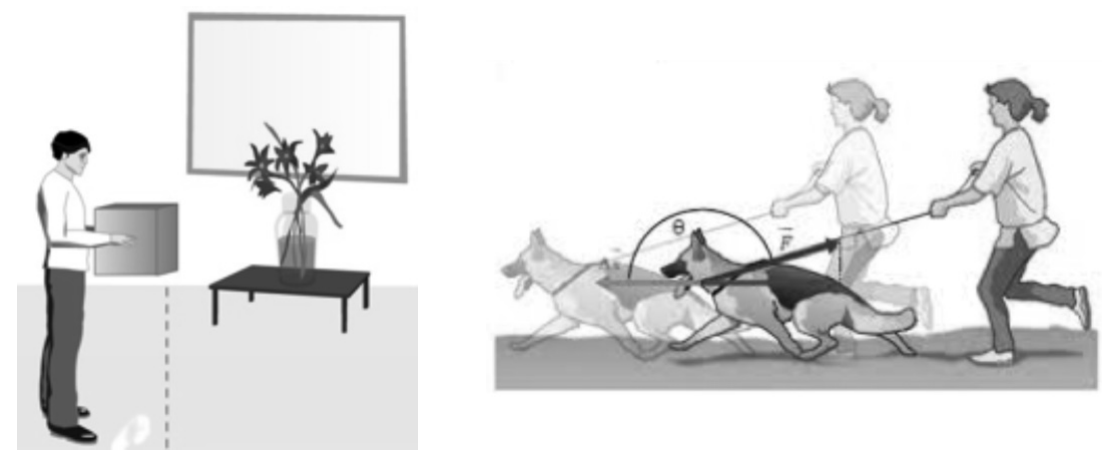

Organizamos un foro entre nosotros para discutir alternativas de producción de energía limpia, sostenible y que se haga accesible a los y las vecinas de la comunidad. Formulamos preguntas relacionadas con las formas de energía limpia que conocemos y cómo evitar que se desvíen, limiten o destruyan las fuentes que las producen.

- Analizo la actividad del foro y para ello utilizo la técnica del PNI:

\begin{tabular}{|l|c|c|}
\hline Lo positivo & Lo negativo & Lo interesante \\
\hline & & \\
& & \\
\hline
\end{tabular}

- Redacto una propuesta con cinco recomendaciones para la protección y conservación de las fuentes de energía renovable y limpia.

- Opino por escrito sobre la importancia del agua y el viento en la producción de energía para el bienestar humano.
Comparamos nuestras definiciones grupales sobre los tipos de energía

Tipos de energía limpia

Eólica: se obtiene de la fuerza del viento.

Geotérmica: se obtiene del calor que posee el interior de la Tierra.

Hidráulica: se obtiene de las energías cinética y potencial de la corriente de agua, saltos de agua y mareas.

Mareomotriz: se obtiene de las mareas mediante su empalme a un alternador para transformarla en electricidad.

Solar: se obtiene al aprovechar la radiación electromagnética del Sol.

Undimotriz u olamotriz: se obtiene a partir de la energía mecánica generada por el movimiento de las olas.

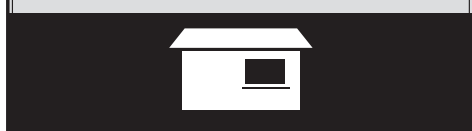

Experimento: transformación de la energía térmica en energía cinética.

Materiales: un recipiente, agua y molinillo de viento.

Procedimiento:

1. Formulo una hipótesis:

- ¿Qué creo que va a suceder con el molinillo de viento cuando lo coloque en la corriente del vapor?

2. Realizo el experimento calentando el agua en el recipiente. Una vez esta ha llegado a hervir coloco el molino de viento en la corriente del vapor que proviene del agua en ebullición. 


\section{Probabilidad simple}

Cuando lanzamos al aire varias monedas esperaríamos que cayeran en cara o escudo en la misma proporción. Explico por qué.

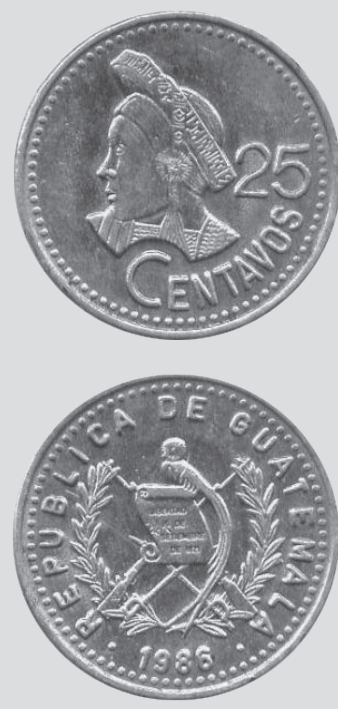

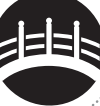

Realizamos un experimento

Copiamos y completamos las siguientes tablas con la información obtenida. Utilizamos monedas de 25 centavos.

1) Lanzamos una moneda al aire 40 veces y contamos cuántas veces cayó en cara y cuántas veces cayó en escudo.

\begin{tabular}{|l|l|l|}
\hline \multicolumn{1}{|c|}{ Resultado } & Frecuencia & Frecuencia relativa \\
\hline 1 cara & & \\
\hline 0 cara & & \\
\hline
\end{tabular}

2) Lanzamos 2 monedas simultáneamente 70 veces. Anotamos nuestros resultados.

\begin{tabular}{|l|l|l|}
\hline \multicolumn{1}{|c|}{ Resultado } & Frecuencia & Frecuencia relativa \\
\hline 2 cara & & \\
\hline 1 cara & & \\
\hline 0 cara & & \\
\hline
\end{tabular}

3) Lanzamos 3 monedas simultáneamente 80 veces. Anotamos nuestros resultados.

\begin{tabular}{|l|l|l|}
\hline \multicolumn{1}{|c|}{ Resultado } & Frecuencia & Frecuencia relativa \\
\hline 3 caras & & \\
\hline 2 caras & & \\
\hline 1 cara & & \\
\hline 0 cara & & \\
\hline
\end{tabular}

Compartimos nuestros resultados con el resto de compañeros y compañeras. Observamos diferencias y similitudes. ¿Qué podemos concluir del experimento anterior?

Construimos un árbol de decisión para cada una de los posibles arreglos de las monedas de los experimentos anteriores. Lo dibujamos en media cartulina y mostramos nuestros esquemas a los demás.

- ¿Qué representa la frecuencia relativa?

- ¿Qué relación encontramos entre la probabilidad y la frecuencia relativa en cada experimento? 
Observamos el gráfico que muestra la cantidad aproximada de precipitación pluvial, en milímetros de agua, que ha caído en una comunidad.

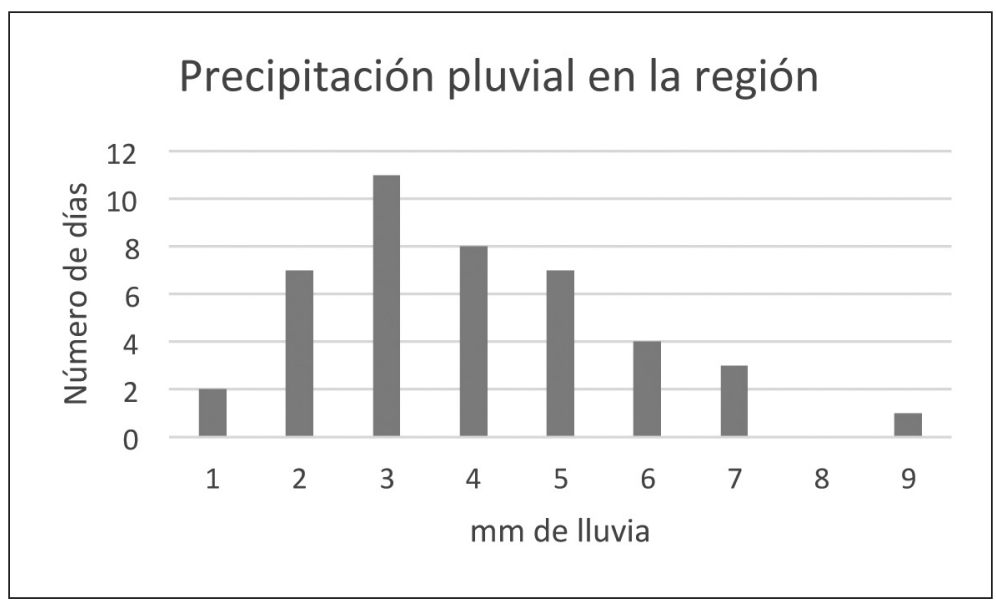

- ¿Por cuántos días se midió la precipitación pluvial en esta comunidad?

- ¿Cuál es la probabilidad de que al seleccionar un día al azar en este haya caído $5 \mathrm{~mm}$ de lluvia?

- ¿Cuál es la probabilidad de que al seleccionar un día al azar en este hayan caído menos de $4 \mathrm{~mm}$ de lluvia?

Preguntamos a nuestros compañeros y compañeras sobre cuántas personas viven en su casa y anotamos los resultados en una tabla como esta:

\begin{tabular}{|l|l|l|}
\multicolumn{1}{c|}{$\begin{array}{c}\text { Cantidad de } \\
\text { integrantes }\end{array}$} & Frecuencia & Frecuencia relativa \\
\hline 2 personas & & \\
\hline 3 personas & & \\
\hline 4 personas & & \\
\hline 5 personas & & \\
\hline 6 personas & & \\
\hline 7 personas o más & & \\
\hline
\end{tabular}

Copiamos el cuadro en media cartulina para poder presentar al resto.

- ¿Qué resultado es el más común? ¿Qué será más probable; que un compañero o compañera tenga una familia formada por 2 personas o por 5 ? Explicamos nuestras respuestas.

Resolvemos:

En una canasta hay 5 huevos grandes, 3 huevos pequeños y 6 huevos medianos. Encontramos la probabilidad de que al sacar un huevo, sin ver, este sea:

$$
\text { - Grande - Mediano - No pequeño }
$$

En una familia conformada por 5 hombres y 3 mujeres se distribuirán las tareas domésticas. Deciden sortear la tarea de lavar la ropa. ¿Cuál es la probabilidad de que esta tarea le toque a una mujer?, ¿qué probabilidad hay que le toque a un hombre?

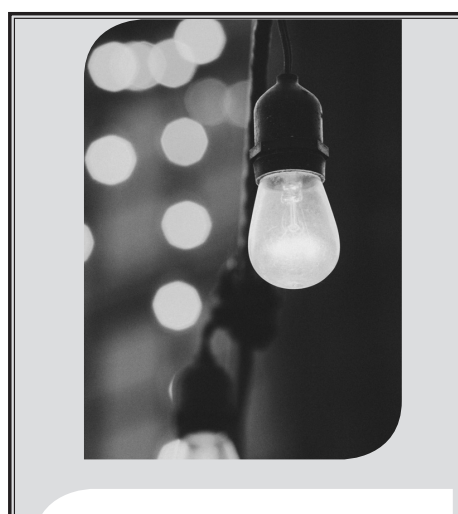

"En Guatemala la electricidad se genera básicamente por medio de las centrales hidroeléctricas, con un porcentaje de capacidad instalada del $52 \%$, las centrales térmicas con un $40 \%$ y los cogeneradores con el restante $8 \%$.

El servicio eléctrico ha alcanzado una cobertura del $42 \%$, siendo una de las más bajas de Latinoamérica. El consumo per cápita es de 205 kilovatios-hora anuales."

Fuente: http://www fao.org/docrep/t2363s / t2363s0w.htm

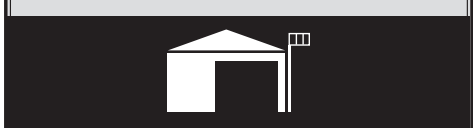

- ¿Qué probabilidad hay de tener electricidad en casa?

- ¿Cuál es la probabilidad de que la electricidad de mi comunidad sea producida por una hidroeléctrica?

- ¿Cómo puedo confirmar este dato?

Elaboramos diagramas con la información obtenida en el foro. Planificamos aportes de la matemática para la realización de la feria científica. 


\section{Formas de solucionar un conflicto}

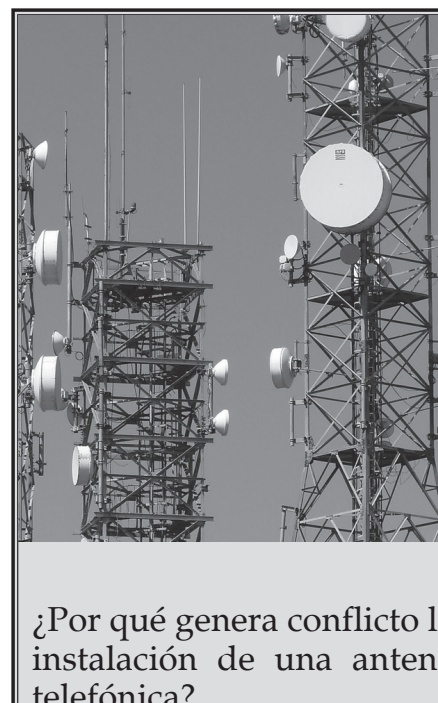

telefónica?

Se "...confirma lo senalado por la Alta Comisionada de las Naciones Unidas para los Derechos Humanos en relación a que protegiendo los derechos humanos se puede contribuir a evitar muchos conflictos que tienen su origen en la pobreza, la discriminación y la exclusión que siguen asediando a la humanidad y destruyen los esfuerzos de desarrollo que se han realizado en los últimos decenios..."

http:/ /icefi.org/wp-content/ uploads / 2014/03/mineriaimpresion.pdf

Opino con respecto al papel que juega el respeto de los derechos humanos en la solución de los conflictos ambientales.
Los conflictos son algo natural en la vida social, surgen desacuerdos entre personas o entre grupos sociales derivados de intereses diferentes que presenta cada grupo. La presencia de un conflicto es una oportunidad para dialogar sobre aquello que está generando el desacuerdo, establecer con claridad los intereses de cada grupo, definir prioridades y valores de la comunidad, alcanzar acuerdos justos sobre la forma en que se va resolver. Todo esto se puede alcanzar mediante la comunicación. Lo peor que se puede hacer es recurrir a la violencia verbal y física para imponer una solución. Hay varias formas pacíficas de afrontar un conflicto, por ejemplo:

1. Manejarlo para que la confrontación baje poco a poco de intensidad y a largo plazo poderlo solucionar.

2. Mediar entre las personas o grupos en confrontación, dialogar, negociar y llegar a acuerdos que solventen el conflicto.

3. Transformar el conflicto de tal manera que se convierta en una oportunidad para vivir mejor.

Trabajemos en equipo.

- Describimos un conflicto que haya surgido en este espacio de convergencia andragógica.

- Recordamos la forma en que afrontamos el conflicto.

- Valoramos la forma en que se afrontó el conflicto y sus resultados.

- Identificamos qué acciones se pudieron mejorar para el manejo del conflicto.

Guatemala es un país muy rico en recursos naturales, Hay comunidades que han sabido usar de forma sostenible los recursos que les rodean como los bosques, los ríos, los cerros. Por la misma riqueza de recursos se ha generado un conflicto, una competencia, por el control sobre y el uso de estos recursos naturales entre dos partes: empresas y población. Las primeras llegan a territorios de comunidades guatemaltecas, y allí instalan grandes industrias como la minería, las hidroeléctricas, torres telefónicas, monocultivos entre otras. En algunos casos esto ha implicado que se limita, a la comunidad, el acceso a los recursos, como cuando se desvía un río para hidroeléctricas o riego intensivo; y en otros, la industria provoca contaminación irreversible, como el desecho de partículas de cianuro en los ríos producto de la minería a cielo abierto. A este tipo de conflicto se le conoce como de carácter ambiental. Son difíciles de resolver debido a que la relación de poder entre las partes, empresas privadas y comunidades formadas por cientos $\mathrm{o}$ miles de pobladores; es desigual. En estas ocasiones es fundamental contar con mediadores que faciliten el diálogo y un Estado que fortalezca los derechos humanos.

- Analicemos el conflicto ambiental más cercano a la comunidad.

- ¿Cuáles son las partes involucradas?

- ¿Cuándo inició?

- ¿Cuál es la contradicción entre las partes? ¿Qué reclama cada una?

- ¿Qué intentos de resolver el conflicto ha habido? ¿Qué resultados han tenido?

- ¿Cuál sería la mejor manera de afrontar dicho conflicto? 


\section{Acuerdos de paz}

Durante más de 30 años, en Guatemala se dio un conflicto armado que provocó la muerte, desaparición y sufrimiento de miles de guatemaltecas y guatemaltecos. Para resolver este conflicto se dio la mediación, diálogo, negociación y consenso que culminaron con la aceptación de un conjunto de acuerdos para vivir en paz. Fue un proceso largo durante el cual se fue llegando a acuerdos. Se inició en 1983 con el surgimiento del grupo Contadora y terminó en 1996 con la firma del Acuerdo de Paz Firme y Duradera.

Algunos acuerdos especifican los procedimientos para terminar con las manifestaciones del conflicto, mientras que otros son procedimientos para resolver las causas del conflicto. El cuidado y preservación del medio ambiente se trata en dos acuerdos:

- Identidad y derechos de los pueblos indígenas

- Aspectos socioeconómicos y situación agraria

Después de 20 años de haberse firmado los Acuerdos de paz, existe poco cumplimiento de los mismos. Resolver conflictos que provienen de problemas estructurales requiere voluntad de modificar ciertas formas de organización económica, social y política en nuestra sociedad.

Investigamos en internet acerca del grupo Contadora y cuáles son los acuerdos de paz. Los leemos en equipos y exponemos a la clase:

- ¿Qué tipo de conflicto buscan resolver estos acuerdos?

- ¿Cuáles son los cambios que establece deben darse en la forma de organización de la sociedad?

- ¿Es importante que este acuerdo se cumpla para el bienestar de la comunidad? ¿Por qué?

- ¿Qué relación hay entre estos a cuerdos y los derechos humanos?

Elaboramos un organizador gráfico que exprese lo más relevante que los y las especialistas expusieron en el foro de la semana anterior.

Formulamos los lineamientos para organizar un conversatorio sobre las experiencias y propuestas para conservar los recursos naturales.

Redacto algunas preguntas para hacerlas en el conversatorio.

Escribo una lista de ideas principales y secundarias que puedan guiar el conversatorio.

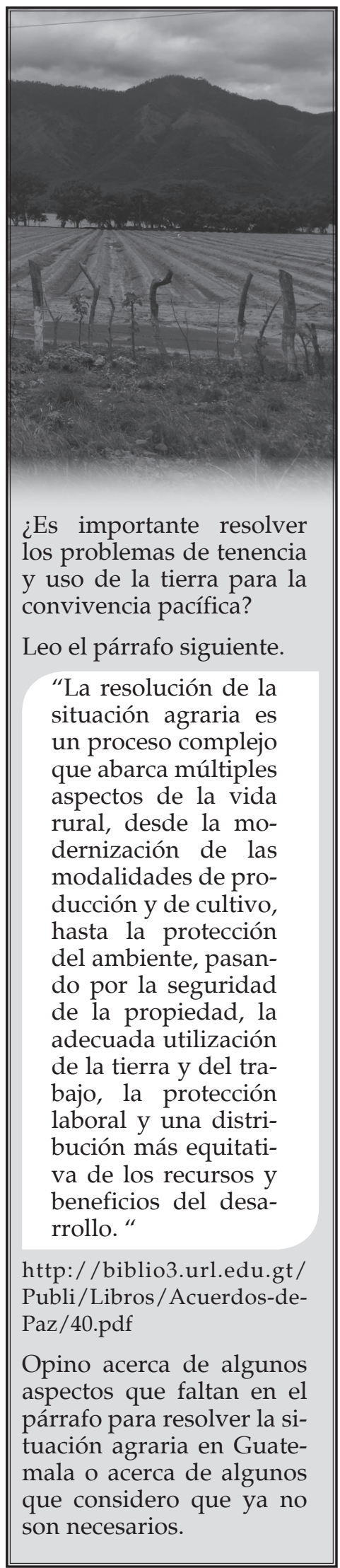




\section{Resolución de conflictos de carácter ambiental}

Algunas actividades de minería estimulan la economía local a través de la oferta de empleo y contratación de proveedores, mejoran los caminos para facilitar el transporte de lo extraído; apoyan la salud y la educación como parte de su responsabilidad social empresarial. Sin embargo, sus prácticas, generalmente, no son amigables con el ambiente, ni con el empleo decente. La minería acumula agua proveniente de las fuentes de agua locales, genera contaminación de los ríos, la tierra y el aire; implementa esquemas de contratación laboral distintas a las condiciones de trabajo digno. El Estado guatemalteco apoya la minería, pero favorece conflictos ambientales al no hacer respetar las normas de protección de los derechos ambientales, laborales, económicos y culturales de los pobladores. Los impuestos y regalías que pagan las empresas mineras son bajos y entran al fondo común del Estado. No llegan a las municipalidades donde operan. Se violan los derechos colectivos de los pueblos indígenas al no efectuar y respetar los resultados de los procesos de consulta previa.

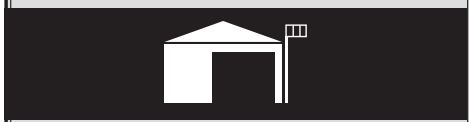

Escribo un decálogo de las razones por las cuales es recomendable proteger los espacios naturales y su aporte a la realización de la actividad física. Argumento cómo la protección y conservaciones del medio ambiente es una forma de aportar al derecho a la salud de la población de mi comunidad y comunidades vecinas.
Conflicto es sinónimo de choque o desacuerdo de ideas, pensamientos, actitudes, comportamientos o intereses. Los conflictos son cotidianos y pueden inducirnos al cambio y a la transformación en nuestra vida personal, familiar y comunitaria. Son algo natural en la sociedad, no podemos considerarlos ni buenos ni malos, depende de cómo respondamos ante las situaciones que los generan.

El conflicto tiene una o varias causas y afrontarlo depende de la disposición de los involucrados y de la etapa en la que se interviene. Generalmente, el conflicto está ahí, se siente, pero las personas involucradas no hacen nada al respecto. Esta situación crea frustración, la cual se manifiesta por medio de reclamos, discusiones y puede llegar a un momento de crisis en donde se manifiesten actos violentos como insultos o agresiones físicas.

Los conflictos socio-ambientales tienen su origen en concepciones distintas que los grupos humanos tienen sobre su relación con la Naturaleza. Con frecuencia se generan en torno a la apropiación de recursos naturales o el uso de tecnologías para transformarlos. Para unos grupos sociales, el medio ambiente es un recurso para la producción y acumulación de recursos económicos; mientras que para otros es su espacio y medio de vida. Su territorio tiene que ver con su ser en armonía con la Madre Tierra

El conflicto surge cuando una concepción del ambiente se impone para usar, manejar, controlar y distribuir los recursos naturales, especialmente el agua y la tierra. Mientras un grupo social causa daños ecológicos o monopoliza los beneficios de la explotación de recursos naturales, el otro sufre los efectos negativos de dichas acciones. La complejidad de este tipo de conflicto depende de la capacidad de diálogo, compromiso y cumplimiento de acuerdo; además de los intereses y derechos económicos y culturales de los grupos sociales en conflicto.

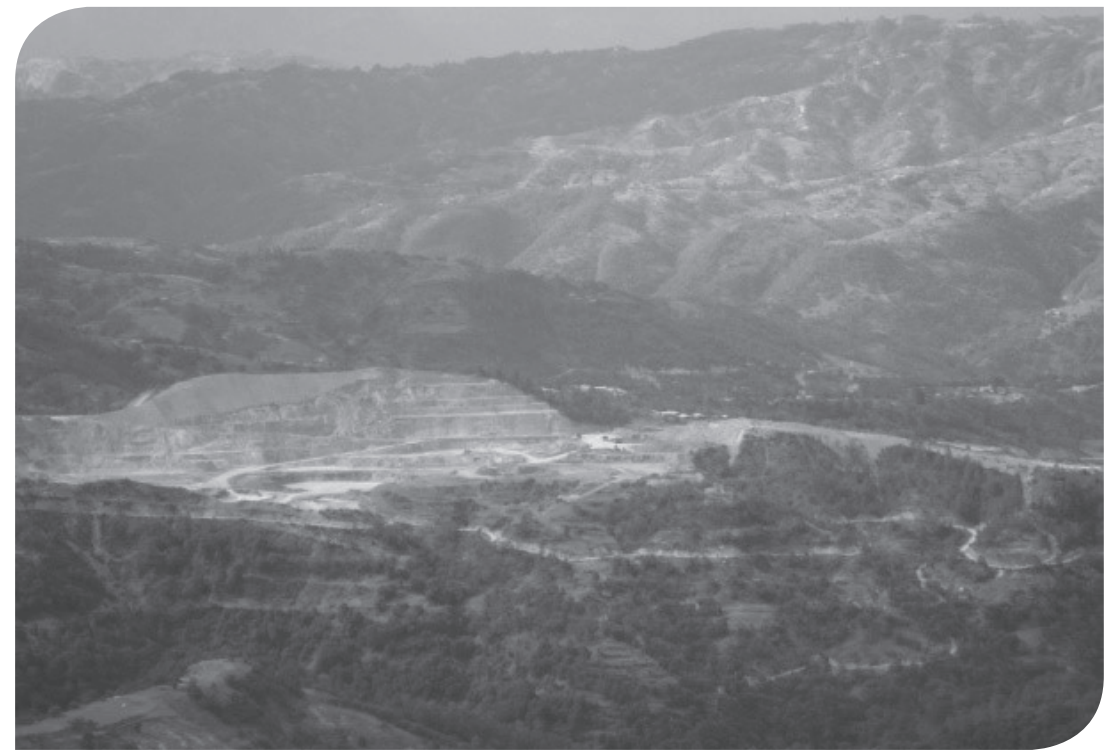


Generalmente hay una situación social y ambiental fuerte de la que se desprenden conflictos específicos, los cuales se generan al enfrentarse conceptos de desarrollo diferentes y hasta contrarios. Uno se centra en la globalización económica y se respalda en la voluntad política; el otro lucha contra la pobreza mediante la priorización de actividades que permitan la satisfacción de necesidades básicas. El diálogo es necesario para generar empatía. Esto significa colocarse en la situación de la otra parte. Conocer la posición de la otra parte es esencial para encontrar una solución que satisfaga a las partes involucradas en el conflicto, mejore sus relaciones y se maneje, solucione o trasforme el mismo.

La Guía para la transformación de conflictos socioambientales, del Programa de las Naciones Unidas para el Medio Ambiente, Perú, señala el proceso de una negociación constructiva para solucionar un conflicto.

\begin{tabular}{|c|c|c|}
\hline $\begin{array}{c}\text { Antes } \\
\text { Preparación }\end{array}$ & $\begin{array}{c}\text { Durante } \\
\text { Encuentro cara-cara }\end{array}$ & $\begin{array}{c}\text { Después } \\
\text { Implementación }\end{array}$ \\
\hline $\begin{array}{l}\text { Identificar y } \\
\text { evaluar }\end{array}$ & Seguir pasos & Ejecución y seguimiento \\
\hline $\begin{array}{l}\text { - Análisis del } \\
\text { conflicto } \\
\text { - Agenda } \\
\text { - Relación } \\
\text { - Comunicación } \\
\text { - Intereses } \\
\text { - Alternativas } \\
\text { - Opciones } \\
\text { - Criterios obje- } \\
\text { tivos } \\
\text { - Compromisos }\end{array}$ & $\begin{array}{l}\text { - "Romper hielo" } \\
\text { - Definir reglas del juego } \\
\text { - Presentación de puntos } \\
\text { de vista } \\
\text { - Elaboración de agenda } \\
\text { común } \\
\text { - Búsqueda de acuerdos } \\
\text { - Compromisos y ajustes } \\
\text { - Formulación del acuerdo }\end{array}$ & $\begin{array}{l}\text { - "Romper hielo" } \\
\text { - Definir reglas del juego } \\
\text { - Presentación de puntos } \\
\text { de vista } \\
\text { - Elaboración de agenda } \\
\text { común } \\
\text { - Búsqueda de acuerdos } \\
\text { - Compromisos y ajustes } \\
\text { - Formulación del acuerdo }\end{array}$ \\
\hline
\end{tabular}

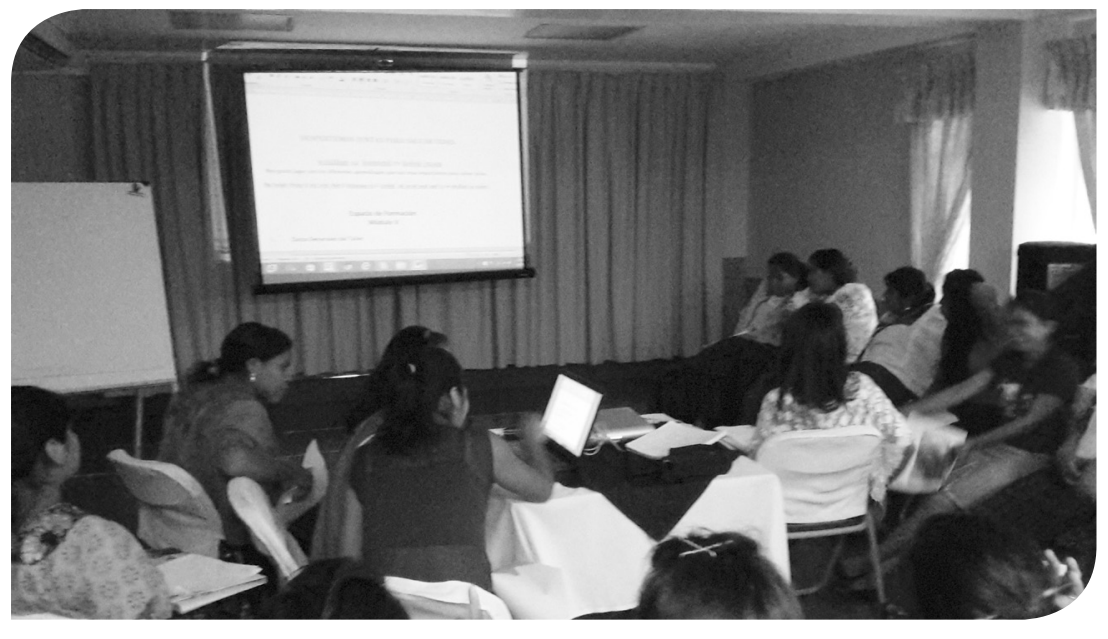

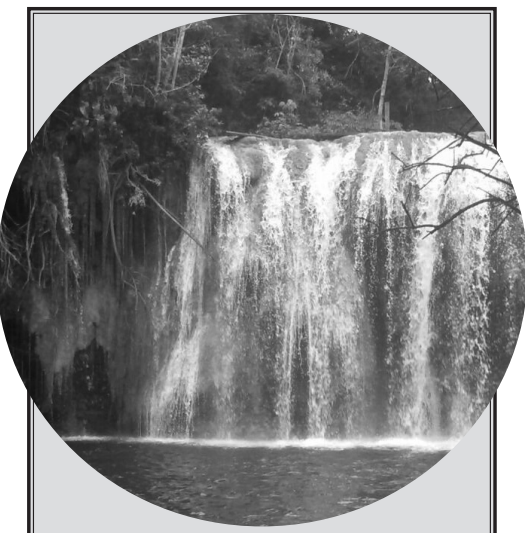

Las hidroeléctricas generan energía limpia, barata y renovable. Su instalación y daños ecológicos y puede provocar conflictos socio-ambientales por el traslado forzoso de poblaciones que ocupan el territorio en que se instalan, problemas de tierras, desvío de ríos, falta de realización o respeto a consultas comunitarias y falta de dotación de energía eléctrica a las comunidades circundantes. Los conflictos han surgido principalmente por falta de información y diálogo entre las empresas, el Ministerio de Energía y Minas y las comunidades para concretar acciones que favorezcan a todas las partes y aceptar las dificultades que cada uno debe afrontar.

- ¿Cómo pueden las empresas que aprovechan los recursos naturales incluir mejoras en sus procesos productivos para respetar los derechos de las comunidades en las que se instalan?

Realizo una gira por $\mathrm{mi}$ comunidad, tomando fotografías de espacios naturales saludables en los que pueda ejercitarme. 


\section{El queísmo}

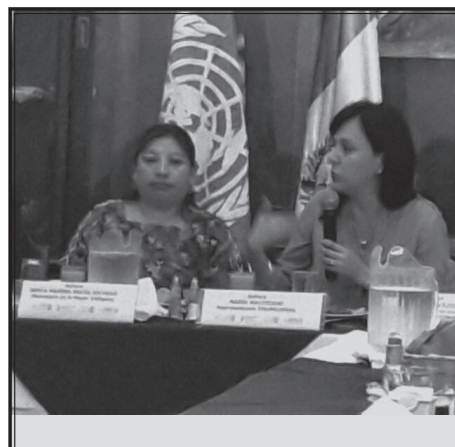

Nuestra participación en un foro, un conversatorio o una feria exige el uso más apropiado del idioma para la exposición ordenada y coherente de nuestras ideas. Un conjunto de argumentos verídicos bien estructurados sobre los que hemos construido nuestra posición. Esto requiere de preparación. Para ello se recomiendan las siguientes herramientas a tener en cuenta:

1. Las normas parlamentarias

2. Normas de participación en diálogos comunitarios

3. Listado de palabras políticamente correctas a usar

4. Herramientas y programas a utilizar en la presentación

Investiguemos sobre estos aspectos en internet y formulemos como equipo los lineamientos para la realización de las actividades próximas.

Elaboro un organizador gráfico sobre las reglas de la escritura.
Se denomina queísmo cuando se usa mal y se utiliza mucho la palabra "que"

a. Uso indebido del "que" cuando sustituye a las palabras donde, como, cuando, por lo que, Ejemplos:

Incorrecto $\rightarrow$ Fue ahí que lo encontré.

Correcto $\rightarrow$ Fue ahí donde lo encontré.

Incorrecto $\rightarrow$ Es así que me gusta el café.

Correcto $\rightarrow$ Es así como me gusta el café.

b. Abuso en el empleo del que, lo cual produce una monotonía en la redacción.

\begin{tabular}{|l|l|}
\hline Incorrecto & $\begin{array}{l}\text { Los que allí estaban, que conocían la situación, expresaron } \\
\text { todo lo que sabían y lo que les parecía, para lograr que se } \\
\text { solucionaran los problemas que habían surgido. }\end{array}$ \\
\hline Correcto & $\begin{array}{l}\text { Los presentes, conocedores de la situación, expresaron } \\
\text { cuanto sabían y su parecer, para solucionar los problemas } \\
\text { surgidos. }\end{array}$ \\
\hline
\end{tabular}

\section{El dequeísmo}

Este error consiste en usar innecesariamente la preposición "de" antes del "que". Sin embargo, no siempre es incorrecto hacerlo. Veamos algunos ejemplos:

\begin{tabular}{|l|l|}
\hline \multirow{2}{*}{ Incorrecto } & Me dijo de que vendría al mediodía. \\
\cline { 2 - 2 } & Creemos de que dice la verdad. \\
\hline \multirow{2}{*}{ Correcto } & Estamos convencidas de que dice la verdad. \\
\cline { 2 - 2 } & Vendrá antes de que se termine el foro. \\
\hline
\end{tabular}

- ¿Cómo sabemos cuándo usar el "de que" y cuando no? Si la frase introducida por el "que" se sustituye por el pronombre demostrativo "eso" y tiene sentido, lo estaremos usando correctamente:

Me dijo que vendría al mediodía. Me dijo eso.

Creemos que él dice la verdad. Creemos eso.

Si la frase introducida por "de que", la sustituimos por "de eso" y tiene sentido, entonces estará correcto:

Estamos convencidos de que él dice la verdad. Estamos convencidos de eso.

Vendrá antes de que se termine la función. Vendrá antes de eso.

Redactemos, en el cuaderno, oraciones con los usos correctos del "que" y el "de que"; pero que se relacionen con la forma correcta de afrontar los conflictos. 


\section{El acta}

Sirve para dejar constancia de lo tratado y acordado en una reunión. Es muy importante conocer cómo se redacta, pues en algún momento necesitaremos elaborar una, ya sea como integrantes de la junta directiva escolar o, en el futuro, en nuestro trabajo o en una organización comunitaria. Un acta consta de tres partes: encabezamiento, desarrollo y cierre.

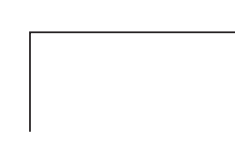

\section{Encabezamiento}

(Número de acta, fecha, lugar, personas que participaron en la reunión).

Desarrollo (Se enumeran las actividades realizadas, punto por punto). mina el acta con: hora de cierre, nombres y firmas de los participantes)

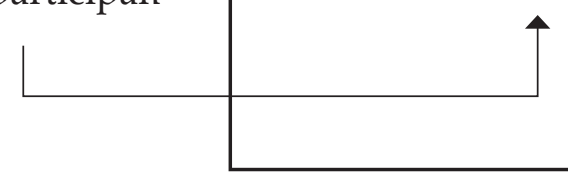

Acta No. 10

Acta de la reunión mensual celebrada por la Directiva de grado, el lunes dos de marzo de dos mil quince, a las catorce horas, en el salón de usos múltiples de El Centro de Educación Extraescolar de San Luis, Petén. Están presentes la directora, Lic. Luisa Tay, la profesora, Ema Pinto e integrantes de la Junta Directiva de Estudiantes de la segunda etapa. Funge como presidenta de grado: Ana Gil, como tesorero: Roberto Cuc y como secretario: Mario Caal.

Comprobada la existencia de suficientes asistentes para que sea válida la reunión -quorum-, se da lectura a los puntos de agenda.

Punto 1: lectura y aprobación del acta anterior.

Punto 2: asuntos financieros.

Punto 3: organización de la feria científica.

Artículo 1. Lectura y aprobación del acta anterior. La Presidenta abre la sesión con la lectura del acta anterior, la cual es aprobada por unanimidad.

Artículo 2. Asuntos financieros. El Tesorero menciona que hay algunos integrantes del grupo que aún no han pagado su cuota del mes. Se discute la necesidad de que cumplan con esta responsabilidad porque los fondos se usan para el bien común.

Artículo 3. Organización de la feria científica. Se discuten varias ideas sobre cómo se realizará.

Se acuerda que se presentará una propuesta de solución a la problemática socio ambiental por cada equipo- Deben enviar el título de su puesto, una explicación y argumento breve. Se invitará a la comunidad a disfrutar de esta feria. Se propondrá a la Asociación de Madres y Padres de Familia que vendan comida especial durante la actividad para recaudar fondos. Se intentará realizar esta feria anualmente.

En mi calidad de secretario, Mario Caal, cierro la reunión y esta acta a las catorce horas con cincuenta minutos. Firman conmigo, la licenciada Luisa Tay, la profesora Ema Pinto, Ana Gil y Roberto Cuc.

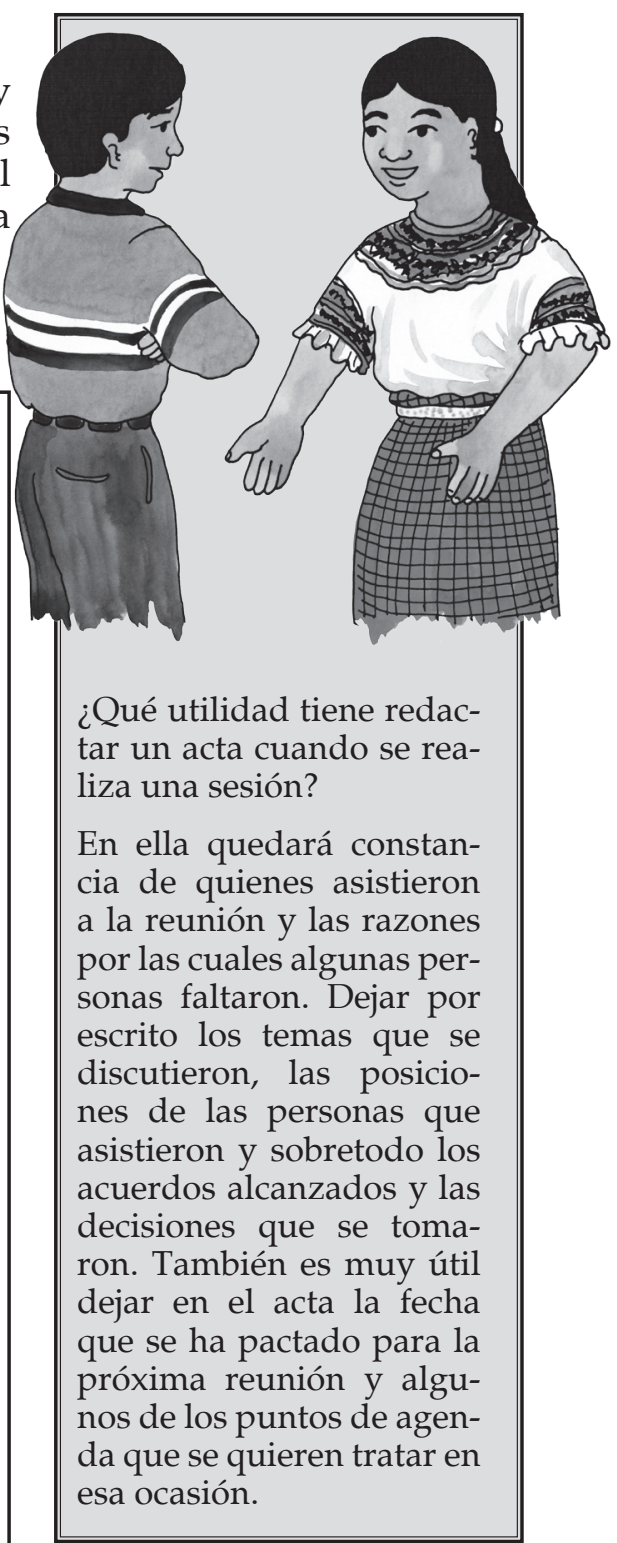

Organicemos una sesión para tratar la celebración de un festival de teatro en nuestra comunidad cuyo tema principal sean los conflictos socio-ambientales. Redactemos un acta para registrar lo discutido en la reunión.

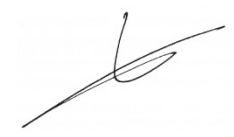




\section{Calentamiento global}

En la zona del ecuador soplan vientos alisios que desplazan las aguas marinas cálidas; pero el fenómeno del Niño no lo permite y hace que las aguas, frente a las costas de Perú y Ecuador, eleven su temperatura, con lo cual alteran el clima y provocan tormentas, inundaciones, tornados y huracanes. El fenómeno de la Niña actúa de forma inversa, las aguas frías se imponen en las corrientes marinas del Pacífico Ecuatorial y provocan sequías. El clima se ha vuelto más extremo, con lo cual aumenta los riesgos, especialmente a las poblaciones más vulnerables de todo el mundo.

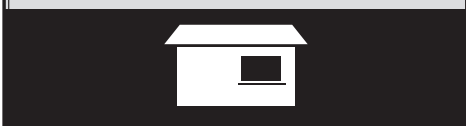

Pregunto a las y los productores de mi comunidad:

- ¿Cómo afecta el cambio climático su trabajo?

Hago cálculos sobre los montos perdidos en inversión, desempleo, reducción de ingresos y compra de alimentos. Reflexiono en los modos de producción que contribuyen al efecto invernadero. Investigo si en la comunidad hay buenas prácticas para contrarrestarlo.
Oímos decir que "el clima está loco", las y los agricultores ya no saben cuándo sembrar porque el período de lluvias ha cambiado, ya no comienza ni termina en las mismas fechas que hace algunos años y cada vez más las lluvias se intercalan con los periodos secos. En los últimos 50 años la temperatura del planeta ha aumentado rápidamente causando cambios en la atmósfera severos: sequías, inundaciones, tornados, ciclones, tormentas de polvo, incendios forestales, olas de calor y el descenso de vientos del ártico. De continuar el calentamiento global algunas consecuencias serían:

- El derretimiento de glaciares, el derretimiento temprano de la nieve y las sequías causarían escasez de agua.

- El aumento del nivel del mar inundaría ciudades costeras.

- El calor desataría nuevas plagas y enfermedades transmitidas por mosquitos y otros insectos.

- La extinción de especies vegetales y animales a causa de la destrucción o transformación de su hábitat.

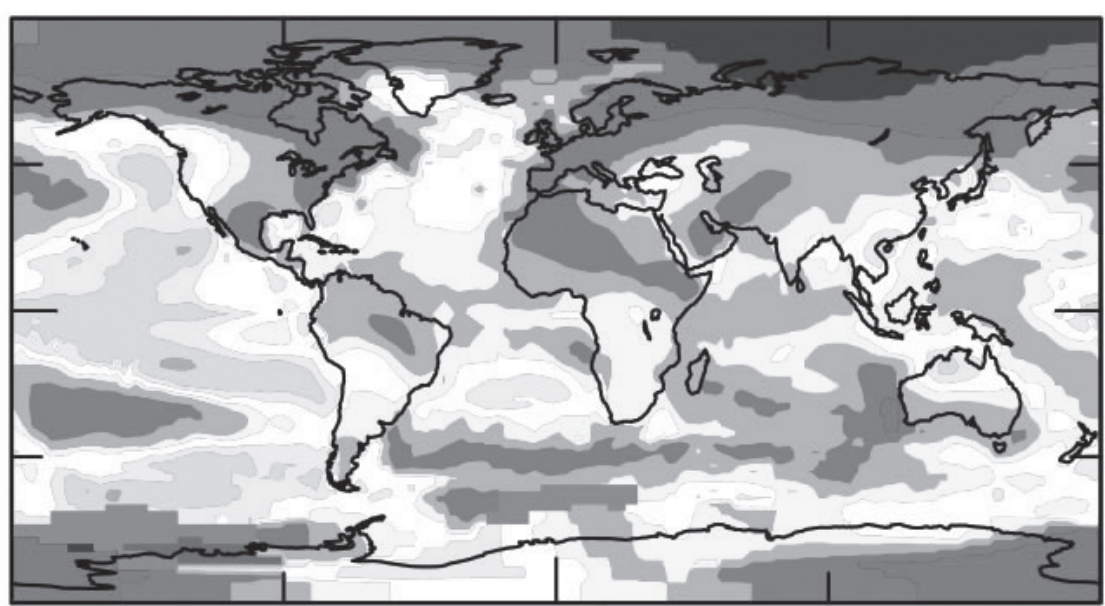

\begin{tabular}{|ll|lll|l|l|l|l|l|lll|}
\hline & & & & & & & & & & \\
\hline
\end{tabular}

Anomalias de Temperatura Global 2011 suman un aumento de $0.51^{\circ} \mathrm{C}$ con respecto al promedio $1950-1980$. El calentamiento sobre la tierra es fácilmente 1.5 veces el promedio global de $0.51^{\circ} \mathrm{C}$ y por encima de $0.76^{\circ} \mathrm{C}$ para grandes tramos de tierra.

Foto: http:/ / cambioclimaticoglobal.com/que-es-el-calentamiento-global.

Elaboro gráficas con información del clima: temperatura, épocas de invierno y verano, lluvia y sequía. Trato de obtener datos hasta de cinco años atrás.

- ¿Qué se evidencia en las gráficas? 


\section{Cambio climático}

Cuando aumentan las concentraciones de gases llamado efecto invernadero, producidas por la deforestación y la quema de combustibles fósiles como petróleo y carbón (fábricas, automóviles), ocurre el cambio climático. En la medida en que estos gases aumentan su concentración en la atmósfera, aumenta la temperatura en el planeta. Esto sucede porque dichos gases (carbono, metano, ozono, vapor de agua y óxido nitroso) dejan pasar los rayos del Sol, pero ya no dejen que salgan de la atmósfera; entre más se concentran, mayor será la temperatura.

El cambio amenaza al planeta y nuestra propia existencia. Por tales motivos, es necesario tomar acciones que garanticen el desarrollo sostenible. Esto significa emplear los recursos naturales, pero reducir la producción de gases de efecto invernadero. Algunas medidas para lograrlo son el manejo de los bosques, desarrollo de nuevas tecnologías, impulso del uso de energías limpias y renovables para eliminar gradualmente la electricidad generada con combustibles fósiles.

Algo que genera muchas discusiones es el efecto de la ganadería vacuna, con un equivalente de $\mathrm{CO} 2$ del $18 \%$, lo que supera la cantidad que emite el tráfico de automóviles a nivel mundial. Además, la ganadería produce un $37 \%$ de emisiones de metano y un $65 \%$ de óxidos de nitrógeno, sobre todo el uso del excremento como abono. Aún se cuestionan estos efectos; pero lo más controversial: cómo sustituir una de las principales fuentes de proteínas de la humanidad.
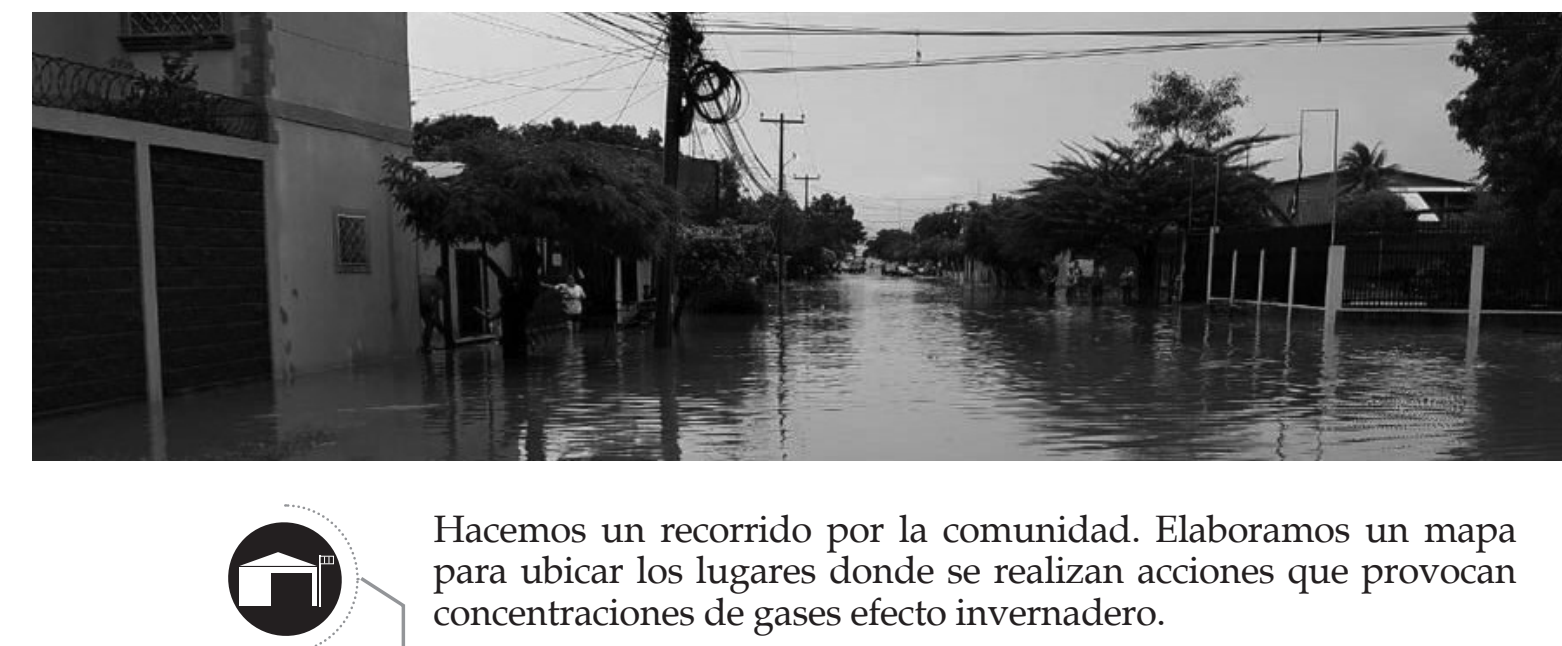

Hacemos un recorrido por la comunidad. Elaboramos un mapa para ubicar los lugares donde se realizan acciones que provocan concentraciones de gases efecto invernadero.

Discutimos, en clase, alternativas y proponemos un plan de mejora continua que podamos presentar a la comunidad en la Feria científica.

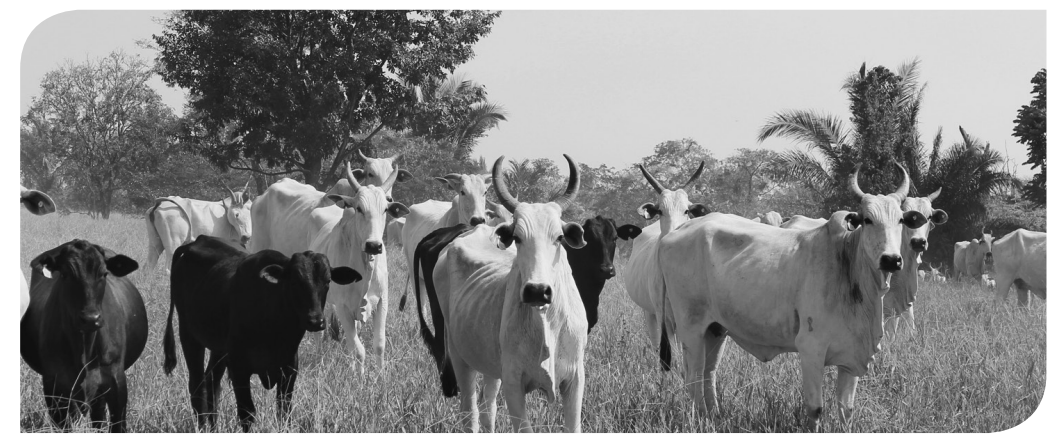

El clima cambia lentamente, hay que organizarse $y$ buscar ayuda para afrontarlo. Algunos cambios son rápidos como las heladas, mientras otros son lentos; pero se repiten: deja de llover, se retrasa la lluvia o cae copiosamente durante algunos días. Un temporal puede: hacer más difícil viajar, transportar productos o trabajar el campo; dañar las cosechas y la calidad de los productos agrícolas, afectar los caminos y carreteras y servicios básicos como el agua y la electricidad; además puede causar inundaciones o escasez de agua.

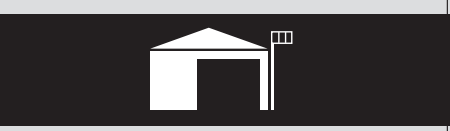

Comprender los cambios del clima nos ayuda a prepararnos, prevenir problemas y buscar formas de adaptarnos. Vamos a realizar un conversatorio por equipos para plantear propuestas de solución a los problemas que hemos venido trabajando. Luego del conversatorio. Planteamos como equipo un proceso de mejora continua para la producción sostenible en la comunidad.

Referencia: http://san.ag/ web/wp-content/uploads /2015/10/17757714009_23 e2332358_o.jpg 


\section{Técnicas de discusión}

\begin{tabular}{|c|c|}
\hline \multicolumn{2}{|l|}{$\begin{array}{l}\text { Solecismo de régimen } \\
\text { Este error es muy común y } \\
\text { afecta la claridad en el len- } \\
\text { guaje. El solecismo de ré- } \\
\text { gimen consiste en usar una } \\
\text { preposición distinta a la } \\
\text { que exige el complemento, } \\
\text { ejemplos: }\end{array}$} \\
\hline De acuerdo a & $x$ \\
\hline De acuerdo con & $\checkmark$ \\
\hline A base de & $x$ \\
\hline Sobre la base de & $\checkmark$ \\
\hline En relación a & $x$ \\
\hline En relación con & $\checkmark$ \\
\hline Mirarse al espejo & $x$ \\
\hline Mirarse en el espejo & $\checkmark$ \\
\hline A cuenta de & $x$ \\
\hline Por cuenta de & $\checkmark$ \\
\hline Diferente a los demás & $x$ \\
\hline $\begin{array}{l}\text { Diferente de los de- } \\
\text { más }\end{array}$ & $\checkmark$ \\
\hline Cumplo en decírselo & $x$ \\
\hline Cumplo con decírselo & $\checkmark$ \\
\hline Vino de casualidad & $x$ \\
\hline Vino por casualidad & $\checkmark$ \\
\hline Quedó de venir & $x$ \\
\hline Quedó en venir & $\checkmark$ \\
\hline Chocar con un árbol & $x$ \\
\hline $\begin{array}{c}\text { Chocar contra un } \\
\text { árbol }\end{array}$ & $\checkmark$ \\
\hline Entrar de gratis & $x$ \\
\hline Entrar gratis & $\checkmark$ \\
\hline Pastillas para la tos & $x$ \\
\hline Pastillas contra la tos & $\checkmark$ \\
\hline Incorrecto & $x$ \\
\hline Correcto & $\checkmark$ \\
\hline
\end{tabular}

Las técnicas de discusión son formas de expresar opiniones y razonamientos con relación a un tema para llegar a conclusiones válidas. Son muy útiles en la educación y tienen estos elementos en común:

1. Un tema sobre el cual se realiza la actividad.

2. Una persona que coordina para moderar la discusión y da la palabra.

3. Las personas participantes investigan el tema y poseen argumentos válidos.

4. El público oyente a veces puede participar con preguntas o comentarios.

5. El tiempo de participación de cada persona es controlado por quien modera.

En estas técnicas se aplicaran las normas:

a. Respeto por las opiniones de todos los participantes.

b. Cumplir con el tiempo establecido para cada intervención.

c. Seguir el orden que se acuerda.

d. Se expone en un ambiente de libertad y de consideración.

\section{Problemas de la comunicación}

La comunicación se dificulta por:

1. Ignorar el sentido común como base de la comunicación.

2. Emplear palabras innecesarias o rebuscadas.

3. Usar un inadecuado tono de voz.

4. Prestar poca atención a los demás.

5. Interrumpir frecuentemente.

6. Dar consejos no pedidos.

7. Impedir el debate y despreciar las opiniones ajenas.

8. Hablar con rodeos.

- Realizamos un debate con el tema "El cambio climático".

- Evaluamos nuestro comportamiento grupal e individual y proponemos medidas para aprender a discutir mejor.

Investigo las técnicas de discusión que se utilizan en los siguientes lugares y escribo la razón por la que se emplean.

1. En el Congreso de la República. 2. En reunión del COCODE.

3. En un programa de radio. 4. En una campaña política.

- ¿Cuál o cuáles de las técnicas de discusión no se practican en tu comunidad?

- ¿Cuál piensas que sería de mayor utilidad? 


\section{La estructura de una obra de teatro}
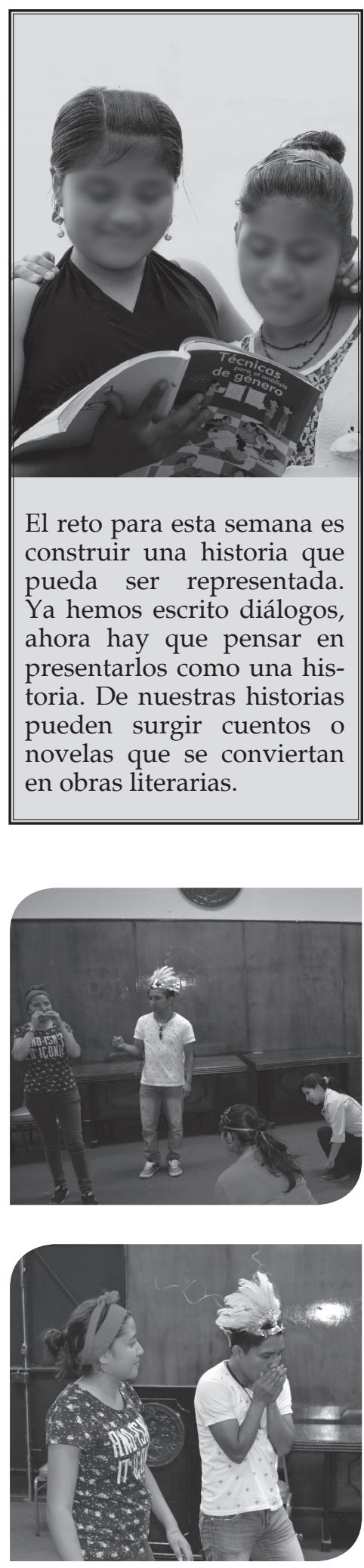

Toda obra de teatro es una historia con un mensaje que se transmite a través de la actuación. Trabajaremos, a través de una historia con los problemas socio-ambientales que nos afectan en la comunidad. La historia tendrá esta estructura:

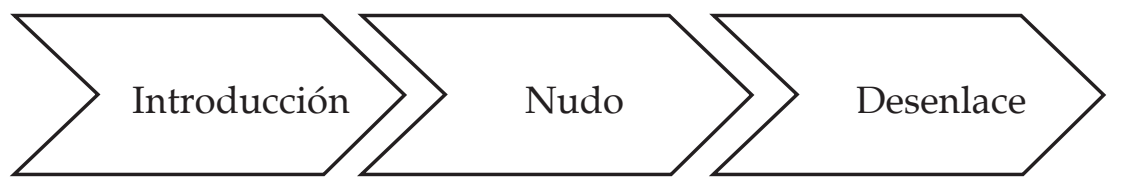

En el área de Comunicación y Lenguaje, hemos leído cuentos y narraciones que poseen dicha estructura y también explicaciones sobre cada uno de sus elementos.

Leamos la siguiente historia y descubramos sus partes:

\section{Rompiendo el molde}

Judith, de cuarenta años, y Camila, de cuarenta y tres, caminan hacia el tanque de la comunidad a lavar la ropa de sus familias. Cada una carga un baño muy pesado. Juanita, una niña de once, va agarrada del delantal de su mamá. En el camino, las alcanzan tres muchachos jóvenes. Andrés, Hans y Julio son los hijos de las dos mujeres, se ve que son fuertes y parecen muy sanos. Cuando las alcanzan les dicen que se equivocaron, que a ellas no les tocaba lavar la ropa ese día. Judith y Camila, asustadas por lo que sus hijos les preguntan: ¿por qué dicen eso? Los tres muchachos cuentan que han tomado la decisión de que la ropa no debe ser lavada solo por las mujeres, que a partir de ahora se van a turnar y les tocará un sábado a las mamás y otro sábado a los hijos, alternadamente. Así que ese día toca a Andrés, Hans y Julio lavar la ropa de la familia. Al regresar, explicarán a sus mamás que han tomado esa decisión porque aprendieron en la escuela que todas y todos tienen los mismos derechos y obligaciones en el hogar y en la comunidad.

(J. Floresache)

- Identificamos la introducción, el nudo y el desenlace de la historia.

- Convertimos esta historia en un diálogo para teatro.

- La dramatizamos o representamos con títeres. 


\section{Problemas locales y globales}

Nuestra comunidad es parte de la sociedad global. Los problemas, como el calentamiento global o el cambio climático, afectan a nuestra comunidad y a todas las comunidades del planeta.

Escribimos la historia que deseamos contar y que se relacione con el cambio climático. Cuidamos que llene los requisitos que vimos en la página anterior. Luego, verifiquemos que posee los elementos necesarios para representarla:

- Personajes. Hay que especificarles género y edad. Unos serán principales y otros, secundarios.

- Escenas y escenarios. La historia, se puede organizar en escenas, que son los momentos en que ocurren las acciones. Si nuestra historia tiene dos escenas, hay que hacer dos escenarios.

- Diálogos. Deben estar bien construidos para que sean efectivos y directos, así la historia será creíble para el público.

- Vestuarios. Habrán de corresponder con el género y la edad.

- Espacio donde se presentará. Es un elemento que influye en la construcción de las escenografías.

\section{Escribo un guion}

El guion es la guía que leen quienes actúan en una obra teatral, en este caso lo hacemos por medio de los títeres. Se puede ordenar así:

- Leo la historia varias veces hasta que la tengo clara.

- Divido la historia en escenas, ejemplo: Escena 1, en casa; Escena 2, en la calle.

- Escribo una descripción de las escenas: El cielo está muy claro y la calle está muy visitada por ejemplo.

- Escribo lo que ocurre antes, durante o después de lo que se actúa. Ejemplo: Se escucha un trueno y comienza a llover, Ana corre por las calles del barrio, hasta que llega a una tienda y entra.

- Ubico los diálogos y los intercalo en las escenas.

La obra se construye para que los títeres entren en acción cuando les toca y no antes ni después.

Representamos nuestros guiones y con las mejores escenas e historias, preparamos una obra colectiva para presentar en la feria científica.
Aprendo el papel de memoria

Es importante que cada participante en una obra sepa de memoria los procesos y momentos en que debe intervenir. Por eso cada quien debe tener por escrito la historia y comprometerse a saber cada aspecto que en ella ocurrirá.

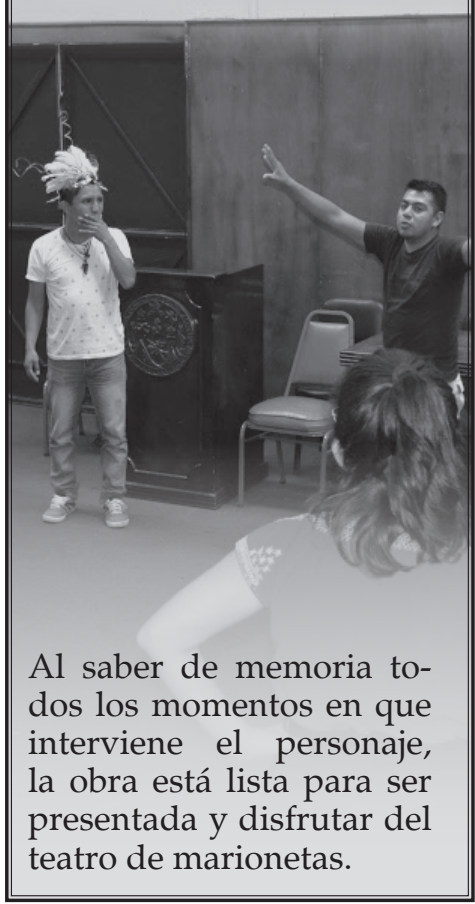

Al saber de memoria todos los momentos en que interviene el personaje, la obra está lista para ser teatro de marionetas. 


\section{El calor y su medición}

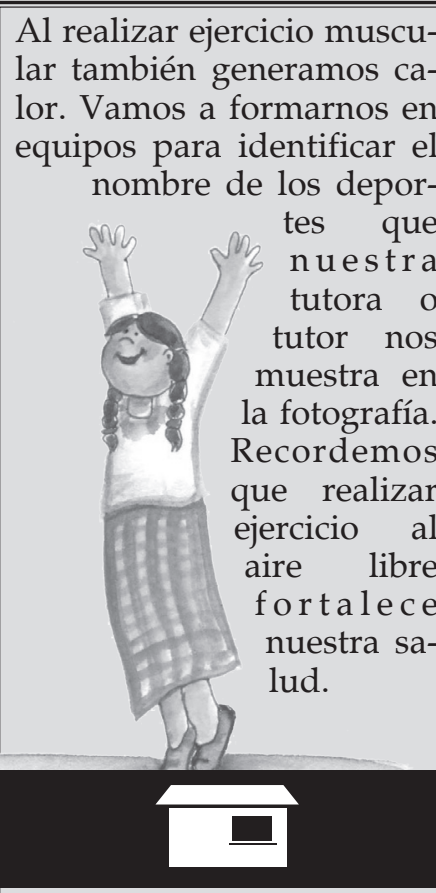

Investigo sobre las dos fases de la fotosíntesis, la lumínica y la oscura.

Calor. Es una forma de energía. Se origina por el movimiento de átomos y moléculas que forman los cuerpos.

Temperatura. Es una magnitud que indica la cantidad de calor presente en un cuerpo.

Termómetro. Instrumento que mide la temperatura, puede estar hecho de mercurio, el cual se dilata o comprime según la cantidad de calor presente en el cuerpo. También es fabricado de alcohol.

Una de las escalas para medir la temperatura es la Celsius o centígrada. Por ejemplo, el agua congelada mide $0^{\circ} \mathrm{C}$ o menos; y alcanza su punto de ebullición a los $100^{\circ} \mathrm{C}$, a nivel del mar.

Animales Ectotérmicos. Son los animales que aprovechan la temperatura del ambiente para regular su propia temperatura.

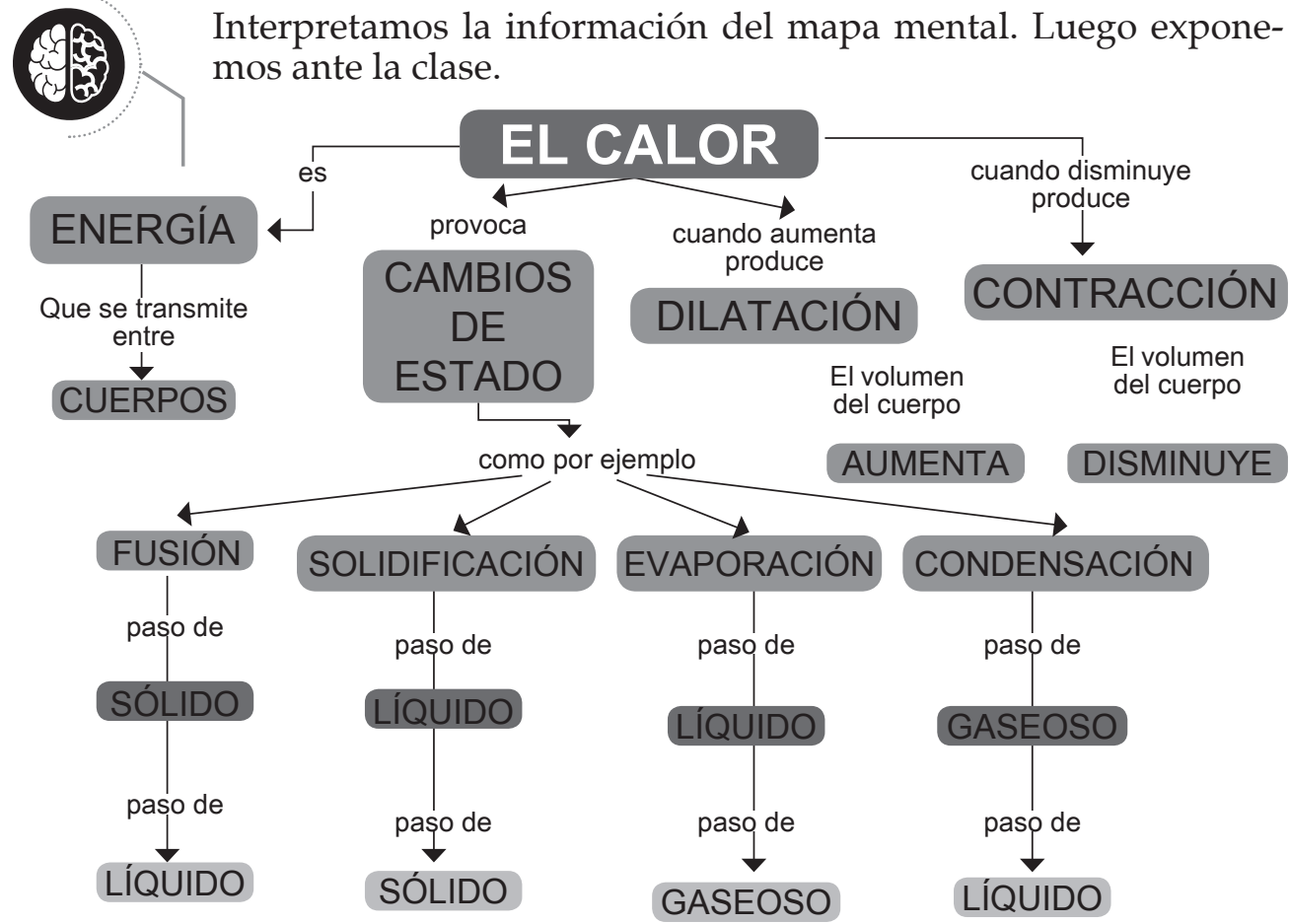

Referencia: http:/ / cmapspublic.ihmc.us/rid=1LD5XKFRL-2DLG69Q-1TNZ/ el\%20calor.cmap?rid=1LD5XKFRL-2DLG69Q-1TNZ\&partName=htmljpeg

Los océanos juegan un papel importante en la estabilidad del clima terrestre, sin ellos nuestro planeta estaría excesivamente caliente durante el día y muy frío de noche. La diferencia de temperatura entre las masas de agua oceánicas, en combinación con los vientos y la rotación de la Tierra, crea las corrientes marítimas. El desplazamiento de la energía en forma de calor, que es liberada desde los océanos o absorbida por las aguas oceánicas, permite que ciertas zonas atmosféricas frías se calienten y que las regiones atmosféricas calientes se refresquen.

Las plantas utilizan el calor para la elaboración del carbohidrato, en la fase oscura de la fotosíntesis. El hidrógeno, formado en la fase lumínica de la fotosíntesis, se une al dióxido de carbono del aire y se da la producción de compuestos orgánicos, principalmente carbohidratos.

Los animales ectotérmicos como peces, anfibios y reptiles requieren calor del ambiente. Cuando la radiación infrarroja proveniente del Sol penetra en la atmósfera, el vapor de agua absorbe y demora la salida de las ondas del calor al espacio exterior; así la energía permanece en la atmósfera y la calienta (efecto invernadero).

Analizamos qué tipo de fenómeno relacionado con el calor se observa en las siguientes situaciones:

1. Una vela que se derrite.

2. Un vidrio empañado

3. Elaboración de hielo

4. Agua hirviendo 
Comentamos en clase lo que sabemos del efecto invernadero. Nos apoyamos en la imagen.

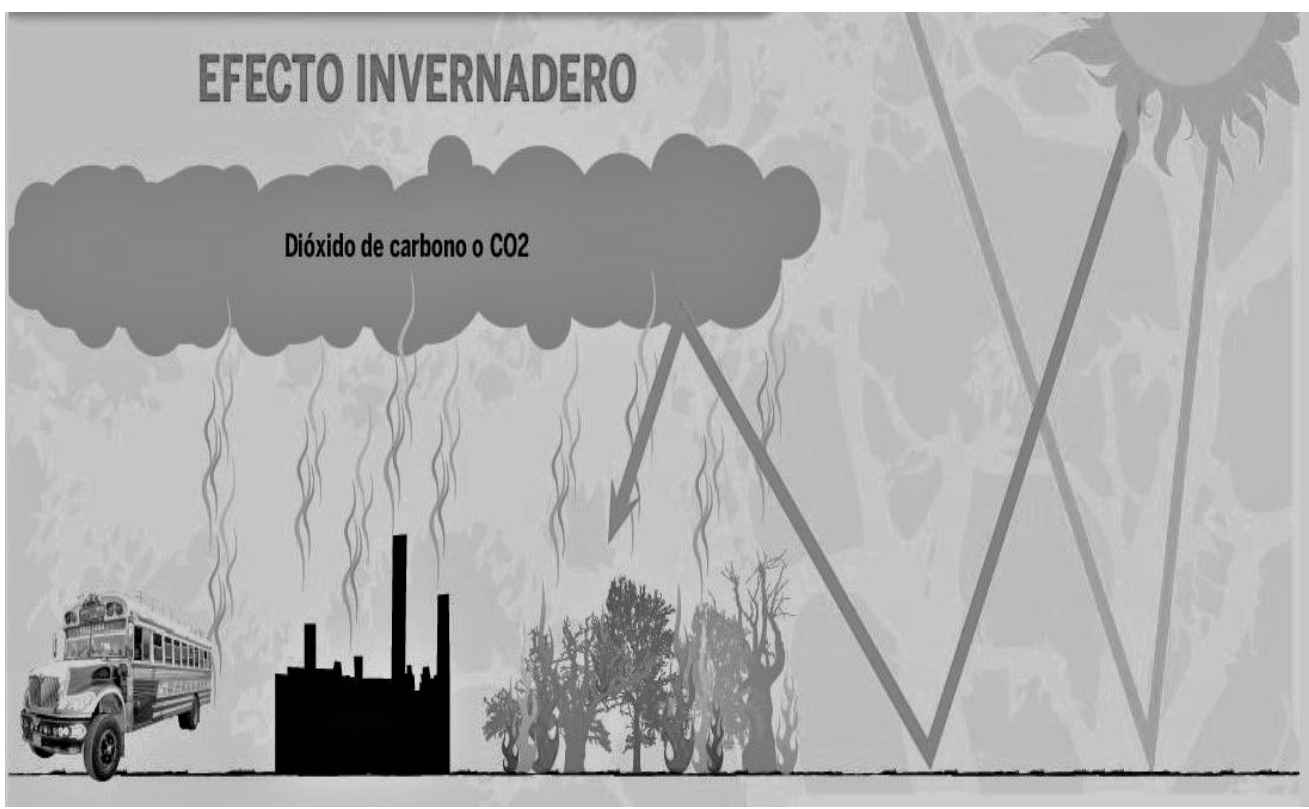

Fuente: http://todosobreelmedioambiente.jimdo.com/efecto-invernadero/

La Tierra tiene innumerables fuentes de energía, algunas son finitas, pues se terminará la materia con la que se producen, como el carbón y el petróleo. Estas además generan gases de efecto invernadero y la pérdida de biodiversidad. Hay recursos que son capaces de proveer energía sin generar el mismo nivel de contaminación y además son virtualmente inagotables por que se regene-ran.

La energía que procede de estas fuentes se conoce como energía renovable. Este es el caso de la energía que se obtiene del sol, del calor de la Tierra, de la fuerza del agua, de las olas del mar y de la degradación de compuestos naturales. Ésta no genera gases de carbono ni otros que producen el efecto invernadero. Por lo que se valoran como medios de energía limpia en la Tierra.

Necesito: olla, granos de elote para poporopo y estufa.

Preparo un poco de grano de elote en la olla, los coloco en la estufa y luego la tapo. Al pasar algunos minutos, habrán cambiado de forma.

Describo lo que sucede y explico por qué sucedió el cambio.

Escribo algunas ideas sobre el aprovechamiento del agua y el viento como fuentes de energía y sugiero incorporarlas como parte del foro.

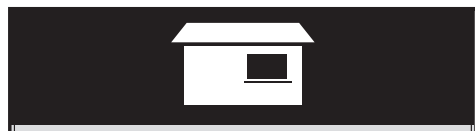

Escribo tres aspectos positivos sobre el aprovechamiento de este tipo de energía y tres dificultades que presenta su uso.

Gases efecto invernadero. Son compuestos químicos en estado gaseoso que se acumulan en la atmósfera, y absorben la radiación infrarroja del Sol con lo cual aumentan y retienen el calor en la atmósfera; entre ellos están el vapor de agua (simplemente $\mathrm{H} 2 \mathrm{O}$ en estado gaseoso), dióxido de carbono (CO2), metano (CH4 como el de las flatulencias de las vacas), los óxidos de nitrógeno (NOx) y muchísimos clorofluorocarbonos que se emiten como resultado de diversas actividades industriales del ser humano.

Calentamiento global. Es el aumento gradual de las temperaturas de la atmósfera y océanos de la Tierra.

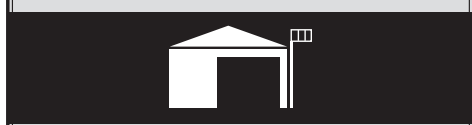

Seleccionamos las mejores presentaciones del experimento, para presentarlo en la feria científica. 


\section{Actividades que preservan el medio ambiente}

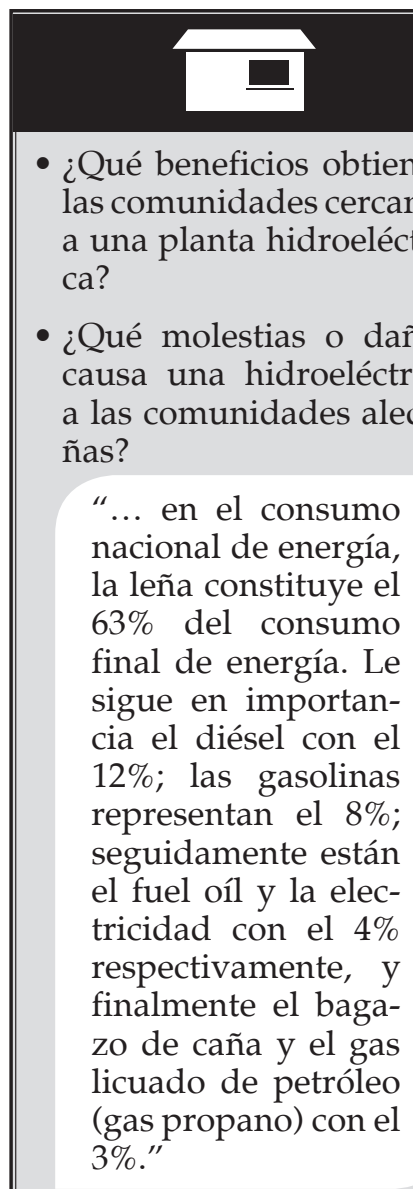

La leña “... es utilizada en forma ineficiente, por cuanto el $81 \%$ de los hogares que la consumen, utilizan la estufa de "Tres Piedras", la cual desaprovecha casi el $90 \%$ de la energía consumida."

http:/ / www.fao.org/docrep/ T2363S/t2363s0w.htm

Sin embargo, el fogón de tres piedras tiene gran significado en la cosmovisión maya porque se relaciona con tres principios creadores unidos en el origen del Universo.

- ¿Cómo se puede mejorar el uso que se hace de la energía en Guatemala?
En Guatemala se ha generado varias actividades productivas para preservar el medio ambiente, entre ellas están:

\begin{tabular}{|l|l|}
\multicolumn{1}{c|}{ Reciclaje de: } & Beneficio ambiental \\
\hline Latas & $\begin{array}{l}\text { Ahorro de energía, menor con- } \\
\text { taminación, reducción de las } \\
\text { actividades extractivas, menor } \\
\text { tala de árboles, reducción del } \\
\text { Envases plásticos }\end{array}$ \\
\cline { 1 - 2 } Papel & \\
\hline Reciclaje del hierro y otros metales & \\
\hline Desechos orgánicos &
\end{tabular}

Para mejorar el reciclaje de los desechos aún falta que se desarrolle una cultura de la clasificación de basura, un sistema de recolección y leyes que normen el proceso. También hace falta que se genere la tecnología para reciclar algunos materiales como el duroport, pañales desechables y toallas sanitarias; así como abandonar su uso y a cambio, utilizar materiales lavables.

\section{Analicen en equipo:}

- ¿Qué materiales se reciclan en la comunidad?

- ¿Tiene sentido clasificar la basura en la comunidad?

Otra actividad productiva que se desarrolla en Guatemala es la producción de energía limpia, la de mayor desarrollo es la hidroeléctrica, aunque ya se produce energía solar, geotérmica, eólica y marina. La ventaja de producir este tipo de energía es que su costo es más bajo, se reduce el uso de combustible de origen fósil, con lo cual se contribuye a reducir el efecto invernadero.

\section{Discutamos:}

- ¿Qué tipo de energía se utiliza en nuestra comunidad?

- ¿Qué diferencia encontramos entre reciclar y reusar?

Proponemos algunas ideas para reusar algunos materiales.

- ¿Qué medidas hacen falta en nuestra comunidad para preservar el medio ambiente?

- ¿Generan conflictos medio ambientales las hidroeléctricas en Guatemala? ¿Por qué?

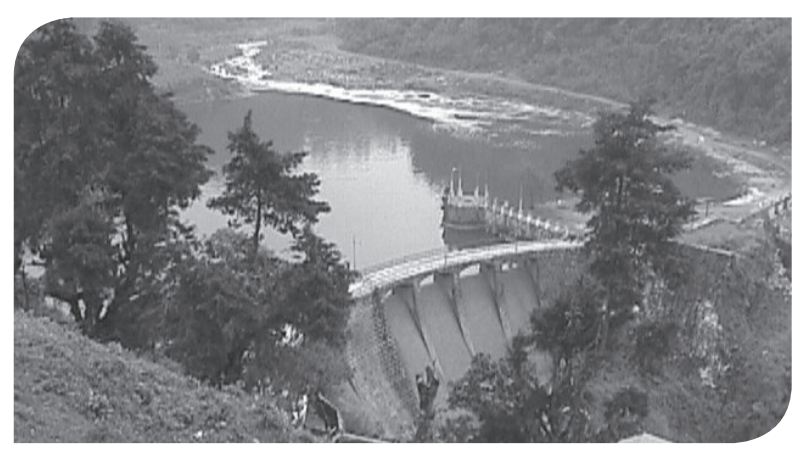

Referencia: http:/ /www.cnee.gob.gt/wp/?page_id=237 


\section{Degradación del ambiente}

En Guatemala, gran parte del suelo ha perdido su cubierta vegetal, lo cual favorece su infertilidad. La mayor parte de agua se encuentra contaminada. El ciclo de lluvia se vuelve cada vez más irregular y la temperatura tiende a subir. La deforestación, los incendios en los bosques y selvas, la caza de animales y el comercio ilegal de especies amenazan muchas especies la flora y fauna. Estos hechos en su conjunto se denominan degradación ambiental.

Dicha degradación ambiental tiene una causa económica debido a que muchas empresas buscando la máxima producción al menor costo, no cuidan de los recursos naturales. También hay una causa institucional debido a que el Estado es muy débil, tiene poca presencia en las comunidades y padece de muchas deficiencias para cumplir con su papel de cuidar las riquezas naturales del país.

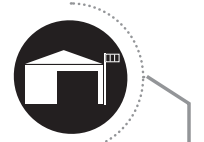

Nos organizamos en equipo para discutir qué es un conversatorio.

Luego organizamos una plenaria para organizar un conversatorio sobre la degradación ambiental en nuestra comunidad.

Elaboramos un cuadro comparativo con las consecuencias de la sobreexplotación de recursos naturales y propuestas de solución.

Formulamos lineamientos para realizar una investigación individual acerca de las consecuencias del cambio climático.

Investigo acerca de:

- Las consecuencias del cambio climático.

- Los recursos naturales y la situación en la que se encuentran en la comunidad.

- Factores físicos y químicos que intervienen en la conservación de dichos recursos naturales.

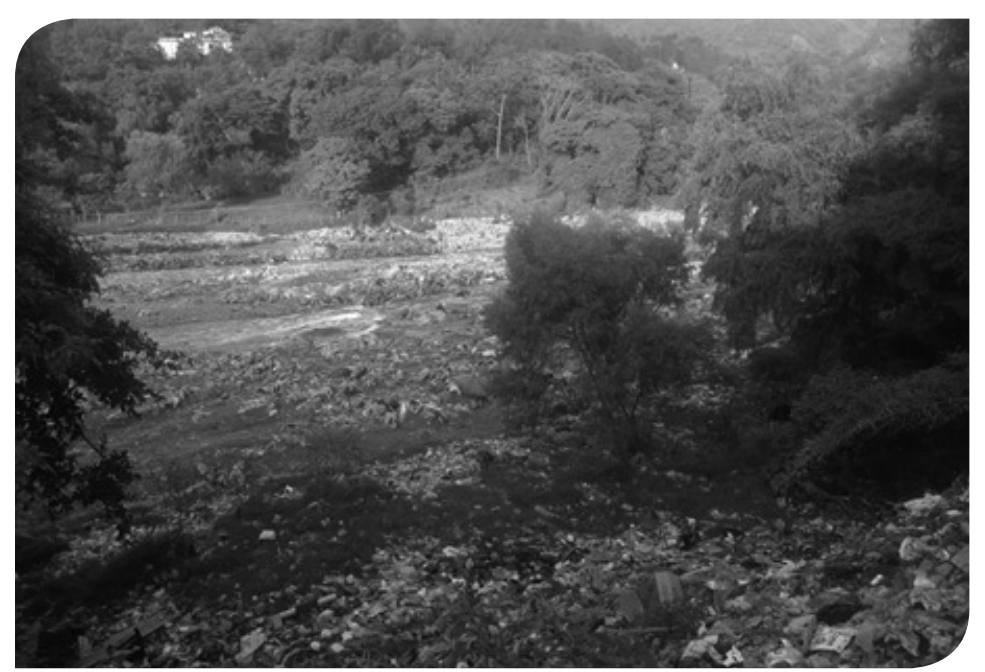

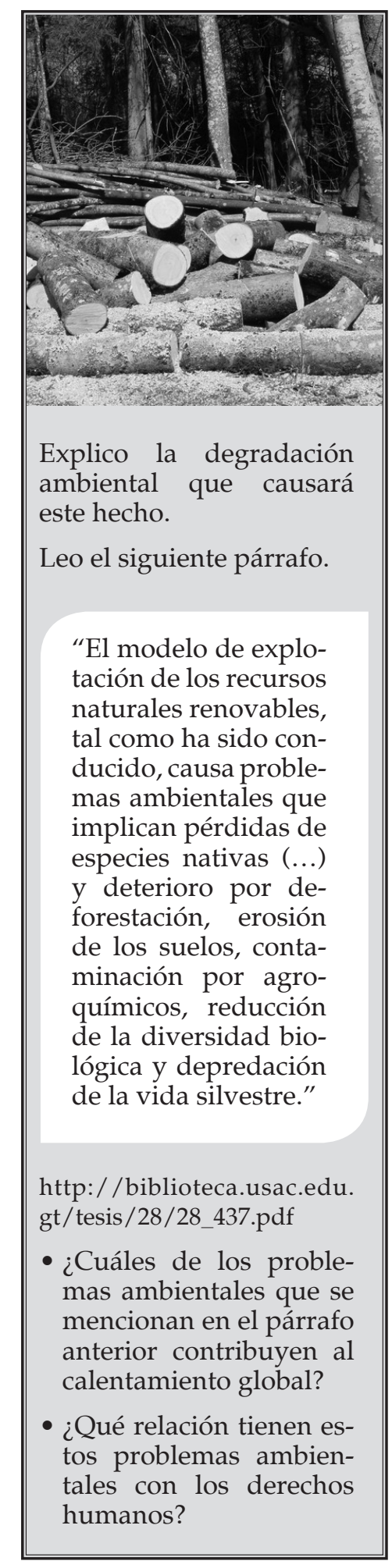

"El modelo de explotación de los recursos naturales renovables, ducido, causa problemas ambientales que implican pérdidas de especies nativas (...) y deterioro por deforestación, erosión de los suelos, contaminación por agroquímicos, reducción diversidad biológica y depredación

http:/ / biblioteca.usac.edu gt/tesis/28/28_437.pdf

¿Cuáles de los problemas ambientales que se anterior contribuyen al calentamiento global?

¿Qué relación tienen es tales con los derechos

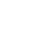




\section{Probabilidades}

El espacio muestral de un experimento son todos los posibles resultados que se pueden dar al realizar el experimento. Se puede representar con listas, tablas de resultados, diagramas de Venn, diagramas de árbol y cuadrículas de dos dimensiones.

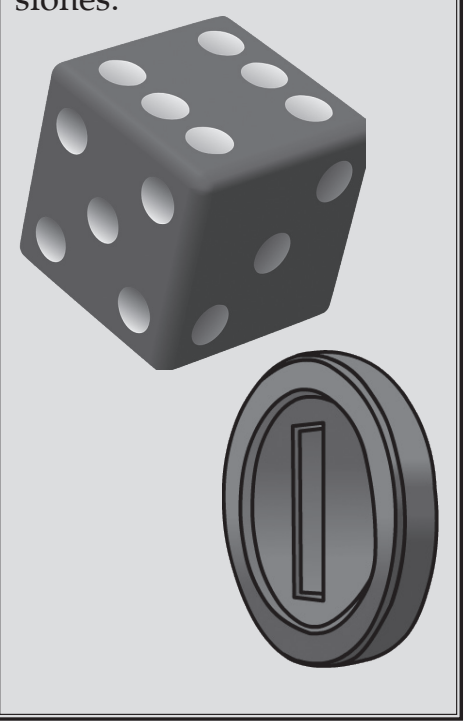

Supongamos que se lanza una moneda al mismo tiempo que un dado. Los resultados de la moneda serán representados con la letra A y los del dado con la letra B. Hallamos el espacio muestral de ese evento y lo representamos con un diagrama de árbol o con una cuadrícula de dos dimensiones. Observamos los ejemplos.

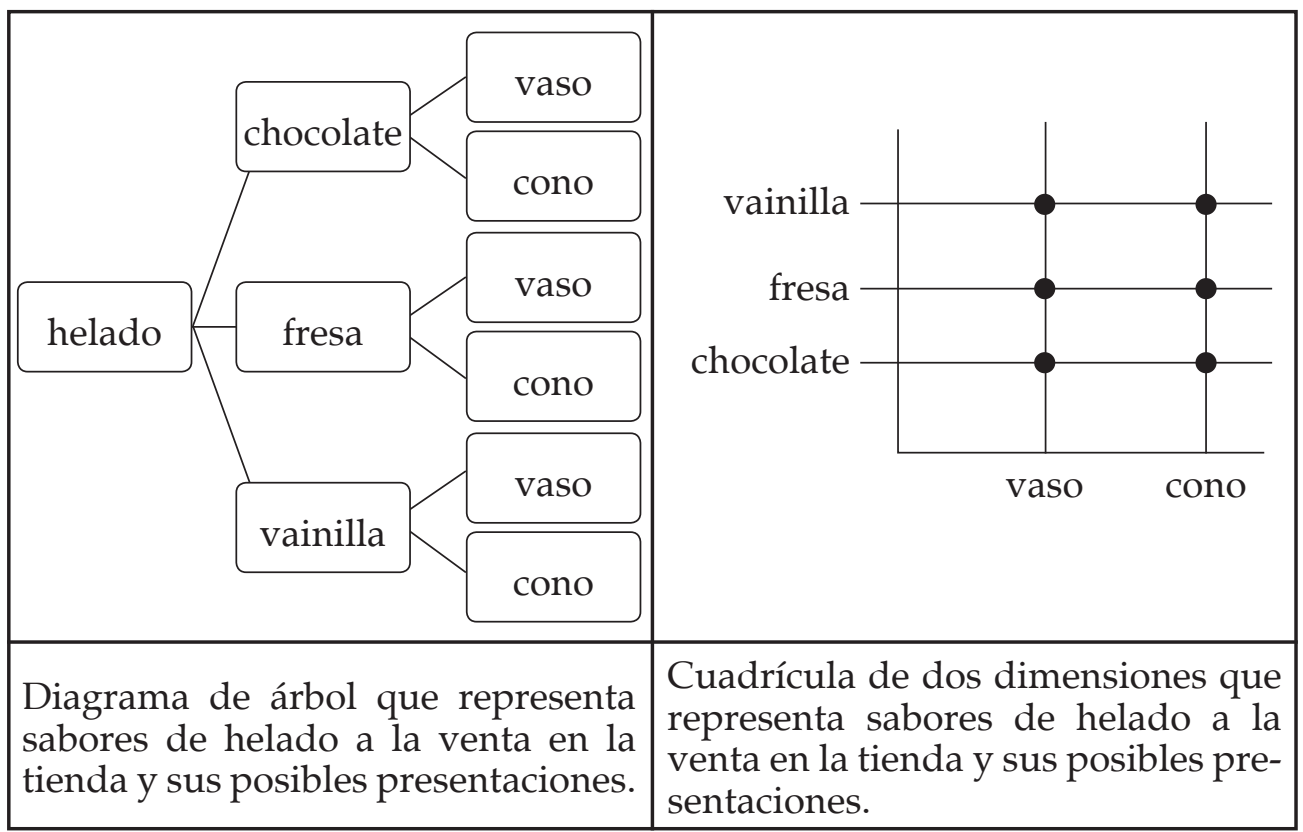

Copiamos y completamos la siguiente tabla con las probabilidades que faltan.

\begin{tabular}{|l|l|l|l|} 
& $P(A \mathbf{y} \boldsymbol{B})$ & $P(\boldsymbol{A})$ & $\boldsymbol{P}(\boldsymbol{B})$ \\
\hline$P$ (cara y 4) & & & \\
\hline $\begin{array}{c}P \text { (cara y número } \\
\text { impar) }\end{array}$ & & & \\
\hline $\begin{array}{c}P \text { (escudo y un núme- } \\
\text { ro mayor que 1) }\end{array}$ & & & \\
\hline $\begin{array}{c}P \text { (escudo y un núme- } \\
\text { ro menor que tres) }\end{array}$ & & & \\
\hline
\end{tabular}

¿Qué conexión encontramos entre $P(A$ y $B)$ y $P(A)$ y $P(B)$ ? Comentamos y discutimos con el resto de compañeras y compañeros.

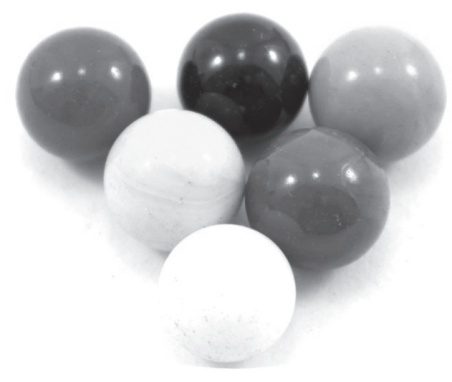


A un grupo de 25 personas se le preguntó por sus preferencias de comida para refaccionar. Les gusta el pan dulce a 15 personas y a 16 les gusta el café. A una persona no le gusta ninguno de las dos y a 6 personas les gustan los dos alimentos. Podemos representar esta situación en un diagrama como este:

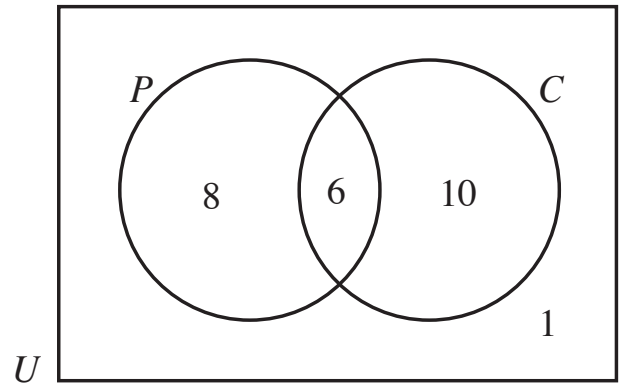

- ¿Cuál es la probabilidad de que a una persona le guste el pan dulce?

- ¿Cuál es la probabilidad de que a una persona no le guste el café?

- ¿Cuál es la probabilidad de que a una persona le guste el pan y el café?

Para contestar a las preguntas anteriores, debemos tomar en cuenta que el total de personas que se entrevistó fue de 25 y que si $\mathrm{A}$ y $\mathrm{B}$ son eventos entonces:

$$
P(A \backslash B)=\frac{P(A \cap B)}{P(B)}
$$

Encuestamos a todos los y las integrantes de la comunidad educativa acerca de sus preferencias por dos tipos de frutas. Luego de recolectar la información, la representamos en un diagrama de Venn. Planteamos preguntas sobre probabilidad y probabilidad condicionada, luego las respondemos.

Observamos y analizamos la información de la siguiente tabla sobre regiones del mundo y cambios en su temperatura ambiental, durante los últimos 10 años.

\begin{tabular}{|l|l|l|l|} 
Región & $\begin{array}{c}\text { Cantidad de países } \\
\text { que observaron } \\
\text { aumento de } \\
\text { temperatura }\end{array}$ & $\begin{array}{c}\text { Cantidad de países } \\
\text { que mantuvieron } \\
\text { su misma } \\
\text { temperatura }\end{array}$ & $\begin{array}{c}\text { Cantidad de países } \\
\text { que observaron } \\
\text { descenso de } \\
\text { temperatura }\end{array}$ \\
\hline África & 40 & 11 & 3 \\
América & 23 & 10 & 2 \\
\hline Asia & 45 & 2 & 1 \\
Australia & 1 & 2 & 0 \\
Europa & 43 & 6 & 1 \\
\hline \multicolumn{1}{|c|}{ Total } & & & \\
\hline
\end{tabular}

Respondemos:

- ¿Cuál es la probabilidad que un país de América haya aumentado su temperatura?

- ¿Cuál es la probabilidad que un país de Europa haya mantenido su misma temperatura?

- ¿Cuál es la probabilidad de que un alumno o alumna tenga reacción?

- ¿Cuál es la probabilidad que, dado que sea mujer, haya tenido reacción?
Internet tiende a convertirse en el medio de comunicación más utilizado en el mundo. El único medio que supera a internet es la televisión. En Guatemala, el medio de comunicación más utilizado es la radio, aunque la televisión e internet compiten con la misma.

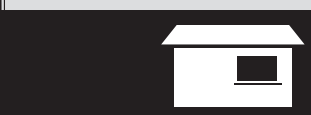

- ¿Cómo hago para tener acceso a internet?

Respondo en mi cuaderno. 


\section{Preparamos la función de títeres}

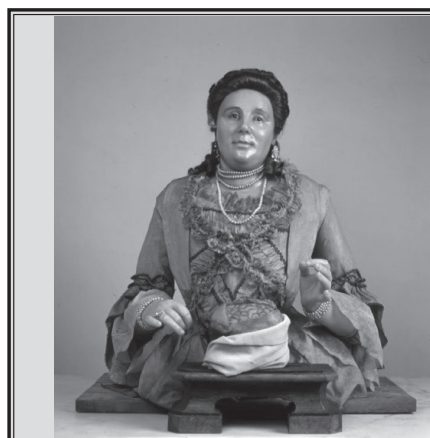

Foto: Ana Morandi Manzolini

Fuente: http:/ / alchetron. com/Anna-Mo

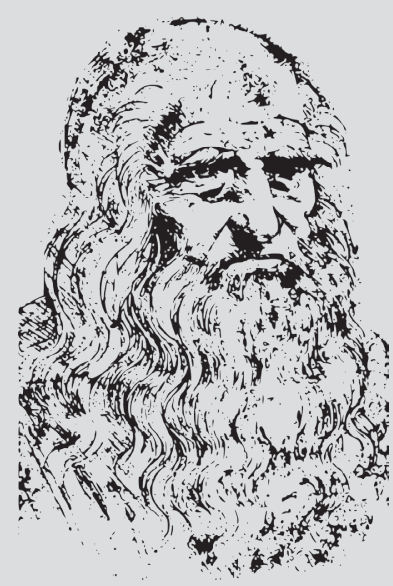

Leonardo da Vinci

¿Artistas o científicos y científicas? La creatividad es una de las cualidades más fascinantes que tenemos los hombres y las mujeres, consiste en darle rienda suelta a la imaginación. Ambos son capaces de arriesgar la comodidad de su entorno con tal de probar nuevas maneras de hacer las cosas. Siempre piensan en cómo cambiar lo que ya está hecho o cómo formular nuevas maneras de ver la vida y disfrutarla.

Jugamos a la dirección de orquesta, tomamos turnos para adivinar quién está dirigiendo al resto de la clase en los movimientos.
Discutimos, con nuestro grupo, los desafíos siguientes:

- ¿Es el diálogo que presentaremos una forma de expresarnos libremente? Al presentarlo, ¿haremos uso de nuestros derechos ciudadanos?

- ¿Qué relación tiene el argumento del diálogo con conflictos socio ambientales o con actividades que dañan el entorno ambiental? Argumentamos nuestra respuesta.

El proyecto de Feria Científica pareciera estar alejado del arte. Pero, tanto la ciencia como el arte son actividades de la inteligencia, interactúan en la vida social y son fuente de desarrollo. Varios de los más grandes científicos y científicas han sido también artistas, o viceversa. Entre ellos:

Leonardo da Vinci, italiano. Pintó la famosa "Mona Lisa", hizo aportes a la Física, Química, Anatomía, Astronomía, Zoología y Geología. Creó el prototipo de máquinas muy importantes para la vida moderna, como el helicóptero.

María Sybilla Merian, alemana. Aprovechó sus dotes de pintora e ilustró la metamorfosis de los insectos, especialmente de las mariposas; con ello sentó las bases de la Entomología moderna.

Ana Morandi Manzolini, italiana. Fue una escultora que también aportó a la Anatomía. Le extendieron un permiso especial para dar clases de Anatomía en la Universidad de Bolonia, porque en su época se les negaba este derecho a las mujeres, así como muchos otros.

Albert Einstein, alemán-suizo-estadounidense. Creador de la teoría de la relatividad y otros grandes aportes a las ciencias. Una parte de su tiempo lo dedicaba a la música, tocaba el violín desde los 6 años de edad. Afirmó que la música inspiraba sus teorías e ideas científicas.

Discutimos, con nuestro equipo, los aportes que podemos hacer a la feria científica en dos aspectos:

- ¿Cómo diseñamos los locales para la feria a partir de materiales de reciclaje?

- ¿Qué técnicas usamos para decorarlos?

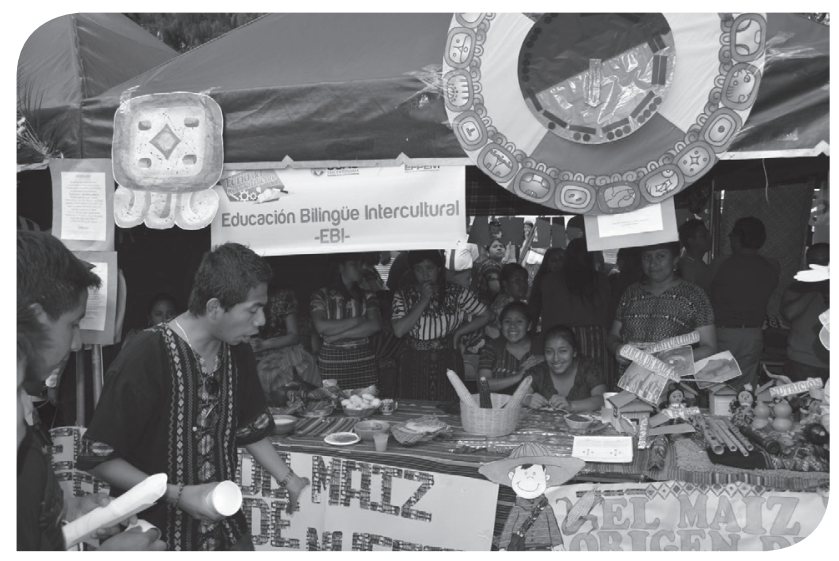

Semana 18

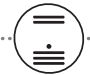




\section{El teatrino para la presentación de títeres}

Nos toca preparar los materiales y ensayar la obra para que sepamos qué hacer en cada escena y que la actuación de los títeres sea eficiente. También debemos construir el espacio donde los títeres actuarán.

Un teatro es un espacio donde unos actores presentan la obra; pero los títeres son actores en miniatura, por lo que haremos un teatro especial para ellos. El teatro de los títeres se llama teatrino, debe ser atractivo para el público y seguro para quienes manejan los títeres. Para construirlo sigamos los pasos:

- Ubicamos materiales de reciclaje y herramientas: cajas de cartón, papel de reuso, palos y ramas, retazos de tela, cáscaras de huevo, hojas de tusa, tijeras, pintura de colores, goma y cinta adhesiva.

- Diseñamos la estructura con las cajas.

- Al tener armado el teatrino, lo decoramos y ambientamos según el entorno en el que se desarrollará el diálogo, con nuestros materiales. Le agregamos una cortina y probamos los espacios donde se ubicarán títeres junto a las y los titiriteros.

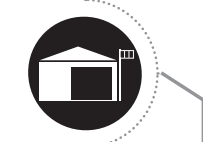

Con nuestro teatrino, ensayamos la obra cuantas veces sean necesarias. Se recomienda usar voces impostadas, es decir voces falsas que imiten las voces de los personajes. Aunque a veces el mismo titiritero maneja hasta dos o más títeres, es recomendable que sea una persona la que maneja cada personaje. Esto, para que no se confundan a la hora de la actuación, y que todas y todos participen.

Lleno los espacios para contar mi experiencia al construir el teatrino y montar la obra de teatro con títeres:

\begin{tabular}{|l|l|l|l|l|}
\hline Actividad & $\begin{array}{c}\text { ¿Cómo } \\
\text { fue la } \\
\text { actividad? }\end{array}$ & $\begin{array}{c}\text { ¿Por qué } \\
\text { me gustó o } \\
\text { desagradó? }\end{array}$ & $\begin{array}{c}\text { ¿Qué fue } \\
\text { lo que } \\
\text { pasó? }\end{array}$ & $\begin{array}{c}\text { Dos datos } \\
\text { interesantes }\end{array}$ \\
\hline $\begin{array}{l}\text { Al armar } \\
\text { la historia } \\
\text { y el guion }\end{array}$ & & & & \\
\hline $\begin{array}{l}\text { Al hacer } \\
\text { el títere }\end{array}$ & & & & \\
\hline $\begin{array}{l}\text { Al con- } \\
\text { struir el } \\
\text { teatrino }\end{array}$ & & & & \\
\hline
\end{tabular}

Teatrino de lado de los titiriteros

El teatrino es el espacio donde se presentan las marionetas o los títeres. Se pueden hacer de diversos materiales y decorarlo de vistosas maneras. Lo más importante del teatrino es que las marionetas o títeres se desplacen por el escenario y se hagan visibles al público.

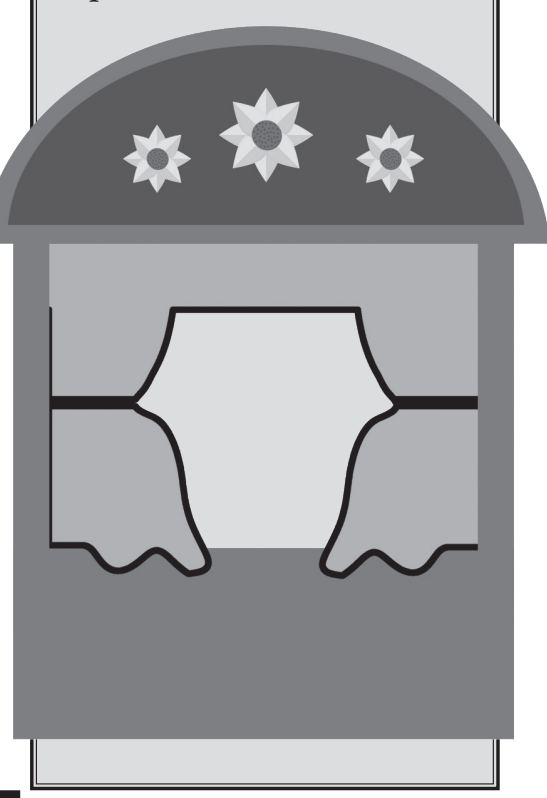




\section{Símboloss signos y señales de uso cotidiano}

-Vos colocha, si que estás sacándole raja a tu chamba.

Regionalismos. Un regionalismo es cualquier palabra o construcción propia de una región. Pueden ser palabras utilizados en determinado lugar con un significado diferente al de otras comunidades. Así, tenemos que, de acuerdo con el país de origen, existen americanismos, guatemaltequismos, mexicanismos, hondureñismos, etc. Por ejemplo:

Niño y niña: chamaco, chava, patoja, chirís, cipote.

Barrilete: papalote, cometa, piscucha

Marrano: cochino, coche, chancho, puerco

Autobús: guagua, burra, camioneta, camión

Hay un sinnúmero de guatemaltequismos debido a la rica influencia lingüística proveniente del intercambio de los idiomas que se hablan en nuestro país. Ejemplos:

Pilas, chucho, chocho, canche, babosear, cuache, acuchuchar y lenes.

\section{$\square$}

Escribo regionalismos que se usan en mi comunidad y selecciono aquellos que puedo incorporar en $\mathrm{mi}$ presentación de la feria.

Hago un glosario en inglés de los términos científicos que más se repiten en mi presentación.

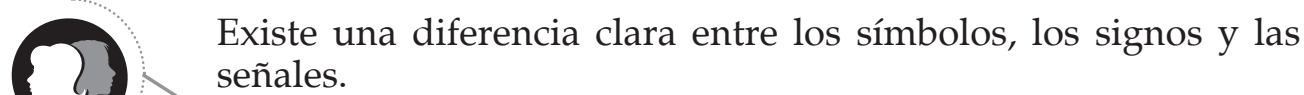
señales.

El símbolo es una imagen, figura u objeto que representa un concepto abstracto reconocido por una comunidad. Puede representas emociones, ideas o valores. Por ejemplo:

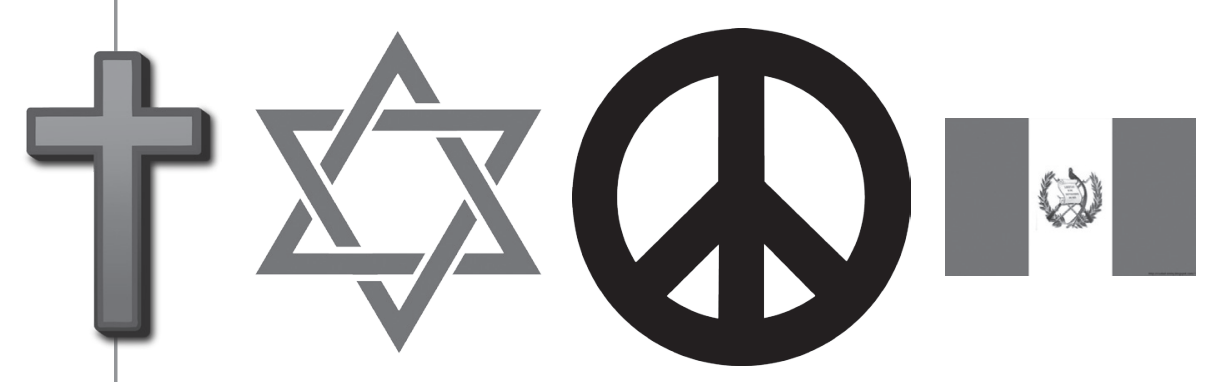

El signo es una iconografía que representa un referente, una indicación: Sus ejemplos más claros son los signos de puntuación y de matemáticas:

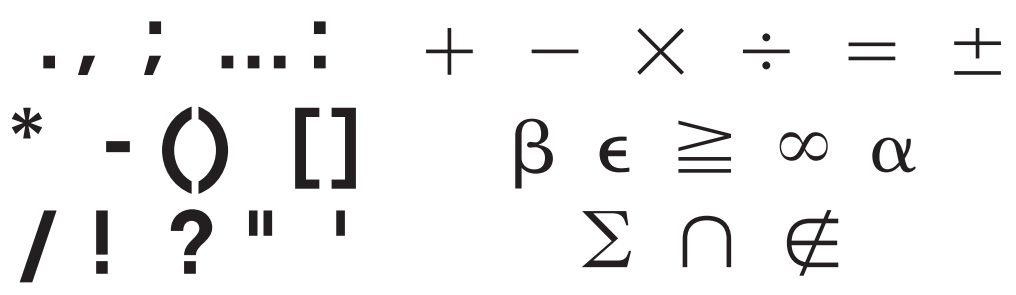

La señal es un signo, seña o marca que indica, recuerda o advierte algo para aportar al orden de la comunidad. Debe ubicarse en lugares visibles para que llegue al mayor número de receptores posible. Entre las más usadas están las señales de ubicación, de instrucciones y de tránsito.
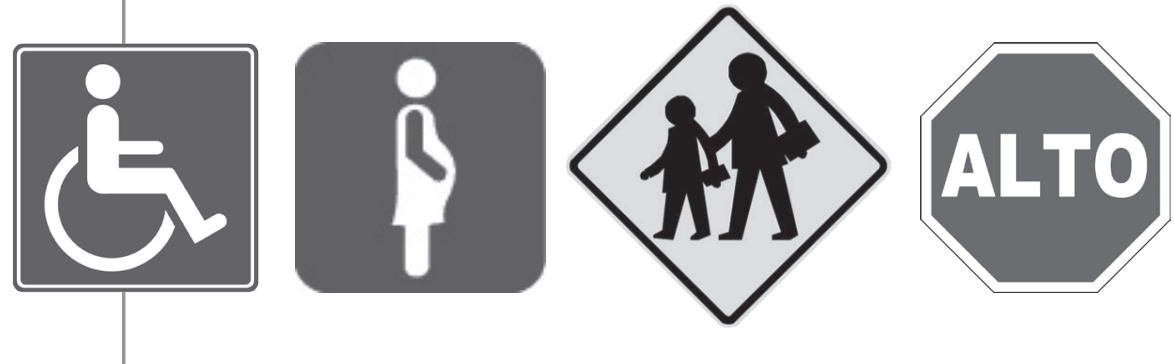

- Identificamos en grupo, qué significa cada una de las señales ejemplificadas.

- Conversamos sobre la importancia de atenderlas y respetarlas para mejorar la convivencia.

- Escribimos una lista de señales que incluiremos en la Feria Científica para orientar a las personas. Desarrollo dos señales en forma de afiche para colocar en la Feria usamos nuestro idioma materno para aclaratoria. 


\section{Diálogos, monólogos y dramatizaciones}

El teatro permite expresarnos tanto en forma oral (voz, entonación) como en forma corporal (gesto y movimientos). Pertenece al género dramático porque utiliza el diálogo o parlamento y es representado por actores. Consta esencialmente de: un texto literario escrito (diálogo) y la representación escénica o actuación.

Dentro de las modalidades de la representación teatral están el monólogo, el diálogo y las lecturas dramatizadas. Desde épocas históricas fue utilizado para hacer reflexionar a las personas sobre conductas que se deseaba afianzar, por ejemplo: en los atrios de las iglesias se llevaban a cabo representaciones muy expresivas de los conflictos entre las virtudes y las pasiones humanas. En este mismo sentido, en educación, se pueden escenificar hechos puntuales de los cuales se generen muchos aprendizajes.

Un monólogo es la representación de una pieza poética o reflexiva que realiza un solo actor. En un diálogo intervienen dos personas; mientras que en una lectura dramatizada, pueden intervenir dos o más personajes. En las tres modalidades se toma en cuenta los factores: voz, con sus modulaciones, pronunciación, entonación y volumen; el lenguaje gestual y corporal; la música de fondo y la iluminación.

Redactamos, en equipo, un diálogo acerca de minería, amenaza o vulnerabilidad del país a los desastres socio-ambientales. Representémoslo en nuestro ECA.

Investigo las características de los textos usados en los monólogos y escribo uno. El tema puede relacionarse con la vulnerabilidad ante los desastres.

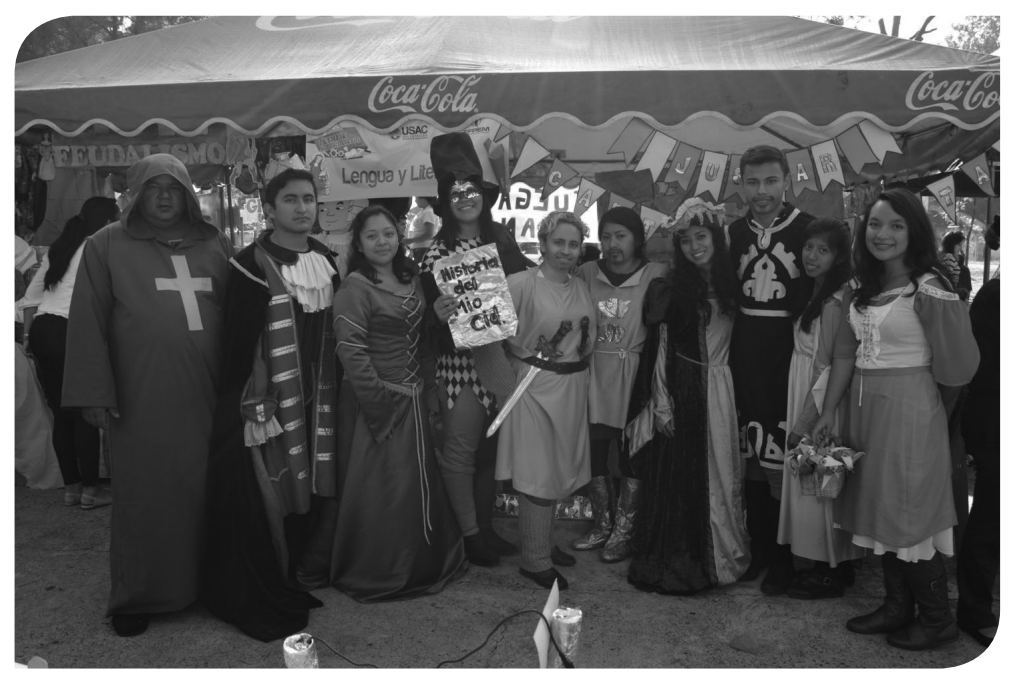

Monologo del agua.

“¿Qué pasó que hoy soy tan pesada por el plomo como en Pasco-Perú, o por el arsénico o el mercurio vertidos en los río por la explotación del oro en Madre de Dios-Perú?, ¿o por los materiales radioactivos como en Europa del Este? ¿Qué pasó que hoy enveneno la tierra otrora fértil o las arterias y cerebro de las madres y de los infantes que me consumen? ¿Qué pasó que hoy hiedo y soy insalubre como en algunos lagos de Brasil? O simplemente he desaparecido en el Mar Aral dejando mi espacio a la sal. ¡Mi frescura y lozanía se han perdido!!! ¿He envejecido, como todo envejece en esta vida? ¡Yo, que me consideraba eterna! ¡Yo, que parecía inagotable y reproducible al infinito!"

Fuente: http:/ / www.alainet. org/es/active/40604 


\section{Importancia de la contabilidad}

Los fondos públicos son el dinero que el Estado posee a través de impuestos, bienes, bonos y otros activos; los emplea para proporcionar bienes y servicios a la ciudadanía. Los fondos públicos son del pueblo por eso todas y todos debemos ser vigilantes de su buen uso a través de la auditoría o fiscalización social.

La Contraloría General de Cuentas (CGC) es la institución encargada de fiscalizar los movimientos contables de las municipalidades y toda institución que reciba fondos del Estado. Su finalidad es asegurar que los fondos públicos se utilicen adecuada y transparentemente para evitar la corrupción.

La Superintendencia de Administración Tributaria (SAT), es una entidad estatal descentralizada que goza de autonomía y personalidad jurídica. Entre sus funciones se incluye administrar el régimen tributario del país, la recaudación, control y fiscalización de todos los tributos tanto internos como los que vienen del comercio exterior.

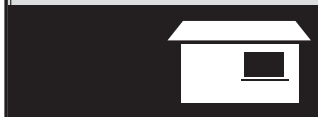

Las municipalidades manejan sus propias cuentas de lo que reciben y ejecutan en calidad de tributos municipales. Solicitemos a la $\mathrm{mu}-$ nicipalidad información sobre sus proyectos, fondos, ejecución y monitoreo.

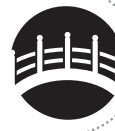

La contabilidad permite identificar, medir, registrar y comunicar información económica para administrar mejor el dinero y tomar decisiones respecto a ingresos, gastos, préstamos, compras e inversiones. Sin una buena contabilidad no tenemos información para evitar deudas, tampoco para impulsar o desarrollar nuestras finanzas.

Toda persona hace cuentas de cuánto dinero recibe, gasta y ahorra; pero la contabilidad es un sistema de registro constante que responde a las leyes tributarias del país. Un banco, por ejemplo, pedirá los estados financieros de un negocio para decidir si le concede un préstamo, necesita asegurarse que la dueña o dueño del negocio podrá pagarle.

Las y los peritos contadores conocen el procedimiento y los registros que deben hacerse en los libros de contabilidad. También saben qué libros exige la Superintendencia de Administración Tributaria (SAT), cuáles son los impuestos que deben pagarse y los plazos para realizar dichos pagos.

La contabilidad se maneja por cuentas, cada una agrupa los valores que conforman el patrimonio de un negocio, por ejemplo: compras, ventas, hipotecas, impuestos por pagar, sueldos por pagar y deudas por cobrar. Cada cuenta se anota en las columnas de los libros:

- En el haber, los importes monetarios o abonos:, cuando alguien paga por el producto o servicio que ha recibido.

- En el debe, lo que se ha gastado.

- En el saldo se anotará la diferencia entre debe y haber: entre lo que cancelamos y lo que recibimos. La suma de ambas columnas deberá ser igual para decir que estamos en balance.

Calculemos los ingresos de nuestro equipo, así como sus gastos y el saldo.

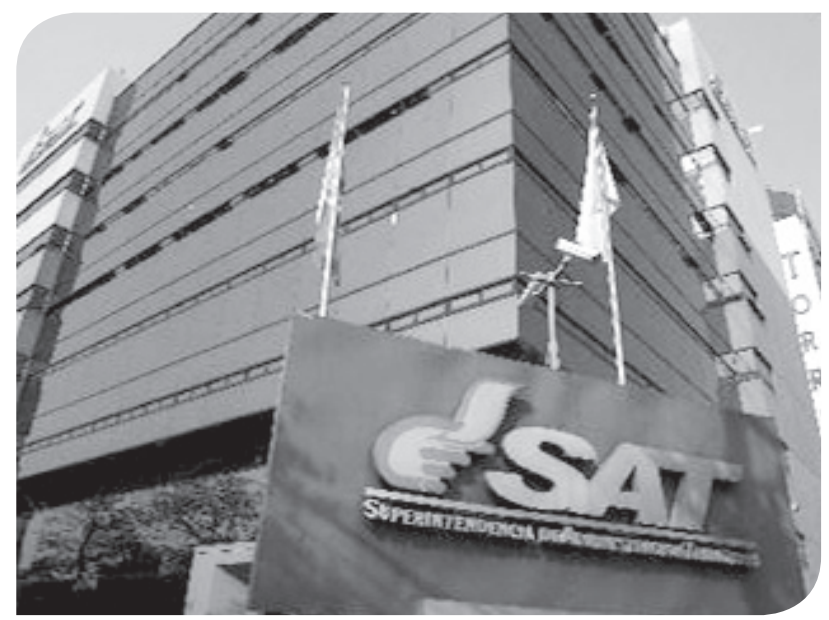

Fuente: http:/ /www.cpa.org.gt/2013/07/02/comision-dedefensa-gremial/

Semana 18

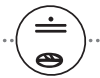


La contabilidad se respalda con documentos de soporte que demuestran las transacciones realizadas. Para que estas transacciones sean válidas, los documentos de soporte deben ser autorizados por la Superintendencia de Administración Tributaria (SAT). Sirven como comprobante para el pago de impuestos:

- Factura. Es el comprobante legal de una compra.

- Factura especial. La elabora una empresa para registrar el pago a una persona que no entrega facturas por la prestación de sus servicios o la venta de sus productos.

- Nota de débito. Sirve para corregir precios de operaciones facturadas, recargar pagos atrasados o cobros de penalización por cheques rechazados.

- Nota de crédito. Respalda los descuentos y rebajas no anotadas en las facturas o las devoluciones de clientes.

En las transacciones actuales se utilizan otros documentos de soporte:

- Tarjeta de crédito. Se emplea para adquirir un producto o servicio y pagar después a la empresa financiera que respaldó el crédito, lo frecuente es que se tenga un mes de plazo, si se paga después, se hará un pago adicional por los intereses.

- Tarjeta de débito. Sirve para pagar por un producto o servicio sin utilizar efectivo, ya que se autoriza para que el vendedor retire el precio de una cuenta bancaria del comprador.

- Cheque. Cumple una función similar a la tarjeta de débito pero se respalda con una cuenta bancaria monetaria, no se puede hacer con una de ahorro.

- Letra de cambio. Es un documento de compromiso que una persona firma para pagar un producto o dinero prestado, el plazo de pago se indica en dicho documento.

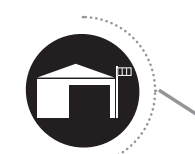

Solicitamos a una o un perito contador que nos amplíe información sobre la contabilidad y nos muestre los libros que utiliza.

Nos organizamos en grupos y obtenemos muestras de los documentos de soporte, los colocamos en carteles en el aula y comparamos los elementos que contienen.
La auditoría es una revisión minuciosa y estricta de la contabilidad de una empresa, organización o proyecto. Su objetivo es vigilar que se apliquen procedimientos y técnicas de acuerdo con las normas de contabilidad para conocer el estado financiero de las empresas, organizaciones o proyectos. Se realiza una auditoría interna (realizada por personal de la entidad), pero también una externa para que personas ajenas revisen y evalúen los estados financieros.

La ciudadanía también puede realizar auditorías sociales a los proyectos ejecutados por los Comités de Desarrollo, las municipalidades y el gobierno para monitorear y evaluar que los fondos se utilicen de manera adecuada y las obras se ejecuten en el tiempo y con la calidad deseada. 


\section{Riesgos ambientales}

La amenaza de sequía es muy alta y extremadamente alta "... en los valles orientales y de la región central, desde Jutiapa, Jalapa, Chiquimula, Zacapa, El Progreso y Baja Verapaz hasta llegar a Quiché. Asimismo, existe una estrecha franja paralela a la costa del Pacífico que posee un efecto de "sombra de lluvia" y pertenece a la zona de vida."

http:/ / biblio3.url.edu.gt / IARNA/serie_amb/3.PDF

- ¿Qué actividades humanas hacen que la sequía sea una amenaza en estas regiones de Guatemala?
En el planeta Tierra, ocurren infinidad de fenómenos naturales, pero un reducido número constituye una amenaza para los seres humanos. Llueve, pero solo se convierte en amenaza cuando dura mucho tiempo y lo hace copiosamente. Se convierte en un riesgo, cuando una comunidad se encuentra a orillas de un barranco, se ha talado los árboles y demás cubierta vegetal de la comunidad, hay una mina cerca del lugar, etc. Entonces el riesgo de que una corriente de agua arrastre casas hacia el barranco, que ocurran derrumbes, socavamientos y dañen a las personas de la comunidad o que el agua se contamine con desechos de una mina es latente. Estos riesgos son clasificados como naturales y son las acciones humanas las que los pueden convertir en desastres. Para remarcar esta relación entre los fenómenos naturales y los desastres en que se puedan convertir por acción de los seres humanos se les nombra desastres socio-ambientales.

Cuando las acciones humanas dañinas al entorno ambiental de una comunidad aumentan el riesgo de que ocurra un desastre se dice que es una comunidad vulnerable.

\section{Trabajamos en equipo}

Si una comunidad está asentada en un terreno con mucho declive y no tiene drenajes, ¿ante qué fenómenos naturales se encuentra vulnerable?

¿Hay fenómenos naturales que, independientemente de las actividades humanas, constituyan una amenaza para las comunidades? Ejemplificamos y explicamos por qué.

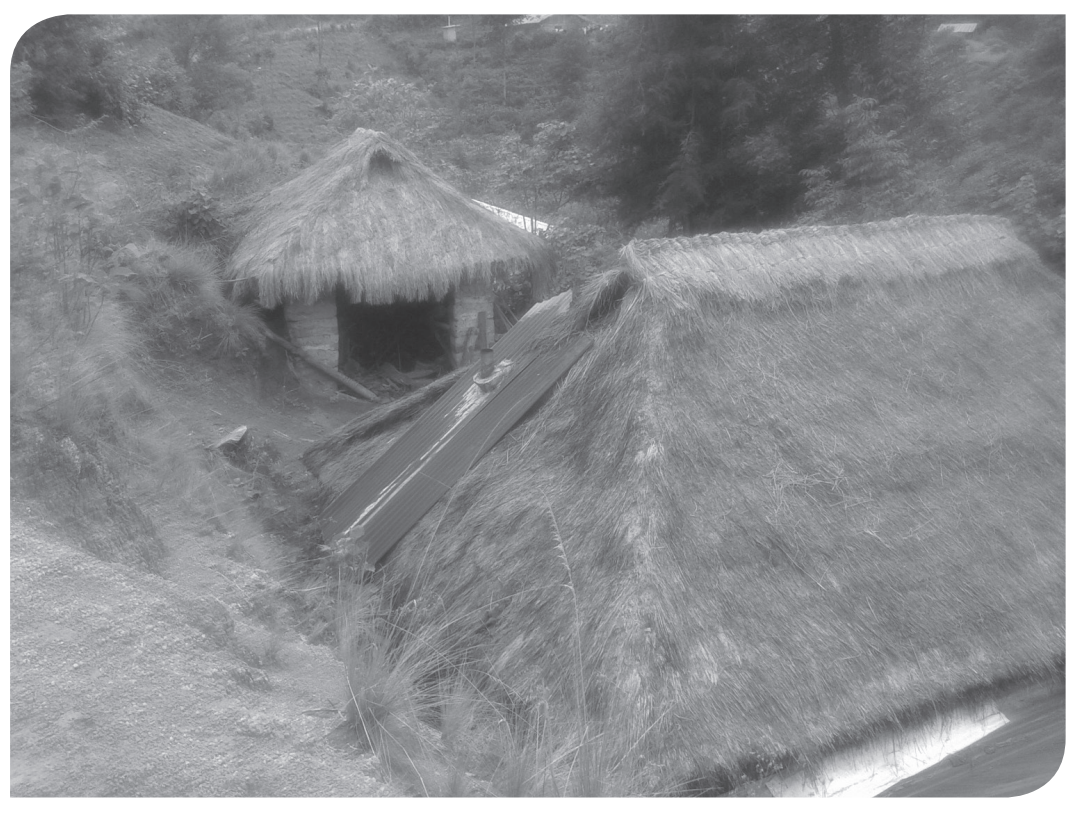




\section{Vulnerabilidad social}

Una comunidad es vulnerable cuando existe el riesgo de que un fenómeno natural se convierta en un desastre para las personas que habitan dicha comunidad. Hay acciones humanas que hacen vulnerable a una comunidad, pero también hay condiciones sociales que la pueden hacer vulnerable. Por ejemplo, el terremoto ocurrido en Guatemala en 1976 fue de 7.5 grados, Richter causó más de 23 mil muertos y damnificó a más de un millón de personas; la mayoría debido a que sus limitaciones económicas sólo les permitía construir sus casas de adobe. Épocas de sequía se registran en todo el mundo y en muchos siglos; pero causan hambruna y desnutrición en las comunidades más pobres.

Los fenómenos naturales pueden convertirse en desastres debido a condiciones de carácter político. Por ejemplo, la crecida de un río puede arrasar una comunidad cuando por efecto de la corrupción o los intereses partidarios no se ha realizado el dragado del mismo.

\section{Trabajamos en equipo}

Redactamos una lista de acciones y condiciones sociales que hacen más vulnerable a nuestra comunidad ante el calentamiento global.

Explicamos cómo se pueden cambiar algunas acciones o condiciones sociales para reducir la vulnerabilidad de nuestra comunidad.

- ¿Qué efecto tiene el respeto de los derechos humanos de las y los integrantes de una comunidad en la vulnerabilidad ante desastres naturales?

Clasificamos el tipo de recursos naturales de nuestra comunidad para organizar mejor la feria científica.

Identificamos los recursos naturales que son explotados intensamente en nuestra comunidad.

Elaboramos lineamientos para redactar un anecdotario de nuestras experiencias en la feria científica.

Redacto el anecdotario de experiencias en la feria científica.

Pienso en algunas ideas para evaluar la realización de la feria científica.

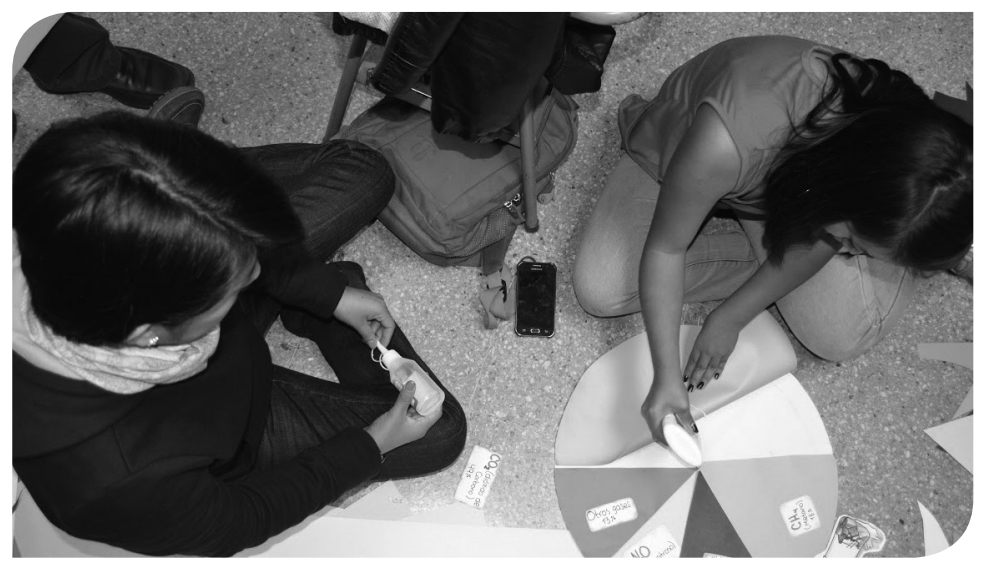

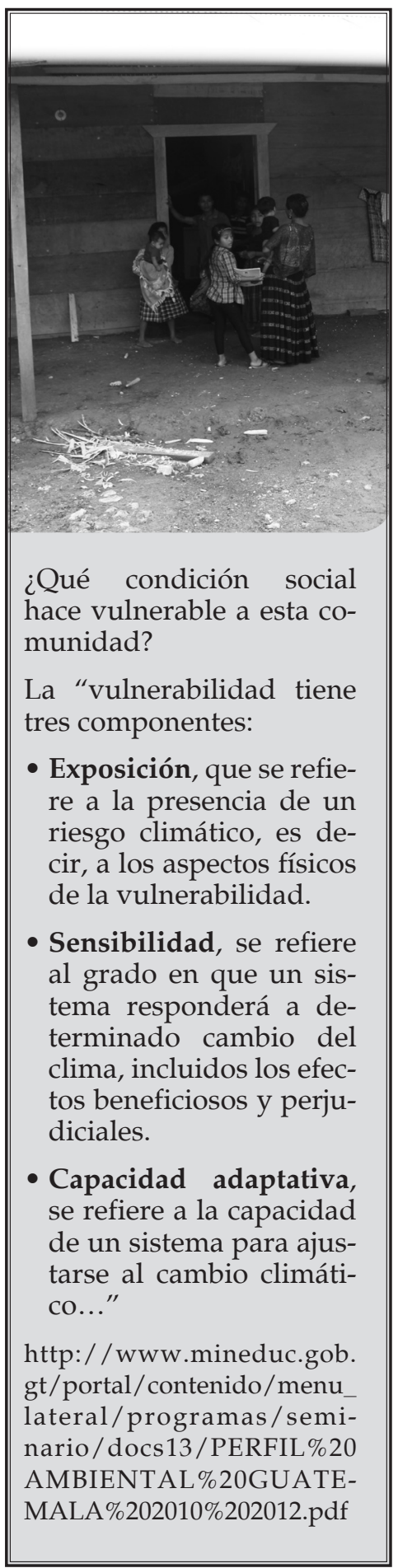




\section{Probobilidad de eventos independientes}

"Los eventos dependientes ocurren cuando una acción elimina un resultado posible, y el resultado no es devuelto antes de que suceda una segunda acción. A esto se le llama elección sin devolución."

Fuente: http://www.montereyinstitute.org/courses / Algebra1/COURSE_TEXT_ RESOURCE/U12_L 2 T3 text_final_es.html
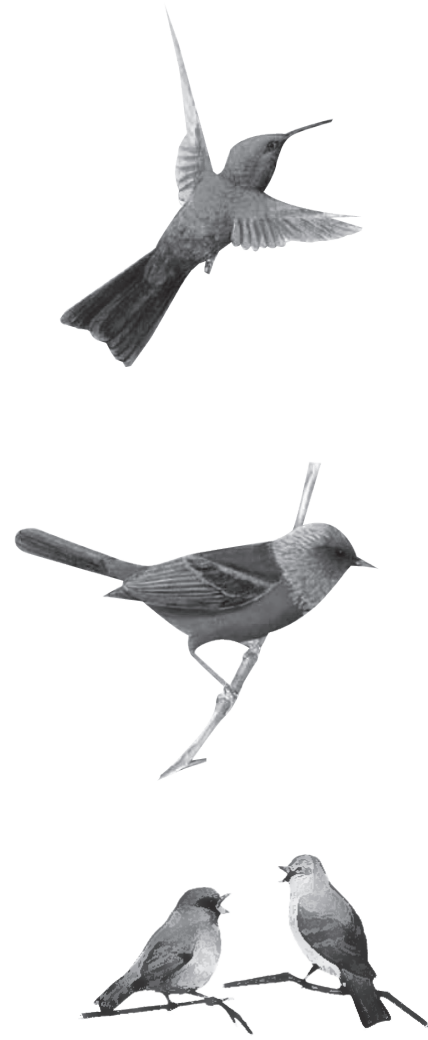

(i)

Un costal contiene 6 zanahorias, 10 tomates, 8 papas y 9 rábanos. Se le pide a una persona que, sin ver, saque del costal una verdura; la vea y la vuelva meter y que saque otra.

A una segunda persona se le pide también que, sin ver, saque del mismo costal una verdura y sin volverla a meter saque otra.

- ¿Cuál es la probabilidad de que la primera persona saque una papa y luego un rábano?

- ¿Cuál es la probabilidad de que la segunda persona saque una papa y luego un rábano?

Muestro mis procedimientos en mi cuaderno.

- ¿Cómo obtuvimos las probabilidades anteriores? Comparamos nuestras respuestas y comentamos. ¿Qué diferencia hay entre el cálculo de la probabilidad de la primera persona y el de la segunda?

- ¿Qué situación, de las anteriores, ejemplifica un caso de eventos independientes? ¿Por qué?

Explicamos y comentamos.

Cuando se combinan varios eventos simples se tiene un evento compuesto. Por ejemplo: una estudiante cortó una flor en el camino, usa zapatos negros e hizo las tareas; otro sería que en una comunidad se corten 100 árboles y que ocurra un vecindario quede soterrado por un deslave. Al calcular la probabilidad de un evento simple debe identificarse si hay o no una relación entre ellos.

El ejemplo de la estudiante es un evento compuesto de carácter independiente porque no existe relación entre los tres eventos simples que la conforman: el que corte una flor no se relaciona con que use zapatos negros y tampoco con que haya cumplido con sus tareas.

Mientras que el segundo ejemplo de evento compuesto es dependiente porque puede haber relación entre cortar los árboles y que luego, con las lluvias ocurra un deslave que provoque un desastre socio ambiental

En conclusión: $A$ y $B$ son eventos independientes si la ocurrencia de uno no afecta la probabilidad de que el otro ocurra. Los eventos independientes pueden ocurrir simultáneamente.

- ¿Qué clase de evento es que trinen los pájaros y salga el arcoíris?

$$
p(A \cap B)=p(A) \cdot p(B)
$$

$A$ y $B$ son eventos dependientes cuando la ocurrencia o no ocurrencia de uno afecta la probabilidad de que el otro ocurra o no ocurra.

$$
p(A \cap B)=p(A) / p(B \cdot A)
$$




\section{Propiedad de los eventos independientes}

En una encuesta se ha preguntado a 1000 personas si consideran que se deben sembrar más árboles para evitar deslizamientos y otros tipos de desastres causados por la deforestación. 480 hombres respondieron en total; de los cuales 324 han dicho que sí y 156 que no. De las 520 mujeres que contestaron 351 dijeron que sí y 169 que no.

Consideremos que $A=$ respondió que sí consideran que se deben sembrar más árboles y $B=$ que haya respondido un hombre ¿Son $A$ y $B$ eventos independientes? Observemos el siguiente proceso:

\begin{tabular}{|c|c|c|}
\hline $\begin{array}{c}\text { 1. Calculamos la probabi- } \\
\text { lidad de } A:\end{array}$ & $\begin{array}{c}\text { 2. Calculamos la } \\
\text { probabilidad de } B:\end{array}$ & $\begin{array}{c}\text { 3. Hallamos la proba- } \\
\text { bilidad de } A \cap B: \\
P(A \cap B)=\frac{324}{1000}\end{array}$ \\
$P(A)=\frac{324+351}{100}=\frac{675}{1000}$ & $P(B)=\frac{480}{1000}$ & $P(A \cap B)$ \\
\hline
\end{tabular}

\begin{tabular}{|l|l|}
\hline $\begin{array}{l}\text { 4. Se cumple: } \\
\frac{324}{1000}=\frac{675}{1000} \cdot \frac{480}{1000}\end{array}$ & $P(A \cap B)=P(A) \cdot P(B)$ \\
\hline
\end{tabular}

Esto quiere decir que el ser hombre o mujer no influyó en las opiniones de las personas encuestadas. Los eventos son independientes.

Mediante diagramas de flujo, elaboramos croquis de ubicación de los estands de la feria. Hacemos el recorrido indicado en el croquis. Resolvemos:

- A una reunión asistieron 20 personas; 11 hombres y 9 mujeres. Si 5 hombres y 3 mujeres llevaron pantalón y se escoge una persona al azar ¿Cuál es la probabilidad de que sea mujer y lleve pantalón? ¿Cuál es la probabilidad de que sea una mujer dado que lleva pantalón?

- Si se lanza una moneda 3 veces consecutivas, ¿Cuál es la probabilidad de que caiga cara las tres veces?

Busco dos ejemplos de sucesos independientes y tres ejemplos de sucesos dependientes que estén relacionados con la producción, el sostenimiento de los recursos naturales y los derechos humanos. Los anoto en mi cuaderno. En la próxima clase, los comparto con el resto de compañeras y compañeros.
Para elaborar un cartel sólo se puede usar un color de cartulina, un marcador y un tipo de recorte, • ¿Cuántas combinaciones puedo hacer?

Cuando clasificamos datos que pertenecen a dos categorías distintas, como género y preferencia por un color, los podemos representar a través de una tabla de contingencia.

\begin{tabular}{|l|l|l|l|}
\cline { 2 - 3 } \multicolumn{1}{c|}{} & \multicolumn{2}{|c|}{ Prefieren el color } & \multicolumn{1}{c|}{} \\
\hline & amarillo & rojo & Total \\
\hline Hombre & 18 & 32 & 50 \\
\hline Mujer & 42 & 8 & 50 \\
\hline Total & 60 & 40 & 100 \\
\hline
\end{tabular}

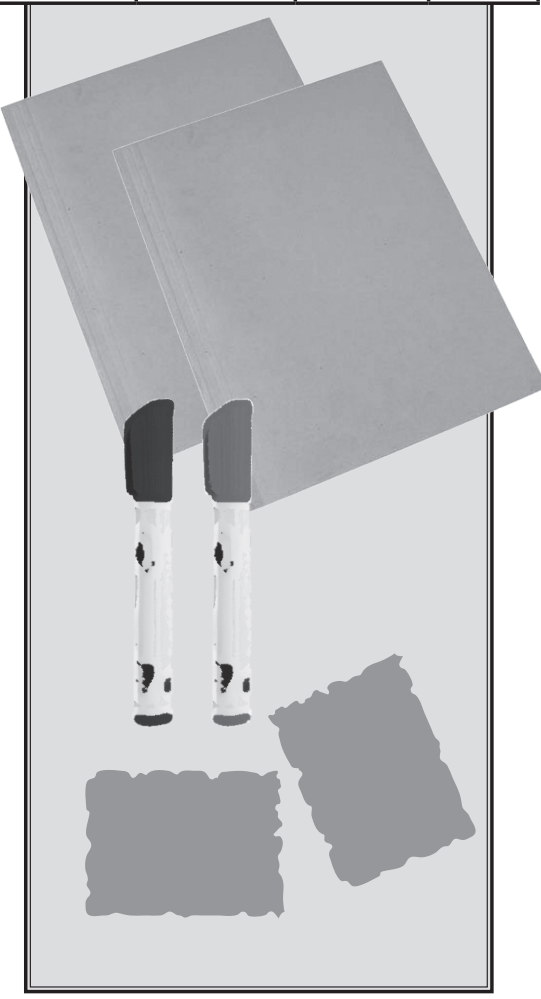

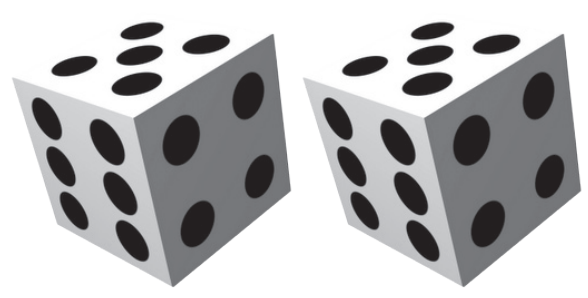




\section{Los minerales y su explotación en Guatemala}

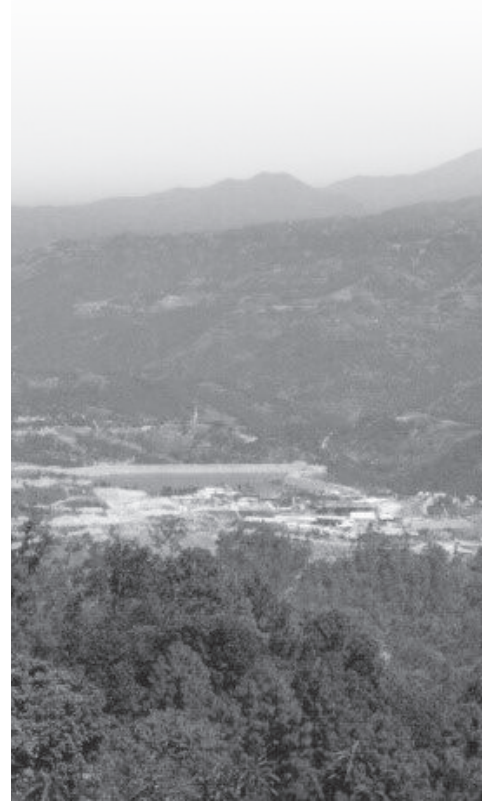

Mina a cielo abierto

De acuerdo al artículo 63 de la ley de Minería (Decreto 48-97), el país recibe únicamente el $1 \%$ de las regalías, producto de la explotación minera, lo cual no alcanza para recuperar el estado original de los suelos y entornos afectados.
- Conversamos, con nuestro equipo, respecto de la minería en Guatemala.

- Organizamos una plenaria y hacemos una lluvia de ideas sobre sus ventajes y desventajas contemplando los siguientes aspectos: ambiental, económico, alimenticio, laboral, convivencia social, desarrollo sostenible.

Los minerales son sustancias cristalinas que tienen una composición química definida; por lo que no pueden descomponerse en sustancias más simples. Están distribuidos en forma desigual en la corteza terrestre, van agotándose a medida que se extraen por lo que se les llama recursos naturales no renovables.

Guatemala es una país muy rico en minerales, tanto metálicos (zinc, cobre, oro, plata y otros), como no metálicos (jade, piedras calizas, entre otros.). Es por ello que desde la época precolombina se práctica la minería en nuestro territorio. En las últimas décadas, varias empresas mineras transnacionales realizan actividades de exploración y explotación de los minerales contenidos en los yacimientos. La minería extrae minerales para utilizarlos como materia prima en la manufactura de productos industriales, material de construcción y joyería entre otros. De acuerdo con el tipo de mineral se clasificarse en:

- Minería de yacimientos de metal, donde pueden extraerse metales como el oro, el hierro, el aluminio o el cobre.

- Minería de canteras, donde se extraen arcillas, granito, mármol, cuarzo entre otros.

- Extracción de minerales energéticos como el petróleo y el carbón.

Estudios e informes sobre la minería han dejado evidencia de las consecuencias de esta actividad económica sobre las personas, los territorios y la economía de las comunidades en las que se sitúa. Su impacto es amplio ya que para desarrollarse depende del uso de otros recursos naturales, como el agua, del empleo de la mano de obra de población de la comunidad, de la adquisición de grandes extensiones de tierra y de inversiones multimillonarias. Por esto antes de autorizar una licencia minera, las empresas están obligadas a presentar al Estado un estudio de impacto ambiental y acatar el resultado de las consultas comunitarias sobre el deseo de las personas que la industria minera se instale en sus territorios.

Converso con adultos de la comunidad acerca de la minería de yacimientos y de canteras. Sus beneficios, perjuicios, oportunidades y amenazas. ¿Sería posible una relación amigable y respetuosa con la Madre Tierra y la minería? 


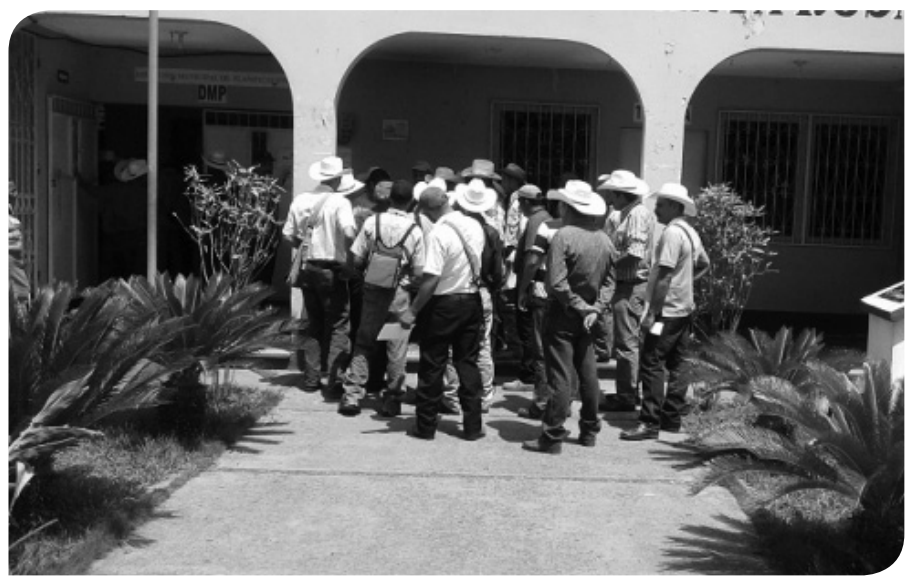

Foto: San Juan Tecuaco, Santa Rosa

Fuente: http:/ /www.pdh.org.gt/noticias/breves-informativas/ item/6053-observan-consulta-comunitaria.html\#.V91CYyjhDIU

Investigamos acerca de los efectos de diversas actividades mineras en Guatemala visitando diversos sitios en la internet.

Identificamos qué consecuencias aportan al desarrollo sostenible y cuáles no.

Realizamos un ensayo de presentación de la Feria científica y verifico los recursos tecnológicos a implementar.

Evaluamos el avance de los aportes que cada equipo desarrolla para la Feria científica.

Algunos impactos que se han demostrado tiene la actividad minera son: Alteración física y química del suelo al compactarlo y remover su capa vegetal Aspersión de sustancias altamente tóxicas, como el cianuro de sodio.

- Aumento de la vulnerabilidad a los desastres socioambientales

- Contaminación de pozos de abastecimiento en las comunidades

- Contaminación del aire debido a las cantidades de partículas de polvo

- Contaminación del agua superficial y aguas subterrráneas con minerales tóxicos o metales pesados

- Disminución en la producción agrícola de la localidad

- Emisión de gases de efecto invernadero por combustiones de carbón y pirometalurgia

- Enfermedades cutáneas y respiratorias en poblaciones aledañas

- Generación de empleo

- Escorrentía y erosión de suelo

- Modificación del paisaje

- Pago de tributo al Estado y las Municipalidad aledañas

- Realización de pequeñas obras comunitarias de capacitación y apoyo a la salud

- Migración por la venta de tierras
El Ministerio de ambiente es el ente encargado en Guatemala para velar porque las empresas u organizaciones que realicen actividades socio económicas presenten un informe de impacto ambiental en donde se detallen las consecuencias que la actividad tendrá sobre el entorno social, económico y medio ambiental. También deben presentar un plan de gestión ambiental para mitigar o eliminar los impactos negativos.

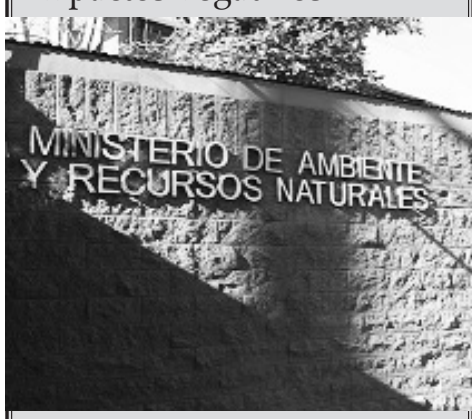

Foto: Edificio del Ministerio de Ambiente y Recursos Naturales

Referencia: http://www. marn.gob.gt/paginas/Institucin

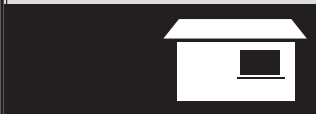

- Investigo si en la comunidad existe actividad minera o estén planes para iniciar trabajos de exploración. Si cerca de nuestra comunidad hay una actividad minera, dialogo con la población para identificar su impresión sobre el impacto que esta ha tenido en la economía, el suelo, el agua, la salud, la alimentación y la convivencia en el lugar.

- Preparo una experiencia científica de Biología, Química o Física para presentarla en la Feria científica. 


\section{El ciclo contable}

El Inventario es un registro ordenado detallado y valorado de los bienes de una persona, comercio $\mathrm{u}$ organización, pero no es un libro del ciclo contable. Detalla la descripción, el precio, el número de unidades y el total de pertenencias: muebles, edificios, terrenos, mercancía, equipo, repuestos, accesorios, entre otros bienes materiales. Permite conocer cuánto tenemos de cada bien y cuál es el monto individual y total para conocer el estado patrimonial, reducir los costos de los pedidos, la pérdida de bienes y las pérdidas por demanda insatisfecha de nuestros clientes o colaboradores.

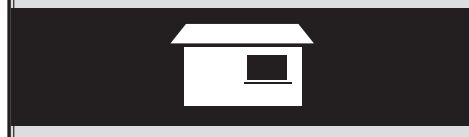

Elaboro un inventario para conocer el estado del patrimonio familiar.

Trabajo en el anecdotario luego de la realización de la feria.
La contabilidad se apoya en los siguientes procesos, libros o módulos principales que integran el ciclo contable:

- Diario. Registra día a día todas las transacciones con partida doble de manera que sea igual la suma del debe y el haber.

- Mayor. Registra los ingresos y gastos de cada rubro o cuenta, por ejemplo: gasolina, transporte, alimentación, etc.

- Balance de Saldos. Muestra los saldos deudores (nuestras deudas) y acreedores (lo que tenemos y nos deben). Nos informa el estado de la empresa. Permite comprobar y detectar cualquier error en el Diario.

- Estados Financieros. Presenta el resultado de las operaciones brindando información sobre la situación financiera, la rentabilidad y la liquidez para tomar decisiones a futuro.

- Cierre. Se realiza después de los estados financieros para preparar las cuentas para el nuevo periodo contable. El periodo contable es determinado por las leyes de Guatemala, del 1 de enero al 31 de diciembre de cada año.

El ciclo contable es el registro de transacciones en un periodo de tiempo definido para conocer el estado financiero de la empresa, organización o proyecto.

La caja chica es una cuenta contable que define un monto pequeño de dinero que se tiene a mano para gastos menores. Una persona es la responsable de su manejo, cada gasto está respaldado por un documento (factura, recibo, vale) que entrega cuando liquida esos gastos para recibir un nuevo monto de dinero. Es falta grave de contabilidad y honestidad tomar o "prestar" dinero para cubrir gastos personales.
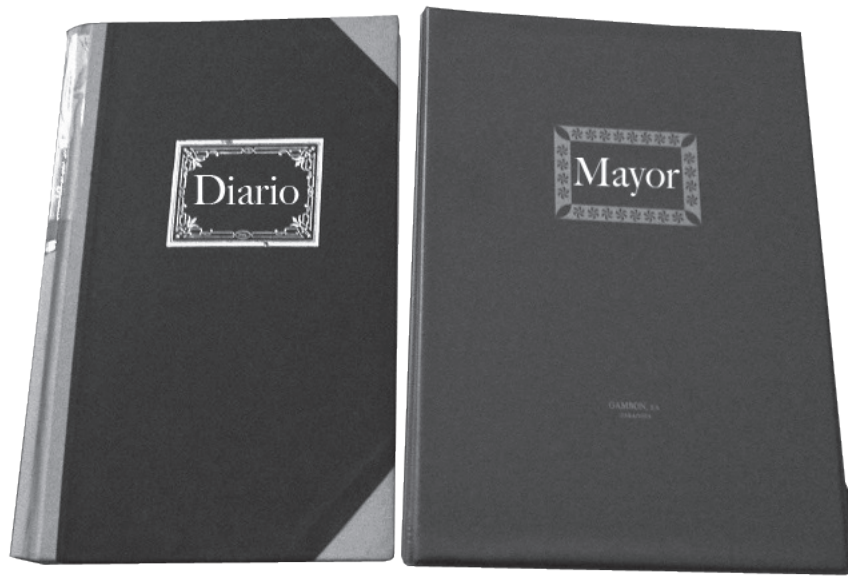

Una vez montados los puestos de la feria, hacemos un inventario de los recursos que estamos utilizando. 
El presupuesto es un cálculo anticipado de los ingresos y egresos de una actividad económica, realización de una obra o servicio; ya sea personal, familiar, para una institución, asociación, cooperativa, empresa o negocio. No forma parte de la contabilidad, pero es importante para planificar nuestras actividades, llevar control de nuestros ingresos y evitar endeudarnos. El Estado de Guatemala funciona a través del Presupuesto general de gastos de la nación. Las corporaciones municipales también elaboran su propio presupuesto para la realización de obras en el municipio. La ciudadanía debe contribuir al presupuesto cumpliendo sus obligaciones tributarias y haciendo auditoría social a las obras públicas. Para realizar con éxito nuestra feria científica es importante comenzar por planificar un presupuesto. Para ello necesitamos conocer con cuánto dinero contamos y cuánto vamos a gastar.

Hacemos una lista de las actividades y recursos que necesitamos, listando todos los gastos por muy pequeños que sean. Sumamos y tenemos el total de dinero que necesitamos. Luego, sumamos el dinero que tenemos disponible para esta actividad: contribuciones de estudiantes, venta de refacciones o donaciones de alguna persona o institución. La diferencia entre los dos montos nos dirá si contamos con fondos suficientes o necesitamos reunir más dinero y decidir qué acciones tomar.

El objetivo de un presupuesto es no gastar más de lo que tenemos, no endeudarnos o si lo hacemos, saber exactamente cuánto dinero extra necesitamos durante cuánto tiempo para devolver lo prestado. En un presupuesto balanceado, los ingresos son iguales a los gastos. Lo ideal es tener más ingresos y destinarlos para ahorro, un fondo de emergencias o una inversión.

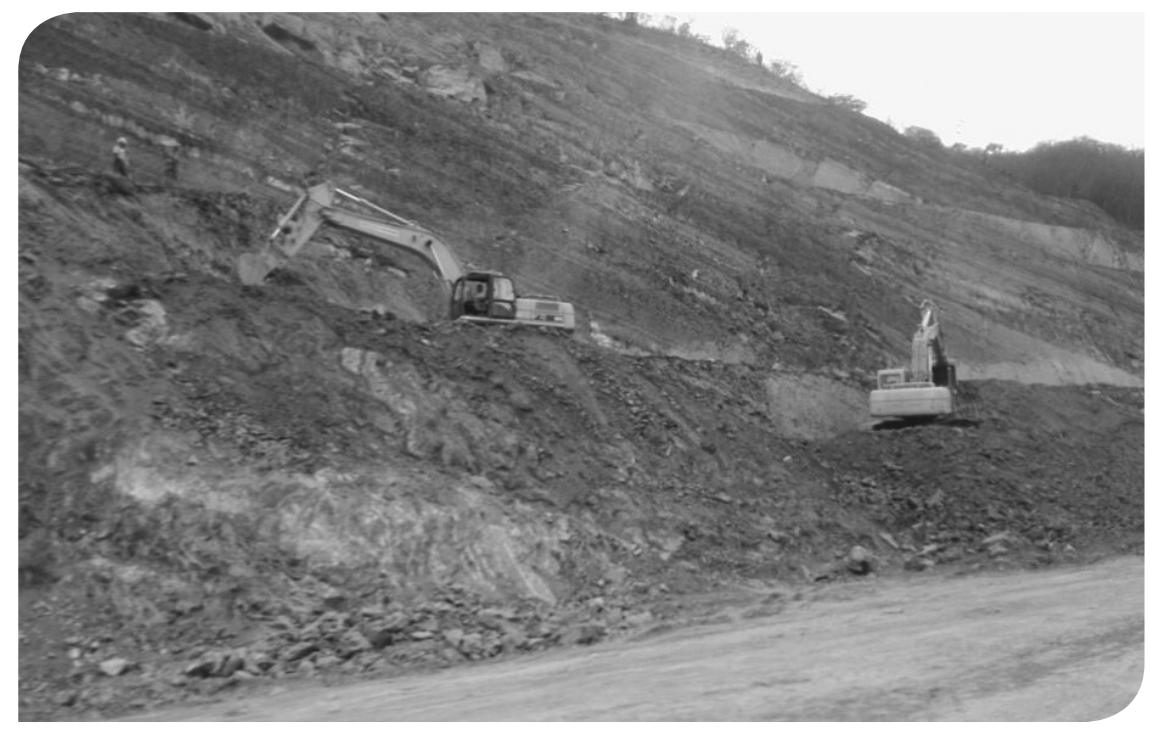

Elaboremos el presupuesto del montaje y presentación de la feria científica.
Generalmente, los presupuestos públicos se han elaborado sin tomar en cuenta el género de las personas beneficiarias. Poco a poco, eso ha cambiado y ahora se realiza un análisis del presupuesto para conocer el impacto de las políticas públicas en las mujeres y niñas. Esto permite influir en la cantidad y calidad del gasto público y valorar la contribución de las mujeres y niñas al desarrollo del país.

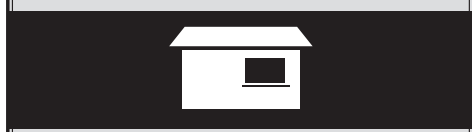

Con apoyo de las personas adultas de mi familia, analizo el presupuesto familiar. Tomo en cuenta los ingresos y gastos de cada integrante. ¿Cuánto del presupuesto se dedica a las mujeres (niñas, adolescentes, adultas y ancianas) del hogar? ¿Se dedica la misma cantidad de dinero y esfuerzo para el desarrollo de niñas y niños? ¿Por qué a veces privilegiamos unas personas más que a otras? 


\section{Arte, ciencia y tecnología}

\section{El tangram}

Es un juego de origen asiático, de figuras geométricas y poligonales. A partir de las figuras básicas, se deben formar otras figuras de diversos tipos, sin superponer nunca una sobre la otra. Su valor consiste en la riqueza visual y el manejo de la imaginación para formar las figuras. Es un ejemplo de la relación entre la ciencia, en este caso, la Matemática y el arte. En Matemáticas es un valioso recurso para la exploración del espacio, para el studio de figuras geométricas, áreas y perímetros.

Para construirlo solo se necesita papel, lápiz y crayones o papel de colores, tijeras y goma.

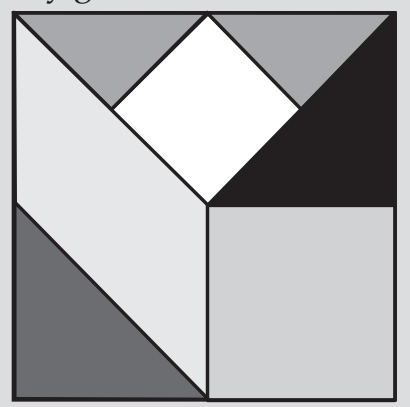

- ¿Me imagino títeres que podrías armar a partir del Tangram?

Estas son algunas de las figuras que se pueden lograr.
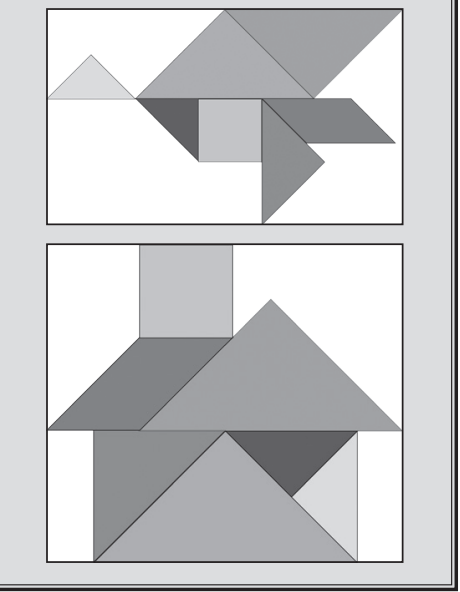

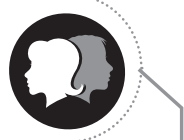

Ya hemos aprendido que hay personas dedicadas a la ciencia, que también han sido o son artistas. En la ciencia hay mucho de arte y en el arte, mucho de ciencia. Hay muchos vínculos entre el arte y la ciencia. Así, la pintura está relacionada con la ciencia de la óptica y la música con la Matemática. Constructores, matemáticos, científicas y artistas dede la antigüedad, han descubierto patrones geométricos communes en la Naturaleza. Esta es la Geometría de la Naturaleza o Geometría Sagrada. Un ejemplo, es el número de oro y la proporción áurea, presente en las plantas, caracoles y en el cuerpo humano. Se considera que las pinturas y esculturas que siguen la proporción áurea, tienden a ser más bellas.

\section{Temas de impacto social para el teatro de marionetas}

Varios son los temas que podemos abordar en la presentación de teatro con marionetas o títeres. Es importante tener en cuenta que la oportunidad de abordar estos temas es algo único, pues afectan a la comunidad y al entorno. Estos pueden ser:

- Contaminación del ambiente sónico

- Contaminación y abuso de los recursos naturales

- Efectos del cambio climático

- Inequidad de género

- Propuestas de conservación del ambiente para el desarrollo sostenible

- ¿Puedo recordar a un hombre y a una mujer que combinaron ambos campos de la inteligencia?

- ¿Cuál es la importancia de incluir el arte en la Feria escolar?

Realizamos el teatrino de marionetas y ensayamos la obra una última vez antes de ser presentada a la comunidad. Tenemos en cuenta los siguientes detalles:

- verificamos que el teatrino sea estable y que no va a caer durante la presentación,

- revisamos la condición de títeres, hacemos ajustes finales para garantizar que sean representativos de los personajes,

- afinamos nuestra voz escuchando el volumen y el tono así como la interpretación que daremos según el personaje que nos corresponde,

- tenemos en cuenta los tiempos de cada diálogo y el tiempo total de la presentación,

- aseguramos que la presentación será visible desde cualquier punto en el que se encuentren las personas del público

- tenemos accesible, a la vista de actrices y actores, un guión del diálogo a utilizar en caso sea necesario. 


\section{Exposición de creaciones artísticas en la Feria}

Es posible que no todos y todas las integrantes del ECA participen maniobrando los títeres. Así que debemos organizarnos y distribuirnos para cada integrante realice una actividad. Habrá quienes podrán ayudar en la utilería, teniendo listo el teatrino y ordenados los títeres según las escenas. Otra manera de participar puede ser organizando a las y los espectadores para que pasen a apreciar las presentaciones con marionetas. Al tener organizado todo lo que corresponde con las obras teatrales, podemos diseñar espacios para presentar otras creaciones artísticas realizadas en el área de expresión artística.

De todas las creaciones artísticas que hemos hecho en el desarrollo de los tres proyectos, podemos ahora elegir los mejores productos para ser expuestos en la feria científica. Por ejemplo:

- El disco de Newton, como una aplicación científica sobre la teoría de la luz reflejada en un prisma. Su dimensión científica penetra también el campo del arte en la combinación de colores.

- El collage como muestra de la combinación de líneas y colores superpuestos en imágenes prediseñadas.

- La canción Qatinamït, de Ch'umilkaj Curruchiche, con sus acordes de guitarra.

- El collage sobre la teoría de las inteligencias múltiples, como otra muestra de la relación científica que hay con las artes.

- La producción de anuncios publicitarios como muestra del uso de la tecnología en sintonía con la producción artística.

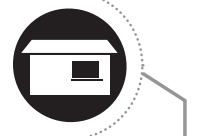

Realizo una lista de mis aprendizajes

Recuerdo y escribo una lista de las experiencias de aprendizaje que tuve en el desarrollo de los tres proyectos. Comento lo que más me gustó de cada sub-área de Expresión artística. Propongo nuevas actividades que me gustaría hacer en mi espacio personal y familiar.

\begin{tabular}{|l|c|c|c|}
\hline \multicolumn{4}{|c|}{ Mis aprendizajes de Expresión Artística } \\
\hline Artes Plásticas & Danza & Teatro & Música \\
\hline & & & \\
& & & \\
\hline
\end{tabular}

Escribo en mi anecdotario las actividades que considero han sido más importantes en mi proceso educativo. Las selecciono según los proyectos realizados.

\begin{tabular}{|l|l|l|l|}
\hline Proyecto 1 & ¿Qué me gustó? & ¿Qué no me gustó? & Comentario \\
\hline Proyecto 2 & & & \\
\hline Proyecto 3 & & & \\
\hline Proyecto 4 & & & \\
\hline
\end{tabular}

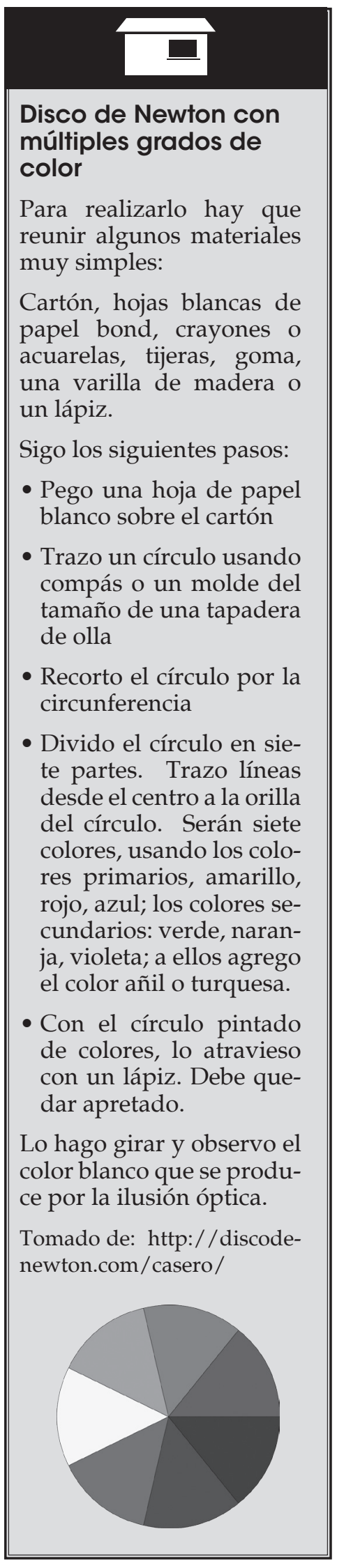




\section{Estrategias para solucionar problemas}
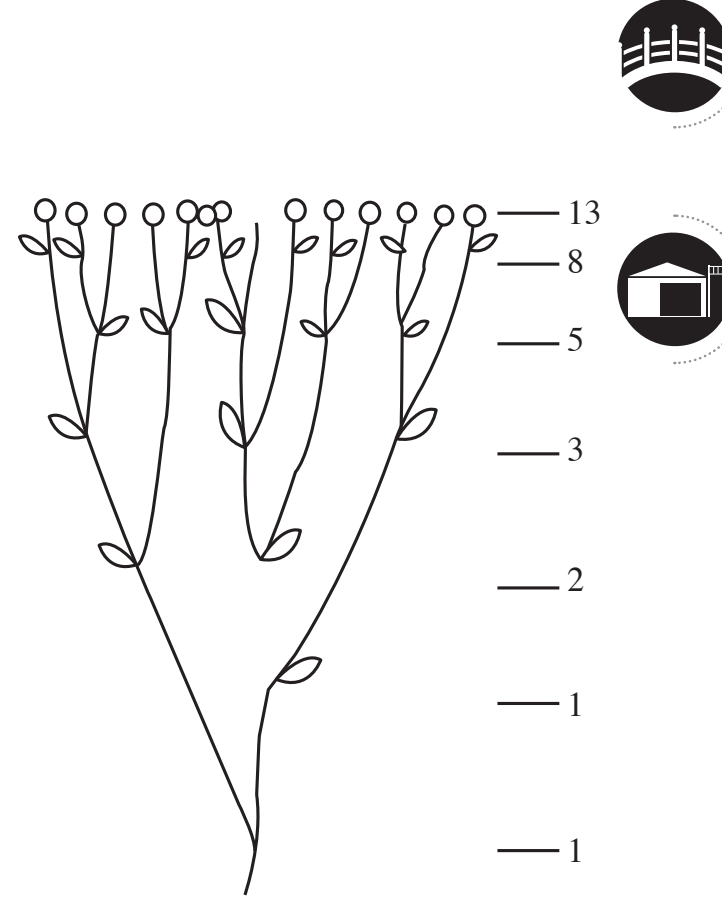

Estamos por realizar la Feria Científica, habrá algunas personas que deseen poner en práctica sus conocimientos y habilidades científicas. Podemos preparar un estand en el que se les invite a resolver problemas e identificar la estrategia científica que usan para resolverlos.

Estos son ejemplos de problemas que podremos presentar en un cartel e invitar a las personas asistentes que formen equipos para resolverlos. Al terminar escribirán en una ficha la respuesta al problema, la información que les sirvió para llegar a la conclusión y las acciones que realizaron para resolverlo,

\section{PROBLEMA 1}

Un cuaderno y un libro pesan más que un libro y un reloj. Un cuaderno y un reloj pesan más que un libro y un cuaderno. ¿Cuál de los objetos pesa más que los demás?

¿Cómo lo resolvieron? ¿Qué método utilizamos? ¿Qué conocimientos matemáticos incluimos en su resolución?

\section{PROBLEMA 2}

Presentamos en tres afiches con objetos que siguen la secuencia de Fibonacci, como las siguientes:

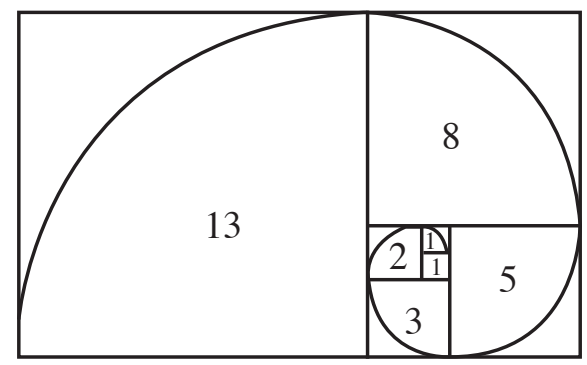

\begin{tabular}{|l|}
\hline Colocamos en un cartel las \\
siguientes recomendacio- \\
nes para que las personas \\
tengan en cuenta al resolver \\
sus problemas. \\
Antes de resolver un pro- \\
blema podemos preguntar- \\
nos: \\
- ¿Comprendo el proble- \\
ma? \\
¿Tengo información sufi- \\
ciente para resolverlo? \\
¿Toda la información del \\
problema nos es útil? \\
- ¿Tengo un plan para re- \\
solverlo? \\
¿Tengo los conocimientos \\
necesarios para resolver- \\
lo?
\end{tabular}

\begin{tabular}{|l|l|l|l|l|l|l|l|l|l|l|l|l|}
\hline & & & & 2 & & & & & & & & \\
\hline & 3 & & & 2 & & & & & & & & \\
\hline & & & 1 & 1 & & & & & & & & \\
\hline & & & & & & & & 8 & & & \\
\hline & & & & & & & & & & & & \\
\hline & & 5 & & & & & & & & & & \\
\hline & & & & & & & & & & & & \\
\hline & & & & & & & & & & & & \\
\hline
\end{tabular}

Pedimos que observen las tres imágenes poniendo atención en la secuencia de números para identificar ¿Qué tienen en común las tres figuras? ¿Cómo se forma la secuencia que están manejando? ¿Pueden encontrar en la Naturaleza objetos que siguen esta secuencia?

\section{PROBLEMA 3}

Presentamos el disco de Newton para que las personas asistentes puedan jugar con él haciéndolo girar y apreciando el efecto visual que provoca. En un afiche a la par del disco colocan las preguntas ¿Qué pasa al girar el disco? ¿Qué cambios hay en lo que vemos? ¿Qué provoca ese cambio en lo que se ve?

Mientras se colocan las fichas de resolución cerca de cada problema, invitamos a las personas a que compartan sus respuestas con las de los otros equipos, comentar la información que aprecian fue usada por los otros equipos y cómo estos problemas se relacionan con el desarrollo sostenible.

Diseño de los estands de resolución de problemas. Mediante la aplicación de diagramas de flujo, en grupos de trabajo, elaboramos croquis de los estands para la feria científica. En plenaria, los presentamos al resto de integrantes del ECA. Ajustamos los croquis conforme a las recomendaciones y necesidades. 
Se calcula que una batería alcalina, desechada inadecuadamente, puede contaminar aproximadamente 165000 litros de agua. Si en una comunidad se tiran a la basura, como mínimo, 200 pares de baterías al semestre, ¿Cuántos litros de agua se estarían contaminando al año por esta situación?

Escribimos la información útil para resolver el problema:

200 pares de baterías son desechadas en un semestre.

Cada batería mal desechada contamina 165000 litros de agua

Elaboramos un esquema que ilustre la situación:

1 año $=2$ semestres
1 par de baterías $=2$ baterías

Desarrollamos el plan para resolverlo:

Paso 1: Hallar cuántas baterías se desechan en un año

$200 \times 2=400$ baterías desechadas al semestre

$400 \times 2=800$ baterías desechadas al año

Paso 2: Determinar cuántos litros de agua se contaminan en un año a causa del mal desecho de las pilas.

$800 \times 165000=132000000$ litros de agua contaminados al año.

Escribo la respuesta:

En la comunidad se estarían contaminando 132000000 litros de agua por un inadecuado desecho de 800 baterías alcalinas.

- ¿Cómo podemos verificar que nuestra respuesta sea correcta?

Pensamos en algunas estrategias para resolver problemas y las anotamos en nuestro cuaderno. Seleccionamos dos problemas en dónde podamos utilizarlas y las aplicamos para resolverlos. Escribimos el proceso en nuestro cuaderno.

Resolvemos y dejamos constancia del procedimiento que utilizamos.

- Un reloj se atrasa dos minutos en cada hora. Si se sincroniza a las 0:00 con otro que marca la hora correcta ¿Qué hora marcará el reloj defectuoso cuando el correcto marque las 2:00 P.M.?

- Julieta camina por lo menos $5 \mathrm{~km}$ cada día. María y Jorge caminan, ambos, como máximo $12 \mathrm{~km}$ al día. ¿Cuánto camina Jorge, como máximo, al día?
Al momento de resolver problemas debemos recordar:

- Un mismo problema puede ser resuelto de distintas maneras.

- Las respuestas incorrectas pueden sernos útiles.

- Los dibujos o esquemas nos pueden ayudar a tener una idea más clara.

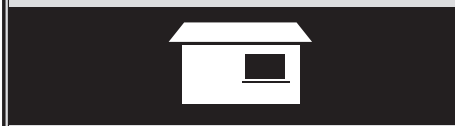

Observo y reflexiono sobre la forma de tirar o manejar la basura en casa. ¿Realizamos alguna práctica de selección y separación de la basura? ¿Desechamos adecuadamente los plásticos, baterías, vidrios y otros contaminantes? Propongo a mi familia, practices sustentables para desechar adecuadamente la basura en casa. 


\section{Presión y fluidos}

\section{Tipos de presión}

- Atmosférica: es la presión que ejerce la atmósfera sobre la superficie de la Tierra.

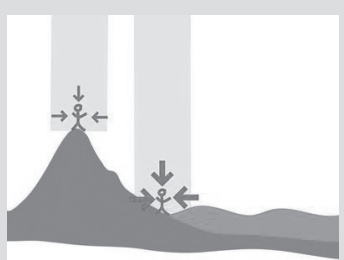

Fuente: http:/ / meteolab. fis.ucm.es/meteorologia/ presion-atmosferica--2

- Hidráulica: es la fuerza ejercida por un fluido.

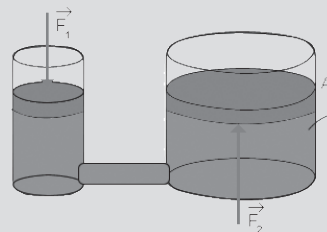

Fuente: http:/ / vinafoelber. tripod.com/id4.html

- Hidrostática: es la fuerza que la masa de un fluido en reposo ejerce sobre las paredes del recipiente que lo contiene.

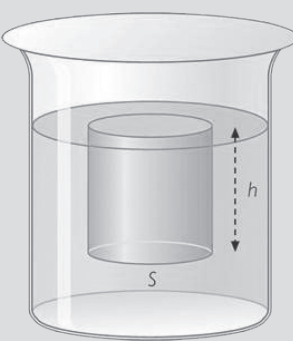

Fuente: http:/ / www.fullquimica.com/2011/04/presionhidrostatica.html

Los gases son más compresibles que los líquidos porque sus moléculas están más separadas y si aplicamos una presión, se comprime. En cambio los líquidos y los sólidos tienen moléculas muy cercanas y su compresibilidad es menor.
Observamos las imágenes. ¿Qué fuerzas intervienen en cada caso? ¿Qué cuerpo ejerce la fuerza? ¿Qué cuerpo recibe la fuerza?
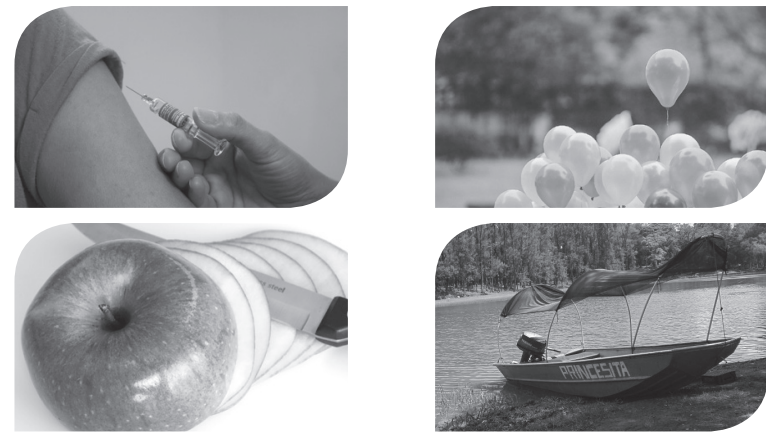

El efecto de una fuerza que se ejerce sobre una determinada área se llama presión. En algunos casos la presión es producida por un cuerpo sólido y en otros por un fluido. Un fluido puede ser un líquido o un gas. Los fluidos, son sustancias que pueden fluir. Adquieren la forma del recipiente que los contenga. Sus fuerzas de cohesión son débiles

Los líquidos ejercen presión sobre los cuerpos sumergidos en ellos o sobre las paredes del recipiente en el que se encuentran. Los gases compresibles son aquellos que su volumen disminuye cuando se les aplican fuerzas.

La presión atmosférica varía por varios factores:

- Altitud: a medida que aumenta la altura en la atmósfera, disminuye la presión, porque disminuye la cantidad de aire.

- Temperatura: el aire caliente tiende a dilatarse y ascender, bajando su presión sobre la superficie terrestre y viceversa.

- Humedad: la cantidad de vapor de agua depende de la evaporación de los océanos u otras fuentes de agua.

Al existir sobre la superficie de la Tierra zonas de la atmósfera con diferente presión se generan movimientos de aire, es decir, se originan los vientos.

En grupo explicamos: ¿Por qué la presión juega un papel importante en estas situaciones?

- Analizamos qué sucedería en nuestros cuerpos si la presión atmosférica desapareciera.

- Reflexionamos si existe alguna relación entre la contaminación del aire y la presión atmosférica.

Investigo en internet, diferentes experimentos relacionados con la presión atmosférica y los preparo para la feria científica. 
Realizamos nuestras exposiciones en la feria científica y nos esforzamos en nuestra participación .

La feria científica es una oportunidad para reproducir experiencias y experimentos científicos y evidenciar:

1. Precisión en el desarrollo de procesos. Los resultados demuestran el logro de los objetivos de la experiencia o experimento.

2. Relación entre los procesos presentados y el manejo racional de los recursos naturales locales.

3. Uso de materiales al alcance y otros.

Elaboro un anecdotario en relación con los siguientes aspectos:

1. Las aplicaciones de los aprendizajes permitió transmitir la importancia del manejo racional de los recursos naturales locales.

2. Los aciertos y errores cometidos en la realización de las experiencias y experimentos científicos.

3. Las dificultades que se presentaron en la aplicación de las relaciones físicas analizadas y otros.

Investigo en internet y consulto con abuelas, abuelos, integrantes del COCODE o personas adultas de la comunidad acerca de su opinion de la minería en la comunidad y el país. ¿Existe exploración minera en la comunidad? ¿Qué ventajas o beneficios perciben? ¿Qué desventajas o perjuicios han observado o conocen?

Dibuja en este espacio el resultado de la experiencia realizada.

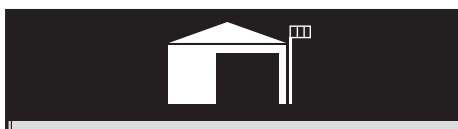

Realizamos dos experiencias científicas con participación de las personas asistentes a la feria.

\section{Experiencia A}

Materiales: vaso con agua teñida con colorante vegetal, pajilla.

Procedimiento: se succiona agua a través de la pajilla hasta la mitad de esta. Sacamos la pajilla de la boca. Observamos lo que sucede. Luego repetimos la acción pero tapamos la abertura superior de la pajilla y observamos que no cae. Explicamos cómo actúa la presión atmosférica.

\section{Experiencia B}

Materiales: un vaso de vidrio con agua, una tarjeta de cartulina.

Procedimiento: colocamos la cartulina sobre el borde del vaso, colocamos dos dedos para evitar que el agua caiga y volteamos el vaso. Retiramos los dedos que detienen la cartulina. Observamos que el agua no cae. Explicamos cómo la presión atmosférica ejerce una fuerza sobre la cartulina. Incluimos estos y otros experimentos simlares en la presentación de la feria científica.

Invitamos a las personas participantes a inferir porqué se dio la reacción que se dio. Explicamos al público las razones científicas de los resultados del experimento. 


\section{Importancia de la expresión oral y escrita}

\section{Muletillas en el discurso}

Consisten en palabras o frases que se repiten a menudo, mientras hablamos. Algunas personas abusan tanto de ellas que no pueden decir una oración completa sin utilizarlas. Algunos expertos sugieren que su uso se origina en la necesidad de tomar un tiempo antes de formular la siguiente idea. Sea como fuere, las muletillas son malos hábitos que adquirimos, muchas veces, debido a la influencia de otras personas o de los medios de comunicación. Son parte de lo que llamamos "ruidos" o "ripio" en el discurso, porque lo interrumpen. Algunas de las más usuales en nuestro medio son:

Digo...

Digamos...

Es decir,..

Lo que es

O sea pues

Este...

Entonces...

Así que...

¿Verdad?

¿Me explico?

¿Me entiendes?

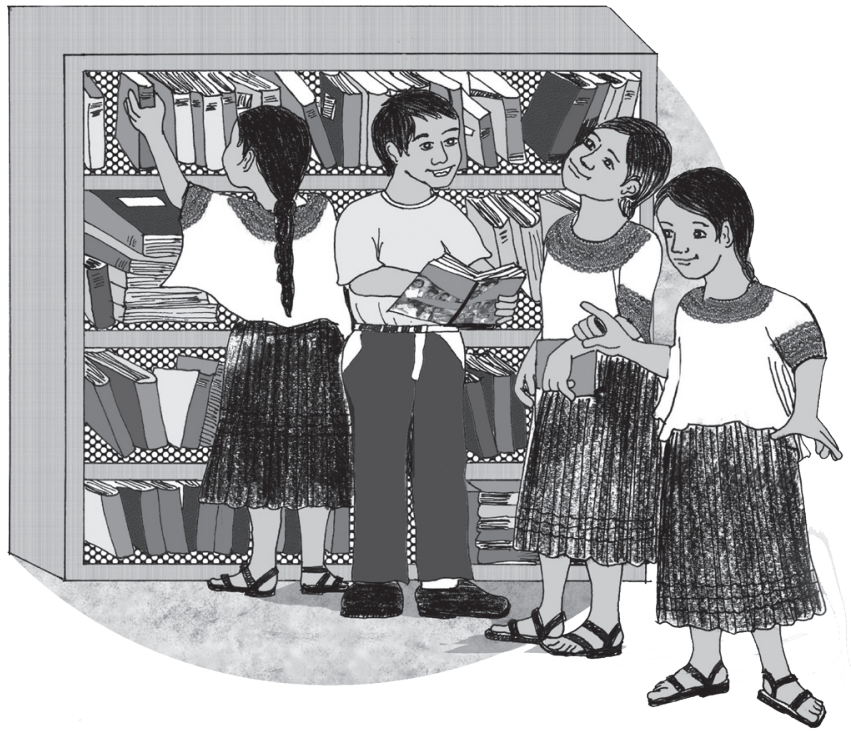

Lo que hablamos y lo que escribimos dice mucho de quienes somos. Nuestras palabras son nuestra imagen. Si nuestro discurso, escrito u oral, está bien organizado, es claro, está gramaticalmente correcto, posee ejemplos precisos y carece de muletillas incómodas, entonces, será capaz de generar un vínculo eficaz entre el emisor y el receptor. Si no cumple con estas características, entonces resultará incómodo de leer o de escuchar. Por otro lado, y, más importante aún, generará desinterés en nuestro mensaje e invitará a nuestro interlocutor o nuestra interlocutora a que nos abandone.

En la vida diaria, en nuestra comunidad, necesitamos comunicar mensajes claros para mejorar la armonía entre sus habitantes. Además, tenemos que estar conscientes de la necesidad de hacer valer nuestros derechos ciudadanos y expresar nuestras necesidades ante las autoridades. Si nuestro discurso es pobre en vocabulario, si no es coherente, si no está estructurado de una manera lógica, de acuerdo con un razonamiento eficaz, entonces, tenemos pocas posibilidades de que se nos atienda.

Todas las áreas del conocimiento son esenciales. Su importancia en nuestras vidas no se pone en duda. Sin embargo, el buen uso de nuestro idioma materno $u$ otros idiomas resulta determinante para conocer las otras áreas del saber y para construir nuestra identidad.

El estudio, la lectura y el uso de los diccionarios, las enciclopedias y los recursos virtuales ponen a nuestro alcance la posibilidad de mejorar nuestra manera de expresarnos. Aún más, está comprobado que, a mayor y mejor uso del lenguaje, mayor inteligencia. Así que nuestro crecimiento personal depende de nuestra voluntad.

Previo a realizar mi exposición, pido a otra persona que me escuche e identifique muletillas que estoy utilizando para eliminarlas de mi discurso. 


\section{Conjugación de verbos irregulares}

Los verbos irregulares son difíciles de conjugar debido a que, al hacerlo, su raíz se altera, no respeta las terminaciones de su verbo modelo. Los verbos irregulares de uso frecuente son: andar, estar, caber, caer, haber, hacer, satisfacer, poder, querer, saber, ser, tener, traer, ver, pedir, conducir, dormir, salir, sentir, decir, oír y venir.

Veamos algunas conjugaciones clave:

Financiar se conjuga igual que el verbo anunciar.

Satisfacer se conjuga como el verbo hacer.

Bendecir se conjuga como el verbo decir.

Traducir, producir e introducir se conjugan como el verbo conducir.

Forzar se conjuga como el verbo recordar.

Prever se conjuga como el verbo ver.

Otros errores que se cometen al conjugar verbos son los siguientes:

1. Que se agregue la s a la segunda persona del singular, en tiempo pasado de cualquier verbo: fuistes por fuiste, comistes por comiste, bailastes por bailaste.

2. Que se pronuncie la n en lugar de la m, en la conjugación de los verbos en copretérito , en la primera persona del plural: íbanos por íbamos, comíanos por comíamos, estábanos por estábamos.

3. El verbo haber tiene dos funciones: como verbo auxiliar y como impersonal. Es verbo auxiliar en los tiempos compuestos y siempre va acompañado de un participio: he comido, has soñado, hayan dormido. Cuando es impersonal NO debe pronunciarse en plural. Ejemplos: hubieron heridos, habrán festejos, se dice hubo heridos y habrá festejos.

En la realización de la feria artística y tecnocientífica colocamos carteles con las señales y además otros en los que redactamos un texto con la descripción de los estands y lemas que promueven propuestas de solución a la problemática socio ambiental de la comunidad. Estos deben estar en tres idiomas, el idioma materno de la comunidad, el español y el inglés.

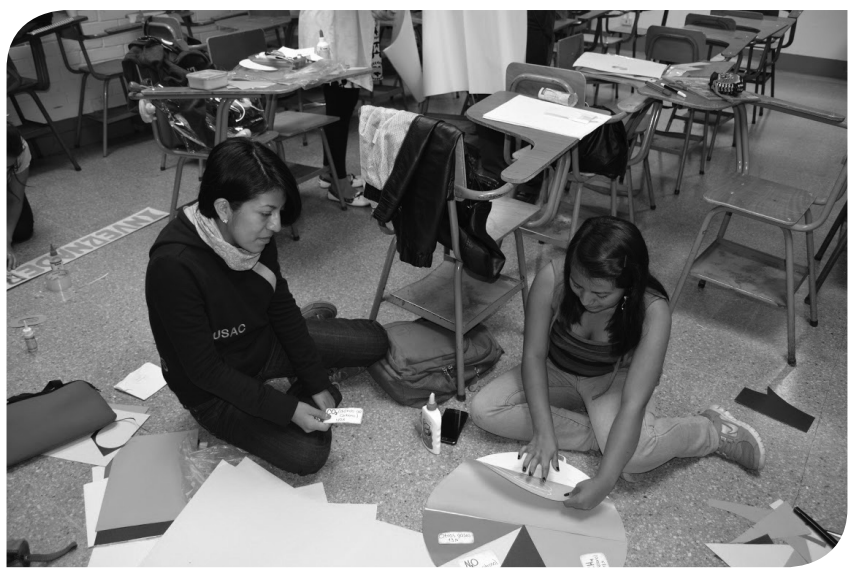

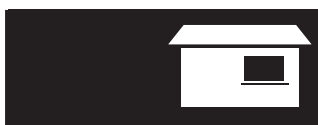

Uso esta referencia de qué es un anecdotario para asegurarme de que lo que estoy trabajando en casa es acertado. Este ejercicio consiste en llevar una crónica de las anécdotas interesantes o valiosas para nuestra vida. Es muy parecido a un diario, con la diferencia de que puede ser llevado en grupo, con las y los amigos, con los compañeros de la escuela o con la familia. Se trata de redactar los momentos únicos que van haciendo la vida digna de ser recordada. Lo que necesitamos es muy sencillo: un cuaderno o un cartapacio con hojas para pegar los textos que vayamos generando y las fotografías, si es posible. También podemos hacerlo de manera virtual, por medio de la internet, si tenemos acceso a ese recurso. 


\section{Ciudadanía y cultura de paz}

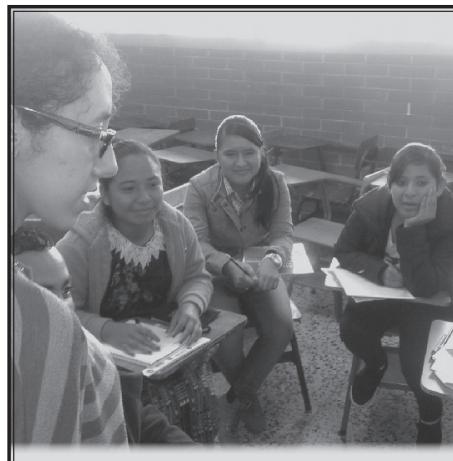

Explico la relación entre cultura de paz y derechos humanos.

"Construir espacios de paz es ir ganando terreno a la violencia y las prácticas que la favorecen. Es decir, es luchar por establecer nuevas formas de convivencia, construidas mediante la participación de las colectividades en prácticas sociales y políticas, en donde prevalece la valoración de la vida sobre cualquier otra circunstancia, el diálogo en la búsqueda de la solución de los conflictos que se presentan en las comunidades..."

http:/ / biblioteca.oj.gob.gt/digitales/16903.pdf

Lo contrario a la cultura de paz es la cultura de la violencia. Comparo ambas culturas mediante ejemplos en mi comunidad.
Las personas tenemos algunas formas de ver lo que sucede en nuestro medio natural y social que se diferencian entre sí y otras que coinciden. Cada persona tiene algunas ideas diferentes a las demás. Cuando convivimos, debemos dialogar para llegar a acuerdos y resolver toda clase de situaciones que nos atañen. Ya hemos estudiado que el diálogo es una herramienta indispensable para afrontar los conflictos. Quienes empleamos el diálogo para llegar a acuerdos construimos una cultura de paz.

Cuando los integrantes de la comunidad dialogan con las autoridades gubernamentales o municipales y acuerdan apoyar sus acciones se ejerce ciudadana responsable y también se construye una cultura de paz. Si las autoridades no cumplen con algunas de sus funciones o con los ofrecimientos que le hicieron a la comunidad, sus integrantes dialogan con ellas y llegan a acuerdos también se ejerce ciudanía y se contribuye a desarrollar una cultura de paz.

Trabajemos en equipo para estimular el diálogo entre las personas asistentes a la feria. Promovemos también el intercambio de ideas con quienes están liderando diferentes procesos en la comunidad.

Luego de que el equipo exponga invitamos a las personas a compartir su opinión en torno a lo que hemos planteado como problema y propuesto como solución. Asignamos a un integrante de nuestro grupo para llevar registro de los que las personas opinan. Podemos colocar un cartel grande con una tabla como la siguiente para llevar el registro y hacerlo visible a la comunidad.

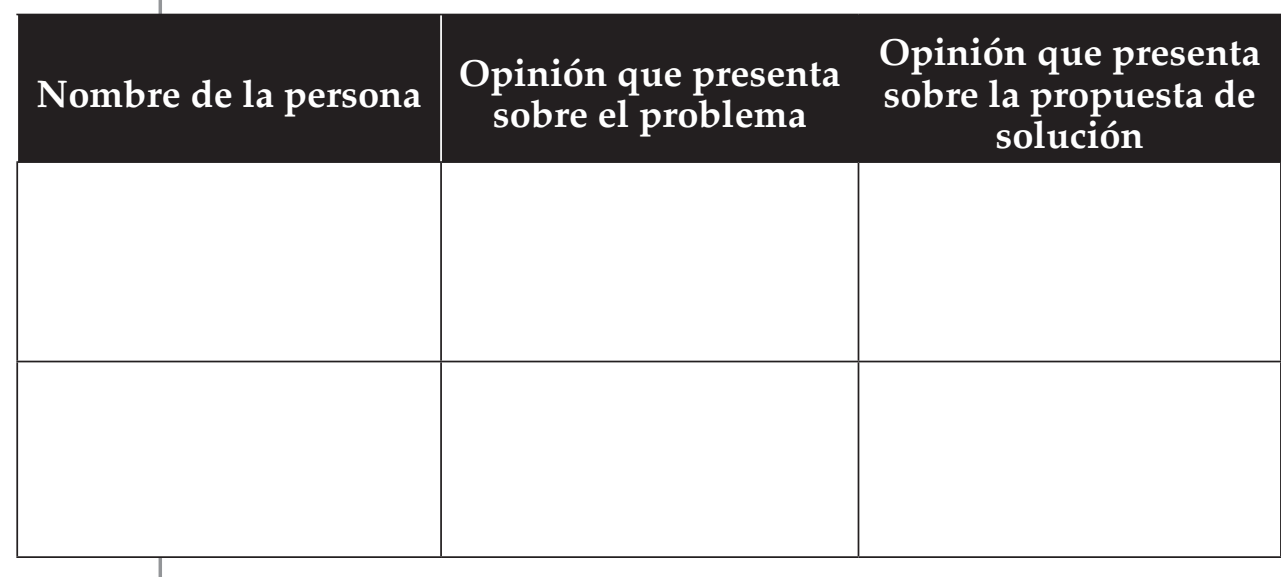

Al cerrar el estand dialogamos entre nosotros sobre el registro llevado. Podemos sacar las conclusiones principales que se obtienen de la feria. Pensamos en futuras acciones que han de realizarse para que las propuestas e ideas puedan llevarse a la práctica.

Narramos una anécdota sucedida en un diálogo de integrantes de la comunidad con alguna autoridad gubernamental o municipal. 


\section{Características de la sociedad guatemalteca}

Como en todas las sociedades, las relaciones económicas marcan la forma de organización y relacionamiento entre las personas en la sociedad guatemalteca. La estructura social, económica y política, ha permitido que a lo largo de nuestra histora algunos grupos concentren los bienes y la riqueza que se produce en el país. Las estadísticas de las últimas décadas muestran que, aunque el país produce más, también aumentan los índices de pobreza. Estas estadísticas reflejan también que la herencia racista de la colonia persiste. Las poblaciones indígenas -maya, garífuna y xinca- sobre llevan la mayor carga de pobreza del país. Esta condición suele explicarse mediante ideas racistas que esconden las verdaderas razones de la desigualdad.

En este marco las relaciones entre personas y medioambiente, así como entre hombres y mujeres son más comunmente caracterizadas por la violencia, la exclusión y la inequidad.

Aún así, existen manifestaciones de emprendimiento popular, iniciativas de defensa a los derechos humanos, propuestas de convivencia intercultural, movimientos por la preservación de los recursos naturales, espacios educativos en el seno de la cultura de paz y políticas que promueven la equidad de género. Así, gracias al trabajo diario y el compromiso de las guatemaltecas y los guatemaltecos se abren brechas para acceder a la educación, al deporte, al arte, a la salud y la recreación. También se expanden las oportunidades de participación ciudadana y política.

Analizamos en equipo si la Feria expresa todo lo positivo que se hace o se puede hacer en nuestra comunidad por la protección de la Naturaleza, la interculturalidad, cultura de paz, equidad étnica entre otras manifestaciones positivas de la sociedad guatemalteca.

Evaluamos la participación de nuestro grupo en las actividades de la Feria y la elaboración del anecdotario: nuestros aportes, lo que nos faltó, la coordinación con los otros grupos, la eficacia de nuestros mensajes, cuál fue la participación de las mujeres, entre otros.
El emprendimiento incentiva a las personas a realizar acciones de manera diferente y generar cambios a nivel económico, social, cultural y ambiental; puede aplicarse en cualquier área de la vida personal y comunitaria. Es pensar y actuar para crear riqueza mediante el aprovechamiento de las oportunidades que proporciona el entorno social y natural. Los proyectos emprendedores pueden ser: social y comunitario, cultural y artístico, deportivo, ambiental y empresarial.

- Opino sobre lo positivo que puede ser el emprendimiento en una comunidad.

Autoevalúo la participación en las actividades de la Feria y el anecdotario.

Redacto una lista de ejemplos de acciones positivas que se dan en mi espacio de convergencia andragógica que pueden contribuir a mejorar mi comunidad en lo económico, cultural, social y político.

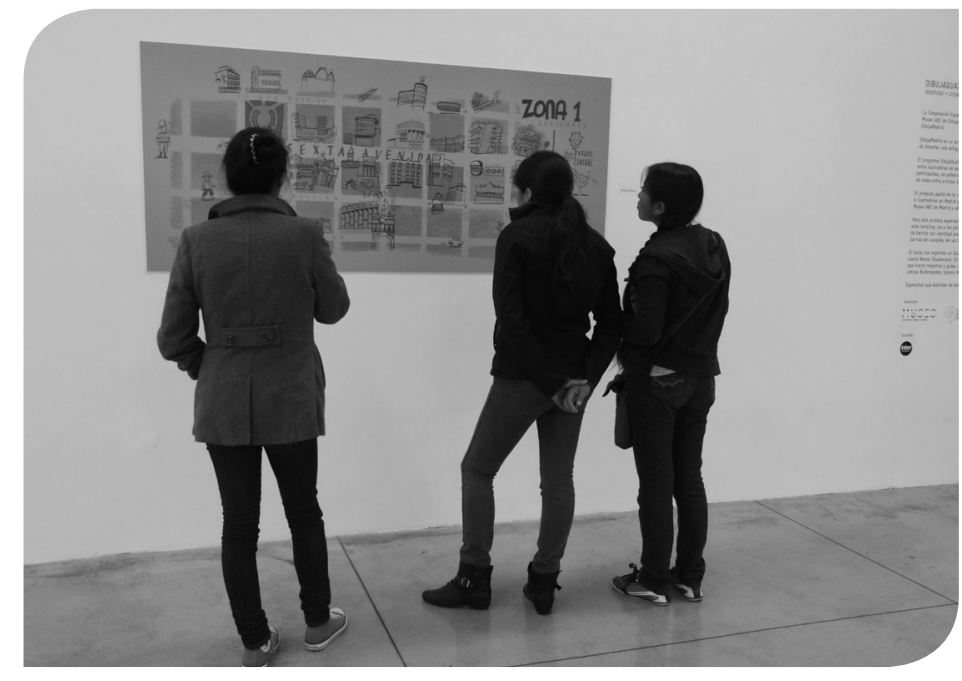




\section{Lo energía, los recursos naturales y el bien común}

Todas las personas necesitamos convivir con otros y con el medio ambiente. La convivencia es una necesidad donde se manifiestan nuestros valores como el respeto, la responsabilidad, la solidaridad y otros valores que son importantes en la comunidad a la que se pertenece. Donde el derecho a la vida, al trabajo y la educación, facilita el avance de todos sin discriminación y protección entre sí.

Todo puede iniciar en el hogar donde se realizan diversas actividades que pueden contribuir a la economía. No se debe olvidar el principio de siembra y cosecha. Que todo es constantemente un ciclo en la vida, y que todas las personas debemos de contribuir para lograr una vida plena, convivir en paz y lograr el bienestar de la sociedad y de la Madre Tierra.
Analizamos el siguiente esquema. Compartimos en clase nuestras reflexiones acerca de:

- Las consecuencias de llegar al límite de los recursos naturales.

- Cómo puede afectar a las personas, el agotamiento de los recursos naturales.

- De qué manera podemos contribuir a proteger y conservar los recursos naturales en la comunidad.

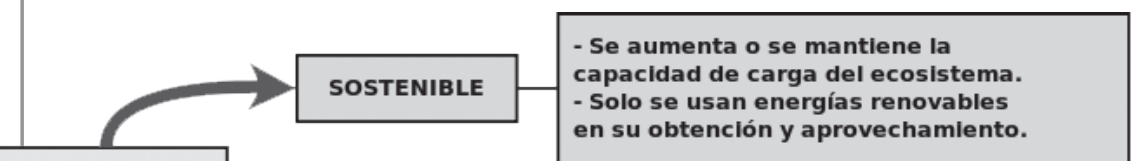

RENOVABLE

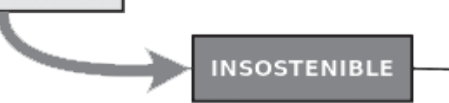

- Se supera la capacidad

de carga del ecosistema.

- Se usan fuentes no renovables y finitas para su obtención o aprovechamiento.

Las funclones vitales del sistema se garantizan con fuentes y recursos renovables y sostenlbles.

\section{NO RENOVABLE}

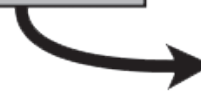

INSOSTENIBLE

Las funciones o pilares vitales del sistema, como la obtención y distribución de alimentos, están basadas en recursos y energías no renovables.

Imagen: http:/ / caminoagaia.blogspot.com/2014/11/solucion-laparadoja-de-jevons-energia.html

A lo largo de este proyecto, hemos aprendido acerca del movimiento de las partículas, las tres leyes de Newton. Estas son las leyes generales de la Mecánica y del movimiento de los cuerpos. Aprendimos la ley de la inercia, la relación entre la masa de una partícula y su aceleración; así como las fuerzas de acción y de reacción. Estudiamos también acerca de las fuentes de energía y su relación con el concepto de trabajo en Física. Este es el desplazamiento que se produce por acción de una fuerza. Finalmente, aprendimos los conceptos de presión y fluidos.

Compartimos en clase nuestras experiencias con relación a:

- Cómo los aprendizajes obtenidos en este proyecto nos permiten valorar la importancia del manejo racional de los recursos naturales locales.

- Cómo podemos mejorar la realización de las experiencias y experimentos científicos.

Redacto un plan mejoramiento individual para ciencias naturales. Para ello, elaboro un anexo en el anecdotario, en el que se visualicen las fortalezas y aspectos a mejorar, según la evaluación de la feria científica, el foro y el conversatorio realizados durante este proyecto. Utilizo la técnica de FODA (Fortalezas, Oportunidades, Dificultades, Amenazas). 


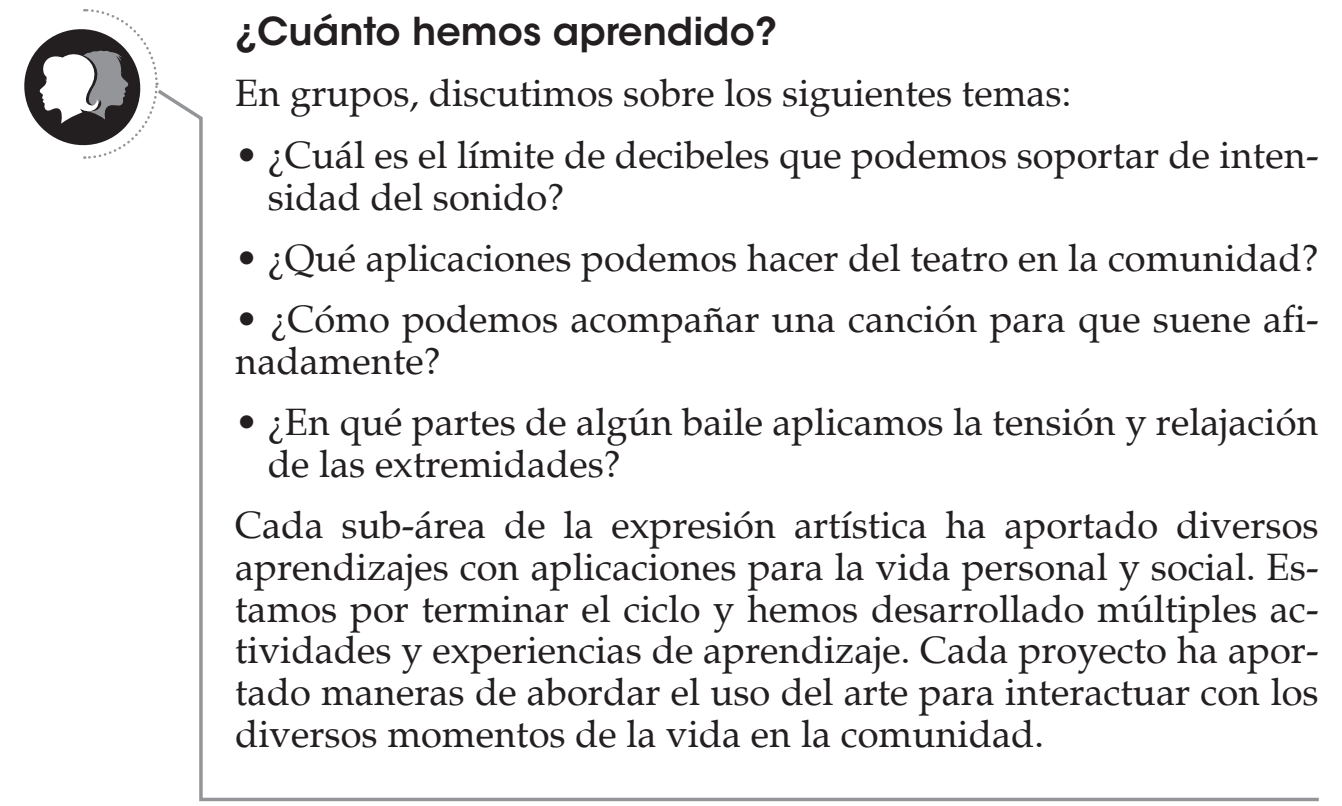

Leo, comento y discuto sobre el siguiente texto:

\section{Arte sin fronteras}

$\mathrm{El}$ arte es una actividad humana que trasciende las fronteras de la diferencia. Todas las sociedades lo practican como una necesidad de expresión y comunicación. La diversidad étnica, lingüística y cultural no es obstáculo para que el arte cumpla su función comunicativa. Esto es porque todos los hombres y mujeres son capaces de apreciarla y conmoverse ante su contemplación. Pero no solo están dotados de la destreza de apreciarla, también pueden crear y recrear las obras artísticas. Por estas razones, el arte no puede ser solo el que hacen los artistas famosos, porque su función no es esa, sino servir de vía para que todos y todas podamos expresarnos y que contribuya a que logremos una vida plena.

\section{Arte y justicia tributaria}

En los países desarrollados el pago de impuestos es una norma que se implementa desde el Estado para el bien común de toda la sociedad. Los impuestos se invierten en el desarrollo social. Así funciona en esos países y es el ideal que anhelamos para el nuestro. Un Estado que se sostiene firme del ingreso de tributos y su distribución racional por las autoridades, es un Estado fuerte. Solo de esa manera es posible que el estado invierta adecuadamente en la promoción del arte y los artistas. Es deseable, que haya inversión en escuelas de arte y en instituciones que promuevan la producción artística.

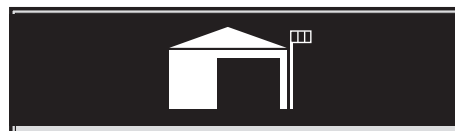

Reflexionamos y dialogamos ¿Cómo sería la vida de la comunidad si hubiera una escuela de arte en cada municipio, en cada barrio y en cada aldea?

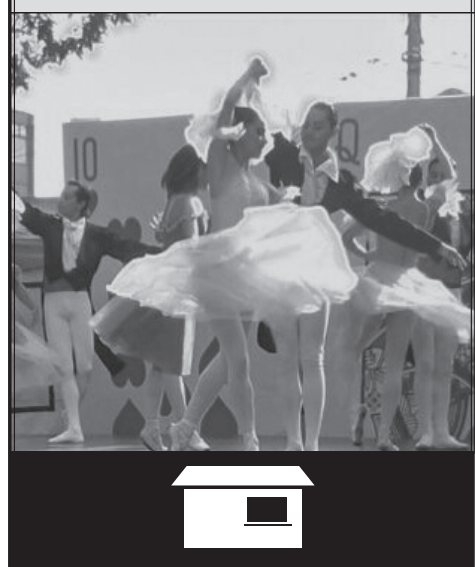

De las actividades realizadas y los aprendizajes logrados hay siempre aspectos que más nos han gustado y otros que no. Los que más nos gustan son los que más rápido y mejor aprendemos. Los que menos nos atraen los olvidamos fácilmente $\mathrm{o}$ no nos dejan aprendizaje. Elaboro un cuadro y trabajo en mi PNI. Implemento las siguientes sugerencias para mejorar lo que aprendí:

- Buscar información para profundizar los temas.

- Realizar más actividades de las que hicimos en clase.

- Consultar con los compañeros que muestran más avance en el área que queremos reforzar. 


\section{La carta y sus partes}

La carta, tradicionalmente, era un papel que portaba un mensaje escrito y que iba contenido dentro de un sobre para proteger su contenido. Con el avance de la tecnología, muchas de las cartas que se envían ahora son virtuales, es decir que se envían por medio de correo electrónico. Este medio de comunicación escrita lo envía una persona con la intención de transmitir un mensaje.

La carta tiene las partes siguientes:

Ciudad y fecha desde donde se envía el mensaje

Tratamiento del destinatario: Señora, Señor, Doctora, Doctor, Licenciada, Licenciado, etc.

Nombre de la persona destinataria o receptora

Dirección a donde va a enviarse la carta

Encabezamiento o saludo

Asunto o la exposición del tema de la carta

Despedida

Firma de la persona remitente o quien envía la carta
Existen varias clases de cartas: personales, formales, legales, comerciales y otras. Dentro de las comerciales están las de solicitud de empleo, las de compra, las de venta y otras.

Señorita

Claudia Morales

$2^{a}$. Avenida 1-23 zona 1

Flores, Petén

Apreciada señorita Morales:

A lo largo de este libro he querido contribuir con su aprendizaje de nuestro hermoso idioma español. Intenté transmitirle mi experiencia acerca del placer que significa descubrir una nueva palabra o aprender a usar el lenguaje con soltura. Espero haberlo logrado y que usted siempre le encuentre el lado dichoso a aprender cosas nuevas.

Además del universo del lenguaje, y como una de sus posibilidades infinitas, este libro lleva también algunas ideas en torno a la comunicación, las ciencias, las matemáticas, la productividad y el desarrollo y las ciencias sociales. Este libro, entonces, funciona como una llave que le abrirá las puertas a una mejor relación con todas las personas que la rodean.

Deseo que cada día trabaje en sus ideas y sus metas para concretar realidades novedosas. Recuerde aquella frase que dice que quien no intenta lo absurdo no alcanza lo imposible. Con ideas claras y sueños definidos las y los jóvenes construirán un mundo mejor.

Haga de sus retos verdaderas aventuras y no se avergüence de ellos por sencillos que sean. Cada triunfo y cada fracaso fortalece su espiritu por igual. Por eso, no claudique en su desafio más grande: la construcción de un país mejor y más justo para su gente. Jome conciencia de si misma, considere sus derechos y atienda sus obligaciones. $\mathcal{C}_{s a}$ es, quizá, la mejor manera de lograr la armonía con su entorno.

Ojalá que este libro también le haya inspirado el respeto y el cariño por nuestra Madre Jierra y nuestra gente, para que algún día pueda sentir en su pecho el batir de alas de ese "verde colibrí reluciente" que es la patria, a decir del poeta Cardoza y Aragón. Gracias por compartir un sueño, por su curiosidad y su deseo de aprender.

Con todo mi aprecio,

GH

Presento el anecdotario para revisar los signos de puntuación, la redacción y los argumentos que incluye.

Evaluamos la actividad general usando una rúbrica construida con toda la clase 


\section{Impuestos y recursos del Estado}

El conjunto de impuestos que rigen en el país, forman parte del sistema tributario. Han sido aprobados por el Congreso de la República, como parte de leyes tributarias. La Superintendencia de Administración Tributaria -SAT-, es una entidad autónoma creada para dar cumplimiento a los Acuerdos de Paz y para modernizar la administración tributaria.

Todas las personas pagamos impuestos, seamos nacionales, del extranjero, hombres o mujeres. Pagamos impuestos cuando pagamos por un producto o servicio. Por eso debemos exigir facturas. Las facturas son documentos que nos sirven para comprobar que pagamos nuestros impuestos. Aseguran que quien vende un producto o servicio, pague al Estado los impuestos que cobra. También pagamos otros tipos de impuestos: circulación de vehículos, bienes inmuebles, ornato, y otros. Asimismo pagamos impuestos sobre nuestros sueldos u honorarios. Algunos impuestos tienen tasa fija, es decir que se paga siempre lo mismo, como el derecho de piso del mercado. Otros son proporcionales. Por ejemplo: con cada compra pagamos el $12 \%$ de Impuesto sobre el Valor Agregado (IVA). El IVA pagado lo podemos descontar del monto de IVA que cobramos y entregamos al gobierno. Veamos:

Juana compra un filtro de agua. Paga y le dan una factura de Q500.00.

Al comprar, Juana pagó el $12 \%$ de IVA, veamos cuál es el precio del producto y cuál es el monto de impuesto pagado:

$$
\begin{aligned}
& 500 / 1.12=446.43 \text { (precio del filtro) } \\
& 500-446.43=53.57 \text { (IVA) }
\end{aligned}
$$

Cuando una empresa no da factura se queda con ese impuesto que nos cobró porque no lo reporta a la Superintendencia de Administración Tributaria (SAT).

Los impuestos se redistribuyen para que funcione el Estado y gocemos de servicios públicos. Cuando damos "mordida", no pagamos impuestos, no monitoreamos la administración pública o no exigimos transparencia en el gasto público, estamos contribuyendo a la corrupción.

Calculamos el IVA de diferentes productos o servicios que hayamos comprado recientemente: bebidas, golosinas, alimentos, ropa, transporte, medicinas.

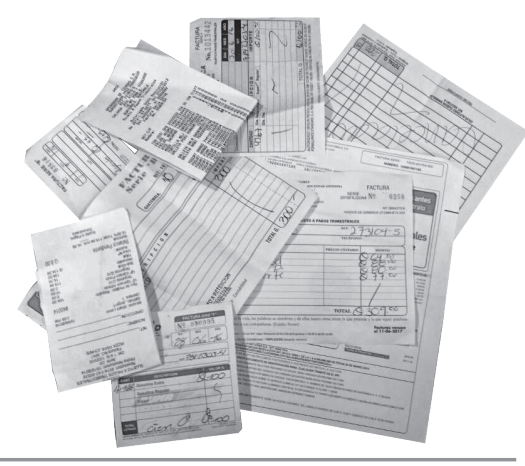

A mayor desigualdad menor número de personas controlan y poseen la mayor parte de los recursos limitando y dificultando a la mayoría la posibilidad de mejorar sus condiciones de vida. El Estado puede contribuir a reducir la desigualdad destinando buena parte del gasto público a ofrecer servicios públicos de buena calidad (educación, salud, vivienda, carreteras asfaltadas, seguridad social y otros) a la población más pobre y vulnerable. La inversión pública en garantía de educación pública de calidad, atención de salud preventiva y salud primaria, caminos rurales, agua potable, saneamiento, electricidad y generación de empleo también es importante para impulsar el desarrollo. Una recaudación de impuestos en la que pague más el que más tiene es base fundamental para financiar el gasto y la inversión pública. Además, se requiere de adecuados mecanismos de control y persecución penal a los evasores de impuestos; pero también la participación activa de la ciudadanía para realizar auditoría social a las autoridades y velar por el uso adecuado de los fondos públicos. 


\section{Marca de clase y desviación estándar}

La marca de clase o punto medio de cada intervalo es el punto que está a la misma distancia del límite inferior y del superior del intervalo. Se halla sacando un promedio entre ambos límites.

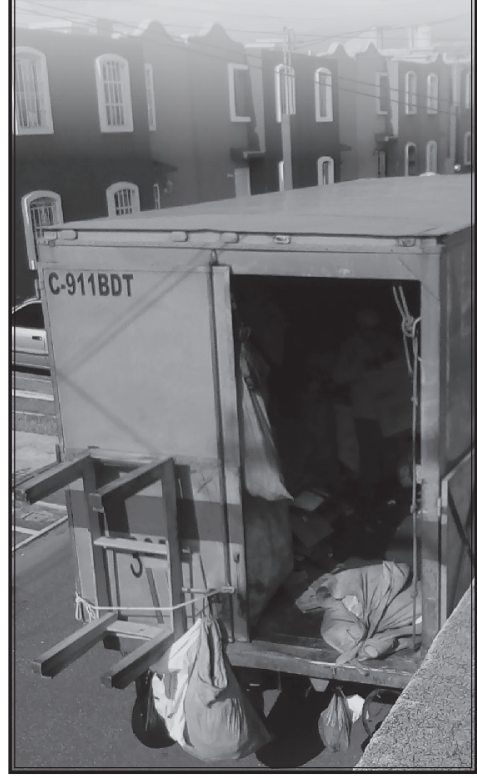

En una comunidad se realizó un estudio sobre el impacto de un taller de formación en medio ambiente, que se impartió a 25 personas. Antes del taller se hizo una encuesta a 50 personas, incluyendo a las 25 que participaron del taller, en donde se les preguntaba cuántas libras de basura por semana, aproximadamente, entregaban a los recolectores de basura. Estos fueron los resultados:

$8,15,13,9,20,19,13,11,10,20,22,25,13,13,19,9,15,26,9,20$

$9,11,8,17,14,11,12,13,14,19,8,12,18,16,12,12,9,10,25,23$

$21,22,17,18,15,11,19,16,10,19$

Un mes después del taller se volvió a encuestar a las mismas 50 personas acerca de la cantidad de basura que sacaban semanalmente, los resultados de las personas que recibieron el taller fueron:

$11,10,9,12,8,9,10,8,8,9,11,10,8,12,10,9,13,11,11,14,9,8$, $10,11,11$

Los resultados posteriores de las personas que no recibieron el taller fueron:

$14,17,15,21,22,19,12,23,22,25,18,14,20,21,12,19,18,17,17$, $20,12,22,21,20,19$

Usamos los datos para completar la tabla:

\begin{tabular}{|c|c|c|c|}
$\begin{array}{c}\text { Cantidad de } \\
\text { libras de basura } \\
\text { descartadas } \\
\text { semanalmente }\end{array}$ & Antes del taller & $\begin{array}{c}\text { Después del taller, } \\
\text { personas que tomaron } \\
\text { el taller }\end{array}$ & $\begin{array}{c}\text { Después del taller, } \\
\text { personas que no tomaron } \\
\text { el taller }\end{array}$ \\
\hline $5-8$ & & & \\
$9-12$ & & & \\
$13-16$ & & & \\
$21-24$ & & & \\
$25-28$ & & & \\
\hline
\end{tabular}

Calculamos la media de cada grupo de datos.

Utilizamos los puntos medios de cada intervalo para hallar las desviaciones estándar de cada grupo de datos.

Comparamos nuestros resultados y discutimos.

- ¿Estas medidas estadísticas nos pueden ayudar a determinar el impacto del taller sobre educación ambiental que se impartió en la comunidad? Explicamos. 


\section{Valores sociales y medio ambiente}

Cuando los y las integrantes de la comunidad realizan actividades para evitar y eliminar la contaminación ambiental, están procurando el bien común. Por ejemplo: cooperar para construir una planta de tratamiento de aguas residuales o un manejo adecuado de la basura. En estas acciones no solo benefician a su comunidad; también benefician a las comunidades cercanas y contribuyen con el bienestar de las futuras generaciones.

Si un grupo de habitantes de una comunidad protege los bosques, selvas o cubierta vegetal; si estas personas realizan una campaña de reforestación, también están siendo solidarias con su comunidad, las generaciones futuras y con otras comunidades. En estas acciones también manifiestan solidaridad con la Naturaleza.

\section{Trabajemos en grupo}

Describimos una actividad que se realizó en la comunidad que contribuyó a preservar el medio ambiente.

Explicamos de qué manera esta actividad contribuye al bien común.

Clasificamos la actividad como de cooperación o de solidaridad y argumentamos nuestra respuesta.

Evaluamos nuestra participación en la Feria Tecno-científica.

- Explicamos cuáles fueron nuestros principales aportes como grupo en las etapas de planificación, preparación y realización de la Feria. Esto lo debemos hacer en cada área de aprendizaje.

- Describimos cuál fue nuestro aporte individual en cada etapa y área.

- Enumeramos cuáles fueron los aprendizajes obtenidos.

- Expresamos qué más pudimos aportar como grupo y otros aprendizajes que deberíamos reforzar o adquirir.

- Con base en lo anterior, elaboramos un plan de mejora para el próximo proyecto educativo.

Redacto un plan de mejoramiento individual para el área de Ciencias Sociales y Formación Ciudadana.

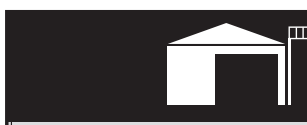

- ¿Puede considerarse la producción de estos objetos una acción que busca el bien común?

En numerosas culturas indígenas, la Tierra es considerada como la Madre. No se le puede hacer ningún daño a ella ni a ninguno de sus productos sin tener una razón válida, casi siempre relacionada con la supervivencia. En muchas culturas, el ser humano es considerado un miembro de la Naturaleza, igual en derechos y no superior a los demás seres vivos.

http://unesdoc.unesco.org/

- ¿Qué relación tiene el contenido de este párrafo con el bien común, la cooperación y solidaridad?

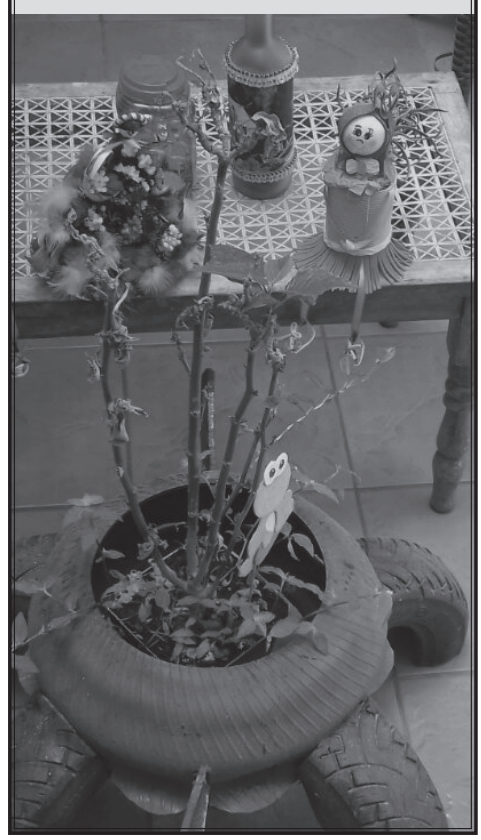


PROYECTO No. 3. Uso sustentable de los recursos naturales

Reflexión sobre mi participación en el desarrollo del proyecto

Marco $\mathbf{X}$ en lalas casillas que considero corresponden a mis actitudes en relación con mi participación y aprendizaje.

\begin{tabular}{|c|c|c|c|}
\hline Actitud & Siempre & Casi siempre & Nunca \\
\hline $\begin{array}{l}\text { Reconozco que en cada actividad realizada mi pro- } \\
\text { pósito fue aprender para la vida. }\end{array}$ & & & \\
\hline $\begin{array}{l}\text { Me interesé por profundizar lo aprendido en clase } \\
\text { y realicé las investigaciones propuestas. }\end{array}$ & & & \\
\hline $\begin{array}{l}\text { Relacioné la información vista en clase con la cultu- } \\
\text { ra, salud, recreación, deporte, ambiente, producti- } \\
\text { vidad y economía de mi comunidad. }\end{array}$ & & & \\
\hline $\begin{array}{l}\text { Los conocimientos recibidos en clase me parecen } \\
\text { importantes para valorar y mejorar el ambiente na- } \\
\text { tural, la salud, el intercambio cultural, la economía } \\
\text { y productividad de mi comunidad. }\end{array}$ & & & \\
\hline $\begin{array}{l}\text { Cada semana, asigné un horario específico a mis } \\
\text { estudios }\end{array}$ & & & \\
\hline Realicé a tiempo las tareas asignadas. & & & \\
\hline $\begin{array}{l}\text { Evité copiar las tareas de mis compañeros porque } \\
\text { les faltaría el respeto y porque limitaría mi apren- } \\
\text { dizaje. }\end{array}$ & & & \\
\hline $\begin{array}{l}\text { En mis investigaciones elegí, analicé y sinteticé la } \\
\text { información y evité copiar la información. }\end{array}$ & & & \\
\hline $\begin{array}{l}\text { Reconozco que mi realidad inmediata puede cam- } \\
\text { biar al utilizar mis nuevos conocimientos. }\end{array}$ & & & \\
\hline $\begin{array}{l}\text { Reconozco las acciones que promueven la salud, re- } \\
\text { laciones entre culturas, producción, el trabajo digno } \\
\text { y la mejora de la economía de mi comunidad. }\end{array}$ & & & \\
\hline $\begin{array}{l}\text { Colaboro a mis compañeros y compañeras en el } \\
\text { proceso de su aprendizaje. }\end{array}$ & & & \\
\hline $\begin{array}{l}\text { Me intereso por aplicar las normas de redacción y } \\
\text { ortografía en los textos que escribo. }\end{array}$ & & & \\
\hline
\end{tabular}




\section{Evaluación por Competencias}

\begin{tabular}{|c|c|c|c|}
\hline Actitud & Siempre & Casi siempre & Nunca \\
\hline $\begin{array}{l}\text { Demuestro respeto a mí persona, compañeros(as), } \\
\text { docentes y centro educativo. }\end{array}$ & & & \\
\hline $\begin{array}{l}\text { Propongo soluciones y aporto ideas cuando partici- } \\
\text { po en equipos de trabajo. }\end{array}$ & & & \\
\hline $\begin{array}{l}\text { Expreso mis sentimientos y pensamientos con res- } \\
\text { peto, sin ofender a otras personas en el momento } \\
\text { oportuno. }\end{array}$ & & & \\
\hline $\begin{array}{l}\text { Respeto la participación, ideas, diferencias físicas, } \\
\text { intelectuales, religión, idioma, cultura y género de } \\
\text { quienes conforman mi clase. }\end{array}$ & & & \\
\hline $\begin{array}{l}\text { Me intereso por hablar y escribir en mi idioma ma- } \\
\text { terno. }\end{array}$ & & & \\
\hline $\begin{array}{l}\text { Utilizo diferentes estrategias para solucionar pro- } \\
\text { blemas. }\end{array}$ & & & \\
\hline $\begin{array}{l}\text { Analizo y utilizo conceptos importantes de ecosis- } \\
\text { temas, economía, productividad, interculturalidad, } \\
\text { salud, deportes y otros. }\end{array}$ & & & \\
\hline $\begin{array}{l}\text { Comparo conceptos y distingo sus diferencias y si- } \\
\text { militudes. }\end{array}$ & & & \\
\hline $\begin{array}{l}\text { Observo fenómenos de la Naturaleza y realizo ex- } \\
\text { perimentos para comprobar aprendizajes. }\end{array}$ & & & \\
\hline $\begin{array}{l}\text { Utilizo las herramientas tecnológicas como apoyo } \\
\text { para mi aprendizaje. }\end{array}$ & & & \\
\hline $\begin{array}{l}\text { Utilizo el arte para expresar mis ideas y sentimien- } \\
\text { tos. }\end{array}$ & & & \\
\hline $\begin{array}{l}\text { Aprecio las diferentes expresiones artísticas (músi- } \\
\text { ca, plásticas, teatro, danza) como desarrollo perso- } \\
\text { nal y social. }\end{array}$ & & & \\
\hline
\end{tabular}

\section{Anecdotario:}

Lleno los espacios para contar mi experiencia con las actividades del proyecto.

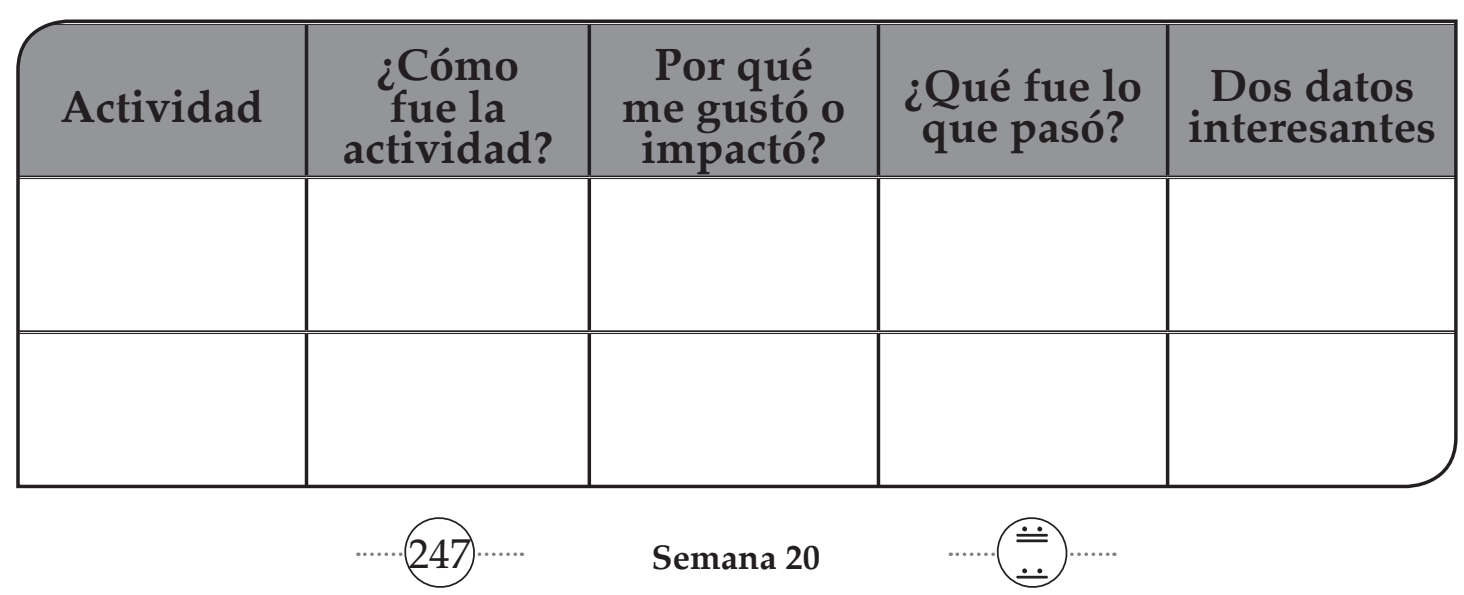


En la presente obra, se reconocen los derechos morales colectivos del Pueblo Maya y de los otros Pueblos de Guatemala: Xinka, Garífuna y Ladino; respecto de sus creaciones culturales y artísticas, entre ellas, su sistema de numeración, arquitectura, escultura, pintura, textiles y demás obras de su creación.

Debido a las características propias del internet, es posible que las fuentes consultadas, se modifiquen o desaparezcan.

Algunas imágenes donde aparecen menores de edad, fueron retocadas intencionalmente, para proteger la identidad de niñas y niños. Parte de las imágenes utilizadas en esta obra, fueron tomadas en préstamo de diferentes sitios web y bases de datos libres de derechos. Otras imágenes fueron cedidas para uso exclusivo de la presente obra por el Ministerio de Educación, Population Council, SEDEM, grupos familiares y personas individuales, quienes tienen la titularidad de las mismas. A continuación se enumeran las fuentes de las imágenes que por razones de espacio, no se les reconociió el crédito directamente al pie de la imagen.

es.123rf.com: pp. 12

https:/ / pixabay.com Cubierta, pp.119, 124, 130, 137, 141, 142, 143, 149, 150, 156: 163, 167, 169, 171, 180, 186, 192, 194, 197, 198, 214, 216, 225, 230, 233, 234, 242

http:/ / www.ccrane.com/CCRadio-SW-AMFM-Shortwave-Radio. P: 16

http:/ /www.freepik.com pp.16, 23, 32, 40 46, 63, 64, 65, 83, 84, 94, 118, 133, 172, 185, 189, 190

http://cienciasdivertidas.weebly.com/comensalismo.html P: 35

http://todofondos.com/bin/fondos/05/23/65d.jpg

http://barrancopolis.com/wp-content/uploads/2016/07/Miss-Lilith.jpg P: 73

https://planetalimon.wordpress.com/tag/agua/ P: 44

http:/ / profesor-wiltonlau.blogspot.com/2014/06/acordes-para-teclado-para-los.html P: 73

https://theguitarsounds.wordpress.com/tag/notas-de-la-guitarra/ P: 73

http:/ /globedia.com/imagenes/noticias/2011/10/19/entrevista-grupo-musical-sobrevivencia_1_929044. jpg P: 73

http://www.gtcultura.com/wp-content/uploads/2016/01/Fstival-Kat-2015.jpg P: 73

http://photos1.blogger.com/blogger/2550/3291/1600/HPIM0415.jpg P: 82

http://genial.guru/inspiracion-psicologia/test-que-hemisferio-cerebral-domina-tu-vida-85155/

http://inacopguatemala.gob.gt/images/icono\%20inacop-u4511.png P: 89

http:/ / www.taringa.net/post/hazlo-tu-mismo/17311827/Como-aprender-a-dibujar-rostros-humanos.html P: 101

http:/ / fotosdepinturasfamosas.com/necesitas-un-cuadro-al-oleo-bodegones / P: 101

http://onu.org.gt/onu-en-guatemala/agencias/oit/ P: 107

http://www.icta.gob.gt/ P: 122

http:/ / www.unisabana.edu.co/fileadmin/Documentos/Sala_de_Prensa/La_Sabana_en_los_Medios/Prensa/2014/el_colombiano-2_julio-la_tercera_v\%C3\%ADa_que_llegó_dela_mano_de_tony_blair-citan_a_diego_cediel.jpg P: 172

Anónimas: pp. 110, 123, 182, 200, 202. Boletín MSPAS: pp. 26 35. Claudia Roche: pp.20-21, 52, 66, 120, 128, 131, 217, 232, 244. Claudia Macz: pp. 97, 136, 144, 155, 161, 173. David Guzmán, (Marimba de Concierto. Ministerio de Cultura y Deportes): pp. 25. DIGEBI-MINEDUC: pp. 8, 10, 30, 37, 39, 42, 45, 57, 58, 62, 68, 69, 70, 71, 74, 75, $80,86,87,88,98,105,106,109,114,126,133,141,145,166,179,181,191,203$, 210, 236. Familia Galindo Barrientos: pp. 61, 107, 121, 134, 146, 149, 158, 166, 170, 176, 177, 178, 179, 183, 184, 187, 189, 201, 205, 207, 213, 222, 238, 243, 245, cubierta, imagen derecha. Familia Santos Garcés: pp. 14, 22 38, 51, 108, 111, 123, 140, 141, 147, 154, 160, $178,180,186,190,199,229,234,241$

Héctor Reyes: pp. 13. INGUAT: pp. 9, 27, 31, 33, 36, 53, 61, 67, 71, 78, 79, 156, 224. Julio Floresache. pp. 24. Lizbeth Gramajo: pp. 226. Margarita Ramírez: pp. 26, Maria Isabel Escobedo: pp. 129. Paula Agustín. pp. 208, 209, 216, 219, 223, 237. Population Council. Pp. 7, 13, 43, 60, 96, 102, 122, 135, 151, 164, 170, 183, 191, 208, 223. Rosa Beatriz Castañeda de Larios: pp. 162. SEDEM: 148, 157, 159, 221, 239. Vilma Chon: pp. 187 


\section{Tabla de razones trigonométricas}

\begin{tabular}{|c|c|c|c|c|c|c|c|}
\hline Angulo & seno & conseno & tangente & Angulo & seno & conseno & tangente \\
\hline $0^{\circ}$ & 0 & 1 & 0 & $46^{\circ}$ & 0,719 & 0,695 & 1,036 \\
\hline $1^{\circ}$ & 0,018 & 1 & 0,018 & $47^{\circ}$ & 0,731 & 0,682 & 1,072 \\
\hline $2^{\circ}$ & 0,035 & 0,999 & 0,035 & $48^{\circ}$ & 0,743 & 0,669 & 1,111 \\
\hline $3^{\circ}$ & 0,052 & 0,999 & 0,052 & $49^{\circ}$ & 0,755 & 0,656 & 1,15 \\
\hline $4^{\circ}$ & 0,07 & 0,998 & 0,07 & $50^{\circ}$ & 0,766 & 0,643 & 1,192 \\
\hline $5^{\circ}$ & 0,087 & 0,996 & 0,088 & $51^{\circ}$ & 0,777 & 0,629 & 1,235 \\
\hline $6^{\circ}$ & 0,105 & 0,995 & 0,105 & $52^{\circ}$ & 0,788 & 0,616 & 1,28 \\
\hline $7^{\circ}$ & 0,122 & 0,993 & 0,123 & $53^{\circ}$ & 0,799 & 0,602 & 1,327 \\
\hline $8^{\circ}$ & 0,139 & 0,99 & 0,141 & $54^{\circ}$ & 0,809 & 0,588 & 1,376 \\
\hline $9^{\circ}$ & 0,156 & 0,988 & 0,158 & $55^{\circ}$ & 0,819 & 0,574 & 1,428 \\
\hline $10^{\circ}$ & 0,174 & 0,985 & 0,176 & $56^{\circ}$ & 0,829 & 0,559 & 1,483 \\
\hline $11^{\circ}$ & 0,191 & 0,982 & 0,194 & $57^{\circ}$ & 0,039 & 0,545 & 1,54 \\
\hline $12^{\circ}$ & 0,208 & 0,978 & 0,213 & $58^{\circ}$ & 0,848 & 0,53 & 1,6 \\
\hline $13^{\circ}$ & 0,225 & 0,974 & 0,231 & $59^{\circ}$ & 0,857 & 0,515 & 1,664 \\
\hline $14^{\circ}$ & 0,242 & 0,97 & 0,249 & $60^{\circ}$ & 0,866 & 0,5 & 1,732 \\
\hline $15^{\circ}$ & 0,259 & 0,966 & 0,268 & $61^{\circ}$ & 0,875 & 0,485 & 1,804 \\
\hline $16^{\circ}$ & 0,276 & 0,961 & 0,287 & $62^{\circ}$ & 0,883 & 0,47 & 1,881 \\
\hline $17^{\circ}$ & 0,292 & 0,956 & 0,306 & $63^{\circ}$ & 0,891 & 0,454 & 1,963 \\
\hline $18^{\circ}$ & 0,309 & 0,951 & 0,325 & $64^{\circ}$ & 0,899 & 0,438 & 2,05 \\
\hline $19^{\circ}$ & 0,326 & 0,946 & 0,344 & $65^{\circ}$ & 0,906 & 0,423 & 2,145 \\
\hline $20^{\circ}$ & 0,342 & 0,94 & 0,364 & $66^{\circ}$ & 0,914 & 0,407 & 2,246 \\
\hline $21^{\circ}$ & 0,358 & 0,934 & 0,384 & $67^{\circ}$ & 0,921 & 0,391 & 2,356 \\
\hline $22^{\circ}$ & 0,375 & 0,927 & 0,404 & $68^{\circ}$ & 0,927 & 0,375 & 2,475 \\
\hline $23^{\circ}$ & 0,391 & 0,921 & 0,425 & $69^{\circ}$ & 0,934 & 0,358 & 2,605 \\
\hline $24^{\circ}$ & 0,407 & 0,914 & 0,445 & $70^{\circ}$ & 0,94 & 0,342 & 2,747 \\
\hline $25^{\circ}$ & 0,423 & 0,906 & 0,466 & $71^{\circ}$ & 0,946 & 0,326 & 2,904 \\
\hline $26^{\circ}$ & 0,438 & 0,899 & 0,488 & $72^{\circ}$ & 0,951 & 0,309 & 3,078 \\
\hline $27^{\circ}$ & 0,454 & 0,891 & 0,51 & $73^{\circ}$ & 0,956 & 0,292 & 3,271 \\
\hline $28^{\circ}$ & 0,47 & 0,883 & 0,532 & $74^{\circ}$ & 0,961 & 0,276 & 3,487 \\
\hline $29^{a}$ & 0,485 & 0,875 & 0,554 & $75^{\circ}$ & 0,966 & 0,259 & 3,732 \\
\hline $30^{\circ}$ & 0,5 & 0,866 & 0,577 & $76^{\circ}$ & 0,97 & 0,242 & 4,011 \\
\hline $31^{\circ}$ & 0,515 & 0,857 & 0,601 & $77^{\circ}$ & 0,974 & 0,225 & 4,331 \\
\hline $32^{\circ}$ & 0,53 & 0,848 & 0,625 & $78^{\circ}$ & 0,978 & 0,208 & 4,705 \\
\hline $33^{\circ}$ & 0,545 & 0,839 & 0,649 & $79^{\circ}$ & 0,982 & 0,191 & 5,145 \\
\hline $34^{\circ}$ & 0,559 & 0,829 & 0,675 & $80^{\circ}$ & 0,985 & 0,174 & 5,671 \\
\hline $35^{\circ}$ & 0,574 & 0,819 & 0,7 & $81^{\circ}$ & 0,988 & 0,156 & 6,314 \\
\hline $36^{\circ}$ & 0,588 & 0,809 & 0,727 & $82^{\circ}$ & 0,99 & 0,139 & 7,115 \\
\hline $37^{\circ}$ & 0,602 & 0,799 & 0,754 & $83^{\circ}$ & 0,993 & 0,122 & 8,144 \\
\hline $38^{\circ}$ & 0,616 & 0,788 & 0,781 & $84^{\circ}$ & 0,995 & 0.105 & 9,514 \\
\hline $39^{\circ}$ & 0,629 & 0,777 & 0,81 & $85^{\circ}$ & 0,996 & 0,097 & 11,43 \\
\hline $40^{\circ}$ & 0,643 & 0,766 & 0,839 & $86^{\circ}$ & 0,998 & 0,07 & 14,3 \\
\hline $41^{\circ}$ & 0,656 & 0,755 & 0,869 & $87^{\circ}$ & 0,999 & 0,052 & 19,081 \\
\hline $42^{\circ}$ & 0,669 & 0,743 & 0,9 & $88^{\circ}$ & 0,999 & 0,035 & 28,64 \\
\hline $43^{\circ}$ & 0,682 & 0,731 & 0,933 & $89^{\circ}$ & 1 & 0,018 & 57,289 \\
\hline $44^{\circ}$ & 0,695 & 0,719 & 0,966 & $90^{\circ}$ & 1 & 0 & Inf. \\
\hline $45^{\circ}$ & 0,707 & 0,707 & 1 & & & & \\
\hline
\end{tabular}

Fuente: http:/ / fernandasimont.blogspot.com/2011/04/tabla-de-funciones-trigonometricas.html 


\section{Áreas y Volúmenes de Cuerpos Geométricos}

\begin{tabular}{|c|c|c|c|c|}
\hline & NOMBRE & FORMA & ÁREAS & VOLUMEN \\
\hline \multirow{2}{*}{ 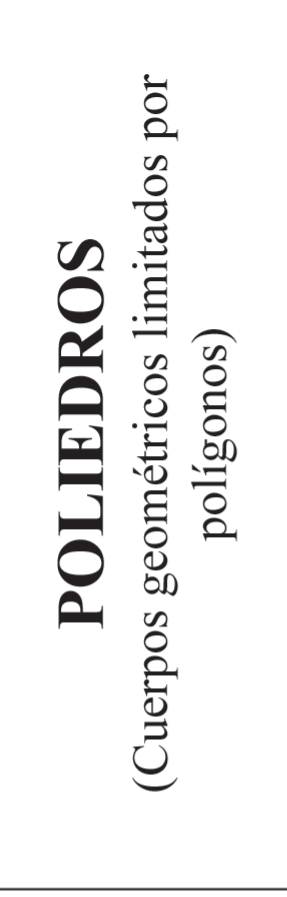 } & PRISMA & & $\begin{array}{c}A_{L}=p_{B} \cdot h \\
p_{B}=\text { perímetro base } \\
A_{B}=\frac{p_{B} \cdot a_{B}}{2} \\
a_{B}=\text { apotema base } \\
A_{T}=A_{L}+2 A_{B}\end{array}$ & $V=A_{B} \cdot h$ \\
\hline & PIRÁMIDE & & $\begin{array}{c}A_{\text {TRIANG. }}=\frac{l_{B} \cdot a_{l}}{2} \\
a_{l}=\text { apotema lateral } \\
l_{B}=\text { lado base } \\
A_{B}=\frac{p_{B} \cdot a_{B}}{2} \\
A_{T}=A_{L}+2 A_{B}\end{array}$ & $V=\frac{A_{B} \cdot h}{3}$ \\
\hline 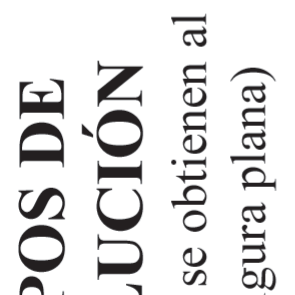 & CILINDRO & & $\begin{array}{c}A_{L}=2 \pi r \cdot h \\
h=\text { altura } \\
A_{B}=\pi \cdot r^{2} \\
A_{T}=A_{L}+2 A_{B}\end{array}$ & $V=A_{B} \cdot h$ \\
\hline 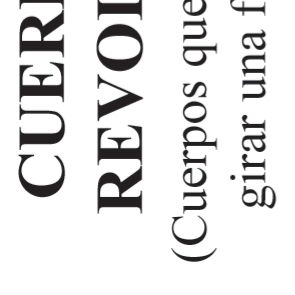 & $\mathrm{CONO}$ & & $\begin{array}{c}A_{L}=\pi \cdot r \cdot g \\
\mathrm{~g}=\text { generatriz } \\
A_{B}=\pi \cdot r^{2} \\
A_{T}=A_{L}+A_{B}\end{array}$ & $V=\frac{A_{B} \cdot h}{3}$ \\
\hline
\end{tabular}

Fuente: https:/ / docs.google.com/viewer?a=v\&pid=sites\&srcid=ZGVmYXVsdGRvbWFpbnxwcm9mZXNvcmNhcm9saW5 hZGlhenxneDo2OWY4MzZiNmE2MmVhYTc0

POPULATION COUNCIL

Ideas. Evidencia. Impacto.

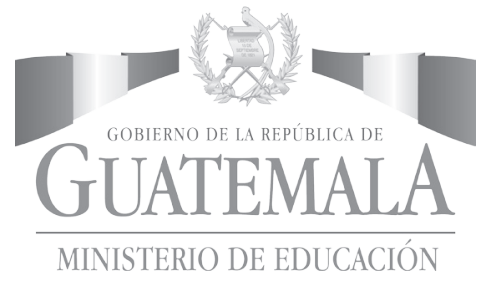

NoVo Foundation create. change. 